\title{
IDENTIDADES EN FRONTERAS UNA CONFIGURACIÓN EN MOVIMIENTO
}

Configuración de identidades culturales en procesos migratorios desde una perspectiva sociocultural. Trayectos biográficos de sujetos migrantes nariñenses asentados desde los años 60 en Candelaria, Valle del Cauca. Colombia.

ANA MARÍA LÓPEZ ROJAS

Universidad Nacional de La Plata

Facultad de Periodismo y Comunicación Social

Doctorado en Comunicación

La Plata, Argentina 


\title{
IDENTIDADES EN FRONTERAS \\ UNA CONFIGURACIÓN EN MOVIMIENTO
}

Configuración de identidades culturales en procesos migratorios desde una perspectiva sociocultural. Trayectos biográficos de sujetos migrantes nariñenses asentados desde los años 60 en Candelaria, Valle del Cauca. Colombia.

Tesis de grado para optar al título de doctora en Comunicación

\author{
Dirección \\ DOCTORA AMPARO MARROQUÍN PARDUCCI \\ Codirección \\ DOCTOR CARLOS FELIMER DEL VALLE ROJAS
}

Universidad Nacional de La Plata

Facultad de Periodismo y Comunicación Social

Doctorado en Comunicación

La Plata, Argentina 
A Samuel, la juguetona inspiración de mi vida. A mi padre, maestro de paciencia y fe. A mi madre, mujer valiente y luz de mi camino. 


\section{Agradecimientos}

Emprender un proyecto de formación doctoral implica un recorrido inesperado lleno de incertidumbres, tiempos extendidos, profundas pasiones, descubrimientos, aprendizajes, certezas y nuevamente... incertidumbres. Este trayecto fue posible, gracias a la nobleza de mi hijo Samuel, compañero de vida, cómplice y paciente, quien también aprendió en esta aventura a conocer la cultura nariñense, a jugar a la chaza y a disfrutar los fines de semana en Candelaria elevando cometa, montando en bicicleta o siendo el mejor asistente de investigación en este proyecto.

Gracias también a mi padre, Carlos Alberto López Hernández, luz y fortaleza de mi vida, polo a tierra en los momentos dificiles, mi gran maestro, el hombre de la sonrisa profunda, la mirada firme y los silencios sabios. Gracias siempre a la gran mujer de mi vida, Estela Rojas González, la madre de mis sueños, la valiente que parió mi espíritu libre y luchador, mi madre a quien honro, reconozco y admiro por su sabiduría infinita, por ese ser simple y complejo que enamoró a mi padre y construyó a su lado el escenario de las enseñanzas fundamentales de mi vida.

Agradezco profundamente a mi familia por su apoyo sin limites, por su confianza y empuje, por enseñarme a creer que siempre se puede y por haber convertido mis proyectos en los suyos. A mi tía María Teresa López y a mi primo y hermano Juan Pablo Ángel, por su entrega y dedicación con mi hijo, por amarnos y acompañarnos en cada reto propuesto y sobre todo, por haberle ofrecido a Samuel un hogar, mientras "la mamita” estaba en Argentina.

Gracias a Alba, a la tía Ruby y a Gil, a los tíos Omar, Chalo y Nan; a Nena y Lili, a Laura, Efraín, Juliana y Camilo, por sus cuidados y complicidades con mi Samuel en su año de estancia en Manizales. La presencia y el compromiso de todos ustedes con mi hijo, me dieron la fuerza para continuar este camino. A mi familia Rojas González, la raíz de mi espíritu de lucha y empeño, la cuna de mi madre y también la cuna de hombres y mujeres trabajadores $y$ perseverantes que han sido mi ejemplo de valentía y superación ;Gracias! 
Mi agradecimiento y admiración a la comunidad nariñense de Candelaria por acogerme con nobleza, por compartir conmigo sus vidas, historias, espacios y costumbres. Mi gratitud por enseñarme a esperar sin mirar la hora, por enseñarme a cumplir una cita sin coordenadas predefinidas de tiempo y espacio, y por haberme enseñado que el sentido del estar juntos está en hacer algo juntos.

A don Alpala, líder incansable; a doña Rosalba por haberme indicado con una mirada y una sonrisa, su deseo de conversar; a don Pedro Castro, trabajador incesante; a don Alberto Díaz por sus historias atravesadas por esa melancolía del pasado que atrapaban cada vez mi sensibilidad; a don Jorge Martínez por su sabiduría y hospitalidad; a don Gabriel Pascuasa por su humildad y por sus relatos apasionados y apasionantes; a Julio Castro por haber sido puente conector de estas historias que fascinaron mi vida para siempre; a don Humberto y doña Beatriz por abrirme las puertas de su casa; a toda la comunidad nariñense que me ha hecho parte de sus celebraciones, de sus historias, de sus vidas y de sus sabores ;Gracias! A María Fernanda Medina por su bondad y su tiempo, por recorrer conmigo Candelaria y por ampliar mi red para que este proyecto pudiera realizarse; a Margarita López y su familia, por su acogida amorosa, muchas gracias.

Mi gratitud también a mis directores, Amparo Marroquín Parducci y Carlos Felimer del Valle Rojas, quienes aceptaron mi propuesta en la distancia y sin conocerme. Me acompañaron durante estos años con agendas y encuentros concertados, intentando siempre alinear el cambio horario de tres países. Gracias por su dedicación y tiempo, por haber acompañado con confianza y con paciencia mis prisas y mis pausas, ustedes se convirtieron en mis motores con sus lecturas oportunas, con sus ideas retadoras, con sus miradas expertas y con sus palabras de reconocimiento y aliento, que no me permitieron desfallecer.

Gracias infinitas a la familia argentina que acogió mi tristeza lejos de mi pequeño Samuel. Paula, Jorge, Mica y toda la familia Sandoval Bermeo que abrió sus puertas a las historias de una colombiana, en las inolvidables sobremesas que en aquella mesa extensible, extendieron sobre todo los afectos, los recuerdos y la memoria de unos meses sin horas saboreando un mate, una mandarina o un vino tinto que remojaba las palabras y las complicidades en ese otro país en el que hallé una nueva familia. 
A Catalina Hurtado, mi amiga y hermana, porque siempre, desde el primer día en el que inicié esta aventura, me ayudó a pensar y a creer que faltaba poco.

Mi agradecimiento a la Pontificia Universidad Javeriana de Cali por haberle apostado a este proyecto de formación que indudablemente se convirtió en una experiencia de vida; pero sobre todo, gracias por ser el escenario de formación permanente de mi ser docente investigadora, bajo el sello invaluable de la Pedagogía Ignaciana que necesariamente ha hecho de mi labor, un reto diario de excelencia y de reconocimiento del otro.

A todos mi gratitud, hoy y siempre. 


\section{Índice}

\section{CAPÍTULO I. PRESENTACIÓN}

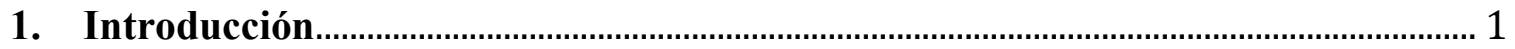

2. Título de la tesis....................................................................................................................... 5

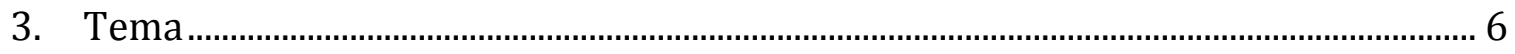

4. Estado del Arte....................................................................................................................... 6

4.1. La construcción de identidades en el contexto de la migración interna en Colombia. Un rastreo de perspectivas y tendencias........................................................................ 6

4.2. Apuntes sobre el estudio de la migración interna en Colombia..................................... 9

4.3. La relación migración - identidad en Colombia. Estrategias de identificación y construcción de sentidos frente a los nuevos espacios............................................................... 19

4.3. La relación migración - identidad en el contexto internacional. Construcciones sociales en las orillas de los territorios........................................................................................ 23

4.5. Reflexiones metodológicas sobre el abordaje de la migración en relación con la

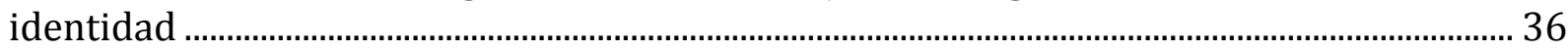

4.6. Mucho sobre migración e identidad, en términos generales y socioantropológicos. Poco desde la comunicación ¿Qué se ha dicho?

5. Referente contextual 45

5.1. Generalidades del proceso migratorio 45

5.2. Descripción general del proceso migratorio en Colombia en la década de los setenta

Tabla 1. Proporción de la población colombiana clasificada como urbana............................ 48

Tabla 2. Colombia, principales tendencias demográficas 1905-1998 …………………….... 49

Tabla 3. Tasas de migración en Colombia ……………………………………………………... 50

Tabla 4. Migrantes y no migrantes en Colombia antes de 1988 .............................................. 53

Tabla 5. Migrantes y no migrantes por porcentajes antes de 1988 ......................................... 55

5.3. El departamento de Nariño como origen de la migración ..................................................... 56

Figura 1. Recorrido migratorio realizado.................................................................................5

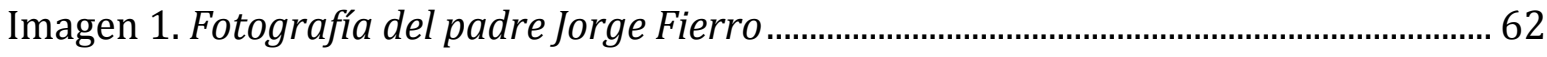


Imagen 2. Primer año de celebración de la fiesta de la Virgen de las Lajas en Candelaria, 1983. 63

Imagen 3. Celebración de la fiesta de la Virgen de las Lajas en Candelaria. 1984. 63

Imagen 4. Estatutos de fundación de la Sociedad parroquial de servicio social Nuestra Señora de las Lajas en Candelaria. 1985 65

Imagen 5. Resolución de personería jurídica conferida a la Sociedad parroquial de servicio social Nuestra Señora de las Lajas en Candelaria. 1986 ............................................ 70

Imagen 6. Procesión de la Virgen de las Lajas en Candelaria. ................................................... 71

Imagen 7. Oleo a la Virgen de las Lajas en Candelaria............................................................ 71

Imagen 8. Celebración de la fiesta de la Virgen de las Lajas en Candelaria. 1986.............. 72

Imagen 9. Celebración de la fiesta de la Virgen de las Lajas en Candelaria. 1992.............. 72

Imagen 10. Documento de la tesorería de la Sociedad parroquial de servicio social Nuestra Señora de las Lajas en Candelaria. 1991..................................................................... 73

Imagen 11. Carpas de comida en la celebración del Carnaval de blancos y negros realizado en Candelaria, Valle del Cauca. .................................................................................... 74

Imagen 12. Presentación de bailes típicos de Nariño en la celebración del Carnaval de blancos y negros realizado en Candelaria. ……………………………………………………... 75

Imagen 13. Vestuario de bailes típicos de Nariño en la celebración del Carnaval de blancos y negros realizado en Candelaria. ................................................................................ 75

Imagen 14. La gente del municipio de Candelaria pintándose de blanco y negro en la celebración del Carnaval de blancos y negros............................................................................. 76

Imagen 15. Cancha de chaza ubicada en el Municipio de Candelaria ..................................... 77

Imagen 16. Canchas de tejo ubicadas en el lado superior de la cancha de chaza de

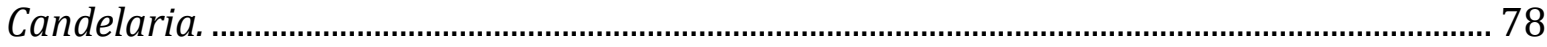

Imagen 17. Juego de rana ubicado en las casetas al costado de la chaza de Candelaria. 78 Imagen 18. Cancha de voleibol ubicada tras las casetas que se encuentran en la cancha

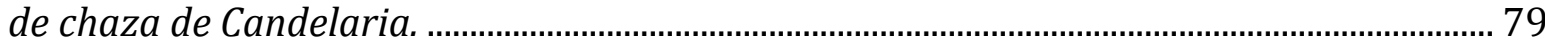

5.4. El Valle del Cauca como uno de los principales receptores de la migración interna en Colombia.. 80

Figura 2. Mapa Región Pacífico colombiana. .81

Tabla 6. Distribución subregional del Valle del Cauca ............................................................... 82 
Figura 3. Mapa área metropolitana del Valle del Cauca.

5.5. Candelaria, Valle del Cauca. Municipio receptor de la migración ..................................... 87

Tabla 7. Distribución porcentual de Candelaria a partir de la migración interdepartamental 88

Tabla 8. Crecimiento de la población de Candelaria, Valle del Cauca. 91

Figura 4. Mapa barrios del municipio de Candelaria 92

Imagen 19. Documento de donación de la urbanización Santa Ana, que el Ingenio Mayagüez le hizo al municipio de Candelaria en 1989.

Imagen 20. Informe financiero de la celebración religiosa de la Virgen de las Lajas realizada en Candelaria en el año 2015.

Imagen 21. Santuario a la Virgen de las Lajas ubicado actualmente a un costado de la cancha de chaza construida en Candelaria.

Imagen 22. Actual altar a Nuestra Señora de las Lajas ubicado en la Parroquia de Nuestra Señora de la Candelaria................................................................................................. 96

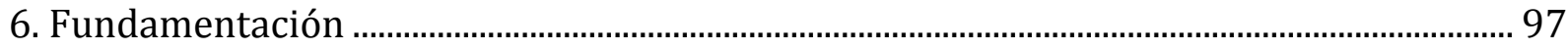

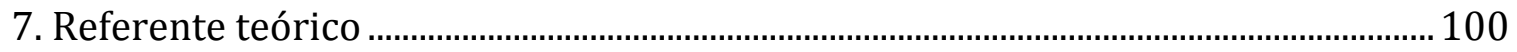

7.1. La migración como objeto de estudio ..............................................................................100

7.2. El concepto de Nación y su relación con las migraciones internas ...............................103

7.3. La desigualdad en el contexto de urbanización, concentraciones de capital y globalización: una mirada desde las migraciones .......................................................................105

7.4. Nosotros somos los de allá y los de acá. Desarrollo teórico de la categoría.................110

7.5. Identidades en fronteras, límites y bordes ..............................................................................117

Tabla 9. Dimensiones de la comunicación.......................................................................................121

Tabla 10. Tipificación de los rituales espontáneos en el marco de los procesos

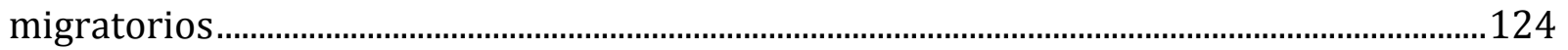

7.6. La pregunta por la identidad en este contexto de enunciación .......................................125

7.7. De las nuevas formas de ser-estar-ir-venir-ser. Abordaje teórico de la identidad

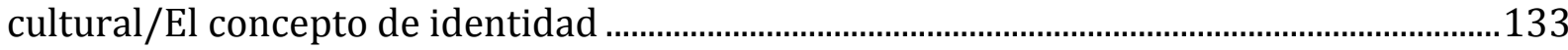

7.8. La configuración de identidades culturales. Un abordaje desde los procesos migratorios de los migrantes nariñenses en el municipio de Candelaria, Valle del Cauca. 
7.9. Categorías de análisis para la aproximación empírica

7.9.1. Relatos de identidad cultural

7.9.1.2 Narrativas de "lo nariñense", en perspectiva crítica y desde una mirada sociocomunicativa.

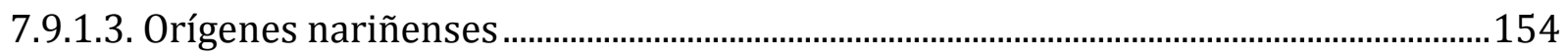

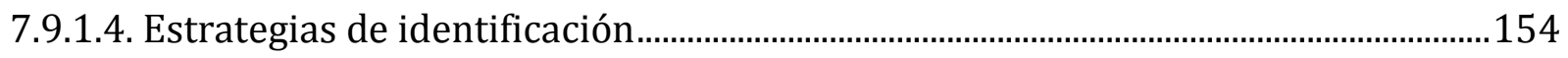

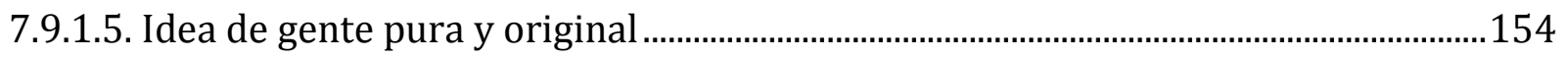

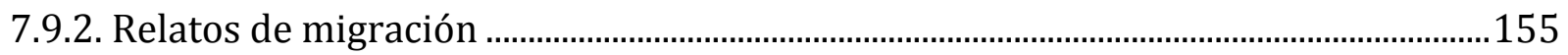

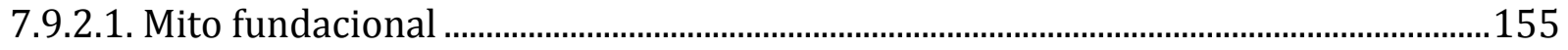

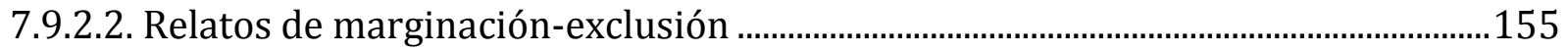

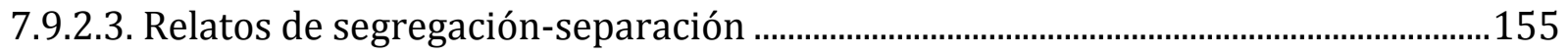

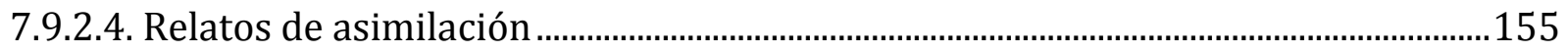

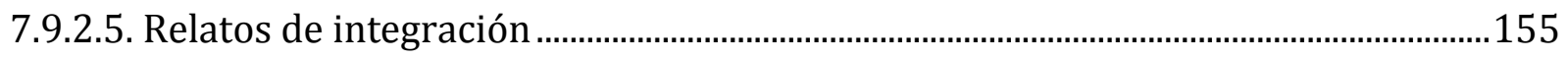

7.10. Las dimensiones de la comunicación. Eje transversal de análisis...............................156

8. Diseño metodológico.

8.1. Matriz de operacionalización de categorías de análisis .......................................................157

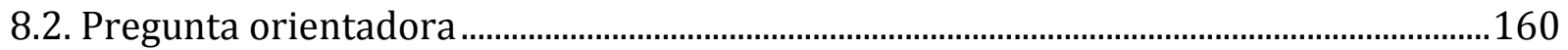

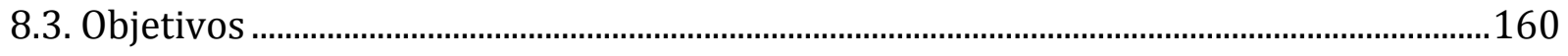

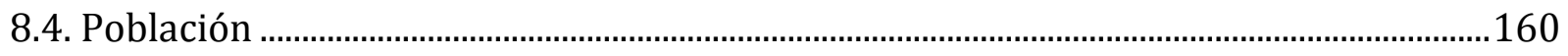

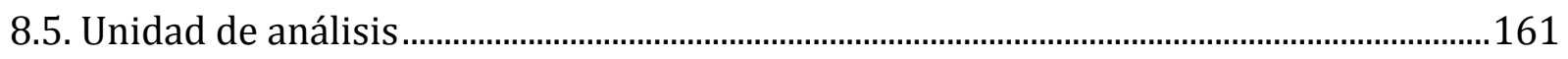

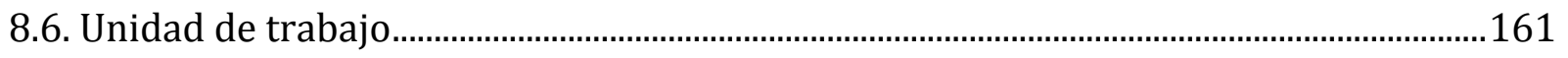

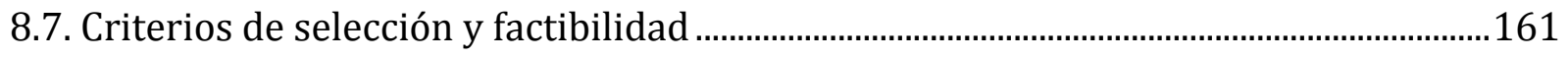

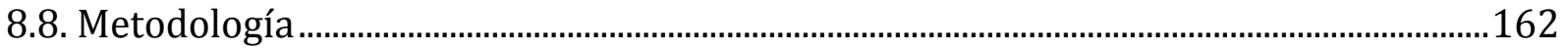

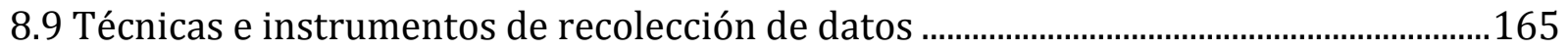

8.9.1. Del método biográfico y los relatos propios de los sujetos............................................165

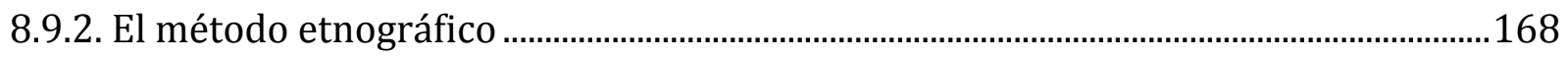

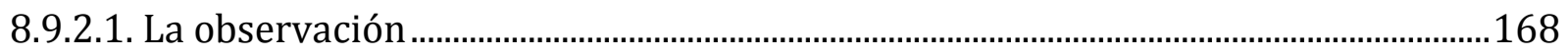


8.9.2.2. La entrevista. Una conversación con las historias de migrantes nariñenses y sus familias.

8.9.2.3. Los grupos de discusión.

8.9.2.4. La revisión documental. Retomando el álbum familiar y los documentos personales.

8.10. Matriz de relación entre micro-categorías de análisis, técnicas de recolección de datos y fuentes de información

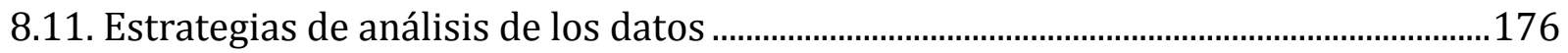

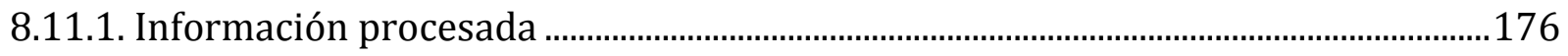

8.11.2. Metodología implementada para la sistematización ....................................................179

8.11.3. Características del programa........................................................................................ 184

8.11.4. Aciertos y desaciertos en el proceso de sistematización..............................................185

Tabla 12. Estrategia de análisis asociada a la evidencia empírica recolectada a partir de

la aplicación de instrumentos

9. Candelaria, Valle del Cauca. Un espacio de tensiones y negociaciones interculturales entre nariñense y vallecaucanos. 188

9.1. Relatos de la migración nariñense en Candelaria, Valle del Cauca.................................193

9.1.1. Mito fundacional. Motivaciones de la migración ...........................................................193

9.1.1.1 Llegar, apoyarse y establecerse ..........................................................................................203

9.1.2. Relatos de marginación - exclusión ……….........................................................................207

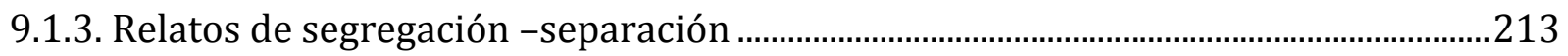

9.2. Relatos de identidad cultural nariñense en Candelaria. Motivaciones de las estrategias de identificación cultural nariñense en Candelaria como posibilidad de establecer tensiones con candelareños

9.2.1. Orígenes nariñenses. La construcción de la identidad como expansión de las pretensiones personales de los migrantes en Candelaria

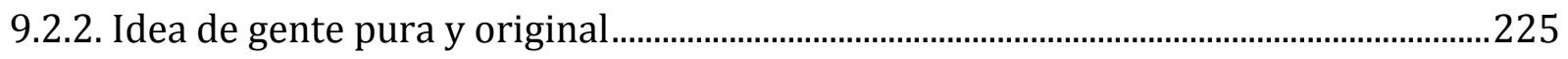

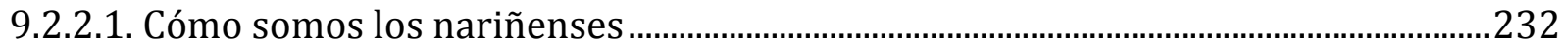

9.2.3. Narrativas de lo nariñense. "Ellos son así": relatos de lo nariñense en Candelaria desde la mirada de los candelareños, un momento de negociaciones y conflictos ...........235 
9.2.4. Ustedes y nosotros. Estrategias de identificación de los nariñenses en Candelaria.

9.2.4.1. El milagro en el abismo: la virgen de Las Lajas ... 253

Imagen 23. Momento previo a la realización de la novena del día 3 en la celebración de la Virgen de las Lajas..... 255

Imagen 24. El grupo de fiesteros disponiendo el altar para la celebración de la novena del tercer día. 255

Imagen 25. Procesión del día 9 en honor a la Virgen de las Lajas 257

Imagen 26. Altar a la Virgen de las Lajas en casa de Humberto Tutalchá. Al lado, fotografía enmarcada del Santuario de las Lajas en Ipiales, Nariño.

Imagen 27. Vitrina con comida típica nariñense ofrecida durante la noche de la procesión a la Virgen de las Lajas.

Imagen 28. Fotografía en la que puede apreciarse el sentido cultural secular de las procesiones.

9.2.4.2. Carnavales de Blancos y Negros: diversión para nariñenses y candelareños......264

Imagen 29. Personas en el municipio de Candelaria pintándose de blanco y negro en la celebración del Carnaval de blancos y negros. 266

Imagen 30. El cuy, comida típica nariñense ofrecida en las carpas dispuestas en la celebración del Carnaval de Blancos y Negros realizado en Candelaria, Valle del Cauca.

Imagen 31. Bailes típicos de Nariño presentados en la celebración del Carnaval de Blancos y Negros realizado en Candelaria.

9.2.4.3. La chaza: el tenis andino.

Imagen 32. Empanadas nariñenses preparadas con harina de yuca. Ofrecidas para la venta en la cancha de chaza.

Imagen 33. Nariñenses jugando a la chaza en la cancha de Candelaria, Valle del Cauca.

Imagen 34. Minga para la construcción de la cancha de Chaza ..............................................277

Imagen 35. Nariñenses espectadores del juego de la chaza .................................................277

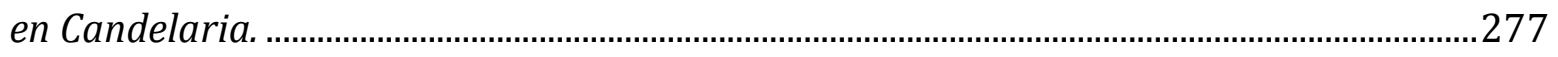

Imagen 36. Cotejo de chaza en Candelaria, Valle del Cauca. ................................................... 278 
Imagen 37. Integrantes del Club de Chaza ubicados de manera intencional de espaladas al santuario a la Virgen de las Lajas ubicado a un costado de la cancha de chaza..........280

9.2.4.4. Las mingas: trabajar, comer y tomar juntos ................................................................2280

Imagen 38. Nariñenses trabajando en minga......................................................................282

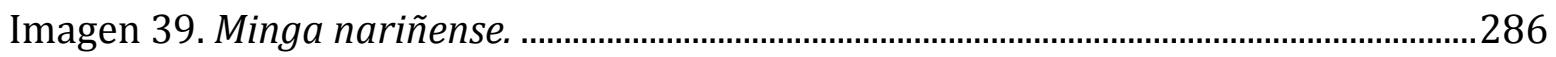

10. Consideraciones finales........................................................................................................292

Imagen 40. Collage de fotografías realizadas a nariñenses y prácticas propias, durante el trabajo de campo ..................................................................................................................310

11. Referencias bibliográficas .............................................................................................. 311

ANEXO 1. Protocolo de la entrevista biográfica ................................................................ 322

ANEXO 2. Protocolo de la entrevista focalizada individual............................................... 327

ANEXO 3. Protocolo de los grupos de discusión ................................................................ 331

ANEXO 4. Protocolo de la observación etnográfica ............................................................ 336

ANEXO 5. Clasificación de la evidencia empírica................................................................ 343

\section{Índice de tablas}

Tabla 1. Proporción de la población colombiana clasificada como urbana ....................48

Tabla 2. Colombia, principales tendencias demográficas 1905-1998_.............................49

Tabla 3. Tasas de migración en Colombia............................................................................50

Tabla 4. Migrantes y no migrantes en Colombia antes de 1988 .........................................53

Tabla 5. Migrantes y no migrantes por porcentajes antes de 1988..................................55

Tabla 6. Distribución subregional del Valle del Cauca ………………………………….....82

Tabla 7. Distribución porcentual de Candelaria a partir de la migración interdepartamental .88

Tabla 8. Crecimiento de la población de Candelaria, Valle del Cauca 91

Tabla 9. Dimensiones de la comunicación 121

Tabla 10. Tipificación de los rituales espontáneos en el marco de los procesos migratorios 
Tablas 11 y 12. Estrategia de análisis asociada a la evidencia empírica recolectada a partir de la aplicación de instrumentos

\section{Índice de figuras}

Figura 1. Recorrido migratorio realizado 57

Figura 2. Mapa Región Pacífico colombiana. .81

Figura 3. Mapa área metropolitana del Valle del Cauca 84

Figura 4. Mapa barrios del municipio de Candelaria 92

\section{Índice de imágenes}

Imagen 1. Fotografía del padre Jorge Fierro.

Imagen 2. Fotografía de 1983. Primer año de celebración de la fiesta de la Virgen de las Lajas en Candelaria. 63

Imagen 3. Fotografía de la celebración de la fiesta de la Virgen de las Lajas en Candelaria. 1984. 63

Imagen 4. Estatutos de fundación de la Sociedad parroquial de servicio social Nuestra Señora de las Lajas en Candelaria. 1985. 65

Imagen 5. Resolución de personería jurídica conferida a la Sociedad parroquial de servicio social Nuestra Señora de las Lajas en Candelaria. 1986 .70

Imagen 6. Fotografía procesión de la Virgen de las Lajas en Candelaria. .71

Imagen 7. Fotografía oleo a la Virgen de las Lajas en Candelaria. .71

Imagen 8. Fotografía de la celebración de la fiesta de la Virgen de las Lajas en Candelaria. 1986. 72

Imagen 9. Fotografía de la celebración de la fiesta de la Virgen de las Lajas en Candelaria. 1992. 72

Imagen 10. Documento de la tesorería de la Sociedad parroquial de servicio social Nuestra Señora de las Lajas en Candelaria. 1991. .73

Imagen 11. Carpas de comida en la celebración del Carnaval de blancos y negros realizado en Candelaria, Valle del Cauca. 
Imagen 12. Presentación de bailes típicos de Nariño en la celebración del Carnaval de blancos y negros realizado en Candelaria. 75

Imagen 13. Vestuario de bailes típicos de Nariño en la celebración del Carnaval de blancos y negros realizado en Candelaria. 75

Imagen 14. La gente del municipio de Candelaria pintándose de blanco y negro en la celebración del Carnaval de blancos y negros. 76

Imagen 15. Cancha de chaza ubicada en el Municipio de Candelaria .77

Imagen 16. Canchas de tejo ubicadas en el lado superior de la cancha de chaza de Candelaria.

Imagen 17. Juego de rana ubicado en las casetas al costado de la chaza de Candelaria.

Imagen 18. Cancha de voleibol ubicada tras las casetas que se encuentran en la cancha de chaza de Candelaria. 79

Imagen 19. Documento que hace referencia a la donación de la urbanización Santa Ana, que el Ingenio Mayagüez le hizo al municipio de Candelaria en 1989. 93

Imagen 20. Informe financiero de la celebración religiosa de la Virgen de las Lajas realizada en Candelaria en el año 2015. 94

Imagen 21. Santuario a la Virgen de las Lajas ubicado actualmente a un costado de la cancha de chaza construida en Candelaria. 95

Imagen 22. Actual altar a Nuestra Señora de las Lajas ubicado en la Parroquia de Nuestra Señora de la Candelaria. 96

Imágenes 23. Momento previo a la realización de la novena del día 3 en la celebración de la Virgen de las Lajas. 255

Imágenes 24. El grupo de fiesteros disponiendo el altar para la celebración de la novena del tercer día. 255

Imágenes 25. Procesión del día 9 en honor a la Virgen de las Lajas 257

Imágenes 26. Altar a la Virgen de las Lajas en casa de Humberto Tutalchá. Al lado, fotografía enmarcada del Santuario de las Lajas en Ipiales, Nariño. 262

Imágenes 27. Vitrina con comida típica nariñense ofrecida durante la noche de la procesión a la Virgen de las Lajas. 263

Imágenes 28. Fotografía en la que puede apreciarse el sentido cultural secular de las procesiones. 264 
Imagen 29. Personas en el municipio de Candelaria pintándose de blanco y negro en la celebración del Carnaval de blancos y negros. 266

Imagen 30. El cuy, comida típica nariñense ofrecida en las carpas dispuestas en la celebración del Carnaval de Blancos y Negros realizado en Candelaria, Valle del Cauca. 270

Imagen 31. Bailes típicos de Nariño presentados en la celebración del Carnaval de Blancos y Negros realizado en Candelaria. 270

Imagen 32. Empanadas nariñenses preparadas con harina de yuca. Ofrecidas para la venta en la cancha de chaza. 273

Imagen 33. Nariñenses jugando a la chaza en la cancha de Candelaria, Valle del Cauca. 274

Imagen 34. Minga para la construcción de la cancha de Chaza..................................... 277

Imagen 35. Nariñenses espectadores del juego de la chaza en Candelaria................. 277

Imagen 36. Cotejo de chaza en Candelaria, Valle del Cauca............................................. 278

Imagen 37. Integrantes del Club de Chaza ubicados de manera intencional de espaladas al santuario a la Virgen de las Lajas ubicado a un costado de la cancha de chaza.280

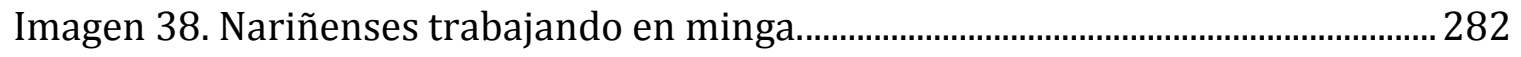

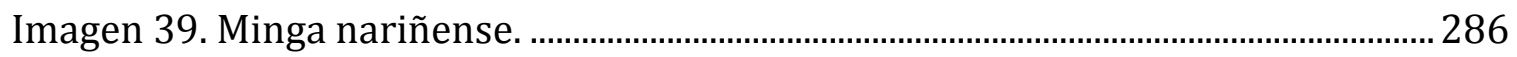

Imagen 40. Collage de fotografías realizadas durante el trabajo de campo a nariñenses y prácticas propias. 


\section{CAPÍTULO I \\ PRESENTACIÓN}

\section{Introducción}

La investigación que se presenta a continuación tiene su origen en el acercamiento que años atrás, en el año 2010, se tuvo con el municipio de Candelaria, Valle del Cauca, Colombia, en el marco del ejercicio de docencia e investigación que para ese entonces, requirió el acompañamiento de algunos estudiantes de Comunicación, en un proceso llevado a cabo, en principio con la Alcaldía del municipio y posteriormente extendido, tanto en intereses como en públicos, para en el año 2012 configurarse en una investigación liderada desde el semillero de investigación en comunicación pública, adscrito al grupo de investigación en Procesos y Medios de Comunicación de la Pontificia Universidad Javeriana de Cali, la cual vinculó directamente a los fundadores del club de chaza, presentes en este municipio desde la década de los años 60.

A partir de la dirección de este proyecto de investigación de pre-grado, empezaron a generarse preguntas e intereses en torno a la colonia nariñense asentada en este lugar, al mismo tiempo que admiración por su capacidad organizativa, curiosidad por conocer sus costumbres, interés por comprender cómo tejían sus relaciones y cómo a partir de estas lograban mantener sus prácticas tradicionales. Una serie de interrogantes que poco a poco fueron teniendo lugar en el planteamiento de esta tesis doctoral y que poco a poco también, fueron mostrando la ruta para una investigación que en escala de lo local fuera marcando hallazgos y aprendizajes de relevancia socio-cultural y de importancia en el contexto de la región pacífico colombiana.

En este escenario de intereses que para este punto ya no se enmarcaban únicamente en la dimensión académica, si no también afectiva por las relaciones que se fueron tejiendo y fortaleciendo en el camino con los nariñenses en Candelaria, empezaron a configurarse las apuestas de investigación, encuadradas en la relación categorial establecida entre la identidad cultural y los procesos migratorios locales. 
Los procesos de configuración y reconfiguración de identidad cultural de migrantes nariñenses en Candelaria, comprendidos a partir de sus propios relatos, se consolidó como el objeto de estudio de esta investigación, proponiendo como unidad de análisis a quince sujetos provenientes de Nariño, asentados en Candelaria, Valle del Cauca, desde hace más de 40 años; y como corpus para la observación, los relatos de estos sujetos y las observaciones realizadas en campo desde el año 2012, con el fin de responder ¿de qué manera la colonia nariñense, asentada en Candelaria, Valle del Cauca, construye su propio relato en torno a su proceso migratorio y a sus procesos identitarios? propuesta como pregunta orientadora de la investigación.

De esta manera, en el presente trabajo doctoral se plantea una búsqueda investigativa arraigada en la perspectiva sociocultural de la comunicación como una apuesta poco explorada en el estudio de los flujos migratorios, en la cual, la configuración y reconfiguración de las identidades tiene un lugar susceptible de ser estudiado, porque propone, por un lado, un abordaje a los relatos y experiencias de los sujetos migrantes, sus estrategias de identificación, sus orígenes y la narrativa que han construido de sí mismos. Por otro lado, se considera la identidad cultural como un proceso de construcción inacabado e inacabable, cambiante y siempre en relación con los contextos y la interacción que se da en tiempo y espacio; todo ello aplicado al caso específico de la colonia nariñense en el municipio de Candelaria, Valle del Cauca, Colombia, a partir de una estrategia de investigación cualitativa.

En este entendido, el lector podrá encontrar una investigación doctoral con una estructura que propone inicialmente los antecedentes de la cuestión focalizados en la relación establecida entre la construcción de identidades y los procesos migratorios. Precisamente la migración interna se considera como punto de mayor interés, en tanto pone la mirada en los abordajes metodológicos que han sido recurrentes en esta relación categorial en la que se enmarca la investigación, con el fin de proponer un punto de cierre de dichos antecedentes desde el aporte que ha hecho la comunicación en este escenario de indagación. 
Por otra parte, se plantea un referente contextual que busca aportarle a la consolidación del objeto de estudio, ubicando el fenómeno de la migración en Colombia y el papel histórico que han jugado departamentos como Nariño y el Valle del Cauca, como expulsores y receptores de migrantes, respectivamente.

En su tercera parte, la investigación propone las apuestas teóricas sobre las que se fundamenta la búsqueda, presentando el entramado teórico y conceptual que da luz a la propuesta, desde el cual se asumen los flujos migratorios como categoría contingente de las migraciones internas, el concepto de nación en relación con estas migraciones, la desigualdad, los procesos de urbanización, las concentraciones de capital y la globalización, a propósito del fenómeno migratorio. Todo esto para presentar, en último término, el desarrollo de la identidad como categoría de análisis, abordada desde el marco de los estudios culturales y acotada a las especificidades de la identidad cultural vista desde los procesos migratorios de sujetos nariñenses en el municipio de Candelaria, Valle del Cauca. Colombia.

En el fragmento final de este apartado teórico, el lector puede encontrar el desarrollo de las categorías que posteriormente guían el análisis de la evidencia empírica recolectada y que concretan, igualmente, el diseño metodológico de la investigación en una matriz de operacionalización que desde el diseño metodológico en adelante, se convierte en el mapa de navegación, siempre que guía el levantamiento de la evidencia empírica y su análisis e interpretación, a la luz de dos categorías de análisis de nivel intermedio: los relatos de identidad cultural y los relatos de migración; cada una de ellas, nutrida por algunas otras categorías de nivel micro que acompañan el tránsito de lo teórico a lo práctico en la propuesta que se presenta.

El diseño metodológico tiene lugar en la cuarta parte del documento. En él, se declara el método en el que reposa la investigación y la ruta seguida para el levantamiento de la evidencia empírica a partir de la aplicación de técnicas de investigación, tales como la entrevista biográfica, la entrevista focalizada, los grupos de discusión, la observación como herramienta fundamental del método etnográfico y la revisión documental, asumiendo como documentos las narraciones personales, cartas, 
diarios, álbumes familiares, biografías y en general, documentos personales vitales para los sujetos-protagonistas de las historias.

En la última parte del capítulo de apuestas metodológicas, se le presenta al lector la estrategia seguida para el análisis y la interpretación de los datos recogidos a lo largo del trabajo de campo, dando cuenta de la información que fue procesada en el marco de la investigación y detallando la matriz de análisis argumental que fue diligenciada con el objetivo de identificar los argumentos que fueron la base fundamental de la conformación ideológica.

A partir de este capítulo, se despliega la presentación de los resultados de la investigación siguiendo igualmente la estructura definida desde la matriz de operacionalización de categorías, que lleva al lector en la fase inicial, al encuentro de los resultados en el esquema de mapas ideológicos o gramática de argumento, en los que se trabajan dos niveles, a saber: el primero asociado a las expresiones de sentido de los sujetos migrantes y de la sociedad receptora y el segundo, en el que se integran lo macro, lo meso y lo específico como ideologemas, en el intento de, por un lado, develar aquellas expresiones de mayor sentido para los entrevistados, por otro lado, organizar la evidencia empírica de acuerdo con su predominio en el discurso y con las relaciones tejidas entre las diferentes expresiones.

Posterior a los mapas, se muestra un análisis basado en estos, desde el cual se identifican los argumentos que son la base fundamental de la conformación ideológica en el escenario dibujado de la configuración identitaria del nariñense, que en el marco de la migración económica a Candelaria, municipio del Valle del Cauca en Colombia, tiene como antecedente histórico el desarrollo de la industria azucarera, por ser un momento en el que la producción agroindustrial demandaba mano de obra tecnificada y barata para el corte de caña de azúcar.

Asimismo, este proceso de la configuración identitaria del nariñense en Candelaria, coincide con la situación económica precaria que atravesaba Nariño hacia la segunda mitad del siglo XX por la falta de dinero circulante y por el aislamiento 
geográfico en el que se encontraba dicho departamento. El asunto aquí, es que ambos antecedentes desencadenan una migración que va a tener consecuencias sociales y culturales que se expanden en Candelaria a través de los procesos de configuración de identidad de los nariñenses; procesos que comienzan a emerger en el trabajo, es decir, en el modo en que estos sujetos migrantes producen y reproducen su vida material, al mismo tiempo que sus tradiciones, prácticas, ideas y costumbres dentro de la sociedad receptora.

De esta manera, la interpretación que se sustenta implica concebir el ethos del trabajo -el modo en que los nariñenses producen su vida material-, no solo como satisfacción de necesidades vitales dentro de la sociedad receptora, sino también como escenario en el que emergen modos de vida que hacen de los nariñenses sujetos migrantes trabajadores, tenaces, solidarios, astutos, fervorosos y arraigados a su región, entre otros rasgos culturales que se reproducen en Candelaria como producto de conflictos y negociaciones identitarias.

Así pues, se presenta una investigación doctoral que conjuga tanto intereses académicos como personales, en un escenario construido y enriquecido cada día por esas historias de los migrantes nariñenses en Candelaria que fueron armando el entramado de lo que aquí se comparte y allanaron un camino que hoy, únicamente cierra una etapa académica pero que en sí mismo, abre muchas otras posibilidades de comprensión y aprehensión.

\section{Título de la tesis}

Identidades en fronteras. Una configuración en movimiento 


\section{Tema}

Configuración de identidades culturales en procesos migratorios desde una perspectiva sociocultural. Trayectos biográficos de sujetos migrantes nariñenses asentados desde los años 60 en Candelaria, Valle del Cauca. Colombia.

\section{CAPÍTULO II. ANTECEDENTES DE LA CUESTIÓN}

\section{Estado del Arte}

\subsection{La construcción de identidades en el contexto de la migración interna en} Colombia. Un rastreo de perspectivas y tendencias.

Inicialmente se definieron las palabras clave que orientarían una búsqueda bibliográfica coherente con los dos ejes principales de la investigación: migración e identidad. En torno a estos conceptos se pensaron motores de búsqueda que no restringieran los hallazgos y que por el contrario, proporcionaran un rastreo que permitiera incluir la mayor parte de los estudios y documentos científicos realizados en Colombia sobre los ejes orientadores de la investigación. Así se definió que procesos migratorios, flujos migratorios, procesos identitarios, construcción de identidades, configuración de identidades, sujetos migrantes, identidad y migración, migración interna Colombia, identidad y migración Colombia, fueran los motores que guiaran la búsqueda en los catálogos bibliográficos de las principales universidades colombianas y en bases de datos académicas interdisciplinares y de ciencias sociales ${ }^{1}$.

Posterior a la consolidación de este primer rastreo bibliográfico, en una matriz que recogió la información de cada registro dando cuenta del título de cada publicación, autor, año de publicación, tipo de publicación, fuente, resumen y observaciones, se procedió a generar una codificación cromática que orientó la revisión de fichas

\footnotetext{
${ }^{1}$ Fueron consultados los catálogos bibliográficos de la Universidad Nacional de Colombia, Universidad de Antioquia, Universidad del Valle, Universidad del Cauca, Universidad Javeriana de Bogotá y de Cali, Universidad ICESI, Universidad de los Andes, Universidad de Nariño, Universidad de Caldas y Universidad de Manizales. Sin embargo, los hallazgos en las Universidades de ciudades pequeñas coincidieron con el rastreo hecho en las bibliotecas de las Universidades más grandes.

Las bases de datos consultadas fueron: Biblioteca digital CLACSO, Academic Search Premier, Proquest, Fuente Académica, EBSCO, Redalyc y JSTOR.
} 
bibliográficas levantadas y la consulta de los documentos encontrados, a nutrir los ejes que consolidaron el informe del estado de la cuestión que se presenta a continuación:

1. El estudio de la migración interna en Colombia.

2. Migración e identidad en Colombia.

3. Migración e identidad internacional.

4. Reflexiones metodológicas sobre el abordaje de la migración en relación a la identidad.

5. Aporte de la comunicación al abordaje de la relación migración-identidad.

Este rastreo y consolidación de la búsqueda de antecedentes, alimentó de manera directa la fase en la que se desarrolló la perspectiva teórica que enmarca la tesis doctoral, considerando que el estado de la cuestión aportó en términos de tendencias teóricas y metodológicas en el abordaje del estudio, perspectivas emergentes y perspectivas no tan exploradas que se fueron configurando como aristas posibles de desarrollo.

En la búsqueda se identificaron diferentes tipos de documentos que abordan el estudio de la migración interna en el país. Entre estos se destaca la amplia producción de trabajos de pregrado, principalmente de carreras como antropología y sociología, los cuales realizan estudios de caso sobre poblaciones migrantes al interior del territorio colombiano. En cuanto a los libros, se encontraron resultados de tesis doctorales principalmente de economía y demografía, al igual que textos que desde los años setenta incursionan en el análisis cuantitativo sobre el tema.

Si bien la búsqueda cubrió una buena parte de las bibliotecas de las universidades con mayor reconocimiento en el país, es de señalar que sobre el tema, se encontró una mayor producción académica en la Universidad Nacional de Colombia, seguida por las universidades públicas regionales como la Universidad del Valle y la Universidad de Antioquia. Lo anterior coincide con que son las universidades de las regiones que históricamente han sido receptoras de poblaciones migratorias, lo que genera en estos centros educativos un interés desde los estudios de pregrado hasta posgrado, por el análisis de las poblaciones migrantes en ciudades como Cali, Medellín y Bogotá. Sin embargo, a pesar de ser un tema ampliamente abordado desde diversas disciplinas en 
Colombia, no se identifican textos que a modo de balance o compilación, den cuenta de la producción académica sobre el tema en el país.

También es evidente en el rastreo realizado, que desde los años setenta, se encuentra una producción sobre el tema de la migración interna en Colombia, principalmente sobre los flujos migratorios atraídos por el mercado laboral, fenómeno estudiado ampliamente en sus inicios por la economía, la que se encuentra como la principal disciplina en estudiar a partir de datos estadísticos estos flujos migratorios producidos por la expansión de industrias como la petrolera y la azucarera en determinadas zonas del país.

Sin embargo, aunque la mirada económica haya sido hegemónica en el abordaje inicial del fenómeno, es preciso mencionar que en Colombia los estudios sobre migración, vincularon de manera temprana categorías de análisis de corte más demográfico; por un lado, debido a la exploración de los datos censales, que para ese periodo empezaron a generar interés. Por otro lado, debido a las implicaciones económicas y laborales que trajo consigo la transición demográfica que vivió el país a mitad del siglo XX, con lo cual, a partir de las transformaciones en el campo y la ciudad, surgieron intereses por cuestiones como las expectativas y subjetividades de esos sujetos que empezaron a transitar en ese nuevo escenario en el que las grandes ciudades atrapaban sus intereses y esperanzas.

Es importante señalar que en el marco de estos estudios económicos -que hacen uso de datos censales-, se empezó a indagar o a cuestionar de manera preliminar sobre las implicaciones culturales de los flujos migratorios y sobre las características culturales de los sujetos, como causales de la migración hacia determinados focos urbanos.

Es en este escenario en donde alrededor de los años noventa, incursionan la sociología y la antropología en el estudio del objeto, esto relacionado con la complejización del fenómeno de movilidad humana en el país. De esta forma, se observa una transición del estudio de la migración laboral, con efectos sobre la economía y el Producto Interno Bruto (PIB), a estudios con una perspectiva más culturalista que ponen 
la mirada en el fenómeno de la migración relacionándolo con otros fenómenos, tales como el narcotráfico y el conflicto armado.

En este escenario, algunas de las disciplinas de las ciencias sociales se interesaron por las consecuencias que para la movilidad de la población en el territorio nacional, tenían estos procesos de desplazamiento forzado y de violencia política. Categorías que fueron emergiendo inicialmente en el discurso y análisis académico sobre los fenómenos

migratorios y que posteriormente fueron permeando escenarios de la política pública y de la vida cotidiana de la población colombiana.

En el marco de estas consideraciones generales, se plantea aquí un informe de antecedentes que posiciona el estado referido a la cuestión de los procesos de configuración y reconfiguración de identidades en poblaciones migrantes. Focalizando el interés en las migraciones internas, debido a la búsqueda particular de la investigación que le da lugar a este informe.

\subsection{Apuntes sobre el estudio de la migración interna en Colombia.}

La migración interna en Colombia ha sido un tema explorado desde diversas disciplinas a la vez que como fenómeno social se ha ido complejizando en sus características demográficas, políticas y recientemente en las implicaciones que ha traído el conflicto armado en la movilización de poblaciones alrededor de todo el territorio nacional. Son pocos los ejercicios académicos que han intentado dar cuenta de la bibliografía que sobre el tema se ha escrito en el país, como mencionan Guataquí y Roa (2010), cada uno de los censos de población desarrollados en el país ha generado una oleada importante de publicaciones académicas sobre el tema, pero si bien hay una vasta bibliografía, no hay trabajos dedicados a recopilar los resultados de estos estudios a modo de estado del arte sobre la cuestión.

Desde mitad del siglo XX se encuentran estudios sobre los movimientos migratorios en algunos departamentos del país. Uno de los casos más estudiados en Colombia ha sido el fenómeno de la colonización antioqueña con el clásico estudio de James Parsons (1949) (como se citó en Guataquí y Roa, 2010), precursor de una serie de análisis geográficos y antropológicos sobre el proceso migratorio. Los estudios iniciales 
sobre migración haciendo uso de datos demográficos datan de los años sesenta, con el estudio pionero de Elizaga (López, 1968) (como se citó en Guataquí y Roa, 2010) quien usó los datos de los censos de 1938 y 1951 y analizó movimientos interdepartamentales y rural-urbanos (Guataquí y Roa 2010).

Diversos autores resaltan como estudio pionero de la migración en Colombia la obra de Álvaro López Toro y Ramiro Cardona, principalmente sus estudios: "Migración y Cambio Social en Antioquia durante el siglo diecinueve” López (1970) y "Análisis demográfico de los censos colombianos, 1951 y 1964” López (1968). Estos estudios de migración realizados desde los años treinta a sesenta se enfocaban en el patrón ruralurbano, concentrándose en el crecimiento demográfico, la industrialización y la dinámica de regiones como Atlántico, Bogotá, Valle y Antioquia. Por sus enfoques económicos y demográficos, hacían un importante uso de los datos de los censos de población, cada vez más rigurosos en la captación de datos referentes al fenómeno migratorio.

Entre otros estudios pioneros que se destacan desde la perspectiva económica y demográfica se encuentra el de Fierro (1973) que estudia la selectividad de los migrantes e indica que la migración rural-urbana obedeció a la desigualdad de oportunidades entre el campo y la ciudad y contribuyó al crecimiento de un sector marginal en las zonas urbanas. Por otro lado, Shultz (1971) resalta la hipótesis de la violencia y la educación como el factor determinante de la migración, y Fields (1980) analiza características de los migrantes y la hipótesis de ingreso esperado de Harris y Todaro (1970), identificando que un alto nivel educativo determina la decisión de migrar al igual que otras variables económicas (Guataquí y Roa 2010).

En su artículo, el economista Harold Enrique Banguero (1985), describe las características de los procesos migratorios internos en el país a partir de los trabajos que hasta esa fecha se elaboraron sobre el tema. A partir de estos trabajos identifica las características de la población que migra, la dirección geográfica de las migraciones, las causas de la migración y el impacto socioeconómico y cultural de este fenómeno en el país. El marco general de su indagación sobre el proceso migratorio colombiano es el proceso acelerado de concentración de población que se desarrolló en el país a mediados 
del siglo XX. El autor introduce este fenómeno mostrando el cambio del porcentaje de población urbana: en 1938 el 32\% de población estaba ubicada en zonas urbanas, en 1951 el $38.9 \%$, en 1964 el $52.4 \%$ y en 1973 el 63\%. Entre otros datos que presenta, encuentra que los estudiosos de la migración han identificado que la tasa de migración campociudad es baja en el periodo 1938-1951 (1.2\% anual), es alta entre 1951 y 1964 (2.3\% anual), y llega a su punto más alto entre 1964 y 1973 (3.2\% anual).

Como se observa en la revisión de estos textos pioneros, los estudios de los años setenta y ochenta, realizaban análisis principalmente estadísticos con base en los datos de los censos de población, desde la economía y la demografía, con un interés por caracterizar a la población migrante, todo lo anterior enfocado en el cambio demográfico que vivía el país a mediados del siglo XX. Un punto interesante en estos trabajos que si bien parten de una mirada económica del fenómeno, es que logran vincular el fenómeno migratorio de los años sesenta no solo con los cambios en la demanda laboral y las nuevas industrias que se ubicaron en determinadas regiones del país, sino también con los cambios demográficos y sociales que transformaron el campo y la ciudad, y que trajeron como consecuencia un cambio en las expectativas y elecciones de vida de quienes serían los sujetos migrantes que llegaron a ciudades como Cali y sus alrededores ${ }^{2}$.

Estos estudios basados en los censos de población han planteado diferentes reflexiones metodológicas sobre los datos obtenidos que permiten analizar el fenómeno migratorio. En el caso colombiano, la pregunta sobre el lugar de nacimiento se incluyó a partir de los censos de 1938 y 1951, en 1973 se incluyen preguntas sobre migración (a partir de las variables lugar de nacimiento y residencia habitual), sin embargo, un principal impedimento para el análisis estadístico de la migración ha sido la carencia de

\footnotetext{
${ }^{2}$ Entre otros trabajos encontrados que fueron publicados en los años setenta y ochenta se encuentran: Cardona Gutiérrez, Ramiro (1970). Migración y desarrollo urbano en Colombia. Asociación Colombiana de Facultades de Medicina, Division de Estudios de población; Fierro, Marco (1973). Algunos problemas relacionados con la migración interna en Colombia. Universidad de los Andes, Facultad de Economía, Centro de Estudios sobre Desarrollo Económico; Giraldo Samper, Diego (1976). Migración interna y salud en Colombia. Asociación Colombiana de Facultades de Medicina; Urrea Giraldo, Fernando (1976). Mercados de trabajo y migraciones en la explotación cafetera. Bogotá: Ministerio de Trabajo y Seguridad Social, SENALDE; Torales, Ponciano (1979). La dinámica interna de los movimientos migratorios en Colombia. Ministerio de Trabajo y Seguridad Social, SENALDE.
} 
datos comparables y confiables así como la poca visibilización de los estudios sobre migración realizados a partir de los datos censales (Guataquí y Roa 2010).

Para los censos 1993 y 2005 se intentó precisar la información sobre el perfil de los migrantes con la inclusión de nuevas preguntas que permitieran hacer la categorización de migrantes de corto y largo plazo, al igual que se ha indagado a partir del criterio cronológico de la experiencia más reciente de migración. Se podría decir que ha habido una constante indagación alrededor de las características de los migrantes, una preocupación por quiénes migran y las implicaciones que el proceso tiene en el desarrollo de las ciudades y en general la estructura urbana del país.

Dentro del rastreo, se evidencia una nueva oleada de estudios sobre el fenómeno que surgió con los trabajos que a partir de finales de los noventa basaron sus análisis en los datos del censo de 1993 como Galvis (2002), Murad Rivera (2003), Espinosa (2003) y Martínez (2006).

Samuel Jaramillo, economista y doctor en urbanismo, en su artículo "Migraciones e interacción regional en Colombia, 1973-1993" Jaramillo (1999), se concentra no sólo en la dimensión propiamente demográfica de la migración sino también en su sentido de interacción socioespacial. Realiza un análisis de la información censal de 1973 y 1993 sobre migración con el fin de identificar los principales flujos migratorios entre las regiones y departamentos del país. Propone un abordaje en el marco de los estudios socioespaciales, resaltando que en los estudios colombianos sobre la integración del territorio se ha identificado que a pesar de una unidad política formal, el territorio colombiano ha estado fragmentado en los diversos periodos de su historia.

Lo anterior según el autor, se ha evidenciado a través de la diversidad cultural presente en las grandes regiones, las cuales presentan diferentes perfiles étnicos, políticos, culturales, entre otros. Esta fragmentación territorial no condujo al desarrollo de una red urbana con un solo núcleo sino con cuatro aglomeraciones urbanas, cada una correspondiente a una región del país como lo mencionaron diferentes autores desde los años setenta. 
El autor presenta una breve discusión sobre las divisiones territoriales que se han considerado en los estudios socioespaciales en Colombia, en este sentido, es interesante observar cómo se privilegia una regionalización sociocultural, resaltando que las principales segmentaciones territoriales si bien han estado ligadas a los desarrollos urbanos, económicos y productivos, han tenido un fuerte componente cultural de las poblaciones residentes en las diferentes regiones del país. El tema de esta regionalización cultural se vincula con el tema de las diversidades culturales de las regiones y departamentos, y por este lado, además de los estudios de los flujos migratorios entre estas regiones, nacen las preguntan alrededor de las implicaciones culturales que tiene para los migrantes y su territorio de llegada, esta movilidad interregional en el país.

En el marco de las diferencias regionales que han estado vinculadas con los flujos migratorios, un estudio pionero en mostrar que las migraciones dependen de los atributos de las regiones de origen y destino es el de Galvis (2002) Determinantes de la migración interdepartamental en Colombia, 1988-1993. Este autor encuentra que más del 50\% de la migración ocurrida entre 1988 y 1993 se dirigió hacia Bogotá, Cundinamarca, Valle, Antioquia y Atlántico. Proponiendo que además de las variables económicas, existen variables como la ubicación espacial relativa de los entes territoriales que afectan también la movilidad de la población.

Teniendo en cuenta el anterior estudio, se señala que en economía regional este elemento (ubicación espacial) es de gran importancia por cuanto los atributos de los distintos puntos geográficos son un punto clave para el estudio de la distribución espacial de la población y de la actividad económica. Adicionalmente a la distancia recorrida, la población tiene en cuenta el sentido del traslado. Es decir que se considera la distancia que se debe recorrer al emigrar y que las personas prefieren desplazarse hacia sitios centrales. De ahí que sea Bogotá un destino bastante atractivo dentro de los posibles que considera un emigrante en Colombia.

Por otra parte, también hay que mencionar en este rastreo uno de los trabajos pioneros recientes, que hace un uso exhaustivo de los datos censales de 1973 y 1993, es el trabajo Las migraciones internas en Colombia: análisis territorial y demográfico según los censos de 1973 y 1993 del economista Ciro Martínez (2006), resultado de su 
tesis doctoral realizada en el año 2001. El autor se concentra en las tendencias espaciales de la migración y las características demográficas de los migrantes, buscando llenar lo que él denomina los vacíos de la investigación sobre la migración en Colombia, rescatando los censos de población como una fuente válida y vigente para explorar el fenómeno migratorio en el país.

Este autor identifica que si bien la migración ha sido un fenómeno explorado académicamente mediante el uso de datos cuantitativos provenientes de los censos que desde 1973 permiten identificar el lugar de nacimiento versus el lugar de residencia de las personas, la migración es uno de los aspectos demográficos con mayores vacíos analíticos y de política pública en el país, mencionando además que "ni siquiera en las grandes ciudades, que continúan enfrentando la presión de una fuerte inmigración y otros tipos de movilidad poblacional, se han desarrollado las bases conceptuales y los instrumentos de planificación territorial que incluyan, de manera formal, el impacto que la movilidad tiene sobre sus poblaciones reales" (Martínez, 2006, p. 22).

Algunos hallazgos generales de este autor residen en una característica de la migración en Colombia que consiste en la concentración de los flujos de población en los centros industriales tradicionales: Bogotá, Atlántico y Valle. Así mismo, sostiene que los migrantes colombianos tienden a moverse en entornos cercanos, generalmente entre departamentos limítrofes, lo que refleja según el autor el peso de factores culturales, las deficiencias de comunicación y una alta segmentación regional de los mercados de bienes y factores de producción. El autor resalta como una de las rutas migratorias la que se dirige hacia el Valle del Cauca desde los departamentos limítrofes como Cauca, Risaralda, Quindío Tolima y Chocó, existiendo además fuertes lazos históricos y culturales con Nariño, Caldas y Huila, siendo estos departamentos el área de influencia del Valle. Todos estos departamentos presentan flujos relevantes hacia el Valle, aproximadamente el $90 \%$ de los inmigrantes totales del Valle tanto en 1973 como en 1993.

Los últimos estudios sobre la migración en Colombia han estado basados en los resultados del censo realizado en el año 2005. Entre estos se encuentra el artículo de Silva y González (2009), que da aproximaciones interesantes sobre los flujos migratorios en el 
siglo XX y XXI, y sus características demográficas como los grupos etarios de mayor migración en cada periodo, la participación de las mujeres en los flujos migratorios ruralurbanos y las características de los departamentos de atracción de migrantes.

Se destaca en este estudio el análisis de la relación de la migración con la búsqueda del mejoramiento de condiciones de vida al analizar que los principales focos de recepción han sido los centros urbanos con mayor número de población y PIB per cápita. Las autoras presentan una vasta revisión bibliográfica sobre los estudios de migración interna en Colombia, destacando como ya se mencionó anteriormente, la fuerte exploración que se ha realizado desde el análisis de los datos censales. Identifican que los estudios sobre la migración resaltan generalmente tres fases migratorias en el país:

1. de zonas rurales a zonas rurales.

2. de zonas rurales a zonas urbanas de desarrollo intermedio (1951-1973).

3. de zonas urbanas a zonas urbanas (1974-2005).

Finalmente, como parte de los estudios postcensales publicados por el DANE, (Guataquí y Roa, 2010), realizan una caracterización de la migración interna en Colombia a partir de la información recogida en el censo de 2005. Entre sus conclusiones comparativas con otros censos, destacan que los picos más elevados del proceso de migración rural-urbana se dieron en 1950 y 1960, y como en la mayoría de trabajos sobre el tema se resalta que el desarrollo de Colombia no estuvo concentrado en la migración hacia una gran metrópoli, por lo que migrantes no se concentran hacia una sola ciudad sino según características de las zonas de atracción. Entre las características históricas de los migrantes identifican la relevancia de migrantes femeninas y la influencia de un mayor nivel educativo como determinante de la migración.

Como resalta Martínez (2006), el marco histórico de la migración en Colombia se caracteriza por el proceso paulatino de despoblamiento de las áreas rurales iniciado desde mitad de siglo XX e impulsado por el contexto de violencia en diferentes regiones del país y las políticas de desarrollo económico que potenciaron la tendencia a la urbanización. Se presenta en la década de 1960 y primeros años de 1970 el mayor proceso migratorio, el cual tuvo como principal característica el paso de la población 
rural hacia zonas urbanas. El autor menciona que este proceso, sin precedentes en el país, es el que ha sido principalmente documentado en los estudios sobre la migración, los cuales resaltan las condiciones de empleo, vivienda y educación que favorecieron la movilidad de la población hacia los centros urbanos.

En la década siguiente, 1980, esta movilidad de población no pudo ser absorbida por las ciudades principales, como menciona el autor, "las administraciones de estas ciudades no estaban en capacidad de proporcionar servicios públicos y empleo a la creciente población que se ubicaba frecuentemente en conglomerados de crecimiento explosivo en zonas por fuera del perímetro legal” (Martínez, 2006, p. 32). En esta década el crecimiento de la población se desplazó hacia centros intermedios alrededor de las grandes ciudades.

En la segunda mitad de 1980 e inicios de 1990, una nueva situación de conflicto social en el país genera un nuevo tipo de desplazamientos, los desplazamientos forzados a raíz de la profundización del conflicto armado con grupos armados al margen de la ley y la guerra de los carteles del narcotráfico. El fenómeno del desplazamiento genera una nueva movilidad de población, esta vez en condiciones precarias ya no en busca de educación y trabajo sino de refugio ante los hechos violentos que afectaron mayoritariamente las zonas rurales (Martínez, 2006).

A medida que el fenómeno migratorio como fenómeno social se fue complejizando, sumando elementos del contexto político y social del país, el recrudecimiento del conflicto armado en los años noventa entre otras variables, los análisis sociológicos, históricos y antropológicos se sumaron al análisis de la movilidad humana en el territorio nacional para intentar comprender nuevos procesos como el desplazamiento forzado, el crecimiento urbano que vino acompañado del surgimiento de la segregación espacial en ciudades como Cali y Medellín, y la atracción de mano de obra por la expansión de la industria petrolera al oriente del país y de la caña, en la región occidental. En este sentido, se suman al estudio de los procesos migratorios los análisis antropológicos del territorio y sociológicos de las condiciones de vida y consecuencias del conflicto armado en la configuración del territorio nacional. 
En este marco, en 1999, a raíz de la creación del Programa Universitario de Estudios sobre Movilidad Humana del Centro de Estudios Sociales -CES- de la Universidad Nacional, se publica la compilación de trabajos presentados en el coloquio Desplazados, migraciones internas y reestructuraciones territoriales, editado por Fernando Cubides y Camilo Domínguez (1999). Esta compilación de ponencias presenta un amplio panorama del fenómeno, planteando el problema del desplazamiento y la migración desde diferentes escenarios. Por un lado, el desplazamiento a causa del conflicto armado, uno de los fenómenos mayormente contemplados en los estudios sobre los flujos de migración interna en el país. Por otro lado, plantean el fenómeno de la migración a causa de la expansión petrolera y los reordenamientos territoriales regionales a causa de la demanda de fuerza laboral, principalmente en la Orinoquia y Amazonia. Por último, introducen el contexto urbano, en el análisis de las consecuencias que en las ciudades colombianas produjeron los flujos migratorios internos, donde se destaca el caso de Cali como principal foco receptor de la migración del pacífico colombiano. En esta compilación se destaca precisamente el análisis del fenómeno de la migración y el desplazamiento en diferentes escenarios: urbanos, rurales y laborales.

En esta compilación, la socióloga Luz Gabriela Arango en los comentarios finales del libro identifica que una de las discusiones de trasfondo planteada en las ponencias recopiladas, se trata de la categorización y diferenciación entre todos los posibles tipos de migrante, diferenciándose el migrante económico, el desplazado interno y el refugiado. Particularmente en la ponencia de Donny Meertens "Desplazamiento forzado y género: trayectorias y estrategias de reconstrucción vital", se discuten las diferencias en las implicaciones posteriores que tiene para el desplazado cuando éste ha sido desalojado de manera forzada a causa de la violencia, a cuando ha sido una decisión voluntaria y como parte de un proyecto de vida como es el caso de los migrantes económicos. El desplazado por el conflicto armado tiene una condición profunda de vulnerabilidad a falta de redes sociales y familiares, solvencia económica y posibilidad de reconstrucción de su trayectoria vital.

La compilación intenta reunir estudios que analizan no solo las dinámicas de desplazamiento a causa del conflicto armado sino también el fenómeno de las 
migraciones internas producidas por el auge petrolero en la región de la Orinoquia, los procesos de colonización relacionados con los cultivos ilícitos, la defensa de territorios ancestrales, y las problemáticas que acarrean los flujos de poblaciones hacia las áreas urbanas, contemplando en estos fenómenos la centralidad de las relaciones sociales y familiares de las poblaciones que se movilizan en el territorio.

Es interesante observar cómo en los años noventa empiezan a incluirse en el análisis de las migraciones la categoría de desplazamiento forzado y la necesidad de categorización y definición de las modalidades migratorias presentadas al interior del país. En esta compilación se encuentra una confluencia de miradas disciplinares sobre los fenómenos migratorios y sus causas, donde se vuelve y se plantea como en otros trabajos, la reflexión sobre la dinámica diferenciada de las regiones, la influencia del conflicto armado pero también de las dinámicas laborales que han ido reconfigurando los territorios y la movilidad de la población colombiana.

La más reciente publicación con estas características interdisciplinares sobre el tema de la migración y el desplazamiento en el país es la editada en 2006 por el antropólogo Gerardo Ardila, en el marco de la cátedra Manuel Ancízar, titulada: "Colombia: migraciones, transnacionalismos y desplazamiento" (Ardila, 2006). Este libro reúne estudios que investigan el fenómeno migratorio desde diversos escenarios, en este caso, desde la migración internacional, los antecedentes de la migración interna en las regiones, el caso del desplazamiento forzado y finalmente el análisis del fenómeno migratorio en territorios fronterizos.

En la compilación se destaca la migración como un fenómeno que ha llamado el amplio interés de los investigadores pero también de los gobiernos. Su análisis se fue ampliando en escenarios, actores, disciplinas, hasta que los científicos sociales colombianos como menciona Gerardo Ardila en la presentación de esta compilación, llegan a un acuerdo sobre el hecho de que las migraciones no implicaban tan solo un conjunto de relaciones de carácter económico, sino que significaban la puesta en marcha de cambios y transformaciones sociales y culturales, tanto en los lugares de origen como en los de tránsito y llegada. (Ardila, 2006, p.27) 
Razón por la cual tampoco se podía desligar el análisis de las migraciones internacionales del de las migraciones internas. En la segunda parte del texto, Fabio Zambrano en su artículo "El contexto histórico de la descentralización en Colombia" discute la composición regional del país, introduciendo las nociones de región, territorio e identidad que desde las ciencias sociales han intentado conceptualizar la idea de Colombia como un país de regiones. En este orden afirma que, si bien hay una definición geográfica de las regiones dada por sus características climáticas, entre otras,

(...) las regiones no son inmutables, sino que están sujetas a profundos procesos de composición y recomposición espaciales, económicos, políticos y especialmente culturales. Esto es el resultado de la progresiva y permanente configuración de la nación de la integración económica y cultural que se ha producido desde hace dos siglos. (Ardila, 2006, p. 270)

De esta manera, se podría decir que en las regiones como parte de estos procesos de recomposición, los migrantes inter e intra regionales han construido esa diversidad cultural regional y recompuesto los territorios regionales, reflexión que es válida contemplar en el análisis de un departamento como el Valle del Cauca y su papel como foco receptor de poblaciones, lo que hipotéticamente podría llevar a pensarlo como un departamento construido y reconstruido cultural y económicamente por diversos procesos en el siglo XX.

\subsection{La relación migración - identidad en Colombia. Estrategias de identificación y construcción de sentidos frente a los nuevos espacios.}

En los hallazgos que se hicieron, puede inferirse que el estudio de la migración en el país ha ido configurando un objeto de estudio en congruencia con la construcción que este ha tenido en estudios internacionales, como se verá más adelante. Así, se evidencia el interés por poner en relación y por medir el impacto de los movimientos migratorios en el crecimiento urbano de algunas ciudades colombianas, en el desarrollo industrial de algunas de sus regiones y en el mercado laboral y sus diversas variaciones, tanto en municipios expulsores como receptores de migrantes. 
En líneas anteriores se mencionó que en el contexto colombiano se han identificado diferentes rutas de acuerdo a las épocas. En consecuencia, se encuentra referencia de migración rural-rural, rural-urbana (de desarrollo intermedio), sobre todo entre la década del 80 al 2000 debido a la intensificación del conflicto armado en el país; urbana-urbana e incluso urbana-rural. Flujos motivados en su mayoría por el conflicto armado, por la búsqueda de oportunidades, por la concentración de la tierra y por el desempleo en algunas regiones colombianas.

Por lo tanto, es importante señalar que aunque en los estudios hallados sobre migración en Colombia, las relaciones antes mencionadas son altamente visibles, emergen otros ejes de estudio recurrentes tales como la violencia social y/o política, que le han dado lugar a categorías de análisis contenidas en la migración, tales como el desplazamiento. Siendo esta relación (migración - desplazamiento o en otros casos, migración - conflicto armado) la que generó mayores registros en la búsqueda de estudios sobre migración en Colombia.

También, se encuentran numerosas investigaciones y documentos que relacionan la migración con las necesidades y demandas del mercado laboral y con las condiciones que el desarrollo industrial ha tenido en diferentes regiones del país, marcando de manera decidida en estos estudios, el abordaje de la economía regional como una de las categorías trabajadas con recurrencia, tal como se mencionó en el apartado dedicado a los estudios de la migración interna en Colombia.

En este escenario se encuentra un marcado interés por los flujos migratorios de algunas poblaciones específicas, siendo la migración boyacense, Tobasura (2003), Tobasura (2006), la migración indígena, Posso (2008), Vélez (2008) y la del Cauca, unas de las más documentadas. Señalando enfáticamente que la migración de población del Chocó y del Pacífico en general ha sido la más estudiada en el marco de sus movilidades, e incluso de la migración y la identidad afrocolombianas, como pudo encontrarse en algunos documentos.

Así pues, se da cuenta de trabajos como el de Jaramillo (2002) que aborda el parentesco y la memoria familiar entre migrantes de la Costa Pacífica en Cali, en una 
investigación de base etnográfica, con análisis de casos micro y reconstrucción de las trayectorias biográficas migratorias, en la que plantea una reflexión entorno a la organización familiar y presenta algunas estrategias de construcción de la identidad familiar en las que la extensión de los lazos a vecinos y amigos, le confiere a los procesos identitarios de los migrantes, una particularidad y un rasgo propio en el margen de las experiencias de movilidad.

En este sentido, el autor plantea dentro de los procesos de configuración de estas identidades familiares, la extensión de los lazos genealógicos a vecinos, amigos o paisanos que han estado presentes en las experiencias de movilidad y que hacen que,

los lazos que se tejen, aunque insertos en amplios vínculos de convivencia y solidaridad en barrios populares - por ejemplo los lazos de "estimación" que documenta Agier para Liberdade (Bahía, Brasil)-, tendrían también una clara instrumentalidad que incluso trascendería la idea de la red familiar y del hogar como los espacios solidarios por antonomasia y llevaría a que el migrante extienda y flexibilice el parentesco con vecinos y paisanos. (Jaramillo, 2002, p.43)

Señalando además que aunque el autor inicialmente no esboza un interés particular por plantear una reflexión de género en esta investigación, finaliza proponiendo un apartado sobre las mujeres como ejes de los saberes familiares dentro del contexto descrito y las describe con un rol protagónico en el mantenimiento y la transformación de la memoria familiar y en los procesos de mediación dentro de las redes y los espacios de la vida en la ciudad. Una arista de los estudios sobre movilidad (la feminización de la migración) explorada con reiterada frecuencia en el creciente abordaje de este objeto de estudio y en donde se encuentran otros trabajos tales como el de Posso (2008) y Olaya (2014) en el que la autora estudia los procesos de individuación y subjetivación de cinco mujeres, desde antes de abandonar sus territorios de origen en medio del conflicto armado, hasta que llegan a Cali.

De otro lado, se mencionó previamente que una de las líneas de estudio más abordada en este campo de indagación, es la que explora la migración de comunidades del Pacífico a diferentes regiones de Colombia y especialmente al Valle del Cauca. En 
este escenario, es inminente destacar los vastos aportes de Barbary, Urrea, Bruyneel y Ramírez (1999); Urrea, Arboleda, y Arias (1999); Urrea, Ramírez, y Viáfara (2001); Viáfara, Urrea, y Correa (2009) y de manera particular, Barbary y Urrea (2004). Referidos en la gran mayoría de documentos, investigaciones y estudios sobre la movilidad interna en Colombia, y específicamente sobre la movilidad de la población afrocolombiana. En estos aportes es de destacar que los autores trabajan de forma focalizada las identidades étnico-raciales en el marco de las diferentes movilidades que tienen lugar en la región Pacífico, en donde Cali es particularmente epicentro y principal receptor de estos flujos.

Dentro de estos trabajos rastreados se encuentra también el de Centeno (2012) que si bien no pone la mirada en la relación migración-identidad, sí hace una reflexión entorno a la consolidación de algunos barrios de la ciudad de Cali, a partir de los flujos migratorios. Planteando a propósito de la configuración de los barrios, algunas formas de apropiación barrial, de arraigos y tensiones, que para los efectos de la presente investigación, pueden ser leídos como parte del proceso de configuración de las identidades de estas poblaciones migrantes, en clave de estrategias de identificación y de construcción de sentidos frente a los nuevos espacios que empiezan a ser habitados. Al respecto, Centeno (2012) enfatiza que

si bien los desarrollos comunitarios en Charco Azul y Cinta Sardi (en términos de lograr el acceso a los servicios, la mejora de sus viviendas o la reivindicación de sus peticiones) no han estado mediados por un proceso democrático en un sentido literal, construir sus territorios como "invasores" les hace tener una historia compartida, una lucha colectiva, y el establecimiento de una red de relaciones, de lo cual han emergido procesos de significación territorial y, con ello, diversidad de sentidos y significados para quienes los vivieron. En ese sentido, estos lugares son sus lugares de referencia, de vida, de vivencialidad y de identidad, aunque ésta sea estigmatizada o estereotipada. (pp.79-80)

De esta manera, la autora pone sobre la mesa un punto sustancial en los procesos de configuración identitaria por parte de los migrantes y que tiene que ver con sus dinámicas de inserción a las ciudades, los municipios o los nuevos lugares donde llegan 
en medio, casi siempre, de tensiones, conflictos, luchas y negociaciones que trasversalizan sus procesos identitarios y que hace de estos procesos de inserción social, experiencias inicialmente particulares y posteriormente colectivas, de empoderamiento, en un escenario de construcción de sentidos y significados compartidos con respecto a los espacios en la ciudad.

En este marco, es posible afirmar que los estudios realizados en Colombia desde la relación migración e identidad, proponen de manera reiterada la configuración identitaria haciendo referencia a las identidades culturales de las poblaciones, a las identidades étnico-raciales y a las identidades regionales. Aportando estudios sobre poblaciones migrantes específicas que a través de sus flujos han contribuido sustancialmente a la configuración regional del país y proponiendo la construcción de las identidades en dos claves principalmente, la primera de ellas, la del mercado laboral, sus ofertas y demandas y la segunda, la de las construcciones y reconstrucciones de territorialidades.

\subsection{La relación migración - identidad en el contexto internacional. Construcciones sociales en las orillas de los territorios.}

Como se mencionaba anteriormente, la migración ha sido un fenómeno social abordado desde diversas aristas analíticas de las ciencias sociales, económicas y geográficas en diferentes momentos históricos, resaltándose la presencia continua de los fenómenos migratorios en todas las épocas y procesos humanos.

Como fenómeno humano, en los estudios de los procesos migratorios se ha resaltado la vinculación de la movilidad humana con procesos identitarios, conformación de naciones, imaginarios culturales y reconfiguraciones territoriales y culturales. Así como en el caso colombiano se han estudiado procesos migratorios de poblaciones específicas como los indígenas, afrodescendientes, antioqueños y boyacenses, a nivel de Latinoamérica diversos estudios han relacionado la categoría migración con las configuraciones de identidades individuales y colectivas en el análisis de diferentes fenómenos migratorios, resaltando los procesos culturales que se han construido en la 
población latinoamericana a partir de la movilidad entre la región y países norteamericanos y europeos.

Uno de los principales trayectos migratorios observados en las sociedades latinoamericanas ha sido el paso de lo rural a lo urbano, pero también migración ruralrural con la tecnificación del campo que atrajo olas migratorias en diferentes países de la región. La cuestión de lo rural en el caso latinoamericano es un tema abordado desde diferentes perspectivas económicas y sociológicas, desde el análisis de clase, étnico racial y laboral. La cuestión agraria es además uno de los temas más polémicos en términos de políticas estatales y la lucha de movimientos sociales como el obrero, el indígena y el campesino.

En el texto ¿Una nueva ruralidad en América Latina? (Pérez, et al., 2001) como resultado de diferentes encuentros de CLACSO, en particular sobre sociología rural, diferentes autores se concentran en una pregunta: ¿hay una nueva ruralidad en América Latina? Planteando una reflexión sobre la ruralidad latinoamericana, en la que resaltan el peso de lo rural en los procesos de consolidación de los Estados latinoamericanos y sus poblaciones. Identifican dos temas centrales de la actual ruralidad: los cambios en el trabajo rural y los movimientos sociales.

La ruralidad en América Latina ha planteado desde diferentes fenómenos la reflexión de la construcción identitaria de las poblaciones campesinas influenciadas por las dinámicas laborales, la llegada de la tecnificación de las agroindustrias y la reconfiguración de los territorios. Hay una importante movilidad migratoria entre países de la región, se destacan en las investigaciones los estudios de la comunidad argentina en Chile, los chilenos en argentina, bolivianos en argentina, entre otras movilidades. En estos estudios hay un interés central en la cuestión agraria de estos países, los cambios en los mercados laborales campesinos y las implicaciones culturales de estos procesos migratorios. En este orden de ideas, los trabajos de tipo más etnográfico proponen un análisis de las migraciones laborales desde un aspecto cultural, entendiendo la cultura como un factor movible, recontextualizado y reinterpretado por los actores según contextos socio históricos y espaciales. 
Los trabajos temporales en la industria de la fruta y la caña en diferentes zonas argentinas y chilenas han llamado la atención de los científicos sociales para explorar en sus estudios la relación entre procesos migratorios vinculados a lo laboral agroindustrial con las estrategias culturales que los migrantes emplean para el sostenimiento de sus redes sociales, sus sentidos del "aquí" y del "allá" cuando empiezan a incorporarse a las dinámicas laborales de esa nueva ruralidad latinoamericana.

En el caso chileno, las políticas agroexportadoras de finales de los noventa demandan una mano de obra estacionaria en la zona rural principalmente para la actividad frutera. Desde este escenario de la actividad frutera de exportación, Salas (1997) explora las dinámicas laborales de los trabajadores temporeros chilenos, resaltando el cambio en las modalidades laborales que trajo la modernización de este sector agrícola, en particular, la modalidad de trabajo temporero. A este propósito, el autor plantea que,

representan una nueva forma de inserción laboral, marcada por la modernización empresarial agraria, que se trata de trabajadores plenamente asalariados pero temporales, y que en general han perdido sus rasgos campesinos, imposibilitados de combinar el salario con el trabajo de la tierra. Esta situación pone de manifiesto cambios profundos que han tenido un efecto en la organización social, en las aspiraciones, en la identidad social y en la posibilidad de acción colectiva. (p. 277)

El autor realiza un análisis del impacto del cambio de las modalidades laborales de los trabajadores agrícolas chilenos en las dinámicas familiares, subjetivas e identitarias de estos antiguos campesinos y ahora mano de obra asalariada. Presenta un amplio contexto de la modernización de la agricultura chilena resaltando las implicaciones que la modernidad ha tenido en el trabajo rural latinoamericano. Como parte de la discusión sobre las transformaciones de lo rural y el cambio del campesinado hacia un sector asalariado del campo, el autor resalta cómo se entremezclan lo tradicional y lo moderno en las nuevas modalidades de trabajo rural, lo cual se puede observar en la reconversión económica y simbólica con que los migrantes campesinos adaptan sus saberes para vivir en la ciudad. De esta suerte, los trabajadores temporeros de su caso de estudio combinan 
antiguas forma de trabajo agrícola, por lo que se pueden observar diferentes etapas históricas de estos sujetos del agro: de campesinos a trabajadores asalariados.

A través de las entrevistas a trabajadores temporeros el autor explora en los relatos biográficos un "antes" y un "ahora", así como un "de aquí" y "de afuera". El antes hace referencia a un pasado en el que la organización campesina era fuerte como medio de socialización y consecución y trabajo de la tierra, un antes de la reforma agraria chilena, el "ahora" por el contrario, se presenta como un negativo, en el que no existe la posibilidad de organización. Espacialmente diferencian a los trabajadores "de aquí" y los "de afuera" existiendo opiniones negativas hacia los foráneos que migran a trabajar en la fruticultura.

El cambio traído por la modernidad en las modalidades de trabajo agrícola según el autor, ha generado unas pérdidas de identidad campesinas que se han trasmutado en identidades variadas, "la "cuestión campesina" también ha cambiado de carácter; ya no se trata de campesinos en proceso de proletarización, sino de la intensificación de las relaciones salariales en un mercado de trabajo temporal” (Salas ,1997, p. 294).

En el texto de las sociólogas Norma Giarracca, Karina Bidaseca y Daniela Mariotti (2001), “Trabajo, migraciones e identidades en tránsito: los zafreros en la actividad cañera tucumana", se resaltan las trayectorias de vida de los migrantes vista desde la influencia de los procesos macrosociales económicos y laborales, en este caso, en una provincia Argentina. En este artículo destacan que el trabajo rural en Argentina se caracterizó desde los inicios del siglo XX por su relación con procesos migratorios, principalmente europeos. Gracias al desarrollo de la industria azucarera, la provincia de Tucumán ha sido receptora de mano de obra vecina, pero a la vez ha sido expulsora de su propia población.

Las autoras se concentran en el fenómeno social que constituyen las migraciones estacionales generadas alrededor de la actividad cañera azucarera y a las consecuencias que tienen en la vida de los pueblos y en las vidas de sus protagonistas, prestando especial interés al impacto que estos traslados transitorios producen en la vida de familias e individuos: 
Las migraciones exponen al individuo a pasar por estados de "incertidumbres valorativas", en tanto pueden constituir o disolver vínculos horizontales que constituyen parte del capital cultural de las poblaciones rurales. Los pueblos pierden gran cantidad de hombres en los meses de las migraciones. Las mujeres, los niños y los ancianos reacomodan sus vidas: cumplen nuevas funciones, afrontan soledades y riesgos. (Giarracca, Bidaseca y Mariotti, 2001, p. 308)

Para indagar por las conformaciones familiares y su vinculación a los procesos laborales y migratorios, las autoras levantan la trayectoria de vida de una familia con la cual tuvieron contacto al inicio de la investigación. A modo de estudio de caso relatan la historia de la familia de Juan, un joven zafrero. Al respecto indican que:

Nuestra perspectiva de análisis -el paradigma orientado al actor Long (1992)- nos orienta a buscar las causas y consecuencias de la vida laboral o las migraciones no sólo en los niveles del mercado de trabajo o de la "población" de la provincia, sino también en el nivel de cómo se inscriben en la historia de cada familia y de cada sujeto. Como sostiene Bertaux (1995), toda historia familiar constituye un espejo donde se refracta la historia social de una sociedad, sus diferentes dimensiones. En esta familia, cada uno de sus integrantes son puntos nodales de una serie de circunstancias, discursos en el sentido de Laclau (1987), que atravesaron los mundos sociales de una de las provincias más complejas del país. (Giarracca, Bidaseca y Mariotti, 2001, p. 322)

Desde esta perspectiva identifican que los sujetos buscan migrar como una estrategia social, como recurso que facilita un cambio poniendo en juego la percepción de un espacio más amplio que el local y el desafío de enfrentar lo que no es familiar. Mencionan que es frecuente encontrar que la decisión de migrar está relacionada con otros, bien sea familiares o vecinos, con quienes se toma la decisión y se dan los primeros pasos:

Cuando el migrante tucumano se inserta en otro espacio, aunque sea rural como el de origen, se produce una interacción con la nueva situación que lo induce a 
buscar pautas de adaptación desde los elementos y dimensiones de su matriz cultural; produce una traducción de sentidos y no una simple adaptación. Asimismo incorpora nuevas elementos, prácticas y códigos del nuevo lugar. Se "lleva" a su lugar de origen experiencias y recursos simbólicos que lo diferenciarán de "los que nunca salieron. (Giarracca, Bidaseca y Mariotti, 2001, p. 330).

En la migración entendida como proceso moldeador de la identidad de los sujetos juega un rol principal la comunidad, como constructo simbólico y social que le da al individuo un sustento de vida en común a pesar de las condiciones de desarraigo, en palabras de las autoras: "El "exterior" a la provincia no es ni mejor ni peor, es distinto, y juega como "otra" posibilidad diferente a la que ofrece el propio terruño" (Giarracca, Bidaseca y Mariotti, 2001, p. 332).

En esta misma línea, Verónica Trpin en su artículo: "Identidades en movimiento: familias chilenas en la fruticultura del Alto Valle de Río Negro, Argentina” Trpin (2007), explora las relaciones en las cuales se insertan hombres y mujeres chilenas que residen y trabajan en "chacras" (unidades productivas destinadas a la producción de peras y manzanas) en el sur de Argentina. Para la autora es relevante identificar la división de tareas basadas en el género y la edad que se presentan en la actividad frutícola, tomando como unidad de análisis las familias chilenas trabajadoras en la zona.

Desde la antropología rural se ha considerado la familia como la unidad que no sólo produce un producto, sino que también debe recrear las condiciones sociales para reproducir su cotidianeidad:

En la llegada al Alto Valle de Río Negro por referencias de un pariente, en la transmisión de los modos de realizar un trabajo hasta entonces desconocido y en el mantenimiento de lazos con sus familiares en Chile y en la zona, se evidencia el protagonismo que adquiere la familia como referencia laboral e identitaria. (Trpin (2007, p. 230)

Este Valle ha sido un polo de atracción de migrantes chilenos desde principios de siglo $\mathrm{XX}$, en un principio como asalariados temporales y después como lugar de 
asentamientos definitivos para grupos familiares. La autora describe la división del trabajo por género y edades. A partir de las conversaciones con las mujeres de las familias estudiadas, la autora narra los diferentes relatos sobre la llegada a la zona, la tenencia de la tierra, los cambios que han tenido en los roles de trabajo e incluso la precarización de las condiciones laborales y las estrategias de pervivencia de las familias y la educación de los hijos.

En cuanto a la construcción de identidad la autora describe la construcción de un "nosotros" frente a un "ellos" en este caso entre los nacionales y los extranjeros, diferencias que sin embargo se diluyen en la medida en que la construcción identitaria de los migrantes chilenos se basa en la recontextualización de sus prácticas nacionales, en este sentido, "La construcción de las identidades de las familias de migrantes no reproduce una pertenencia original sino que dialoga con nuevos contextos y en nuevas condiciones. Sin embargo, la familia constituye el soporte para su reproducción a lo largo del tiempo" (Trpin ,2007, p. 251).

Además de estas exploraciones de la vida rural latinoamericana desde el foco de los procesos migratorios y la re constitución de identidades nacionales y culturales, se encuentran estudios que se interesan por los procesos migratorios hacia las zonas urbanas, es el caso de la migración argentina a chile que ha llegado a la zona urbana de este país.

Con el artículo "La identidad al otro lado de la Cordillera: migración, identidad e integración" Florencia Jensen (2012) busca contribuir a la comprensión del proceso de reconstrucción de las identidades socioculturales de los migrantes argentinos en Santiago de Chile, explorando la relación con el proceso de integración social de dichos migrantes en las sociedades receptoras. Se concentra en los retos de adaptación que implica para el sujeto migrante la llegada a su destino. Para la autora llegar al destino implica "adaptarse", implica conocerlo, conocer sus calles, sus gentes, sus códigos; implica encontrar una actividad, un trabajo, un nuevo hogar, personas qué conocer (Jensen, 2012). 
La autora sostiene que migrar es un proceso de inserción e integración y de reconfiguración de la identidad tanto individual como colectiva, "múltiples identidades se encuentran, coexisten, se acercan, se alejan, dialogan y disputan, todo ello no exento de conflicto" (Jensen, 2012, p. 16). En este sentido, la autora desarrolla una amplia discusión alrededor de la noción de identidad y del giro subjetivo de la cultura moderna a partir del que aparecen nuevas formas de abordar la cuestión de la(s) identidad(es), y con ello los enfoques constructivistas.

A partir de entrevistas en profundidad semiestructuradas a residentes argentinos en Chile encuentra que la migración argentina en Chile no presenta mayores dificultades en el proceso de integración, esto debido según su análisis a que "en el imaginario social en Chile la imagen de sí mismo se ha asociado más cercana al tipo europeo que al indígena, a tal punto de invisibilizar a las comunidades indígenas autóctonas y, más recientemente, a las comunidades de migrantes andinos (peruanos y bolivianos). Por consiguiente, al migrante argentino se lo asocia más al tipo europeo, por lo cual, se le acepta, valora e integra sin conflicto” Jensen (2012, p. 24).

Los migrantes argentinos llegan con altos niveles educativos y son incorporados a empleos formales teniendo mayor acceso a bienes y servicios. Los entrevistados reconocen que en el proceso de integración incorporan costumbres y hábitos del mundo social chileno, como pueden ser los modismos, las reglas sociales, las formas de acceso a diferentes ámbitos, o bien ciertos gustos culturales. Para la autora hay un importante proceso de adaptación y aceptación de migrantes argentinos, en parte porque sus expresiones de identidad nacional quedan relegadas al ámbito privado e incorporan rápidamente la cultura chilena, "No se trata de una interacción de las prácticas de dos colectivos que entran en contacto, sino que más bien se acerca a la lógica de la asimilación cultural o la aculturación" (Jensen , 2012, p. 27).

Caso contrario al de los argentinos en chile descrito por Florencia Jensen, se observa en el caso de los bolivianos en la ciudad de Buenos Aires, un fenómeno que ha llamado la atención de diferentes investigadores. Estos estudios describen los procesos culturales que la población boliviana ha usado como estrategias de pervivencia cultural, 
haciendo actos públicos en los que destacan sus fiestas nacionales, usan trajes tradicionales y reinventan en un nuevo espacio urbano su identidad boliviana.

Al respecto Gavazzo (2006), en su artículo "Las danzas de Oruro en Buenos Aires: tradición e innovación en el campo cultural boliviano", realiza una completa narrativa etnográfica de las tradicionales danzas bolivianas realizadas en el contexto migratorio de la población asentada en Buenos Aires. La autora plantea la relevancia de la dimensión cultural en los procesos migratorios, procesos en los cuales se trasladan cuerpos, ropas, lenguajes, prácticas y creencias, un "equipaje cultural". Entiende la cultura como un proceso de construcción de significados que se dan en medio de un campo de poder, la cultura por tanto, cambia constantemente en relación a los contextos socio históricos en los que se produce.

En el caso de la migración boliviana en Buenos Aires la autora se pregunta ¿qué papel juega la cultura que los inmigrantes bolivianos traen desde su lugar de origen, y que recrean permanentemente en el contexto migratorio, en las relaciones sociales que allí construyen, tanto entre sí como con los "otros"? intenta identificarlas diferencias que hay entre la práctica de las danzas de Oruro que se dan en el lugar de origen con las que se realizan en la re contextualización en la ciudad de Buenos Aires.

Describe la práctica del baile de Oruro a partir del vestuario, el cual se lleva directamente desde Bolivia y se considera "el original", la música, que en Bolivia es con músicos en vivo y en Buenos Aires se reproduce en cassette o cd, y los motivos del baile que se diversifican en diferentes festividades en Buenos Aires respecto a las fechas patronales de Bolivia. Indica como una de las principales motivaciones en el contexto de Buenos Aires la nostalgia de los migrantes, pues esta población

busca reproducir su lugar de origen en su nuevo lugar de residencia. De hecho, puede decirse que este es uno de los más grandes motivos expresados por los bolivianos que asisten a las diversas fiestas y eventos en donde se bailan las danzas de Oruro, como motivo para participar en los conjuntos. Como símbolos de la bolivianidad, participar activamente (por ejemplo, a través de una danza) en 
un evento cultural de la colectividad los acerca a su lugar de origen. (Gavazzo, 2006, p. 85)

Las anteriores afirmaciones sustentan su posición teórica que entiende la cultura como campo en términos de Pierre Bourdieu y como una serie de tradiciones y emergencias en términos de Bauman. Al contrario de los que los enfoques tradicionales han propuesto, la cultura no es estática ni homogénea en un grupo, la autora muestra cómo la cultura se re contextualiza y se generan prácticas en grupos no homogéneos, diversos, que reinterpretan los significados de la práctica cultural en medio de un contexto migratorio, en este caso el de los bolivianos en la capital Argentina.

Desde una perspectiva similar, Susana María Sassone (2007) en el artículo "Migración, territorio e identidad cultural: construcción de "lugares bolivianos" en la Ciudad de Buenos Aires" analiza el comportamiento sociogeográfico de los migrantes bolivianos en los barrios del Sur de la Ciudad de Buenos Aires. Haciendo uso de una amplia estrategia etnográfica que combina la observación participante, la cartografía social, las entrevistas biográficas, la revisión documental y un amplio trabajo de campo, la autora analiza la migración de población boliviana a la ciudad de Buenos Aires desde la perspectiva de la geografía cultural, centrándose en el comportamiento socio geográfico y étnico de construcción de lugares bolivianos en esta zona urbana.

La autora hace uso de la noción de "lugar" para resaltar la construcción de espacios de vida y apropiación de territorio que conlleva la llegada de una población foránea a una zona urbana. Desde este concepto expone cómo los migrantes bolivianos llegan en busca de trabajo a Buenos Aires y desarrollan mecanismos de apropiación del lugar, guiados por la exclusión y la solidaridad étnica. Como parte de la apropiación de lugares la población desarrolla estrategias propias de la cultura andina que permean y dan sentido de identidad a los migrantes bolivianos. Identifica como estas estrategias la religiosidad popular, las fiestas y bailes, las comidas y condimentos, y las asociaciones étnicas. Estas estrategias se traducen en prácticas espaciales, acciones diversas y materialidades por medio de las cuales se organiza la vida cotidiana y el calendario a lo largo del año que permiten vivir lo boliviano. 
Sassone relata estas estrategias haciendo uso de la narrativa y la fotografía, en las que describe los bailes, ritos religiosos y los espacios en los que son realizados. Identifica diversos lugares que cumplen con diferentes funcionalidades y a los que se dan sentidos de pertenencia, entre los que logra clasificar encuentra: "Lugares" de residencia, "Lugares" de comercio, "Lugares" de ocio y recreación y "Lugares" de servicios. Concluye la autora que esta mirada geográfica permite identificar la construcción del "allá" en el "aquí,, a través de la construcción de lugares cargados de significados culturas e identitarios como colectivo para los migrantes bolivianos.

Finalmente, tomando también como caso de estudio la población boliviana en Argentina, María Gabriela Bianchi Díaz, Victoria Trelles y Rosa Ángela Fittipaldi realizan un análisis de sistemas y redes migratorias con especial énfasis en las redes sociales construidas por los migrantes en el artículo "Sistemas y redes migratorias: implicancias socio-espaciales de la migración boliviana en Hilario Ascasubi” (Bianchi, Trelles y Fittipaldi, 2010).

Las autoras destacan que la demanda y la oferta laboral entran en contacto en el interior de una trama de relaciones a través de las cuales la información sobre el trabajo disponible es adquirida por los individuos. De allí su incorporación de conceptos como capital social y redes sociales, centrándose en el papel que cumplen los entramados de relaciones que construyen los migrantes antes y durante la movilidad. Insisten en cómo el capital social con que se cuenta en el lugar de destino influye en la decisión de migrar, privilegiando la movilidad hacia zonas donde se encuentran conocidos, amigos y parientes.

En el caso de los bolivianos, con testimonios recogidos en campo, relatan la llegada y asentamiento de esta población a partir de los cultivos de caña y cebolla que se potenciaron en la región de Hilario Ascasubi:

La decisión de radicación suele relacionarse estrechamente con la posibilidad de resolver la situación laboral, contexto ampliamente favorecido por la articulación de familiares o paisanos, como también lugareños conocidos, que tienen injerencia el medio local y los nichos ocupacionales donde el migrante puede 
integrarse, o que constituyen el sostén para amortiguar alguna situación de difícil resolución. ( Bianchi, Trelles y Fittipaldi, 2010, p. 242)

Su principal idea es que el mercado laboral se mueve a través de las redes sociales que movilizan información de trabajo y que convoca posible mano de obra, generándose cambios en el territorio y en las formas de producción en este territorio a partir de la llegada de migrantes bolivianos. En este escenario, en el que vale señalar el interés particular que se evidencia en la documentación rastreada por el estudio de los bolivianos en Buenos Aires, no puede faltar la mención del trabajo de Grimson (2011) en el que el autor propone el espacio público como ese espacio en donde interlocutan las identidades y justo a partir de la reconstrucción de relatos de identidad, va tejiendo esos sentidos del nosotros y de los otros, del aquí y del allá que configuran el ser boliviano en Buenos Aires.

En la investigación el autor refiere dos espacios comunicativos, el de la interculturalidad, en donde tienen lugar las tensiones y negociaciones identitarias y el de la intraculturalidad, en donde se dan lugar las estrategias de identificación que las colectividades migrantes generan para una especie de sobrevivencia en la nueva ciudad o en el nuevo país. Recuperando de esta manera los relatos de nacionalidad que producen los bolivianos que viven en Buenos Aires. Es evidente hasta aquí que los fenómenos migratorios de las poblaciones latinoamericanas no se presentan solamente al interior de los países en la dirección rural-rural y rural-urbano, sino también en los ya ampliamente estudiados fenómenos migratorios internacionales. Diferentes estudios cualitativos que plantean nuevas propuestas metodológicas y posturas epistemológicas, han profundizado en el análisis de los procesos identitarios de las comunidades latinoamericanas en países como España y Estados Unidos como procesos de migración internacional y procesos de integración cultural. Es el caso de los salvadoreños y sus rutas migratorias hacia el norte del continente, principalmente hacia Estados Unidos.

En su texto "Tres veces mojado. Migración internacional, cultura e identidad en El Salvador" Marroquín (2005) resalta la migración como un proceso que afecta la estructura económica, pero que también cambia la conformación de la identidad sociocultural. En el caso de los salvadoreños como resalta la autora, el fenómeno 
migratorio se ha presentado desde inicios del siglo XIX, potenciándose gracias a las dinámicas políticas y sociales presentadas en los países centroamericanos hacia la década de 1980. Destaca que los procesos de globalización complejizan y replantean conceptos fundamentales de la identidad como el Estado-nación.

La autora vincula el tema migratorio, particularmente el de las remesas con las nuevas matrices culturales que se configuran. Le interesa la relación entre la cultura salvadoreña, sus procesos de identidad, las remesas y la migración en El Salvador. Mediante un sondeo en ocho municipios la autora encuentra en el discurso de las personas tres identidades que se configuran desde la migración: la del migrante, la del familiar del migrante y la de los locales.

Marroquín vincula a su análisis el papel de los medios de comunicación, las nuevas y viejas tecnologías de comunicación, la música pop y los corridos, y diversos elementos de consumo cultural que trasversalizan el proceso identitario que se construye desde el ser migrante. En diferentes trabajos ha indagado justamente por la construcción de "lo migrante" como elemento de la identidad salvadoreña, resaltando el papel de los procesos migratorios en la construcción de un "país imaginado".

Así como se han estudiado los procesos migratorios de poblaciones latinoamericanas hacia países norteamericanos, uno de los principales flujos migratorios actuales como lo es el dirigido hacia países europeos, particularmente hacia España desde países como Colombia, Ecuador y Perú, han sido indagados desde la perspectiva de las trayectorias migratorias y los procesos identitarios que se despliegan de esta experiencia. Entre estos estudios se destacan los realizados sobre la población peruana en España: "Identidad e inmigración: un estudio cualitativo con inmigrantes peruanos en Madrid" (Labrador, 2001) y "Procesos de construcción de identidad entre la población inmigrante" (Veredas, 1999).

Además de los estudios que se han concentrado en la movilidad de población entre países latinoamericanos en el ámbito laboral rural y hacia países norteamericanos y europeos, algunos autores han estudiado el caso de las poblaciones indígenas como migrantes hacia zonas urbanas. Es el caso de los estudios sobre la comunidad Mapuche 
en Chile, población que ha migrado hacia las zonas urbanas desde los años cuarenta y cincuenta, concentrándose en 2002 el 70\% en zonas urbanas según datos de Álvaro Bello. Este autor en su artículo Migración, identidad y comunidad Mapuche en Chile entre utopismos y realidades (Bello, 2002) publicado en la revista Asuntos Indígenas que incluye diferentes estudios sobre comunidades indígenas del mundo, discute la relación entre la migración de los mapuche de Chile y la etnicidad, en su dimensión política y simbólica. Concluye que la migración es más que un proceso de movilidad, en el caso de los indígenas mapuche, ha evidenciado esquema de dominación, desplazamiento forzado y cambios estructurales de la sociedad chilena que no consideran la pluralidad étnica y cultural de este país.

Desde una perspectiva transnacional, los trabajos de Laura Velasco Ortiz exploran los procesos migratorios de indígenas mexicanos hacia Estados Unidos. En sus artículos "Migración, género y etnicidad: mujeres indígenas en la frontera de Baja California y California” (Velasco, 2000), “Agentes étnicos transnacionales: las organizaciones de indígenas migrantes en la frontera México-Estados Unidos” (Velasco, 2002) y su libro "Desde que tengo memoria: narrativas de identidad en indígenas migrantes" (Velasco, 2005), la autora presenta los relatos de vida de indígenas migrantes y sus estrategias de supervivencia en la vida cotidiana, exponiendo a partir de los relatos indígenas la transformación en la identidad étnica que acompaña al fenómeno migratorio.

\subsection{Reflexiones metodológicas sobre el abordaje de la migración en relación con la identidad}

Asumiendo los enfoques recurrentes que ha tenido el abordaje del fenómeno migratorio como objeto de estudio, puede señalarse que desde la perspectiva economicista es reiterado el uso de diseños metodológicos con un enfoque más estadístico que se valen recurrentemente de técnicas de investigación de carácter cuantitativo que generalmente expresan los resultados en términos de medición y cruce de variables.

Sin embargo, es importante resaltar que el interés generado por la migración como fenómeno social y cultural, desde disciplinas como la antropología y la sociología, propició un giro hermenéutico en torno a los movimientos migratorios también en el 
contexto colombiano, en donde a partir de las décadas del 70 y del 80, en el marco de la crisis del paradigma positivista desde la perspectiva de las ciencias sociales, tuvo lugar el rastreo de otras preguntas y relaciones categoriales de carácter más descriptivo, correlacional y comprensivo que empezaron a proponer el diálogo entre la migración y categorías como la identidad, desde la que se vinculan subjetividades, identidades colectivas, identidades culturales e identidades étnicas (Ramos, et al., 2009), Casasa (2008), Hoffmann (2007), Sassone (2007), Trpin (2007), Demera (2007), Rangel, Hermel, Oliveira, Jorge y Hofstaetter (2005), Velasco (2004), del Olmo (2003), Bello (2002), Labrador (2001), Mariscal (1995), Veredas (1999), Salas (1997), Jensen (2012).

En el marco de estos enfoques se asientan diseños metodológicos de carácter cualitativo en los que se rastrea la inclusión de la etnografía como método de aproximación a este objeto de estudio, con la presencia claro está, de las técnicas tradicionales del método etnográfico tales como la observación (participante y no participante), los diarios de campo, la revisión de archivos históricos y un uso recurrente de la entrevista como técnica de recolección de información, la cual en trabajos como el de Mendoza (2012), se identifica como una técnica precisa para facilitar el abordaje de categorías emergentes en el marco de esta perspectiva, tales como mapas mentales ${ }^{3}$ y sentidos de lugar ${ }^{4}$, en este caso, de un grupo de inmigrantes mexicanos residentes en Albuquerque, Nuevo México a quienes se les aplicaron entrevistas diseñadas a partir de tres líneas de análisis: trayectorias laborales y migratorias, vida social y geografía, con el objetivo de estudiar las posibles implicaciones de sus vivencias y construcciones de los lugares por parte de este colectivo de inmigrantes, así como del sentido de pertenencia a los mismos (sentido de lugar); y comprender tanto la conservación, consolidación o pérdida de vínculos sociales con México, como los procesos de asentamiento en los Estados Unidos.

\footnotetext{
${ }^{3}$ Desde la propuesta que realiza el investigador, se asume la perspectiva de (De Alba 2004; De Castro 1997). Desde la que los mapas mentales indican la representación de un lugar en términos espaciales, y permiten ver cómo las personas analizan el espacio, cómo lo organizan y cómo este espacio está hecho de lugares familiares o relevantes para cada persona.

${ }^{4}$ El investigador retoma a (Massey, 1995) para quien el "sentido de lugar", implica inicialmente, entender el lugar como una construcción social, como una subjetivización. Además de considerar que el lugar es la transformación del espacio y que dicha transformación se da en tanto los individuos viven en él su cotidianidad y lo llenan de contenidos y significados a partir de sus experiencias vividas en él.
} 
Se mencionó antes que desde los enfoques economicistas se evidenciaba un interés por la incidencia de factores generacionales, de género, clase, etnia y de origen geográfico en este tipo de estudios. Sin embargo, en los estudios de carácter más culturalista se desplegaron diseños metodológicos que pusieron en relación a los movimientos migratorios con perspectiva de género y que aunque relacionan la categoría de migración, tanto con masculinidades como con feminidades, sí es notable la focalización de la migración femenina como una de las prioridades y tendencias en la permanente re-configuración que ha ido teniendo este objeto de estudio (Velasco, 2000). Resaltando también que estos estudios que empezaron a relacionar la perspectiva de género con la migración, le dieron lugar a la indagación por las dinámicas familiares en el escenario de los movimientos migratorios (Urrea, Arboleda y Arias, 1999; Jaramillo, 2002; Ramos, et al., 2009; Rangel, Hermel, Oliveira, Jorge y Hofstaetter, 2005); además de insertar en el marco de la indagación, un interés por las maneras en que los mismos migrantes narran sus experiencias migratorias.

En este escenario, vale señalar que de la misma manera como se rastrearon propuestas metodológicas enmarcadas e inspiradas en un enfoque etnográfico clásico, también se encontraron propuestas tales como la de Hernández (2012) desde la que se validó la inclusión de la "etnografía multilocal", Marcus (2001), la cual, según lo argumenta el autor, permite configurar objetos de estudio multilocales que transitan interrelacionados en el sistema mundo y que para la búsqueda particular de esta investigación resulta de especial interés, tanto por permitir mapear el movimiento y dinámica de las sociedades actuales, como por la introducción de categorías de análisis tales como las geografía imaginaria ${ }^{5}$ que el autor propone como la que permite la definición de esas fronteras que son construidas mental y socialmente sobre algunos lugares, muchas veces no conocidos, pero a los cuales se les atribuyen ciertas cualidades.

Categorías como esta, implicaron despliegues metodológicos en los que, tal como propone el investigador, los discursos y las representaciones se validaron y potenciaron

\footnotetext{
${ }^{5}$ En el artículo, la geografía imaginaria es entendida como un conjunto de representaciones creado por un grupo a partir del conocimiento parcial de la cultura de otro geográficamente localizado. Said, E. (2004)
} 
como los medios a través de los que era posible acercarse a la cotidianidad y permitieron también asignarle cualidades al territorio y a la cultura.

En este sentido, cabe mencionar que es en el escenario descrito en donde emerge el interés por las maneras como los migrantes se narran e interpretan ellos mismos sus experiencias de movilidad, albergando interrogantes por aspectos de carácter diacrónico y sincrónico, en cuyas relaciones categoriales tienen lugar el allá y el aquí como focos de análisis y con ellos el método biográfico como otro de los enfoques metodológicos rastreados. Así, fueron encontradas propuestas como la de Jaramillo (2002) que aporta una investigación de base etnográfica, con análisis de casos micro de migrantes de la Costa Pacífica en Cali y realiza una reconstrucción de las trayectorias biográficas migratorias de estos migrantes.

Abordando categorías como la identidad familiar y reconociendo, como la mayoría de los autores que han trabajado el tema de la migración en el Valle del Cauca, la relevancia de trabajos como los de Quintín (1998) y Arboleda, Urrea, \& Arias (2000), en el marco de la utilización de los trayectos biográficos como método para dar cuenta de este objeto de estudio. Estos últimos autores, Urrea, Arboleda, \& Arias (1999) publicaron también un artículo en el que presentaron un análisis de seis casos de construcción de redes familiares de migrantes de la Costa Pacífica ubicados en el Distrito de Aguablanca en Cali.

En el diseño metodológico propuesto, los investigadores privilegiaron en las trayectorias, la composición de la red en sus principales etapas hasta 1996. En este caso se señalan como técnicas de aproximación a la evidencia empírica, además de la observación dirigida sobre eventos cotidianos en el interior de las redes analizadas, las entrevistas en profundidad semidirigidas y de tipo abierto sobre trayectorias de vida, especialmente migratorias, residenciales y laborales. Siendo recurrente esta última técnica en todas las investigaciones y documentos rastreados para el estado del arte.

Por otra parte, y aunque su foco de interés no se centra en migraciones internas en Colombia, el trabajo de Pedone (2010) es referenciado de manera significativa en el rastreo realizado por realizar un aporte metodológico para el estudio de las migraciones. 
La autora en este artículo presenta un estudio de caso sobre una cadena y red migratoria procedente de la provincia de Loja (sur de Ecuador) en sus trayectorias hacia Europa y en la construcción y consolidación de sus procesos de transnacionalismo. Propone un trabajo de campo etnográfico desde una perspectiva transnacional y transatlántica (origen/destino) y se vale de técnicas de investigación de carácter más cualitativo como la observación participante, de nuevo, la entrevista en profundidad, los grupos de discusión y los contactos periódicos con los líderes migrantes (Pedone , 2010).

La autora manifiesta que la relación entre el estudio de las redes migratorias y los relatos biográficos facilita el análisis y la comprensión de aspectos particulares como los efectos del proceso, los cambios que afectan de manera global a la vida de los individuos, tanto en su vida cotidiana como en sus referentes simbólicos; validando que en las entrevistas surgen las percepciones que el inmigrante tiene de la sociedad de llegada y de otros colectivos de inmigrantes y señalando como un elemento interesante en este abordaje metodológico, las entrevistas aplicadas tanto en el lugar de destino de los migrantes, como en su lugar de origen.

También vale señalar que para el efecto de hacer una reflexión metodológica entorno a los abordajes de la migración, resultó de interés la revisión del artículo de Prat (2007) quien ofrece una panorámica sobre relatos e historias de vida en relación a los procesos migratorios. El autor propuso en su diseño el análisis de las vidas de emigrantes a América, las vidas de emigrantes a Centroeuropa y las vidas de emigrantes en España. Utilizando para esto relatos autobiográficos individuales o múltiples. Por último, se hace mención de dos trabajos, el primero de Velasco (2004), quien a partir de relatos de vida hace un acercamiento a las experiencias significativas alrededor de las que se constituye una generación de migrantes, analizando los relatos de veinticuatro líderes de dieciséis organizaciones de indígenas migrantes, ubicados en la frontera entre México y Estados Unidos y provenientes de la región Mixteca del estado de Oaxaca.

La autora analiza en la narrativa de la identidad colectiva, la articulación entre tres dimensiones: relaciones sociales, espacio y tiempo, explorando lo que ella llama episodios narrativos, con lo cual hace referencia a los momentos que focalizan las 
relaciones sociales más significativas para estos migrantes y que en este estudio funcionan como huellas de la memoria grupal.

En este diseño metodológico se propone que a través de los episodios narrativos se escenifica la historia personal pero cruzándola con otras historias individuales, lo cual hace que cobre su sentido social, justo en ese encuentro espacio-temporal, que es relatado como un indicador de colectividad o comunidad. En este trabajo se señala una primera línea de intersección o un primer episodio narrativo que se refiere al lugar de nacimiento de cada migrante y un segundo episodio narrativo que hace referencia a la experiencia migratoria específicamente; señalándose que, la migración como experiencia común adquiere especificidad de acuerdo con los lugares de destino y con las vivencias en cada lugar.

Es interesante en este estudio ver cómo a partir de los relatos se logra observar la multiplicidad de espacios y tiempos que integran la identidad narrativa. Por cuanto ese yo colectivo, esa identidad grupal, está absolutamente impactada por la constante movilidad que experimenta el individuo, que a su vez hace que su experiencia vital contenga categorías sociales que provienen de espacialidades totalmente distintas y lejanas; que según la autora, sólo pueden ser integradas por el individuo en forma narrativa. Proponiendo con esto que la experiencia migratoria espacializa la memoria colectiva, haciendo que la historia del grupo sea la de su dispersión y movilidad geográfica.

El segundo trabajo referido anteriormente, es el de Centeno (2012) que específicamente en el contexto colombiano buscó comprender las trayectorias de inserción social de personas afrocolombianas migrantes a la ciudad de Cali entre 1995 y 2005, y la relación de dichas trayectorias con las formas de construcción y resignificación de los territorios habitados por estos migrantes.

La investigadora propuso el acercamiento al objeto de estudio a través de entrevistas a profundidad, observaciones participantes y revisión de documentos escritos y de material audiovisual como fotografías y cortometrajes, logrando con esto la construcción de relatos biográficos relacionados con la historia migratoria de un grupo de 
afrocolombianos, a través de los que Centeno se acercó a las interacciones, rutinas, relaciones, conflictos y alianzas entre los migrantes y sus vecinos habitantes de los barrios Mójica II, Charco Azul, Cinta Sardi y la Colonia Nariñense.

Es destacable que en el marco de estos diseños se evidencia la marca de tres momentos, lo que algunos autores plantean como los puntos de inflexión, que en las diferentes investigaciones rastreadas, direccionan los relatos de vida, los relatos autobiográficos o en otros casos, los trayectos biográficos construidos. Estos son:

1) La situación de la persona antes de migrar (motivaciones, planes).

2) El viaje y la estancia en el lugar de destino (dificultades enfrentadas, inserción en el campo laboral, construcción de relaciones socio-afectivas).

3) La vida en destino. (trabajo, condiciones de vida, relaciones con la gente, incluido el mismo grupo ) Decisiones de quedarse en el lugar de destino o de retorno al lugar de origen.

Convirtiéndose en una estructura orientadora de los relatos que los investigadores toman como insumo para conocer y comprender fenómenos sociales tales como la migración interna, que en este caso particular concentra la atención y que a través del método biográfico se torna como una categoría susceptible de estudio en relación con estrategias de inserción social, con la subjetividad, la identidad, los sentidos de familia, de colectividad, de etnia, de territorio; con los conflictos, tensiones y negociaciones entre quienes llegan y quienes reciben, con las rutinas y rituales en diálogo y con las configuración de relaciones entre las diferentes poblaciones migrantes y las diversas poblaciones receptoras.

\subsection{Mucho sobre migración e identidad, en términos generales y socioantropológicos. Poco desde la comunicación ¿Qué se ha dicho?}

Para finalizar este informe en el que se presenta el estado de la cuestión que ocupa el interés de la investigación aquí propuesta, es clave decir que el abordaje de las ciencias de la comunicación sobre este objeto de estudio, ha ido emergiendo en el escenario de las 
ciencias sociales de manera posterior a que la antropología, la sociología e incluso la historia, pusieran su interés e los flujos migratorios como fenómeno social.

Señalando además que este interés se ha ido configurando sobre todo, en torno a indagaciones y preguntas movilizadas desde la dimensión massmediática del campo de conocimiento de la comunicación; planteando un abordaje de los flujos migratorios cuya intencionalidad en la búsqueda y construcción de conocimiento, ha girado alrededor del papel que juegan y han jugado los medios de comunicación en los procesos de integración de las comunidades inmigrantes en sus lugares de destino, en torno a los discursos y las construcciones sociales que los mass media contribuyen a generar sobre el fenómeno migratorio, y por supuesto, alrededor de los estereotipos y construcciones discursivas positivas y negativas sobre los flujos migratorios.

En este escenario y aún hoy, tres décadas después de los medios a las mediaciones, un fenómeno como la migración, continúa siendo visibilizado y abordado por la comunicación, más desde los medios que desde las mediaciones mismas, proponiendo desde esta arista pocos estudios visibles en las bases de datos científicas consultadas. Lo anterior propone un estado de la cuestión con un sesgo evidente en el abordaje que se ha hecho del fenómeno desde la comunicación y permite identificar la perspectiva sociocultural de la comunicación como una apuesta poco explorada en el estudio de los flujos migratorios, en la cual la configuración y reconfiguración de las identidades tiene un lugar susceptible de ser abordado, asumiendo la dimensión interpersonal de la comunicación.

Así considerado, es de resaltar el aporte que desde esta perspectiva ha hecho Grimson (2005) quien aborda este objeto de estudio desde un enfoque de la comunicación que trasciende la mirada mediática y pone la fuerza en los procesos de construcción y apropiación del sentido, no solamente en las relaciones mediatizadas sino también, y de manera principal, en las relaciones interpersonales. Aportando un análisis de la migración-identidad desde relaciones comunicativas directas, sin desprenderse totalmente de las relaciones mediatizadas por la tecnología; y desde escenarios comunicativos en donde confluyen por un lado, el grupo sociocultural que para el caso del estudio de Grimson corresponde a los bolivianos, y por otro, diferentes grupos 
sociales y culturales, otros actores a los que se vincula por ejemplo la sociedad receptora, en este caso, la sociedad de Buenos Aires.

Grimson propone así un abordaje del fenómeno que pone en diálogo la mirada de la antropología con la mirada comunicacional para "recuperar los relatos de la nacionalidad que producen los bolivianos que viven en Buenos Aires" (Grimson, 2005, p. 24). Relatos construidos tanto en los procesos comunicativos de la vida cotidiana, como en la relación que los migrantes establecen con los medios de comunicación, entendidos estos últimos como elementos utilizados para construir sus narrativas identitarias; en una apuesta transdisciplinar que le permite al autor, reconstruir "las perspectivas de los actores en un proceso dialógico para contribuir a un conocimiento menos parcializado sobre las culturas de los inmigrantes". (Grimson, 2005, p. 25) Y que en últimas, permite develar esos sentidos de la diferencia y la igualdad que se construyen y deconstruyen, frente a una cultura asumida como hegemónica.

En esta misma línea vale mencionar también los aportes que Rizo (2004) realiza a partir de su tesis doctoral movilizada por el interés de responder a la pregunta de ¿cómo tiene lugar la redefinición de la identidad de los inmigrantes en un contexto como El Raval (Barcelona) y cómo se puede explicar desde la comunicación? La autora explora la redefinición de las identidades a partir de narraciones hechas por los migrantes y focalizando el interés en las formas de autorepresentación que tienen estos en el contexto urbano. Es de señalar que propone un abordaje del objeto de estudio desde la perspectiva de la comunicación interpersonal, haciendo un cruce con algunos conceptos básicos de la teoría social de Pierre Bourdieu, tales como campo, habitus y prácticas culturales, en el entendido de que estos "proporcionan un espacio conceptual válido para una aproximación al estudio de la ciudad como proveedora de identidades flexibles" (Rizo, 2004, p. 13).

Rizo parte del principio de que la comunicación es una dimensión constitutiva de lo social, planteando un vínculo entre comunicación e identidad por cuanto la identidad es producto de los procesos de interacción social y un proceso de negociación, tensión y ajuste que desde la propuesta que hace la autora, "conforma la construcción de la 
intersubjetividad y el mundo de significados compartidos” (Rizo, 2004, p. 203), por lo cual, la interacción para Rizo es una condición sine qua non de los procesos identitarios.

Estos aportes mencionados, que ponen a la comunicación en diálogo interdisciplinar, proponen las relaciones establecidas por los migrantes con el otro, con los otros, con los espacios que los reciben y con los espacios que abandonan, como aristas susceptibles de ser estudiadas y comprendidas desde el campo de la comunicación, sugiriendo los sentidos que se construyen en la interacción con ese otro, con esos otros y con los espacios, como una posibilidad que permite pensar las identidades en tránsito y en permanente construcción.

\section{CAPÍTULO III. DE LA CONSTRUCCIÓN DEL OBJETO DE ESTUDIO}

\section{Referente contextual}

\subsection{Generalidades del proceso migratorio}

Para iniciar, es importante señalar que la migración ha sido un fenómeno social pensado, en un gran número de estudios, en relación con escenarios internacionales, sin considerar tal vez que "en términos cuantitativos y cualitativos hay contextos históricos en los cuales los desplazamientos territoriales internos de los estados nacionales son más importantes que los internacionales" (Grimson, 2011, pp. 34-35). Punto que justamente focaliza el interés de la propuesta que aquí se socializa, en tanto el estudio se concentra en los procesos de configuración y reconfiguración identitaria de una población, en este caso la nariñense, protagonista de flujos migratorios internos a varios departamentos de Colombia, entre ellos, el Valle del Cauca, considerado como destino por las posibilidades de trabajo y de ofrecer una mejor calidad de vida.

En este marco, es necesario señalar que dentro de los factores que determinan la redistribución del territorio nacional, la migración interna funge como uno de los componentes de cambio y fuerza modeladora. Al respecto Everett Lee, autor referente en el tema la define como un cambio permanente o semipermanente de residencia, sin restricciones de distancia o si se trata de actos involuntarios o voluntarios (Lee, 1966). 
Dentro de los argumentos que justifican el evento de la migración interna, se encuentra la procura de maximizar una función de utilidad Silva y González (2009), la cual debe girar en torno a los atributos de las regiones de origen y destino y a las características personales del migrante Lee (1966); de esta forma puede afirmarse que el acto de la migración persigue como resultado retornos asociados a la inversión y los costos del efecto de migrar (Silva y González, 2009).

Dentro de los determinantes para el ejercicio de la migración, el grado de urbanización, las oportunidades laborales, el grado de industrialización y la calidad de vida Silva y González (2009), surgen como algunos de los factores más referidos en la bibliografía consultada. Sin embargo, tratar de identificar los determinantes puntuales de la decisión de migrar es una tarea ardua y altamente contextual, Lee (1966) por ejemplo argumenta sus determinantes en el lugar de origen, el lugar de destino y las barreras existentes entre los dos, aunque, tal y como lo refiere críticamente Banguero (1985), Lee dice poco al respecto de factores específicos determinantes del desplazamiento.

De las diferentes consultas realizadas con el fin de contextualizar la investigación que aquí se propone, la mayoría coincide con que el aporte de Todaro (1969) es uno de los más destacados, refiriendo que la tasa de migración del campo a la ciudad, se explica en relación a la diferencia promedio de ingresos existentes entre el campo y la ciudad, ponderada a su vez por el nivel de desempleo existente en las zonas urbanas, sin embargo algunas otras consideraciones teóricas han tratado de explicar la migración vinculando aspectos como, la tenencia de la tierra, el nivel educativo, la oportunidad de empleo, el mejoramiento de la calidad de vida, restando importancia a factores como la distancia, o el estrato social (Banguero, 1985, p. 26).

En este escenario y para entender mejor los factores que desde esta perspectiva motivan la migración interna, puede considerarse el aporte de Silva y González (2009) investigadoras que realizaron una agrupación de las variables que han utilizado diferentes estudios para aplicar según sea el contexto, al caso de la migración interna, estas variables son: distancia, ingresos o PIB, impuestos locales, mercado laboral, precios, clima, comercio, educación, mortalidad infantil, otras características geográficas e 
infraestructura, población, pobreza, propiedad, regiones, sector, transferencias e inversión municipal, urbanización y violencia (Silva y González, 2009, p. 125).

Por su parte el Departamento Administrativo Nacional de Estadística DANE, una de las fuentes de información más destacada en el aporte de datos de carácter estadístico y demográfico para facilitar la comprensión y el análisis de la migración interna, a partir de los censos de población, afirma en el censo más reciente correspondiente al año 2005, que de las 41.468 .384 personas censadas en Colombia, el 61,9 \% declaró residir, al momento del censo, en el mismo municipio de nacimiento; mientras que el $36 \%$, nació en un municipio diferente al de residencia. Departamento Administrativo Nacional de Estadística (DANE, 2012).

Según el Departamento Administrativo Nacional de Estadística (DANE, 2012) los departamentos con mayor población nacida ( $80 \%$ del censo o superior) en el mismo lugar del censo son La Guajira, Amazonas, Córdoba y Nariño, mientras que Guaviare, Cundinamarca, Meta y Risaralda, figuran con una población de nacidos en otros municipios superior a la de nativos. En el término medio, Casanare, Putumayo y Quindío aparecen con distribuciones iguales.

\subsection{Descripción general del proceso migratorio en Colombia en la década de los setenta}

Es de señalar que en el caso colombiano, para la década de los años setenta, las movilizaciones poblacionales en este sentido fueron muy activas. Incluso, hasta la década del noventa Silva y González (2009), incidiendo en una transformación de las poblaciones rurales de baja densidad y en la configuración paulatina de nuevos centros urbanos o en algunos casos, de periferias urbanas en las ciudades ya constituidas. Para el caso de Colombia, es importante tener en cuenta que en la actualidad cuenta con aproximadamente cuarenta millones de habitantes, concentrados en un territorio de 1.4 millones de kilómetros cuadrados, lo cual indica una densidad de 35 habitantes por kilómetro cuadrado, sin embargo, existe un desequilibrio en términos de ubicación de la población debido a que departamentos tales como Orinoquía y Amazonía, poseen una densidad de menos de un habitante por kilómetro cuadrado (Martínez, 2006). Agregando que Martínez (2006) afirma que la tasa de crecimiento de la población colombiana es 
relativamente baja, ubicada por debajo del 2\%. Banguero (1985) por su parte, refiere que el análisis de la migración interna en el país debería concentrarse en los últimos cuarenta años (1973- presente), ya que durante este corte temporal se ha podido observar un crecimiento acelerado de esta dinámica; frente a lo cual Martínez (2006) afirma que es durante las décadas del sesenta y el setenta en las que el país vivió su más intenso éxodo rural, lo cual permite confirmar las delimitaciones propuestas por Banguero.

Algunos datos procedentes de su investigación permiten contextualizar el crecimiento que fue teniendo la población urbana, una variable importante al estudiar el comportamiento histórico del proceso migratorio en Colombia (Banguero, 1985, p. 23):

Tabla 1. Proporción de la población colombiana clasificada como urbana

\begin{tabular}{|c|c|}
\hline Año & $\begin{array}{c}\text { Proporción de la } \\
\text { población colombiana } \\
\text { clasificada como urbana }\end{array}$ \\
\hline 1938 & $32,00 \%$ \\
\hline 1951 & $38,90 \%$ \\
\hline 1964 & 52,4 \\
\hline 1973 & $63,00 \%$ \\
\hline 1980 & $66,40 \%$ \\
\hline 2000 & $72,50 \%$ \\
\hline
\end{tabular}

Fuente: Construcción propia a partir de Banguero (1985)

Estos datos permiten señalar el crecimiento paulatino que fue teniendo la población urbana en Colombia (ver tabla 1), frente al decrecimiento de la población rural, y con esto, por su puesto, el cambio de la distribución poblacional que ha ido teniendo el país, por cuenta de las migraciones internas. Lo cual permitirá más adelante, referir la generalidad de las rutas migratorias internas en el país. 
Otro aporte que permite identificar las principales tendencias demográficas, desde un corte temporal más amplio (1905-1998), es el que realiza Martínez (2006) en su investigación (ver tabla 2):

Tabla 2. Colombia, principales tendencias demográficas 1905-1998

\begin{tabular}{|c|c|c|c|c|}
\hline \multirow{2}{*}{ Años } & \multirow{2}{*}{ Población total } & \multirow{2}{*}{$\begin{array}{c}\text { \%oblación } \\
\text { Urbana }\end{array}$} & \multicolumn{2}{|c|}{ Tasas de crecimiento } \\
\cline { 4 - 5 } & & & Total \% & Urbano \% \\
\hline 1905 & $4,134,632$ & & & \\
\hline 1912 & $5,072,604$ & & $28,90 \%$ & \\
\hline 1918 & $5,855,077$ & & $21,80 \%$ & \\
\hline 1928 & $7,855,000$ & $31,00 \%$ & nd & \\
\hline 1938 & $8,701,816$ & $29,10 \%$ & $20,20 \%$ & $3,90 \%$ \\
\hline 1951 & $11,548,4182$ & $38,70 \%$ & $22,30 \%$ & $43,60 \%$ \\
\hline 1964 & $17,484,508$ & $52,00 \%$ & $31,90 \%$ & $54,70 \%$ \\
\hline 1973 & $22,915,229$ & $59,30 \%$ & $29,60 \%$ & $37,30 \%$ \\
\hline 1985 & $29,265,499$ & $67,20 \%$ & $20,40 \%$ & $31,40 \%$ \\
\hline 1993 & $36,089,725$ & $70,90 \%$ & $18,10 \%$ & $28,20 \%$ \\
\hline 1998 & $40,428,748$ & & $18,00 \%$ & \\
\hline
\end{tabular}

Fuente: Construcción propia a partir de Martínez (2006)

La confrontación de los datos obtenidos en los dos cuadros anteriores permite observar cierta coherencia entre los datos de ambas fuentes, resaltando que el crecimiento porcentual de la población urbana en Colombia, sigue un tránsito progresivo en aumento, por lo menos hasta finales del siglo XX, según los datos encontrados. Al respecto de las proyecciones en materia de proporción de la población colombiana clasificada como urbana para el año 2000, se encuentra que: 
El proceso de urbanización resultante fue acelerado y como consecuencia el porcentaje de población urbana supera hoy el 70\%. Sin embargo, y en contraste con el resto de América Latina, donde es usual que las ciudades capitales concentren la mitad o más de la población total del país, Colombia se destaca por conservar una red más o menos amplia de ciudades de tamaño intermedio. (Martínez, 2006, p. 22)

Por otra parte, el aporte de Silva y González (2009) indica que para el año de 1964, 6,3 millones de los 17,5 millones de habitantes del país, era considerado como migrante. A tal fecha, la violencia empezó a sumar importancia como un factor determinante de la migración interna (ver tabla 3); sin embargo también se consideraban otros factores principales, tales como la escasez de oportunidades, los altos incrementos de población en las áreas rurales y la concentración de la tierra, que causarían como efecto la migración interna en el país (Silva y González, 2009). En los aportes realizados por Banguero (1985) se indica el siguiente flujo anual promedio:

Tabla 3. Tasas de migración en Colombia

\begin{tabular}{|c|c|c|c|}
\hline $\begin{array}{c}\text { Período } \\
\text { intercensal }\end{array}$ & $\begin{array}{c}\text { Migrantes del } \\
\text { campo a la } \\
\text { ciudad }\end{array}$ & $\begin{array}{c}\text { Flujo anual } \\
\text { promedio }\end{array}$ & $\begin{array}{c}\text { Tasa anual de } \\
\text { migración } \\
\text { campo ciudad }\end{array}$ \\
\hline $1938-1951$ & $\mathrm{x}$ & $\mathrm{x}$ & $1,20 \%$ \\
\hline $1951-1964$ & $2,438,152$ & 187550 & $2,30 \%$ \\
\hline $1964-1973$ & $2,426,575$ & 269619 & $3,20 \%$ \\
\hline 2000 & $\mathrm{x}$ & $\mathrm{x}$ & $\begin{array}{c}1,2 \% \text { (tasa } \\
\text { esperada) }\end{array}$ \\
\hline
\end{tabular}

Fuente: Construcción propia a partir de Banguero (1985)

Como puede observarse, las décadas del sesenta y setenta indican las mayores tasas anuales de migración interna, incluso resaltando que los rangos tomados por períodos tienen una pequeña variación en el tercer rango en cuanto delimita un menor número de años para el estudio, aún así, este período de tiempo (1964-1973) es el que 
denota la tasa más alta de migración campo-ciudad, situación que es coherente con los datos que el presente marco contextual ha ido presentando pero además, coherente con la época de migración de la población que ocupa el interés de esta investigación. Es decir, la época en la cual la colonia nariñense asentada actualmente en Candelaria, se desplaza al Valle del Cauca.

Esta situación se diferencia de las características que tenía la distribución de la población en el país en la década del treinta, en donde, según Martínez (2006) se denotaba la población rural imperante sobre la urbana:

(...) más de dos terceras partes de la población colombiana vivían en los campos. A principios de la década del 50 el país continuaba siendo eminentemente rural, con el $60 \%$ de su población viviendo en áreas de ese tipo, pero el conflicto social estaba generalizado y se apreciaban los primeros impactos de una tendencia a la urbanización, que se consolidaría en la década siguiente. (Martínez, 2006, p. 26)

En este sentido, la migración interna en Colombia ha tenido diferentes motivaciones conforme a las realidades de cada época. Lo que obliga a entender el fenómeno migratorio en el margen de la contextualización histórica de cada momento, entendiendo así que los diferentes eventos de carácter sociopolítico, económico y cultural, son los factores que inciden en esta dinámica de configuración poblacional.

Al respecto, Martínez (2006) propone como factores intervinientes, el desarrollo de campañas de salud, particularmente ligadas a vacunación masiva, control de tuberculosis y campañas de información para el mejoramiento de las prácticas sanitarias, el incremento del gasto público en educación y sus efectos en la reducción del analfabetismo y la cobertura académica, el reconocimiento a la mujer en su participación democrática y su derivado acceso al mundo laboral y a la educación, la entrada en vigencia del frente nacional como elemento hacia la pacificación del país y la aplicación de un modelo proteccionista y desarrollista que fomentaban la agricultura y la industria. Factores que además tuvieron un gran impacto sobre la sociedad colombiana, estimulando la industrialización, el desarrollo de la infraestructura y el fomento del 
comercio internacional, procurando, un mejoramiento social y económico sin precedentes, pero focalizado en las áreas urbanas.

(...) las mejoras se concentraron en unas pocas regiones y ciudades que se consolidaron como principales focos de localización de las actividades económicas. Se acentuaron los desequilibrios entre estos centros y el resto del territorio nacional cuya economía permanecía ligada a la agricultura tradicional, organizada en pequeñas parcelas de muy escasa productividad. Además, extensas regiones de la costa Pacífica y las llanuras orientales, estaban (y aún están) totalmente aisladas del interior y excluidas de los procesos de desarrollo. (Martínez, 2006, p. 28)

Como efecto de las transformaciones y su exclusiva delimitación regional:

Todos los factores mencionados actuaron para que en la década del 60 y primeros años de la del 70, se presentara un proceso migratorio sin precedentes en el país, caracterizado fundamentalmente por la transferencia de la población rural a las áreas urbanas, en busca de empleo, vivienda y educación, proceso que ha sido ampliamente documentado en los primeros análisis de migración con que se cuenta en Colombia, y al que se ha aplicado tradicionalmente el calificativo de verdadero éxodo rural. (Martínez, 2006, p. 28)

Finalmente, esta dinámica de concentración poblacional en las grandes ciudades, ha tenido como efectos demandas por vivienda e infraestructuras de distribución de bienes y servicios que rebasan cualquier capacidad pronosticada; afectaciones sobre la calidad de vida, tanto de los principales departamentos expulsores como de los receptores, y a su vez una repoblación alternativa de los centros intermedios aledaños, por sus menores precios de los suelos, mayor calidad de vida y otros factores, que resultaron ser atractivos para habitantes de los grandes centros urbanos que se encontraban afectados por el conflicto (Martínez ,2006).

Al respecto, es importante identificar los principales departamentos expulsores y receptores, considerando que un primer factor que podría dar forma a la dinámica de migración interna, es la mezcla entre la división política por regiones, y las características geográficas del país alineadas a la estructura de las cordilleras, situación que ha que ha 
obligado a que dicho ejercicio migratorio se dé, la mayor parte de las veces dentro de cada región y en la mayoría de los casos del campo (o pequeño municipio) a las ciudades.

Considerando entonces los departamentos expulsores, la literatura refiere que: (...) durante el periodo 1964-1973, los departamentos que se destacan por su condición de expulsores fueron Boyacá, Caldas, Cundinamarca (sin Bogotá), Tolima, Huila, Risaralda, Quindío, Magdalena, Chocó, Cauca, Nariño y Santander; los cuales son departamentos que se caracterizaron por una producción mayoritaria en el sector primario y una elevada tendencia a la concentración de tierra (Silva y González, 2009).

Para continuar contextualizando el comportamiento de las migraciones interdepartamentales, se exponen los importantes avances de Martínez (2006) en relación con los migrantes y no migrantes antes de 1988 (ver tabla 4):

Tabla 4. Migrantes y no migrantes en Colombia antes de 1988

\begin{tabular}{|c|c|c|c|}
\hline DEPARTAMENTO & $\begin{array}{c}\text { TOTAL } \\
\text { POBLACIÓN }\end{array}$ & $\begin{array}{c}\text { NO MIGRANTES } \\
\text { ANTES DE 1988 }\end{array}$ & $\begin{array}{c}\text { MIGRANTES } \\
\text { ANTES DE 1988 }\end{array}$ \\
\hline Antioquia & 2.183 .885 & 1.937 .624 & 246.261 \\
\hline Atlántico & 1.096 .702 & 818.730 & 277.972 \\
\hline Bogotá & 3.729 .900 & 2.169 .806 & 1.560 .094 \\
\hline Bolívar & 958.826 & 811.246 & 147.580 \\
\hline Boyacá & 763.993 & 59.667 & 704.326 \\
\hline Caldas & 570.381 & 467.842 & 102.539 \\
\hline Caquetá & 174.520 & 104.044 & 70.476 \\
\hline Cauca & 656.080 & 589.177 & 66.903 \\
\hline Cesar & 455.083 & 322.367 & 132.716 \\
\hline Córdoba & 722.052 & 671.043 & 51.009 \\
\hline Cundinamarca & 920.812 & 704.357 & 216.455 \\
\hline Choco & 222.748 & 202.038 & 20.710 \\
\hline Huila & 447.805 & 372.610 & 75.195 \\
\hline
\end{tabular}




\begin{tabular}{|c|c|c|c|}
\hline La Guajira & 183.760 & 139.627 & 44.133 \\
\hline Magdalena & 584.184 & 495.285 & 88.899 \\
\hline Meta & 328.397 & 174.619 & 153.778 \\
\hline Nariño & 911.669 & 888.089 & 23.580 \\
\hline Norte de Santander & 586.942 & 486.065 & 100.877 \\
\hline Quindío & 246.729 & 154.552 & 92.177 \\
\hline Risaralda & 443.064 & 282.608 & 160.456 \\
\hline Santander & 811.709 & 691.452 & 120.257 \\
\hline Sucre & 412.571 & 367.725 & 44.846 \\
\hline Tolima & 687.735 & 578.139 & 109.596 \\
\hline Valle & 1.919 .496 & 1.389 .000 & 530.496 \\
\hline Arauca & 78.706 & 43.186 & 35.520 \\
\hline Casanare & 83.211 & 61.524 & 21.687 \\
\hline Putumayo & 115.671 & 64.032 & 51.639 \\
\hline San Andrés & 32.974 & 18.012 & 14.962 \\
\hline Amazonas & 22.641 & 20.026 & 2.615 \\
\hline Guainía & 8.553 & 6.360 & 2.193 \\
\hline Guaviare & 31.210 & 10.183 & 21.027 \\
\hline Vaupés & 11.179 & 10.235 & 944 \\
\hline Vichada & 21.661 & 14.485 & 7.176 \\
\hline Total País & 20.424 .849 & 15.125 .755 & 5.299 .094 \\
\hline
\end{tabular}

Fuente: Construcción propia a partir de Martínez (2006)

La anterior descripción permite revisar la situación general de migrantes y no migrantes en el país, y poner la mirada en datos que incluso pueden brindar la posibilidad de clasificación de los departamentos con mayores o menores índices en el comportamiento de ambas variables. (Ver tabla 5). 
Tabla 5. Migrantes y no migrantes por porcentajes antes de 1988

\begin{tabular}{|c|c|c|}
\hline DEPARTAMENTO & $\begin{array}{c}\% \text { NO } \\
\text { MIGRANTES }\end{array}$ & $\%$ MIGRANTES \\
\hline Boyacá & 8 & 92 \\
\hline Guaviare & 33 & 67 \\
\hline Meta & 53 & 47 \\
\hline San Andrés & 55 & 45 \\
\hline Arauca & 55 & 45 \\
\hline Putumayo & 55 & 45 \\
\hline Bogotá & 58 & 42 \\
\hline Caquetá & 60 & 40 \\
\hline Quindío & 63 & 37 \\
\hline Risaralda & 64 & 36 \\
\hline Vichada & 67 & 33 \\
\hline Cesar & 71 & 29 \\
\hline Valle & 72 & 28 \\
\hline Casanare & 74 & 26 \\
\hline Total País & 74 & 26 \\
\hline Guainía & 74 & 26 \\
\hline Atlántico & 75 & 25 \\
\hline La Guajira & 76 & 24 \\
\hline Cundinamarca & 76 & 24 \\
\hline Caldas & 82 & 18 \\
\hline Norte de Santander & 83 & 17 \\
\hline Huila & 83 & 17 \\
\hline Tolima & 84 & 16 \\
\hline Bolívar & 85 & 15 \\
\hline
\end{tabular}




\begin{tabular}{|c|c|c|}
\hline Magdalena & 85 & 15 \\
\hline Santander & 85 & 15 \\
\hline Amazonas & 88 & 12 \\
\hline Antioquia & 89 & 11 \\
\hline Sucre & 89 & 11 \\
\hline Cauca & 90 & 10 \\
\hline Choco & 91 & 9 \\
\hline Vaupés & 92 & 8 \\
\hline Córdoba & 93 & 7 \\
\hline Nariño & $\mathbf{9 7}$ & $\mathbf{3}$ \\
\hline
\end{tabular}

Fuente: Construcción propia a partir de Martínez (2006)

El ordenamiento porcentual de la participación de la migración por departamento antes de 1988, coloca al departamento de Nariño como el de menor porcentaje de migrantes para este momento histórico del país, con un porcentaje de migración del 3\% al respecto de su población. Por su parte, el Valle del Cauca se encontraría en la mitad superior de la tabla, con un porcentaje de migración del $28 \%$.

La investigación de García (2013) que proponía un modelo basado en la teoría de redes con el cual se daría cuenta del fenómeno migratorio en Colombia, permitió observar que Bogotá, Valle del Cauca, Antioquia, Cundinamarca, son los departamentos en los que se ha producido la mayor intensidad migratoria: Bogotá, Valle del Cauca y Antioquia, como receptores, y Cauca, Nariño y Bolívar como expulsores, esto para la situación actual, sin embargo al confrontar los datos actuales, con los resultados previos a 1988 Martínez (2006), se puede observar la transformación del flujo migratorio en la historia de Colombia.

\subsection{El departamento de Nariño como origen de la migración}

"La colonia nariñense", como se autodefinen las personas provenientes de Nariño, que actualmente se encuentran asentadas en el municipio de Candelaria, Valle del Cauca, 
e incluso sus hijos, muchos de ellos ya nacidos en Candelaria, se encuentra en el municipio vallecaucano, desde hace más de 40 años, migra desde el sur de Colombia (ver figura 1) desde finales de la década del 60 y de manera más significativa, en la década de $\operatorname{los} 70$.

Figura 1. Recorrido migratorio realizado

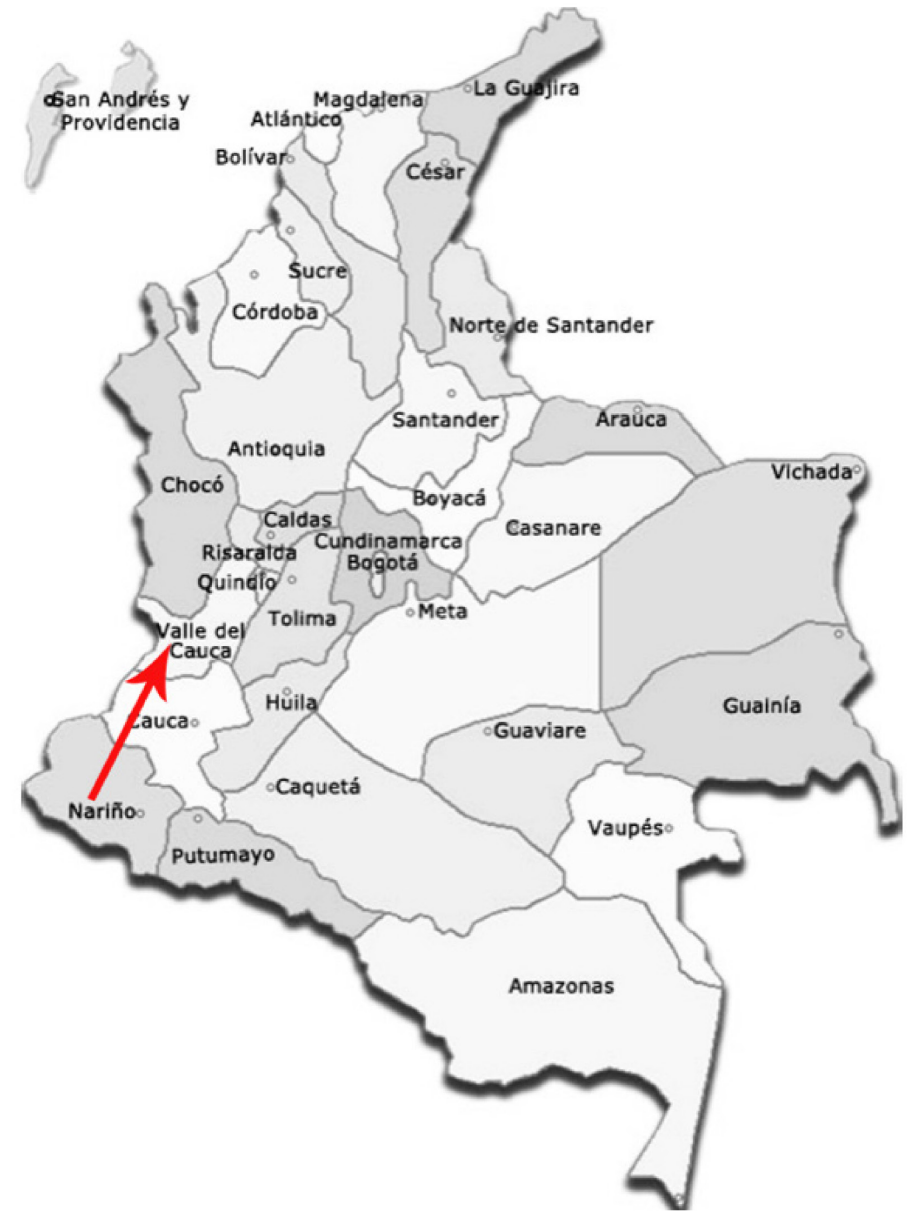

Fuente: Construcción propia

Es importante referir que Nariño es un departamento que cubre una superficie de $33.268 \mathrm{~km}^{2}$ del territorio colombiano y tiene una población total de 1.243 .929 habitantes con una densidad poblacional de 37.1 personas por kilómetro cuadrado y aproximadamente un $23 \%$ de la población residiendo en la capital departamental, Pasto. Organización Internacional para las Migraciones (OIM, 2001). 
Es identificado en diferentes estudios como departamento expulsor de su población de origen. Y específicamente en la década de 1970, se encuentra que el departamento dependía de una economía tradicional y con uno de los niveles productivos más bajos, frente a los demás departamentos del país. Características que permiten respaldar esa migración que en su momento, estuvo motivada por factores socioeconómicos tales como la demanda de empleo, mejores salarios, estabilidad laboral, seguridad social, y en general, el mejoramiento de las condiciones de vida, el atractivo de grandes ciudades, y algunas manifestaciones de violencia o simplemente las sugerencias de un "paisano" ya emigrado (Gamboa y Moreno, 1996), lo cual dejaba en las grandes ciudades un atractivo de ubicación final para el nariñense.

En el marco de esta dinámica social de la migración interna referida, Nariño es considerado uno de los departamentos expulsores en Colombia asumiendo que la intensidad de los flujos migratorios, varía enormemente de un lugar a otro, dada la gran diversidad económica y cultural del país, de manera que mientras las zonas más deprimidas económicamente pierden proporciones importantes de su población por efecto de la migración (Nariño, Córdoba, Sucre, Cauca), las zonas de mayor desarrollo o en proceso de expansión económica, ganan y se saturan de inmigrantes; "la dirección de los flujos migratorios se dirige de las zonas más deprimidas económicamente a las zonas de mayor crecimiento o expansión económica. Entre las primeras se identifican: Nariño, Córdoba, Sucre y Cauca; y entre las segundas: Bogotá, Caquetá y San Andrés" (Cubides y Dominguez, 1999, p. 172).

Los informes del DANE (2012) permiten confirmar el papel de Nariño dentro de los flujos migratorios interdepartamentales, especialmente ratificando que Nariño también es considerado actualmente, como uno de los departamentos con mayor población nativa (nacidos en el mismo municipio) con una participación cercana al $80 \%$ del total de su población censada en el año 2005, y de igual forma, se caracteriza por tener un bajo índice de población foránea, situación que sigue confirmando su papel como departamento expulsor y no receptor de migrantes. 
De esta manera, la situación de Nariño como departamento expulsor, se ratifica desde otras miradas desde las que se afirma que: para el 2005 se encuentra que los departamentos con menores índices de atracción son Nariño, Amazonía, Vaupés y Guajira. En total, estos departamentos expulsan aproximadamente 53.000 habitantes; esto es equivalente a una tasa de emigración promedio de 6,84\% ( Silva y González, 2009).

El fenómeno de la migración proveniente del departamento de Nariño desde la década de 1920, se justifica inicialmente en las presiones que sufrieron y sufren los indígenas y campesinos nariñenses por sus tierras de resguardo y sus minifundios, situación que lanzó y sigue lanzando a muchos de ellos hacia el Putumayo (Cubides y Dominguez, 1999). En este escenario, hay que decir que uno de los departamentos que históricamente se rastrea como acogedor de los nariñenses, es el Valle del Cauca, y específicamente su ciudad capital, Cali, que particularmente en sus zonas de ladera, se ha ido configurando en gran medida, a partir de los flujos migratorios de diferentes poblaciones, tal como lo refiere Urrea (2012), al decir que el conglomerado orientado, ha sido el área geográfica de mayor focalización de los flujos migratorios del Pacífico, norte del Cauca y sur del Valle y en Ladera, sin dejar de presentarse flujos migratorios de poblaciones negras en cuantías menores, el peso mayor han sido las corrientes de población mestiza, mestiza indígena y blanca, históricamente una parte de ella de la región andina caucana y nariñense.

Vale decir que inicialmente, muchos de los nariñenses que llegaron al Valle del Cauca, trabajaron como obreros en la vía férrea que comunicaba a Cali con Buenaventura y después fueron ubicándose como corteros de caña y operarios en los ingenios azucareros de la región; contribuyendo de manera significativa al desarrollo agropecuario e industrial del Valle del Cauca, en un momento histórico en el que la industria azucarera (actualmente la actividad económica más importante de la región) se estaba configurando, tal como se referirá más adelante.

Por su parte, un estudio de 2001 realizado por la Organización Internacional para las Migraciones (OIM) hizo referencia al papel de Nariño como departamento expulsor, y los destinos más recurrentes para los migrantes: 
Históricamente, un gran número de familias e individuos de Nariño migró a Putumayo para participar en las sucesivas "bonanzas" del departamento, incluyendo petróleo, plantaciones de hule, y finalmente la producción de cocaína. De hecho, se estima que el 70\% de la población actual en Putumayo tiene sus raíces en Nariño. Estos patrones migratorios explican en gran parte el creciente número de familias de desplazados que han llegado a Pasto, Ipiales, Taminango y otros municipios luego del incremento del conflicto y las actividades de fumigación en Putumayo. Según la RED, únicamente 192 familias estaban registradas hasta diciembre del 2000. Al igual que en otros departamentos afectados por el desplazamiento causado por fumigaciones, la tasa de rechazo en las declaraciones de las PDI es bastante alta. Organización Internacional para las Migraciones. (OIM, 2001)

Considerando la situación actual de la migración en Nariño, y sus argumentos, la OIM (2001) también reveló algunos de los factores que podrían incidir en los nariñenses en el momento de tomar la decisión de migrar, dentro de ellos se hace referencia a la precaria situación económica mientras que otras investigaciones refieren el escaso desarrollo y la condición aislada y empobrecida del departamento (Martínez, 2006). El estudio también revela el papel del Valle del Cauca como departamento receptor de los nariñenses en migración, planteando que: “...el $67 \%$ de las familias manifiesta que su lugar de residencia en 1990 era el departamento de Putumayo...El 33\% restante reportó Cauca, Valle del Cauca, Santander y Tolima como lugares de residencia en 1990..." (OIM 2001).

Al respecto, también es relevante decir que los nariñenses asentados hoy en Candelaria, provenían en su gran mayoría de pueblos pequeños y corregimientos veredales; principalmente de Funes, Ipiales, Samaniego, Ancuya, entre otros, donde generalmente se dedicaban a la agricultura (Gamboa y Moreno, 1996).

En el rastreo bibliográfico realizado e incluso en las indagaciones hechas en el marco de esta investigación, se encuentra que la fuerza de trabajo nariñense comenzó a ser muy apetecida en el Valle del Cauca por su disciplina, dedicación y capacidad de trabajo. Su mano de obra fuerte y de bajo costo, le hizo grandes aportes a los ingenios, lo 
cual empezó a marcar oportunidades laborales para las familias que ya se encontraban en la región y también para los amigos y familiares que quedaban en Nariño y que de la misma manera soñaban con encontrar un trabajo y "sacar adelante a la familia".

Apenas yo salí del ejército y pensé en venirme para el Valle porque aquí lo único que nos traía a los nariñenses era el trabajo... aquí en el Valle del Cauca lo que más nos llamó la atención fue de que el todo era ser nariñense para darle trabajo a uno, entonces como aquí existían los Ingenios, primer lugar por ejemplo yo llegué a Manuelita trabajé allá pero después me vine a vincular a Candelaria. Pero la realidad de los nariñenses y la vinculación de tanto nariñense en Candelaria es el trabajo porque el nariñense era muy honrrado para trabajar y no necesitaba otra cosa que otra recomendación de ser nariñense para darle trabajo. (Jorge Martínez ${ }^{6}$, entrevista personal, 2015)

Fue entonces como las necesidades económicas y laborales generaron una migración en cadena de los nariñenses a algunos departamentos de Colombia, siendo el Valle del Cauca uno de los destinos más apetecidos. Algunos de ellos llegaron con sus familias ya constituidas y otros solos, lo cual hizo que fueran configurando sus familias en la región a la cual llegaron y que sus hijos empezaran, algunos a crecer, y muchos otros, a nacer en esta región.

Así, fue emergiendo la colonia nariñense en Candelaria, con su historia, sus relatos, sus costumbres y sus "identificaciones" 7 , constituyéndose como colectividad "no solo en la interacción con grupos socioculturales diversos, sino a través de la producción de espacios de identificación en los que pueden desarrollarse disputas culturales y

\footnotetext{
${ }^{6}$ Nariñense que vivió el proceso migratorio en Candelaria.

${ }^{7}$ Las identificaciones aquí se entienden desde la propuesta que hace Hall, Stuart. 2003. «¿Quién necesita la identidad?» En: Stuart Hall y Paul du Gay (Eds.), Cuestiones de Identidad. Buenos Aires: Amorrortu Editores. En donde "Las identificaciones nunca se construyen plena y definitivamente; se reconstituyen de manera incesante y, por eso, están sujetas a la volátil lógica de la reiterabilidad. Son lo que se ordena, consolida, recorta e impugna constantemente y, a veces, se ve forzado a ceder el paso".
} 
políticas atravesadas por los modos de relacionarse con la "sociedad receptora"" Grimson, 2005, p. 26).

Inicialmente fueron teniendo lugar celebraciones religiosas tradicionales en Nariño como la fiesta de la Virgen de las Lajas, que empezó a celebrarse en Candelaria tras la iniciativa del padre Jorge Fierro (ver imagen 1), quien en 1983 convocó a un grupo de oriundos de Nariño y les propuso tal celebración, la cual a partir de dicha fecha empezó a llevarse a cabo anualmente, apoyada por el "Comité de Festejos" que los mismos nariñenses conformaron para liderar este tipo de certámenes y que hoy día es conocido como el comité de "los fiesteros" (ver imágenes 2 y 3 ).

Imagen 1. Fotografia del padre Jorge Fierro

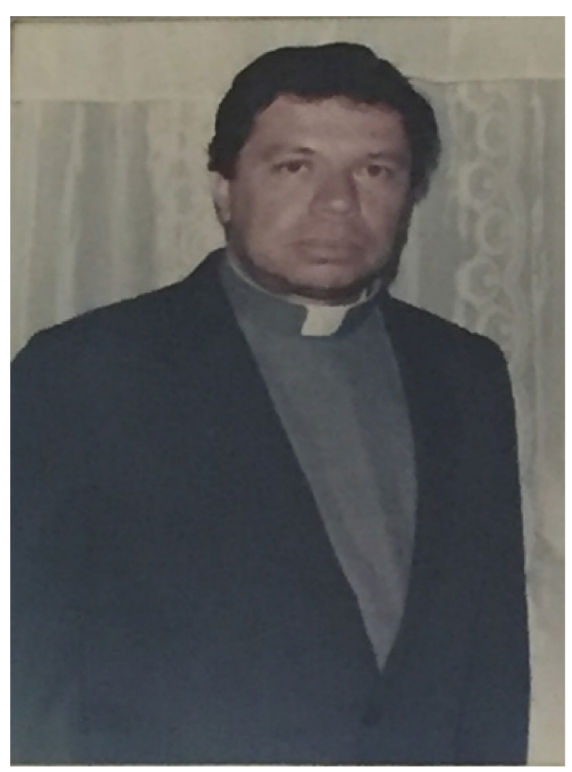

Fuente: fotografía tomada el 10 de diciembre de 2015 del archivo del despacho de la parroquia Nuestra Señora de la Candelaria, Valle del Cauca. 
Imagen 2. Primer año de celebración de la fiesta de la Virgen de las Lajas en Candelaria, 1983.

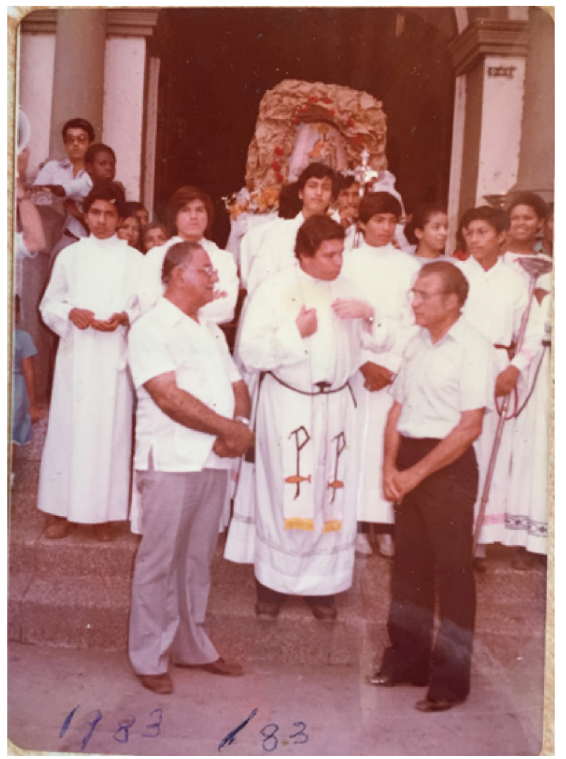

Fuente: fotografía tomada el 10 de diciembre de 2015 del álbum personal del señor Jorge Rodrigo Martínez

Imagen 3. Celebración de la fiesta de la Virgen de las Lajas en Candelaria. 1984.

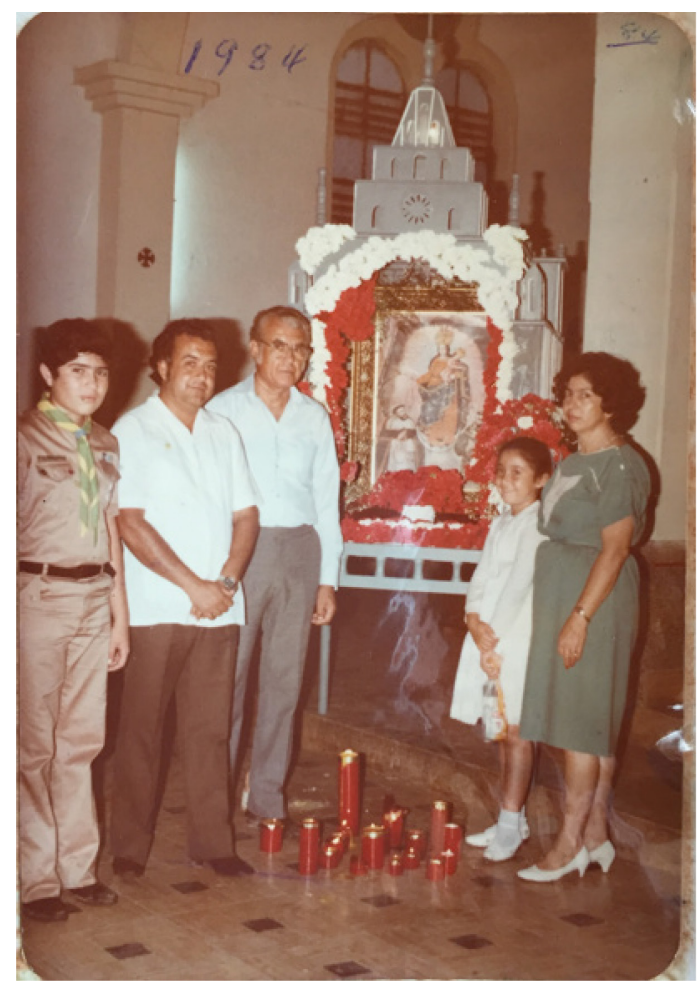

Fuente: Tomada el 10 de diciembre de 2015 del álbum personal del señor Jorge Rodrigo Martínez. 
Para el año de 1985, algunos miembros de la comunidad parroquial que para entonces ya estaba conformada por candelareños y nariñenses, decidieron organizarse y empezaron a trabajar en la configuración de la Sociedad parroquial de servicio social Nuestra Señora de Las Lajas del municipio de Candelaria (ver imagen 4), a través de la cual buscaron fortalecer y posicionar, no solo la celebración religiosa, sino otras actividades que vinculaban a la comunidad en general y que hoy día se conoce como la Fundación Nuestra Señora de Las Lajas.

Es de señalar que para el año de 1986, esta sociedad se constituyó legalmente con personería jurídica ante la gobernación del Valle del Cauca, entidad que para la época, reconocía tal figura; adquiriendo esta personería para propiciar y facilitar la interlocución con otros actores del municipio (alcaldía, organizaciones empresariales, comunidades, fundaciones) y para organizar los gastos de los dineros que los contribuyentes empezaron a aportarle a la sociedad conformada por los fiesteros (ver imagen 5).

La organización que logró el grupo (ver imagen 10), fue consolidando dentro del municipio una celebración de la Virgen de las Lajas cada vez más solemne, trayendo bandas musicales desde Nariño y posteriormente, mandando a pintar el oleo de la Virgen a un artista nariñense. Oleo que hoy día se encuentra en un altar dentro de la parroquia candelareña y que año tras año, es el que cargan en la procesión de la Virgen de las Lajas. (ver imagen 7) 
Imagen 4. Estatutos de fundación de la Sociedad parroquial de servicio social Nuestra

Señora de las Lajas en Candelaria. 1985

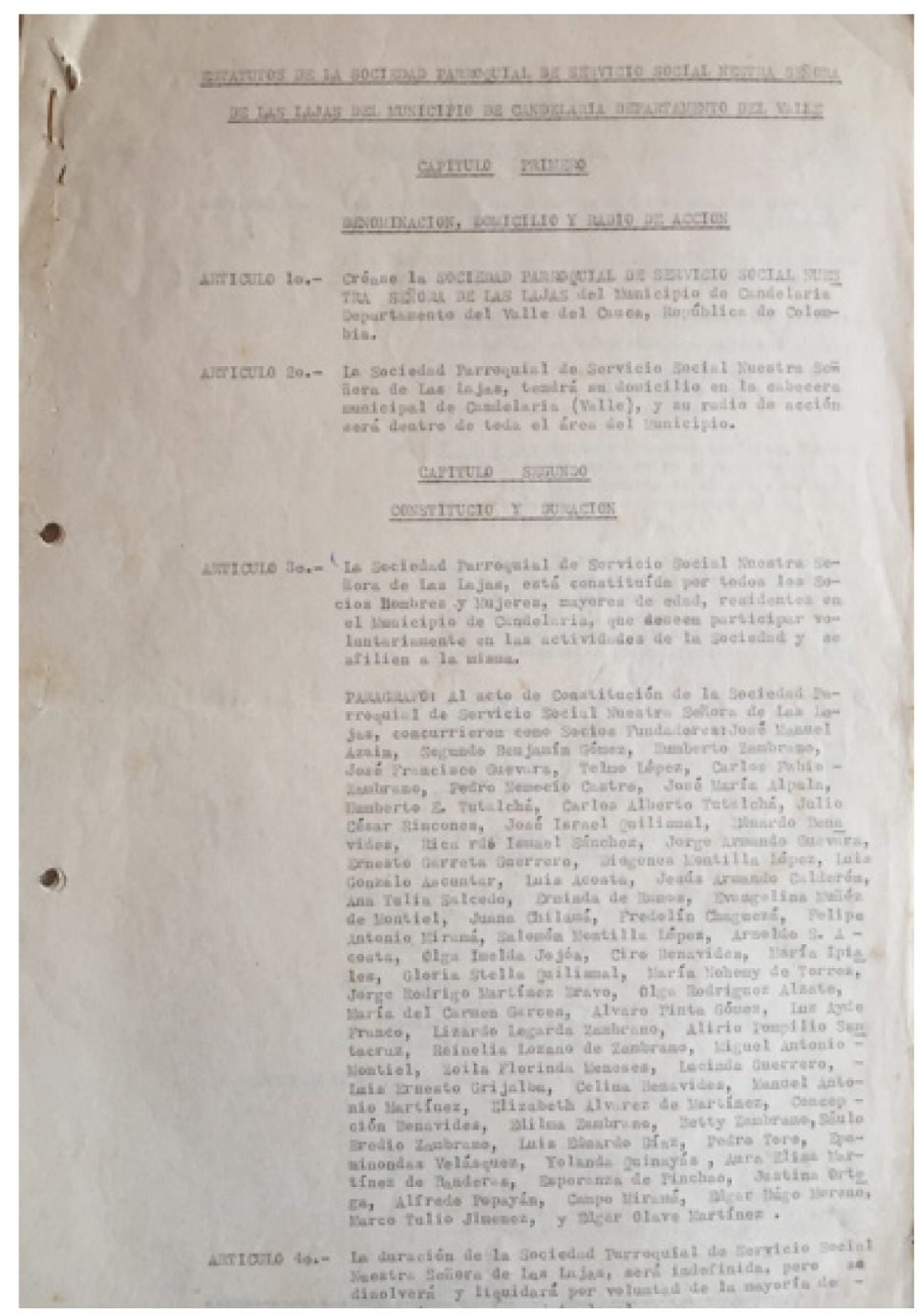




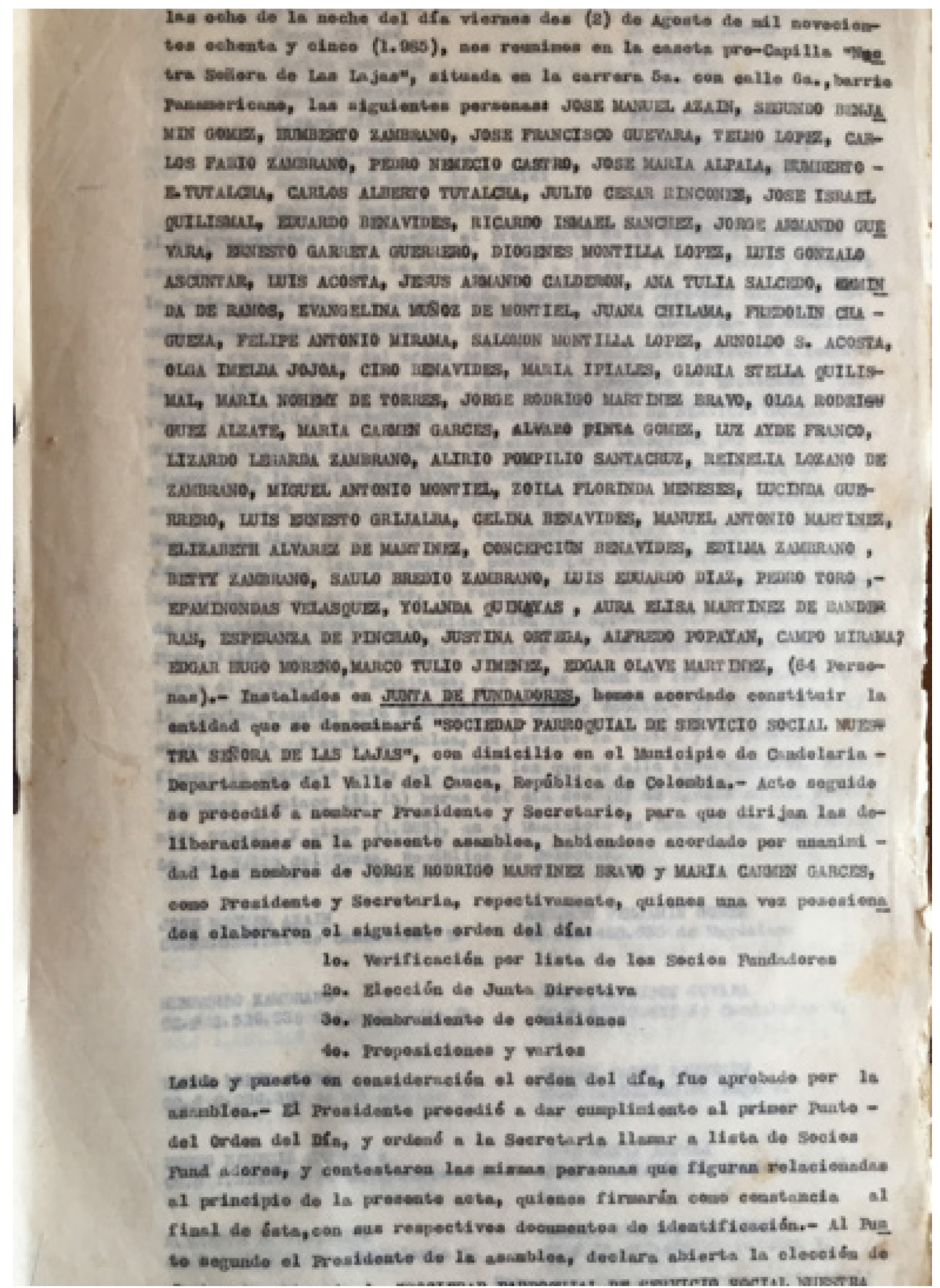




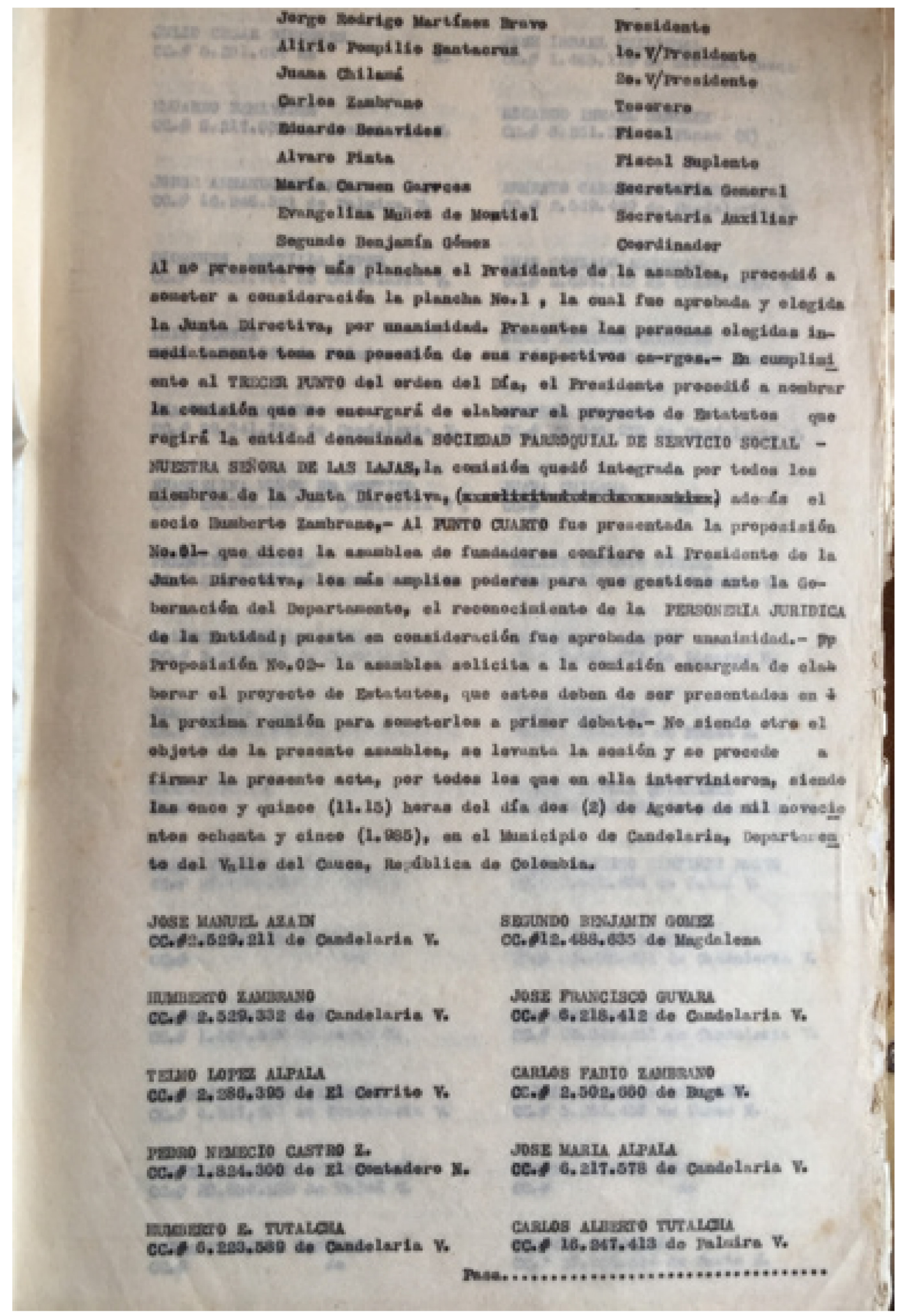




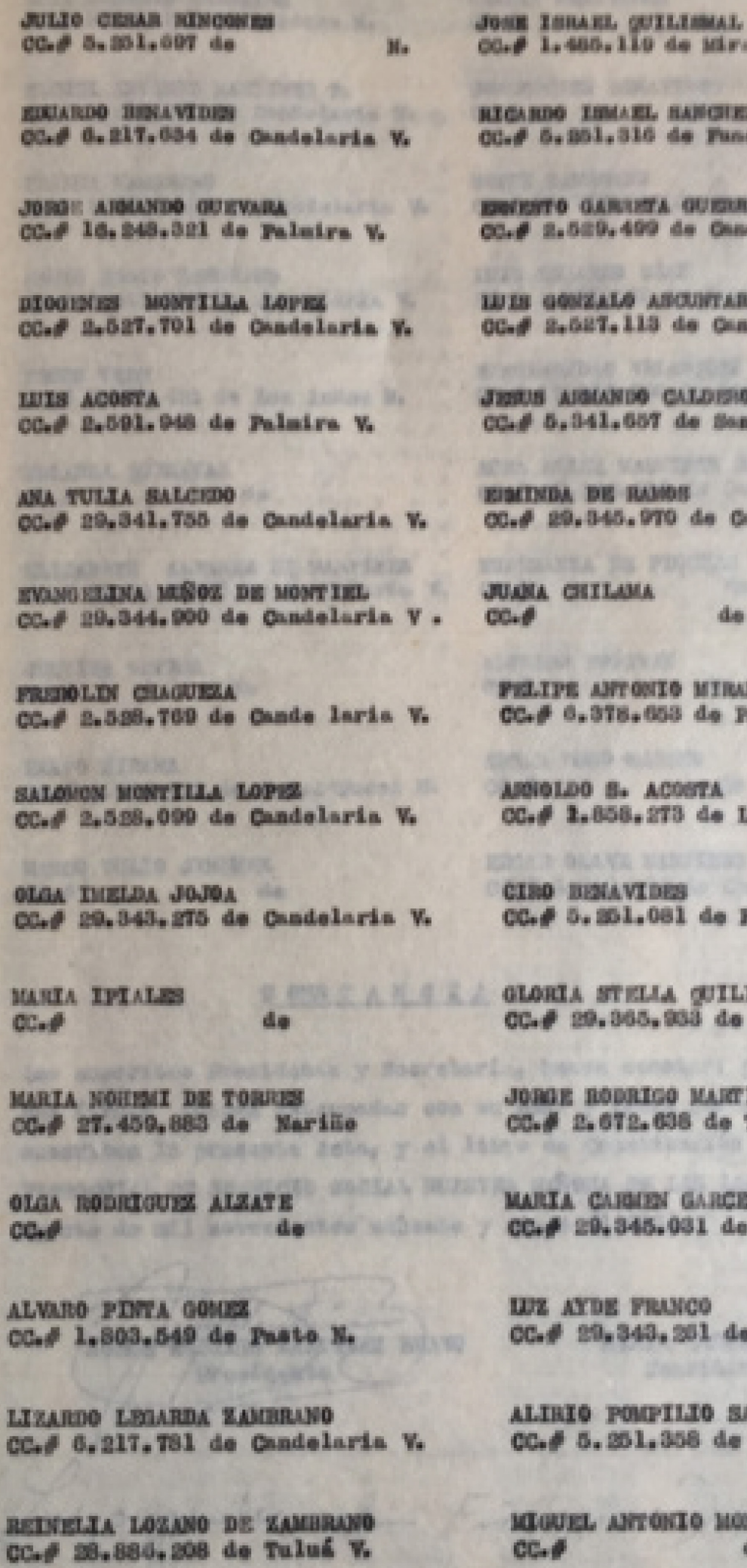




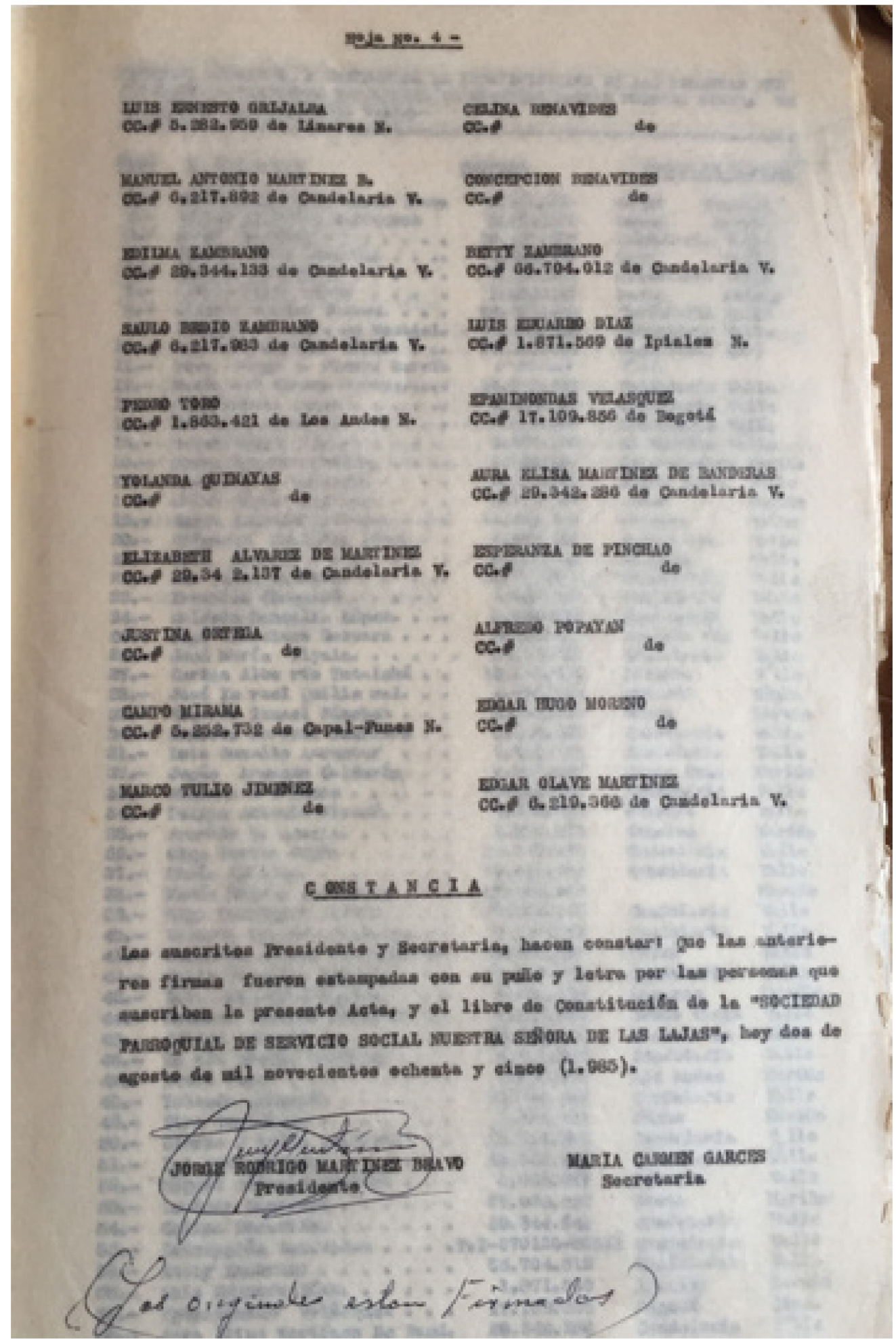

Fuente: fotografía tomada el 10 de diciembre de 2015 del archivo personal del señor Jorge Rodrigo Martínez. 
Imagen 5. Resolución de personería jurídica conferida a la Sociedad parroquial de servicio social Nuestra Señora de las Lajas en Candelaria. 1986

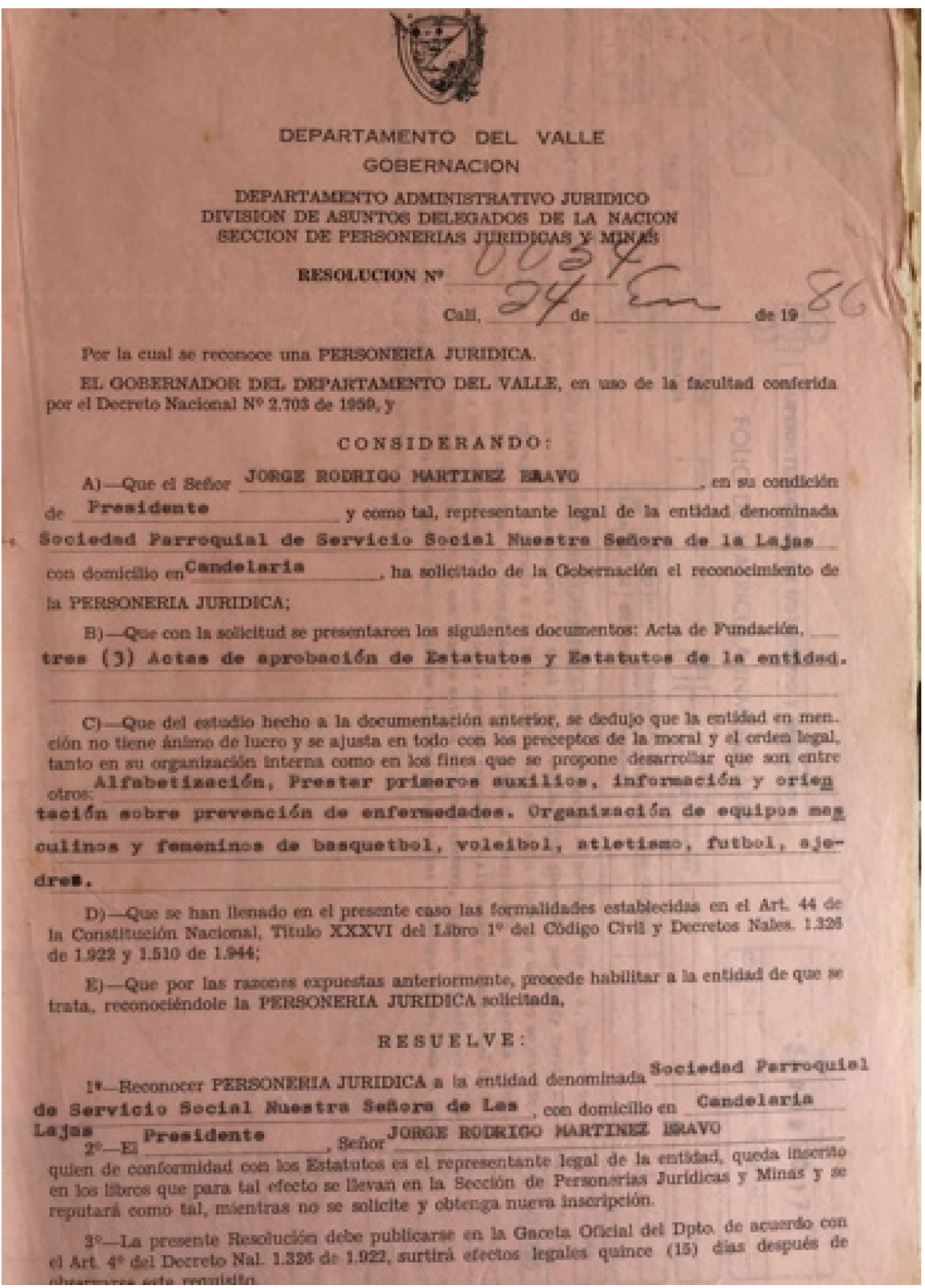

Fuente: fotografía tomada el 10 de diciembre de 2015 del archivo personal del señor Jorge Rodrigo Martínez. 
El festejo religioso culmina con una procesión y posteriormente con una fiesta cívica que inicialmente convocaba a la comunidad a reunirse alrededor del parque principal del barrio Panamericano y actualmente, en el parque principal del municipio alrededor del cual se encuentra la alcaldía municipal y la parroquia de Nuestra Señora de la Candelaria. (ver imágenes 6, 8 y 9)

Imagen 6. Procesión de la Virgen de las Lajas en Candelaria.

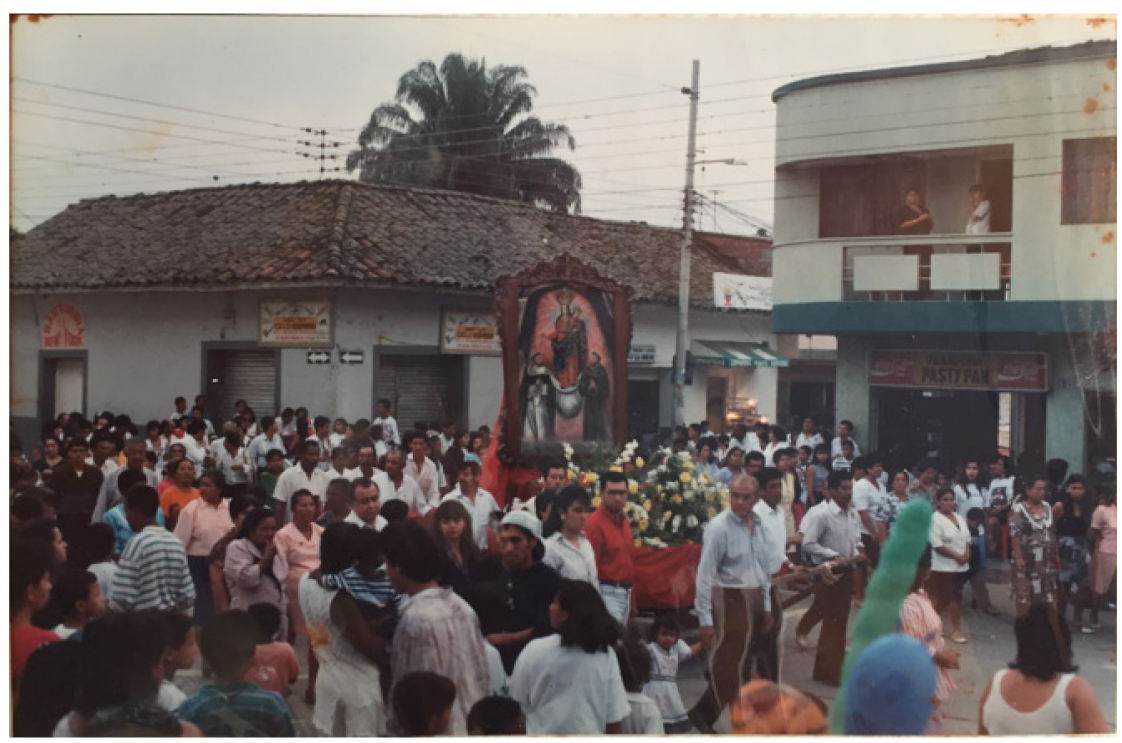

Imagen 7. Oleo a la Virgen de las Lajas en Candelaria.

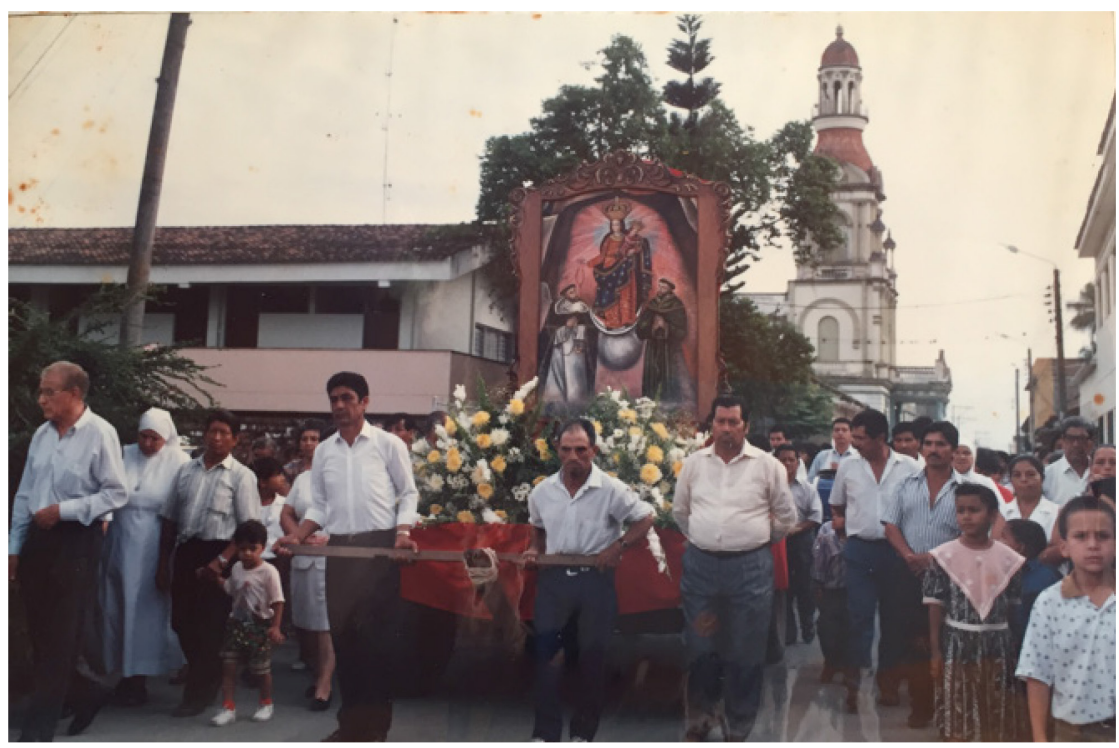


Imagen 8. Celebración de la fiesta de la Virgen de las Lajas en Candelaria. 1986.

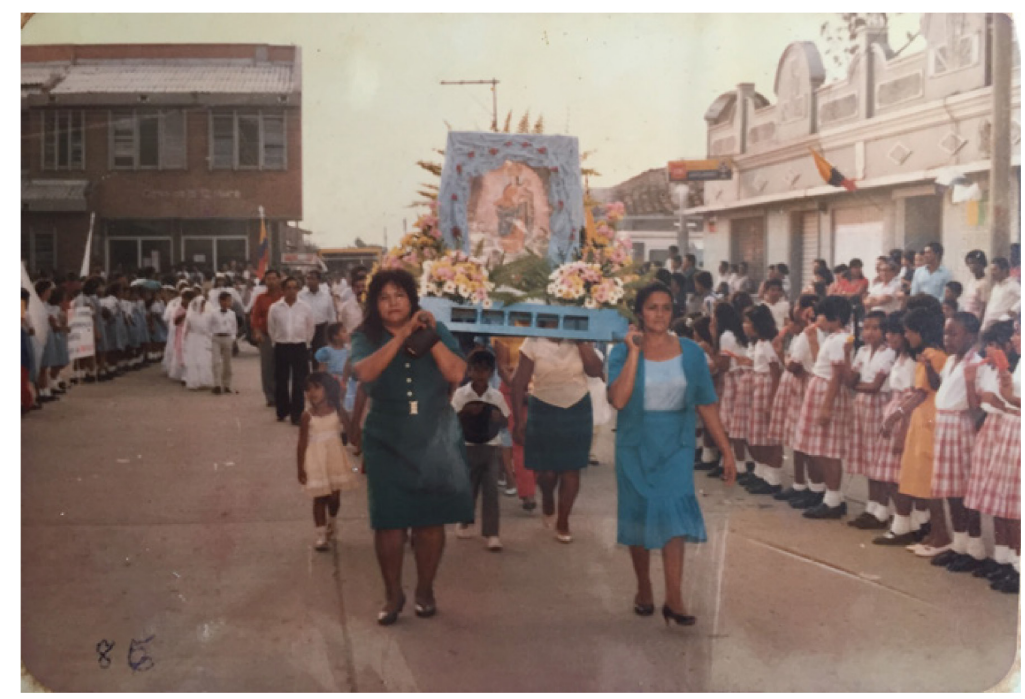

Imagen 9. Celebración de la fiesta de la Virgen de las Lajas en Candelaria. 1992.

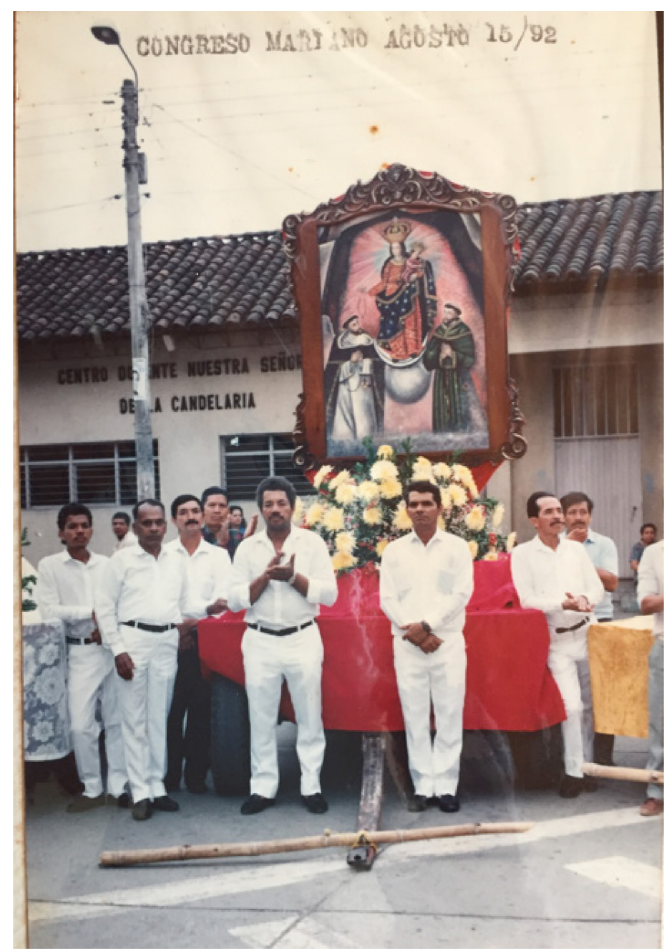

Fuente: Fotografías tomadas el 10 de diciembre de 2015 del álbum personal del señor Jorge Rodrigo Martínez. 
Imagen 10. Documento de la tesorería de la Sociedad parroquial de servicio social

Nuestra Señora de las Lajas en Candelaria. 1991.

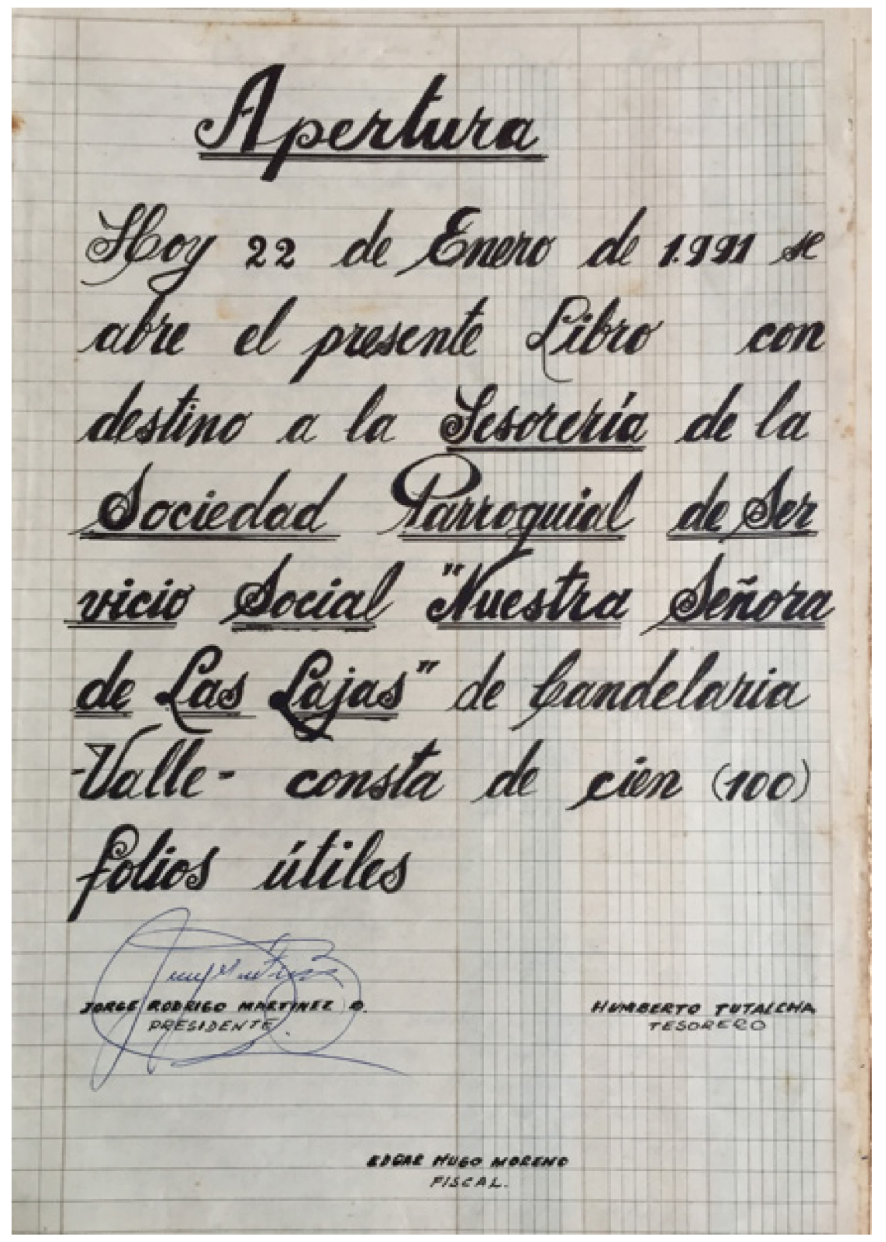

Fuente: fotografía tomada el 10 de diciembre de 2015 del archivo personal del señor Jorge Rodrigo Martínez.

Además de la institucionalización de la fiesta de la Virgen de las Lajas, en 1988 se institucionalizó también el carnaval de Blancos y $\operatorname{Negros}^{8}$ que en sus inicios convocaba

\footnotetext{
${ }^{8}$ Los orígenes de este carnaval (Celebrado en Nariño durante la primera semana de enero y celebrado en la misma época por la colonia nariñense en Candelaria) están ligados a las fiestas andinas ancestrales, a las que posteriormente se integraron tradiciones europeas y africanas. El 5 de enero, la población de esclavos negros celebraba "un día de libertad" y se lanzaba a las calles a revivir su música africana y en un gesto que expresaba su anhelo de igualdad, tiznaban con carbón a los blancos que encontraban a su paso. La alegría de la fiesta que desde entonces se le llamó la "fiesta de los negritos" contagió a los blancos que en muchas oportunidades participaron en la celebración. A finales del siglo XIX nuevos sectores sociales como el campesinado y los artesanos se integraron al carnaval para jugar un papel fundamental en la producción manufacturera; en este contexto aparece el 6 de enero como "el día de los blanquitos", día en que los
} 
la participación de las familias nariñenses en comparsas preparadas con la utilización de elementos, prácticas propias y danzas típicas de Nariño. Carnaval al que actualmente confluye la sociedad candelareña, habitantes del mismo Nariño, y personas de municipios del Valle del Cauca aledaños a Candelaria en un evento que año tras año, se celebra en enero con la participación de la reina del carnaval en un recorrido por las calles principales del municipio que antes culminaba también en el barrio Panamericano y que hace aproximadamente tres años, tiene lugar en la cancha de chaza o en el polideportivo del municipio (ver imágenes 12 y 13).

Imagen 11. Carpas de comida en la celebración del Carnaval de blancos y negros realizado en Candelaria, Valle del Cauca.

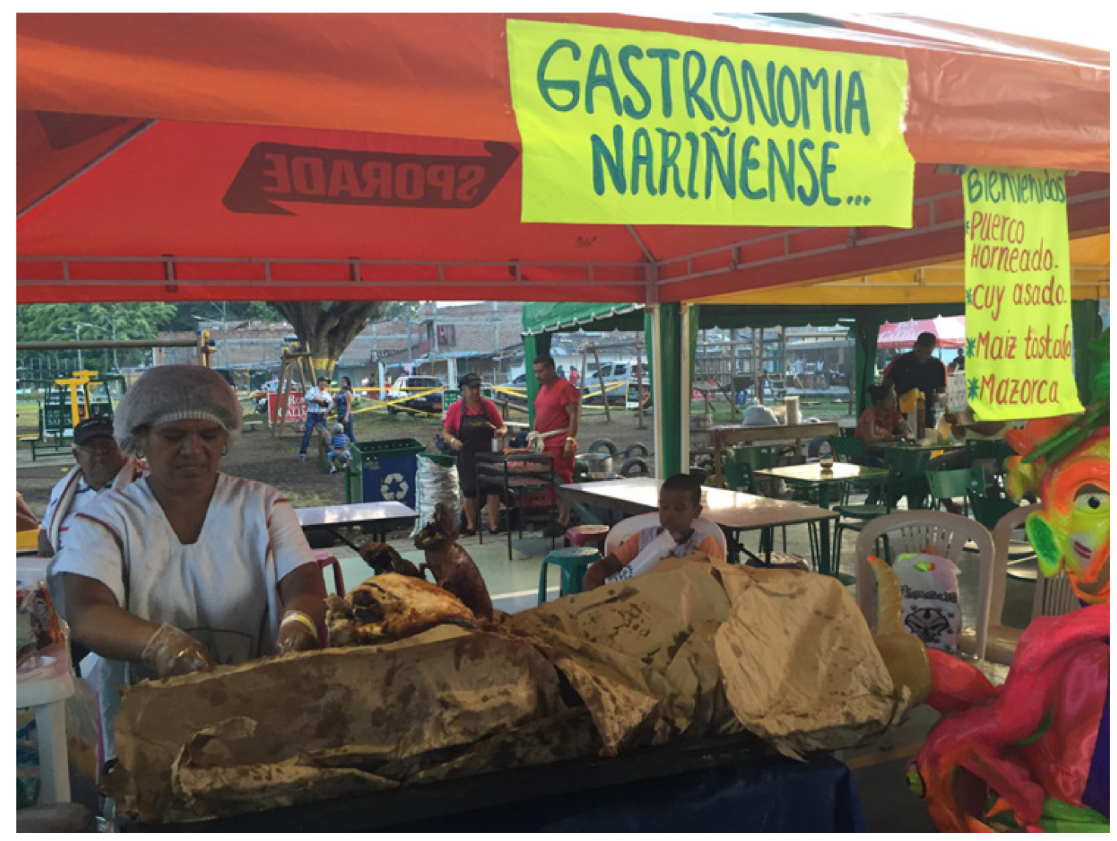

Fuente: fotografía tomada el 23 de enero de 2016.

artesanos de las carrozas participan desde 1920 con toda su creatividad y su trabajo manual plasmados en grandes esculturas de papel (Alcaldía municipal de Pasto, 2010) 
Imagen 12. Presentación de bailes típicos de Nariño en la celebración del Carnaval de blancos y negros realizado en Candelaria.

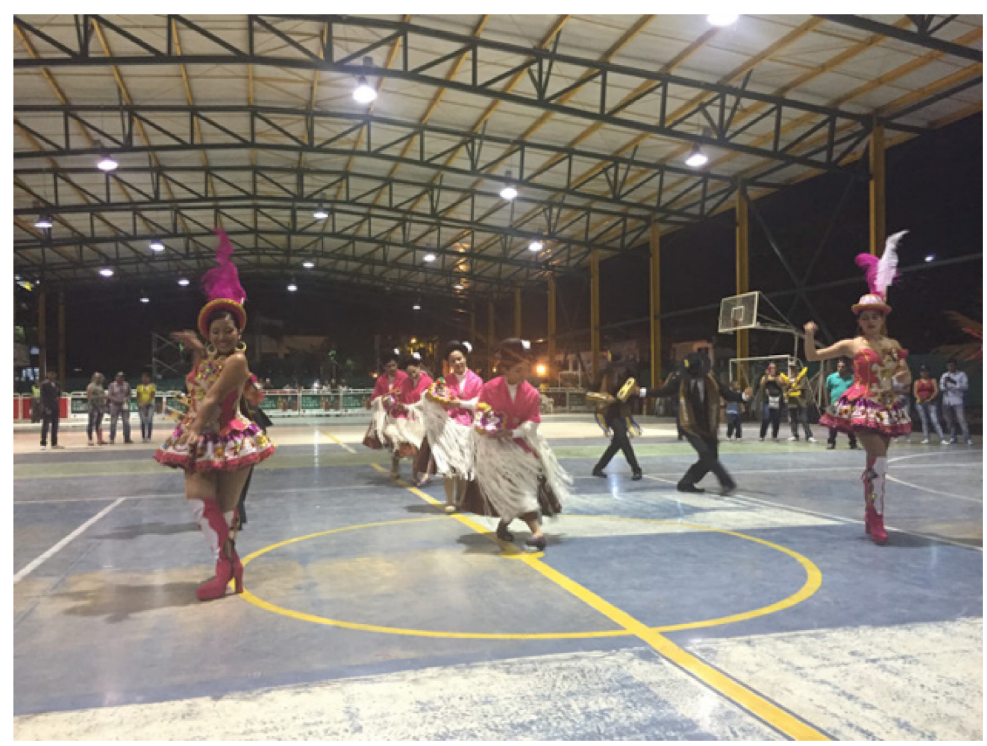

Imagen 13. Vestuario de bailes típicos de Nariño en la celebración del Carnaval de blancos y negros realizado en Candelaria.

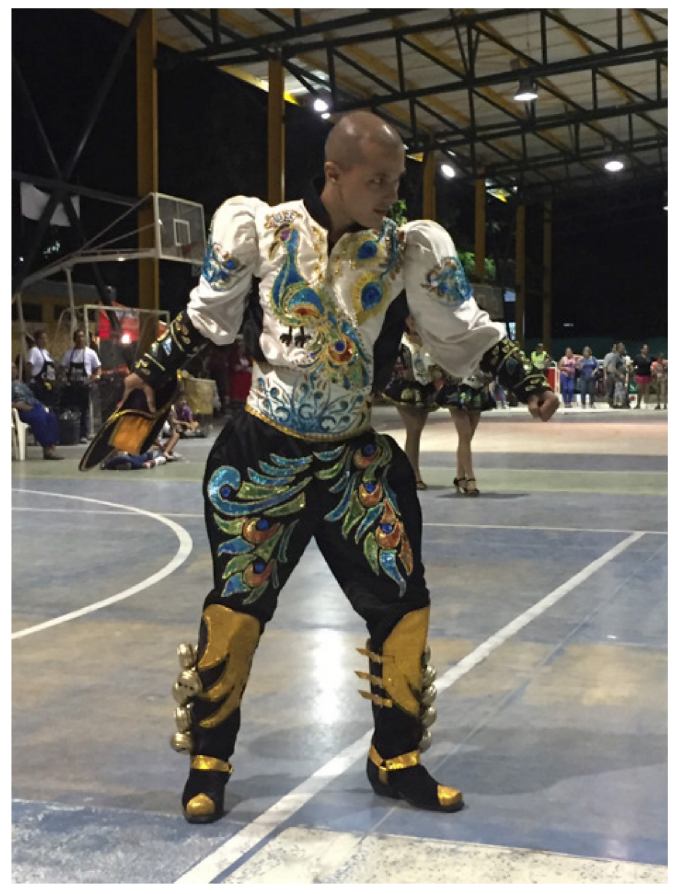

Fuente: fotografías tomadas el 23 de enero de 2016. 
Para el año de 1989, posterior a la conformación de un comité organizador de la festividad, la alcaldía municipal emitió el decreto 004, en el que institucionalizó el Carnaval de blancos y negros como una fiesta de Candelaria. Carnaval que en Pasto, Nariño, fue declarado por la UNESCO en el 2009, como patrimonio cultural e inmaterial de la humanidad ${ }^{9}$ y que desde finales de la década de los 80 , se celebra en Candelaria, un municipio del Valle del Cauca en donde sus habitantes cada año, un día del mes de enero, se pintan de blanco y negro (ver imagen 14) entre las comparsas y los bailes típicos de Nariño, bailan con la amenización musical de grupos nariñenses originales y viven el carnaval, tal como si estuvieran en Pasto (ver imagen 11).

Imagen 14. La gente del municipio de Candelaria pintándose de blanco y negro en la celebración del Carnaval de blancos y negros.

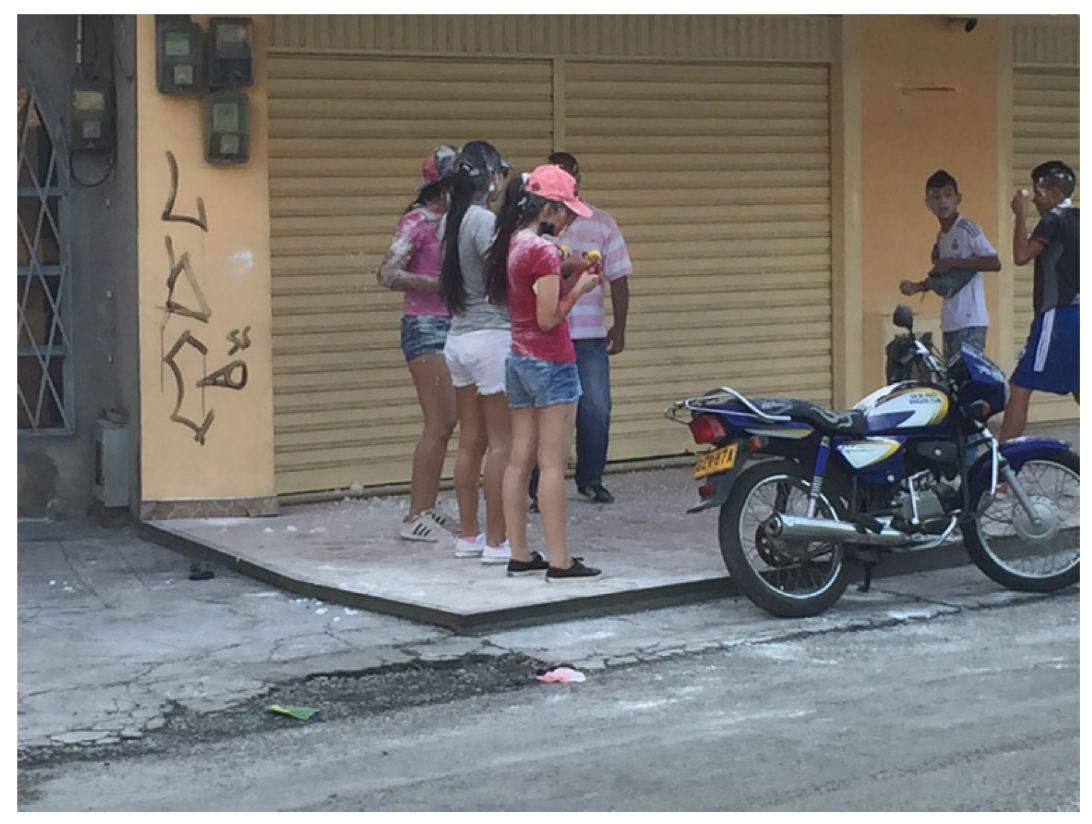

Fuente: fotografía tomada el 23 de enero de 2016.

\footnotetext{
${ }^{9}$ En el 2010, después de que la UNESCO declarara el Carnaval de blancos y negros como patrimonio cultural e inmaterial de la humanidad, el Ministerio de Cultura de Colombia lo incluyó en la lista representativa de patrimonio cultural inmaterial y aprobó un plan especial para la salvaguardia de esta festividad.
} 
También hay que mencionar que el juego de la chaza ${ }^{10}$ (ver imagen 15), un deporte tradicional del departamento de Nariño, es otra de las prácticas que los nariñenses trajeron a Candelaria. La cancha de chaza es hoy día un escenario multifuncional (ver imágenes 16, 17 y 18) en donde algunos se encuentran para jugar rana, otros a jugar naipe, muchos otros a jugar tejo, mientras que otros solo van a las casetas para escuchar música, observar el cotejo y compartir una cerveza. En general, el lugar donde se encuentra hoy la cancha se ha convertido en un espacio de encuentro para el municipio en general; y en el escenario en donde se llevan a cabo la mayoría de las celebraciones nariñenses dándose cita también la señora que vende la chicha o la que vende el helado de paila; productos típicos de la gastronomía nariñense.

\section{Imagen 15. Cancha de chaza ubicada en el Municipio de Candelaria}

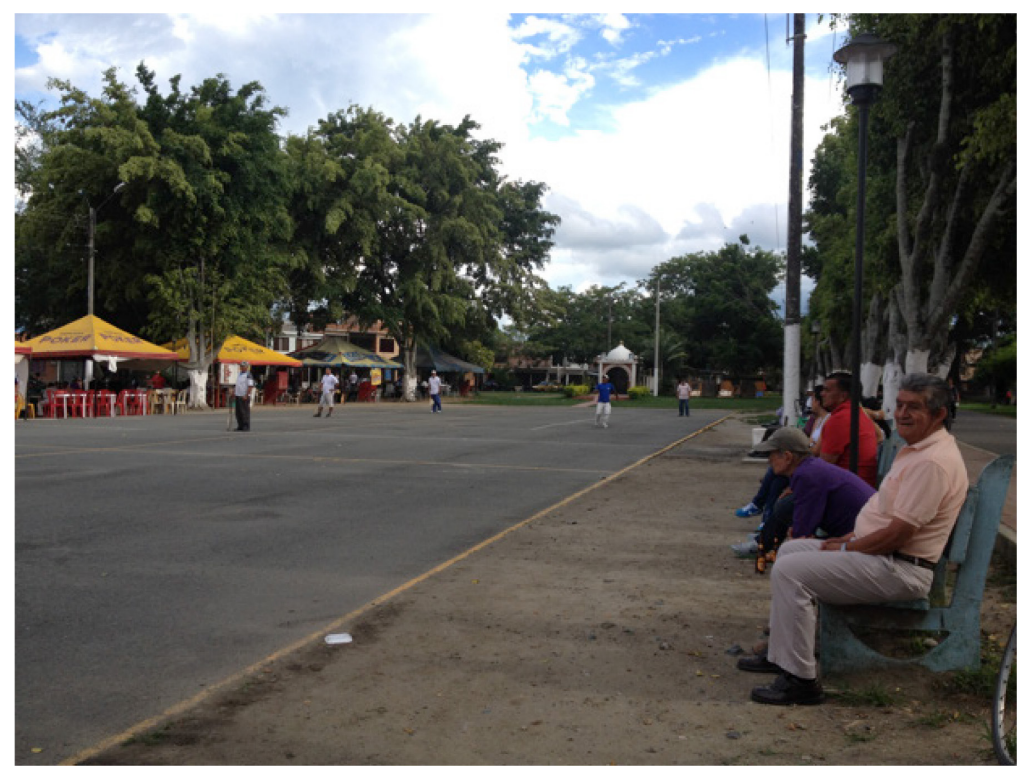

\footnotetext{
${ }^{10}$ El juego de chaza es originario de España. Posteriormente llegó a Perú, después a Ecuador y de ahí pasó a Nariño. De allí, y con la llegada de la comunidad oriunda de este departamento, llega el juego a Candelaria, municipio del Valle del Cauca, en donde se juega a la chaza desde 1968.

La construcción de la cancha que hoy día existe en Candelaria, es el resultado del esfuerzo mancomunado de la colonia nariñense que poco a poco fue uniendo fuerzas para lograr este espacio deportivo que hoy es un escenario multifuncional en el que no solo se juega a la chaza, sino que se ha convertido en un sitio de encuentro, de fiesta popular, en el espacio en donde se convocan las mujeres para jugar al tenis a las 6:00 de la mañana, más tarde, a eso de las 9:00, llegan los adultos mayores que hacen parte del grupo Vida, a realizar sus aeróbicos; también se presta para que los niños patinen, en la tarde los nariñenses juegan a la chaza y en la noche se juega al fútbol.
} 
Imagen 16. Canchas de tejo ubicadas en el lado superior de la cancha de chaza de Candelaria.

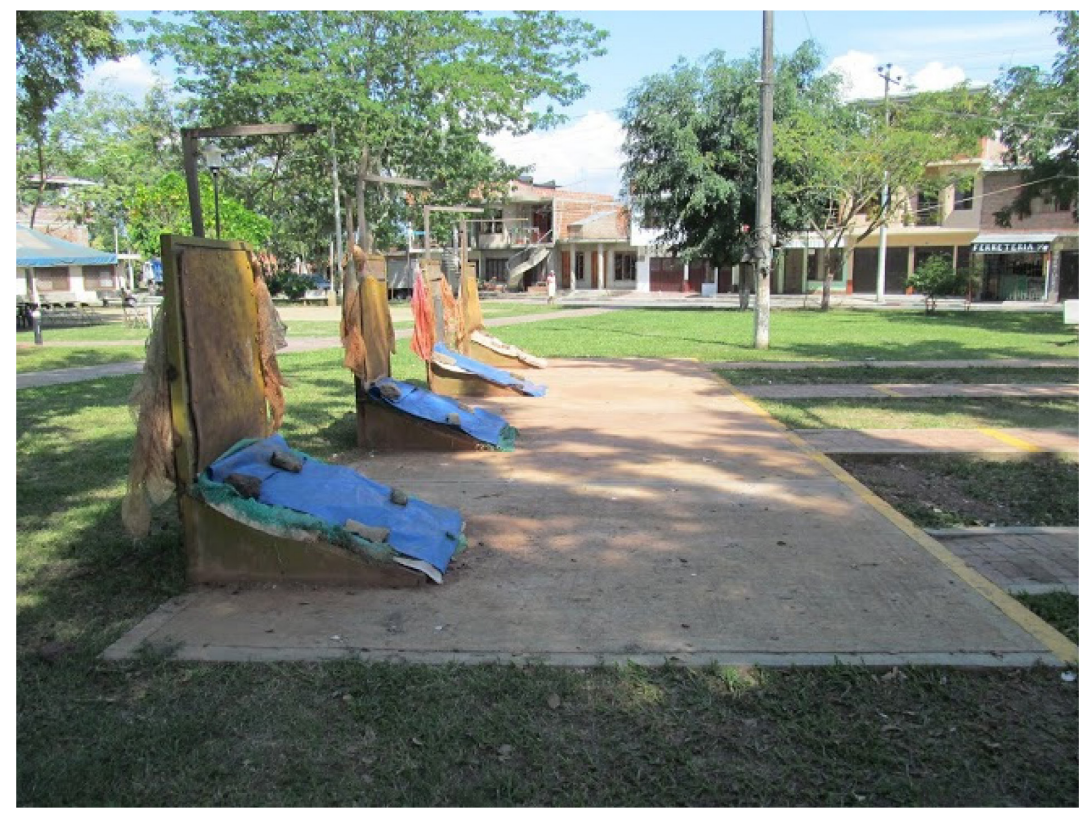

Imagen 17. Juego de rana ubicado en las casetas al costado de la chaza de Candelaria.

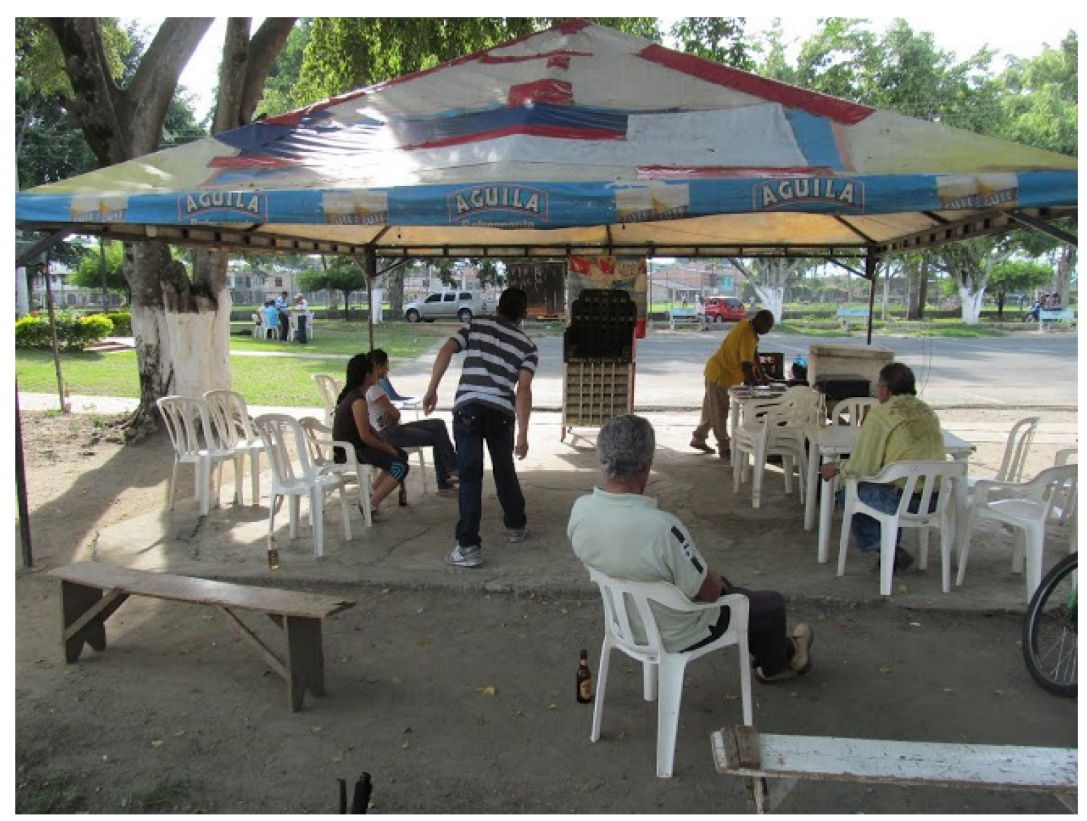


Imagen 18. Cancha de voleibol ubicada tras las casetas que se encuentran en la cancha de chaza de Candelaria.

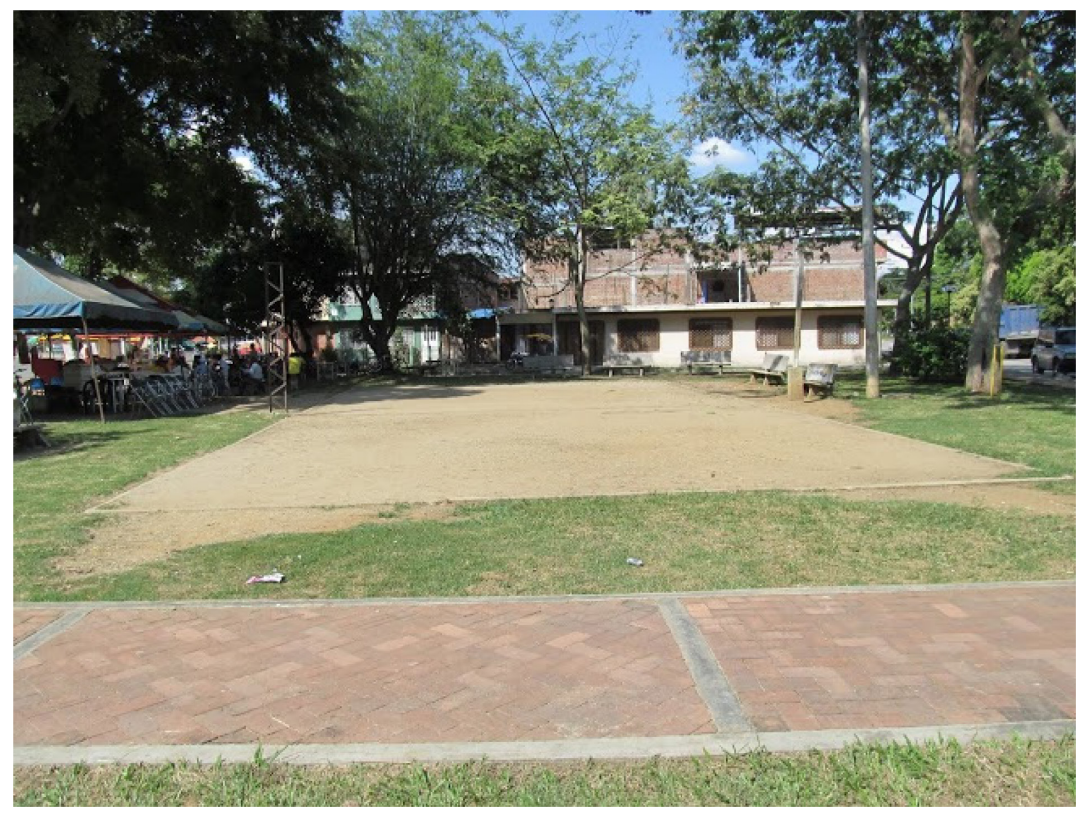

Fuente: fotografías tomadas en noviembre de 2013.

Los nariñenses cuentan hoy que para ese entonces (1968) la cancha era en tierra y estaba ubicada en donde hoy se encuentra el polideportivo del municipio. Después estuvieron ubicados en diferentes lugares hasta que en 1977 se les otorgó un terreno en comodato y en ese mismo año crearon la junta y la personería jurídica con el fin de organizarse. Dicha junta es la que hoy toma decisiones, administra el espacio, hace cumplir las normas, genera las sanciones cuando hay que hacerlas y autoriza o prohíbe la existencia de las casetas que se ubican alrededor, unas carpas de Bavaria cuyo impuesto lo cobra la junta directiva de la chaza ( $\$ 10.000$ a cada carpa, cada ocho días) para con este dinero facilitar el funcionamiento del lugar a través del pago de servicios públicos; pagar la premiación y la logística de los torneos de chaza liderados por ellos, o en el caso contrario, apoyar al grupo cuando deben realizar alguna salida para jugar en otra ciudad.

La definición de la personería jurídica y de la Junta de los Fundadores del Club de Chaza en 1977, se hizo, según el testimonio de algunos nariñenses, respondiendo a la solicitud del gobierno local que les exigió organizarse para poder apoyar sus iniciativas, 
"usted sabe que en toda parte hay política y la política dijo, vea ¿por qué no se organizan? nosotros les ayudamos" (Gabriel Pascuasa, entrevista personal, 2015). Fue así como surge la Junta, respondiendo a la necesidad de organizarse para lograr el propósito de construir la cancha de chaza, la que como recuerdan algunos "cuando nosotros principiamos a trabajar aquí, le mandamos una carta allá, al ingenio Mayagüez y el gerente nos dio 200 bultos de cemento para que pudiéramos seguir trabajando”. Alpala, comunicación personal (2015). Posteriormente, cada jugador aportó uno o dos bultos de cemento y su mano de obra y lograron construir la cancha que hoy es un terreno pavimentado de 100 metros de largo por 10 metros de ancho.

\subsection{El Valle del Cauca como uno de los principales receptores de la migración interna en Colombia.}

En este sentido, y considerando el papel del Valle del Cauca como departamento receptor de migrantes de diferentes procedencias, pero para el caso particular, de migrantes del departamento de Nariño, es importante indicar antes que el Valle del Cauca es un departamento que cubre $22,140 \mathrm{~km}^{2}$ del territorio colombiano y tiene una población total de 3.474.695 habitantes, lo cual lo ubica como el tercer departamento más poblado del país, con una densidad poblacional de 157 personas por kilómetro cuadrado. Agregando que su capital departamental, Cali, también representa la tercera ciudad más poblada del país, después de Bogotá y Medellín (OIM , 2001).

El Valle del Cauca es considerado un departamento cuya configuración ha estado siempre impactada por los diferentes grupos migratorios que han llegado a él; ubicándolo como uno de los departamentos con mayor índice de receptividad de migrantes internos en el país. Al respecto el DANE indica que la población nacida en otro territorio y que actualmente reside en el Valle del Cauca, corresponde a cerca de la tercera parte de la población total del departamento, que entre otras, es uno de los departamentos con mayor volumen poblacional en el país (DANE, 2012).

Así mismo el Valle del Cauca figura como un departamento con una de las mayores participaciones en inmigrantes recientes, con un $9.1 \%$ de población inmigrante sobre su total, ubicándose como el cuarto departamento con participación de inmigrantes, superado solo por Antioquia, Bogotá, D.C., y Cundinamarca. 
El Valle del Cauca también es considerado uno de los departamentos con menor tasa de emigración junto con Antioquia que ostenta tasas inferiores a veinticinco por mil habitantes. Así mismo, este departamento se constituye como uno de los mayores receptores de población junto con Cundinamarca, Casanare, Meta, Santander, Huila y el Eje Cafetero, con tasas que sobrepasan treinta migrantes netos por cada mil habitantes (DANE, 2012). Pasando a su papel como objeto de emigración, el Valle del Cauca es considerado un departamento integrado económicamente (tal y como se observará en la tabla 6 de distribución subregional), lo cual lo ubica como pionero en la región de la Costa Pacífica frente al papel de Nariño, ubicado en la misma zona de influencia (ver figura 2): la región de la Costa Pacífica, conserva sectores completamente aislados y empobrecidos, en los departamentos del Chocó, Cauca y Nariño. La costa pacífica del departamento del Valle está más integrada y cuenta con el puerto de Buenaventura, el único notable sobre esta costa (Martínez, 2006).

\section{Figura 2. Mapa Región Pacífico colombiana}

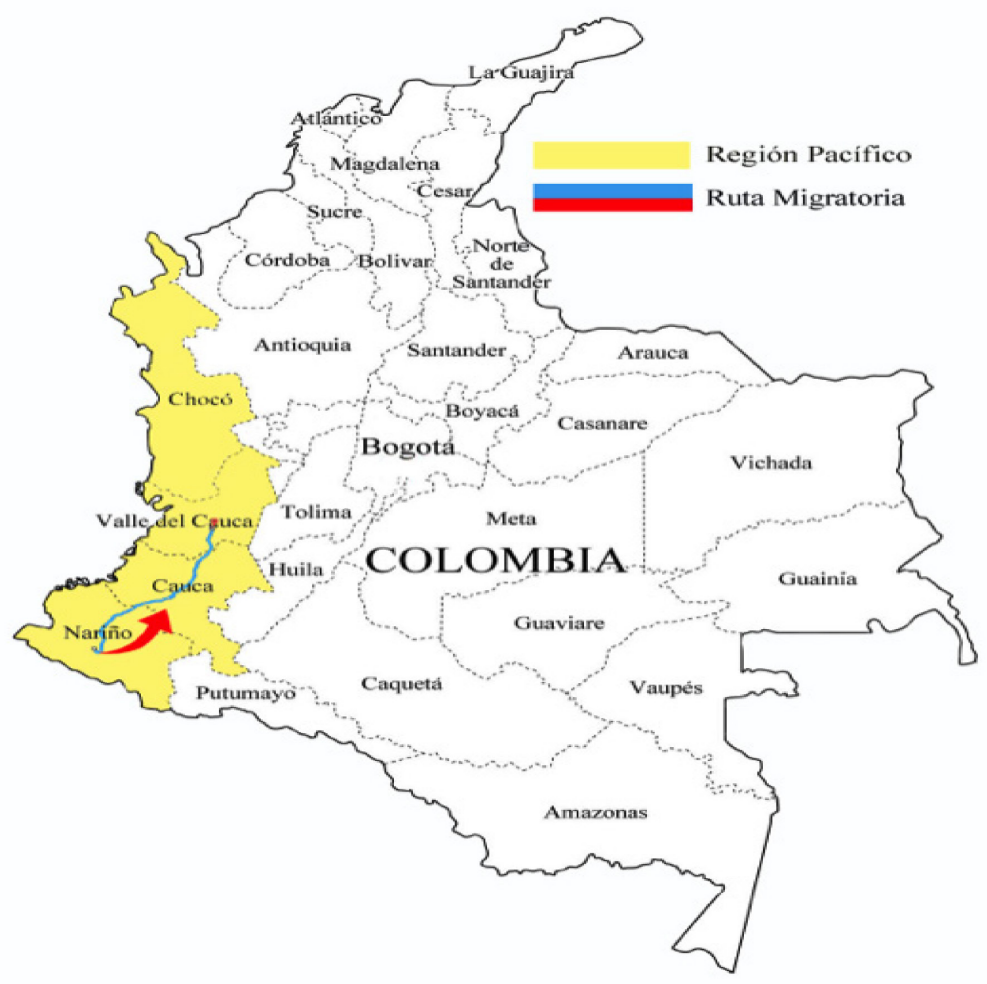

Fuente: construcción propia 
Lo que se reconoce hoy día como el territorio vallecaucano, objeto de una serie de subdivisiones que se han consolidado de la mano con el desarrollo económico y además con el conflicto armado, los procesos de asentamiento humano y su relación con el medio ambiente. Centro Nacional de Memoria Histórica (2014) de esta forma:

(...) los 42 municipios del departamento se distribuyen subregionalmente así: en la subregión norte 18 municipios; la subregión sur con la capital a la cabeza (Cali) y 11 municipios más; la subregión centro con 11 municipalidades y la subregión Pacífica, que... estaría conformada... por Buenaventura...Calima - Darién, Dagua y Jamundí...(Centro Nacional de Memoria Histórica, 2014, p. 30).

Simplificando la comprensión de la subdivisión propuesta por el Centro Nacional de Memoria Histórica y el Instituto Von Humboldt, el Departamento del Valle del Cauca deriva en las siguientes subregiones (Ver tabla 6):

Tabla 6. Distribución subregional del Valle del Cauca

\begin{tabular}{|c|c|c|}
\hline $\begin{array}{l}\text { DIVISIÓN } \\
\text { REGIONAL }\end{array}$ & TERRITORIOS & CARACTERISTICAS \\
\hline \multirow{8}{*}{ REGIÓN PACÍFICA } & \multirow{8}{*}{$\begin{array}{l}\text { Buenaventura } \\
\text { // Dagua }\end{array}$} & Potencial maderero \\
\hline & & Potencial pesquero \\
\hline & & Potencial Hídrico \\
\hline & & Potencial de biodiversidad \\
\hline & & Extracción de minerales \\
\hline & & Pesca \\
\hline & & Turismo \\
\hline & & Recreación \\
\hline \multirow{4}{*}{$\begin{array}{c}\text { ÁREA } \\
\text { METROPOLITANA }\end{array}$} & \multirow{4}{*}{$\begin{array}{c}\text { Cali // Yumbo // } \\
\text { Jamundí // } \\
\text { Palmira // } \\
\text { Candelaria }\end{array}$} & Potencial de valor agregado \\
\hline & & Potencial de empleo regional \\
\hline & & Potencial Industrial \\
\hline & & Potencial Agroindustrial \\
\hline
\end{tabular}




\begin{tabular}{|c|c|c|}
\hline & & $\begin{array}{l}\text { Centro de concentración de la Ley } 218 \text { de } 1996 \\
\text { (más conocida como la Ley Páez) de incentivos } \\
\text { tributarios en la transformación del aparato } \\
\text { productivo caucano y en la atracción de inversión } \\
\text { al departamento. }\end{array}$ \\
\hline \multirow{2}{*}{$\begin{array}{c}\text { EJE PRODUCTOR Y } \\
\text { TRANSFORMADOR } \\
\text { DE CAÑA DE } \\
\text { AZUCAR }\end{array}$} & \multirow{2}{*}{$\begin{array}{c}\text { Palmira // } \\
\text { Pradera // Florida } \\
\text { // Candelaria }\end{array}$} & Potencial Cañero \\
\hline & & Potencial Metalmecánico (Palmira) \\
\hline \multirow{3}{*}{$\begin{array}{c}\text { EJE } \\
\text { AGROINDUSTRIAL }\end{array}$} & \multirow{3}{*}{$\begin{array}{l}\text { Buga // Tuluá // } \\
\text { Roldanillo // La } \\
\text { Unión. }\end{array}$} & $\begin{array}{l}\text { Potencial productor y transformador de cultivos } \\
\text { comerciales }\end{array}$ \\
\hline & & Potencial de la industria láctea \\
\hline & & Potencial Viti-Vinícola \\
\hline \multirow{5}{*}{ ZONAS CAFETERAS } & \multirow{5}{*}{$\begin{array}{l}\text { Cartago // Sevilla } \\
\text { // Caicedonia }\end{array}$} & Potencial Ganadero \\
\hline & & Economía de subsistencia campesina \\
\hline & & Territorio Étnico Andino y del Pacifico \\
\hline & & Potencial Turístico-Recreativo \\
\hline & & Economías de servicios \\
\hline
\end{tabular}

Fuente: construcción propia a partir de Centro Nacional de Memoria Histórica (2014)

Nótese que en esta división regional del departamento, los municipios de Yumbo, Jamundí, Palmira y Candelaria conforman el área metropolitana, lo cual refiere una ubicación geográfica estratégica por su cercanía a Cali, ciudad capital del departamento, desde donde el sistema de transporte para estos cuatro municipios es constante y las vías de acceso y transporte entre ellos son múltiples. Incluso, así se menciona en el Plan básico de ordenamiento territorial del municipio cuando se afirma que,

el transporte terrestre y aéreo en el sector del Valle del Cauca ha sido fundamental en el desarrollo del departamento. La carretera Panamericana y la vía que une el interior del departamento con el puerto de Buenaventura han marcado ejes de progreso. En el caso del municipio de Candelaria la construcción del puente que 
une Cali con Juanchito determinó un punto de relación e influencia con la metrópoli caleña. (Alcaldía de Candelaria, 2004-2007, p.17)

Esta cercanía entre la capital vallecaucana y el municipio de Candelaria (ver figura 3), le ha generado a este, algunas ventajas y potencialidades desde el punto de vista económico, tanto por la presencia de grandes industrias como también por la aparición de algunos centros poblados entre Cali y Candelaria que necesariamente han dinamizado la movilidad desde y hacia la capital del departamento. Señalando que, la emergencia de estos poblados no ha respondido necesariamente a la planificación, como sí a la espontaneidad y necesidades de vivienda y movilidad de la población (Alcaldía de Candelaria, 2004-2007, p. 22).

Figura 3. Mapa área metropolitana del Valle del Cauca

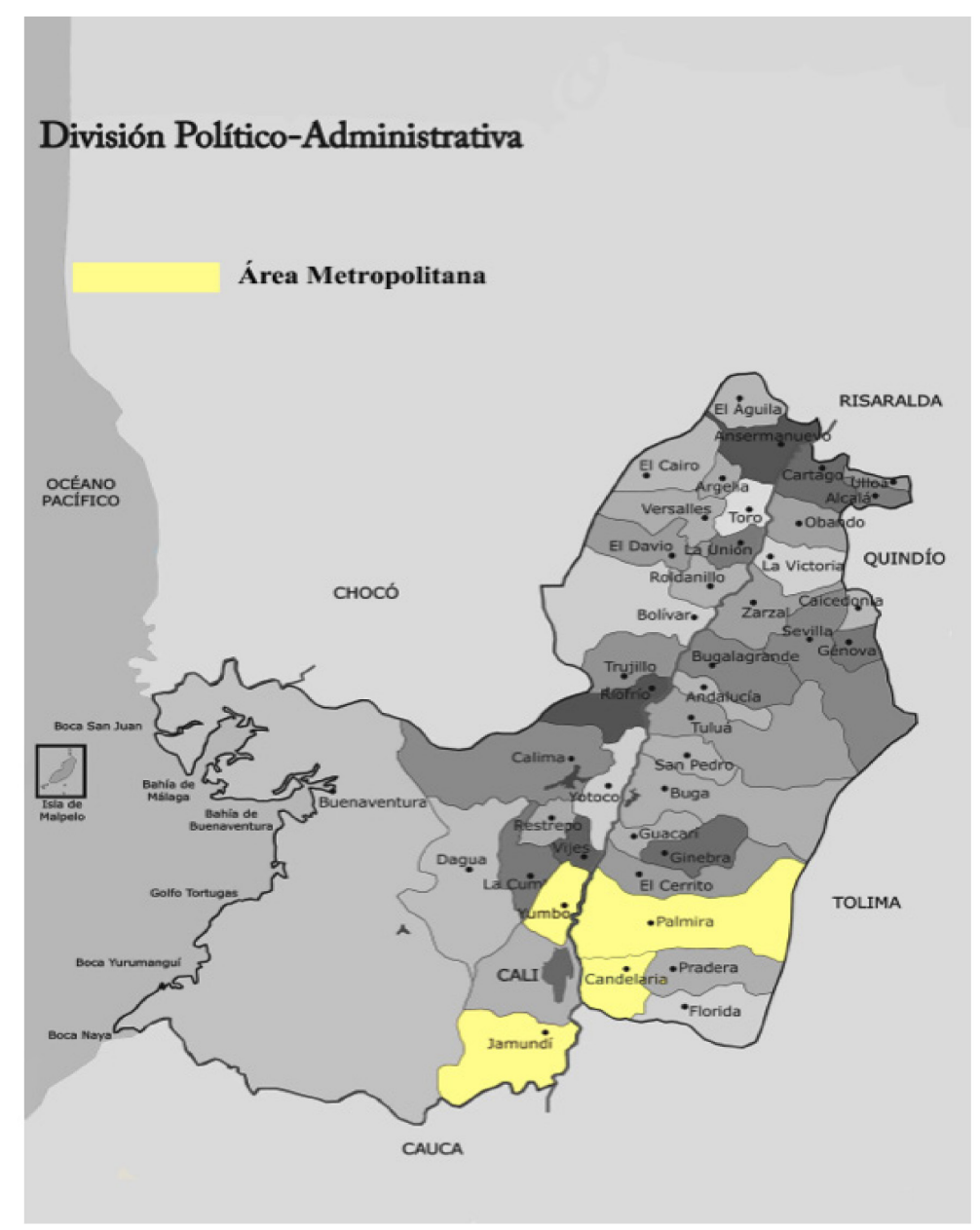

Fuente: construcción propia 
Por otra parte, también es de señalar que dentro de los eventos que permitieron la configuración regional del Valle del Cauca se pueden referir aquellos que menciona el Centro Nacional de Memoria Histórica (2014):

- La resistencia indígena ante la invasión española que se mantuvo hasta bien entrado el siglo XVII.

- Desplazamiento de las comunidades indígenas originarias.

- Legalización de la posesión de tierras a españoles, dando lugar a su propiedad y fundando los poblados de Vijes (1539), Cartago (1540), Roldanillo, Bolívar y Riofrío (1567), Buga (1569), Guacarí (1570), Toro (1573), La Unión (1603), Yotoco (1622), Tuluá (1639) y San Pedro (1795).

- Colonización interior adelantada por comunidades negras, mulatas y especialmente mestizas.

- La tenencia de la tierra, que desde el siglo XIX se había conformado como una estructura agraria diversa de pequeños y medianos propietarios que convivieron con la hacienda ganadera y cañera tradicional.

- Mantenimiento de una sociedad predominantemente rural gracias al estancamiento económico y mercantil, y el aislamiento geográfico del siglo XIX.

- La colonización antioqueña establecida en el territorio en un proceso de poblamiento disperso que inició a mediados del siglo XIX, producto de la cual emergieron los poblados de Zarzal (1809/1909), El Cerrito (1825), La Victoria (1835), Andalucía (1836), Obando (1840), Bugalagrande (1886), Alcalá (1891), El Águila y Versalles (1894), Sevilla (1903), Argelia (1904), CalimaDarién (1907), Ginebra (1909), Caicedonía (1910), Restrepo (1913), El Cairo (1920), Trujillo y Ulloa (1922) y El Dovio (1936).

- Aplicación del dominio de norte a sur practicado por los antioqueños, que aventajaron a los caucanos en su pretensión de colonizar la zona.

- El desarrollo de infraestructura vial y comercial en el siglo XX acompañado de la transformación y la consolidación de las haciendas tradicionales en ingenios azucareros de corte industrial. 
Este potencial que desde diferentes perspectivas representa el Valle del Cauca en el pasado y aún en la actualidad, lo ubica sin duda como un departamento con un papel protagónico en la atracción de comunidades migrantes, la mayoría de ellas cercanas a la región. Según el Centro de Memoria Histórica:

Para los años cincuenta, el Valle del Cauca había incursionado en un proceso de industrialización horizontal, que involucraba simultáneamente varios sectores de la economía, potenciando a la vez el crecimiento urbano y la emigración de población rural. (Centro Nacional de Memoria Histórica, 2014, p. 49)

Por otra parte y haciendo referencia a las tasas de urbanización, es de mencionar que el Valle del Cauca evidencia uno de los mejores comportamientos a nivel nacional, ubicándose como un centro tradicional de desarrollo y un polo de crecimiento, según lo indica la literatura. Silva y González (2009), situación que justifica el por qué el Valle del Cauca ha sido y es caracterizado como uno de los departamentos más receptores de migrantes y con mayor ganancia neta en el intercambio de nativos (Silva y González, 2009).

Sin embargo, el análisis contextual del Valle del Cauca y su papel protagónico sobre la migración de los nariñenses no puede dejar de lado la consideración de la industria azucarera teniendo en cuenta que en 1938 ya existían siete ingenios azucareros, en los que el $66,9 \%$ del total del suelo de su propiedad ya se encontraba sembrado con caña. Sin embargo, hasta los años cuarenta los azucareros todavía no constituían un subsector de la clase dominante, claramente diferenciado del estamento tradicional. Centro Nacional de Memoria Histórica (2014) incluso algunas referencias indican que para el año 1945, de los treinta y seis centros industriales de Colombia de acuerdo con el empleo industrial, seis pertenecían al Valle del Cauca y de los seis, tres se desarrollaban en la explotación azucarera (Gamboa y Moreno,1996).

La creación de la Asociación de Cultivadores de Caña de Azúcar de Colombia Asocaña, fundada el 12 de febrero de 1959, marca la organización del sector azucarero, teniendo en cuenta que al comienzo de los años cincuenta, ya existían cincuenta ingenios azucareros en el departamento (Centro Nacional de Memoria Histórica, 2014). E incluso, 
considerando que ya en la década comprendida entre 1930 a 1940, la producción azucarera se había duplicado, pasando de 14.052 .2 a 29.271 toneladas de azucar, triplicándose en las dos décadas siguientes (las de los años cuarenta y cincuenta) que pasó de 40.085.7 a 140.608 toneladas de azucar (Alcaldía de Candelaria, 2004-2007, p. 16).

Estas características fueron posicionando al Valle del Cauca como un departamento pujante. Agregando que históricamente la revolución cubana influyó en gran medida en este posicionamiento, debido al bloqueo económico y a la ruptura de relaciones que en 1962 se dio entre Estados Unidos y Cuba; justo en un momento en el que el papel de Cuba era protagónico como proveedor de azúcar refinada a los países del norte. Lo cual facilitó el escenario para que la producción azucarera en el Valle del Cauca tuviera un auge mayor y se convirtiera este en un departamento, como ya se ha mencionado, atractivo para los migrantes de los demás departamentos de la región en la primera mitad del siglo XX. Así lo revela la consulta bibliográfica, pues en la primera mitad del siglo XX también aparecieron en el Valle del Cauca los primeros ingenios azucareros, actividad que obtuvo renombrada importancia nacional con la expansión territorial del sector en la región, lo cual llevó a concentrar más de la mitad de la producción nacional a finales de la década de 1920.

El fuerte incremento en la demanda de azúcar desde los años treinta, intensificó y posicionó el monopolio de la actividad cañera del país en el departamento, al desaparecer los esfuerzos productivos en el Tolima y la región Caribe a comienzos de los años 40 . Todo lo anterior, y sumado con la apertura de los mercados externos en los 60, permitió al sector azucarero establecerse como la actividad agraria de mayor crecimiento y expansión en la región (Escobar, Moreno y Collazos, 2013).

\subsection{Candelaria, Valle del Cauca. Municipio receptor de la migración}

Según el Centro Nacional de Productividad (CNP), el crecimiento de la industria azucarera fue impulsado entre otros factores, por el aumento de la población derivada del proceso de migración hacia las ciudades en formación. Centro Nacional de Productividad, CNP (2002) dentro de las cuales, acorde con el interés investigativo del presente documento, no puede dejar de considerarse a Candelaria, Valle del Cauca, como 
eje de algunos de esos trayectos biográficos que permitirán posteriormente ilustrar la configuración de identidades migratorias en este municipio.

A pesar del prospecto económico que representa Candelaria, Valle del Cauca para la economía azucarera, de acuerdo con el informe del DANE en el año 2005, el porcentaje de Necesidades Básicas Insatisfechas del municipio es del 13.73\%, ubicándolo como uno de los más bajos del departamento. El 3.9\% no cuenta con vivienda, el $0.5 \%$ no tiene acceso a servicios públicos, el $13.9 \%$ se encuentra en hacinamiento, el $5.3 \%$ sufre de inasistencia escolar y el $12.9 \%$ es dependiente económicamente, tal y como lo señala un informe oficial de la alcaldía (Vásquez, 2008).

Candelaria se localiza al sur de la subregión central del Departamento del Valle del Cauca, limitando al norte con el municipio de Palmira, al oriente con los municipios de Pradera y Florida, al sur con el departamento del Cauca con los municipios de Puerto Tejada y Miranda y al occidente con el municipio de Cali. Su extensión total es de 285 $\mathrm{km} 2$, dividida en un área urbana de 0,275 km2 y un área rural de 289,16 km2. Su población es de 73.546 habitantes con una densidad poblacional de 232 habitantes por kilómetro cuadrado (Vásquez, 2008). Por otra parte, es importante tener en cuenta que la configuración del municipio de Candelaria, ha estado fuertemente influenciada por la migración interdepartamental (ver tabla 7), lo que revela el DANE (2005).

Tabla 7. Distribución porcentual de Candelaria a partir de la migración interdepartamental

\begin{tabular}{|c|c|}
\hline ORIGEN & PORCENTAJE \\
\hline $\begin{array}{c}\text { DE } \\
\text { CANDELARIA }\end{array}$ & 38,7 \\
\hline $\begin{array}{c}\text { DE OTRO } \\
\text { MUNICIPIO }\end{array}$ & 61,1 \\
\hline DE OTRO PAIS & 0,2 \\
\hline
\end{tabular}

Fuente: elaboración propia a partir de Departamento Administrativo Nacional de Estadística, DANE (2005) 
Lo que entre otras, permite soportar el que sea Candelaria justamente, uno de los municipios del Valle del Cauca, receptores de la colonia nariñense. El municipio de Candelaria figurara entre los centros azucareros que para 1945 se había desarrollado junto con el Cerrito y Zarzal y aunque la caña no era el único producto cultivado, si se consolidó como el más proyectado hacia el fortalecimiento de la economía del Valle del Cauca (Gamboa y Moreno, 1996).

Según Gamboa y Moreno (1996), la producción azucarera de Candelaria para el año de 1959 sería de 7.824 hectáreas, una producción mucho más alta en relación a sus otros cultivos, que incluían banano, cacao, café, limón, naranja, plátano, piña y uva. De los anteriores solo le seguiría en tamaño el café, con 729 hectáreas, lo que permite identificar la importancia del cultivo azucarero para el municipio. Sin embargo, es importante mencionar también que en la actualidad existe una marcada disminución del aporte del municipio a la economía azucarera, representando un área sembrada actual, de solo 174 hectáreas, situación que puede justificar la situación precaria actual, presentada por su alcaldía en sus informes oficiales (Vásquez, 2008).

Por su parte, el Ingenio Mayagüez es uno de los ingenios azucareros que en mayor medida aportó y aún aporta a la explotación azucarera en el municipio y en el departamento. Este Ingenio, cuyo inicio de operaciones se registra en 1937, representó el mayor aporte en soluciones de empleo para los habitantes del municipio e incluso, con el aumento en la demanda de caña de azúcar, el ingenio tuvo que ampliar su oferta de trabajo para atraer mano de obra de otros municipios y departamentos. Su historia de conformación, permite argumentar el interés migratorio del departamento de Nariño al municipio de Candelaria, ya que en el año de 1956, este complejo industrial contribuía a la producción nacional del azúcar con 17.000 toneladas (Gamboa y Moreno, 1996), requiriendo para dicho nivel productivo, mano de obra no calificada que se dedicara sobre todo, a las labores de cultivo y corte de caña.

Por esta razón, el Ingenio Mayagüez empezó a liderar actividades de enganche en departamentos como Nariño, pagando a contratistas para que viajaran con el objetivo de enganchar con sus ofertas laborales a esa fuerza de trabajo que en el momento era tan necesaria. Convirtiéndose, dichos enganches, en la primera oleada de migrantes 
provenientes de Nariño al municipio de Candelaria y la segunda oleada, después de 1965, producto ya de las decisiones personales de algunos nariñenses que viajaron motivados por las historias de los paisanos que ya habían emigrado. Lo cual devino además, en un crecimiento acelerado de la población candelareña entre mitad de los años sesenta y principios de los años noventa (Ver tabla 8).

Es importante mencionar que los enganches que realizaba el Ingenio, los hacía en zonas del departamento de Nariño en las que tradicionalmente se había dado el cultivo de caña para justamente atraer mano de obra con conocimiento sobre su cultivo y su corte. Por esta razón, se encuentra una gran mayoría de migrantes nariñenses provenientes de pequeños municipios como Samaniego, Sandoná y Ancuyá.

Dicha gestión empresarial tuvo tres consecuencias principales que impactaron directamente la dinámica de la migración interna; la primera, la oferta de trabajo en las modernas y complejas instalaciones de la fábrica; la segunda, la oferta de trabajo en el campo para labores de siembra, riego y corte de la caña, así como también en otros oficios dentro de los que se incluía el de limpieza, mantenimiento de cercos entre otros. Y la tercera, la generación de trabajo para contratistas, tanto para el ingenio como para los proveedores de servicios de cultivo y otros (Gamboa y Moreno, 1996). Esta situación significó:

(...) la influencia directa de la inmigración de personas o grupos, especialmente nariñenses a Candelaria, acrecentando el número de población, situación que es positiva en aspectos como la solución para la demanda de mano de obra requerida por el municipio para el desarrollo de la agroindustria, también en la ampliación del mercado interno de Candelaria. Pero negativa porque el desmesurado crecimiento de la población, traerá en un futuro no muy lejano, altas tasas de desempleo. (p. 52) 
Tabla 8. Crecimiento de la población de Candelaria, Valle del Cauca

\begin{tabular}{|c|c|c|c|c|c|c|}
\hline AÑOS & $\mathbf{1 9 5 1}$ & $\mathbf{1 9 6 4}$ & $\mathbf{1 9 7 3}$ & $\mathbf{1 9 8 5}$ & $\mathbf{1 9 9 3}$ & $\mathbf{2 0 0 5}$ \\
\hline $\begin{array}{c}\text { TAMAÑO } \\
\text { CENSAL }\end{array}$ & 17174 & 27435 & 33761 & 47073 & 61247 & 70296 \\
\hline DIFERENCIA & 0 & 10261 & 6326 & 13312 & 14174 & 9049 \\
\hline $\begin{array}{c}\text { CRECIMIENTO } \\
\text { PORCENTUAL }\end{array}$ & 0 & $59,70 \%$ & $23,06 \%$ & $39,43 \%$ & $30,11 \%$ & $14,77 \%$ \\
\hline
\end{tabular}

Fuente: Construcción propia a partir de Centro Nacional de Memoria Histórica (2014)

Dentro de las preocupaciones que alertaban del riesgo por cuenta de la alta migración nariñense al municipio, se encontraban los diferentes proyectos que buscaban tecnificar el corte de caña, uno de los procesos que en mayor medida aportaba a la generación de empleo. Así mismo, se contemplaban los riesgos asumidos por la explotación laboral ejercida sobre todos aquellos jóvenes que serían pagos con salarios irrisorios, adicional a la falta de seguridad laboral y social (Gamboa y Moreno, 1996).

Hay que mencionar también que en el marco del desarrollo agroindustrial que tuvo Candelaria, hacia finales de la década del 70 el municipio dispuso un terreno para la construcción de viviendas, dando origen al que actualmente es el barrio Panamericano que en su momento y aún hoy, es el más grande de la cabecera municipal (Ver figura 4). Esta disposición del municipio y posteriormente, al inicio de la década de los 90 , una disposición de otro terreno por parte del Ingenio Mayagüez para la construcción de lo que hoy se conoce como el barrio Santa Ana, y que en el momento surgió como una urbanización con el fin de beneficiar a algunos de sus trabajadores que aún no tenían casa propia (ver imagen 19), fueron oportunidades aprovechadas por los migrantes de Nariño para mejorar sus condiciones de vida en el municipio ya que la mayor parte de los lotes, le fueron adjudicados a personas de este origen. 
Figura 4. Mapa barrios del municipio de Candelaria ${ }^{11}$

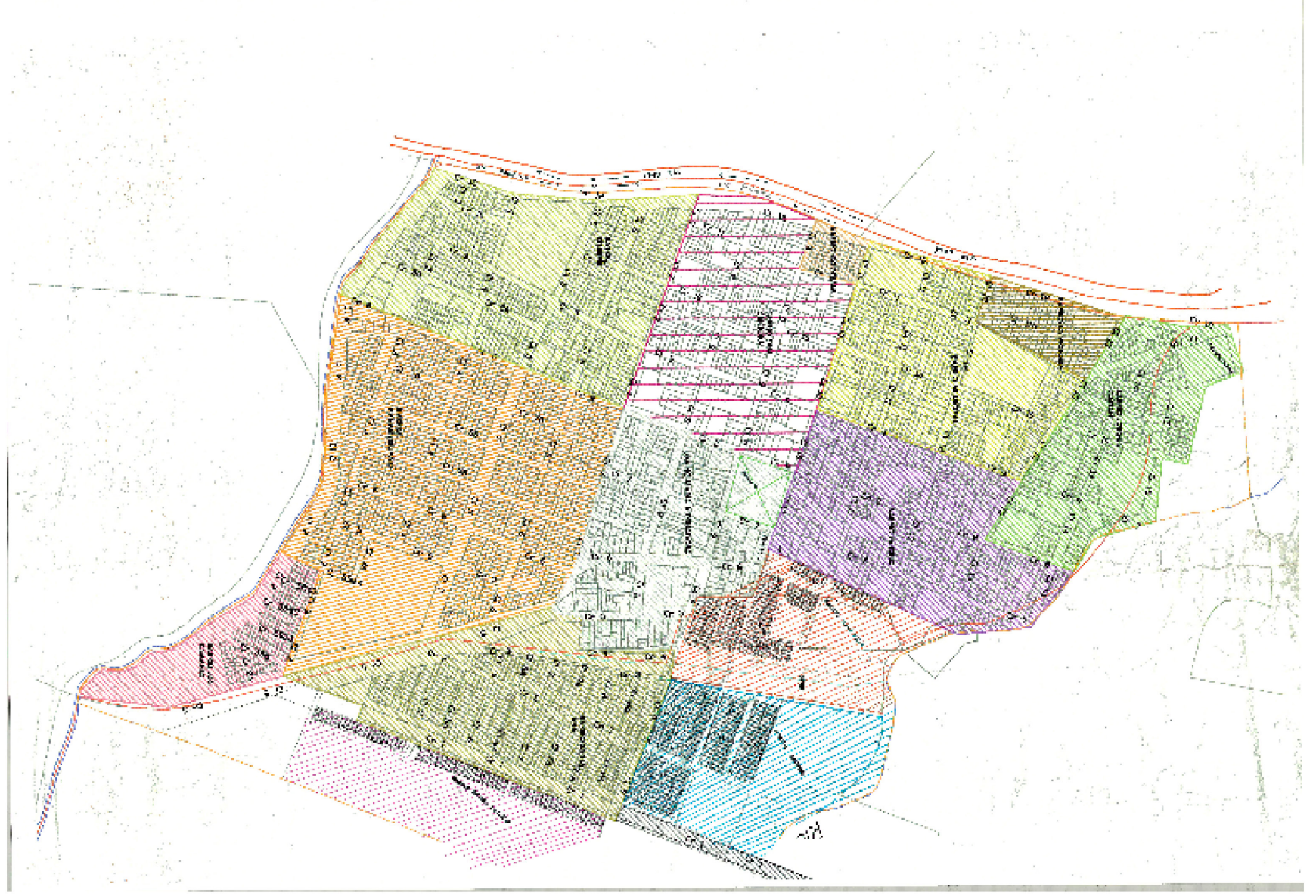

Fuente: tomado de la Parroquia Nuestra Señora de la Candelaria.

\footnotetext{
${ }^{11}$ Es importante tener en cuenta que el mapa que presenta la distribución del municipio por barrios, aportado por la parroquia, presenta trazados los barrios Zaffra y Llano Dulce que aunque en efecto existen, aún no se encuentran oficialmente en el mapa aportado por la Alcaldía de Candelaria.

Teniendo en cuenta el valor de los recorridos urbanos y el imaginario que sus habitantes tienen de su territorio, se decide trabajar con el mapa aportado por la Parroquia, en tanto el trabajo de campo realizado, permite dar cuenta de la existencia de estos barrios.
} 
Es de mencionar que aunque en el momento de llegada de la colonia nariñense, esta se concentró en los barrios que se mencionan, hoy día, su presencia en el municipio no se encuentra tan localizada ya que los nariñenses, sus celebraciones, prácticas deportivas y festividades, tienen lugar en todos los barrios de Candelaria y movilizan la gestión y apoyo de las diferentes instituciones del municipio (Ver imagen 20) que tal como se verá en la fotografía, hacen sus aportes para llevar a cobo las diferentes prácticas nariñenses.

Imagen 19. Documento de donación de la urbanización Santa Ana, que el Ingenio Mayagüez le hizo al municipio de Candelaria en 1989.

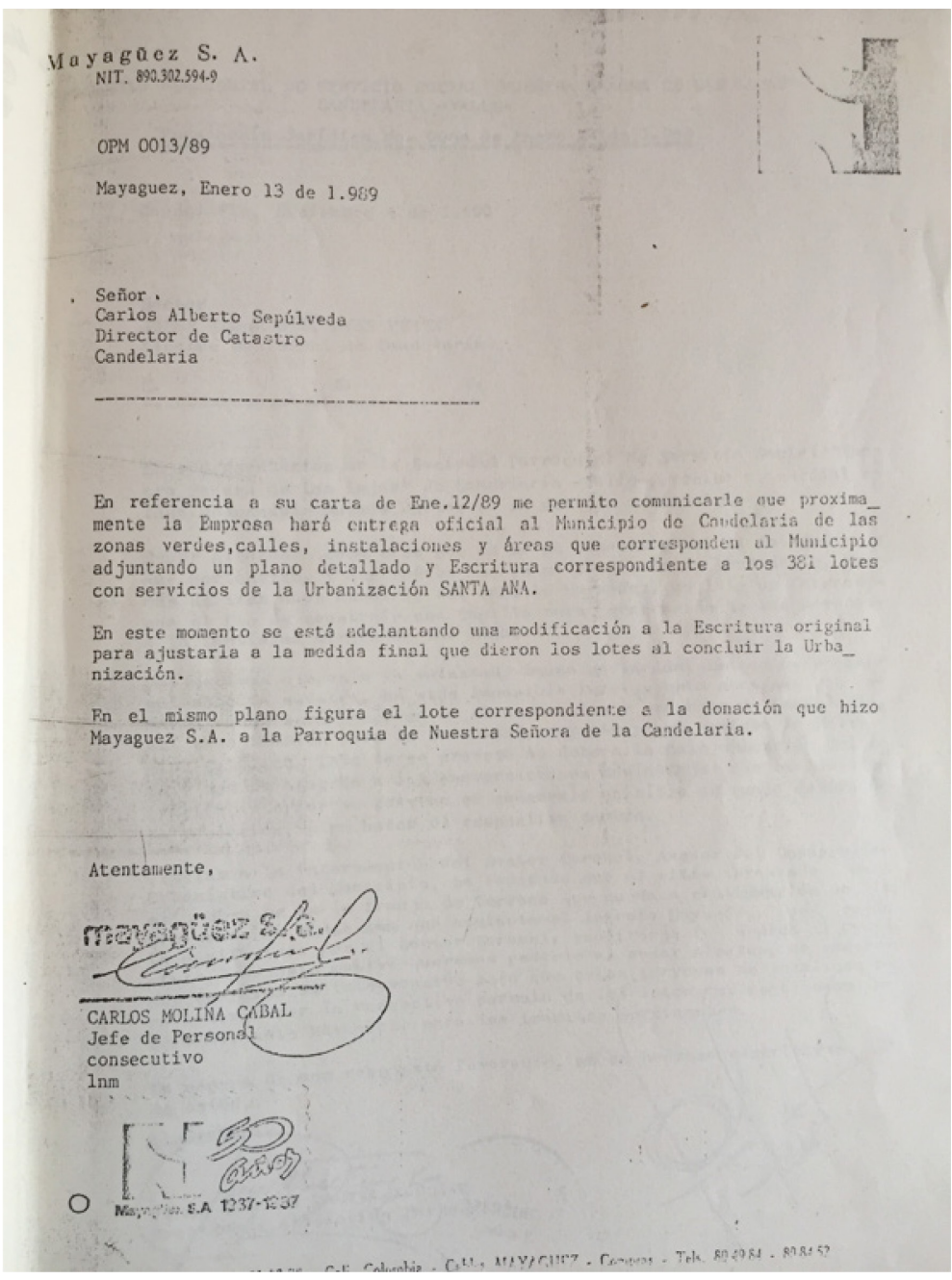

Fuente: fotografía tomada el 10 de diciembre de 2015 del archivo personal del señor Jorge Rodrigo Martínez. 
Imagen 20. Informe financiero de la celebración religiosa de la Virgen de las Lajas realizada en Candelaria en el año 2015.

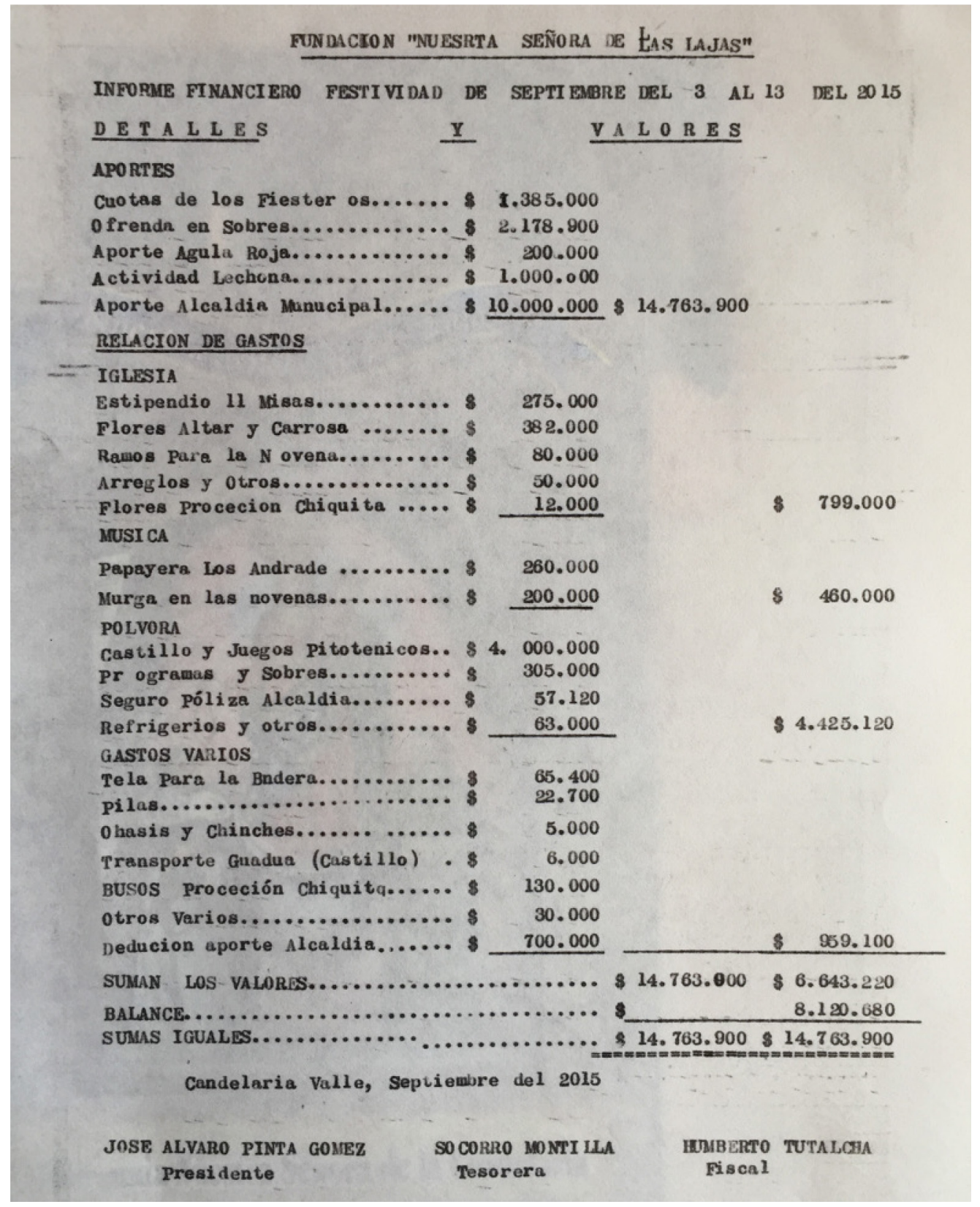

Fuente: fotografía tomada el 10 de diciembre de 2015 del archivo personal del señor Jorge Rodrigo Martínez. 
Finalmente, se puede decir que el marco contextual de la presente investigación ha logrado representar un avance deductivo, pasando por las generalidades del procesos migratorio interno, su enfoque al caso colombiano, la contextualización del Departamento de Nariño como actor expulsor, el papel del Valle del Cauca como receptor de la migración interna, y finalmente el papel protagónico del Municipio de Candelaria, en la recepción de migrantes nariñenses; un análisis del contexto que permitirá más adelante ayudar a explicar la configuración de identidades y procesos migratorios desde los trayectos biográficos de los sujetos migrantes asentados en el municipio de Candelaria, Valle del Cauca, en donde hoy tienen lugar prácticas y espacios (ver imágenes 21 y 22) de identificación nariñense, en diálogo y tensión con las prácticas y espacios de identificación vallecaucana.

Imagen 21. Santuario a la Virgen de las Lajas ubicado actualmente a un costado de la cancha de chaza construida en Candelaria.

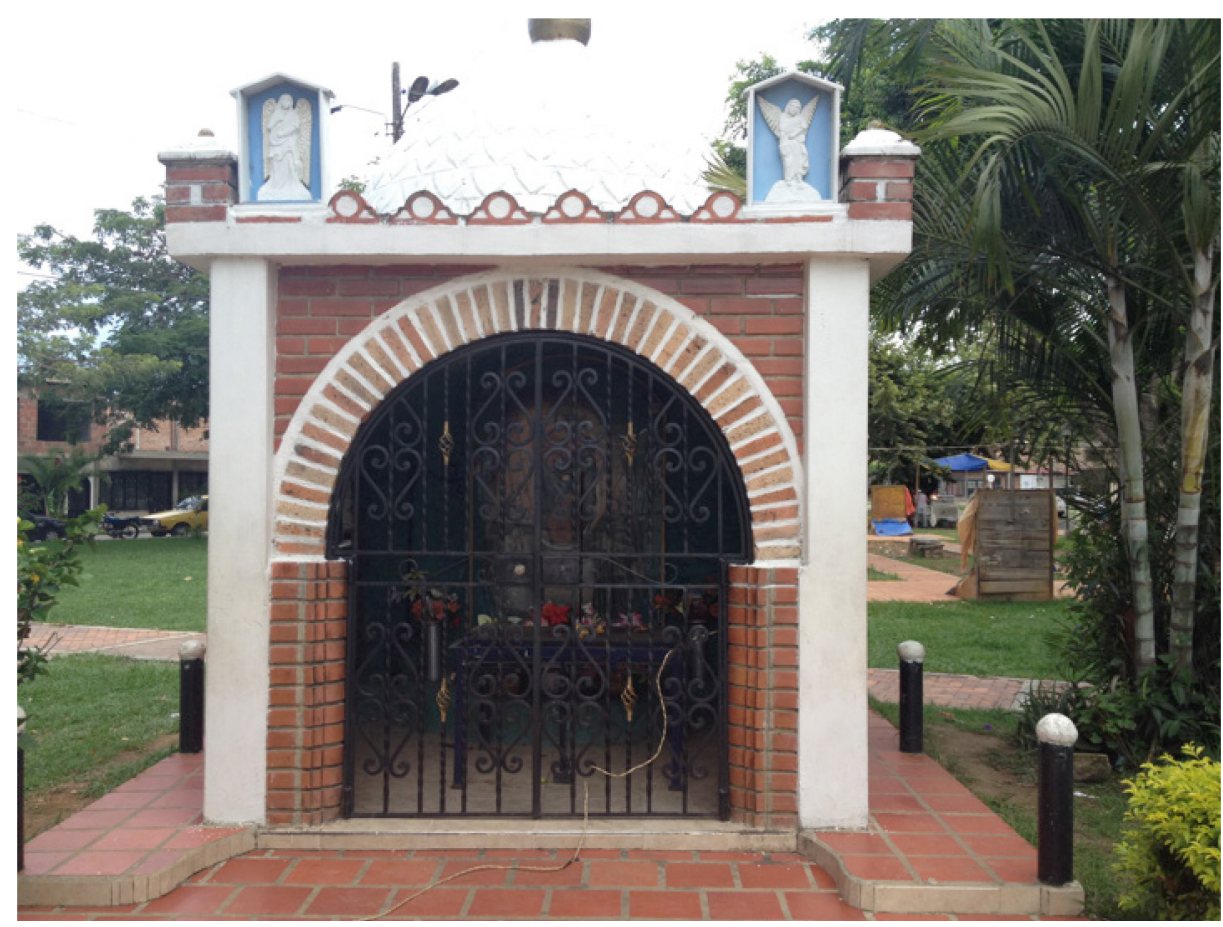

Fuente: fotografía tomada en octubre de 2014. 
Imagen 22. Actual altar a Nuestra Señora de las Lajas ubicado en la Parroquia de Nuestra Señora de la Candelaria.

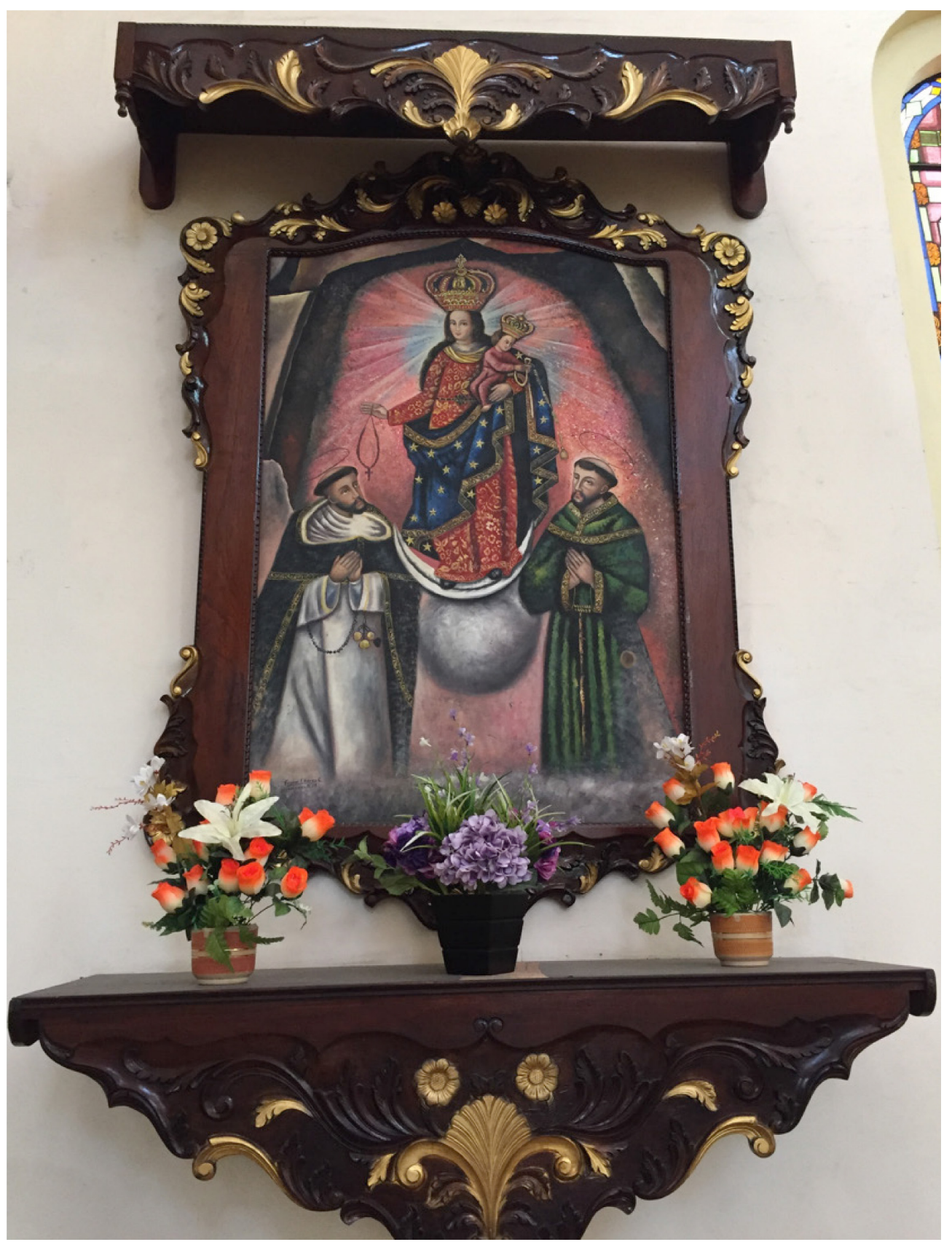

Fuente: fotografía tomada el 10 de diciembre de 2015 en la Parroquia Nuestra Señora de la Candelaria. 


\section{Fundamentación}

Si bien el concepto de movilidad humana se aborda frecuentemente como uno de los fenómenos sociales de la modernidad, hay que señalar que esta ha sido una constante en los procesos de configuración de las sociedades de todos los tiempos. La movilidad ha tenido lugar desde la antigüedad en culturas como la egipcia que llevaba a cabo migraciones forzadas para garantizar la mano de obra de sus construcciones faraónicas. Los griegos y romanos movilizaban poblaciones enteras para marcar sus colonias como territorio propio. Los chinos hicieron migraciones rurales hacia regiones agrícolas. Los árabes se expandieron junto con la migración de esclavos, mientras los europeos durante la primera época de colonización americana, elegían una parte de la población para retenerla y posteriormente generar asentamientos y trasladar de forma masiva grupos de indígenas y esclavos que eran utilizados como fuerza de trabajo; mientras los turcos promovieron a sus centros administrativos, una migración selectiva (Marmora, 2003).

Por lo anterior, puede afirmarse que de la mano de los procesos de movilidad humana han ido emergiendo las sociedades antiguas y modernas. Siendo un fenómeno que actualmente implica cuestiones como la migración internacional, el refugio político, el desplazamiento forzado y procesos de urbanización relacionados con los traslados masivos del campo a la ciudad, los cuales han despertado el interés de las ciencias sociales que desde sus diversas disciplinas y campos del conocimiento, han puesto la mirada durante las últimas décadas en el tema de las migraciones que en el contexto reciente responde, entre otros sucesos, a la caída del muro de Berlín como símbolo de la tensión ideológica entre este y oeste, y económica entre norte y sur.

En el intento de dar cuenta acerca de los diferentes abordajes que ha tenido la movilidad humana, hay que señalar que por su parte la antropología ha orientado una conceptualización al respecto; la construcción conceptual de la categoría del migrante como categoría cultural. Si bien coexiste a menudo una delimitación clara de las respectivas tareas entre la sociología y antropología al respecto, y si bien la antropología ha experimentado - como otras ciencias sociales- las limitaciones inherentes a su función social y a su carácter aplicado, sin embargo, ha contribuido, gracias a su mirada particular, a conferir al inmigrado una existencia social previa a su existencia migratoria, 
y a insertarle en un marco referencial propio y coherente, independientemente de los fenómenos de dependencia económica, a nivel internacional. A partir de entonces, el "migrante" deja de tener una existencia social exclusivamente definida a través de los criterios normativos e ideacionales de la sociedad receptora. Por añadidura, su presencia como colectivo facilita, dentro de esta misma sociedad, un espacio nuevo de dinámica cultural (Provansal, 1996).

En este sentido, es evidente que la movilidad humana, ha implicado repensar nociones como la de territorio, ya no en relación con un espacio físico y fijo que se habita, sino considerando la relación territorio-sujeto, en la cual el sujeto que lo habita, lo significa y lo resignifica política, social, económica y culturalmente, diluyendo la correspondencia entre una territorialidad inmóvil, contenida en un espacio no cambiante.

Por otra parte, ha sido recurrente en ese pensar la migración humana, el hecho de considerar los flujos migratorios, casi siempre del tercer al primer mundo, del sur al norte, y generalmente motivados por el objetivo de mejorar condiciones económicas. Sin embargo, es importante entender que este ha sido un fenómeno que ha estado presente en la configuración de las diferentes sociedades y que cada época migratoria, ha marcado motivaciones distintas en los actores, construcción de escenarios diferentes e impactos distintos en cada momento de la historia. Lo cual entre otras, ha permitido desmitificar las motivaciones de la migración y los destinos, no siempre recurrentes que tienen los migrantes.

Así por ejemplo, se reconoce que los procesos migratorios del siglo XIX facilitaron la consolidación de los Estados nación y que posterior a la revolución industrial y a los procesos modernizadores que esta trajo consigo, tuvieron lugar cambios en las formas de producción, en las maneras de vida y de organización, y transformaciones sustanciales en las dinámicas de configuración y reconfiguración de las diferentes sociedades; procurando entre otras cosas, los procesos de urbanización de las que hoy son las grandes ciudades y el traslado de las sociedades rurales a las urbes, logrando con esto el cambio de un modo de vida rural a uno urbano. Además de la presencia de medios de comunicación cada vez más masivos y con la capacidad de 
producción y reproducción en serie que en últimas, incidieron también en la ampliación de las tradicionales fronteras locales y regionales y posibilitaron el imaginar-se y el pensar-se en otros "nuevos" lugares. Sin embargo, pensar en la migración hoy, implica entre otras cosas pensar en el intercambio de capitales culturales, sociales y políticos que han sido el marco de emergencia de nuevos elementos y condiciones que plantean otros retos en el abordaje de este fenómeno. Convocando así a pensar los procesos migratorios, en un momento en el que los estados-nación se encuentran ya configurados, desde aristas de pensamiento y reflexión que enmarcan fenómenos transversales, tales como la construcción de identidades locales en el escenario de la globalidad y por tanto, la construcción de las identidades globales también.

En este sentido, hoy tiene lugar la caracterización de la migración y el interés permanente por describir, explicar y comprender cuestiones tales como, quiénes migran, cuáles son las motivaciones y causas principales de migración, si la población migrante es en su mayoría femenina o masculina, si regresan a sus lugares de origen, si deciden permanecer en el lugar de destino o si son rechazados por las poblaciones receptoras. Incluso, la mirada actual que los estudios sociales le dan a este fenómeno, implica considerarlo ya no como el que contribuye a la consolidación de los Estados, sino todo lo contrario, los procesos migratorios como los que definen, redefinen, configuran, reconfiguran, construyen y de-construyen estos Estados y sus mismos actores que los habitan y transitan.

Así, el panorama actual de las migraciones, además de motivar un sin número de estudios sociales, ha orientado de manera indiscutible las acciones de los Estados en términos de políticas públicas, convenios fronterizos y acuerdos entre gobiernos. Proponiendo de esta manera nuevos retos a los Estados y a sus instituciones, que deben empezar a dinamizarse en la búsqueda de responder a las dinámicas emergentes del actual contexto global. No obstante, también es importante reconocer que pensar el fenómeno migratorio no implica únicamente las cuestiones referidas a un territorio al que le competen las políticas públicas para con los ciudadanos, sino también, y de manera decidida, pensar en el impacto que tiene esta dinámica en la reconfiguración de nociones como la de nacionalidad, y en la misma relación sujeto - territorio, en la que el sujeto no 
sólo se configura y reconfigura subjetivamente en relación con el otro, sino también, en la cual va construyendo y reconstruyendo significativamente el territorio que habita.

Se propone entonces el marco para pensar el estudio de los procesos identitarios en una población migrante de Colombia. Considerando para el estudio la movilidad humana como macrocategoría de análisis, pero particularmente, la migración económica que resulta álgida en la configuración histórica de algunos municipios de la región suroccidente del país, en este caso, del municipio de Candelaria, en el Valle del Cauca. Para esto, se asumirá también el flujo migratorio como una meso-categoría que permita delimitar el abordaje de la movilidad como fenómeno contingente de diversas dinámicas sociales y de transitoriedad.

\section{CAPÍTULO IV. APUESTAS TEÓRICAS}

\section{Referente teórico}

\subsection{La migración como objeto de estudio}

Tal como se ha mencionado, el concepto de migración se aborda frecuentemente como uno de los fenómenos sociales de la modernidad, sin embargo, hay que señalar que esta ha sido una constante en los procesos de configuración de las sociedades de todos los tiempos y un fenómeno que ha convocado el interés por ser estudiado desde diversas disciplinas y desde hace varias décadas. Durante los años 60 y hasta mediados de los 70 , fue el modelo de la modernización el que marcó la tendencia para abordar este objeto de estudio. Desde este modelo se planteaba la migración del campo a la ciudad como el resultado y la condición necesaria dentro del proceso de transición entre la sociedad tradicional y la sociedad moderna.

Este enfoque, enmarcado en la teoría clásica de las migraciones que se nutre de la economía neoclásica, asume al migrante como un individuo racional e independiente cuya decisión de migrar es tomada por considerarla la mejor opción entre algunas otras y realizando un análisis del costo-beneficio que esto pueda traerle; fue el que justamente 
puso a las migraciones internas, y con ellas el aumento de la población urbana, como la clave del éxito de las economías nacionales y como el camino del progreso.

Desde mediados de los años 70, los flujos migratorios fueron abordados a partir de lo que se conoce como el modelo de la dependencia que propone a las relaciones de explotación como la causa de los movimientos migratorios, poniendo en relación el desarrollo y los flujos de personas. Sin embargo, este fue un modelo que puso su interés en factores estructurales, dejando un poco de lado la indagación por los flujos migratorios diversos y los factores de carácter microsocial, relacionados con los sujetos que migran.

Un tercer modelo desde el cual la migración fue abordada como objeto de estudio, es el modelo de la expulsión-atracción (push and pull), conocido también como hidráulico, desde el que se plantea que los movimientos migratorios son el resultado de la pobreza y el atraso económico de los lugares expulsores de migrantes. Este modelo, proporciona incluso listados de factores de expulsión y de atracción que siguen dejando de lado la posibilidad de explicar cuestiones tales como por qué los movimientos migratorios están focalizados en algunas regiones de países pobres y no en la totalidad de estos países y por qué estos flujos no se dan desde otros países con los mismos índices de pobreza.

Posteriormente, desde la nueva economía de las migraciones, la decisión de migrar ya no se miraba como responsabilidad de un individuo, sino de un colectivo (generalmente familia o grupo de parientes) que de manera conjunta, busca la manera de aumentar los ingresos del grupo y disminuir los riegos a los que pueda enfrentarse quien migra. Poniendo en todo caso el interés de los estudios en factores económicos, pero ya esbozando otro tipo de indagaciones que fueron dando lugar a otras perspectivas teóricas y metodológicas en el abordaje de este objeto de estudio. Fue emergiendo entonces un interés por la migración como fenómeno social y cultural, abordado principalmente desde disciplinas como la antropología y la sociología y dándole lugar al giro culturalista en torno a los movimientos migratorios, desde donde empezaron a configurarse otras preguntas y relaciones categoriales de carácter más descriptivo, correlacional y comprensivo que comenzaron a proponer el diálogo entre la migración y categorías como 
la identidad, desde la que se vinculan subjetividades, identidades colectivas, identidades nacionales, identidades étnicas e identidades culturales.

En este marco tuvieron lugar los que fueron llamados los primeros estudios urbanos de campo, abordados desde perspectivas metodológicas más etnográficas y con unos postulados teóricos en torno a la ciudad y a sus habitantes como objeto de estudio. Son estos los estudios que hacia 1915, fueron movilizados desde la Universidad de Chicago por la escuela de Chicago que en cabeza de Robert Park pusieron la mirada en temas como la desorganización social, la marginalidad y la crisis del campo como consecuencia del proceso acelerado de industrialización y urbanización que estaba viviendo Estados Unidos, además de interesarse por la movilidad consecuente de la población que estaba ubicada en áreas rurales, a los centros industriales y urbanos del país (Park, 1999).

Para Park, las grandes ciudades eran el lugar de una nueva forma de existencia, de nuevas maneras de interacción con los otros además de ser el lugar de nuevas maneras comunitarias de organización. Todo esto, desde la perspectiva del autor, por la diversidad étnica y profesional que puede encontrarse en el medio urbano, por las diversas formas culturales y tecnológicas que tienen lugar allí y por las maneras de dividir el trabajo y las funciones; contrario a lo encontrado en las comunidades pequeñas (en el medio rural) que describe como más apegado al terruño, a sus ritmos cotidianos y sin esa carga secularizadora y racional, característica del medio urbano (Park, 1999).

En palabras de Park (como se citó en Hall, 1996):

Este simple movimiento de la población de un lugar a otro -por ejemplo la actual migración de negros hacia el norte- es una influencia perturbadora. Desde el punto de vista de la gente que emigra, este movimiento tiene un aspecto liberador, en el sentido que les abre nuevas oportunidades económicas y culturales, pero desequilibra tanto las comunidades que han abandonado como las comunidades a las que se dirigen. Al mismo tiempo no deja de resultar desmoralizador para los propios emigrantes y, sobre todo, añadiría, para la generación más joven. (p. 380) 
Fueron justamente estos estudios los que motivaron otras indagaciones y exploraciones también en el seno de la escuela de Chicago, que más adelante, hacia 1947, propusieron las patologías sociales producidas en muchos inmigrantes del campo a la ciudad como la consecuencia de esa ruptura que implica salir de la sociedad rural o de la sociedad folk como fue llamada (una sociedad pequeña y homogénea), a la sociedad urbana, cuyo símbolo eran las grandes ciudades; impersonales, diversas, heterogéneas y desorganizadas. Así, desde este marco de comprensión, quienes emigraban del medio rural a las urbes sufrían una fuerte desorganización cultural que en parte justificaba los diversos problemas de los migrantes en el medio urbano.

En este sentido, la escuela de Chicago puso la mirada en el fenómeno migratorio, ya no visto desde una perspectiva de raza sino desde los cambios en los universos culturales, sociales, políticos y económicos, enfrentados por los migrantes, en ese desplazarse de un lugar a otro.

\subsection{El concepto de Nación y su relación con las migraciones internas}

Si bien la Nación como categoría ordenadora de los territorios emerge de manera reciente en la historia moderna, es importante tener en cuenta que diversos autores la han abordado y problematizado, de tal forma que vista a la luz de las migraciones internas, como en este caso, vuelve la mirada sobre el territorio local y sobre las tensiones y negociaciones que en este tienen lugar, tal como sucede en un escenario de interacción entre nariñenses y candelareños, como es el caso de Candelaria en el Valle del Cauca.

En este sentido, cabe mencionar que el texto "Comunidades Imaginadas. Reflexiones sobre el origen y la difusión del nacionalismo" (1993), Benedict Anderson retoma a Renan para afirmar que la esencia de una nación está en que todos los individuos tengan muchas cosas en común y también que todos hayan olvidado muchas cosas; esto responde al hecho de que los individuos en el marco del Estado Nación, según el autor, se sienten y se imaginan como una comunidad que comparte lazos tales como el patriotismo y la conciencia nacional, esto es, la circunstancia de pertenecer a un mismo grupo con raíces culturales semejantes. Estas raíces culturales dan cuenta de un mismo 
origen de conciencia que involucra a todos los individuos y se remonta a hechos históricos conocidos por todos, entre los que se encuentran los procesos económicos y políticos que como el modelo de producción económico, la unidad de moneda y la diversidad lingüística, hacen del lugar de origen y de un espacio compartido, una nación en la que, pueden prevalecer rasgos de compañerismo y fraternidad, así como luchas interculturales por tratar de cambiar una posición subordinada.

Lo anterior guarda coherencia con lo dicho por Herder al describir a la nación como un grupo étnico homogéneo, cuya cultura nacional lo lleva a afirmarse original y típicamente en un territorio; una afirmación original y típica como esta, bien puede ocurrir entre grupos que representan distintas naciones y quieren afirmarse ante las demás en un solo espacio que está en pugna, o también puede suceder entre grupos culturales que dentro de una misma nación representan diferencias de valor, hábito y educación, más no diferencias étnicas.

Esto último es lo que sucede con las migraciones internas que se originan en el marco de los Estados Nacionales por los rápidos procesos de urbanización concentrados en una o más ciudades, las cuales terminan por reivindicar lo dicho por Renan al referirse a la esencia de una nación como aquella en la que los individuos, de igual manera, pueden llegar a olvidar muchas cosas o entrar en tensiones.

Las tensiones se producen por las luchas interculturales que se desatan entre los individuos pertenecientes a una misma nación, pero no a las mismas ciudades. En un Estado Nación hay ciudades que gozan de un desarrollo económico y tecnológico superior, debido a la ubicación geográfica y al dinero circulante, de esta suerte, los individuos emigran de su ciudad por factores de expulsión y de atracción hacia otras localidades en las que pueden lograr mejorar sus remuneraciones y su nivel de vida. Es aquí cuando las diferencias de valor, hábito y educación a las que hace referencia Ernest Renan (2010) se ponen en juego, en el sentido en que los grupos culturales que deciden migrar a otras regiones por un ideal de progreso y por el deseo de mejorar su existencia, pueden tratar de cambiar su posición subordinada, es decir, el hecho de provenir de una región premoderna o precapitalista que impide el desarrollo económico y personal. 
Por último, el cambio de la posición subordinada de un grupo cultural migrante dentro de la sociedad receptora, se lleva a cabo a través de estrategias de identificación que, si bien reflejan procesos de resistencia a las prácticas y costumbres de la sociedad que los recibe, asimismo, reflejan una unidad intercultural que para Anderson continúa reivindicando la importancia del concepto de nación como grupo étnico homogéneo y como pueblo con una misma cultura nacional, idioma y conformación típica que a pesar de las migraciones internas, las transiciones abruptas y precipitadas conserva la unidad cultural del Estado Nación:

las comunidades no deben distinguirse por su falsedad o legitimidad, sino por el estilo con el que son imaginadas. Los aldeanos javaneses han sabido siempre que están conectados con personas que jamás han visto, pero esos lazos fueron imaginados alguna vez de manera particularísima, como redes infinitamente extensas de parentesco y clientela. (p. 25)

\subsection{La desigualdad en el contexto de urbanización, concentraciones de capital y globalización: una mirada desde las migraciones}

La globalización es un modo de producción económico que se implanta en los países de Europa Occidental durante el primer tercio del siglo XX, debido a la transformación que sufre el capital industrial en capital financiero, al desarrollo acelerado de la industria y a la extensión ilimitada del mercado interno; dicha extensión del mercado es un proceso inherente al capitalismo y hace alusión al funcionamiento de este sistema, cuya lógica reside en la renovación constante de la producción, y por tanto, en la implantación del mercado mundial, la creciente capacidad productiva y el desarrollo de la circulación de mercancías que trasciende las fronteras del Estado Nación.

La globalización depende de la ampliación de la órbita de poder que conduce a la conquista de nuevos mercados, a la incorporación de países no capitalistas en la lógica de la economía mundial, al saqueo, a la esclavitud y a la explotación de yacimientos, entre otras. Las condiciones materiales de vida que a fines del siglo XIX y principios del XX condujeron a una mayor competencia entre capitalistas, promovieron al mismo tiempo la 
acumulación de capital por otras vías. Es así como se pasa de una fase de desarrollo industrial en el capitalismo a una fase financiera o, global, en la que el capital empieza a rendir más beneficio cuando su acumulación no solo depende de los beneficios que produce el trabajo humano, sino también del excedente que producen los distintos activos financieros no humanos como la exportación de capitales, las cuentas bancarias, los depósitos, las transacciones y los empréstitos del Estado. Por este motivo, en la globalización el beneficio económico no solo se obtiene con la posesión de industrias y la concentración de la producción, sino también con el acaparamiento de las tierras, según la ubicación estratégica y la diversidad de materias primas que contengan.

Esto se explica por la forma en que funcionan los excedentes del capital: al comienzo del día los capitalistas concentran en sus bolsillos cierta cantidad de dinero y al final del día terminan con más. Esta suma es la ganancia que se obtiene luego de producir un excedente, ya sea sobre el trabajo necesario o sobre el interés que genera la emisión de valores y las transacciones en el mercado. Este excedente no puede quedarse inactivo, tiene que reinvertirse para seguir produciendo ganancias, motivo por el cual, la especulación de terrenos viene a constituir una de las formas en que se movilizan y reproducen capitales por todo el mundo.

La posibilidad de invertir capitales en distintas partes del mundo supone la subordinación de los Estados a la dominación del capital financiero, y por consiguiente, la pérdida gradual de la independencia de los países. La pérdida de la soberanía nacional comienza con la fractura del mercado interno, que en la globalización se produce por la formación de asociaciones internacionales monopolistas que acumulan riqueza por medio de la exportación de capitales, de la explotación de las materias primas de la mayor parte de los territorios estratégicos del mundo entre las potencias económicas más importantes.

Esto último revela una forma de desigualdad entre las naciones del mundo, a saber, entre las principales potencias económicas y los países en desarrollo, que por lo general, son saqueados por las transnacionales que están al servicio de las potencias para invertir sus capitales en territorios del sur como Colombia en los cuales es provechosa la inversión, debido a la diversidad de materias primas, a los yacimientos de oro, al clima y 
a la ubicación geográfica... al final ocurre que las distintas crisis desencadenadas por la desregulación de los mercados afectan más a los países subdesarrollados, pues como lo afirma Stiglitz (2002), dichas regiones son como minúsculos botes que por la rápida liberalización de su mercado nacional y por la apuesta de sus productos en el mercado global, navegan en un mar embravecido, antes de que las grietas de sus cascos hayan sido reparadas, antes de que el capitán haya sido entrenado, antes de subir a bordo los chalecos salvavidas, en fin, antes de reunir las condiciones económicas y políticas necesarias para ser competitivos en la economía financiera.

No obstante, en el marco de la globalización existen otras formas de desigualdad que se desarrollan en los países en vías de desarrollo que como Colombia, inician una fase de urbanización y modernización determinada por el proceso de proletarización, es decir, por la transformación que viven los campesinos cuando dejan de ser propietarios de la tierra para convertirse en obreros asalariados de la mediana industria. Dicha proletarización, para el caso que concierne a esta investigación (migración de nariñenses al municipio de Candelaria, Valle del Cauca) no se lleva a cabo por un despojo sufrido por y lanzado directamente hacia los nariñenses, sino por falta de oportunidades dentro del lugar origen. Es así como los campesinos y dueños de la tierra en algún momento de la historia, se ven imposibilitados a reproducirse en su territorio, y en consecuencia, se ven forzados a trabajar en la mediana industria, generando, de esta manera, un proceso de desplazamiento de la producción artesanal por la fabril.

El desplazamiento hacia la producción fabril y mediana industria viene acompañado de procesos de exclusión de pequeños productores de áreas rurales, cuya principal fuente de abastecimiento era el acceso a la tierra. Luego del desplazamiento hacia la producción fabril, los que antaño eran propietarios se convierten en mano de obra barata lista para integrarse en la pequeña y mediana industria, sin más pretensiones que la de ser un engranaje más dentro de la gran maquinaria que trae consigo el capitalismo, es por esto que, la existencia de un excedente estructural de fuerza laboral, implica una masa de trabajadores por cuenta propia inequívocamente desempoderados $\mathrm{y}$, por tanto, sin opciones reales de oportunidades de acumulación. 
En la década de los años 1960 la migración de Nariño a Candelaria implicó la incorporación de pequeños y medianos productores -quienes eran en el departamento de Nariño dueños de la tierra- como abastecedores de materias primas, especialmente en el campo del corte de caña, dentro del auge de la industria azucarera del Valle del Cauca; esta circunstancia dio lugar a la figura que se conoce desde la literatura clásica de la economía política, a saber, productores asalariados, en la medida en que el campesinado pierde la autonomía de los procesos productivos y de las decisiones claves para su futuro.

En consecuencia, puede decirse que la proletarización del campesinado trajo consigo desigualdad en el sentido en que esta población pasó a depender de comerciantes y usureros que cumplían muy bien la función que les fue encomendada por el capitalismo: extraer excedente. Así mismo, la desigualdad se articuló a las condiciones de explotación y, también, a las de acaparamiento de oportunidades de acumulación, lo que para autores como Juan Pablo Pérez (2014) llevó a las poblaciones campesinas ahora asalariadas- a un profundo proceso de exclusión social entendido como desempoderamiento del campesino.

La exclusión social es una de las tantas consecuencias de la globalización, si se entiende que este momento de la historia condujo a un cambio de los procesos productivos precapitalistas y a la separación del polo urbano -representante de la modernización capitalista- y del polo rural -referente de tradicionalidad y atraso-. Esto quedó reflejado en el proceso de modernización que tuvieron algunas ciudades y municipios de Colombia, tales como el Valle del Cauca y el municipio de Candelaria, que con el boom de la industria azucarera, añadieron a la modernización una rápida migración interna, cuya población migrante -nariñenses- después de haber desempeñado el papel de propietaria de la tierra y autónoma de sus procesos productivos, llegó a la sociedad receptora siendo una clase obrera formal. En este sentido, la urbanización que es condición sine qua non de los procesos de globalización, de igual forma conduce a masivas migraciones internas que exacerban la primacía de los sistemas urbanos (Pérez, 2014). 
La primacía de los sistemas urbanos dentro del marco de la globalización genera un excedente laboral rural que decide migrar de su lugar de origen por la imposibilidad de obtener un mejor nivel de vida o de lograr una mejor remuneración, por eso, "si se asume esta perspectiva habría que decir que estamos ante una movilidad más forzada que voluntaria, la cual traslada a las ciudades los problemas del campo" (Pérez, 2014, p.245). Desde este punto de vista, las migraciones internas están mediadas por la exclusión y la desigualdad, en tanto que el territorio de origen deja de representar el lugar crucial para abastecer a los grupos familiares y culturales, porque en últimas, deja de significar el lugar donde se puede "tener" (producir y reproducir la vida material).

Por último, la discusión entre globalización, desigualdad y concentraciones de capital, tiene que ver con la relación existente entre lo global y lo local, que vuelve a llamar la atención sobre la movilidad y las migraciones internas, porque lo que está en juego es el tipo de recurso -fuerza de trabajo- que se puede movilizar (comprar - vender) en un mismo territorio a causa de la influencia que ejerce un fenómeno social como el de la globalización. El modo de producción económico global funciona a través de la expansión de la órbita del poder del capital y de la mayor acumulación de excedente, lo cual se logra, principalmente, a través de los procesos de urbanización y de modernización de las sociedades que, como ya se ha dicho, incluyen migraciones internas por el acceso al mercado laboral que conlleva el desarrollo económico y el progreso; una vez los sujetos migrantes logran acceder a este tipo de mercado, pasan a ser capital humano listo para ser explotado por los dueños de los medios de producción.

La desigualdad que media entre la globalización y la modernización de las sociedades, además de estar directamente relacionada con las relaciones que se establecen entre los países desarrollados y subdesarrollados, remite, necesariamente, a la separación del campo de la ciudad y de la tierra del capital, sobre las cuales se erige el capitalismo y emergen las migraciones. En el marco de las migraciones internas, como la de Nariño a Candelaria durante los años 60, es natural encontrarse con métodos de atesoramiento que exigen mano de obra para ser explotada en el corte de caña durante una jornada de trabajo 
que se extiende más de lo necesario ${ }^{12}$. Sin embargo, un método de atesoramiento como este utilizado para producir riqueza en sociedades capitalistas en ascenso, origina tensiones y resistencias por parte de los sujetos migrantes que hacen frente y se oponen a la exclusión social que el nuevo orden liberal impone; en este orden de ideas, puede hablarse tanto de un campo de explotación de la fuerza de trabajo como de la resistencia de los migrantes, que bien puede expresarse, siguiendo a Juan Pablo Pérez Sáinz, en "una globalización desde abajo", es decir, en la posibilidad que existe en el contexto de la globalización, de insertarse a través de las migraciones internas en las nuevas dinámicas económicas que elevan la posición económica y social de un determinado grupo cultural.

\subsection{Nosotros somos los de allá y los de acá. Desarrollo teórico de la categoría}

Resulta recurrente en las definiciones de migración rastreadas, el componente de movimiento geográfico, que implica el cruce de límites de carácter administrativo o político y motivado, casi siempre, por mejorar la calidad de vida personal y familiar de quienes migran. Además de entenderse como una respuesta para adaptarse a cambios diversos de índole demográfico, climático, económico, político o social.

Considerando esta dimensión espacial de los flujos migratorios, se proponen como modalidades de estos movimientos poblacionales, las migraciones transfronterizas que asumen los desplazamientos entre países vecinos, las migraciones transnacionales que consideran los flujos migratorios a países más alejados del lugar de origen e incluso a otros continentes, las trasmigraciones que implican el movimiento haciendo escala previa en un país diferente al destino final considerado; y las migraciones internas que implican los movimientos poblacionales dentro de un mismo país y que son las que justamente focalizan la atención de esta investigación.

\footnotetext{
${ }^{12}$ El tiempo de trabajo necesario, el tiempo de trabajo excedente y el tiempo de trabajo extraordinario constituyen la jornada de trabajo del obrero. Para que el obrero pueda producir en condiciones físicas normales una mercancía, su fuerza de trabajo gastada debe ser retribuida en una determinada suma de medios de vida. Sin embargo, el obrero trabaja más del tiempo necesario y este tiempo no es pagado, sino que es el excedente que el capitalista se embolsilla bajo la acumulación de capital, y bajo el tiempo de trabajo extraordinario que se produce con la mayor productividad en la industria, a raíz de la aplicación de tecnología superior y a la generación de valores superiores, en comparación con la productividad media del trabajo. Al final, estas condiciones conllevan el degeneramiento físico e intelectual del obrero, pues este no alcanza a reponer su energía gastada en tiempo de descanso ni en dinero para reponer sus medios de vida.
} 
Sin embargo, en el ejercicio de explicar y comprender el fenómeno migratorio, no solo es considerada la dimensión espacial sino también la temporal, la cual hace que entender los flujos migratorios atraviese también el conocer los tiempos de duración de los movimientos poblacionales Blanco (2000), entendido esto como el tiempo que los migrantes alcanzan a estar en el lugar de destino. Desde esta dimensión, es posible entonces encontrar otras modalidades de los movimientos poblacionales, tales como los movimientos pendulares que hacen referencia a los flujos de población que aunque impliquen el cruce de fronteras (administrativas o políticas) no implican un cambio de residencia. Es decir, que los movimientos pendulares enmarcan los traslados cortos de personas que van y vienen en busca de servicios de salud o educación, o que tienen sus lugares de trabajo en un lugar distinto al de residencia.

En este sentido, también se encuentran los movimientos temporales que igualmente implican el movimiento y el cruce de límites geográficos pero necesariamente con cambio en el lugar de residencia por un período de tiempo determinado. Y los movimientos definitivos, Dureau, Méndez y Florez (1996) que son los que enmarcan el interés de esta investigación y que implican el traslado de la población, cruzando límites administrativos y políticos estableciendo el lugar de residencia en el lugar de destino de manera permanente y que para su análisis, según Arroyo (2006) se requiere tener en cuenta las motivaciones que inciden en la decisión de migrar y las características que tienen los destinos elegidos, para atraer a los migrantes. Siendo estas, las causas que motivan las migraciones, otra de las tipologías consideradas desde la perspectiva de algunos autores que plantean que dentro de estas motivaciones pueden encontrarse las de tipo ecológico, político o económico (Blanco, 2000).

La autora señala además dentro de las tipologías de la migración la relacionada con los sujetos de la decisión que refiere migraciones forzadas, espontáneas y dirigidas. Blanco (2000). Siendo las primeras las que implican un movimiento no voluntario del migrante y en muchos casos, la imposibilidad de decidir el lugar de destino; mientras que las espontáneas, que focalizan el interés de esta investigación, son las que se hacen de manera voluntaria, sin ninguna mediación institucional y sin que el migrante se vea forzado a realizar el movimiento migratorio por ninguna circunstancia. 
Por último, las migraciones dirigidas que podrían también focalizar la atención investigativa, en tanto estas conservan el carácter voluntario de la migración pero el movimiento se realiza mediado por instituciones que ayudan a disminuir los riesgos a los que pueda enfrentarse quien migra; vinculándose a esta tipología las estrategias de reclutamiento de mano de obra que muchas industrias suelen llevar a cabo para su fortalecimiento.

Al asumir este marco como referencia para el estudio de la migración interna, hay que mencionar también que estos movimientos poblacionales generan, además de los impactos económicos y demográficos, tanto en los lugares de origen como en los de destino, unas transformaciones sociales y culturales intrínsecas a la interacción y al contacto que se establece entre quienes llegan y quienes estaban, cada quien, desde la perspectiva de Stuart Hall, con un pasado imaginado y una ancestralidad compartida, con una historia común y con costumbres diversas que entran en diálogo y tensión en un escenario de inclusiones y exclusiones y de configuración y reconfiguración de sentidos.

Justamente allí, en este escenario que Grimson denominó campo de interlocución y que puede entenderse también como un espacio de intercambio y de conflicto entre códigos culturales diversos, han emergido perspectivas teóricas que abordan desde diferentes miradas estos contactos inter e intra culturales; algunos refiriéndose a ellos como procesos de aculturación que Berry (1997) definió como la transformación cultural que se tiene por influencia de otras culturas con las que se tiene contacto directo y continuado y que supone más que una pérdida de las tradiciones, de las creencias, de los hábitos y de las costumbres, unos procesos de re-interpretación y re-apropiación de nuevos elementos culturales que en todo caso deviene en una transformación de la cultura tradicional.

Pero el modelo de aculturación no refiere una pérdida de la cultura original sino un sostenimiento de tradiciones, creencias y costumbres de la cultura propia, de manera simultánea con el deseo de tejer relaciones y de interactuar con la cultura que acoge a los que llegan. 
Por otro lado, está el modelo de asimilación que Gordon (1964) propuso como la necesidad que tiene el grupo migrante de tomar distancia de su grupo de origen para lograr la inserción en la sociedad que lo recibe. Sin embargo, desde la perspectiva propuesta por Berry (1997), la asimilación es entendida como un nivel de aculturación, así como la integración, la segregación y la marginación, que a su vez son actitudes asumidas por la población migrante frente a sus procesos de aculturación. En este marco de comprensión, la asimilación se entiende como un proceso de abandono de la identidad cultural de origen para asumir los códigos culturales de la sociedad receptora, siendo la integración un nivel de aculturación en el que el migrante desea y lucha por mantener su identidad cultural de origen pero en un ejercicio simultáneo por ser parte de la sociedad que lo recibe.

En cuanto a la segregación, esta hace referencia a la ausencia de relación entre la sociedad receptora y la población migrante, refiriendo el mantenimiento de los códigos culturales y de las tradiciones de origen. Sin embargo, se conoce con el término de segregación cuando la distancia es impuesta por la sociedad de acogida ya que cuando es una decisión tomada por la población migrante, el término con el que se le conoce a este nivel de aculturación es separación. Por su parte, el nivel de marginación refiere el rechazo a incorporarse en la sociedad que recibe, rechazo evidente no solo desde la distancia puesta en términos culturales sino también en términos psicológicos, en tanto el mismo migrante está convencido de no formar parte de, de no pertenecer o de ser ajeno a la sociedad que lo recibe. Aclarando que al mismo tiempo que se rechaza la sociedad receptora, hay también un distanciamiento de la cultura de origen.

Sin embargo, cuando esta situación es impuesta por la sociedad receptora, el término con el que se conoce este rechazo es exclusión. Y aquí, es importante mencionar que en algunas situaciones las condiciones de exclusión tienen que ver con la ubicación de los migrantes en los sectores más empobrecidos de los lugares donde llegan, por las mismas características de precariedad con las que vienen. Estas zonas se van configurando entonces como el escenario de llegada y acogida de migrantes, lo que deviene en una segregación espacial que según Solanes (2008) inevitablemente trae como consecuencia no solo la estigmatización de los migrantes sino también su exclusión 
social, lo cual dificulta mucho más la inserción de los migrantes en las sociedades receptoras.

En el escenario de las migraciones internacionales, la exclusión implica además la marginación que tiene el migrante en la toma de decisiones sobre aspectos de interés colectivo, es decir, una exclusión del ejercicio de sus derechos políticos que marca aún más el hecho de no formar parte de la sociedad receptora. Al respecto, Méndez (2008) sostiene que "la nacionalidad es el vínculo jurídico-político que liga a una persona física con un Estado y, hasta el momento, ha sido el criterio fundamental para determinar la pertenencia a una comunidad política" lo que pone en juego la relación nacionalidadpertenencia, extendiendo para el migrante el espectro para ser asumido como un ajeno, un otro, un de allá.

Esta exclusión, a pesar de ser pensada principalmente en el marco de las migraciones trasfronterizas, transnacionales y de las trasmigraciones, también tiene sus impactos en las migraciones internas de grupos poblacionales que incluso en el escenario de la municipalidad no logran ejercer sus derechos políticos por diferentes aspectos, entre ellos la actualización de la documentación o la imposibilidad de ser elegidos por considerarse extraños o de afuera. Confirmando que el extranjero, el extraño en el escenario local, '....se singulariza por una diferencia 'de naturaleza' que se establece sobre la base de una discontinuidad formulada explícitamente entre un 'dentro', del que no forma parte, y un 'fuera' al que pertenece” (Landowski, 1993, p. 102).

Por otra parte, en términos de aculturación, la exclusión y la segregación no son posibilidades únicas. Como ya se mencionó, también se dan procesos de integración que en ocasiones se hacen posibles por la cooperación entre las personas que muchas veces ponen en común recursos, no sólo económicos sino sociales, para alcanzar objetivos colectivos y satisfacer las necesidades de algún paisano que también haya decidido migrar. Este tejido se ha conocido con el nombre de redes, resultado de las relaciones sociales que se van tejiendo y que vinculan a su haber los recursos intangibles de las comunidades y de las familias, supera en la mayoría de los casos los lazos de 
consanguinidad, articulando lazos de vecindad, para servir de respaldo emocional y económico a los miembros de dicha red en la que:

El migrante obtiene [en origen] valiosa información sobre condiciones y ofertas concretas de trabajo, así como de opciones de vivienda y de asesoría para todo tipo de trámites, gracias a relaciones de alta confianza. Como se ve, la red de solidaridad empieza a manifestarse incluso antes de la partida del futuro migrante. Llegado el momento del viaje, también son solidarias, familiares, secretas y altamente confiables las vías por las que el migrante objetiva su decisión. El proceso de establecerse en el lugar de destino se logra del mismo modo, es decir, a través de canales ya trazados por redes familiares o comunitarias. Por lo general, acoge al migrante un nido de paisanos conocidos. (De la Torre, 2004, p. 107)

Tiene así lugar la teoría de las redes de contacto, a propósito de los movimientos migratorios. Una teoría desde la que se estudia este fenómeno poniendo la mirada en los vínculos que le permiten al migrante conectarse con otros migrantes en el lugar de destino, con otros que regresaron nuevamente a su lugar de origen, con quienes están considerando también la posibilidad de emigrar, con amigos, vecinos y familiares que tanto en los lugares de origen como en los de destino, se convierten en la red de apoyo para lograr el objetivo y para disminuir en lo posible los riesgos que se puedan presentar en el trayecto.

Estas redes le suministran a quien migra, información importante sobre los trayectos, los costos, las rutas y medios de transporte, además de proveer en muchos casos vivienda y dinero para facilitar el comienzo de la historia migratoria y contactos para que los paisanos migrantes logren insertarse prontamente en el mercado laboral de los lugares de destino. Tal como lo señala Massey, Arango, Hugo, Kouaouci, Pellegrino, y Taylor (1993) estas son redes que cada día crecen y se retroalimentan con los que van llegando en tanto se van adicionando recursos y sobre todo, capital social con cada nuevo miembro que se incorpora, definiendo estas redes de contacto, desde la perspectiva de las migraciones, como

Un conjunto de lazos interpersonales que conectan a los migrantes antiguos, 
migrantes y no migrantes, en las zonas de origen y de destino a través de lazos compartidos de parentesco, amistad y comunitario. Estos lazos reducen los costos y riesgos de la migración y aumentan el rendimiento económico esperado. Las conexiones de red constituyen una forma de capital social al que las personas pueden recurrir para obtener acceso al empleo en el extranjero. Una vez que el número de migrantes alcanza un umbral crítico, la expansión de las redes reduce los costos y riesgos del movimiento, lo que hace que la probabilidad de migrar aumente, provocando movimientos adicionales, ampliando aún más las redes, y así de manera sucesiva. Con el tiempo el comportamiento migratorio se extiende hacia afuera para abarcar segmentos más amplios de la sociedad emisora. (Massey, Arango, Hugo, Kouaouci, Pellegrino y Taylor, 1993, p. 448-449) ${ }^{13}$

Desde esta mirada, tanto las relaciones familiares y las relaciones de amistad como las interconexiones que se dan entre migrantes de todas las épocas, no migrantes, potenciales migrantes y retornados, cobran un sentido importante para el estudio de los flujos migratorios. Señalando además que el enfoque teórico de redes permite explicar por qué los movimientos migratorios tienen continuidad pese a que en muchos casos los factores que atraían a los migrantes a algún lugar de destino hayan cambiado, así como también los factores por los cuales los lugares de origen fueron en algún momento expulsores.

Por su parte, Demarchi (2012) sugiere que la existencia de estas redes de contacto "es la estructura que posibilita que las identidades se recreen y revitalicen e incluso se articulen, del mismo modo que permite crear nuevas relaciones y sentidos de pertenencia y construcción de nuevos lugares." Para la autora "la identidad no solo hace referencia a un grupo étnico, sino también a un espacio geográfico y cultural. Los migrantes, en sus nuevos destinos, recrean cotidianamente identidades a partir de recuerdos, gastronomía, relatos, costumbres, leyendas, festividades. Demarchi (2012) propone que mediante una celebración religiosa se refuerza la imagen de la comunidad y se facilita la perpetuidad de determinados estilos de vida que definen a la cultura del migrante. Esta fiesta es un marco de comunicación en el cual existen códigos preestablecidos y compartidos por un grupo y

\footnotetext{
${ }^{13}$ El documento original se encuentra en inglés. La traducción es propia.
} 
que forman parte, al igual que otras prácticas, del proceso de identificación de los migrantes.

\subsection{Identidades en fronteras, límites y bordes}

En este marco se dibuja el interés por indagar en torno a los procesos identitarios de una población migrante (la colonia nariñense) asentada en Candelaria, Valle del Cauca. Reconociendo que "si las identidades nacen y se construyen siempre tomando conciencia de la diferencia, es decir en relación con los otros, los encuentros de la vida cotidiana postulan concepciones y jerarquías disímiles que entran permanentemente en conflicto." (Grimson, 2005, p. 58). Tensión que ciertamente, en el caso específico aquí propuesto, implica unas negociaciones interculturales, un "trueque" de códigos y una resignificación de ambas culturas: la vallecaucana y la nariñense. Entendiendo que:

Las personas y los grupos se identifican de ciertas maneras o de otras en contextos históricos específicos y en el marco de relaciones sociales localizadas. Por ello, el primer elemento de toda identificación es su carácter relacional: al mismo tiempo que establece un "nosotros" define un "ellos". La nación, el género, la clase, la raza, la etnia, pueden constituir en diferentes contextos de interacción parámetros perceptivos que definen relaciones sociales entre "nosotros" y "los otros" (Grimson, 2001, p. 29). Emerge así un interés por conocer cómo la colonia nariñense, asentada en Candelaria, construye su propio relato en torno a su proceso migratorio y a sus procesos identitarios. Indagación que pretende ser movilizada a partir de un objetivo general que busca la reconstrucción de los relatos de migración e identidad en los procesos comunicativos que se dan en la vida cotidiana de estos sujetos migrantes.

Se reconoce aquí, no solo que la identidad está dentro del discurso de Hall (2003) sino también que "la narración es un modo fundamental de construcción de sentido en la vida cotidiana" (Ford, 1994, p. 135) por lo cual, se proponen justamente, esos escenarios de encuentros diarios concertados y no concertados, de pugnas y negociaciones, donde se tejen y destejen las relaciones entre ellos mismos y entre ellos y la comunidad candelareña y donde tienen lugar las prácticas cotidianas de la colonia nariñense en 
Candelaria, como las claves para indagar sobre los procesos migratorios y sobre los procesos identitarios de esta colectividad.

Estos diferentes escenarios de diálogo, de disputa, de negociación y de intercambio identitario son planteados desde la perspectiva de Grimson (2005) como campos de interlocución, en el marco de los que se dan algunos tipos de comunicación que el autor propone como comunicación directa y mediatizada; asumiendo la escena comunicativa como intercultural e intracultural. De esa manera, Grimson propone el cruce entre los tipos de comunicación y las escenas comunicativas, dando lugar a cuatro dimensiones de análisis para los procesos identitarios que el autor estudia en el caso de los bolivianos asentados en Buenos Aires. A saber: comunicación directa intra e intercultural y comunicación mediatizada intra e intercultural.

El autor propone la interculturalidad como "aquellas circunstancias en las cuales dos grupos que producen identificaciones diferentes $\mathrm{y}$, por lo tanto, construyen códigos comunicacionales imbricados con modos de posicionamiento distintos en la sociedad, se relacionan y comunican produciéndose conflictos, negociaciones, acuerdos e innumerables malos entendidos" (Grimson, 2005, p.43). Remitiendo la escena comunicativa intracultural a los procesos y prácticas que tienen esas culturas de origen para sobrevivir y transformarse en el lugar de recepción.

En la propuesta que hace este autor, es clave tener en cuenta que:

los bolivianos se constituyen como "colectividad" no sólo en la interacción con grupos socioculturales diversos, sino a través de la producción de espacios de identificación en los que pueden desarrollarse disputas culturales y políticas atravesadas por los modos de relacionarse con la "sociedad receptora. (Grimson, 2005, p. 26).

De manera tal que en los espacios de identificación se construye el sentido del nosotros y de los otros, considerando el nosotros como constituido por y constituyente de ese otro, en situaciones diversas de negociaciones y disputas identitarias que no necesariamente implican la vinculación, o la integración a las sociedades receptoras, sino 
también situaciones de estigmatización que propician, muchas veces, identificaciones estigmatizadas.

En este escenario, cabe mencionar que según el autor, desde los estudios enmarcados en el campo de la comunicación intercultural, ha sido recurrente hacer aproximaciones a las percepciones, usos y apropiaciones del espacio, el tiempo, los olores, sabores, tacto y demás dimensiones de la comunicación, desde el enfoque de las identidades nacionales. Sin embargo, también sostiene que las diferencias culturales trascienden las Estados nación, los departamentos y las ciudades, aunque bien hayan intervenido en la configuración de los rasgos distintivos.

Es de señalar que la idea de comunicación que propone Grimson no implica únicamente los encuentros y acuerdos entre grupos sino también y sobre todo, es una idea amarrada a la presencia de conflictos, desacuerdos, desencuentros y tensiones dados en el contacto intercultural y que el autor sugiere analizar a través de algunas dimensiones comunicativas: el lenguaje verbal, el espacio, el tiempo, la kinésica y el tacto. Señalando que cualquiera de ellas puede, en ciertos casos, ser más relevante que las demás conforme a las diversas situaciones de interacción dadas en momentos históricos específicos y según las especificidades de los interlocutores (Grimson, 2001). Así pues, ese contacto entre culturas implica justamente un contacto entre olores, sabores, sonidos, palabras, colores, corporalidades y espacialidades a través de las que se construyen códigos de comunicación y estructuras de significación.

Entendiendo entonces el lenguaje verbal, el espacio, el tiempo, la kinésica, el tacto y otros canales de comunicación no verbal como dimensiones de la comunicación desde la perspectiva de Grimson, se propone sobre la palabra (el lenguaje verbal) que las personas aprenden a lidiar de maneras diferentes con las diversidades culturales con las que están en contacto. Así, puede suceder que las acepten, las disfruten, las clasifiquen, las detesten o las estigmaticen. Agregando que el choque cultural para el autor no se da justamente por la diferencia cultural entre las personas o grupos sino por la diferencia que es desconocida, la diferencia que el otro o los otros no esperan y en tal medida, no pueden clasificar (Grimson, 2001). 
En términos del espacio, es de mencionar que las diversas maneras como este es usado, significado y apropiado, dan cuenta también de los diversos modos de configuración del nosotros frente a los otros. Entendiendo que los usos y la manera de significar la espacialidad es particular de cada grupo y se propone entonces como elemento distintivo de las diversas grupalidades en tanto las maneras de estructurar y de disponer los espacios es tan distinta como las maneras de habitarlos y de experimentarlos.

En este marco, Grimson citando a Pritchard, refiere la existencia de distancia física y estructural, asumiendo que la primera no tiene nada que ver con la proximidad o distanciamiento cultural, social o político y que la segunda, implica cercanías sociales que en diversos casos se dan a pesar de los límites y de las fronteras geográficas, jurídicas y políticas, refiriendo la presencia de esas redes sociales que en el escenario de las migraciones, se mantienen aún en la distancia física. En este orden, se marca la diferencia entre una espacialidad geográfica y física y una espacialidad social en la que por supuesto, se construyen y deconstruyen entre otras cosas, sentidos de identidad.

Con el fin de asumir el tiempo como dimensión comunicativa, se retoma a Edward Hall (1990) quien sostiene que el tiempo habla más plenamente que las palabras. Este tiene diferentes maneras de significación para los grupos de personas, las cuales pueden en algunos casos estar relacionadas con fiestas nacionales, celebraciones religiosas, festividades culturales, períodos apropiados o no para la siembra, e incluso, prácticas de la vida cotidiana que se realizan (en cada grupo) en cierto momento del día, generando extrañeza y asombro cuando dicha práctica se sale de los tiempos tradicionales.

De esta suerte, Grimson (2001) propone que es posible encontrar pueblos en los que el tiempo no es una unidad cuantificable y observan su paso teniendo en cuenta el proceso de maduración de las plantas o el crecimiento de los animales, sugiriendo con esto que las diversas maneras de usar y de significar el tiempo, son también modos de configuración colectiva. Por su parte, la kinésica es referida por el autor como el conjunto de los movimientos corporales: gestos, posturas, movimientos de brazos, manos y piernas y expresiones faciales. 
Para terminar, la dimensión táctil y algunas otras que no implican la comunicación verbal, refieren otras formas de comunicación que también son distintas entre las culturas. Distinciones que pasan por cuestiones como el tocar o no a alguien, las partes del cuerpo que se tocan y las que no, las que se tocan en público y las que no, el cuándo poder tocar y cuándo no. Sin decir con esto que pueda generalizarse o convertir estos patrones culturales en estereotipos de las diversas culturas.

Tabla 9. Dimensiones de la comunicación

\begin{tabular}{|c|c|}
\hline \multirow{5}{*}{$\begin{array}{l}\text { Dimensiones de la } \\
\text { comunicación }\end{array}$} & $\begin{array}{l}\text { Lenguaje verbal (la palabra): Las personas aprenden a lidiar de } \\
\text { maneras diferentes con las diversidades culturales con las que } \\
\text { están en contacto. Así, puede suceder que las acepten, las } \\
\text { disfruten, las clasifiquen, las detesten o las estigmaticen. } \\
\text { Agregando que el choque cultural para el autor no se da } \\
\text { justamente por la diferencia cultural entre las personas o grupos } \\
\text { sino por la diferencia que es desconocida, la diferencia que el otro } \\
\text { o los otros no esperan y en tal medida, no pueden clasificar. }\end{array}$ \\
\hline & $\begin{array}{l}\text { El espacio: Las diversas maneras como este es usado, significado y } \\
\text { apropiado, dan cuenta de los diversos modos de configuración del } \\
\text { nosotros frente a los otros. Los usos y la manera de significar la } \\
\text { espacialidad es particular de cada grupo y se propone entonces } \\
\text { como elemento distintivo de las diversas grupalidades en tanto las } \\
\text { maneras de estructurar y de disponer los espacios es tan distinta } \\
\text { como las maneras de habitarlos y de experimentarlos. }\end{array}$ \\
\hline & $\begin{array}{l}\text { El tiempo: Tiene diferentes maneras de significación para los } \\
\text { grupos de personas, relacionadas en algunos casos con fiestas } \\
\text { nacionales, celebraciones religiosas, festividades culturales, } \\
\text { periodos apropiados o no para la siembra, e incluso, prácticas de } \\
\text { la vida cotidiana que se realizan (en cada grupo) en cierto } \\
\text { momento del día. Las diversas maneras de usar y de significar el } \\
\text { tiempo, son también modos de configuración colectiva. }\end{array}$ \\
\hline & $\begin{array}{l}\text { Kinésica: Conjunto de movimientos corporales: gestos, posturas, } \\
\text { movimientos de brazos, manos y piernas y expresiones faciales. }\end{array}$ \\
\hline & $\begin{array}{l}\text { EL tacto y otros canales de la comunicación no verbal: no } \\
\text { implican la comunicación verbal, refieren otras formas de } \\
\text { comunicación que también son distintas entre las culturas. El tocar } \\
\text { o no a alguien, las partes del cuerpo que se tocan y las que no, las } \\
\text { que se tocan en público y las que no, el cuándo poder tocar y } \\
\text { cuándo no }\end{array}$ \\
\hline
\end{tabular}

Fuente: elaboración propia basada en los aportes de Grimson (2001) 
Grimson (2001) plantea que cuando se afirma que los argentinos tienen una manera de besar (por ejemplo), se parte del supuesto de relacionar identidad y cultura, desde la perspectiva de la nacionalidad, ante lo que el autor sugiere que a pesar de ser una relación que hace parte del sentido común, no es tan cierto en tanto no es posible homogeneizar las prácticas culturales, aunque se hable de un mismo país. En este sentido, la nacionalidad, la etnicidad e incluso la regionalidad, son aquí una posibilidad de identificación, entre muchas otras.

Por otra parte, otra dificultad para hacer dicha afirmación es el componente histórico que recae en las maneras como los diferentes grupos de personas se identifican y cómo varían sus prácticas culturales en los diferentes momentos de su historia como colectividad, frente a lo cual Grimson propone que antes de afirmar que los argentinos se besan de determinada manera, es preferible decir que los porteños se están besando de esta o aquella manera. Partiendo de la perspectiva intercultural propuesta por Grimson, se reconoce como escenario de la interculturalidad aquel en el que se dan lugar personas o grupos que no tienen historias sociales comunes, ni un pasado imaginado, ni una ancestralidad compartidos; personas y grupos con diferentes rutinas incorporadas como es el caso de los procesos migratorios que convocan a un nosotros y a unos otros a interactuar en el marco de un tipo de comunicación directa o mediatizada y en la escena comunicativa que para Grimson puede ser inter o intracultural.

Con lo anterior se proponen cuatro campos analíticos que ya fueron mencionados, a saber: comunicación directa inter e intracultural y comunicación mediatizada inter e intracultural. Grimson (2001, p. 97) como un esquema propicio para comprender procesos de reafirmación e invención de identificaciones en lo que el autor denomina, un campo intercultural. Vale decir que en la interacción de las personas o grupos no solo tienen lugar los desencuentros y conflictos. Se dan casos en los que los interlocutores logran superar las dificultades de asimetrías de significación Grimson (2001) y otros, en los que definitivamente no se logra y se generan estrategias de segregación y distinción, más que estrategias de identificación.

En últimas, Grimson propone un modelo para analizar las relaciones entre 
personas o entre grupos de diferentes culturas que se dan lugar en contextos específicos y cuyo encuentro está transversalizado como ya se ha dicho, por la interacción y la historicidad.

Es el caso de los nariñenses asentados en Candelaria, en cuyo escenario también vale referir la o las pérdidas que traen consigo este tipo de procesos migratorios, pérdidas ambiguas desde la perspectiva de Boss (2000), confusas o incompletas, en donde claramente como se cita en Jaes (2002) "la gente y los lugares queridos están físicamente ausentes, pero al mismo tiempo están agudamente presentes en la mente del inmigrante”. Pérdidas que tal como cita Jaes (2002) bien pueden tratarse de una ausencia física que psicológicamente continúa presente (tal es el caso de los desaparecidos) y que implica una espera abierta y sin cierre, o bien, una pérdida en la que la persona se encuentra físicamente presente pero psicológicamente ausente, como en el caso de un miembro de la familia que se aísla emocionalmente.

Ambas pérdidas, en el marco de la migración, pueden darse de manera simultánea, tanto en ese extrañamiento de los lugares y personas queridas que siempre están presentes en los recuerdos y en las añoranzas, o en esa nostalgia que implica la adaptación y que en algunos casos puede dejar a un miembro de la familia aislado emocionalmente, aún estando presente de manera física. Este escenario de las pérdidas puede de cierta manera sugerir que el preservar los rituales o las costumbres cotidianas como las comidas, las maneras de vestir o los juegos, son intentos del migrante para que el choque de su movimiento sea menor, el intento de llevar algo suyo consigo representado desde la propuesta de Jaes (2002) en elementos tales como el tipo de casa que crea el migrante, el lenguaje que habla, lo que cocina, las redes de amistad que forma, las relaciones que mantiene con su comunidad de origen y las tradiciones e identidades que transmite a sus hijos.

Todas estas prácticas son denominadas rituales espontáneos desde la perspectiva de Jaes (2002), y se entienden como las maneras que crea el migrante para lidiar y afrontar sus pérdidas ambiguas; las cuales además, le permiten ir tejiendo puentes de presencia física y psicológica que en últimas le facilitan llenar sus ausencias en tanto 
escenarios y tradiciones portables, portátiles, que además de mantener los lazos y las relaciones con la sociedad de origen, también generan transformaciones en las sociedades receptoras, convirtiéndolas en espacios más cercanos, más familiares, menos ajenos.

Así, estos rituales espontáneos son tipificados por Jaes (2002) como rituales de conexión que implican conductas que el migrante ritualiza para establecer y sostener a través del tiempo, el contacto con quienes quedaron en el lugar de origen; los rituales de recreación que involucran la reproducción de los lugares de encuentro del pasado. Son escenarios y prácticas transportables y reproducidas tanto en el ámbito público como privado, con la intención de traer momentáneamente el espacio cultural conocido; los rituales de la memoria que implican el contar historias del pasado para crear una narrativa de lo que fue y para investir de significado y construir un sentido en torno a los cambios imperantes. Por último, los rituales culturales tradicionales que sugieren una preservación de las tradiciones, las festividades y creencias, asumiendo que la preservación de estos elementos permite la continuidad e identidad familiar y facilita el vínculo comunitario.

Tabla 10. Tipificación de los rituales espontáneos en el marco de los procesos migratorios

\begin{tabular}{|c|c|c|c|c|c|c|}
\hline \multirow{2}{*}{\begin{tabular}{|l}
$\begin{array}{c}\text { Rituales de conexión } \\
\text { (doble via) }\end{array}$ \\
Visitas
\end{tabular}} & \multirow{2}{*}{\begin{tabular}{|l|}
\multicolumn{1}{|c|}{$\begin{array}{l}\text { Rituales de } \\
\text { recreación }\end{array}$} \\
$\begin{array}{l}\text { Reproducción de } \\
\text { lugares del encuentro } \\
\text { del pasado }\end{array}$ \\
\end{tabular}} & \multirow{2}{*}{\begin{tabular}{|c|}
\multicolumn{1}{|c}{$\begin{array}{c}\text { Rituales de b } \\
\text { memoria }\end{array}$} \\
$\begin{array}{l}\text { Contar historias } \\
\text { acerca del pasado }\end{array}$
\end{tabular}} & \multicolumn{4}{|c|}{$\begin{array}{l}\text { Preservación de rituales alturales tradicionales. Para preservar la } \\
\text { continuidad e identidad familiar y vinaulo comunitario }\end{array}$} \\
\hline & & & $\begin{array}{l}\text { Rituales de cido } \\
\text { de vida (ritos de } \\
\text { pasaje) }\end{array}$ & | Rituales cotidianos & Rituales religiosos & $\begin{array}{l}\text { Rituales de salud y } \\
\text { de cura folkdórica }\end{array}$ \\
\hline $\begin{array}{l}\text { Envíos de mensajes } \\
\text { (cartas, telegramas) }\end{array}$ & $\begin{array}{l}\text { Reproducción de } \\
\text { obres }\end{array}$ & $\begin{array}{l}\text { Repetir anécdotas de } \\
\text { los lugares de origen }\end{array}$ & $\begin{array}{l}\text { Matrimonios- } \\
\text { bautismos- } \\
\text { aniversarios- } \\
\text { funerales }\end{array}$ & Comidas familiares & Festividades & $\begin{array}{l}\text { Rituales acerca de } \\
\text { la sa lud, la } \\
\text { enfermedad y la } \\
\text { cura }\end{array}$ \\
\hline Envíos de dinemo & $\begin{array}{l}\text { Reproducción de } \\
\text { sabores }\end{array}$ & $\begin{array}{l}\text { Contar detalles sobre } \\
\text { su historia migratoria }\end{array}$ & & Juegos & Rezos & \\
\hline $\begin{array}{l}\text { Envío de objetos } \\
\text { (fotografías, a muletos) }\end{array}$ & $\begin{array}{l}\text { Reproducción visual } \\
\text { de los espacios }\end{array}$ & & & Maneras de vestir & Devociones & \\
\hline $\begin{array}{l}\text { Envio de comidas y/o } \\
\text { ingredientes }\end{array}$ & $\begin{array}{l}\text { Reproducción de } \\
\text { sonidos }\end{array}$ & & & $\begin{array}{l}\text { Higiene personaly } \\
\text { del hogar }\end{array}$ & & \\
\hline & $\begin{array}{l}\text { Reproducción del } \\
\text { lenguaje del pueblo } \\
\text { de orisen }\end{array}$ & & & $\begin{array}{l}\text { Maneras de } \\
\text { saludar }\end{array}$ & & \\
\hline
\end{tabular}


De esta manera, se plantea una propuesta que sugiere el estudio de la migración a partir del diálogo entre culturas. Las que llegan y las que reciben. Proponiendo la posibilidad de que el migrante viva en dos mundos y no entre dos mundos. Son pues, desde Jaes (2002), los rituales espontáneos de los migrantes los que permiten recuperar lo conocido en medio del cambio.

\subsection{La pregunta por la identidad en este contexto de enunciación}

La identidad ha sido un concepto clave, abordado por las diferentes disciplinas de las ciencias sociales, desde donde este ha sido trabajado tanto para su construcción, como para su deconstrucción. De ahí que se reconozca en disciplinas como la filosofía, el psicoanálisis, la antropología y la sociología los aportes en la configuración y comprensión de dicho concepto. Algunas de estas perspectivas sostienen la identidad como algo inmóvil y estable que se da a partir del nacer y el morir haciendo parte de un clan, de una tribu o de un grupo particular, de ahí que desde esta mirada cuyo foco estaba puesto en las sociedades tradicionales, la identidad en cuanto tal no era problematizada. Un miembro de un grupo ganaba su identidad a partir del ejercicio de roles específicos dentro del grupo o clan al cual pertenecía y este a su vez predefinía el trayecto de cada individuo.

En la modernidad, se reconoce la identidad como algo dinámico y cambiante, de igual manera, desde el punto de vista de Ramos (2009) se reconoce que la identidad constituye una construcción social que surge por medio de la interacción de un actor con su entorno. En vista de que el ámbito de la interacción se encuentra en constante movimiento, las formaciones identitarias de los sujetos sociales carecen de un contenido definitivo o permanente. De ahí que la identidad o las identidades, sean un constructo social vivo y en movimiento que responde a una relación dialógica entre el sujeto y su entorno.

Desde esta perspectiva, el individuo tiene la posibilidad de elegir su identidad y de volver a elegir una y otra vez entre las múltiples opciones de identidades. Sin 
embargo, "para ello se debería ganar el reconocimiento social para asumirlas" (Muñoz, 2007, p. 82). De ahí que las identidades construidas y re-construidas de manera permanente, sean siempre distintas. Entre otras cosas, porque además de las transformaciones contextuales que enfrenta la cotidianidad de cada individuo, también incide la pertenencia cada vez más recurrente a diferentes y múltiples grupos, lo cual va haciendo más compleja la construcción de la identidad en un escenario en el cual el otro es constituyente de un yo, que a su vez constituye ese otro y que en últimas requieren (ambos) de un reconocimiento mutuo para la configuración de su identidad.

Se plantea entonces, por un lado, la mirada de la identidad desde una perspectiva premoderna, que confería al grupo o a la tribu la identidad como su función. Por otro, la mirada que la modernidad le hace al concepto como creación individual. Sin embargo, hay que mencionar también que posterior a la II Guerra Mundial, y a propósito del debate sobre la cultura de masas y los medios de comunicación que emergieron en la postguerra, la cuestión de la identidad empezó a relacionarse con la imagen proyectada, con el estilo y con la apariencia. De ahí que la problematización que se le hace a la identidad desde la modernidad esté relacionada con la manera como nos percibimos y nos representamos frente a los demás y en últimas, la idea de identidad asociada con los bienes que consumimos.

Por consiguiente, desde esta perspectiva no se concibe una posibilidad ilimitada de identidades sino finita y relacionada, claro está, con el consumo de cierto tipo de bienes, lo cual ya había sido anticipado por Herbert Marcuse al sostener que,

(...) la libre elección de amos no suprime ni a los amos ni a los esclavos. Escoger libremente entre una amplia variedad de bienes y servicios no significa libertad si estos bienes y servicios sostienen controles sociales sobre una vida de esfuerzo y de temor, esto es, si sostienen la alienación. Y la reproducción espontánea, por los individuos, de necesidades súperimpuestas no establece la autonomía; solo prueba la eficacia de los controles. (Marcuse, 1993, p. 38) 
Planteando la discusión en torno a una objetivación del ser en tanto se es por lo que se tiene, por lo que se consume y más aún, por lo que se consume en común con... de ahí que esa manera de mostrarse ya mencionada, adhiera a cada sujeto a algo que está completamente tipificado y entre tanto, que las identidades entonces estén construidas de una forma mercantil. En este sentido, la crítica de Marcuse que señala la enajenación en relación con el consumo, sugiere la pérdida de subjetividad en ese definirnos a partir de lo que nos es dado y no de lo que somos.

Sin embargo, cabe señalar también que entre la década del 40 y del 50, cuando el debate centraba su atención en la ya mencionada cultura de masas, los estudios culturales reservaban un valor a la discusión sobre las culturas populares y aunque la noción de identidad fue abordada desde la fundación misma de esta escuela, cabe decir que el concepto tuvo un abordaje particular por los estudios culturales de segunda y tercera generación, a partir de los años 70 y hasta la década de los 90 , en los que la pregunta por la identidad y por los procesos de configuración del yo y del nosotros, empezaron a movilizar acciones en el espacio público relacionadas con los modos particulares de representación de las distintas identidades. Incorporando la perspectiva de género, la etnia, las discusiones sobre la desigualdad, entendida como diferencia de clases y entonces, la cultura obrera y las culturas juveniles y populares como focos de interés, en la exploración realizada desde el marco de estos estudios.

Las aproximaciones que hicieron Hall y Jefferson (2000), ambos graduados del Centre for Contemporary Cultural Studies de Birmingham, a la música popular, al estilo, a la moda y a las culturas juveniles, puso la mirada de estos estudios en el consumo enmarcado en la sociedad capitalista, además de promover la clasificación de las grupalidades y de las personas en categorías socioculturales como lo fueron los jóvenes que en su momento focalizaron la mayor atención de esta escuela de pensamiento. Sin embargo, es importante señalar que desde la perspectiva de estos estudios, si bien la configuración identitaria implica la selección de unos objetos que están dados previamente, este ejercicio selectivo se reivindica como una apropiación y resignificación de estos objetos, una construcción de maneras, escenarios y elementos de 
auto representación que permite, en últimas, unos modos propios de construir identidades.

En uno de los capítulos del texto, se encuentra que para Clarke (2000), la generación de estilos subculturales involucra la selección diferencial a partir de la matriz de existencia. Lo que sucede no es la creación de objetos y significados desde la nada, sino más bien la transformación y el re-arreglo de lo que es dado (y prestado) dentro de un molde que acarrea un nuevo significado, su traducción hacia un nuevo contexto y su adaptación. Además de proponer el proceso de configuración de la identidad grupal en relación con las reacciones, tanto positivas como negativas de los otros grupos frente al nosotros. Confiriéndole al estilo una funcionalidad limítrofe, por cuanto define límites de pertenencia o no pertenencia a un grupo. Así, Hoggart, Williams y Thompson, provenientes de la clase obrera y militantes de la nueva izquierda inglesa, empezaron a pensar en el marco de estos estudios en temas y problemáticas que en el momento de postguerra resultaban siendo bastante álgidos. Es por esta vía que emerge la pregunta por la inserción de la cultura masiva mediática norteamericana en la vida cotidiana de las clases populares inglesas, invirtiendo el foco de los intereses que hasta el momento estaba puesto en la cultura de las élites, a la indagación por la cultura popular y por lo que esta hace en su cotidianidad con las mercancías culturales; planteando además la pregunta por la resistencia a la cultura hegemónica, a partir del uso de estas mercancías.

Hay que mencionar en este punto que la perspectiva de estudios culturales busca fundamentos teóricos en la idea de cultura gramsciana en la cual se propone la hegemonía como categoría y desde donde el conjunto de elementos y representaciones de la cultura dominante se produce, se impone y se sostiene con la venia de las clases subalternas que vinculan a una buena parte de la burguesía, los asalariados, el campesinado y el proletariado. Proponiendo por un lado, la cultura como el lugar de convivencia entre filosofías, sentido común y prácticas que nos constituyen, y por otro, la hegemonía relacionada con el proceso en el que ciertos sectores intentan prevalecer sobre otros. En Gramsci la hegemonía es una construcción que toma como elemento fundamental la ideología. El autor plantea que en el poder no hay una clase sino fracciones de clases, lo cual significa que cuando se configura un gobierno lo hace con fisuras entre sí, haciendo necesaria una acción persuasiva hacia los sectores que se quieren involucrar, y 
proponiendo a los medios de comunicación, a la escuela y a la iglesia como los aparatos ideológicos del estado a través de los que la clase dominante se impone sobre las clases subalternas.

Lo que se ha mencionado, teje el escenario en el que Hall (2006) más adelante empieza a cuestionarse en torno al papel de la clase social como motivadora de ciertas acciones de la sociedad, poniendo la discusión en el lugar de los conflictos socioculturales tales como la raza, el sexo, la religión y la región. Proponiendo entonces la cultura en el mismo escenario de la economía, en tanto inciden, ambas, en los procesos de construcción de las identidades. Superar la discusión desde la perspectiva de clases, le da lugar entonces a otro tipo de estudios que empiezan a plantearse desde las identidades de género y desde las maneras de representar la feminidad en medios de comunicación, insertando en la perspectiva de los estudios culturales, la pregunta por los medios de comunicación y particularmente por las representaciones que estos movilizan y construyen, de esos grupos socioculturales.

Se dibuja así la apuesta teórica y metodológica de los estudios culturales alrededor de las prácticas sociales de la vida cotidiana, entendidas como textualidades con sus respectivas dimensiones simbólicas y claro está, con su dimensión estética que implica la producción de sentidos en los diferentes procesos comunicativos o escenas comunicativas, tal como lo entiende Grimson (2005). Así, se rastrea en este escenario de estudios e investigaciones, la fuente de la cual se nutre el campo de la comunicación desde la perspectiva cultural, y claro está, desde donde se le da lugar a la pregunta por la identidad, como pregunta emergente en la que podría asumirse el tránsito de la comunicación hacia la cultura o el desplazamiento de lo que Jesús Martín Barbero denominó, "De los medios a las mediaciones" (Martín, 1987), en el momento en que "la comunicación se nos tornó cuestión de mediaciones más que de medios, cuestión de cultura y, por tanto, no solo de conocimientos sino de re-conocimiento" (p.10).

La mirada puesta en la cultura se inserta entonces de manera inevitable en esas nuevas categorías emergentes que empezaron a dar cuenta de las cambiantes estructuras sociales y económicas, ancladas por su puesto, a los cambios del sistema capitalista. 
Escenario en el que en la sociedad de consumo, en el periodo de postguerra ya descrito, el sujeto era el cliente o comprador de los bienes y servicios ofertados. Emergiendo desde estos estudios una contra-lectura de las mercancías como productos sociales, y por lo tanto, con un valor simbólico con la capacidad de producir sentido y del consumo como

el lugar donde las clases y los grupos compiten por la apropiación del producto social; como el lugar de diferenciación social y distinción simbólica entre los grupos; como sistema de integración y comunicación; como proceso de objetivación de deseos; como proceso ritual. (García, 2006, p. 82).

Allí pues, en este tránsito, se alberga la indagación por la identidad como concepto, siendo esta, no solo una pregunta situada en el seno de los estudios culturales sino la pregunta estructuradora del tránsito hecho por el campo de la comunicación a la cultura. En el que esta (la cultura) no se piensa ya desde la consideración del pasado o de sociedades desaparecidas, sino desde las dinámicas de la vida cotidiana de las sociedades actuales, definidas y re-definidas de manera permanente, configuradoras de escenarios de lucha y de apropiaciones simbólicas en donde tienen lugar todas las escenas comunicativas, desde la perspectiva de Grimson.

Asumiendo lo anteriormente descrito, también vale la pena situar la cuestión de la identidad en América Latina en donde esta ha estado ligada, entre otras cosas, a la construcción de territorialidades y en donde el surgimiento de diversas dinámicas culturales ha estado anclado no solo a las múltiples maneras de expresión de las culturas, sino a las distintas composiciones migratorias. De esta manera, situar a los estudios culturales en el contexto latinoamericano implica particularmente pensar en estudios alrededor de las prácticas que han ido construyendo y de manera permanente, deconstruyendo otras-nuevas formas de identidad.

Así, podría comulgarse con Hall (2003) quien además de plantear la identidad desde el dinamismo de las sociedades actuales, propone hablar en plural de -las identidades- afirmando que estas "nunca son singulares, sino construidas de múltiples 
maneras a través de discursos, prácticas y posiciones diferentes, a menudo cruzados y antagónicos. Están sujetas a una historización radical, y en un constante proceso de cambio y transformación" (Hall, 2003, p. 17).

Lo anterior permite pensar la identidad como maneras particulares de ser y estar. Que según el autor implica necesariamente el juego de la différance proponiendo así que la identidad

obedece a la lógica del más de uno. Y puesto que como proceso actúa a través de la diferencia, entran a un trabajo discursivo, la marcación y ratificación de límites simbólicos, la producción de «efectos de frontera». Necesita lo que queda afuera, su exterior constitutivo, para consolidar el proceso. (Hall, 2003, p. 16)

Es decir, necesita de ese otro o de esos otros y entre tanto, el auto reconocerse y el ser reconocido como parte de una colectividad, lo que a su vez significa reconocerse y ser reconocido como ajeno a otros grupos. Por lo tanto, se plantea para entender la identidad, la diferenciación de ese otro o de esos otros como elemento fundamental y en últimas, su construcción en y a través de la diferencia, no fuera de ella. Esto pone en escena ese “afuera constitutivo" (Derrida, 1981; Laclau, 1990 y Butler, 1993) evocado por el mismo Hall, que incluso podría también pluralizarse como esos afueras constitutivos, que hacen que las identidades estén relacionadas "con las cuestiones referidas al uso de los recursos de la historia, la lengua y la cultura en el proceso de devenir y no de ser; no «quiénes somos» o «de dónde venimos» sino en qué podríamos convertirnos, cómo nos han representado y cómo atañe ello al modo como podríamos representarnos" (Hall, 2003, p. 18). Las identidades, en consecuencia, se constituyen dentro de la representación y no fuera de ella. Así como también dentro de la diferencia como ya se mencionó.

En este sentido es que la tercera generación de los estudios culturales le abre un escenario preciso al estudio de la identidad en un contexto como el de América Latina en el que convergen pluralidad de etnias y culturas y en donde además se han ido configurando identidades en tensión con las hegemonías culturales, políticas, económicas 
y sociales y en el marco de procesos migratorios, de defensa de territorios, y de luchas por la visibilización de minorías.

Así, el mismo Hall (2003) (como se citó en Laclau, 1990) reconoce que,

la constitución de una identidad social es un acto de poder afirmando de esta manera que, «Si (...) una objetividad logra afirmarse parcialmente, solo lo hace reprimiendo lo que la amenaza. Derrida demostró que la constitución de una identidad siempre se basa en la exclusión de algo y el establecimiento de una jerarquía violenta entre los dos polos resultantes: hombre / mujer, etc.» (p.19)

Poniendo con esto la construcción de las identidades no solo dentro de la representación y de la diferencia, sino también dentro de la configuración misma del poder. Es decir, las identidades y las hegemonías en construcción paralela.

Esto último sugiere también el antagonismo de Laclau desde donde se propone la configuración identitaria a partir de un otro o de unos otros que en relación permanente son constituidos y constituyentes y se configuran de manera simultánea y antagónica; por lo dicho en líneas anteriores

(...) es porque un campesino no puede ser un campesino, por lo que existe un antagonismo con el propietario que lo expulsa de la tierra. En la medida en que hay antagonismo yo no puedo ser una presencia plena para mí mismo. Pero tampoco lo es la fuerza que antagoniza: su ser objetivo es un símbolo de mi no ser $\mathrm{y}$, de este modo, es desbordado por una pluralidad de sentidos que impide fijarlo como positividad plena. (Laclau y Mouffe, 1987, p. 145)

En este escenario, en el que para Hall se construyen las identidades, también se inserta un elemento significativo reconocido en la afirmación que hace el autor al plantear que,

Las identidades surgen de la narrativización del yo, pero la naturaleza necesariamente ficcional de este proceso no socava en modo alguno su efectividad 
discursiva, material o política, aun cuando la pertenencia, la «sutura en el relato» a través de la cual surgen las identidades resida, en parte, en lo imaginario (así como en lo simbólico) y, por lo tanto, siempre se construya en parte en la fantasía o, al menos, dentro de un campo fantasmático. (Hall, 2003, p. 18)

Esto pone en discusión la identidad, también dentro del discurso, por lo cual sería condición sine qua non para pensarla asumiendo una perspectiva histórica que permita, claro está, ubicar particularmente la configuración de identidades en el marco de diversas prácticas discursivas. Es evidente pues, que la perspectiva propuesta por los estudios culturales pone a la investigación y a los estudios sociales de cara a un abordaje no fragmentado de las realidades cotidianas y de las sociedades cambiantes contemporáneas. Propone el escenario para un pensamiento interdisciplinar y por supuesto, intercultural, con la intención de darle respuesta a lo que Richard (2005) menciona como

los nuevos deslizamientos de categorías entre lo dominante y lo subalterno, lo central y lo periférico, lo global y lo local, que recorren las territorialidades geopolíticas, las representaciones sexuales y las clasificaciones sociales. Migraciones de objetos e hibridez del conocimiento se dan cita en los cruces que oponen los estudios culturales a las formaciones sedentarias del saber autocentrado de las tradiciones canónicas. (p. 460)

\subsection{De las nuevas formas de ser-estar-ir-venir-ser. Abordaje teórico de la identidad cultural/El concepto de identidad}

Así entonces, la identidad como concepto en las Ciencias Sociales, ha estado en el centro de diversos debates teóricos, epistemológicos e incluso empíricos, por lo que para apropiar la noción de identidad a un objetivo particular de investigación, se hace necesario recurrir a la genealogía misma de este concepto, la cual ha transitado por todo el devenir de las Ciencias Sociales y las transformaciones del mundo moderno. Stuart Hall, uno de los derroteros de los estudios culturales, constituye un referente pertinente para localizar la categoría de identidad en la indagación por la construcción de 
identidades culturales de comunidades particulares actuales, ubicadas en los procesos de globalización pero también de localización de las poblaciones latinoamericanas.

Para Hall la indagación por la identidad también parte de la pregunta por lo étnico y lo multicultural en el marco del mundo contemporáneo, por lo que es pertinente para el análisis de un caso ubicado en esta región del mundo hablar desde el margen, desde una perspectiva poscolonial que construya conceptos desde el cuestionamiento histórico de los mismos. En su conocido texto Hall y du Gay (2003) intentan identificar ¿Por qué la cuestión de la identidad surgió con una forma tan precisa y al mismo tiempo tan deconstruida y descentrada?, explorando diferentes abordajes dados al problema de la identidad, resaltando justamente su carácter problemático, en tanto categoría de análisis. Concluye que autores como Althusser, Lacan, Foucault y Butler han dado el impulso para la reteorización de la identidad en su complejidad discursiva sin que su desconstrucción implique la abolición como concepto, el cual sigue siendo útil tanto para el desarrollo teórico social como para la representatividad política.

Para el autor es relevante cómo de manera general en las ciencias sociales el concepto de identidad ha sido deconstruido, criticando severamente las concepciones de una identidad integral, originaria y unificada. Esta crítica antiesencialista, abrió un amplio debate sobre las concepciones teóricas de la identidad, debate que el autor propone abordar considerando en primera medida, la crítica deconstructiva general a la que fueron sometidos diversos conceptos esencialistas, dándose una "borradura" de conceptos clave. En segunda medida, enmarca la discusión desde una necesidad de señalar dónde surge la irreductibilidad del concepto de identidad, destacando este concepto como una herramienta teórica central para la cuestión de la agencia y la política. De esta manera, la discusión sobre la problemática conceptual del término identidad se plantea desde diferentes disciplinas, destacando que la mayor implicación del debate se centra en pensar al sujeto en su nueva posición desplazada o descentrada dentro del paradigma.

Es así como introduce el concepto Identificación, el cual destaca como menos comprendido y "casi tan tramposo como el de identidad" pero que ha intentado articular la relación entre sujetos y prácticas discursivas, lo que el autor destaca en la obra de 
Foucault, para quien no es necesaria una teoría del sujeto cognosciente sino una teoría de la práctica discursiva. El concepto identificación en su uso psicoanalítico, se entiende en lo que Freud denomina "la primera expresión de una lazo emocional con otra persona" (Hall, 2003, p. 16).

De esta manera, Hall aclara que si bien estos conceptos no son trasladables en toda su particularidad a los aspectos relacionados con la identidad, son los novedosos repertorios de significado que este concepto ha desembocado, destacando cada vez lo estratégico y posicional del concepto de identidad:

El concepto acepta que las identidades nunca se unifican y, en los tiempos de la modernidad tardía, están cada vez más fragmentadas y fracturadas; nunca son singulares, sino construidas de múltiples maneras a través de discursos, prácticas y posiciones diferentes, a menudo cruzados y antagónicos. (Hall, 2003, p. 17)

Hall insiste en que es necesario, por tanto, situar las identidades y los debates sobre este concepto, dentro de unos momentos históricos precisos, puesto que, tal como loplantea,

en realidad las identidades tienen que ver con las cuestiones referidas al uso de los recursos de la historia, la lengua y la cultura en el proceso de devenir no de ser; no quienes somos o de dónde venimos sino qué podríamos convertirnos, cómo nos han representado y cómo atañe ello al modo como podríamos representarnos. (Hall, 2003, pp.17-18)

De manera que, las identidades se construyen dentro del discurso y no fuera de él, se producen en ámbitos históricos e institucionales específicos, se construyen a través de la diferencia, a través de la relación con el Otro, en el afuera constitutivo como ha sido denominado por Derrida, Laclau y Butler. Al plantearse la identidad como una construcción a partir de la diferencia y constantemente desestabilizada por lo que excluye, se abren diversos debates y cuestionamientos sobre su significado y la posibilidad de su teorización, al respecto, Hall presenta una serie de argumentos que intentan responder las diversas preguntas que surgen de este debate, presentando el uso 
que él mismo ha dado al término identidad. Para Hall las identidades son representaciones que se construyen a través de una falta, una división desde el lugar del otro. Así, destaca autores que han articulado esa dimensión discursiva con la constitución de los sujetos, resaltando la crítica a Lacan sobre la formación de la subjetividad, la cual denomina un callejón sin salida en la discusión por la identidad. En este mismo callejón sin salida menciona a Foucault, quien también lleva a cabo una historización radical de la categoría del sujeto dentro del discurso, preocupándose, por cómo se constituyen los sujetos, discusión central para un debate sobre la identidad:

Para Marx, para Althusser, para Foucault, nunca bastó con elaborar una teoría que explicara cómo se convoca a los individuos a su lugar en las estructuras discursivas. Siempre fue preciso exponer, además, cómo se constituyen los sujetos; y en esta obra Foucault se esforzó por mostrarlo, con referencia a prácticas discursivas, a la autorregulación normativa y a tecnologías del yo históricamente específicas. (Hall, 2003, p. 32)

Para los años noventa, desde una perspectiva foucaultiana, Judith Butler aborda las transacciones complejas entre el sujeto, el cuerpo y la identidad, elaborando un argumento desde la postura de que el sujeto se construye discursivamente y que no hay antes o al margen de la Ley. Butler argumenta que todas las identidades actúan por medio de la exclusión a través de la construcción discursiva de una afuera constitutivo. Así, Butler destaca la problemática de las identidades tratadas políticamente, pues en la construcción de sujetos políticos, las identidades pueden ser premisas fundacionales que toman como base una universalidad y unidad del sujeto, lo que puede ser problemático en el marco de entender la identidad como supuesto cambiante y construido. Esto sin embargo no lleva a Butler a abandonar las nociones de identidad, en cambio toma la de identificación como parte de su argumento, considerando las identificaciones como imaginarios de pertenencia de un "nosotros".

Los cambios históricos, sociales y culturales, acompañados de las transformaciones de la ciencia en su objeto de conocimiento, han llevado al viraje de las perspectivas de la identidad tanto conceptualmente como en la realidad social. Este viraje 
ha puesto en el centro de estos cruces de transformaciones, el problema de la diferencia, como constitutiva de los procesos identitarios de los seres humanos. La identidad como concepto es resultado de los cambios propios que ha sufrido la ciencia como objeto de conocimiento. Así, además de estos descentramientos intelectuales, teóricos y conceptuales de la identidad, Hall ubica también unos descentramiento de la identidad provenientes de la vida social y cultural, transformaciones mundiales y fenómenos sociales, que han sacudido las identidades de grandes colectivos que se creían estables: la raza, el género y la clase.

Desde la concepción psíquica de la identidad, toma importancia la relación con el otro, la construcción de la diferencia como proceso:

La identidad está dentro del discurso, dentro de la representación. Es constituida en parte por la representación. La identidad es una narrativa del sí mismo, es la historia que nos contamos de nosotros mismos para saber quiénes somos. El efecto más importante de esta reconceptualización de la identidad es el subrepticio regreso de la diferencia. (Hall, 2010, p. 345)

Esta diferencia para Hall, debe ser entendida desde la noción de Derrida:

En Derrida, uno encuentra una noción del differance que reconoce la interminable y continua naturaleza de la construcción del significado, pero reconoce también que hay siempre el juego de la identidad y de la diferencia, el juego de la diferencia a través de la identidad. Uno no puede pensar uno sin el otro. ( Hall, 2010, p. 345)

En esa relación entre la identidad y la diferencia, Hall introduce la cuestión de la etnicidad, argumentando que la etnicidad es lo que se requiere para pensar las relaciones entre la identidad y la diferencia. No hay manera, me parece a mí, en la cual las personas del mundo pueden actuar, hablar, crear, entrar desde los márgenes y hablar, o puedan comenzar a reflejar su propia experiencia, a menos que vengan de algún lugar, de alguna historia, de heredar ciertas tradiciones culturales. Lo que hemos aprendido acerca de la teoría de enunciación es que no hay enunciación sin posicionalidad. Uno tiene que 
posicionarse en algún lugar en aras de decir cualquier cosa. Así, nosotros no podemos prescindir en ese sentido de nuestra propia posicionalidad que es connotado por el término de etnicidad (Hall, 2010).

El tema de la diferencia viene, en el hecho de que la relación con ese pasado, con esa posicionalidad, es compleja, y la etnicidad tiene que reconocer su posición en relación con la importancia de la diferencia, dando lugar a una variedad de experiencias, entre estas, las que no se ubican solo en ese pasado sino también en los presentes vividos, para Hall:

Eso es la nueva etnicidad. Es una nueva concepción de nuestras identidades porque no ha perdido el asidero del lugar y el suelo desde el que podemos hablar, pero ya no estamos contenidos dentro de ese lugar como una esencia. Da cuenta de una más amplia variedad de experiencias. Forma parte de la enorme relativización cultural que el globo entero alcanza históricamente -de modo horrible como ha sido en parte- en el siglo XX. (Hall, 2010, p. 348)

Una de las ventajas de la perspectiva de este autor radica en lo que podría denominarse su pensamiento "complejo", pues por un lado afirma que la realidad está constituida discursivamente y que el discurso como hecho social consigue efectos tan reales como cualquier otra práctica social, sin tratarse de un puro "textualismo". Por otro lado, también resalta cómo las condiciones materiales no pueden reducirse a los discursos, siendo un autor que enfatiza en la comprensión de las coyunturas. Su concepción de la cuestión de la identidad podría decirse que articula dos elementos: la identidad y la diferencia. Esta primera entendida como la forma en que el individuo se narra a sí mismo (discurso) a través de su experiencia pasada y presente y en consideración de los múltiples escenarios vitales (condiciones materiales e históricas), y la diferencia, entendida como constitutiva de la identidad en la medida que esa narración del sí mismo siempre estará en relación con los otros, con quienes comparte esas experiencias vitales. 
Así, Hall presenta esta serie de argumentos que impulsaron el cuestionamiento y la teorización de la identidad como un asunto de significación política. ¿Cómo entender entonces el concepto de identidad? Ofrece en particular una noción de identidad acompañada de una definición de las identificaciones, enmarcadas en la cronología misma del concepto, que ampliamente expone en sus textos. Así según estos lineamientos de Hall, la identidad sería,

(...) el punto de sutura entre, por un lado, los discursos y prácticas que intentan interpelarnos, hablarnos o ponernos en nuestro lugar como sujetos sociales de discursos particulares y, por otro, los procesos que producen subjetividades, que nos construyen como sujetos susceptibles de decirse. De tal modo, las identidades son puntos de adhesión temporaria a las posiciones subjetivas que nos construyen las prácticas discursivas. (Hall, 2003, p. 20).

Como parte de su discusión frente a las diferentes aristas a las que conlleva hablar de la identidad, el autor introduce el concepto de identificación que en su argumento pareciera ser un concepto similar al de identidad pero con mayores bondades explicativas, en el sentido de que parte del hecho de la existencia del ámbito imaginario de las identidades, entendiendo los procesos de identificación como representaciones que el sujeto construye de su realidad y en relación a un "nosotros".

Al parecer, la cuestión de la identidad o, mejor, si se prefiere destacar el proceso de sujeción a las prácticas discursivas, y la política de exclusión que todas esas sujeciones parecen entrañar, la cuestión de la identificación, se reitera en el intento de rearticular la relación entre sujetos y prácticas discursivas. La identificación resulta ser uno de los conceptos menos comprendidos: casi tan tramposo como identidad, aunque preferible a este; y, sin duda, no constituye garantía alguna contra las dificultades conceptuales que han acosado a este último. Su uso implica extraer significados tanto del repertorio discursivo como del psicoanálitico, sin limitarse a ninguno de los dos; el enfoque discursivo ve la identificación como una construcción, un proceso nunca terminado: siempre en proceso (Hall, 2003). 
Más que hablar de identidad como algo acabado, deberíamos hablar de identificación, y concebirla como un proceso inacabado. La identidad se yergue, no tanto de una plenitud de identidad que ya está dentro de nosotros como individuos, sino de una falta de totalidad, la cual es "llenada" desde fuera de nosotros, por medio de las maneras en que imaginamos que somos vistos por otros. Psicoanalíticamente, la razón por la cual estamos en continua búsqueda de "identidad", construyendo biografías que unen las diferentes partes de nuestros "yos", es para volver a captar este placer fantaseado de completitud (plenitud) (Hall, 2010).

Sin embargo, la identidad por sí sola, implica un concepto como bien lo demuestra, móvil, heterogéneo, casi que de difícil aprehensión para quien espera una noción básica sobre la cual trabajar la realidad social. Así, el autor particulariza la identidad en una de sus formas, la identidad cultural, abordándola desde el análisis de las diásporas de occidente. Las diásporas de Occidente, como nuevos sujetos postcoloniales han emergido como sujetos con una identidad cultural particular, en medio de la inmensa diferencia que caracteriza a la población negra caribeña. Para Hall, la identidad cultural siendo el lugar de enunciación desde el que hablamos teniendo en cuenta una historia y una cultura específicas, parte del principio constitutivo de la diferencia, siendo una identidad colectiva construida desde la similitud y la diferencia de una población como sobre un pasado imaginado compartido, y unos procesos de interacción con el Otro.

Esta experiencia de diáspora para Hall, está definida no por una esencia o pureza sino por el reconocimiento de una heterogeneidad y diversidad, por una concepción de identidad que vive con la diferencia. Para el autor la identidad cultural podría definirse como:

(...) la identidad cultural en términos de una cultura compartida, una especie de verdadero sí mismo [one true self] colectivo oculto dentro de muchos otros sí mismos más superficiales o artificialmente impuestos, y que posee un pueblo [people] con una historia en común y ancestralidad compartida. Dentro de los términos de esta definición, nuestras identidades culturales reflejan las experiencias históricas comunes y los códigos culturales compartidos que nos proveen, como "pueblo", de marcos de referencia y significado estables e 
inmutables y continuos, que subyacen a las cambiantes divisiones y las vicisitudes de nuestra historia actual. (Hall, 2010, pp. 349-350)

Esta concepción jugó un papel relevante en las luchas postcoloniales y sigue siendo fuerte entre las culturas marginadas. Esta es la identidad que ha intentado ser redescubierta. Basándose en Fanon, Hall se pregunta si tal vez no se trate de un redescubrimiento sino de una producción de una identidad, ya que esta no sería redescubierta partiendo de su existencia esencial, sino más bien producida desde un contexto histórico determinado. Esta concepción de identidad esencial redescubierta, sin embargo, ha sido la base del surgimiento de los movimientos sociales. Diferente a la anterior, una segunda visión de la identidad cultural, admite que,

(..) Al igual que los muchos puntos de similitud, también hay puntos críticos de diferencia profunda y significativa que constituyen "eso que realmente somos"; o más bien "en lo que nos hemos convertido" puesto que la historia ha intervenido en nosotros. No podemos hablar muy extensamente, con cierta exactitud, sobre "una experiencia, una identidad", sin aceptar el otro lado: las rupturas y discontinuidades (...). (Hall, 2010, p. 351)

Esta segunda visión considera que las identidades están sometidas a constantes transformaciones y sujetas al juego continuo de la historia, la cultura y el poder. Lejos de estar basadas en la mera "recuperación" del pasado que aguarda a ser encontrado, y que cuando se encuentre asegurará nuestro sentido de nosotros mismos en la eternidad, las identidades son los nombres que les damos a las diferentes formas en las que estamos posicionados, y dentro de las que nosotros mismos nos posicionamos, a través de las narrativas del pasado (Hall, 2010).

La identidad no sigue un curso en línea recta y continua a partir de un origen establecido, en el caso de las identidades negras del Caribe la experiencia colonizadora rompió, expropió una identidad, lo que da lugar a Hall a insistir en que la identidad cultural no es una esencia establecida que permanece inmutable al margen de la historia y la cultura. 
El pasado continúa hablándonos, pero no se dirige a nosotros como un "pasado" simple y real porque nuestra relación con él, como la relación de un niño con su madre, existe desde siempre "a partir de la separación". Se construye siempre a través de la memoria, de la fantasía, de la narrativa y del mito. Las identidades culturales son puntos de identificación, los puntos inestables de identificación o sutura, que son hechos dentro de los discursos de la historia y de la cultura. No son una esencia sino un posicionamiento. Así, siempre hay políticas de identidad, políticas de posición, que no tienen garantía total en una "ley de origen" trascendental y no problemática (Hall, 2010).

En el caso de la población negra mundial, la paradoja es que fueron factores como el desarraigo de la esclavitud los que unificaron a esos pueblos a través de sus diferencias. Así, Hall describe el elemento común de este pasado negro, que comparten las comunidades en el mundo entero, pero a la vez, la persistencia de la diferencia, por ejemplo, es diferente Martinica de Jamaica, una diferencia profunda de historia y cultura, pero al compararse con el occidente desarrollado serían "lo mismo" lo marginal, lo subdesarrollado, el "otro". De manera que, "los límites de la diferencia se reposicionan continuamente con relación a diferentes puntos de referencia" (Hall, 2010, p. 353).

Hall describe para el caso caribeño tres presencias para pensarse la ubicación y reubicación de las identidades culturales en el Caribe: la presencia africana, la presencia europea y la presencia americana. La presencia africana para Hall ha sido el significante privilegiado de las nuevas concepciones de identidad en el Caribe (el pasado común). Sin embargo, el África original ya no está allí, pues ha sido transformada, África pertenece irrevocablemente a lo que Edward Said (1978) alguna vez llamó una "historia y geografía imaginaria"; que ayuda a "la mente a intensificar su sentido de sí mismo, al hacer más radical la diferencia entre lo que se encuentra cerca a ella y lo que está lejos". "Ha adquirido un valor imaginativo o figurativo que podemos nombrar y sentir" (Said 1978, p. 33). Nuestro sentido de pertenencia a ella constituye lo que Benedict Anderson (1982) llama "comunidad imaginaria". A esta África, que es una parte necesaria del imaginario del Caribe, no podemos, literalmente, retornar de nuevo (Hall, 2010). 
Esta cuestión de la identidad además de cambiar a través del desarrollo de la teoría social, se relaciona estrechamente con el carácter de cambio en la modernidad tardía, en particular con el proceso de "globalización", pues la modernidad está definida por la experiencia del cambio constante y una forma de vida reflexiva en la que las prácticas sociales se examinan y reforman constantemente. Autores como Giddens, Harvey y Laclau, analizan esta modernidad enfatizando en su discontinuidad, fragmentación, ruptura y dislocación.

Esta pluralización de las identidades, mencionadas en la concepción del sujeto posmoderno, tiene para Hall consecuencias políticas, por lo que resalta a partir de la ejemplificación el "juego de identidades" que se vive en la vida política contemporánea, e incluso en el diario vivir de los sujetos. Sin embargo, ¿Cómo este "sujeto fragmentado" se sitúa en términos de sus identidades culturales? La identidad cultural particular que desarrolla Hall es la identidad nacional, siendo ésta una principal fuente de la identidad cultural. En este marco, Hall argumenta en relación a las identidades nacionales, que estas,

No son elementos con los cuales nacemos, sino que son formadas y transformadas dentro de y en relación con la representación. Sólo sabemos qué es ser "inglés" por la manera en que la "inglesidad" ha venido a ser representada, como un conjunto de significados, por la cultura nacional inglesa. Se sigue que una nación no es solamente una entidad política sino algo que produce significados, un sistema de representación cultural. (Hall, 2010, p. 380)

Para Hall, las culturas nacionales están compuestas tanto por instituciones culturales como por símbolos y representaciones, siendo un discurso, una construcción de significados que influencia la concepción de los individuos mismos. Basado en Benedict Anderson, Hall considera la identidad nacional como una "comunidad imaginada" que se narra a ella misma. Hall destaca cinco elementos: 1. la narrativa de la nación, cómo se cuenta y se vuelve a contar en la historia nacional, las literaturas, los medios y en la cultura popular; 2. el énfasis en los orígenes, la continuidad, la tradición y la eternidad; 3. la invención de la tradición, el conjunto de prácticas que inculcan ciertos valores e 
implican una continuidad con un pasado histórico; 4. el mito fundacional, la historia que sitúa el origen de la nación, "el pueblo"; 5. La idea de gente pura y original o "pueblo".

Sin embargo, ¿son estas identidades nacionales únicas en realidad? Para Hall, por muy diferentes que sean sus miembros, una cultura nacional busca unificarlos en una identidad cultural que los muestra como pertenecientes a la misma gran familia nacional. Destaca en este sentido, tres conceptos resonantes de lo que constituye una cultura nacional como una "comunidad imaginada": las memorias del pasado, el deseo de vivir juntos, la perpetuación del patrimonio. Una cultura nacional en este sentido, es también una estructura de poder cultural, en su objetivo de unificación cultural.

En lugar de pensar en las culturas nacionales como unificadas, debemos pensar en ellos como constituyendo un dispositivo discursivo que representa la diferencia como unidad o identidad. Están atravesadas por profundas divisiones y diferencias internas, y "unificadas" solamente por el ejercicio de diferentes formas de poder cultural. Sin embargo -como en las fantasías del yo "entero" del que habla el psicoanálisis lacanianolas identidades nacionales siguen siendo representadas como unificadas (Hall, 2010).

Las identidades nacionales como identidades culturales constitutivas de la individuación de los sujetos contemporáneos, han llamado la atención teórica para el abordaje de la complejidad del tema de la identidad. Así, en la misma línea que Hall, Alejandro Grimson, desde las particularidades latinoamericanas, ha abordado los procesos de construcción de identidades culturales desde la interculturalidad, presente en los territorios de América Latina. El autor realiza un recorrido sobre los conceptos de cultura e identificación bajo el marco de los estudios de las naciones (Grimson, 2001).

Sobre el concepto de cultura, resalta las polisémicas teorías antropológicas surgidas sobre el tema. Un consenso general sobre el término ha supuesto que el concepto cultura fue creado para establecer variedades, no jerarquías, pues hace mención desde sus primeros usos en la teoría antropológica al estudio de la diferencia, de la diversidad humana en las formas y sentidos de concebir el mundo. El uso del término ha sido 
potenciado a través del uso de dimensiones temporales y espaciales para su análisis, de manera que,

La cultura es histórica y ninguna sociedad puede comprenderse sin atender a su historicidad, a sus transformaciones. A su vez, toda sociedad se ubica en un espacio y se encuentra en interrelación con otras sociedades. Entre otras razones, esa interrelación hace imposible una homogeneidad cultural. Por lo tanto, los estudios sobre sociedades y culturas analizan necesariamente su historia y su contacto. (Grimson, 2001, p. 25)

El elemento espacio temporal con el que es entendido el término cultura, implica entender los elementos compartidos por un grupo, lo cual permite hablar de una cultura o prácticas culturales compartidas, no deben ser buscados en los rasgos culturales objetivos (vestimenta, lenguaje, comida) sino más bien:

en las experiencias históricas y en las creencias y prácticas que esa experiencia ha generado. Una formulación de este tipo implica necesariamente la imposibilidad de establecer creencias y prácticas inmutables, ya que nuevas experiencias implicarían diferentes modificaciones. Por otra parte, implica también que no hay uniformidad, ya que cada experiencia es vivida y procesada de modos diversos por distintas clases, regiones, grupos etarios, étnicos, hombres y mujeres. (Grimson, 2001, p. 28)

De esta manera, Grimson argumenta que el concepto cultura es útil para entender cómo se organizan las diferencias y los conflictos en una sociedad, así como para analizar las relaciones entre personas y grupos. La categoría de identificación, es el término que usa el autor para reflexionar sobre el ya debatido concepto de identidad. Las afiliaciones identitarias y el significado de estas en las sociedades, remite a los debates sobre la alteridad, con modalidades categoriales y taxonómicas que clasifican a los grupos humanos según un origen social o determinado rasgo cultural. A la luz de la historicidad que contiene el mismo concepto de cultura, para Grimson, "Las personas y los grupos se identifican de ciertas maneras o de otras en contextos históricos específicos y en el marco 
de relaciones sociales localizadas" (Grimson, 2001, p. 29). Identifica dos elementos de toda identificación (la cual asimila el autor como formas de clasificación):

Su carácter relacional: "Al mismo tiempo que establece un "nosotros" define un "ellos", la nación, el género, la clase, la raza, la etnia, pueden constituir en diferentes contextos de interacción parámetros perceptivos que definen relaciones sociales entre "nosotros" y "los otros".

Su carácter histórico: "ese "nos/otros" es al mismo tiempo el resultado de sedimentaciones de un proceso histórico como una contingencia sujeta a transformaciones. (Grimson, 2001, p. 31)

Las clasificaciones de grupos humanos, las diferencias entre un nosotros y un ellos, las identificaciones, demarcan fronteras entre grupos que, sin embargo, no son fronteras naturales ni esenciales, por lo que la convivencia entre grupos fronterizos no plantea una asimilación o fusión, sino que en la dinámica de la interacción lo que se presentan son roces y conflictos, constitutivos de todas formas, de la dinámica de clasificación e identificación. De esta manera, las identificaciones no obedecen a una realidad anterior de cultura sino que resulta de intereses y necesidades, de manera que, los rasgos culturalmente compartidos por un grupo que los diferencian de otro, pueden ser acentuados en diferentes circunstancias históricas en relación a contextos e intereses específicos.

Actualmente, existe un amplio consenso acerca de la imposibilidad de una definición "objetiva" y estática de la identidad de cualquier grupo humano. Es decir, hay un cierto acuerdo sobre la necesidad de concebir las identificaciones como proceso relacional que resulta de condiciones y construcciones históricas. Esto implica que ningún grupo humano es esencial o naturalmente étnico, nacional o racial, sino que esas categorías refieren a los modos en que un grupo se vincula a los otros en un momento histórico. Las adscripciones identitarias no son "naturales", no están determinadas ni por "la sangre" ni por el "lugar de nacimiento" y son productos de incesantes construcciones, imaginaciones e invenciones (Grimson, 2001). 
Para profundizar en el análisis de las construcciones sociales de las culturas y las identidades, Grimson reflexiona sobre la nación, en cuanto a sentido de pertenencia y referencia identitaria, y como organización de la diversidad y la desigualdad en una sociedad.

Al igual que con los conceptos de cultura e identidad, con la idea de nación se han desarrollado diversos análisis que fueron pasando desde los años ochenta a perspectivas vinculadas al constructivismo histórico, de manera que la nación, como la cultura y las identidades se entendía como un constructo social y no como una entidad primaria e invariable, al igual que la nacionalidad y el nacionalismo. Así, para Grimson, las naciones son sistemas de diferencias que producen diversidad y alteridades. Grimson sostiene que la idea de nación se vincula con tres conceptos relacionados:

- Campo de interlocución: los grupos humanos se encuentran inscritos en un contexto espacio-temporal determinado, por lo que "un campo de interlocución es un marco dentro del cual ciertos modos de identificación son posibles mientras que otros quedan excluidos" Grimson (2001, p. 41), el Estado nación es uno entre muchos campos de interlocución. A lo largo de la historia una sociedad crea categorías identitarias que se van incorporando en las personas, las cuales son susceptibles de reconstruirse

- Caja de herramientas: las categorías identitarias surgen en un momento de la historia adquiriendo una gama de significados. Ese conjunto de categorías creadas se podría denominar caja de herramientas identitarias: "Cada grupo o actor, en un momento específico, podrá identificarse con algunas de esas categorías, y no con otras, si pretende convertirse en interlocutor" Grimson (2001, p. 45). "Las identificaciones que en otros contextos fueron poderosas (por ejemplo, identificaciones políticas o de clase) pierden fuerza en otros contextos históricos y pueden reaparecer en situaciones futuras." Grimson (2001, p. 45).

- Sentidos de las categorías: estas categorías están históricamente dotadas de sentidos, que de igual forma pueden transformarse, siendo uno de los principales objetos de disputa en la lucha social. 
Con base en los análisis realizados por Segato, Grimson desarrolla las formaciones de diversidad en Estados Unidos, Brasil y Argentina, los cuales basan su constitución como nación en la diversidad de sus poblaciones, sin embargo, en tres términos totalmente distintos. La reflexión del autor lleva a plantearse cuestiones alrededor de ¿Cómo se plantean las fronteras entre el "nosotros" y los "otros" en contextos determinados? Siendo las identificaciones cambiantes según contextos, en los cuales además los individuos hacen uso de una caja de herramientas identitarias según intereses y dotan estas identificaciones o categorías de identidad de sentidos diversos según factores espacio temporales, la identificación de la construcción de fronteras identitarias plantea un reto para quien quiere acercarse al tema empíricamente. Pensándolo en contextos determinados, la búsqueda de las identificaciones está en el camino de la búsqueda de esas fronteras en las cuales los individuos reconocen una alteridad y una identidad que les es propia.

Tanto para Hall como para Grimson, los procesos de construcción de identidades culturales, nacionales y de otra índole han sido transformados en el devenir de los procesos de globalización que han replanteado las formas de esas identidades nacionales. A este análisis Hall suma las consecuencias que tiene sobre el proceso identitario nacional el proceso de globalización, lo que ha desarrollado una serie de dislocaciones de la identidad incorporando lo global en lo local.

En la exploración contemporánea sobre el tema de la identidad, los procesos de globalización y revolución de las tecnologías de la información han tomado especial relevancia. Así, el sociólogo Manuel Castells, para explorar el tema de la identidad, parte de la premisa de que la revolución de las tecnologías de la información y la reestructuración del capital han inducido una nueva forma de sociedad, la sociedad red, caracterizada por la globalización y su organización en redes, la flexibilidad e inestabilidad en el trabajo y transformación de las experiencias de vida de los individuos. En este marco analiza la construcción de la identidad en estos procesos globalizantes, que han llevado a un proceso de individualización en los términos entendidos por Giddens, y a la construcción de sujetos colectivos que reivindican su lucha identitaria para la transformación social, cultural y política. 
Castells (2003) propone una definición de identidad basada en la concepción de sujetos (individuales y colectivos) que le asignan un sentido a su experiencia a partir de un conjunto de atributos culturales. Identifica tres tipos de identidad, a partir de los cuales guía su análisis de los procesos identitarios en la sociedad red: la identidad legitimadora, identidad de resistencia e identidad proyecto. En el texto el autor se centra en varios procesos de construcción de identidad colectiva en el marco de la sociedad red: el fundamentalismo religioso, el nacionalismo, la identidad étnica, y la identidad territorial. En su análisis profundiza en casos como el fundamentalismo islámico y cristiano, el nacionalismo en la desintegración de la Unión Soviética y la identidad afroamericana contemporánea, todos procesos protagonistas en las nuevas sociedades globalizadas.

En cuanto a las identidades territoriales el autor analiza las denominadas comunidades locales, basado en sus estudios urbanísticos sobre la conformación de comunidades urbanas, para Castells, en los territorios locales, en estas comunidades urbanas, la gente se resiste al proceso de individualización y tiende a agruparse territorialmente, generando con el tiempo sentimientos de pertenencia y en algunos casos una identidad cultural. Para esto, plantea, deben darse procesos de movilización social, participación en movimientos urbanos mediante los que se descubren intereses comunes; identificándose allí una identidad de resistencia característica de la sociedad red.

Por identidad, en lo referente a los actores sociales, entiendo el proceso de construcción del sentido atendiendo a un atributo cultural, o un conjunto relacionado de atributos culturales, a que se da prioridad sobre el resto de las fuentes de sentido. Para un individuo determinado o un actor colectivo puede haber una pluralidad de identidades. No obstantes, tal pluralidad es una fuente de tensión y contradicción tanto en la representación de uno mismo como en la acción social:

(...) las identidades son fuentes de sentido más fuertes que los roles debido al proceso de autodefinición e individualización que suponen. En términos sencillos, las identidades organizan el sentido, mientras que los roles organizan las funciones. Defino sentido como la identificación simbólica que realiza un actor social del objetivo de su acción. También propongo la idea de que, en la sociedad red, por razones que 
desarrollaré más adelante, para la mayoría de los actores sociales, el sentido se organiza en torno a una identidad primaria (es decir, una identidad que enmarca al resto), que se sostiene por sí misma a lo largo del tiempo y el espacio. (Castells, 2003, p. 29)

\subsection{La configuración de identidades culturales. Un abordaje desde los procesos migratorios de los migrantes nariñenses en el municipio de Candelaria, Valle del Cauca. Colombia}

A partir de las perspectivas expuestas, para el análisis de la construcción de identidades en el marco de procesos migratorios, se construyó una conceptualización y posterior operacionalización de las categorías "construcción de identidades” y "movimiento migratorio" que permiten el acercamiento empírico al caso de la colonia nariñense asentada en el municipio de Candelaria, Valle del Cauca. Desde la perspectiva teórica de los estudios culturales, en esta investigación se considera la construcción identitaria como un proceso inacabado que se da en el marco de prácticas discursivas, como una construcción que resulta de un proceso de narrativización del yo. Es la historia o las historias que nos contamos para saber quiénes somos y a su vez, las maneras en que nos imaginamos que somos vistos por los otros (Hall, 2003).

Hall (2010) entiende este proceso de construcción como un acto de poder en el que se establece jerarquías, se excluye algo y se definen límites simbólicos entre un "ellos" y un "nosotros", proponiendo con esto una construcción paralela entre las identidades y las hegemonías. Se reconoce aquí, no solo que la identidad está dentro del discurso Hall (2003) sino también que "la narración es un modo fundamental de construcción de sentido en la vida cotidiana" Ford (1994, p. 135), por lo cual, se proponen justamente, en el caso de los migrantes nariñense, los escenarios de encuentros diarios concertados y no concertados, de pugnas y negociaciones, donde se tejen y destejen las relaciones entre ellos mismos y entre ellos y la comunidad candelareña y donde tienen lugar sus prácticas cotidianas en Candelaria, aspectos claves para indagar sobre los procesos migratorios y sobre los procesos identitarios de esta colectividad. 
La colectividad nariñense en Candelaria se constituye también en la interacción cotidiana y en las relaciones interculturales que establece (entre otros) con la cultura vallecaucana, con otros grupos migratorios que tienen presencia en el municipio, con la iglesia, con los ingenios azucareros y con la clase política candelareña. Además, claro está, de la producción de esos espacios de identificación mencionados por Grimson, que generan el marco de aproximación a los sentidos que sobre la migración y la identidad, se construyen en los procesos comunicativos de estos sujetos, en su vida cotidiana.

En este sentido, se consideran los relatos de identidad cultural, entendida esta como una identidad colectiva, lo que para Hall en términos de Anderson podría ser una "comunidad imaginada" Anderson (1993) que se narra a sí misma y que se va constituyendo desde la similitud y la diferencia y sobre procesos de interacción. La identidad cultural implica tener una historia, unos códigos, un pasado imaginado y una ancestralidad compartidos, parte del principio constitutivo de la diferencia a partir de un otro que es a su vez, constituido y constituyente. Si bien Anderson propone la idea de comunidades imaginadas desde el análisis del nacionalismo y la construcción de los estados-nación, Hall (2010) resalta el acercamiento que desde este enfoque se da al análisis de las identidades colectivas, ya sean nacionales, regionales o étnicas, todas estas atravesadas por procesos similares de construcción compartida de referentes simbólicos, narrativas y prácticas.

A la construcción de una identidad cultural, en el caso a estudiar, se suma un proceso migratorio definitivo, a partir del cual se constituyó la comunidad nariñense como colectividad. Así, se pretende analizar la construcción identitaria de estos sujetos migrantes a partir de su construcción como colectivo, de la identidad cultural como nariñenses que migraron de su región de origen y se establecieron en un municipio a partir de las negociaciones y conflictos simbólicos y culturales con los nativos candelareños. El caso a analizar se trata de una migración interna espontánea y dirigida, realizada entre dos departamentos del occidente colombiano de manera voluntaria y por motivaciones económicas. Las migraciones dirigidas conservan el carácter voluntario de la migración pero el movimiento se realiza mediado por instituciones que ayudan a disminuir los riesgos a los que pueda enfrentarse quien migra; tal como sucedió en los 
períodos de migración nariñense al Valle del Cauca, cuando en el marco del crecimiento que tuvo la industria azucarera en el departamento se generaron estrategias desde algunos ingenios azucareros para traer mano de obra desde Nariño y desde otros departamentos.

Este proceso migratorio, como lo señala la teoría abordada, genera unos impactos económicos y demográficos tanto en los lugares de origen como de destino, además de una serie de dinámicas interculturales a la llegada de los migrantes y el contacto con los habitantes originarios. Se genera allí lo que se podría entender como un campo de interlocución, en el sentido de Grimson, un espacio de intercambio y de tensiones entre códigos culturales.

En el marco de este intercambio cultural, resulta un proceso de integración en el que se dan lugar las redes de apoyo de los migrantes. Esos vínculos que se establecen con otros migrantes (de todos los tiempos), no migrantes, amigos, familiares, vecinos y hasta potenciales migrantes que se unen para hacer un intercambio de recursos económicos, culturales, sociales con el fin de apoyar el proceso migratorio. Estas redes son lazos interpersonales como lo entienden Massey, Arango, Hugo, Kouaouci, Pellegrino y Taylor (1993), que vinculan a migrantes y no migrantes, y que según Demarchi son justamente la estructura que posibilita que las identidades se recreen, se revitalicen y se refuerce la imagen de colectividad (en este caso nariñense) en un escenario que desde la perspectiva de Demarchi es entendido como marco de comunicación (Demarchi, 2012).

En este sentido son relevantes entonces los relatos migratorios, ya que hacen referencia a las historias o los fragmentos de historias que refieren la experiencia de migración en sus diferentes momentos. El antes de migrar, considerando las motivaciones y el papel de las redes de apoyo en la toma de la decisión; el durante la migración que refiere las rutas y los momentos vividos en el trayecto del lugar de origen al lugar de destino; el momento de llegada al lugar de destino, las relaciones de diversa índole establecidas con la sociedad receptora, las estrategias para permanecer en contacto con la sociedad de origen y la manera como se va configurando la colectividad en destino. Estos relatos implican también la consideración de la manera como los migrantes y las sociedades receptoras asumen y narran sus procesos de aculturación, entendido este como 
el proceso no de pérdida de la cultura original sino de reinterpretación de los nuevos elementos culturales que van emergiendo tanto para quienes reciben, como para quienes llegan. Generándose, en el marco de estos procesos de aculturación, actitudes y relatos de marginación-exclusión, segregación-separación, asimilación e integración (Berry, 1997).

Los anteriores supuestos teóricos que vinculan la construcción de identidades, los procesos migratorios y los relatos que sobre estos dos fenómenos construyen los sujetos y las colectividades, son el marco mediante el cual se aborda el análisis de la colonia nariñense en Candelaria. En este caso, se consideran como dimensiones de acercamiento a la realidad empírica de un proceso de construcción de identidad, la propuesta de comunidades imaginadas de Anderson (1993) a partir de lo desarrollado por Hall; la identidad y la diferencia: el "ellos" y el "nosotros", que en Grimson (2005) son entendidos como campos de interlocución, para Jaes (2002) son rituales espontáneos de conexión en el marco de procesos migratorios y en Demarchi (2012), marcos de comunicación $^{14}$.

\subsection{Categorías de análisis para la aproximación empírica}

\subsubsection{Relatos de identidad cultural}

\subsubsection{Narrativas de "lo nariñense", en perspectiva crítica y desde una mirada sociocomunicativa.}

Son las maneras como se cuenta y se vuelve a contar lo nariñense desde afuera: desde la literatura, desde los medios y desde la cultura popular.

\footnotetext{
${ }^{14}$ Ver matriz de operacionalización de categorías de análisis. Las dimensiones de análisis asociadas a la macrocategoría de construcción de identidad, tomadas de Anderson y reelaboradas a la luz de Hall, Grimson, Jaes y Demarchi; y las dimensiones de análisis asociadas a la macrocategoría de movimiento migratorio tomadas de Berry, son resultado de un proceso de operacionalización de conceptos que buscó retomar los planteamientos teóricos expuestos, organizándolos en categorías de análisis pertinentes para el problema de investigación y susceptibles de observar en la unidad de análisis propuesta. El conjunto de supuestos teóricos tratados fueron ordenados en macro categorías, meso categorías y micro categorías, en un ejercicio de concreción en el que se construyeron definiciones operacionales para la observación de las macro categorías construcción de identidades culturales y movimientos migratorios, lo anterior con el fin de adaptar los preceptos teóricos del enfoque de los estudios culturales a la producción de los datos empíricos.
} 


\subsubsection{Orígenes nariñenses}

Se asume aquí una relación con el origen territorial y cultural que remite a lo que es tradicional del departamento de Nariño.

\subsubsection{Estrategias de identificación}

Son las prácticas que la comunidad genera para inculcar ciertos valores, costumbres y tradiciones que implican continuidad con el pasado nariñense. Jaes lo denomina rituales de invención de la tradición, Demarchi lo llamó marcos de comunicación y Grimson, campos de interlocución. Los tres autores coinciden en que estas prácticas (celebraciones religiosas, fiestas nacionales o regionales, juegos, etc.) son escenarios de interlocución en los que se define y redefine la cultura del migrante, se refuerza la imagen de la comunidad y se perpetúan estilos de vida.

Por lo tanto, forman parte de los procesos de configuración de identidad en tanto permiten la construcción de nuevos lugares y espacios de identificación en donde se construyen sentidos del nosotros y de los otros. Son estas prácticas, los escenarios de reafirmación e invención de las identificaciones, que además, permiten recuperar lo conocido en medio del cambio y tejer puentes de presencia física y psicológica en los nuevos espacios que se van haciendo más cercanos, más familiares y menos ajenos a través de esas maneras que va creando el migrante para lidiar y afrontar las pérdidas que trae consigo el movimiento migratorio. Se van construyendo a través de estas prácticas, códigos de comunicación, estructuras de significación y modos de configuración colectiva en el campo intercultural que propone la migración.

\subsubsection{Idea de gente pura y original}

Entendida como la historia que nos contamos, la narrativa del sí mismo, el discurso propio, es decir, lo que nos hace nariñenses en Candelaria. 


\subsubsection{Relatos de migración}

\subsubsection{Mito fundacional}

El mito fundacional se entiende aquí como la historia que sitúa el origen de lo nariñense en Candelaria. Hace referencia específica a la indagación por el inicio del proceso migratorio.

\subsubsection{Relatos de marginación-exclusión}

En estos relatos se evidencia el rechazo de la población inmigrante a incorporarse en la sociedad receptora, pero además, en medio de un distanciamiento simultáneo de la identidad cultural de origen. Cuando es la sociedad receptora quien impone el distanciamiento, se habla de exclusión y cuando es la sociedad inmigrante quien decide rechazar a la población receptora, se habla de marginación.

\subsubsection{Relatos de segregación-separación}

La segregación implica una ausencia de relación entre quienes llegan y quienes estaban. Cuando es la sociedad receptora quien impone la distancia se habla de segregación y cuando la decisión es tomada por la población inmigrante, se habla de separación. Refiriendo en este proceso el mantenimiento de los códigos culturales originales.

\subsubsection{Relatos de asimilación}

En ellos se evidencia un proceso de abandono de la identidad cultural de origen para asumir los códigos culturales de la sociedad que recibe.

\subsubsection{Relatos de integración}

Estos relatos dan cuenta de un proceso en el que el migrante lucha por mantener su identidad cultural de origen pero simultáneamente en el ejercicio de ser y hacer parte de la sociedad receptora. 


\subsection{Las dimensiones de la comunicación. Eje transversal de análisis}

Por otra parte, es importante señalar que además de estas categorías observables, siguiendo la propuesta de Grimson (2001), se han considerado las dimensiones de la comunicación como ejes transversales para el análisis de las microcategorías ya mencionadas. Entendiendo que la comunicación desde la perspectiva del autor asume un proceso de interacción simbólica en donde tienen lugar dos o más estructuras de significación y que deviene la configuración de sentidos y la apropiación de estos por parte de los actores vinculados al proceso.

De tal manera que el lenguaje y con él las maneras de clasificar-se y de clasificar al otro o los otros; los diversos modos de apropiarse y usar los espacios, las distintas maneras de organizar y hacer uso del tiempo; los movimientos del cuerpo y las formas de tocar y de aproximarse al otro, son desde esta propuesta, los ejes transversales que permitirán comprender esos procesos de configuración identitaria en un grupo de migrantes nariñenses que a lo largo del tiempo ha ido generando unos campos de interlocución dentro de los que, como ya se dijo, "ciertos modos de identificación son posibles mientras otros quedan excluidos... los actores y grupos se posicionan como parte del diálogo y el conflicto con otros actores y grupos" (Grimson, 2001, p. 41).

Proponiendo con esto las narrativas de lo nariñense, los orígenes nariñenses, las estrategias de identificación, la idea de gente pura y original, el mito fundacional y los diversos relatos de aculturación de la comunidad nariñense en Candelaria, como el nivel micro de observación de sus narrativas de identidad y migración dado a la luz de las dimensiones de la comunicación ya expuestas. 


\section{CAPÍTULO V. APUESTA METODOLÓGICA}

\section{Diseño metodológico}

\subsection{Matriz de operacionalización de categorías de análisis}

A partir de los postulados teóricos anteriormente expuestos, se propuso la siguiente matriz en la que se operacionalizaron las categorías que viabilizaron el análisis de los datos recogidos en el marco de la presente investigación, permitiendo hacer un tránsito entre la propuesta teórica y los datos empíricos, a la luz de la pregunta orientadora que buscaba responder ¿de qué manera la colonia nariñense, asentada en Candelaria, Valle del Cauca, construye su propio relato en torno a su proceso migratorio y a sus procesos identitarios? 


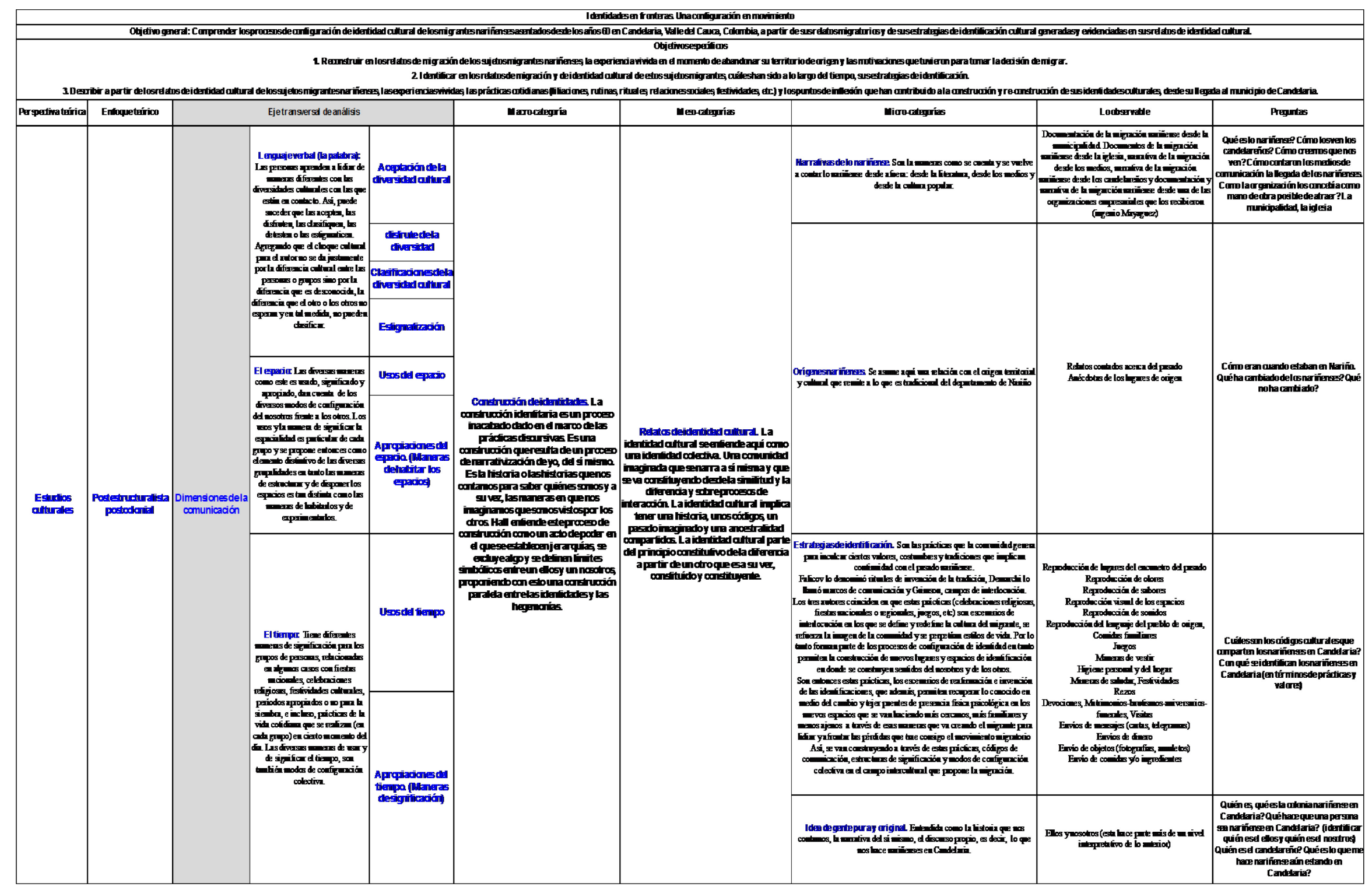




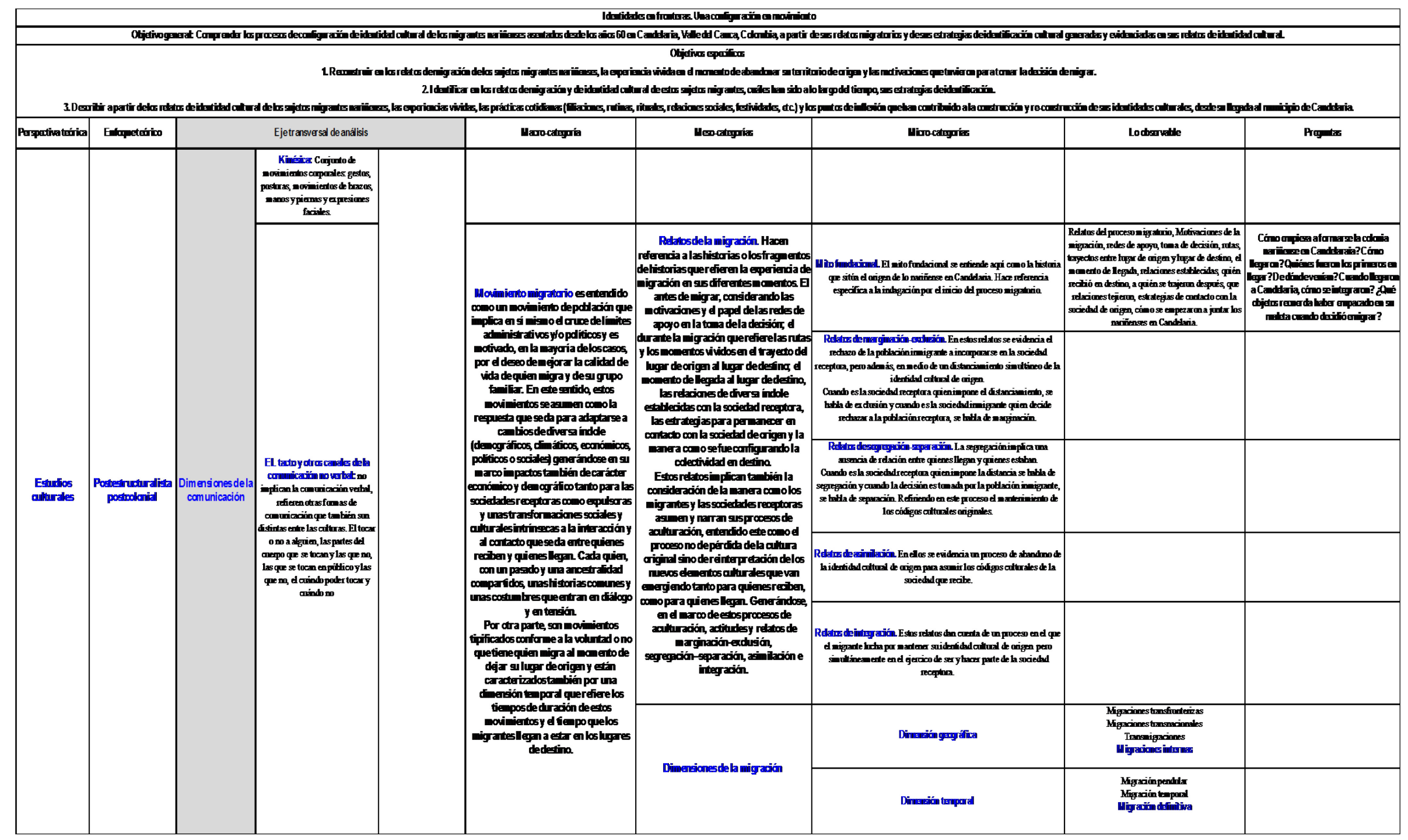




\subsection{Pregunta orientadora}

¿De qué manera la colonia nariñense, asentada en Candelaria, Valle del Cauca, construye su propio relato en torno a su proceso migratorio y a sus procesos identitarios?

\subsection{Objetivos \\ Objetivo General}

Comprender los procesos de configuración de identidad cultural de los migrantes nariñenses asentados desde los años 60 en Candelaria, Valle del Cauca, Colombia, a partir de sus relatos migratorios y de sus estrategias de identificación cultural generadas y evidenciadas en sus relatos de identidad cultural.

\section{Objetivos específicos}

1. Reconstruir en los relatos de migración de los sujetos migrantes nariñenses, la experiencia vivida en el momento de abandonar su territorio de origen y las motivaciones que tuvieron para tomar la decisión de migrar.

2. Identificar en los relatos de migración y de identidad cultural de estos sujetos migrantes, cuáles han sido a lo largo del tiempo, sus estrategias de identificación.

3. Describir a partir de los relatos de identidad cultural de los sujetos migrantes nariñenses, las experiencias vividas, las prácticas cotidianas (filiaciones, rutinas, rituales, relaciones sociales, festividades, etc.) y los puntos de inflexión que han contribuido a la construcción y reconstrucción de sus identidades culturales, desde su llegada al municipio de Candelaria.

Teniendo en cuenta los postulados anteriores, se definió:

\subsection{Población}

Conjunto de sujetos migrantes provenientes de Nariño, asentados en Candelaria, Valle del Cauca desde hace más de 40 años. 


\subsection{Unidad de análisis}

Sujetos migrantes provenientes de Nariño, asentados en Candelaria, Valle del Cauca desde hace más de 40 años.

\subsection{Unidad de trabajo}

15 sujetos provenientes de Nariño, asentados con sus familias en Candelaria, Valle del Cauca, desde hace más de 40 años.

\subsection{Criterios de selección y factibilidad}

El criterio de selección del escenario respondió inicialmente a la cercanía del municipio de Candelaria a la ciudad de Cali, aspecto que hizo factible el desarrollo de la tesis no solo en términos presupuestales y logísticos sino también de seguridad. Sin embargo, además de la cercanía geográfica de esta municipalidad, se pensó en algunos componentes que pudieran enriquecer el proceso de la investigación, entre ellos el tamaño (en términos poblacionales), debido a que se considera que un municipio con un número reducido de habitantes implica una mirada en escala micro en donde tienen lugar procesos particulares de configuración y reconfiguración identitaria, característicos de lo local.

En este sentido, se eligió el municipio de Candelaria en el Valle del Cauca, habitado por un aproximado de 75.000 personas y cuya configuración poblacional además, está definida por comunidades étnicas y culturales plurales que a lo largo de la historia de Candelaria se han ido asentando allí. Configurando un territorio pluriétnico y pluricultural que le añade características especiales al abordaje de la temática planteada.

En este contexto sociocultural se escogió un grupo perteneciente a la colonia nariñense (grupo representativo de Candelaria) conformado por adultos mayores entre los 55 y 70 años de edad, quienes en la década de 1970, migraron en cadena y cuyas causas de migración estuvieron definidas especialmente por los factores socioeconómicos como la demanda de empleo, mejores salarios, estabilidad laboral y seguridad social. Este grupo de nariñenses provino, en su gran mayoría, no de la capital del departamento, sino de los pueblos pequeños y sus veredas. Algunos de ellos se desplazaron con sus familias 
ya constituidas y otros solos, lo cual facilitó que fueran configurando sus familias en el Valle del Cauca y que sus hijos empezaran, algunos a crecer, y muchos otros, a nacer en esta región.

Este factor motivó, en gran medida, la selección de los sujetos, el hecho de que su movilidad no fuera reciente ni temporal sino que por el contrario, haya sido permanente y hayan decidido "construir" la vida y por tanto configurar y reconfigurar sus identidades en otro territorio. Se propuso así el trabajo con diez y ocho sujetos, todos ellos con familias configuradas de diferentes maneras, por lo que interesó la diversidad de relatos que en cada uno de ellos pudieron encontrarse sobre los ejes de interés de la investigación.

En este punto interesó de manera particular acudir a "los memoriosos" a quienes tienen la memoria de estos trayectos migratorios. Memoria que en términos generacionales, es conferida a los abuelos, en este caso, quienes tomaron la decisión inicial de migrar a un municipio desconocido y quienes empezaron a construir y reconstruir las identidades en un escenario de tránsito. Estos aspectos permitieron la construcción de relatos de identidad en la migración, y por supuesto, la diferenciación discursiva entre los diversos actores de estos procesos identitarios. Por lo anterior, fue importante para esta investigación contar tanto con los relatos de quienes hace 40 años llegaron solos y empezaron a armar su familia en Candelaria, como de quienes llegaron en pareja y empezaron a tener sus hijos o a criarlos, en un municipio ajeno.

\subsection{Metodología}

Siguiendo la propuesta de Sautu, Boniolo y Elbert (2005) se reconocieron para el diseño metodológico tres fases fundamentales, presentes en cualquier investigación dentro de las ciencias sociales: el planteamiento teórico, la formulación de los objetivos con la identificación de las técnicas para la recolección de datos y la definición de la estrategia de análisis de la información recogida. Fases que en coherencia con el método, permiten, ya sea configurar una narración que recoja las trayectorias de vida completas o bien, fragmentos o trayectos de vida que hayan tenido lugar en alguna etapa específica de 
la vida de los sujetos-actores de la investigación. En este caso, un grupo de sujetos migrantes que desde hace más de 40 años están asentados en Candelaria, Valle del Cauca y la focalización de su trayecto migratorio.

En este entendido, a partir de los supuestos teóricos trabajados y del problema de la construcción de identidades en el marco de procesos migratorios, se planteó un abordaje a los relatos y experiencias de los sujetos migrantes, sus estrategias de identificación, sus orígenes y la narrativa que han construido de sí mismos como colectividad. Considerando la identidad como un proceso de construcción inacabado, cambiante y relacionado con los contextos y la interacción en el tiempo y espacio, teniendo en cuenta el caso de la colonia nariñense en el municipio de Candelaria, Valle del Cauca, a partir de una estrategia cualitativa de investigación.

En el sentido de Hall y Grimson, la identidad es una construcción discursiva que resulta de un proceso de narrativización del sí mismo, en la que se establecen unos límites entre un "nosotros" y un "ellos". El abordaje que se propuso de la realidad social presente en el fenómeno identitario y migratorio de los nariñenses consideró la multiplicidad de voces, discursos y dinámicas sociales que se entrecruzan en el fenómeno social focalizado. De esta manera, se planteó la exploración del problema desde dos perspectivas: el método biográfico y el método etnográfico. El acercamiento a los discursos de los migrantes, planteó la necesidad de un acercamiento a sus relatos biográficos y así mismo, dado que la construcción de identidades se da en escenarios de interacción, lugares de significado y el desarrollo de prácticas colectivas, se acudió al método etnográfico para la exploración de este universo cultural que enmarca los procesos identitarios de la población nariñense.

Es importante precisar que los sujetos con quienes se propuso el acercamiento, son de origen nariñense y tuvieron la iniciativa de moverse desde su lugar de origen (Nariño) a Candelaria, Valle del Cauca como lugar de destino. Vale decir que algunos de los migrantes son personas con quienes se ha tenido contacto desde el año 2013 a partir de algunas experiencias de investigación llevadas a cabo con la participación de 
estudiantes de Comunicación de la Pontificia Universidad Javeriana de Cali, Colombia ${ }^{15}$. Dicho contacto ha permanecido en el tiempo, no solo a través de la realización de actividades de carácter institucional sino también de la realización de encuentros y actividades espontáneas, producto de la cercanía que se fue generando con la comunidad nariñense.

Esta cercanía previa, permite señalar que en general, la decisión inicial de migrar al Valle del Cauca fue tomada por hombres que hoy están entre los 52 y los 68 años de edad, la mayoría de ellos con estudios de básica primaria sin concluir, pero con un vasto conocimiento de las labores agrícolas. Hoy día adultos mayores pensionados (casi todos) del gremio azucarero de la región. Una gran parte de ellos llegaron a Candelaria (municipio del área metropolitana del departamento del Valle del Cauca) finalizando la década de los años 60. Pocos de ellos traían en su haber algún tipo de propiedad. Sin embargo, es frecuente encontrar en sus historias, cómo a través de los años fueron consiguiendo sus viviendas propias, casi todas ubicadas en el estrato tres del municipio de Candelaria.

Con respecto a los demás miembros de la familia, se encuentran las esposas que en su mayoría son mujeres entre los 50 y 60 años de edad, amas de casa dedicadas a las labores del hogar; los hijos, jóvenes o adultos jóvenes con un nivel educativo de bachillerato concluido y algunos con estudios técnicos y tecnológicos desarrollados. Otros de ellos lograron concluir sus estudios universitarios o se encuentran en este proceso. Finalmente los nietos, niños y/o adolescentes, la mayoría en edad escolar, que asisten a los colegios y escuelas cercanas. Algunos de ellos, en edad universitaria, se desplazan diariamente hasta Cali para llevar a cabo sus estudios técnicos, tecnológicos y universitarios.

\footnotetext{
${ }^{15}$ El primer proyecto de investigación que vinculó a algunas de las personas con las que se trabajó en la presente investigación se denominó "Los espacios públicos locales y su configuración a partir de las prácticas políticas y comunicativas de los sujetos que los habitan. Un acercamiento a los casos de Santander de Quilichao en el departamento del Cauca y Candelaria en el departamento del Valle del Cauca, Colombia". El proyecto estuvo financiado por la oficina de investigación de la PUJ Cali y su código de registro ante esta dependencia fue el 20100352.
} 
Igualmente, es de mencionar que durante la elaboración del plan de tesis y el planteamiento de las fases teóricas y diseño metodológico de la investigación que se propuso, se retomó de manera permanente la cercanía con la comunidad a partir de visitas espontáneas y de encuentros concertados.

\subsection{Técnicas e instrumentos de recolección de datos}

\subsubsection{Del método biográfico y los relatos propios de los sujetos}

El diseño metodológico de la investigación propuesta, reposó en la perspectiva del método biográfico que tradicionalmente ha sido utilizado por la sociología y la antropología con el objetivo de "reconstruir las experiencias personales que conectan entre sí "yos" individuales que interactúan en familias, grupos e instituciones" (Bechis, et al., 1999).

Es importante señalar que desde este tipo de investigación, inicialmente se entiende al sujeto-protagonista en un contexto histórico y social particular y a partir de este, se da el despliegue del tema o de la historia que cohesiona la narración. En este sentido, tal como es citado Louis Smith en Sautu (1999, p. 23) se sostiene que "la biografía siempre tiene forma discursiva escrita". Reconociendo, desde el aporte de las autoras, que la escritura de esta narración se encuentra determinada tanto por el tema cohesionador, como por las perspectivas epistemológicas y disciplinares de los investigadores.

De esta manera, el método biográfico implica un estilo de investigación que va configurando su estructura narrativa en torno a las maneras como los mismos protagonistas narran su historia, describen sus experiencias y las van interpretando. Protagonistas que bien pueden ser entendidos como sujetos individuales o como parte de una colectividad. De ahí que el propósito central del método sea "revelar las interpretaciones subjetivas de los protagonistas, tratando de descubrir cómo construyen su propio mundo" (Sautu, 1999, p. 23). Entendido así, el método biográfico recoge la descripción de experiencias, sucesos, situaciones o trayectos que tienen lugar en contextos sociales específicos, reiterando, tal como lo plantea Sautu, que las 
investigaciones adscritas a este método tienen tres elementos característicos en ellas: la existencia del yo que es quien vive las experiencias, unos sucesos ubicados en contextos históricos y sociales particulares y unos puntos de inflexión reconocidos como las marcas de sucesos vitales para el sujeto, significantes de transformaciones o de momentos destacados en las experiencias de vida.

Tradicionalmente el método biográfico se ha valido de técnicas como la entrevista semiestructurada y en profundidad (individual o colectiva) para recabar la información y los datos necesarios para una narración en la que se reconstruyan dichas experiencias en la vida de las personas quienes, necesariamente, emergen en contextos relacionales y dialógicos con el otro o con los otros.

De esta manera se propuso un trabajo de campo en el que se abordaron relatos biográficos individuales de 8 sujetos nariñenses de origen ${ }^{16}$, y relatos biográficos grupales, recabados a través de grupos de discusión, en los que participaron entre cinco y ocho migrantes nariñenses ${ }^{17}$, todos ellos asentados en Candelaria desde los años 60 , proponiendo para la construcción de los relatos una polifonía de voces que incorporó las narraciones de los personajes que migraron primero, con las de quienes nacieron en el municipio de Candelaria, y vivieron aquellos años en los que los nariñenses empezaron a llegar al municipio.

Se indagó por las motivaciones y expectativas de los sujetos nariñenses, previo a su desplazamiento al municipio de Candelaria. Considerando aquí importante, el conocer cómo percibían su vida y sus oportunidades personales, familiares y laborales antes de tomar la decisión de migrar y qué elementos de su municipio de origen valoraban principalmente antes del desplazamiento para contrastar con los elementos que valoraron y que los motivaron a tomar la decisión de dejar su lugar de origen.

\footnotetext{
${ }^{16}$ El acercamiento se llevó a cabo con la señora Rosalba Getial y los señores Jorge Rodrigo Martínez, Aurelio Realpe, José Alpala, Gabriel Pascuasa, Pedro Castro, Luis Alberto Díaz y José Montilla.

${ }^{17}$ En los grupos de discusión participaron José Diógenes Ruíz, Ricardo Ismael Sánchez Ceballos, José Bernardo Rivera, Segundo Benjamín Delgado Chamorro, Rubén Salcedo, José María Alpala, Humberto Tutalchá, Segundo Pantoja, Beatriz Erazo, Arquimides Díaz, Miguel Calderón, José Yela, Julio Castro, Gabriel Pascuasa, José Yepes y José Ruiz.
} 
Así, pensando en comprender el inicio del proceso migratorio, se propició en la reconstrucción de los relatos de migración de estos sujetos migrantes nariñenses, la recreación de la experiencia vivida en el momento de abandonar su territorio de origen, la recuperación de la memoria en torno a, como ya se dijo, las motivaciones que tuvieron para tomar la decisión de migrar y también se identificaron en estos fragmentos biográficos los diversos relatos de aculturación (marginación - exclusión, segregación separación, asimilación e integración) y las transformaciones que estos tuvieron a través del tiempo.

Entendiendo esta intencionalidad de la investigación, due clave indagar por las maneras como el grupo de sujetos migrante, empezó a percibir el nuevo escenario habitado, qué les gustaba, qué no, qué los motivaba a estar ahí, qué los expulsaba de él, quién los acogía, cómo, por qué se sentían acogidos por algunos y por otros no, qué instituciones empezaron a ser importantes para ellos y por qué, en qué momento se reunían, quiénes, en qué lugares, qué actividades realizaban, si tenían o no líderes, si tuvieron momentos de crisis económicas, emocionales y cómo las lograron superar, qué elementos consideran ellos que fueron determinantes para quedarse y construir sus familias en un nuevo escenario.

Nutriendo entonces, a partir de estos relatos, microcategorías como los orígenes nariñenses y las estrategias de identificación que han generado y generan aún para preservar ciertas costumbres, valores y tradiciones que los hace reconocerse como parte de una colectividad. En este sentido, a partir de estas narraciones de migración e identidad cultural se indagó por las prácticas cotidianas de los sujetos vinculados a la investigación, a partir de su migración al Valle del Cauca. Sus rutinas, preferencias, sus actividades realizadas en el tiempo libre, los lugares recurrentes, los grupos a los que empezaron a pertenecer, sus celebraciones culturales y religiosas, sus recorridos recurrentes en el nuevo municipio, sus trayectos del fin de semana, la descripción del barrio al que llegaron en contrastación con el barrio que dejaron y las actividades que en general empezaron a realizar después de su llegada a Candelaria para identificar también en los migrantes nariñenses, esa idea de gente pura y original que los ha acompañado y los acompaña todavía, esa historia que se cuentan y le cuentan a los otros sobre ellos 
mismos y sobre las particularidades que los han hecho ser y aún los hacen ser, los nariñenses en Candelaria.

\subsubsection{El método etnográfico}

Proveniente de la antropología, el método etnográfico pretende revelar los significados de las prácticas sociales a través de la participación y observación de las interacciones que constituyen la realidad social de un grupo estudiado. La etnografía se ha valido principalmente de la observación (participante y no participante) y de la entrevista (individual o colectiva) para el acercamiento al análisis de realidades sociales.

\subsubsection{La observación}

El principal objetivo de la observación es la descripción de grupos, situaciones y escenarios sociales a través de la vivencia y experiencias de las personas implicadas. La observación constituye la principal técnica de acercamiento a un universo social, por lo que implica también el acceso a la comunidad, la creación de lazos, la identificación de sujetos relevantes para el análisis y la definición del paso a paso empírico de la estrategia metodológica del trabajo de campo. El proceso de observación constituye el acercamiento primario del investigador con su objeto de estudio, considerando al propio investigador como sujeto social que busca interactuar con la otredad.

Contrario a lo que podría pensarse, la observación etnográfica no es solamente la mirada descriptiva de una realidad cotidiana, es también el acercamiento reflexivo, detallado y sistemático a un hecho social. La realización de jornadas de observación debe estar mediada por el registro de las actividades, de actores implicados y de contexto, por lo que una herramienta fundamental para el ejercicio de observación son las notas de campo y las guías o rejillas de observación que permitan orientar el ejercicio del investigador, con la intención de capturar esos procesos y ese contexto en su integridad, anotando sus diferentes mecanismos y propiedades (Hammersley y Atkinson, 1994).

Entendido así, a partir de ejercicios de observación se abordaron los lugares y prácticas que han identificado a la colonia nariñense en el municipio de Candelaria, para lo cual se identificaron principalmente tres escenarios de observación: La cancha de 
Chaza, El santuario y la celebración del día de la Virgen de las Lajas y la celebración del carnaval de blancos y negros.

Señalando que tanto el juego de la chaza como la celebración del carnaval de blancos y negros y del día de la Virgen de las Lajas en Candelaria, son tres de los espacios de relaciones de identificación para la colectividad nariñense en Candelaria, por lo que se propusieron aquí como escenarios iniciales de indagación en tanto se configuran en este contexto como esa puesta en relación del pasado con el presente migratorio.

Es decir, se partió del supuesto de que para la colonia nariñense, en esta práctica deportiva y en estas celebraciones "se intersecta la construcción de una tradición que se asume como conocida desde tiempos inmemoriales con las dificultades de una realidad percibida como ajena" (Grimson, 2005, p.77). Y que en tal sentido, el carnaval, el juego y la celebración de la Virgen, son puntos de encuentro entre el antes y el ahora, entre el allá y el aquí y tienden entonces el "puente entre lo que es vivido como propio y como ajeno, como conocido y desconocido, como previsible e imprevisible..." (Grimson, 2005, p. 78) vinculándose (el juego, el carnaval y la celebración religiosa) a la vida cotidiana de estos sujetos.

Los ejercicios de observación estuvieron apoyados por el registro de notas de campo que incluyeron fotografías de dichos escenarios y de las prácticas. Para esto se diseñó una rejilla de observación (Ver ANEXO 4. Protocolo de la observación etnográfica) con el objetivo de tener una herramienta que facilitara el proceso de inicio de las jornadas de observación y a la vez sirviera como guía durante el mismo. La rejilla de observación guió las anotaciones que se realizaron en el diario de campo a partir de unas categorías básicas para registrar en los diferentes momentos en que se realizó el ejercicio.

Es de anotar que este instrumento no constituye parte de la técnica como tal, es decir, puede considerarse o no, pues el método para llevar a cabo las anotaciones de campo es desarrollado por el propio investigador dependiendo de las condiciones de los espacios e incluso de la creatividad que tenga al realizar sus anotaciones. 
También es importante mencionar que además de estos tres escenarios propuestos, se plantearon otros que aunque no fueron el centro del análisis, apoyaron el ejercicio de observación. Así, se realizaron ejercicios de observación tanto en las visitas que se hicieron a los hogares de los nariñenses como también en los encuentros concertados con ellos en otros espacios tales como el parque principal del municipio, las cafeterías de Candelaria y algunas fincas.

Por último, es de mencionar que las notas de campo antes mencionadas se reconocen aquí como un ejercicio personal del investigador, en el que "se relatan los espacios, las gentes, y los fenómenos que se conoce o de los que se tiene noticia. En diarios de campo y relatos de viajes también aparece la subjetividad del autor/a, y se concede espacio a la reflexión" (García, 2000, p. 12).

\subsubsection{La entrevista. Una conversación con las historias de migrantes nariñenses y sus familias}

En conjunto con la observación, la entrevista permite el acercamiento profundo a las prácticas, los discursos, percepciones y valores que tienen los sujetos sobre sus realidades sociales. Para Sautu, Boniolo y Elbert (2005) "la entrevista es una conversación sistematizada que tiene por objeto obtener, recuperar y registrar las experiencias de vida guardadas en la memoria de la gente" (p.48).

Así, con las entrevistas individuales y colectivas se quiso explorar tanto los relatos migratorios como los relatos de identidad, privilegiando estos como relatos colectivos que se fueron construyendo a partir de la experiencia compartida y reconociendo además, tal como lo señala Silvia Rivera Cusicanqui, que "Las personas entrevistadas, de una u otra manera, enfrentan a la cámara poniendo en escena su relato, desordenando y reordenando el esquema de entrevista con salidas y giros imprevistos" (Rivera, 2010, p. 232) en donde definitivamente, "Las percepciones de interrogadores e interrogados se transforman, en un proceso largo donde acaba por surgir un "nosotros" cognoscente e intersubjetivo" (Rivera, 2010, p. 228). 
Es importante señalar que para esta intencionalidad de indagación, los relatos biográficos de los sujetos migrantes, fueron reconstruidos y cotejados con la parte de los relatos biográficos que se lograron reconstruir a partir de las entrevistas focalizadas a 8 habitantes de Candelaria ${ }^{18}$ que en la misma época vivieron la llegada de los nariñenses al municipio.

Teniendo en cuenta lo anteriormente mencionado, para la reconstrucción de los trayectos biográficos propuestos, se realizaron:

- Ocho entrevistas biográficas (Ver ANEXO 1. Protocolo de la entrevista biográfica) a uno de los primeros migrantes que llegaron a trabajar en Candelaria, la mayoría de ellos al Ingenio Mayagüez.

- Cuatro entrevistas focalizadas a sujetos clave ${ }^{19}$, por su rol desempeñado dentro de la comunidad nariñense asentada en Candelaria.

- Ocho entrevistas focalizadas a habitantes de Candelaria que en la misma época vivieron la llegada de los nariñenses al municipio. (Ver ANEXO 2. Protocolo de la entrevista focalizada individual)

- Una entrevista grupal realizada como exploración a cinco integrantes del grupo de nariñenses.

\subsubsection{Los grupos de discusión}

En la exploración que se propuso de los fragmentos biográficos de estas personas se pretendía identificar los elementos que le dieron la particularidad al proceso migratorio nariñense y a su posterior proceso de construcción de colectividad cultural en el municipio de Candelaria, para este fin, se aplicaron algunos grupos de discusión que facilitaron la reconstrucción de estos trayectos biográficos de migración y que permitieron a través de ellos, recuperar en la memoria de la colonia nariñense en Candelaria, sus experiencias vividas cuando decidieron abandonar su lugar de origen y las motivaciones que tuvieron para emprender la ruta hacia un departamento ajeno.

\footnotetext{
${ }^{18}$ Los candelareños entrevistados fueron: Clara Díaz, Camilo Muñoz, Edgar Olave, Luis López, Isaías Gamboa, Milena Medina, Víctor Mondragón y Zoraida Zamorano.

${ }^{19}$ Las personas entrevistadas fueron: Jorge Martínez, Isabel Osorio, Julio Castro y Milton Posos.
} 
En estos fragmentos biográficos se reconstruyó lo que categorialmente se entiende en esta propuesta como el mito fundacional, en la búsqueda de comprender el origen que tuvo lo nariñense en Candelaria, la manera como al inicio del proceso migratorio se fueron configurando como un nosotros en el lugar de llegada, las estrategias que fueron implementando para reconocerse a sí mismos como nariñenses y para que los candelareños los percibieran como parte de esta colectividad.

Además, se propuso construir unos trayectos biográficos que permitieran recuperar los relatos de identidad cultural que han producido y producen estos sujetos migrantes, motivando relatos en referencia a las prácticas significativas de la vida cotidiana de estos sujetos y a las maneras como cuentan los escenarios que en diferentes momentos de su historia de migración, han producido, sostenido y valorado como propios, además de esos espacios que perciben como los lugares de negociación y conflictos identitarios con la comunidad de acogida: la sociedad candelareña.

En este caso, con los grupos de discusión se buscó explorar el discurso social de algunos colectivos nariñenses, reconociendo que esta es una técnica, tal como lo afirma Ibáñez (como se citó en Bonilla, Del Valle y Martínez, 2012) que se inserta en el campo de la historia oral, cuya producción de discurso es generado a través de un proceso comunicativo, dentro de un marco social de la situación de la entrevista colectiva.

En ese entendido, se realizaron tres grupos de discusión (Ver ANEXO 3. Protocolo del grupo de discusión) así:

- Un grupo de discusión realizado con nariñenses pertenecientes al club de chaza.

- Un grupo de discusión realizado con nariñenses pertenecientes al club de chaza, a los fiesteros (Virgen de las Lajas) y al comité organizador del Carnaval de Blancos y Negros.

- Un Grupo de discusión realizado con nariñenses para indagar acerca de los espacios que en Candelaria son significativos para ellos. 


\subsubsection{La revisión documental. Retomando el álbum familiar y los documentos personales}

Existe una serie de materiales documentales que son relevantes en las investigaciones etnográficas y que han sido incorporadas en el método como fuentes secundarias para el etnógrafo. La revisión documental es también otra de las técnicas recurrentes en el método biográfico. Teniendo en cuenta como documentos, las narraciones personales, cartas, diarios, álbumes familiares, biografías y en general, documentos personales vitales para los sujetos-protagonistas de las historias.

Para le presente investigación se propuso la revisión de los álbumes, fotografías u documentos personales de los señores Rosalba Getial, Jorge Rodrigo Martínez, Aurelio Realpe, José Alpala, Gabriel Pascuasa, Pedro Castro, Luis Alberto Díaz y José Montilla. Los mismos con quienes se hizo la reconstrucción de los trayectos biográficos. Además se hizo la revisión de los archivos oficiales que daban cuenta de lo que en su momento fue la migración nariñense desde la municipalidad y del archivo de la parroquia de Nuestra Señora de la Candelaria.

\subsection{Matriz de relación entre micro-categorías de análisis, técnicas de recolección de datos y fuentes de información}

Se propuso también una matriz en la que se relacionaron las micro-categorías de análisis con las técnicas a través de las cuales se esperaba nutrir estas micro-categorías, las fuentes con quienes se esperaba recabar la evidencia empírica y unas preguntas iniciales para viabilizar el diseño de los instrumentos de recolección de la información.

En esta matriz se plantearon dos técnicas de aproximación transversales a todas las micro-categorías de análisis: la observación y la entrevista biográfica. Además de

unas técnicas de aproximación paralelas que permitieron generar una triangulación metodológica con el objetivo de saturar las categorías de análisis: 


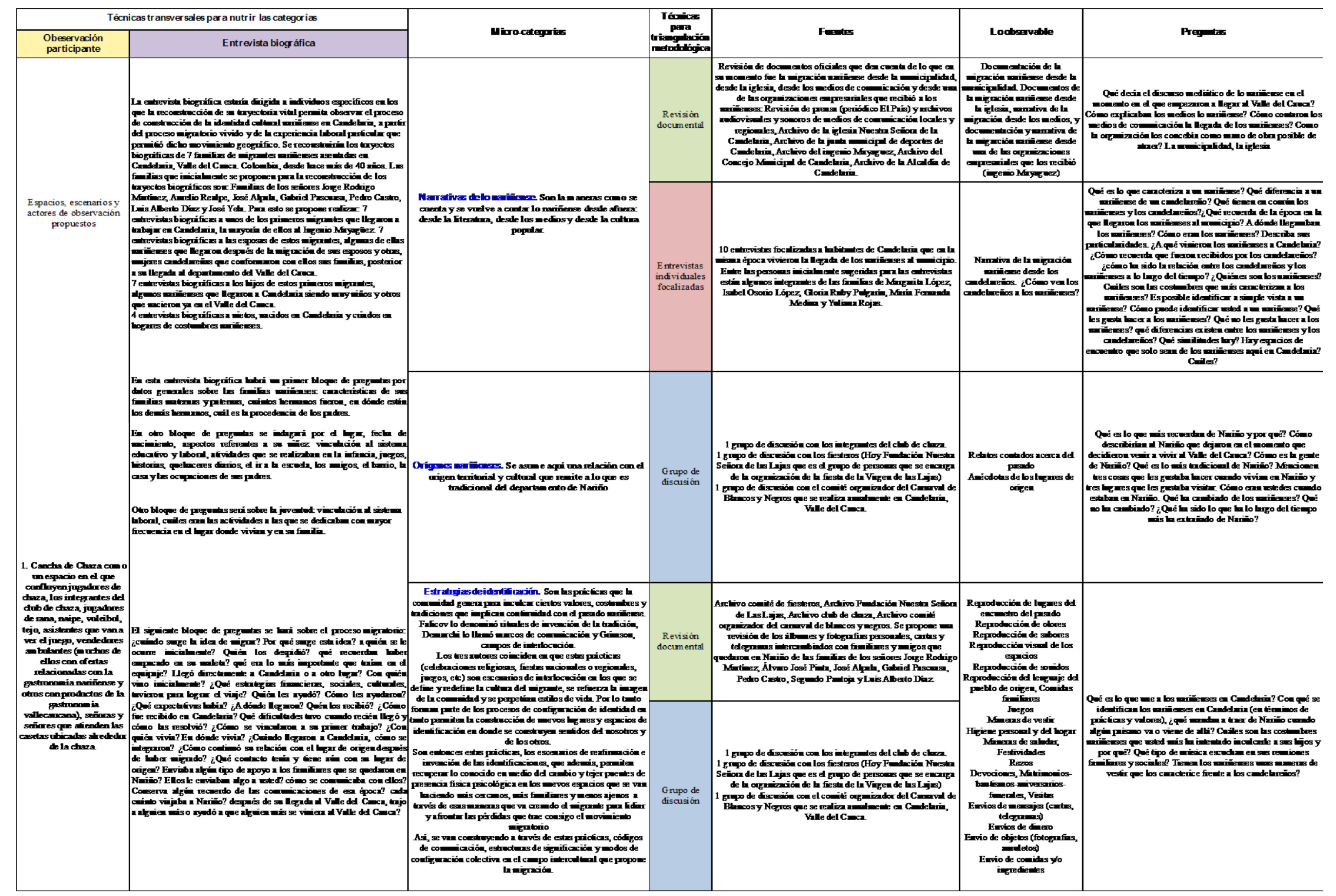




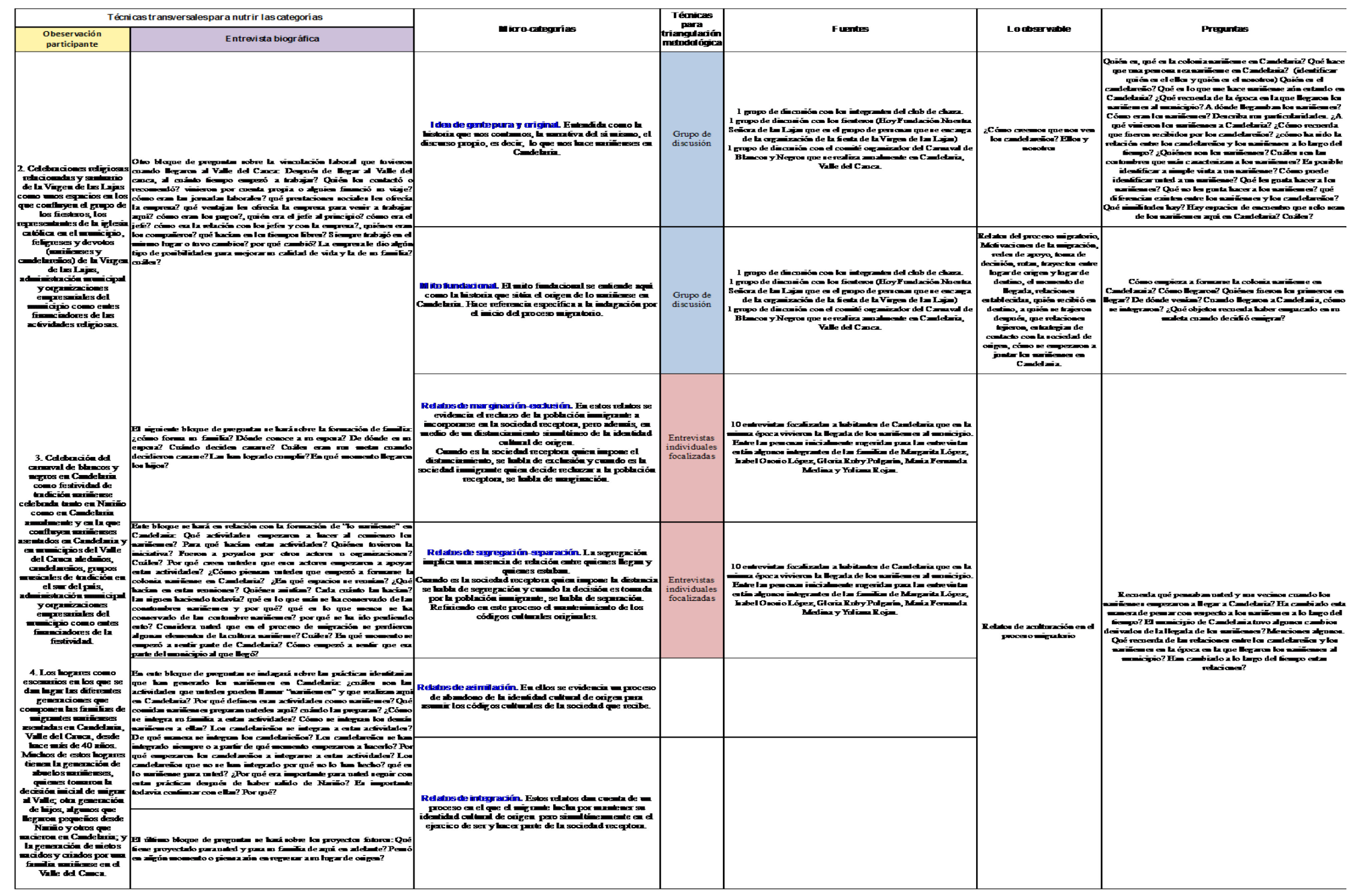




\subsection{Estrategias de análisis de los datos}

Esta fase requirió inicialmente depurar la información hallada a través de la aplicación de los instrumentos para facilitar así el descubrimiento de los significados que se encontraron en los relatos que las personas hicieron de sus vidas. Relatos que en este caso se focalizaron en las experiencias de migración, el momento de salida del municipio de origen, el trayecto y las experiencias vividas antes de llegar al destino, el momento de llegada al municipio receptor y las prácticas de identificación generadas a lo largo del tiempo por la colonia nariñense asentada en Candelaria, Valle del Cauca, Colombia.

\subsubsection{Información procesada}

La etapa de procesamiento y sistematización de la evidencia empírica recolectada para la investigación, se llevó a cabo posterior a la transcripción fiel ${ }^{20}$ de cada una de las entrevistas y de cada grupo de discusión realizado. Así, se contó con los documentos correspondientes a veintiún entrevistas aplicadas a personas originarias de Nariño que actualmente están asentadas en Candelaria y a población de Candelaria; de la misma manera que con los documentos de transcripción de 3 grupos de discusión realizados con el fin de indagar sobre espacios significativos para los nariñenses en Candelaria y sobre prácticas tradicionales de los nariñenses en Candelaria como lo son la celebración de la Virgen de las Lajas, el Carnaval de blancos y negros y el juego de Chaza.

A continuación se relacionan las entrevistas y los grupos de discusión que fueron procesados:

\footnotetext{
${ }^{20}$ En total fueron transcritos 1600 minutos de grabación que correspondieron a 460 páginas de transcripción.
} 
Entrevistas grupales e individuales:

\begin{tabular}{|c|c|c|}
\hline Número & $\begin{array}{l}\text { Característica } \\
\text { entrevistado }\end{array}$ & Nombre \\
\hline 0 & Nariñenses & $\begin{array}{c}\text { Entrevista grupal realizada como exploración a } 5 \\
\text { integrantes del grupo de nariñenses que se encontraban } \\
\text { en la cancha de chaza. (2014) }\end{array}$ \\
\hline 1 & Nariñense & Alberto Díaz \\
\hline 2 & Nariñense & Aurelio Realpe \\
\hline 3 & Nariñense & José Alpala \\
\hline 4 & Nariñense & Rosalba Getial \\
\hline 5 & Nariñense & Gabriel Pascuasa \\
\hline 6 & Nariñense & Jorge Martínez (2016) \\
\hline 7 & Nariñense & Pedro Castro \\
\hline 8 & Nariñense & José Montilla \\
\hline 9 & Nariñense & Milton Posos \\
\hline 10 & Nariñense & Jorge Martínez (2015) \\
\hline 11 & Nariñense & Julio Castro \\
\hline 12 & Asistente parroquia & Isabel Osorio \\
\hline 13 & Candelareño & Clara Díaz \\
\hline 14 & Candelareño & Camilo Muñoz \\
\hline 15 & Candelareño & Edgar Olave \\
\hline 16 & Candelareño & Luis López \\
\hline 17 & Candelareño & Milena Medina \\
\hline 18 & Candelareño & Victor Mondragon \\
\hline 19 & Candelareño & Zoraida Zamorano \\
\hline 20 & Candelareño & Isaías Gamboa \\
\hline
\end{tabular}




\section{Grupos de discusión:}

\begin{tabular}{|c|c|}
\hline $\begin{array}{c}\text { Característica grupo } \\
\text { de discusión No. }\end{array}$ & Asitentes al grupo \\
\hline José Diógenes Ruíz \\
\hline $\begin{array}{c}\text { Ricardo Ismael Sánchez Ceballos } \\
\text { realizado con } \\
\text { nariñenses } \\
\text { pertenecientes al } \\
\text { club de chaza }\end{array}$ & \begin{tabular}{c} 
Segundo Benjamín Delgado Chamorro \\
\hline
\end{tabular} \\
\hline Rubén Salcedo \\
\hline
\end{tabular}

\begin{tabular}{|c|c|}
\hline $\begin{array}{c}\text { Característica grupo de } \\
\text { discusión No. } 2\end{array}$ & Asitentes al grupo \\
\hline $\begin{array}{c}\text { Grupo de discusión realizado } \\
\text { con nariñenses pertenecientes } \\
\text { al club de chaza, a los fiesteros } \\
\text { (Virgen de las Lajas) y al comité } \\
\text { organizador del Carnaval de } \\
\text { Blancos y Negros }\end{array}$ & Beatriz Erazo \\
\hline & José Alpala \\
\hline
\end{tabular}




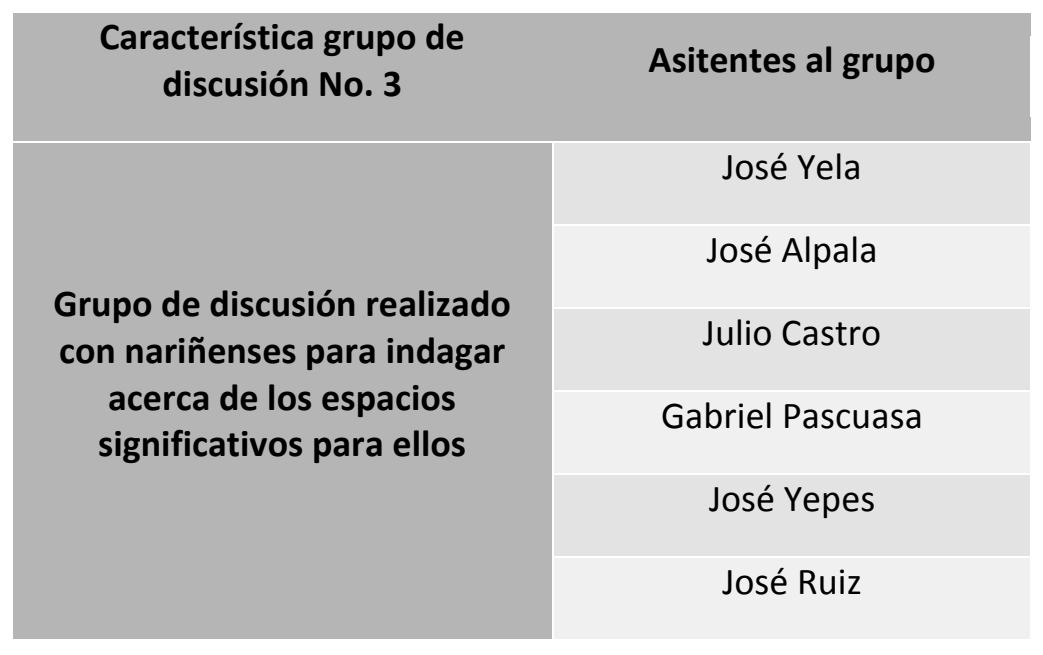

Considerando lo anterior y dado que las entrevistas biográficas, las entrevistas focalizadas y los grupos de discusión, sugieren como resultado relatos de cada sujeto entrevistado, se propuso la técnica de análisis argumental del discurso para los relatos, con perspectiva oral. Asumiendo que esa relación de escucha que implican las técnicas conversacionales "enfrenta a un mínimo de dos personas, portadoras de sus propias peculiaridades sociales e históricas (...)" (Rivera, 2010, p.227) y que incluso, tal como sostiene la autora, esa experiencia de escuchar los testimonios, pone con frecuencia al investigador social en un lugar en el que al mismo tiempo que conversa, va desmontando estereotipos que trae previamente.

\subsubsection{Metodología implementada para la sistematización}

El proceso de sistematización de la evidencia empírica propuesto en el marco de la presente investigación, estuvo compuesto por dos momentos correspondientes con el nivel de análisis logrado en cada uno de ellos. Inicialmente, la sistematización de datos en Atlas Ti que permitió un primer nivel de análisis de carácter descriptivo a partir de un ejercicio de clasificación de los datos recolectados en campo (Ver ANEXO 5. Clasificación de la evidencia empírica) conforme a las categorías de análisis propuestas y posteriormente, la sistematización de la evidencia empírica en una matriz de análisis argumental que proponía la posibilidad de aplicación a textos de carácter oral, verbal, escrito, visual y verbal escrito, a partir de la incorporación de categorías para abordar todos los soportes, lo cual posibilitó además, el análisis de algunos componentes 
presentes en el discurso oral de las personas que hicieron parte del estudio y un nivel más abductivo en cuanto a la interpretación de los datos.

Así, el análisis de los datos implicó en su fase inicial, una descripción (no interpretativa) de los relatos, seguida de su interpretación, para finalizar con la construcción del sentido intrínseco en dichas narrativas.

A continuación, la matriz de análisis argumental que fue diligenciada para cada entrevista y para cada grupo de discusión:

\section{Nivel lingüístico, centrado en el manejo ideológico del lenguaje}

\begin{tabular}{|c|c|c|c|}
\hline $\begin{array}{c}\text { Sujetos y } \\
\text { Predicados }\end{array}$ & Actitud & $\begin{array}{l}\text { Compromis } \\
0\end{array}$ & Gradación \\
\hline $\begin{array}{l}\text { Enunciados } \\
\text { relevantes, basados } \\
\text { en la fórmula } \\
\text { básica: qué se dice } \\
\text { (Predicado) de } \\
\text { quién (Sujeto). Citas } \\
\text { textuales, } \\
\text { entrecomilladas. }\end{array}$ & $\begin{array}{l}\text { La actitud se refiere a } \\
\text { cómo el entrevistado expresa sus } \\
\text { opiniones, descripciones, etc., } \\
\text { desde el punto de vista de sus } \\
\text { afectos, sentimientos y emociones. } \\
\text { Incluye reacciones emocionales, } \\
\text { juicios y evaluaciones. Recursos } \\
\text { que transmiten sentimientos } \\
\text { positivos o negativos. }\end{array}$ & $\begin{array}{l}\text { Se refiere a } \\
\text { la fuente de la } \\
\text { actitud, de dónde } \\
\text { proviene la } \\
\text { valoración. Por } \\
\text { ejemplo, de si } \\
\text { mismo, de alguna } \\
\text { autoridad o entidad. }\end{array}$ & $\begin{array}{c}\text { Se gradúa los } \\
\text { significados valorativos. } \\
\text { Por ejemplo, Fuerza } \\
\text { (intensidad de la actitud, } \\
\text { se sube o baja el volumen } \\
\text { de los sentimientos) o } \\
\text { Foco (valoración de los } \\
\text { enunciados, si son } \\
\text { centrales o periféricos). }\end{array}$ \\
\hline
\end{tabular}

2. Nivel actancial, centrado en la observación de los actores del relato

\begin{tabular}{|c|c|c|c|}
\hline Rol & Actores & $\begin{array}{l}\text { Espacio / } \\
\text { Tiempo }\end{array}$ & $\begin{array}{l}\text { Universo } \\
\text { Simbólico }\end{array}$ \\
\hline $\begin{array}{l}\text { El rol se refiere a cómo } \\
\text { el entrevistado presenta a los } \\
\text { diferentes actores que refiere, } \\
\text { como también a sí mismo, en el } \\
\text { sentido del rol que cumplen en } \\
\text { la comunidad, en la historia, etc. } \\
\text { Es el rol que se le asigna a los } \\
\text { diferentes actores en la } \\
\text { entrevista, incluido el propio } \\
\text { entrevistado }\end{array}$ & $\begin{array}{l}\text { Consiste } \\
\text { en indicar los } \\
\text { distintos } \\
\text { sistemas-actores } \\
\text { (personajes, } \\
\text { instituciones, } \\
\text { etc.), que } \\
\text { aparecen en la } \\
\text { entrevista. }\end{array}$ & $\begin{array}{c}\text { Consiste } \\
\text { en señalar el } \\
\text { cuándo (pasado, } \\
\text { presente y futuro) } \\
\text { y el dónde } \\
\text { (territorio, fuera del } \\
\text { territorio) actúan } \\
\text { determinados } \\
\text { sistemas-actores } \\
\text { en la entrevista. }\end{array}$ & $\begin{array}{l}\text { Consiste } \\
\text { en señalar los } \\
\text { elementos } \\
\text { culturales que } \\
\text { tienen sentido en } \\
\text { el texto y que son } \\
\text { productos y } \\
\text { productores de } \\
\text { dicho sentido. }\end{array}$ \\
\hline
\end{tabular}

\begin{tabular}{|c|c|c|c|c|}
\hline $\begin{array}{l}\text { Rela } \\
\text { to } \\
\text { Fundacional }\end{array}$ & $\begin{array}{l}\text { Relato de } \\
\text { Pertenencia }\end{array}$ & $\begin{array}{l}\text { Rela } \\
\text { to de } \\
\text { adopción }\end{array}$ & $\begin{array}{r}\text { Relato } \\
\text { de Integración }\end{array}$ & $\begin{array}{l}\text { Relato } \\
\text { de Síntesis }\end{array}$ \\
\hline $\begin{array}{l}\text { Part } \\
\text { e del relato }\end{array}$ & $\begin{array}{c}\text { Parte del } \\
\text { relato que se refiere a }\end{array}$ & $\begin{array}{r}\text { Refe } \\
\text { rencias a lo }\end{array}$ & $\begin{array}{l}\text { Aquí } \\
\text { se hace }\end{array}$ & $\begin{array}{c}\text { En } \\
\text { este relato se }\end{array}$ \\
\hline
\end{tabular}




\begin{tabular}{|c|c|c|c|c|}
\hline $\begin{array}{c}\text { que se } \\
\text { refiere a la } \\
\text { génesis del } \\
\text { éxodo: } \\
\text { ¿Cómo } \\
\text { comenzó } \\
\text { todo? }\end{array}$ & $\begin{array}{l}\text { la nostalgia del origen. } \\
\text { Elementos que se } \\
\text { extrañan en la primera } \\
\text { fase, antes de } \\
\text { comenzar a adoptar lo } \\
\text { nuevo...las primeras } \\
\text { resistencias a lo } \\
\text { nuevo... }\end{array}$ & $\begin{array}{c}\text { que se va } \\
\text { adoptando } \\
\text { del "nuevo } \\
\text { hogar" }\end{array}$ & $\begin{array}{l}\text { referencia a } \\
\text { una mayor } \\
\text { participación y } \\
\text { compromiso } \\
\text { con la } \\
\text { adopción de } \\
\text { lo nuevo. }\end{array}$ & $\begin{array}{c}\text { evalúan, se } \\
\text { resumen las } \\
\text { tensiones } \\
\text { entre el origen } \\
\text { y el "nuevo } \\
\text { hogar" }\end{array}$ \\
\hline
\end{tabular}

3. Nivel basado en los indicadores de la oralidad

\begin{tabular}{|c|c|c|c|}
\hline Memoria & Repetición & Fórmulas & Tematización \\
\hline $\begin{array}{c}\text { Referencias a } \\
\text { una memoria } \\
\text { personal y/o } \\
\text { colectiva a } \\
\text { través de la cual } \\
\text { se construye el } \\
\text { sentido. }\end{array}$ & $\begin{array}{c}\text { Estrategias } \\
\text { de }\end{array}$ & $\begin{array}{c}\text { Esquemas } \\
\text { utilizados } \\
\text { paración } \\
\text { información. }\end{array}$ & $\begin{array}{c}\text { Estrategias } \\
\text { para } \\
\text { asegurar la } \\
\text { transmisión } \\
\text { orgal. } \\
\text { ordenar la } \\
\text { ordormación } \\
\text { información }\end{array}$ \\
\hline
\end{tabular}

4. Nivel de integración de lo verbal y lo visual

\begin{tabular}{|c|c|c|}
\hline Nivel Verbal & Nivel Visual & Nivel Verbovisual \\
\hline $\begin{array}{c}\text { Información } \\
\text { explícita del } \\
\text { texto verbal de } \\
\text { la entrevista, } \\
\text { especialmente } \\
\text { opiniones. }\end{array}$ & $\begin{array}{c}\text { Información explícita } \\
\text { en la lectura de la } \\
\text { imagen, } \\
\text { especialmente la } \\
\text { visibilidad e }\end{array}$ & $\begin{array}{c}\text { Relaciones funcionales de } \\
\text { invisibilidad de actores, } \\
\text { etc. }\end{array}$ \\
$\begin{array}{c}\text { visual (íconos, índices, } \\
\text { símbolos, signos } \\
\text { escriturales, fotográficos, } \\
\text { pictóricos, gráficos, etc.) }\end{array}$ \\
\hline
\end{tabular}




\section{Nivel argumental, con base en los aspectos generales}

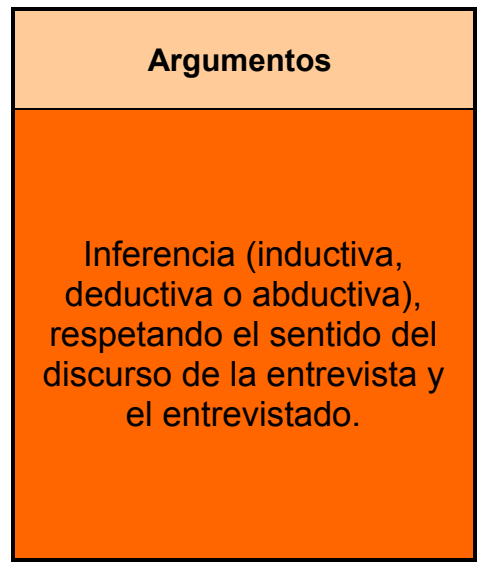

Un análisis, realizado con el objetivo de identificar los argumentos, en tanto expresiones cuasi-lógicas utilizadas para esquematizar y representar la realidad y que son de naturaleza ideológica y social (Giménez, 1981). De ahí que la columna final considerada en la matriz (en color rojo), lo esté, en tanto se pretendía visualizar la conformación de estas "claves ideológicas". Por otra parte, a partir de las categorías de análisis definidas previamente en el marco del proyecto de investigación, su conceptualización y la identificación de las variables, se llevó a cabo un proceso de operacionalización con fines de sistematización de estas categorías, para rastrear los datos observables a través de los discursos de los nariñenses y de los candelareños. Las categorías y los datos observables se describen a continuación: 


\begin{tabular}{|c|c|}
\hline Categorías & Variables (Lo observable) \\
\hline \multirow[t]{7}{*}{ Orígenes nariñenses } & Nombre \\
\hline & Edad actual \\
\hline & Nivel educativo \\
\hline & Edad en que llegó a Candelaria \\
\hline & Lugar de procedencia \\
\hline & Características del lugar de procedencia \\
\hline & Actividad a la que se dedicaba en el lugar de procedencia \\
\hline \multirow{6}{*}{$\begin{array}{l}\text { Estrategias de } \\
\text { identificación }\end{array}$} & Reproducción de lugares de encuentro \\
\hline & $\begin{array}{l}\text { Reproducción de olores, sabores (comida), sonidos } \\
\text { (música) }\end{array}$ \\
\hline & Formas de vestir/ corporales \\
\hline & Ritos y prácticas \\
\hline & Envío de mensajes/objetos/comida \\
\hline & Envío de dinero \\
\hline \multirow{4}{*}{$\begin{array}{l}\text { Idea de gente pura y } \\
\text { original }\end{array}$} & Como somos los nariñenses \\
\hline & Como son los candelareños desde los nariñenses \\
\hline & Como son los nariñenses desde los candelareños \\
\hline & Como somos los candelareños \\
\hline \multirow[t]{8}{*}{ Mito fundacional } & Motivos de la migración \\
\hline & Redes de apoyo \\
\hline & Llegada \\
\hline & Relaciones establecidas en el nuevo territorio \\
\hline & Quienes migraron después \\
\hline & Formas de contacto con el lugar de origen \\
\hline & Primer empleo \\
\hline & Como se comenzaron a juntar en Candelaria \\
\hline
\end{tabular}




\begin{tabular}{|c|c|}
\hline $\begin{array}{l}\text { Relatos de } \\
\text { marginación - } \\
\text { exclusión }\end{array}$ & Situaciones de marginación-exclusión \\
\hline \multirow{2}{*}{$\begin{array}{l}\text { Relatos de separación } \\
\text { - segregación }\end{array}$} & Situaciones de segregación separación \\
\hline & Problemas con los nariñenses \\
\hline \multirow{2}{*}{$\begin{array}{l}\text { Relatos de } \\
\text { asimilación }\end{array}$} & Pérdida de prácticas en los nariñenses \\
\hline & Pérdida de prácticas en los candelareños \\
\hline \multirow{7}{*}{$\begin{array}{l}\text { Relatos de } \\
\text { integración }\end{array}$} & Integración a través de la ubicación y trayectoria laboral \\
\hline & Integración a través de la vivienda. \\
\hline & Integración a través de las prácticas \\
\hline & Relación entre candelareños y nariñenses \\
\hline & Aportes de los nariñenses a Candelaria \\
\hline & Solidaridad de vecinos y amigos \\
\hline & Posibilidades de retorno \\
\hline
\end{tabular}

Una vez definidas estas variables sirvieron como insumo para la elaboración de los códigos en el programa Atlas. Ti, con el cual se procesó toda la información de las entrevistas y grupos de discusión.

\subsubsection{Características del programa}

El Atlas Ti es un software especializado en el manejo de información cualitativa que permite procesar ágilmente el material recolectado en campo y clasificarlo a partir de categorías de análisis que son previamente propuestas por el investigador y que en este proceso se convierten en códigos. El software facilita un ejercicio de codificación de los datos cualitativos a partir de estas categorías de análisis, el cual permite un tratamiento descriptivo inicial de los datos que resultan de cada uno de los grupos o perfiles de personas del estudio que encausa la definición de un grupo de hallazgos sobre el tema de investigación. 
A partir de este procesamiento informático se obtienen archivos en Word organizados por códigos que corresponden a las categorías y variables de análisis anteriormente descritas, los cuales permiten hacer una lectura panorámica y analítica de toda la información recolectada, en este caso, a partir de las entrevistas y grupos de discusión. Con este insumo se realizó un primer informe consolidado con la evidencia empírica que nutre cada una de las categorías y que en un primer momento asume un nivel descriptivo en cuanto a la interpretación y análisis de la evidencia empírica, para posteriormente, facilitarle al investigador el nivel interpretativo de la información con unos datos ya clasificados y ordenados por categorías.

\subsubsection{Aciertos y desaciertos en el proceso de sistematización}

Inicialmente es de señalar que la clara definición del problema de investigación y el proceso de categorización y operacionalización de las categorías de análisis definidas en el planteamiento de este, facilitó la identificación de las variables observables de cada una de las categorías. En este proceso fue clave un primer momento de acercamiento a la evidencia empírica, a través de la lectura de las entrevistas realizadas a los nariñenses y candelareños; sin embargo, se identificó que en el marco de la aplicación de entrevistas semiestructuradas, aunque siempre se tenían unas preguntas eje (características de los nariñenses, prácticas propias, diferencias con los candelareños), no siempre se siguió el mismo formato porque cada conversación obtenía matices distintas y los diálogos, por su desarrollo, generaban intereses particulares tanto en el entrevistador como en el entrevistado; lo cual hizo que las diferentes salidas por variables no tuvieran el mismo volumen de información.

Igualmente, se identificó que debido a las características socioeconómicas de la

población tales como el bajo nivel educativo y la edad, algunas preguntas no fueron de fácil compresión lo que hacía que los entrevistados respondieran a otras situaciones o se desviaran del tema. Sin embargo, en general, tanto las entrevistas como los grupos de discusión permitieron recoger la información suficiente para el análisis a la luz de las categorías de investigación propuestas. 
Por otra parte, para la revisión documental que incluyó las fotografías de los álbumes, documentos personales y oficiales y documentación del archivo parroquial y municipal, que hicieron parte del corpus, se propuso la técnica de análisis verbo visual de Gonzalo Abril (2013) y la técnica de análisis multimodal del discurso, a partir de la propuesta de Kress y Van Leeuwen (1996 - 2001).

Para esto se sugirió una matriz de análisis visual como la propuesta por Gonzalo Abril (2013. P. 54)

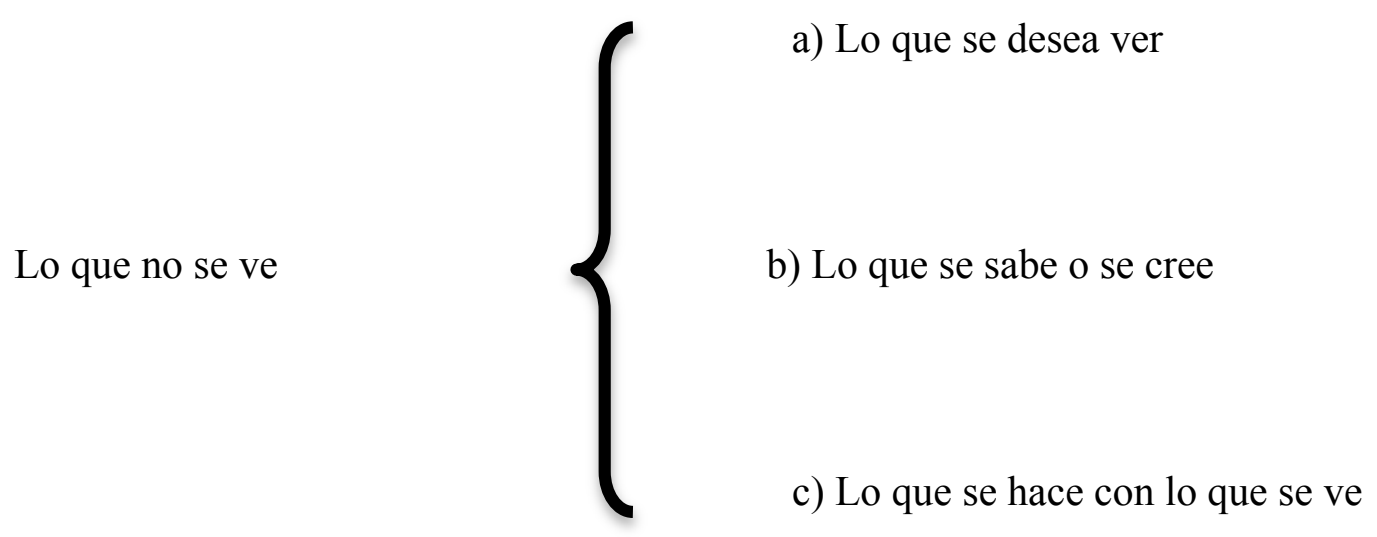

En una fase posterior, que implicó la contrastación del nivel descriptivo con los sujetos migrantes, se hizo un ejercicio de interpretación que permitió, por último, tejer las significaciones para construir el sentido de los relatos. En la siguiente tabla se sintetiza lo descrito en relación a las técnicas de recolección de la información a las que se acudió para el levantamiento de la evidencia empírica y al tipo de análisis de datos que se propuso teniendo en cuenta el tipo de dato que resultó de la aplicación de cada técnica en el trabajo de campo: 
Tabla 12. Estrategia de análisis asociada a la evidencia empírica recolectada a partir de la aplicación de instrumentos

\begin{tabular}{|c|c|c|}
\hline $\begin{array}{c}\text { Técnicas de recolección } \\
\text { de información }\end{array}$ & Tipo de información obtenida & Técnica de análisis de información \\
\hline Entrevistas biográficas & Relatos orales transcritos & Análisis argumental \\
\hline $\begin{array}{l}\text { Entrevistas focalizadas } \\
\quad \text { (individuales) }\end{array}$ & Relatos orales transcritos & Análisis argumental \\
\hline Grupos de discusión & Relatos orales transcritos & Análisis argumental \\
\hline $\begin{array}{l}\text { Observación } \\
\text { participante }\end{array}$ & $\begin{array}{l}\text { Notas de campo sobre espacios, sus } \\
\text { actores y prácticas; fecha, hora y en } \\
\text { general, las condiciones en las que } \\
\text { se realicen los ejercicios de } \\
\text { observación. }\end{array}$ & Análisis de descripciones factuales (Potter) \\
\hline Revisión documental & $\begin{array}{l}\text { Imágenes fotográficas de los } \\
\text { álbumes familiares, cartas y } \\
\text { telegramas. }\end{array}$ & $\begin{array}{l}\text { Para las imágenes de los álbumes se } \\
\text { proponen la técnica de análisis verbovisual } \\
\text { y la técnica de análisis multimodal del } \\
\text { discurso a partir de la propuesta de KRESS } \\
\text { Y VAN LEEUWEN. } \\
\text { Para esto se sugiere una matriz de análisis } \\
\text { visual como la propuesta por Gonzalo } \\
\text { Abril. } \\
\text { Para las cartas y telegramas, se sugiere } \\
\text { también el análisis multimodal a partir de } \\
\text { la propuesta de KRESS Y VAN } \\
\text { LEEUWEN. }\end{array}$ \\
\hline
\end{tabular}

Fuente: elaboración propia 


\section{CAPÍTULO VI. DESARROLLO ANALÍTICO}

\section{Candelaria, Valle del Cauca. Un espacio de tensiones y negociaciones interculturales entre nariñense y vallecaucanos}

La migración económica del departamento de Nariño al Valle del Cauca, municipio de Candelaria, llevada a cabo durante la segunda mitad del siglo XX en Colombia, concierne a un proceso de modernización de la industria azucarera colombiana, cuyos efectos pueden evidenciarse en la construcción y expansión de ingenios azucareros distintos a los que ya existían para el año 1930, como son los de Manuelita, Providencia y Riopaila.

Mayagüez fue uno de los ingenios resultado de la expansión agroindustrial azucarera, el cual se creó en 1937 por la iniciativa de Nicanor Hurtado Pérez y Ana Julia Holguín, quienes comenzaron a producir panela en un trapiche, y más tarde compraron tierras aledañas para la siembra de caña de azúcar, convirtiendo el trapiche en una compañía agroindustrial bajo la consolidación de un ingenio azucarero; de igual forma, Mayagüez fue uno de los ingenios que más población migrante demandó del departamento de Nariño, pues la fuerza de trabajo del nariñense era apetecida por la destreza y mano de obra segura que requería el corte de caña, además de la disposición del nariñense por salir adelante, la mentalidad de empuje y de querer mejorar sus condiciones materiales de existencia fueron indispensables en el momento de tomar la decisión de migrar al Valle del Cauca, dado que la carestía de la vida en Nariño se acentuaba cada vez más por la falta de dinero circulante y el impacto de la economía tradicional que primaba en dicho departamento.

El desarrollo de la agroindustria azucarera y la situación económica en la cual se encontraba Nariño, hacen parte de las causas de la migración económica que se llevó a cabo de manera masiva en los años 60. Esta migración económica adquiere especial relevancia por ser la protagonista de la configuración de la identidad de los migrantes nariñenses asentados en Candelaria, quienes a partir de conflictos y negociaciones identitarias en y con la sociedad receptora, pudieron reproducir los modos de vida propios 
de una cultura erigida sobre la base de un ethos del trabajo que diferenciaba al nariñense de otros grupos y colectivos sociales.

La construcción de lo nariñense en Candelaria es una de las dinámicas identitarias que surge como proceso de reafirmación de las prácticas, costumbres y fiestas nariñenses en la sociedad receptora. Esta reafirmación identitaria depende de un hecho histórico que sitúa al trabajo de los nariñenses y su disposición a ejecutar actividades que requieren destreza y habilidad manual, como condición necesaria para iniciar los procesos de configuración de identidad de los sujetos migrantes dentro de Candelaria. La producción de trabajos pesados, aunado a la disposición que tienen los nariñenses de llevar a cabo labores que exigen un mayor rendimiento de su fuerza de trabajo constituyen, justamente, el ethos del nariñense en el trabajo, es decir, una fisonomía cultural que se expresa en la práctica de un saber técnico - racional que le proporciona al nariñense las estrategias de identificación dentro de la sociedad receptora, una vez se pone en marcha la migración económica de los años 60 .

El ethos del trabajo del nariñense es el resultado de un saber técnico que obtiene de las relaciones de producción que establece en el trabajo, y que lo conducen a adquirir una disposición para ejecutar trabajos manuales que exigen destreza y una mayor inversión de mano de obra, con la que espera maximizar la producción para mejorar sus ingresos. Este ethos también es el resultado de un saber racional que el nariñense pone en práctica cuando actúa de acuerdo a un sentido del ahorro, el cálculo y la previsión, y que exterioriza cuando aprende a maximizar su producción para emplear sus ganancias en el cumplimiento de metas y proyectos pensados a futuro, como por ejemplo en la adquisición de un lote para construir vivienda propia.

En este sentido, la configuración de la identidad cultural de los nariñenses en Candelaria tiene como punto de partida el trabajo, pues es en este escenario donde los nariñenses empiezan a interactuar con sus paisanos como colectividad y a reproducir prácticas y costumbres que se erigen sobre un ethos, que si bien se construye en la producción de la vida material, a partir del proceso migratorio comienza a expandirse a 
otras esferas sociales y culturales como un estratagema de comunicación utilizado por los nariñenses para afirmar su identidad dentro de la sociedad receptora.

Esta sociedad en la que buscan insertarse los nariñenses produce más negociaciones identitarias que conflictos. Los migrantes de Nariño construyen sus identidades en el marco de un diálogo con los relatos de integración producto de la interacción entre la cultura nariñense y candelareña, y del proceso migratorio que imbrica el trabajo, esto es, el proceso productivo de la vida material que se convierte en un escenario propicio para que emerjan los relatos construidos desde los nariñenses, quienes proponen nuevas formas de interacción que implican nuevos modos de vida anclados en lugares y prácticas de identificación.

El análisis de los relatos que develan una identidad intercultural entre nariñenses y candelareños, de igual forma, tiene como fin desentrañar las disputas que se producen en diferentes espacios representativos para ambas colectividades en torno a los significados de "pastuso", de "burro de carga" y de otros rasgos como la vestimenta y el acento. En los relatos de identidad de los sujetos migrantes pueden encontrarse diversos elementos que, dentro del contexto de adaptación a la sociedad receptora, muestran posicionamientos identitarios distintos a los que comúnmente circulan en Candelaria. Los nariñenses que migraron a Candelaria, cuando son tildados de "pastusos", responden apelando a la ignorancia de sus interlocutores; en este sentido, en uno de los grupos de discusión conformados por los fundadores de la Chaza, los nariñenses recuerdan que los candelareños se referían a ellos más o menos de la siguiente manera: "ahí están los pastusos, entonces eso era como a uno buscarle el lado flaco a uno para que se enojara pero nosotros no, no nos enojamos porque nos digan pastusos" (entrevista personal, 2016).

Al respecto, un candelareño reconoce incluso que catalogaba, casi que en forma de chiste, al nariñense como pastuso, queriendo resaltar con ello que hacía las cosas al revés: “en algún momento como por chiste se decía, ah este parece pastuso, este parece pastuso, está haciendo las cosas como no son, al revés o algo así" (entrevista personal, 2016). 
Aunque puede decirse que no tan "al revés" cuando se contempla que dicho apelativo era empleado para referirse, sobre todo, al tipo de trabajo pesado que el nariñense practicaba en el corte de caña, cuya labor el candelareño no estaba acostumbrado a ejecutar, "nos decían a nosotros, pastusos, burros porque nosotros, cortando caña ¡y mire los pastusos burros!" (entrevista personal, 2016)

Los nariñenses, al ser tildados de "pastusos" responden apelando a la ignorancia de sus interlocutores, y por qué no, regocijándose de ella.

(...) aquí cada uno, somos de un municipio de Nariño, si nos dicen pastusos es lo mismo si nos dicen nariñenses, para nosotros es lo mismo, porque como nadie conoce los municipios del departamento de Nariño por lo menos aquí, pero a nosotros no nos gusta eso. Empecemos a grabar, yo soy José Ruiz y soy de Soto Mayor Nariño. Mi nombre es Ricardo Ismael Sánchez de Funes Nariño. Mi nombre es José Bernardo Rivera y vengo de Guachavés Nariño. Como ya lo había dicho antes cierto, soy de Linares Nariño y yo soy de Buesaco Nariño. (entrevista personal, grupo de discusión nariñense, 2016).

De esta forma, los nariñenses en el marco de un relato de identidad cultural que utiliza la argumentación como herramienta del lenguaje para tomar una posición respecto a las acusaciones de los candelareños, dejan por sentado que estas últimas no los hacen enojar, precisamente, por ser resultado del desconocimiento de los candelareños en torno al lugar de origen de los nariñenses.

Aquí los nariñenses demuestran que, a pesar del relato de exclusión de los candelareños ante el significado de la palabra "pastusos" -que en este caso tiene que ver con el hecho de identificar a los sujetos migrantes con personas que "hacen las cosas como no son o al revés"-, toman ante ello una actitud que los sitúa dentro de un grupo que cuenta con un capital cultural mayor que el de la sociedad receptora, elemento que logra ser identificado cuando se sabe que Nariño es un departamento que consta de 64 municipios. Esto último constituye una estrategia desarrollada por los nariñenses en el marco de la relación intercultural que establecen con los candelareños, con quienes las 
negociaciones y los conflictos corren parejas cuando de lo que se trata es de buscar un posicionamiento en la sociedad receptora.

Ahora bien, el posicionamiento que los nariñenses fueron obteniendo en Candelaria durante el proceso migratorio, obedece al significado y a la práctica de nociones tales como las de ascenso económico y ascenso simbólico; la primera categoría hace referencia a las condiciones que los nariñenses generaron para comenzar a organizarse como grupo y colectividad. La segunda categoría se refiere a la capacidad cognitiva de hacerlo, de poder llevar a cabo el "saber como" vincularse y reproducir prácticas en la sociedad receptora. Sin embargo, ambos ascensos son una consecuencia de la puesta en práctica del ethos del trabajo de los nariñenses, porque este implica la realización de un saber técnico en el trabajo de corte de caña, lo que a su vez tiene que ver con el hecho de generar condiciones en un nuevo espacio receptor para organizarse como colectividad, y darle desarrollo a las ideas, costumbres y prácticas nariñenses en función de una identidad configurada sobre la base de conflictos y negociaciones en Candelaria.

En este escenario de comprensión, se presentan los resultados del análisis y la interpretación de la evidencia empírica, a la luz de las categorías definidas previamente en la matriz de operacionalización, la cual propuso una ruta para la comprensión de los procesos de configuración identitaria de estos sujetos migrantes, a partir de dos categorías macro: los relatos de migración y los relatos de identidad cultural. Cada una de ellas, nutrida por unas categorías de orden micro contenidas en estas, las categorías vertebrales de la investigación.

De esta manera, el informe de análisis se estructura inicialmente con la búsqueda de la gramática de argumentos y su posterior representación mediante una cartografía de la gramática de argumentos (Giménez, 1981) o mapas ideológicos, en los que se trabajan dos niveles, el primero de ellos asociado a las expresiones de sentido de los sujetos migrantes y de la sociedad receptora; y el segundo, en el que se integran lo macro, lo meso y lo específico como ideologemas, en el intento por un lado, de develar aquellas expresiones de mayor sentido para los entrevistados y por otro, de organizar la evidencia 
empírica de acuerdo con su predominio en el discurso y con las relaciones tejidas entre las diferentes expresiones.

De forma seguida se presenta un análisis en el que a partir de los mapas ideológicos construidos, se identifican los argumentos que son la base fundamental de la conformación ideológica y que permiten aquí, interpretar cuestiones tales como el nivel desde el cual se percibe, se construye y se origina la identidad; conocer la incidencia de aspectos materiales o simbólicos en las estrategias de identificación configuradas por estos sujetos migrantes y entender también las formas de comunicación que prevalecen y los modos de relación que se dan entre sí, y con los demás grupos presentes en el municipio de Candelaria. Así pues, se presenta a continuación el desarrollo analítico:

\subsection{Relatos de la migración nariñense en Candelaria, Valle del Cauca. \\ 9.1.1. Mito fundacional. Motivaciones de la migración}




\section{RELATOS DE MIGRACIÓN}

$\downarrow$

\section{MITO FUNDACIONAL}

$\downarrow$

entonces el Valle con

tantos ingenios que

tiene, azucareros

$$
\downarrow
$$

se vine a llenar de puros nariñenses y aquí porque por el mismo trabajo que

hay y en Pasto en el departamento de Nariño no lo hay $\downarrow$

que si yo me vengo yo traigo el nieto y traigo el sobrino, traigo todo así.

\section{$\downarrow$}

se crece toda la colonia de Nariño y así se ha crecido en Candelaria, por ese mismo sentido,

primeramente por el económico

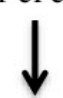

que ahí en Nariño no hay trabajo y aquí lo hay

\section{Nariñenses asentados en Candelaria}

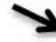

lo que motivó venirme para

acá... ya la forma de buscar el

dinero, el trabajo y

sostenerme y darme mis gustos que necesitaba

$\downarrow$

y ya después cuando yo tuve 16 años él me llamo

que me viniera y ya estuve acá

$\downarrow$

me vine para acá y yo

le dije a mi mamá, yo

me voy por un año y

ya vuelvo y nunca

pasó eso

$\downarrow$

me quede por acá

entonces eso me motivo más que todo

\section{$\downarrow$}

y luego ya vino una mujer ya a formalizar un hogar, y

los hijos y todo eso.

un día domingo le dije a mi mujer vámonos mija que ya tenemos hijos, $\downarrow$

llegamos aquí y aquí si ya sabían, pues ella ya tenía al papá, la mamá, los

hermanos. Llegamos a la casa de ellos

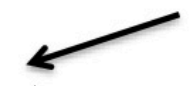

entonces ya me estuve como un mes y así me fui, me coloqué aquí en vámonos para el Valle otra vez pues el transporte, para venirse al Valle, todo el mundo

pues allá campesinos no había

sino que trabajar y trabajar

entonces era muy pobres, pobres

\section{$\downarrow$}

y entonces yo le pedí a la

virgen, fui a pedirle a la virgen que me llevaran al ejército para

poder salir de allá porque no había otro modo.

$$
\downarrow
$$

salir de allá es como los que piensan en irse ahorita para Estados Unidos, es difícil!

no era cualquier cosa!

$$
\downarrow
$$
en ese día ya era un problema en ese tiempo

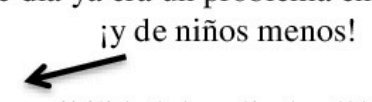

tener la posibilidad de salir de allá del campo, esa fue la promesa para poder ayudar a mi familia y así fue, entonces ya desde eso le agradezco a la
Mayagüez

entonces le dije yo a mi papá, conozco el Valle me voy para allá a conseguir trabajo para poderlo ayudar y entonces volví otra vez donde la virgen a pedirle pues que en ese viaje me fuera bien. 
como la familia de la señora mía viven aquí en Candelaria entonces llegamos a donde una cuñada, donde la hermana

$$
\text { de la esposa mía. }
$$

Si, ahí también vivía la suegra todo eso, ahí nos estuvimos como unos 6 meses

$\downarrow$

entonces ya días después salimos de ahí porque ya había como pagar un arriendo todo eso.

\section{Yo sabia pues que por} ahí jornaleando el pasaje no era costoso, reuní el pasaje, pero

yo sabia que acá

estaba mi hermano y así fue.

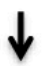

Él ya estaba trabajando acá. $\downarrow$

Mientras mi hermano me ayudaba allá en la empresa Mayagüez, porque no tenia la libreta, el hermano mío tenía mucha relación porque era juiciocito para trabajar allá en la

$$
\stackrel{\text { empresa }}{\downarrow}
$$

entonces le comentó al mayordomo y dijo: traiga con el recibo de la libreta, tráigalo, entonces, me vinculé a Mayagüez a trabajar allá y ya

Y por aquí se quedaron varios, hay como unos 10 paisanos de

$$
\text { los que yo les dije }
$$

por lo menos los paisanos que ya venían después se les ayudaba, se prestaba mucho por el trabajo, había mucho trabajo, demasiado trabajo

\section{RELATOS DE MIGRACIÓN}<smiles>[131IH]</smiles>

\section{MITO FUNDACIONAL}

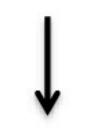

Hay como 3 paisanos que yo le dije,

vengasen para acá

\section{$\downarrow$}

el trabajo uno sabe que el salario en Nariño es difícil, en cuestión de empleo en Nariño

$$
\text { eso es fatal }
$$

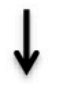

no vengasen para acá ustedes están jóvenes, pueden trabajar acá y hace

$$
\text { sus platicas }
$$$$
\downarrow
$$

entonces por eso le digo, el trabajo es muy principal acá, en Nariño pues es bueno pero por la comida y todo eso, porque pues allá uno la trabaja pero por plata es difícil, eso allá es difícil no es como acá que es quincenal, no como antes que era cada ocho.

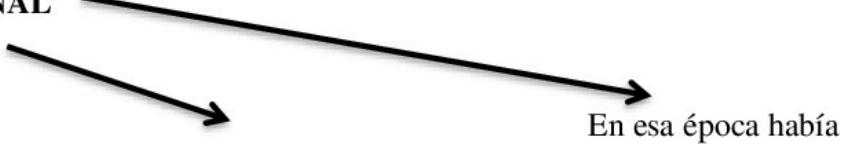

lo que pasa es que cuando mucha gente que estaba la gente, los paisanos que llegaban allá llegaban bien organizaditos $\downarrow$

los que venían por acá trabajaban y cuando llegaban, llegaban con su

radio

y resulta pues que viendo esas aquí en el Valle $\downarrow$

y entonces siempre en el departamento de Nariño habían algunas crisis económicas, de trabajo

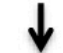
oportunidades en ese tiempo, que había entonces cuando trabajo aquí en el Valle en el corte de caña llegaban de acá con ese radiecito, todo el mundo no

lo tenía allá

salió un paisano y familiar, salieron a pasar vacaciones y me dieron una inducción de cómo venir y todo eso y me vine con ellos.

entonces yo dije, ¡bueno! algún día yo también me voy para el Valle y yo tengo que tener $\mathrm{m}$ radio

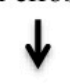

posteriormente aquí encontré un familiar, él nos dio la alimentación y la posada mientras conseguimos el trabajo $\downarrow$

posteriormente a los 15, 20 días hubo la entrevista en la empresa y logré conseguir el trabajo y de ahí no salí hasta que me pensione. 


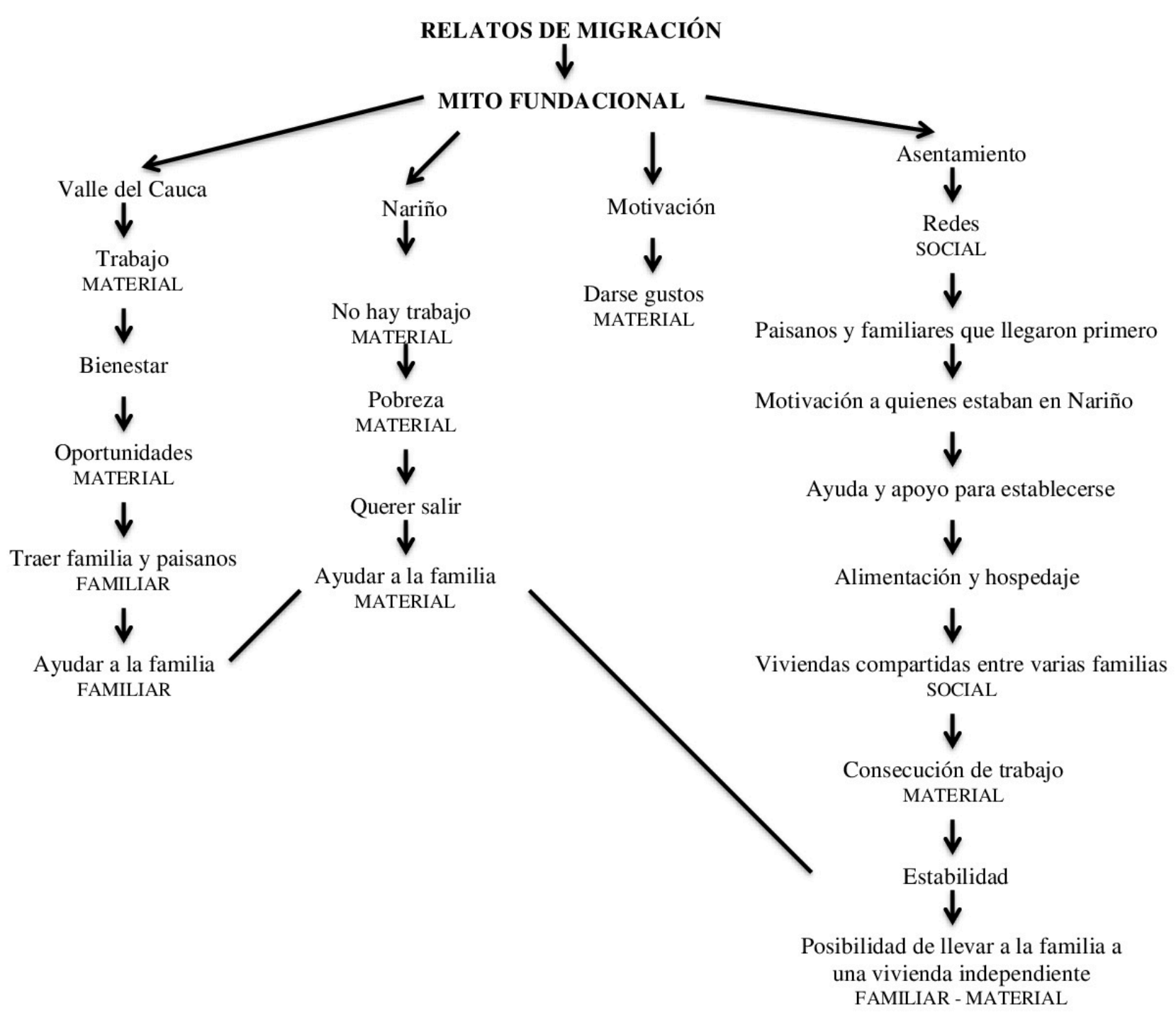


Se ha mencionado anteriormente que la migración nariñense se origina principalmente en la falta de oportunidades de trabajo que se tenía en los lugares de origen, además de la demanda creciente de Candelaria durante los años 60, de mano de obra para los ingenios azucareros que se estaban formando y que no lograba ser suplida por los habitantes de Candelaria. Esta situación, fue aprovechada por los nariñenses debido también a la reputación de buenos trabajadores que fue ganada por los primeros inmigrantes y que incluso, pudo ser considerada como carta de presentación y respaldo para el recién emigrado de dicho departamento.

Principalmente lo que motivó venirme para acá fue la violencia de mi papá, después ya la forma de buscar el dinero, el trabajo y sostenerme y darme mis gustos que necesitaba, porque con mi papá no se podía eso, mi papá era todo para la casa y si nos daba un vestidito en el año era mucho, entonces eso me motivo más que todo y luego ya vino una mujer, ya a formalizar un hogar, y los hijos y todo eso. (entrevista personal, Gabriel Pascuasa, 2016)

Sin embargo, también se evidencia entre los entrevistados una idea de progreso que además de la demanda de la industria azucarera, motivó la migración, en la búsqueda no solo de conseguir un trabajo para satisfacer las primeras necesidades de sus hogares, sino de poder acceder a otros elementos que representaban para ellos un ascenso social simbólico, por cuanto en sus lugares de origen no podían ser adquiridos, inicialmente por falta de recursos pero además, porque no se encontraban. 
lo que pasa es que cuando la gente, los paisanos que llegaban allá llegaban bien organizaditos, en ese tiempo era moda el traje, ahora ya no se ve pues el vestido que decíamos, llegaban bien organizaditos y entonces en ese tiempo era, no se si usted alcanzó a unos radiecitos que había, se los terciaban, el transistor se llamaban, y eso todo el mundo no lo tenía allá, los que venían por acá trabajaban y cuando llegaban, llegaban con su radio y claro, allá había una emisora mucho que la sintonizaban al Ecuador y pues la música ecuatoriana, esa emisora se llamaba entonces, ya no existe, Radio Saracay, entonces cuando llegaban de acá con ese radiecito, todo el mundo no lo tenía allá, llegaban entonces yo dije, ¡bueno! algún día yo también me voy para el Valle y yo tengo que tener mi radio transitor. (entrevista personal, José María Alpala, 2016).

Así, siendo el nariñense un sujeto emprendedor capaz de realizar labores en grupo que exigen una mayor inversión de músculo, nervios y cerebro; estas condiciones reunidas configuran la fuerza de trabajo necesaria para forjarse un mejor futuro. El hecho de que los nariñenses hubieran pensando en la posibilidad de trasladarse a otros lugares para mejorar su calidad de vida, tiene que ver con las diferentes manifestaciones de existencia de una sociedad precapitalista como la de Nariño, puesto que el trabajo agrícola característico de este departamento, no le garantizaba a sus habitantes un modo de vida distinto al del consumo inmediato.

El asunto aquí es que los nariñenses a medida que se involucraban en el trabajo de la tierra, al mismo tiempo desarrollaban un nivel de conciencia que les permitía formarse un criterio propio sobre su situación laboral, la cual consideraban no muy provechosa, sobre todo si se trataba de suplir otro tipo de necesidades que implicaban confort y además "darse ciertos gustos". Así lo cuenta Gabriel Pascuasa en su relato:

principalmente lo que motivó venirme de mi para acá antes de la violencia de mi papá, después ya la forma de buscar el dinero, el trabajo y sostenerme y darme mis gustos que necesitaba, porque con mi papá no se podía eso, mi papá era todo para la casa y si nos daba un 
vestidito en el año era mucho, entonces eso me motivó más que todo y luego ya vino una mujer ya a formalizar un hogar y los hijos y todo eso. (entrevista personal, Gabriel Pascuasa, 2016).

Antes de llegar a Candelaria los nariñenses se dedicaban al trabajo agrícola, por este motivo construyeron sus relaciones sociales sobre la base de la economía tradicional. Esta situación lejos de conducirlos a la ampliación del mercado y al desarrollo del capitalismo industrial, los condujo a la satisfacción de sus pretensiones personales, es decir, a jornalear para poder ayudar a sus familiares y parientes más cercanos con quienes conformaban su propia comunidad

(...) uno hay que hablar la verdad, yo no tuve escuela eso como lo normal, casi fue en la parte del campo cuando mi mamá y mi papá dijeron vaya a la escuela, yo ya estaba grandecito, yo lo que quería era trabajar y ayudarle a mi papá y a mi mamá porque ya empecé a ganar y a jornalear. (entrevista personal, Gabriel Pascuasa, 2016).

Los proyectos personales que hasta entonces se habían trazado los nariñenses pertenecían más a un contexto donde la economía era atrasada y las proyecciones acordes con un mundo en el que “jornalear” para ayudar a los parientes más próximos era una de las principales metas, sino la más importante y constituyente del sentido de comunidad y de solidaridad, que como ya se dijo, orienta las acciones de los sujetos migrantes.

No obstante, el relato de Gabriel Pascuasa es clave en cuanto marca el paso de un mundo premoderno a un mundo moderno, mostrando con ello la formación de nuevos ideales y aspiraciones que hacen hincapié en el confort y en cierto tipo de comodidades que solo se hacen conscientes en las personas cuando emergen modos de vida anclados en una estructura económica y política diferente, tal como la del Valle del Cauca, a saber, una sociedad que para la segunda mitad del siglo XX se moderniza con el auge de la agroindustria azucarera que comienza a reclamar mano de obra segura para el corte de caña, pero sobre todo, personas capaces de adquirir una posición social distinta en el momento en que deciden dejar de ser campesinos que trabajan directamente la tierra bajo propiedad familiar, para pasar a ser trabajadores asalariados o "jornaleros", como bien lo mencionan los mismos nariñenses. 
De esta manera, las pretensiones personales de los nariñenses fueron transformándose hasta el punto de tener como aspiración trasladarse a otro territorio, $\mathrm{y}$ más precisamente migrar al Valle del Cauca, por ser un lugar que les ofrecía mejorar su calidad de vida y ascender en la escala económica y social. Pero para tener una aspiración como esta, fue necesario que los nariñenses observaran con nuevos ojos el territorio de origen, lo cual quiere decir que los sujetos migrantes adquirieron una nueva cosmovisión sobre el espacio que desde la infancia definió su identidad cultural. Esto puede evidenciase en los relatos de los nariñenses que se refieren a los aspectos que los motivaron a marcharse de su territorio, tal como el de Aurelio Realpe, para quien la situación económica de su lugar de origen fue su principal motivación a la hora de tomar la decisión de migrar a Candelaria:

Porque en Nariño anteriormente era muy escaso el trabajo, entonces el Valle con tantos ingenios que tiene azucareros, entonces se viene a llenar de puros nariñenses, porque por el mismo trabajo que hay, porque en el departamento de Nariño no lo hay, entonces ¿qué pasa? Que se viene a aglomerar un poco de personas de Nariño, que por ejemplo, que si yo me vengo yo traigo el nieto y traigo el sobrino, traigo todo así, y así se crece toda la colonia de Nariño y así se ha crecido en Candelaria, por ese mismo sentido, primeramente por el económico que ahí en Nariño no hay trabajo (...). (entrevista personal, Aurelio Realpe, 2016)

La configuración y apropiación de nuevas cosmovisiones vienen acompañadas de cambios en la estructura económica y política de una determinada sociedad, que para el caso que concierne a esta investigación, tiene que ver con el paso del campo a la ciudad y el proceso de urbanización que acompaña a la modernización de cualquier grupo social. En este orden de ideas, cuando la principal motivación de las personas deja de ser la producción para el consumo inmediato y se empieza a pensar en otras vías para tener comodidades y confort, o incluso cuando el trabajo se compara con el de otras regiones, hasta llegar a la conclusión de que en el propio territorio no hay -“porque en Nariño anteriormente era muy escaso el trabajo, entonces el Valle con tantos ingenios que tiene azucareros, se viene a llenar de puros nariñenses (...) que ahí en Nariño no hay trabajo"-, 
es cuando el territorio y el lugar de origen dejan de representar en el imaginario de las personas el espacio donde poder producir y reproducir la vida material.

Esto fue lo que le sucedió a los nariñenses que decidieron migrar en los años 60`s masivamente a Candelaria, Valle del Cauca: se formaron un criterio sobre su situación laboral bajo las condiciones de un modo de producción autárquico y tradicional como el de Nariño, en el que trabajar para subsistir hacía parte de las formas de realización del individuo. No obstante, a medida que los nariñenses fueron adquiriendo un nivel de conciencia mayor sobre otros tipos de realización personal que consistían en "darse ciertos gustos", y en la medida en que fueron conociendo por medio de familiares y personas cercanas lugares diferentes que como Candelaria prometían mejorar la calidad de vida, el propio territorio se quedó corto, por tratarse ahora de hacer real y efectiva una nueva imagen de realización personal forjada y adquirida dentro de la agricultura y el arado de la tierra, pero capaz de hacer desear a los nariñenses la reproducción de la vida material sobre la base de nuevas circunstancias que trascienden la mera existencia inmediata o el simple trabajar para suplir las necesidades básicas.

Es de señalar también que en algunas ocasiones se presentaron situaciones de migración y retorno, nariñenses que llegaron a Candelaria y consiguieron trabajos que les permitieron ahorrar para después retornar; pero que en últimas no lograron establecerse económicamente en sus pueblos de origen, enfrentando nuevamente la decisión de emigrar, esta vez con la experiencia y el conocimiento de que podrían conseguir fácilmente empleo en el Valle del Cauca y con ello mejorar sus condiciones.

Trabajé en agricultura, bueno trabajé dos años y me fue tan mal que perdí todo lo que llevé, un día domingo le dije a mi mujer: vámonos mija, que ya tenemos hijos, vámonos para el Valle otra vez. Llegamos aquí y pues ella ya tenía al papá, la mamá, los hermanos; con la mujer llegamos a la casa de ellos, entonces ya me estuve como un mes y así me coloqué aquí en Mayagüez, y ahí si ya me coloqué [establecí]. (entrevista personal, Gabriel Pascuasa, 2016). 
Así, el caso de la migración de la población nariñense hacia Candelaria, motivada y dinamizada por diversos factores, se configura como una migración multi-motivacional, que involucra aspectos racionales, de dependencia y lo conocido como push and pull, en donde a la falta de oportunidades de trabajo en Nariño, a la demanda laboral de la industria azucarera vallecaucana que se estaba consolidando, y a esa idea de progresar en un nuevo lugar, se sumaron las condiciones de trabajo como las que ofrecía la industria de la caña, condiciones que no eran comparables con las de sus lugares de origen, no solo porque los salarios se doblaban e incluso se triplicaban, sino también, y sobre todo, porque en el Valle tenían acceso a la seguridad social de la época, a bonificaciones extras y a los programas que los ingenios generaban para facilitar el bienestar de sus trabajadores.

Todo esto, propone un escenario de migración de carácter definitivo (Arroyo, 2006) debido a que en mínimas ocasiones la población retornó. Además de que para los nariñenses el trabajo invertido en la agricultura no se vio recompensado con el pago ni con el beneficio obtenido que daba solamente para lo básico, lo cual muestra que la determinación de migrar a Candelaria responde a razones históricas y socioeconómicas, cuyo punto de partida es la crisis que se desata cuando en una sociedad -como la nariñense- las condiciones materiales de existencia (el modo de producción económico) no corren parejas con los ideales, pretensiones personales y proyectos pensados como posibilidad de ascenso social y económico. Dicho en otras palabras, la migración es un hecho social que tiene entre otras causas, la crisis que surge cuando la economía de un país, una ciudad o región deja de garantizar la existencia de las personas y el sustento de sus proyecciones económicas.

Ante un hecho como este las relaciones de orden social, cultural y político se transforman en medios de expresión de tensiones y antagonismos sociales que muestran el sentido en que los sujetos migrantes configuran un imaginario centrado en el esfuerzo personal por tener una condición económica distinta a la tradicional: comenzar por adquirir una concepción sobre el territorio como aquel lugar donde es posible ser, más no tener, es decir, la opción de continuar reproduciendo prácticas y costumbres que definen aspectos centrales de la identidad en el lugar de origen, más no continuar produciendo 
insatisfactoriamente la vida material en un territorio que se queda corto para sujetos que tienen nuevos ideales de ascenso -he aquí una de las principales transformaciones de orden social que acarrea una nueva cosmovisión del territorio junto con la pretensión de marcharse a otro lugar donde poder hacer efectivas otras formas más dinámicas de realización-.

En este sentido, la decisión de los nariñenses de migrar a Candelaria es un hecho social que obedece a una crisis económica, y más exactamente, a los antagonismos sociales que surgen en el momento en que lo ofrecido por el territorio no basta para suplir satisfactoriamente las necesidades; para José Montilla, las crisis de Nariño fueron determinantes para migrar al Valle del Cauca, puesto que estas repercutieron en la demanda de trabajo, hasta el punto, puede decirse, de dejar a los nariñenses "libres" 21 de encontrar otras oportunidades de empleo,

en esa época había muchas, ya había gente que estaba aquí en el Valle y entonces siempre en el departamento de Nariño habían algunas crisis económicas, de trabajo y resulta pues que viendo esas oportunidades en ese tiempo había trabajo aquí en el Valle en el corte de caña, salió un paisano y familiar, salieron a pasar vacaciones y me dieron una inducción de cómo venir y todo eso, y me vine con ellos. (entrevista personal, José Montilla, 2016).

\subsubsection{Llegar, apoyarse y establecerse}

En el relato de José Montilla se evidencia que la migración de los nariñenses hacia Candelaria, está caracterizada también por unas fuertes redes de contacto en el lugar de llegada. Los entrevistados relatan que muchos de ellos tenían en Candelaria a familiares que motivaron la migración cuando iban a visitar sus pueblos, contándoles sobre oportunidades de trabajo que se estaban generando y manifestándoles su apoyo ante una posible migración; señalando aquí que algunos no tenían familiares, sin embargo las

\footnotetext{
${ }^{21}$ La palabra "libres" se utiliza aquí en un doble sentido para demostrar que los nariñenses debido a la crisis económica por la que estaba atravesando el departamento de Nariño, quedaron sin más opción que la de buscar en otros lugares algún empleo que les permitiera salir adelante.
} 
redes vecinales eran tan fuertes, que permitían que llegaran solamente buscando a sus paisanos.

Pues viendo esas oportunidades, en ese tiempo había trabajo aquí en el Valle en el corte de caña, salió un paisano y familiar, salieron a pasar vacaciones y me dieron una inducción de cómo venir y todo eso, me vine con ellos y posteriormente aquí encontré un familiar y él nos dio la alimentación y la posada mientras conseguimos el trabajo, posteriormente a los 15, 20 días hubo la entrevista en la empresa y logré conseguir el trabajo y de ahí no salí hasta que me pensioné. (entrevista personal, José Montilla, 2016).

Nosotros agarramos, uno como dice de muchacho agarre y se va, sin saber a dónde va a llegar, yo simplemente tenía el conocimiento de paisanos que eran de ahí, del pueblo mismo, que era creo Popayán, entonces yo llegué y acá en el parque me lo encontré, casualmente yo me bajo del bus y me lo encontré a él ahí. (entrevista personal, Gabriel Pascuasa, 2016).

Este apoyo entre paisanos consistía en facilitar el alojamiento en las viviendas durante unos días o meses, ayudar a encontrar trabajo en los ingenios que recién se estaban constituyendo, guiar con respecto a dónde ir, con quién contactarse y en muchas ocasiones, ayudar con la alimentación, mientras el recién llegado se acomodaba. Incluso, los mismos candelareños cuentan que los nariñenses tenían una casa que servía de albergue para recibir a los nuevos coterráneos que iban llegando:

...ellos llegaban aquí en un principio, a una casa que le llamaban la casa nariñense, ella está ubicada de aquí más o menos dos cuadras, de aquí de mi casa dos cuadras, allí llegaban ellos y era la embajada, los muchachos, yo hablo muchas cosas es porque como me tocaban los alumnos, ellos decían es que apenas llegaron mis papás, llegaron a la embajada, la embajada era la casa nariñense que ellos tenían. (entrevista personal, Clara Díaz, 2016) 
Por otra parte, y también gracias a estas redes de apoyo, el tiempo de espera para emplearse generalmente era poco, llegaban a los ingenios, hacían la solicitud de empleo y casi inmediatamente eran enviados a Cali a realizarse exámenes médicos. Posteriormente, cuando conseguían el empleo, alquilaban cuartos en casas de los mismos nariñenses, casas que algunos señalan que se caracterizaban por el hacinamiento, porque vivían muchas familias en el mismo espacio.

El ubicarse laboralmente con rapidez, permitió a los nariñenses contar con estabilidad económica debido a los altos salarios recibidos en la época, esta situación tuvo como consecuencia la independencia de sus paisanos, en tanto comenzaron a construir sus casas, amoblarlas y a mejorar las condiciones de vida de sus esposas e hijos; incluso, para aquellos que llagaron solteros, las redes de apoyo constituidas por nariñenses, les permitió conseguir esposas y lograr lo que ellos denominan organizarse.

Seguimos viviendo ahí, nos asignó una pieza y ya como familia misma, así fue hasta que ya cada uno se va independizando, porque ya va comprando sus cosas, todo eso y ya el primo dijo: ya vayan buscando donde se alimentan, busquen que queden mejor, hasta que pues ya con el tiempo coge uno ya cancha como se dice, experiencia y va consiguiendo la compañera. (entrevista personal, José Montilla, 2016).

Además de las fuertes redes de apoyo de los nariñenses, las mismas condiciones laborales que brindaba la empresa, permitieron que los nariñenses progresaran económicamente en Candelaria, debido a que los salarios en la industria de la caña eran más altos que los ofrecidos en otros cultivos, contaban con prestaciones sociales y los mismos ingenios azucareros les brindaban la oportunidad para la compra de lotes y posteriormente para la construcción de vivienda; viviendas que en Candelaria han sido reconocidas por ser muy grandes y por tener una gran cantidad de habitaciones que permitieran recibir a nuevos migrantes, con patios que eran aprovechados para la crianza de animales, especialmente los cuyes que hacen parte de su alimentación y de la gastronomía tradicional nariñense. 
Esto propició la conformación de familias extensas, integradas por familias de compañeros de trabajo que habitaban las casas durante muchos años, compartiendo espacios como cocinas y baños, además de los gastos de vivienda, las costumbres, los valores y la crianza de los hijos.

Bueno para conseguir esa casa pues siempre me encontré con otro paisano que ya murió también, tomamos una casa en arriendo, entre las dos familias, y usted sabe que entre los paisanos nosotros siempre hemos sido solidarios, nos ayudamos mucho, eso tiene la colonia nariñense, solidaria, no es como a veces la pintan, solidaria, entonces ahí estuve siete años, a los siete años, el señor me dijo: Don Montilla ustedes han estado en mi casa y la han hecho como cosa propia y la han mantenido, bien entonces yo [se] la voy a vender. (entrevista personal, José Montilla, 2016)

Muchos de ellos siguieron reproduciendo la lógica de migración trayendo a familiares, especialmente a los hombres que quedaban en Nariño, para trabajar en los ingenios, otros mandaron a traer a los padres que habían quedado solos para vivir con ellos y para cuidarlos; todo esto fue reduciendo sus nexos con el lugar de origen. Sin embargo, se encuentra en los relatos, que permanecían en contacto a través de llamadas telefónicas con primos, tíos y hermanos, además de las visitas anuales que muchos de ellos cuentan que aún hoy realizan.

La migración como toda acción social tiene implicaciones en las relaciones sociales, por este motivo es un proceso que involucra transformaciones y adaptaciones culturales. El traslado no es solo de los sujetos o de los grupos migrantes, o de los objetos materiales que los acompañan, sino también de símbolos y prácticas. Así, la migración en grupo se convierte en una estrategia para trasladar y mantener la cultura, de ahí que este tipo de migración a través de pequeñas comunidades permite simular y mantener los ritmos cotidianos del lugar de origen (Park, 1999). En el caso de la población nariñense en Candelaria, la migración en grupo y familiar, permitió crear un nicho en el nuevo lugar, situación facilitada por las propias características del municipio de Candelaria que estaba en proceso de construcción. 
En este sentido, la migración no puede ser entendida como un acto solitario, parte de su éxito, por lo menos en este caso, radica en las redes con las que cuenta el migrante o el grupo de migrantes, las cuales no son solamente de consanguinidad, sino que son construidas por las relaciones de vecindad y por vínculos emocionales. Como señala De la Torre (2004), la redes se convierten en un apoyo que permite disminuir los riesgos que implica el proceso migratorio; esto no solo se refleja en el dar instrucciones sobre cómo llegar, sino, como se dio en este caso, en ofrecer hospedaje y alimento durante los primeros días, así como un apoyo para lograr la inserción laboral.

De esta forma, la llegada masiva de los nariñenses a Candelaria hizo que estas redes cada vez fueran más robustas, se vieran más fortalecidas e implicaran una ampliación del capital social para los nuevos migrantes (Massey et al., 1993), que fueron construyendo una idea en la sociedad receptora de lo que es ser nariñense, confiriéndole a la red un rol fundamental en la posibilidad de que las identidades se recreen y revitalicen, se cree sentido de pertenencia y se construyan nuevos lugares de sentidos compartidos.

Entendido así, el proceso migratorio de Nariño al Valle del Cauca convirtió a los nariñenses en trabajadores asalariados de la mediana industria azucarera, quienes atraídos por los rumores que escucharon de sus familiares, personas cercanas y paisanos que migraron antes que ellos al Valle, conocieron los beneficios de trabajar en el corte de caña, y como consecuencia, tomaron la determinación de viajar y de impulsar un importante porcentaje de la población nariñense, que de igual forma, pasó a ocupar una condición social y económica distinta como jornalera o asalariada, pero que puso en práctica diversas estrategias de identificación con el fin de conservar las tradiciones, hábitos, pretensiones e ideales que desde siempre caracterizaron a los nariñenses como "gente pura y original".

\subsubsection{Relatos de marginación - exclusión}




\section{RELATOS DE MIGRACIÓN $\downarrow$ \\ RELATOS DE SEGREGACIÓN - SEPARACIÓN \\ $\downarrow$}

Nariñenses asentados en Candelaria

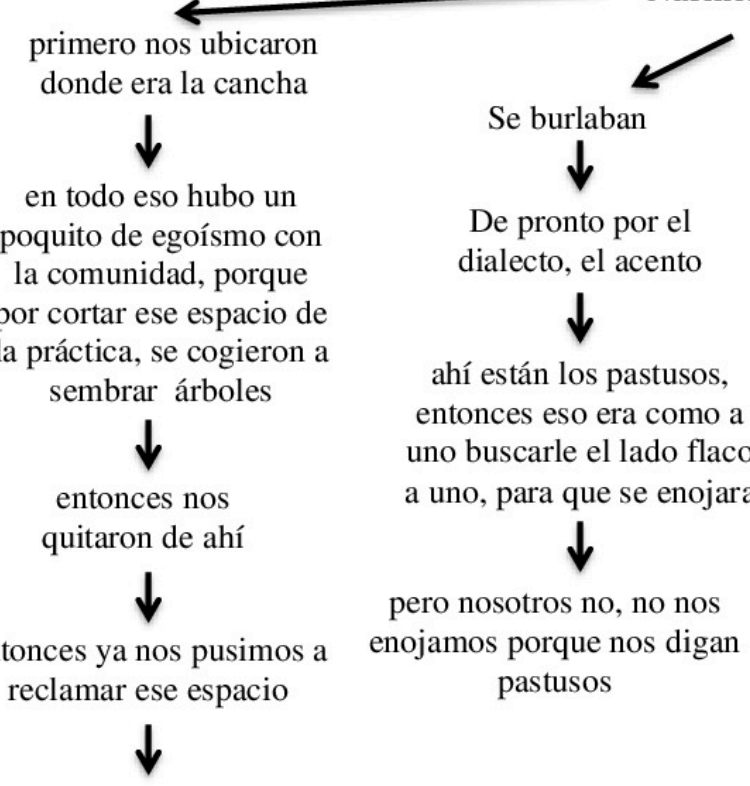

Aquí hay gente, los vecinos de aquí les disgustaba

a veces trataban de encerrar, trataban de cohibirnos

$$
\downarrow
$$

y el doctor Correa, yo me acuerdo que dijo -son mis trabajadores y a ellos me los dejan practicar allí

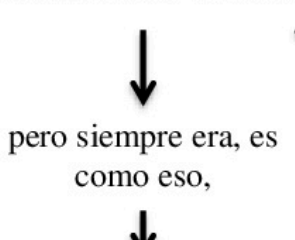

el candelareño siempre quería ser como el avispado, como el vivo, como el que se las sabe todas

\section{$\downarrow$}

pero yo pienso que eso

ha disminuido también mucho

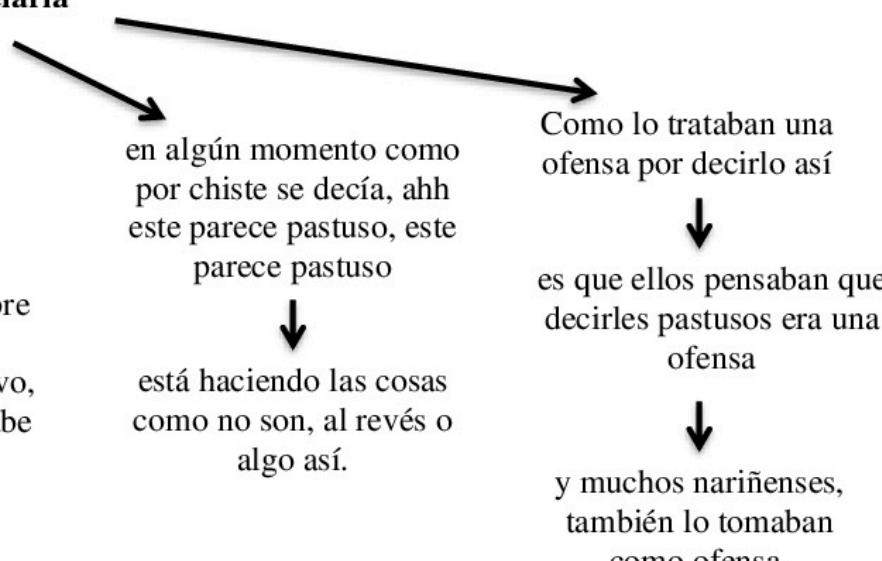

como ofensa. 


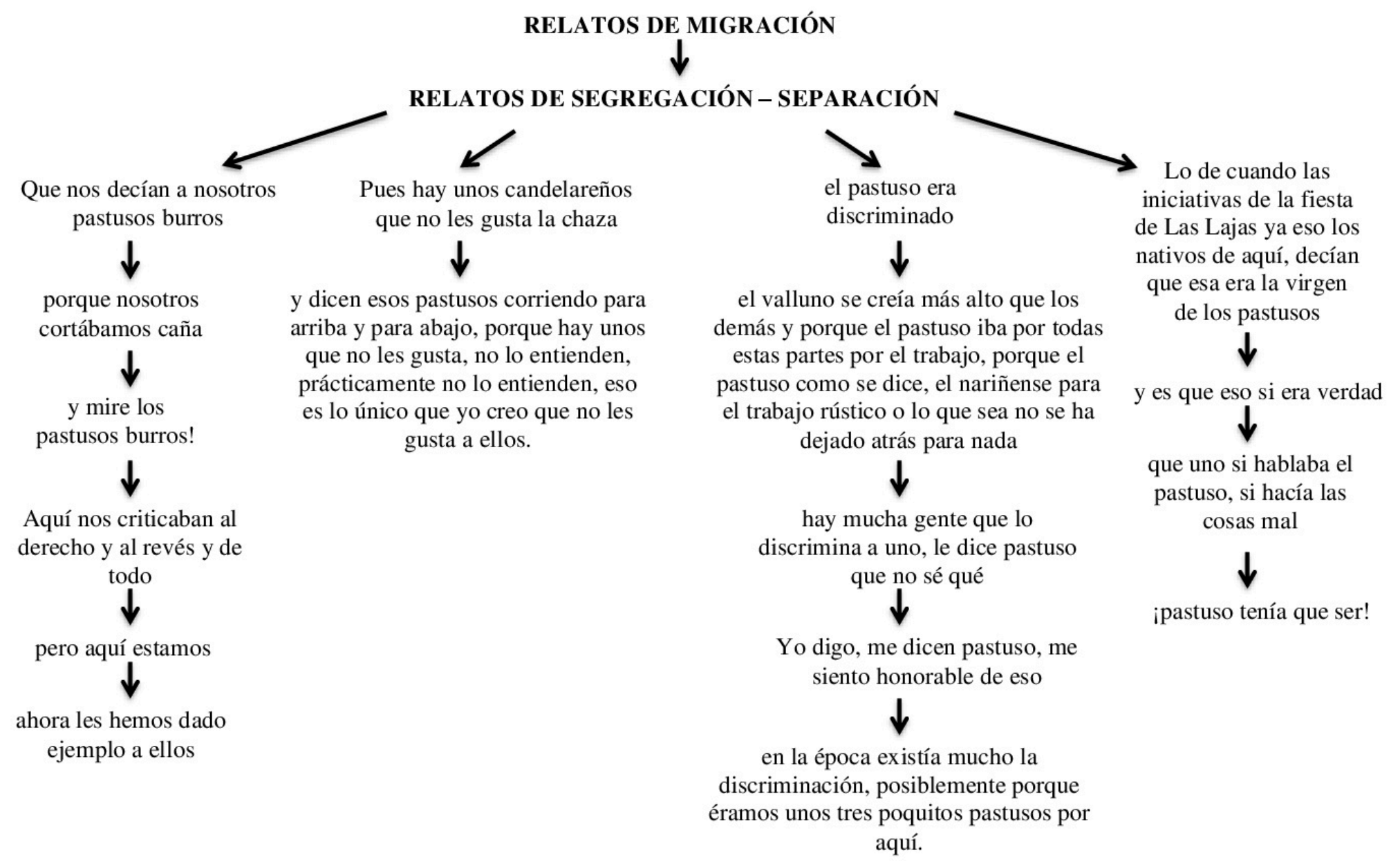




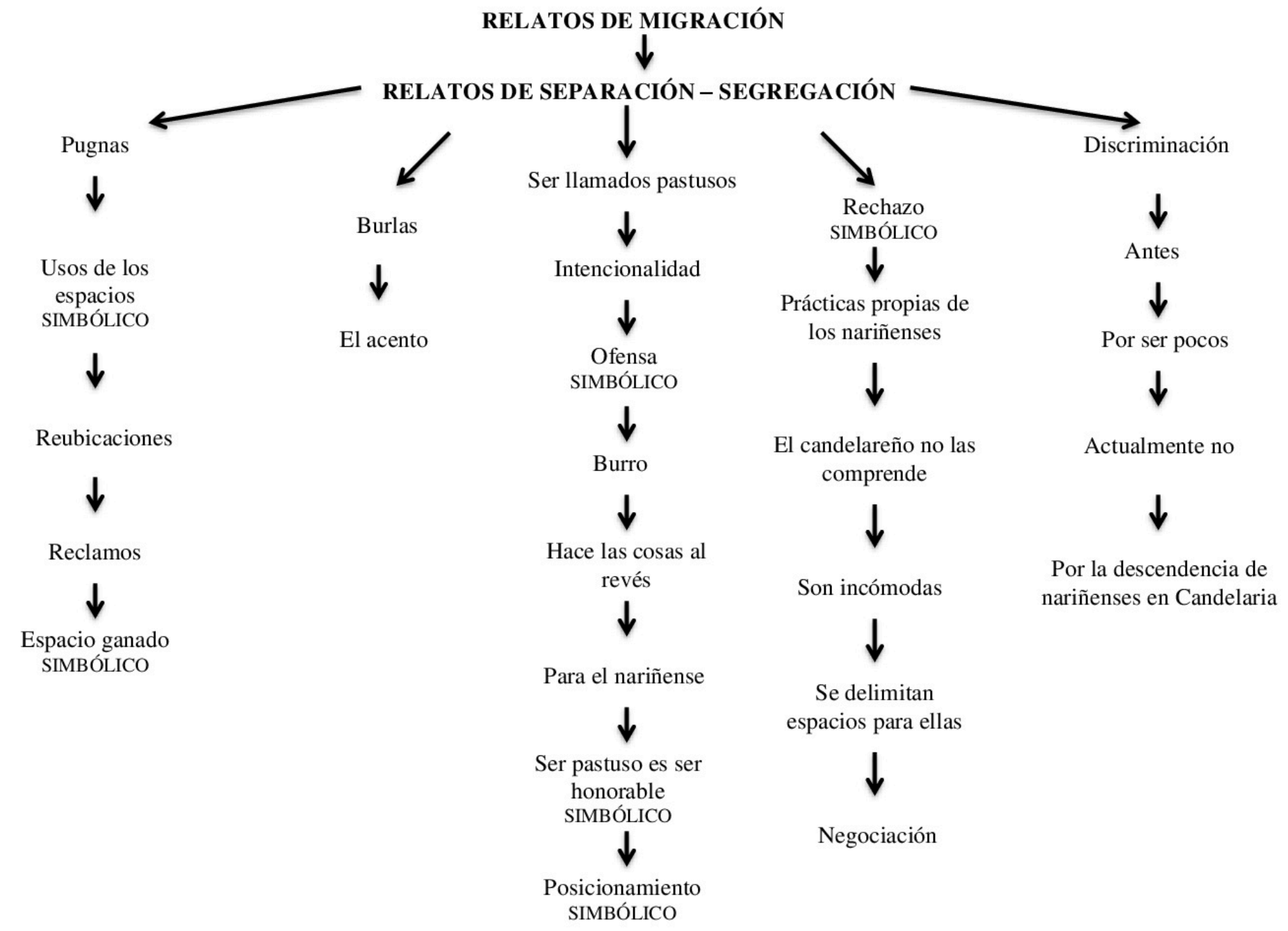


Hay situaciones de distanciamiento entre nariñenses y candelareños que conllevan a que los primeros rechacen a la sociedad receptora dando lugar a relatos de marginación; en relación con esto vale la pena observar uno de los relatos construidos por el grupo de discusión -Chaza-, en el que los nariñenses realizan una afirmación acerca del proceso de aculturación que han sufrido los candelareños al acoplarse a la cultura nariñense:

Entonces por ese sentido hoy en día con los que yo he compartido, con los que yo trato porque aquí no hay solamente candelareños, porque hay gente negra, también mucha gente que comparte con uno, con nosotros muchas veces vecinos, de todo, entonces yo miro a los candelareños que hoy en día tienen casi la misma cultura de nosotros, porque ellos se han acoplado o nos hemos acoplado todos, porque aquí estamos viviendo se puede decir tres generaciones, la generación candelareña, la generación nariñense y la negra... yo sé no podemos discriminar a nadie, nosotros somos todos iguales y por eso es que queremos que esto salga para adelante y logremos que Candelaria siga siendo la más bonita de lo que es. (entrevista personal, Grupo de Discusión Chaza, 2016)

En el relato precedente es determinante que los nariñenses declaren que los candelareños "tienen casi su misma cultura" por haberse acoplado a ella. Aunque ofrezcan decir que todos se han acoplado, utilizan en su discurso la partícula "o" como si esto fuera más una posibilidad que una realidad efectiva. Además el solo hecho de afirmar que "todos se han acoplado", ya de suyo indica que este acoplarse está dirigido a su misma cultura, más no a la candelareña o incuso a la negra que también nombran en su discurso.

Lo que esto muestra es un distanciamiento hacia lo candelareño por parte de lo nariñense, el cual puede deberse a la concepción arraigada que los sujetos migrantes tenían sobre el trabajo cuando llegaron a Candelaria; tal concepción recuerda la disposición de ejecutar labores pesadas o trabajo duro que el candelareño no estaba dispuesto a hacer, según Manuel Alberto Díaz, 
del valluno, con todo el perdón de usted, el valluno a lo único que no le gustaba era trabajar en ese tiempo, el tiempo que yo llegué aquí no les gustaba trabajar, mire que cuando yo llegué aquí había como sacarse unas 8 casas, pero el techo era de hoja de caña, y ahí vivían ellos, pero nunca les decían, vea habiendo tanta empresa para trabajar. (entrevista personal, Alberto Díaz, 2016)

Una vez más el trabajo vuelve a estar presente, no ya como lugar de encuentro y de negociaciones, sino más bien como elemento identitario -que por el ethos y la disposición que desde siempre guardaron los nariñenses hacia él-, cumple el papel de ser casi que una barrera identitaria a la hora de establecer una unidad intercultural con la sociedad receptora y de compartir un mismo modo de producción económico. Esto es así, si se tiene en cuenta que para los sujetos migrantes la producción de la vida material, desde el momento en que pertenecieron a un mundo tradicional y de sujeción a la tierra, significó el desarrollo de las capacidades físicas y también de la conciencia, que luego sirvió para que los nariñenses se dieran cuenta de las condiciones laborales bajo las cuales apenas podían suplir sus necesidades más básicas.

El asunto es que el trabajo para los nariñenses hace parte de su ethos y de su identidad cultural como forma de desarrollar el sentido de comunidad y solidaridad que acompaña sus acciones. Al respecto, cobran importancia las experiencias de vida que tuvieron los nariñenses con sus familiares, antes de tomar la decisión de migrar a Candelaria, pues recuérdese que dichas experiencias estuvieron mediadas por el trabajo pesado, que ya estaban acostumbrados a realizar mancomunadamente. Estas relaciones mancomunadas entre los familiares y los sujetos migrantes, constituyen una unidad desde la cual los nariñenses empezaron a proyectar el sentido de comunidad en sus acciones, a saber, un sentido de ayuda, apoyo y gratitud que perpetuaron desde y para su colectividad:

pues, ellos les halan con ganas al comercio, son algunos casa tenientes digamos porque hay unos que hicieron con el boom de la caña, se hicieron a varias casas y alquilan esas casas y, pero a la cosa como del compromiso cívico, comunitario ellos no son muy, no se integran, ellos son difíciles de integrarse, entre ellos sí, pero entre, para el 
resto de la comunidad no, entonces eso es lo que de pronto falta que ellos se...(entrevista personal, Camilo Muñoz, 2016).

Finalmente, el rechazo de la colectividad nariñense hacia la sociedad receptora como relato de marginación puede que se deba a la imposibilidad de establecer relaciones con sentido comunitario y de solidaridad desde la producción de la vida material; a falta de una mentalidad de empuje y de tenacidad en el trabajo por parte de los candelareños, los nariñenses deciden apartarse, más cuando por ser como "son", trabajadores y emprendedores solían ser tachados de "burros de carga" por parte de la sociedad receptora.

\subsubsection{Relatos de segregación -separación}

Los nariñenses se distanciaron de la sociedad receptora cuando escucharon comentarios de los candelareños sobre el nuevo trabajo que comenzaron a realizar en Candelaria. El corte de caña era un trabajo pesado que los candelareños no estaban acostumbrados a realizar, a diferencia de los nariñenses que por el ethos del trabajo que siempre los caracterizó, estaban dispuestos a ejecutar; fue así como se impuso una barrera identitaria entre ambos grupos culturales marcada por "el desempeño laboral", un desempeño que fue reconocido a los nariñenses por parte de los candelareños, desde relatos como los de Milena Medina, para quien es clara la diferencia entre la mano de obra valluna y la nariñense en tanto este último "tiene un gran desempeño laboral y es muy responsable", mientras que al negro caucano o de Buenaventura no le interesa el trabajo:

Tienen un gran desempeño laboral, que eso es muy importante, muy responsables, a diferencia de la mano de obra que se tiene acá, del negro caucano, del negro de Buenaventura que no le interesa, se emborrachó y no fue al trabajo, ellos no, ellos son muy responsables y empieza también otro fenómeno de esa responsabilidad, son personas muy ahorrativas. (entrevista personal, Milena Medina, 
A parir de este relato puede identificarse el reconocimiento por parte de los candelareños de uno de los rasgos identitarios más importantes de la cultura nariñense como lo es la disposición hacia el trabajo. Para la sociedad receptora, este fue el rasgo que le permitió al municipio de Candelaria progresar, en el sentido de seguir el proceso de urbanización y de industrialización del boom de la industria azucarera a través del desarrollo de la economía y del aumento del nivel de vida de los nariñenses (representado en la construcción y adquisición de viviendas modernas de hasta tres plantas).

Hasta aquí puede verse claramente que no hay tensiones respecto al reconocimiento del desempeño laboral nariñense. No obstante, las tensiones comienzan a generarse cuando el candelareño llama a los nariñenses "pastusos" y los identifica como burros de carga; la primera expresión a la que se hace referencia es problemática desde el punto de vista de los nariñenses porque los candelareños la utilizaban como señalamiento a un grupo cultural que "hacía las cosas al revés". A este propósito, cabe recordar el relato en el que uno de los candelareños describe que en forma de chiste identificaban a los "pastusos" con gente que "hacía las cosas al revés o algo así": "en algún momento como por chiste se decía, ah este parece pastuso, este parece pastuso, está haciendo las cosas como no son, al revés o algo así".

Lo que más molestaba a los nariñenses en situaciones como esta era que los candelareños los identificaran a todos como "pastusos", como si toda la colectividad nariñense fuera procedente de la capital del departamento de Nariño -Pasto-; este sin duda fue un rasgo identitario y una estrategia de identificación que manifestaron los sujetos migrantes en la forma de defender ante la sociedad receptora el territorio de origen al cual pertenecían, una manera de mostrarles a los de allá que Nariño es un departamento que se compone de más de sesenta municipios, algunos de los cuales fueron el lugar de nacimiento de muchos de ellos:

(...) aquí cada uno, somos de un municipio de Nariño, si nos dicen pastusos es lo mismo si nos dicen nariñenses, para nosotros es lo mismo, porque como nadie conoce los municipios del departamento de Nariño por lo menos aquí, pero a nosotros no nos gusta eso. Empecemos a grabar, yo soy José Ruiz y soy de Soto 
Mayor Nariño. Mi nombre es Ricardo Ismael Sánchez de Funes Nariño. Mi nombre es José Bernardo Rivera y vengo de Guachavés, Nariño. Como ya lo había dicho antes cierto, soy de Linares Nariño y yo soy de Buesaco Nariño. (entrevista, Grupo de Discusión comunidad nariñense, 2016)

Cuando los nariñenses son tildados de "pastusos", responden apelando a la ignorancia de sus interlocutores; en este sentido, vemos como empieza a surgir un distanciamiento de los sujetos migrantes hacia la sociedad receptora originado en uno de los relatos de segregación que sitúa a los nariñenses como "pastusos" y además como "burros de carga": "nos decían a nosotros, pastusos, burros porque nosotros, cortando caña, iy mire los pastusos burros!”. En síntesis, los candelareños como población que tuvo la función de recibir a los de allá, un grupo cultural evidentemente lejano de sus prácticas y costumbres, impusieron al inicio del proceso migratorio un distanciamiento con los nariñenses que llevó a una ausencia de relación entre ambas culturas. Sin embargo, esta ausencia de relación se fue expandiendo cuando los nariñenses continuaron imponiendo el distanciamiento con la sociedad receptora como vía para situarse hegemónicamente dentro de ella, es decir, como mecanismo para mostrarle a los candelareños sus tradiciones, valores y ritos inculcados desde los distintos municipios que fueron cuna de casi el $90 \%$ de la población nariñense, que hacia la segunda mitad del siglo XX, tomó la determinación de migrar al municipio de Candelaria, Valle del Cauca.

El municipio de Candelaria antes de la migración tenía una estructura arquitectónica premoderna, por lo que se refiere a las casas con techo de hoja de caña, que bien le servía de vivienda a los candelareños antes del proceso migratorio; sin embargo, los nuevos ideales que condujeron a los nariñenses a desear otras condiciones de existencia, de igual forma los llevaron a rechazar este modo de vida de los candelareños, tanto que nariñenses como José Montilla comenzaron a tejer las redes de solidaridad a las que estaban acostumbrados en su lugar de origen, con el fin de construir su propia vivienda con ladrillo y concreto:

...para eso comenzando con mi persona, que ya era un poquito más conocido por todos los nariñenses, entonces nos íbamos juntando, la solidaridad un ejemplo, 
cuando yo hice mi casa, pero que la casa que hice, la hice ya de ladrillo con concreto y todo eso, porque la que compré ya era un ramada digámoslo así, entonces ahí yo me alisté con las gallinas, la bebida y toda la comida, porque en Nariño se hace minga entonces uno se prepara en la comida y en la bebida, y yo les dije a los compañeros un día por decir algo, compañeros para el sábado voy a tener la fundición de la plancha de la casa donde yo vivo, los que me van a ayudar a fundir la plancha, entonces para yo aprestarme, y dijeron todos. (entrevista personal, José Montilla, 2016)

En el relato se evidencia que el sentido de solidaridad de las acciones de los nariñenses no solo está aunado al trabajo sino también a la construcción de la vivienda; las redes de solidaridad que alguna vez establecieron en el trabajo mancomunado de la agricultura, se vieron proyectadas en la sociedad receptora como una de las estrategias de identificación que les permitió conservar sus prácticas y costumbres en medio del proceso migratorio que, entre otras cosas acarrea pérdidas Jaes (2002), frente a la separación física y simbólica del territorio.

En este punto, es importante resaltar que la disposición hacia el trabajo y el sentido de solidaridad que define las relaciones sociales entre nariñenses, tanto en el trabajo como en la vida cotidiana, son los rasgos identitarios que ocasionan entre nariñenses y candelareños la decisión, por parte de los primeros, de poner distancia con los segundos. Esta decisión puede ser el resultado de una mentalidad que se relaciona estrechamente con un modo de "ser" nariñense que al confrontarse con otro -como el candelareño-, distante de los ideales de progreso y de la búsqueda de una vida más dinámica y afín con el confort y las comodidades, tiende a separarse de aquello que tal vez le hace recordar a los nariñenses las condiciones sociales y económicas que con tanto esfuerzo han superado al tomar la determinación de migrar y habitar en lo desconocido.

Dicho en otras palabras, existe entre los nariñenses y los candelareños un relato de separación que se origina en la oposición de ideales y de proyecciones sociales cada una de las cuales busca el desarrollo de su colectividad por vías distintas: los nariñenses por medio de la realización de un trabajo pesado, del ahorro y de la adquisición de viviendas 
con estructuras más modernas capaces de ofrecer mayores comodidades. Mientras los candelareños, más allá de buscar progreso en el cambio de sus condiciones de existencia, se conformaron con ellas, incluso en el momento en que los nariñenses comenzaron a mostrarles que podían ser distintas.

Asimismo, el relato de separación al cual se está aludiendo tiene que ver con el sentido de comunidad y de solidaridad que desde sus ideales y proyecciones sociales reivindican tanto nariñenses como candelareños; la conformación con una realidad que entró en una etapa de asenso económico, pero a la que no estaban listos para enfrentar los candelareños, por la ausencia de una mentalidad de empuje en el trabajo, y en general, por no disponer de ideales que los impulsaran a querer obtener ascenso económico, fue uno de los factores, sino el más importante que interpuso una frontera identitaria entre ambos grupos culturales. Esta frontera se hizo aun más evidente cuando candelareñas como Milena Medina comenzaron a notar que los nariñenses eran personas "muy metidas en sus círculos” y solidarias únicamente con sus paisanos,

si me preocupa algo de ellos, muy metidos en sus círculos entonces no son personas que no le generen mucho desarrollo a su comunidad porque son, por que sean solidarios, son solidarios con ellos, eso es lo que yo he podido percibir de ellos, solidarios con ellos, entonces esta la colonia nariñense y es la colonia nariñense entonces la chaza es allí y es de ellos y ese es, si me entiendes?...los veo como un poquito amarrados. (entrevista personal, Milena Medina, 2016)

Pero ¿por qué esperar que dos grupos culturales con metas e ideales distintos, reivindiquen un mismo sentido de comunidad y de solidaridad en sus acciones? El sentido de comunidad y de solidaridad de los nariñenses está orientado a prácticas y costumbres que se ven reflejadas en la ayuda que reciben de sus paisanos o parientes más próximos cuando requieren conseguir un empleo, un lugar donde vivir o mano de obra gratuita para construir su casa en minga (es decir, en comunidad, mientras los nariñenses trabajan en la construcción de las viviendas, comparten la comida y la bebida que les 
preparan sus esposas como forma de alentarlos en esta ardua labor en la que no se utiliza el trompo ${ }^{22}$ ).

Por el contrario, en los relatos de Camilo Muñoz y de Milena Medina en los cuales cada uno describe respectivamente a los nariñenses como personas que "no se meten en la cosa cívica" y además "muy metidos en sus círculos", puede entreverse que el sentido de comunidad y de solidaridad de los candelareños está orientado al bienestar del municipio, entendiendo por ello la defensa de las tradiciones, fiestas y ritos de Candelaria frente a las nuevas prácticas y costumbres que vienen a reproducir los nariñenses en la sociedad receptora. Razón por la que puede concluirse que el sentido de comunidad que los candelareños y los nariñenses reivindican, adquiere fuerza si se observa dentro del contexto que involucra el bienestar de cada grupo, esto es, la defensa y la conservación de la identidad cultural frente a una colectividad, ya sea la nariñense o la candelareña, que con su presencia y la reproducción de sus prácticas, puede llegar a representar la pérdida de los rasgos identitarios que los definen a cada uno desde la idea de "gente pura y original".

En este orden de ideas, cada grupo cultural reivindica un sentido de comunidad y de solidaridad de acuerdo a sus imaginarios y rasgos identitarios; la reivindicación de este sentido, por lo menos en lo que concierne a los nariñenses, se logra mediante la aplicación de diversas estrategias de identificación cultural que cumplen la función de generar continuidad con el pasado nariñense dentro de la sociedad receptora. En lo que respecta a los candelareños, estos de igual manera irán desarrollando códigos de comunicación para posicionarse en Candelaria con sus tradiciones culturales, dando lugar a una situación de interlocución entre las distintas identidades culturales.

\footnotetext{
${ }^{22}$ Los nariñenses denominan trompo a las máquinas que permiten mezclar el concreto y cuyo mecanismo funciona con motores que trabajan con gasolina o con electricidad. El uso de esta máquina si bien agiliza el proceso de construcción, era costoso para los nariñenses por cuanto debían rentarlo por horas para su utilización. Por esta razón acudían a la minga, actividad en la que se agrupaban varios nariñenses a trabajar en la construcción de la casa de uno de ellos, mientras las esposas cocinaban y preparaban las bebidas para los trabajadores voluntarios. La comida y las bebidas corrían por cuenta del dueño de la casa en construcción como contraprestación al apoyo brindado por los demás nariñenses.
} 
9.2. Relatos de identidad cultural nariñense en Candelaria. Motivaciones de las estrategias de identificación cultural nariñense en Candelaria como posibilidad de establecer tensiones con candelareños

9.2.1. Orígenes nariñenses. La construcción de la identidad como expansión de las pretensiones personales de los migrantes en Candelaria 


\section{RELATOS DE IDENTIDAD CULTURAL}

$\downarrow$

ORÍGENES NARIÑENSES

$\downarrow$

Nariñense asentado en Candelaria

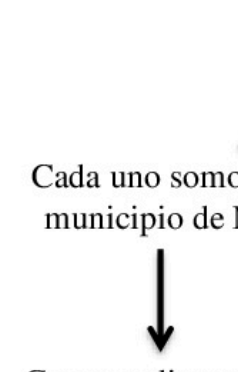

Como nadie conoce

los municipios del departamento de Nariño

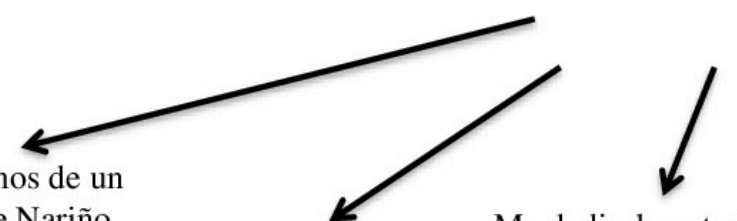

Ya dicen muchos Me dedicaba a trabajar de usted, es pastuso

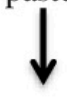

yo no soy pastuso,

eso sí lo estoy,

porque el que es pastuso es el que es

de Pasto.

Propiamente, nacido en Pasto.

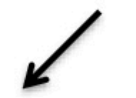

mientras que nosotros somos de Nariño, yo soy nacido en

Santa Cruz, Nariño. la tierra, uno, hay que

hablar la verdad, yo no

tuve escuela, eso como

lo normal casi fue en la parte del campo

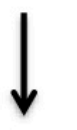

Yo lo que quería era trabajar y ayudarle a

$$
\text { mi papá }
$$

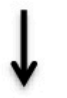

Allá le enseñan mucho de todo, la agricultura, los oficios de casa, eso es normal.

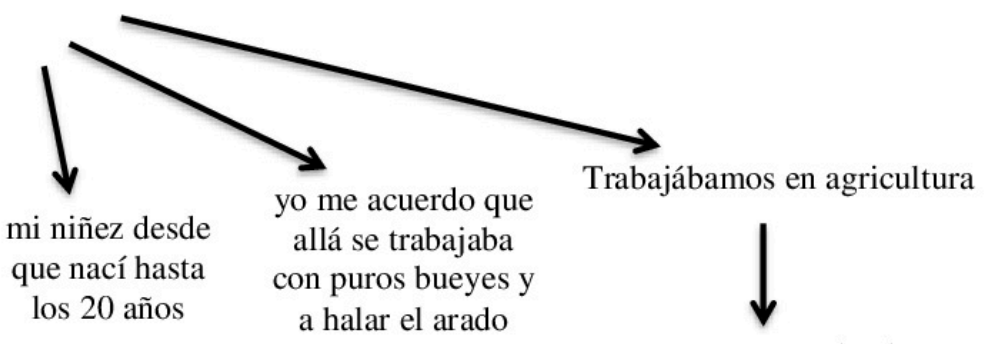

yo estuve ayudando a mi casa a mi papá, porque ellos

eso fue en la agricultura con $\mathrm{mi}$ padre y un hermano $\downarrow$

nos manteníamos de la agricultura, tierra fría donde yo me crié donde sembramos papá, trigo, cebada, yuca, con todo esas cosas de tierra fría. sembraban bastante<smiles>[14CH3]</smiles>

yo miraba así cualquier lotecito por ahí y sembraba yo ahí<smiles>[Te]</smiles>

de eso yo me mantenía ¡para qué! nos daba.

Pero no más era

ayudándole a él 


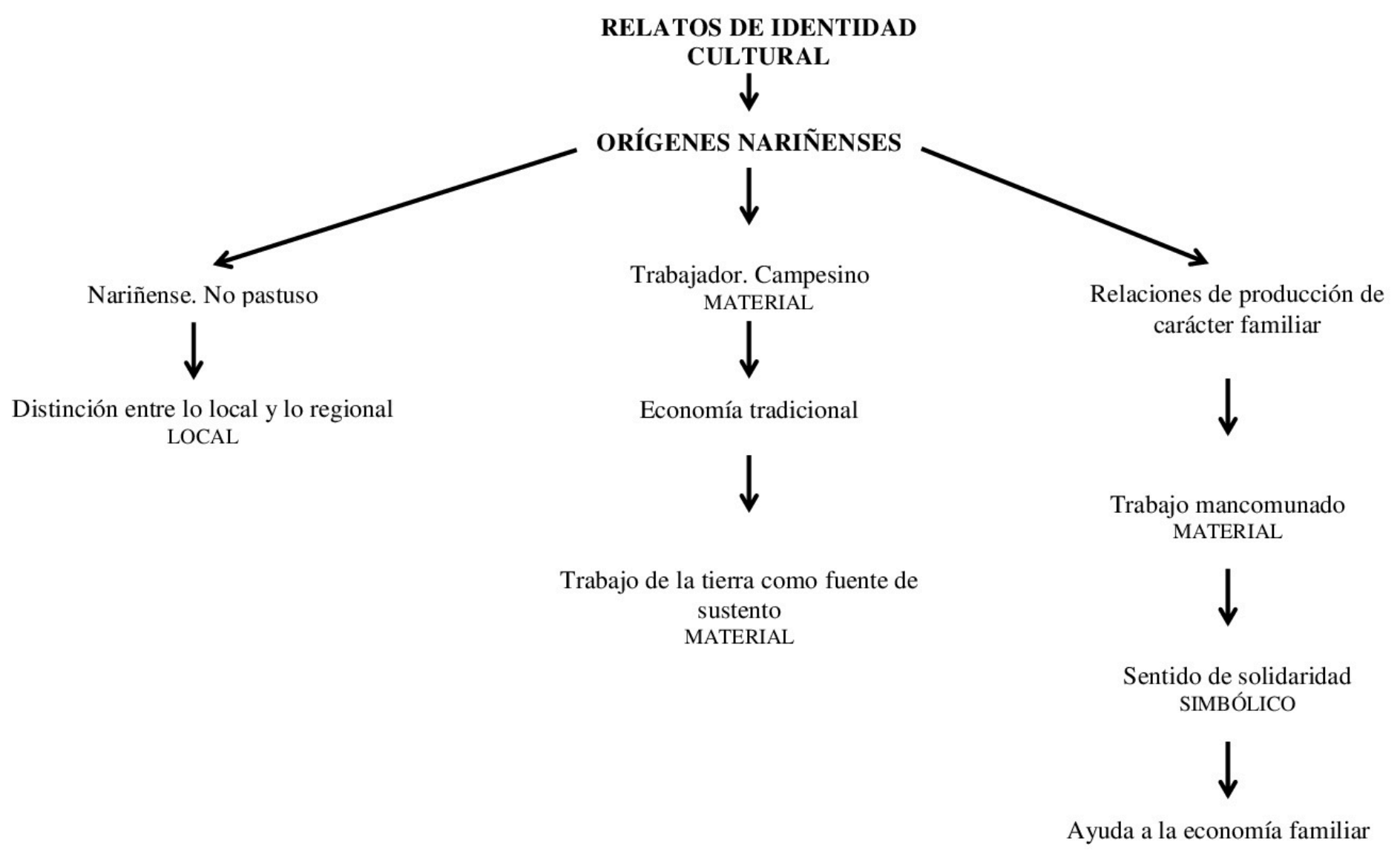


Como se ha mencionado, la migración nariñense tiene orígenes en varios municipios del departamento de Nariño, que abarcan gran parte de la geografía andina del departamento, pueblos cercanos a Pasto (la capital) como Consacá, Funes, Túquerres y Santa Cruz o cercanos a la frontera con el Ecuador como Ipiales y Cumbal. Estos municipios se han caracterizado especialmente por estar compuestos por población de origen rural, dedicada a la agricultura, de ahí que muchos de los migrantes durante su niñez y adolescencia se dedicaran a las actividades del campo como parte de una dinámica de economía campesina, donde sus familias eran propietarias de pequeñas extensiones de tierra, siendo frecuente que tanto hombres como mujeres se dedicaran a las labores del campo o del hogar; de ahí que la gran mayoría de esta población se caracterice por haber migrado con un bajo nivel educativo, haciendo de su migración una migración no cualificada, aunque de gran calidad laboral. Frente a esto José Montilla señala:

Entonces en esa época cuando trabajaba con ella y éramos donde el patrón, a veces nos colocaban a nosotros en una parte y a las mujeres en otra, para limpiar trigo, que se daba allá en Nariño, a quitarle la maleza. (entrevista personal, José Montilla, 2016)

Es importante rescatar que los pioneros de la migración del departamento de Nariño a Candelaria fueron, en su mayoría, hombres nacidos en la década de 1940, que llegaron a instalarse en el municipio vallecaucano, algunos de ellos con sus esposas y familias y otros solos. Es decir, que hubo también una migración de núcleos familiares que contaban con el soporte de familias extensas o redes de vecinos y paisanos, lo cual entre otras cosas, permitió y facilitó el mantenimiento de la cultura y sus distintas prácticas.

En el marco de este contexto, puede afirmarse que la relación que los nariñenses establecen con su origen territorial y cultural, remite a las prácticas, costumbres, festividades y celebraciones más tradicionales del departamento; reconociendo nuevamente uno de los elementos más característicos de Nariño, la economía tradicional, 
sobre la cual se construyen relaciones de producción basadas en el trabajo agrícola, en el cultivo de la tierra y en la producción ganadera.

Hacia los años 60's, tiempo de auge del proceso migratorio, los nariñenses empleaban el arado y la siembra para cubrir sus necesidades; este es el caso de Gabriel Pascuasa, quien al rememorar su niñez, relata el tipo de trabajo que solía desempeñar su padre, cuya labor asistía convirtiéndose en uno de los momentos más significativos de esta etapa temprana de vida,

pero yo me acuerdo que allá se trabajaba con puros bueyes y a halar el arado, yo de grandote que era en esas laderas pues, en terreno fangoso, metía para poder no dejarme arrastrar de los bueyes, metía al hombro y mi papá atrás con un juete, cuando medio me soltaba o me caía, ahí me levantaba a juete. (entrevista personal, Gabriel Psacuasa, 2016)

Las experiencias de vida que refieren los nariñenses con sus familiares, antes de tomar la decisión de migrar a Candelaria, están mediadas por el trabajo pesado que estaban acostumbrados a llevar a cabo; por eso es que la actividad económica y las relaciones familiares constituyen una unidad en la que ambas se determinan e influyen mutuamente, en el sentido en que los padres y abuelos de los sujetos migrantes fueron quienes los impulsaron cuando eran niños a trabajar la tierra, no solo por el auge de la producción agrícola en el departamento de Nariño, sino también por las relaciones sociales y de producción que emergen de este modelo económico tradicional, las cuales caracterizan y destacan al nariñense donde quiera que vaya.

En este sentido, cuando Gabriel Pascuasa se refiere al momento en que practicaba el arado y al esfuerzo que tenía que hacer para no dejarse arrastrar por los bueyes, menciona a su padre por cumplir el papel importante de alentarlo en una labor que exige destreza y una mayor inversión de fuerza de trabajo. Si bien es cierto que las condiciones económicas y políticas de Nariño, no permitían tener otro tipo de economía más desarrollada, debido al aislamiento geográfico y a la ausencia de dinero circulante para ser acumulado y expandido en el comercio por toda la región, también es cierto que el 
trabajo de la tierra -que sustenta, justamente, la economía tradicional- da lugar al establecimiento de relaciones sociales vinculantes, de solidaridad, de apoyo y de comunidad. Estas relaciones que configura el nariñense en su lugar de origen y en la práctica de una actividad económica, que es la que le permite subsistir en su territorio, luego van a ser fundamentales como estrategias de identificación en la sociedad receptora; a este propósito, Pedro Castro se refiere a la ayuda que le prestaba a su padre en la siembra, pues más que una actividad realizada sobre la base del deber, era un apoyo ofrecido por un sentir propio de solidaridad,

trabajábamos en agricultura pero pues casi un poquito yo estuve ayudando a mi casa a mi papá, porque ellos sembraban bastante, yo miraba así cualquier lotecito por ahí y sembraba yo ahí, de eso yo me mantenía para que nos daba, pero no más era ayudándole a él, porque él tenía que trabajar y nosotros teníamos trabajadores y todo. (entrevista personal, Pedro Castro, 2016)

En este relato pueden resaltarse dos elementos importantes concernientes al modo de vida nariñense; el primero es el trabajo de la tierra como fuente de sustento económico antes de tomar la decisión de migrar a Candelaria. El segundo tiene que ver con las relaciones sociales que se tejen en torno al trabajo de la agricultura, relaciones que a su vez dan cuenta de un sentido de comunidad y de solidaridad que orienta las acciones de los nariñenses, después de que interiorizan la acción de "ayudar" como un hecho importante y como el resultado de una decisión que se toma conscientemente.

Cuando Pedro Castro afirma en su relato que su familia se dedicaba a la agricultura y que tenía trabajadores que apoyaban esta labor, es relevante que a pesar de que su padre contara con mano de obra adicional, se ocupara en ayudarle y en encontrar cualquier lotecito para poder sembrar. Esto es lo que comienza a definir la identidad del nariñense y el sentido de solidaridad que le otorga a sus prácticas y a sus acciones, en virtud de la naturaleza propia de la actividad económica -que por lo general requiere de trabajo mancomunado- y de las relaciones de producción (de carácter familiar) que constituyen una unidad determinante frente al desarrollo de la fuerza de trabajo de los nariñenses. Dicha aptitud, aunada a las condiciones económicas precapitalistas del 
departamento de Nariño, de igual forma constituyen el germen de una decisión que acarrea la migración a una región que le ofrecía al nariñense mejores posibilidades de ascenso económico sobre la base de un oficio pesado como el corte de caña.

\subsubsection{Idea de gente pura y original}




\section{RELATOS DE IDENTIDAD CULTURAL} $\downarrow$

IDEA DE GENTE PURA Y ORIGINAI

$\downarrow$

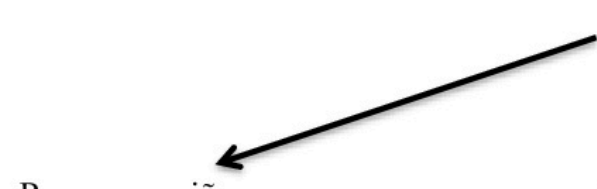

Pues soy nariñense como digo de cepa pero vivo aquí hace 40 años

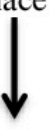

como le digo, ni el dialecto nos ha cambiado

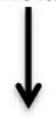

Los años que estemos no sentimos de nuestra tierra, la tierra que nacimos

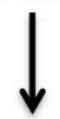

no se puede negar nada de ella, porque si está negando la tierra está negando a la madre
La gente nariñense somos de una cultura yo

digo que, en parte

cultural, un amor muy grande por lo cultural

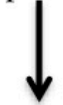

la gente de Nariño, es gente noble, poco

conflictiva y muy

dedicada a querer

hacer las cosas bien

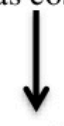

a querer que el entorno

donde se vive este mejor

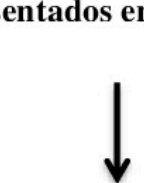

La gente nariñenses nos caracterizamos por ser muy poco

explosivos, muy

poco controvertidos

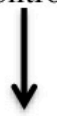

sobretodo es la forma de compartir entre el grupo de nariñenses

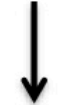

los nariñenses tenemos la capacidad de unirnos para buscar una expresión cultural

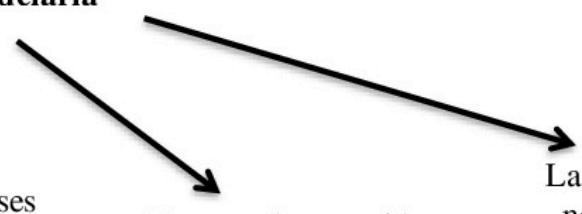

Nosotros hemos sido muy fuertes, para el trabajo del campo, para el trabajo

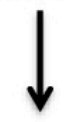

entonces eso nos ha dado una acogida muy bien para todas las partes
La base fundamental que nosotros tenemos es el carisma de ser respetuosos, honrados, cariñosos, eso es la cultura y lo que nosotros tenemos donde sea

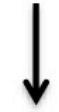

por eso donde nosotros a cualesquier municipio o

departamento donde nosotros lleguemos, siempre somos apetecidos

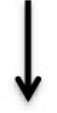

Porque somos una para el trabajo, es para lo que nos toque, el todo es que nos digan -vea esto hay que hacerlo-, y nosotros lo hacemos, eso lo tenemos, lo más fundamental 


\section{RELATOS DE IDENTIDAD CULTURAL \\ $\downarrow$}

IDEA DE GENTE PURA Y ORIGINAI

$\downarrow$

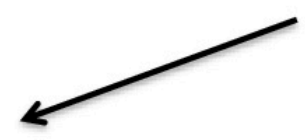

Nariñenses asentados en Candelaria

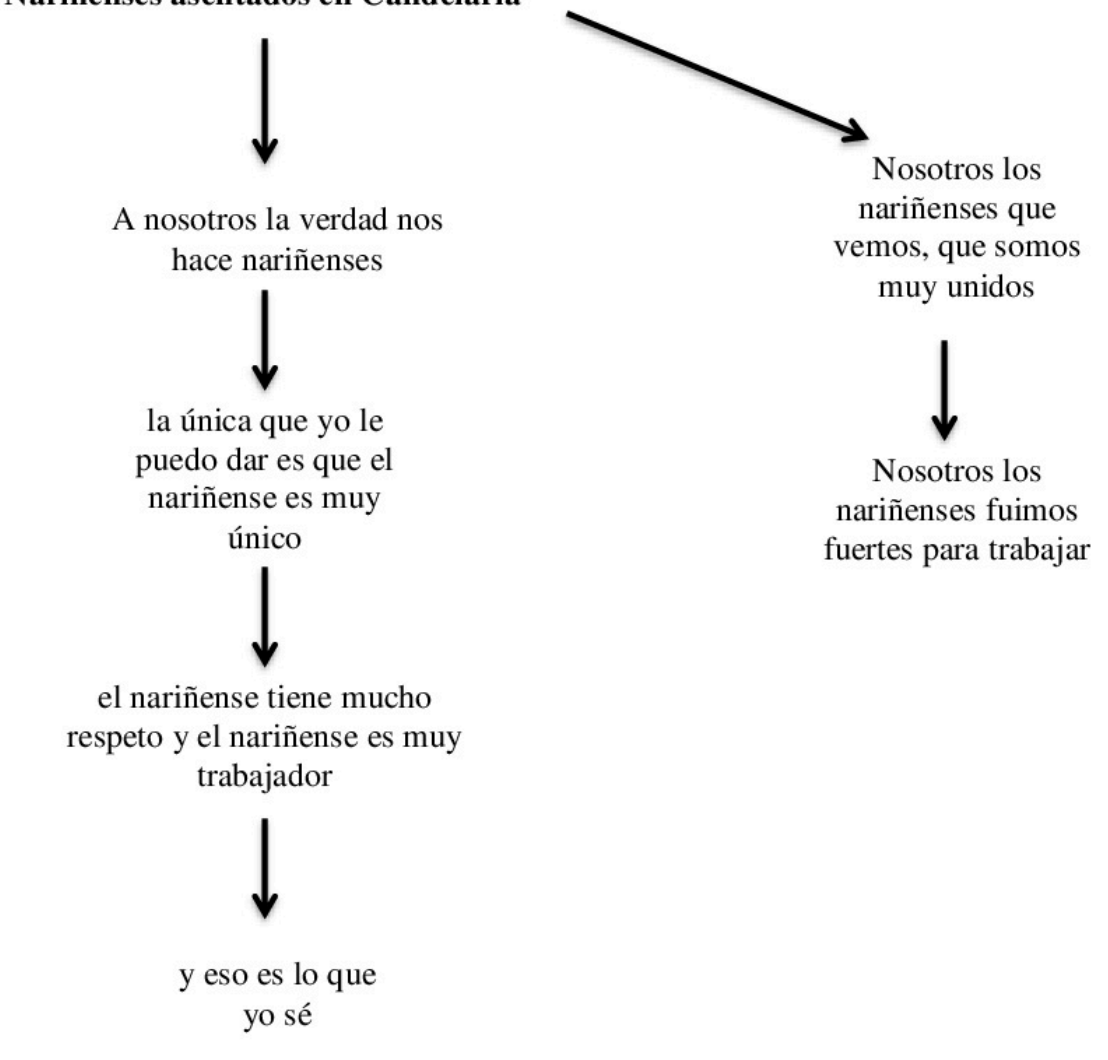

El nariñense por lo general se ha caracterizado por se

respetuoso más que todo $\downarrow$

a lo que le toque ir<smiles>[CH][AlH]</smiles>

nosotros los nariñenses

nos cuidamos uno del

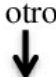

somos todos muy colaboradores en lo que<smiles>[AlH2][AlH2]</smiles>

somos muy unidos todos

$$
\downarrow
$$

Para cualquier evento es muy organizada la colonia nariñense, para las fiestas de las vírgenes, para las juntas, para todo es muy organizada. 


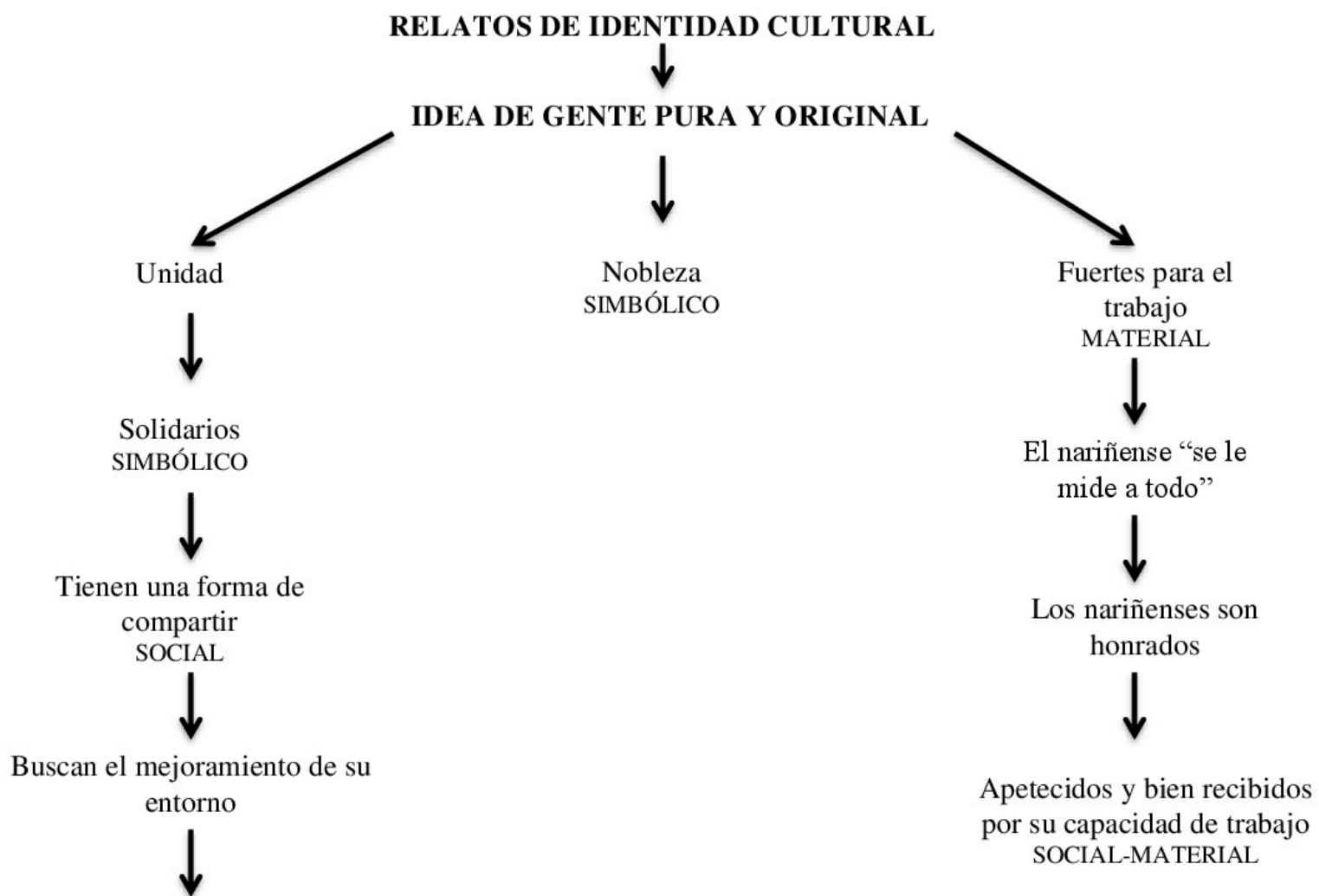

Capacidad organizativa 
Todo proceso migratorio influye en las condiciones materiales de existencia y en los modos de vida que los sujetos migrantes optan por cambiar pensando en la posibilidad de obtener un ascenso económico en la escala de estratificación social. Fue así como los nariñenses optaron por cambiar un modo de vida basado en la economía tradicional por otro más moderno basado en el corte de caña que por aquel entonces les ofrecía la industria azucarera; y se afirma que esta nueva labor fue más moderna no por ser llevada a cabo exclusivamente mediante el manejo de maquinaria e industria pesada -pues el corte de caña por lo general se hacía manualmente con el uso del machete-, sino porque fue una actividad que le brindó a los nariñenses condiciones de seguridad y bienestar laboral estables de las que no había podido ser partícipe por estar inmersos en un mundo premoderno y de relaciones de sujeción a la tierra.

Las condiciones materiales de existencia cambiaron para los nariñenses, en tanto comenzaron a desempeñar una labor que exigía mayor destreza y habilidad manual que las requeridas por la agricultura, y en cuanto su salario como jornaleros les permitió pensar en tener una familia y una casa donde vivir cómodamente a medida que su situación económica iba mejorando. A este respecto, Camilo Muñoz -uno de los candelareños que conoce aspectos esenciales del proceso migratorio de Nariño al Valle del Cauca- relata cómo los nariñenses iniciaron dicho proceso, algunas veces bajo situación de hacinamiento en casas o piezas que les arrendaban paisanos que habían viajado antes que ellos al Valle, o familiares y parientes más cercanos que les brindaban un lugar donde quedarse hasta que podían conseguir por sus propios medios una casa donde vivir con su núcleo familiar,

...ellos llegaban a las casas de los amigos y familiares y se iban hacinando mientras tanto en una casa, y de ahí salían y como en ese tiempo diga usted, yo me acuerdo que se ganaba un cortero de caña $\$ 350.000$ semanales, que eso era un poconón de plata, ellos se fueron haciendo rápido a sus propiedades y ellos recibían a los otros, y a los otros y los tenían allí y luego se iban yendo e iban haciendo ellos mismos ¿no?, eran sus propios como se dice. (entrevista personal, Camilo Muñoz, 2016) 
Frente a las relaciones de orden social y económico que los nariñenses entablaron en la sociedad receptora, es importante hacer mención del proceso de adaptación a las nuevas labores en uno de los ingenios azucareros que más demandó mano de obra barata y dispuesta al trabajo pesado como lo fue Mayagüez; este ingenio es importante porque fue el lugar donde le fue posible a los nariñenses "tener" o encontrar otra forma de producir su vida material, de una manera mucho más rentable y acorde con el aumento del nivel de vida que se obtiene después de que las necesidades se multiplican junto con los medios para satisfacerlas. En la medida en que las necesidades se multiplican, la producción para satisfacerlas se extiende, creándose distintas industrias que le abren paso al mercado y a la acumulación originaria del capital que consiste fundamentalmente en la transformación del campesino en obrero y en la implantación del trabajo asalariado como única fuente de ingresos.

Cuando los nariñenses decidieron migrar a Candelaria por razones históricas y socio- económicas para trabajar en el corte de caña, se efectuó un cambio tanto en la naturaleza de la labor que ejercían en su lugar de origen como en la retribución económica a la que estaban acostumbrados, y al final, esto condujo a que los sujetos migrantes se convirtieran en asalariados de la industria azucarera que podían gozar de los beneficios y seguridades laborales que trae consigo la modernización, tales como la estabilidad laboral, el alza de los salarios y hasta la enseñanza e instrucción de los obreros; Alberto Díaz fue uno de los nariñenses a quien le atrajo de Candelaria, no solo el monto del nuevo salario que iba a recibir por cortar caña, sino los días trabajados por los que merecía recibir el sueldo y las subvenciones sociales representadas en subsidios, primas y cesantías.

Pero bueno me fui a trabajar, y aquí le pagaban a los 8 días y yo me pagaron a los ocho días porque yo entré viernes, jueves y sábado y me pagaron esos tres días y era buena plata porque me había ganado $\$ 40$ en ese tiempo, eso era mucha plata para mí y eso fue lo que a mí me atrajo propiamente del trabajo y me puso. Y esto es una empresa le dije al hermano, le pregunté “¿qué es lo que le pagan tanto a uno?" y esto y esto aquí le pagan bien, le dije me pagan bien, propiamente a ti te pagan hasta por tus hijos, el subsidio, te van a pagar primas, prima de navidad, te 
van a pagar intereses y te van a pagar cesantías, pero le dije ¿Todo eso? Pues bueno pero yo me quedé así, yo me quedé trabajando y le digo pues que yo me desesperaba trabajando, porque yo me rendía el trabajo, cuando a la otra semana yo dije pues, yo no sé qué es lo que tengo por aquí, y me senté el día viernes ya aquí cuando llegué, le dije donde arrendaba que allá le daban unos papeles ahí diciendo todo el peso de la caña y todo eso, me puede sacar cuenta, yo tenía 70 toneladas, y aquí con 70 toneladas ¿cuánto es lo que me van a pagar?, cuando voy viendo allá, disque $\$ 100$ y eso era como ganarse 10 millones de pesos en ese tiempo. (entrevista personal, Alberto Díaz, 2016)

Ahora bien, el aumento del nivel de vida de los nariñenses al migrar a Candelaria, bien puede comprenderse como un momento necesario para la superación de un tipo de existencia anclado en la tradición y en las relaciones de sujeción a la tierra. Dentro del proceso migratorio, la superación de un modo de vida como este es importante para los nariñenses porque de esta forma pueden objetivar los ideales y pretensiones personales que forjaron en Nariño gracias al nivel de conciencia alcanzado en medio de la realización de una labor que exige destreza y habilidad manual; el ethos del trabajo del nariñense constituido, justamente, por el saber técnico y racional que lo lleva a adquirir una disposición para realizar trabajos manuales pesados y a poner en práctica cierto tipo de saber racional que influye en la forma de actuar acorde con el ahorro, el cálculo y la previsión, es el fundamento del sentido que orienta las acciones sociales de los nariñenses cuando deciden migrar a Candelaria para mejorar su calidad de vida.

En este orden de cosas, puede decirse que la identidad cultural del nariñense se conservó en la sociedad receptora a pesar de los cambios sufridos por la producción de nuevas relaciones económicas cimentadas en la industria. Esto porque hubo una superación necesaria en cuanto a la satisfacción óptima de necesidades se refiere, pero al mismo tiempo, una conservación de los elementos más esenciales que definen la identidad de los sujetos migrantes y su modo de ser nariñense expresado en prácticas, costumbres, ritos y tradiciones que al seguir presentes en otro territorio, demostraron que el fenómeno migratorio de Nariño al Valle del Cauca, influyó de manera crucial en el “tener" más no en el "ser". 
A este propósito, Erich Fromm puede resultar esclarecedor para el análisis y la definición de estos dos conceptos -tener y ser- que transversalizan parte de esta investigación, "La diferencia entre ser y tener está entre una sociedad interesada principalmente en las personas, y otra interesada en las cosas (...) tener y ser son dos modos fundamentales de la experiencia, las fuerzas que determinan la diferencia entre los caracteres de los individuos y los diversos tipos de caracteres sociales" (Fromm, 1976, pp. 34, 36).

"El ser" de los nariñenses es su identidad comprendida desde el punto de vista del carácter individual y social que los define como "gente pura y original", es la historia que marca su trayectoria como colectividad tanto dentro como fuera del territorio, la narrativa del sí mismo y del discurso propio... en últimas, los rasgos que definen su fisonomía cultural y que reproducen dentro de la sociedad receptora para recuperar lo conocido en medio del cambio.

\subsubsection{Cómo somos los nariñenses}

"Ser" significa tener identidad, el hecho de formarse como sujetos a partir de prácticas, costumbres, ideales y ritos que se construyen individual y socialmente para manifestar y afirmar la esencia de quien es, y por qué no, de quienes como los nariñenses "son tanto los de allá como los de acá"; gente pura y original que debido al proceso migratorio media entre el lugar de origen y la sociedad receptora, con el fin de tejer puentes de presencia física y psicológica en los nuevos espacios que se vuelven más cercanos y más familiares cuando los rasgos que definen la fisonomía cultural nariñense se hacen conscientes para ser reproducidos.

Las pretensiones personales de los nariñenses acerca de la posibilidad de mejorar sus condiciones de existencia material, hacen parte de la mentalidad de empuje que constituye uno de los rasgos de su fisonomía cultural. Pero hay otros rasgos que a través de los relatos de identidad cultural identifican y construyen los nariñenses como parte del discurso propio que sirve de canal de comunicación para contar lo nariñense. 
Acercarse a lo nariñense implica conocer el "ser" propio de una colectividad que se ha esforzado por conservar su identidad dentro de la sociedad receptora. Esta identidad se ha convertido para los nariñenses en un hecho importante de su conciencia, si se tiene en cuenta que han desarrollado la capacidad de verse y reconocerse a sí mismos desde sus prácticas, costumbres, tradiciones y ritos, aun desde un espacio distinto a su lugar de origen. De acuerdo con esto, Manuel Alberto Díaz - un nariñense nacido en Santacruz Nariño que migró al Valle del Cauca hacia los años 70 con la intención de visitar a un hermano, y luego con la idea de quedarse para trabajar en el ingenio azucarero de Mayagüez-, se describe a sí mismo y a la colectividad nariñense en general como gente "única" en tanto respetuosa, trabajadora y sensata con los demás:

a nosotros la verdad nos hace nariñenses, lo único que yo le puedo dar es que el nariñense es muy único y el nariñense tiene mucho respeto y el nariñense es muy trabajador, y el nariñense nunca lo maltrata nadie, a no ser de que le den el motivo y eso es lo que yo sé. (entrevista personal, Alberto Díaz, 2016)

Los rasgos identitarios que definen a la colectividad nariñense y que Alberto Díaz identifica desde la disposición para trabajar y guardar respeto hacia los demás, son los rasgos que de igual forma reconocen otros nariñenses como características significativas a la hora de entablar negociaciones con la sociedad receptora. Lo anterior puede observarse en uno de los relatos construidos por el grupo de discusión -Chazaconformado por varios nariñenses que en conjunto ofrecieron una idea sobre las particularidades que más representan a la "gente de Nariño":

La gente de Nariño vea, la base fundamental que nosotros tenemos es el carisma de ser respetuosos, honrados, cariñosos, eso es la cultura y lo que nosotros tenemos donde sea, la honradez, la franqueza porque eso es lo más importante que los nariñenses tenemos y por eso donde nosotros a cualesquier municipio o departamento donde nosotros lleguemos, siempre somos apetecidos ¿Por qué? Porque somos uno para el trabajo, es para lo que nos toque, el todo es que nos digan vea esto hay que hacerlo, y nosotros lo hacemos, eso lo tenemos lo más fundamental. (entrevista Grupo de Discusión Chaza, 2016) 
Las negociones que se entablan dentro de la sociedad receptora tienen que ver con la forma en que los nariñenses se hacen reconocer, así como con los rasgos identitarios de los sujetos migrantes que reconocen quienes hacen parte de la sociedad que recibe; se trata de la identidad cultural que favorece dentro del proceso migratorio la vinculación del nosotros con los otros, es decir, el reconocimiento entre dos culturas diferentes, pero con la capacidad de aceptar la diferencia a través de la construcción de un entramado de referencias comunes que se instituye a partir de la igualdad -que para efectos de precisión conceptual, puede entenderse como la posibilidad de configurar en el nuevo contexto urbano, lugares y prácticas de identificación interculturales.

A este respecto, el relato de Pedro Castro es importante porque hace referencia a la forma en que los nariñenses coexisten entre el Valle y Nariño como vía para conservar la igualdad desde la diferencia. Es por esto que los hábitos adquiridos en el lugar de origen y en medio de las tradiciones fueron conservados por los nariñenses, del mismo modo que los candelareños preservaron el sentido de sus prácticas sin intención alguna de imponerlo a quienes migraron a su lugar de origen,

pues soy nariñense como digo de cepa, pero vivo aquí hace más de cincuenta años y a mis hijos son de aquí vallunos, entonces estamos entre Valle y Nariño, entonces como le digo ni el dialecto nos ha cambiado, que porque estamos con los nariñenses se nos olvida lo del Valle? no, estamos aquí y se nos olvida lo del nariñense? tampoco, siempre las cosas se nombran por lo que es acá y las cosas acá se nombran por lo de allá, las nombra igual que aquí, no va cambiando como se nombran las cosas y hay muchas cosas que aquí le ponen un nombre y allá es otro. (entrevista personal, Pedro Castro, 2016)

Hay un punto de encuentro entre nariñenses y candelareños que llama especialmente la atención, por el hecho de posibilitar una de las negociaciones más importantes para la configuración de una identidad intercultural erigida sobre la preservación y el reconocimiento de los rasgos fisonómicos tanto de nariñenses como de candelareños. 
9.2.3. Narrativas de lo nariñense. "Ellos son así": relatos de lo nariñense en Candelaria desde la mirada de los candelareños, un momento de negociaciones y conflictos 


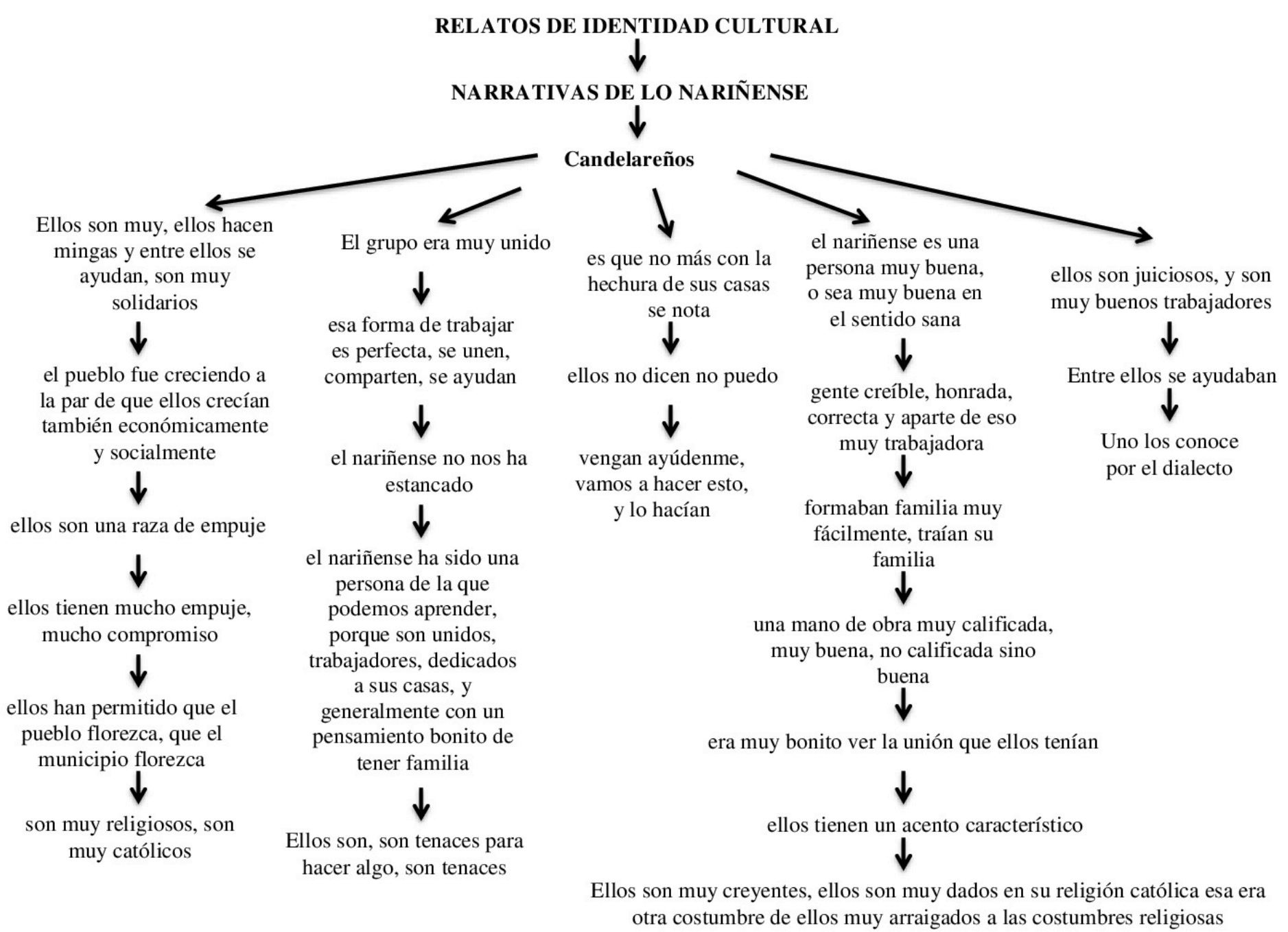




\section{RELATOS DE IDENTIDAD CULTURAL \\ $\downarrow$ \\ NARRATIVAS DE LO NARIÑENSE}

\section{$\downarrow$}

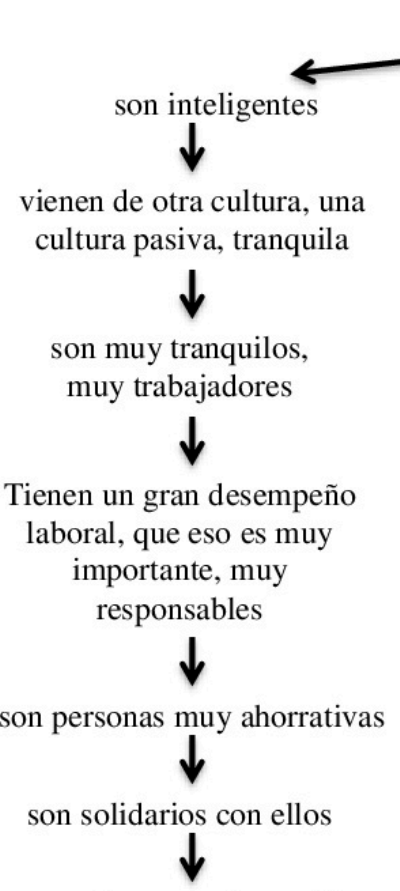

eso es lo que yo he podido percibir de ellos, solidarios con<smiles>[AlH2]</smiles>

también podemos distinguirla por su forma de caminar, por su forma de hablar

\section{La parte religiosa de}

ellos es muy arraigada

son muy participativos

en las cosas de la iglesia

\section{$\downarrow$}

hay mucho nariñense ahí y

muy con esa cuestión

religiosa, en esa parte son

solidarios y están allí

$$
\downarrow
$$

porque es que ellos son muy religiosos, ellos son muy religiosos,

entonces si ves a los adoradores, a

los señores del santo sepulcro muchos son nariñenses.

$$
\downarrow
$$

todas esas cosas que te marca la iglesia católica para ellos son

$$
\text { fundamentales }
$$

$$
\downarrow
$$

A ellos que les gusta mucho esta parte del ahorro, esta parte de todo esto de ahorrar, precisamente en la cooperativa

Candelareños

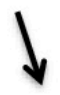

son muy unidos, ellos

hacían mingas para construir su viviendas

$$
\downarrow
$$

hacían todo eso,

preparaban sancocho, odos los alimentos que ellos preparaban en la casa y eso era muy comunitario

$\downarrow$
Los nariñenses son muy
religiosos
son personas muy
nobles, muy arraigados, el arraigo familiar, arraigo personal y el arraigo de la región marcan

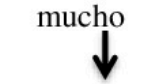

son una comunidad que es muy solidaria, se ayuda entre ellos, se apoya

\section{$\downarrow$}

ellos son muy solidarios ellos son una gente buena y trabajadora, luchadora

$$
\downarrow
$$

con mucho amor por la familia

los nariñenses, perdóneme doctora, eran berracos

\section{$\vartheta$}

esa gente era luchadora, trabajadora

siempre están buscando que la unidad de ellos se mantenga

Los nariñenses ya están enseñados a las mingas y a todo eso

$$
\begin{array}{cc}
\downarrow & \begin{array}{c}
\text { el ejercicio del trabajo } \\
\text { comunitario, las mingas }
\end{array} \\
\text { ellos son muy constantes } & \text { para poder hacer una casa, a } \\
\text { en el trabajo } & \text { punta de cerveza, a punta de } \\
\downarrow & \text { comida, digamos dice } \\
\downarrow & \text { mucho lo que hacen los }
\end{array}
$$

son muy perseverantes en todo, y cuando se proponen una meta, ellos tratan de lograrla

$$
\text { nariñenses }
$$

\section{nosotros le hemos} aprendido a ellos su constancia, perseverancia, el interés 


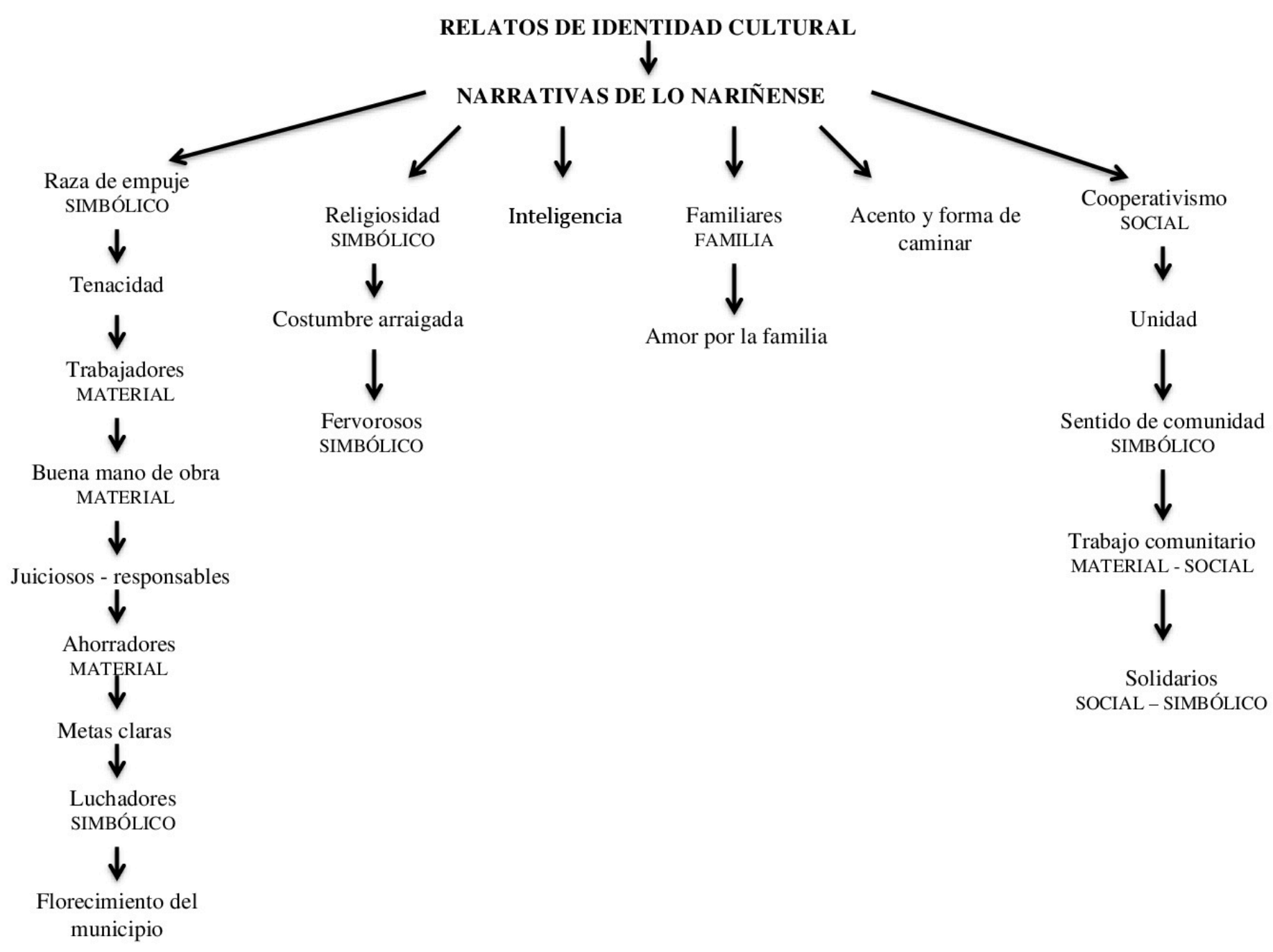


El punto en cuestión es el desarrollo económico, social y urbanístico que tuvo el municipio de Candelaria cuando los nariñenses migraron y comenzaron a trabajar en el corte de caña con la principal motivación de mejorar su calidad de vida; esta circunstancia aunada al empuje y a la mentalidad que tenían los nariñenses de salir adelante, tuvo como resultado la consolidación del proceso de modernización que se estaba llevando a cabo en el Valle del Cauca gracias al boom de la industria azucarera. Lo que realmente sucedió en torno a dicha modernización no fue más que el florecimiento económico obtenido por la visión, ideales y pretensiones personales del nariñense, pues al final este sujeto se convirtió en la pieza clave dentro del engranaje de la industria, si se tiene en cuenta que movilizó con sus ideas las condiciones necesarias para hacer de Candelaria un municipio en vías de desarrollo.

Por cierto, estos fueron los rasgos identitarios que reconocieron los candelareños en el momento en que los nariñenses empezaron a transformar su municipio, rasgos que al ser aceptados y reconocidos dieron pie a situaciones de encuentro, pero también de desencuentro entre los grupos culturales. Veamos.

Pues lo que caracteriza a ellos son una raza de empuje, ¿no? son definitivamente visionarios del futuro, ellos son dueños aquí de muchos negocios y como te dije anteriormente, se metieron a la política, ellos tienen mucho empuje, mucho compromiso, aunque no son muy cívicos, digo yo que no se meten a la cosa cívica, pero por el lado económico, ellos han permitido que el pueblo florezca, que el municipio florezca pero a ellos les hace falta meterse en la cosa cívica, en la cosa, digamos nosotros somos comunales, ellos ahí poco participan, entonces hemos notado como que a eso no le halan como se dice prácticamente. (entrevista personal, Camilo Muñoz, 2016)

En el relato de Camilo Muñoz hay dos afirmaciones que cabe tener en cuenta si se trata de comprender la interculturalidad -los conflictos y las negociaciones identitarias que marcan todo proceso migratorio-; en primer lugar, es claro que la disposición del nariñense hacia el trabajo y en general las prácticas y hábitos que lo caracterizan como "una raza de empuje", fueron los rasgos identitarios que favorecieron una mayor 
proximidad con la sociedad receptora, toda vez que influyeron provechosamente en el municipio de Candelaria, Valle del Cauca. En este sentido, puede decirse que los nariñenses fueron "tenaces" no solo para el trabajo pesado, sino también para la construcción de sus viviendas o "la hechura de sus casas", tal como se evidencia en los siguientes relatos de nariñenses:

Estas personas con el recurso compraron vivienda, compraron y generaron infraestructura pero el diseño de las casas era precisamente con el propósito de crear muchas habitaciones para permitir la llegada, digamos que ellos sirvieron como un colchón, amortiguar la llegada de otros que eran también coterráneos, de diferentes lugares de Nariño que eran vecinos o parientes y así fue dándose, se fue dando digamos el traslado de la comunidad de Nariño aquí a Candelaria. (entrevista personal, Víctor Mondragón, 2016)

Ellos son tenaces para hacer algo, son tenaces, es que no más con la hechura de sus casas se nota, cómo hacen, cómo hacen, ellos no dicen no puedo, "vengan ayúdenme, vamos a hacer esto", y lo hacían (...). (entrevista personal, Clara Díaz, 2016)

Lo anterior, además de presentar algunas características del proceso de poblamiento que tuvo el municipio de Candelaria, en el marco de uno de los fenómenos que ha contribuido de manera decidida en la configuración de las sociedades modernas: la migración, proceso que entre otras cosas le ha dado lugar a la transición de sociedades tradicionales a modernas; es en el caso particular de la migración nariñense a Candelaria, lo que contribuyó con la transformación urbanística del municipio vallecaucano, que a propósito del auge de la industria de la caña de azúcar en la región, tuvo cambios no solo en términos de densidad poblacional sino también, en la infraestructura del mismo, a partir del desarrollo urbanístico que propiciaron los nariñenses.

De esta manera, la tenacidad propia del nariñense le mostró al candelareño que era posible aprovechar las condiciones de un municipio en vías de desarrollo para construir viviendas en material, aunque para ello tuvieran que ahorrar, la mayoría de las veces, 
durante algún tiempo dentro de la cooperativa de trabajadores de Mayagüez (COOTRAIM) hasta reunir el dinero suficiente para "meterle plancha" a su vivienda. Para José María Alpala y Rosalba fue significativo el día en que decidieron emplear sus ahorros en la remodelación de su casa, porque fue un trabajo conjunto -en minga- entre don Alpala y sus paisanos, por medio del cual lograron recrear los códigos de comunicación y estrategias de significación con el pasado,

por eso yo agradezco y la empresa era pues que me apoyaba mucho por el trabajito pues, entonces cuando yo ya me preparé ya tenía un ahorrito allá, y entonces dije, "vamos a ver qué hacemos, reformamos el techo o le metemos nuevo, y todo y de ahí vino Don Pedro, otros amigos, uno de ellos ya es muerto, no sé si por aquí esta (...) el proyecto mío era cambiar el techo entonces todos los que nos ayudaron dijeron "no Alpala, haga un esfuercito y métale la plancha, entonces Don Pedro y otro amigo que ya murió dijo no, vamos por votación aquí (Risas) vamos por votación, vamos por techo o le metemos plancha. Y le tiramos plancha. (entrevista personal, Alpala y Rosalba, 2016)

Los códigos de comunicación que los nariñenses logran recuperar con este tipo de prácticas, traen de vuelta el sentido de comunidad y de solidaridad que orienta sus acciones dentro de la sociedad receptora, aun cuando candelareños como Camilo Muñoz afirmen lo contrario. Es en este punto donde puede destacarse la segunda afirmación del relato de Camilo, la cual tiene que ver, justamente, con cierta falta de sentido comunal o cívico por parte de los nariñenses, pues según dice "a ellos les hace falta meterse en la cosa cívica, en la cosa, digamos nosotros somos comunales".

Hay una clara diferencia que establecen los candelareños frente al sentido de comunidad puesto en práctica por los nariñenses dentro de la sociedad receptora; al parecer la manera en que tejen redes de apoyo para ayudar a los paisanos que necesitan conseguir un empleo y hasta un lugar donde pasar la noche mientras compran una casa o lote para construir su propia vivienda, no se expresa de la misma manera para con los candelareños, o lo que es lo mismo, no se presta para otras personas externas a su colectividad. 
¿Cuál es el sentido de comunidad y solidaridad que reivindican nariñenses y candelareños indistintamente? La respuesta a esta pregunta implica hablar de los relatos de marginación - exclusión y de segregación -separación.

9.2.4. Ustedes y nosotros. Estrategias de identificación de los nariñenses en Candelaria. 


\section{RELATOS DE IDENTIDAD CULTURAL \\ $\downarrow$ \\ ESTRATEGIAS DE IDENTIFICACIÓN \\ $\downarrow$}

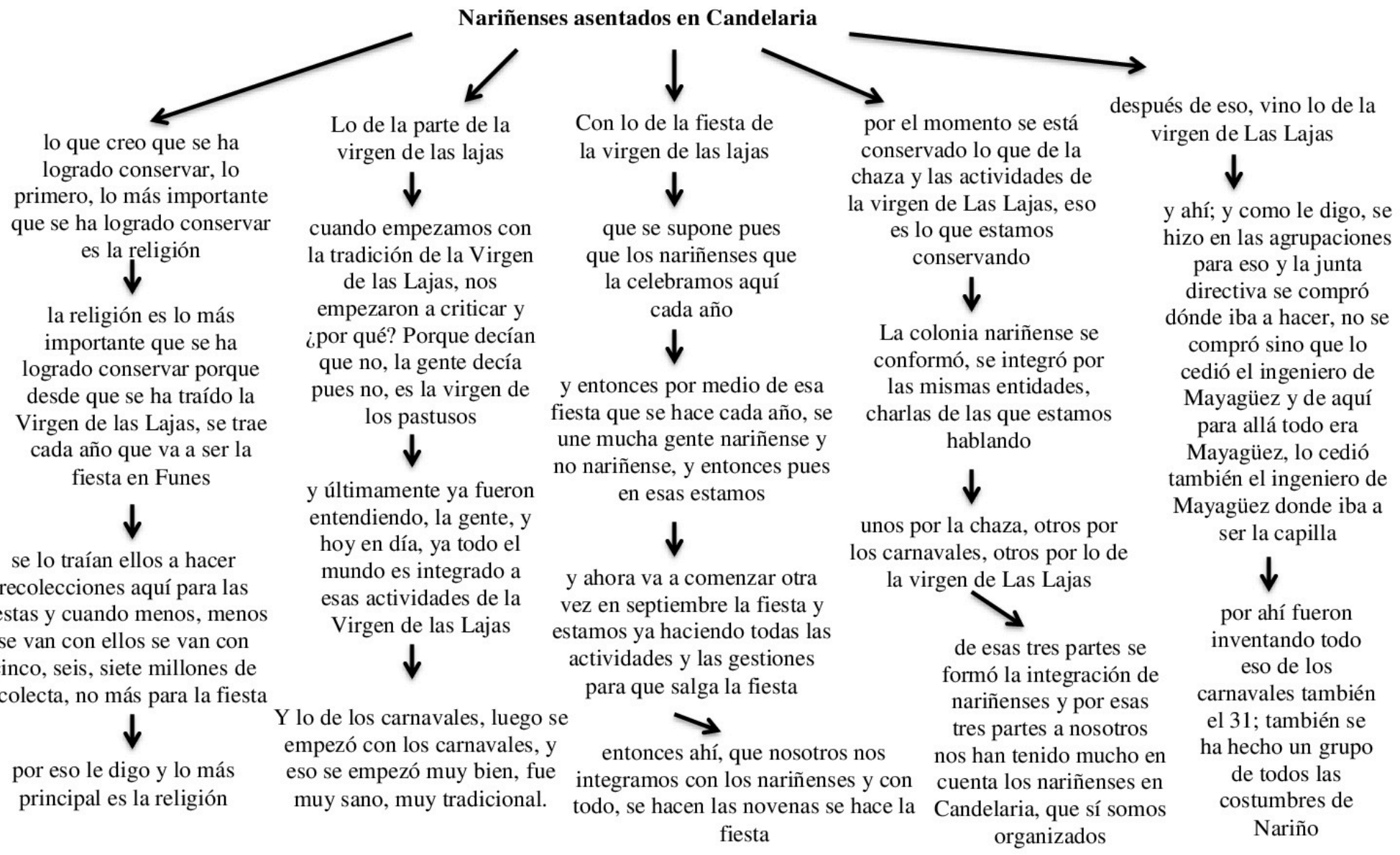




\section{RELATOS DE IDENTIDAD CULTURAL $\downarrow$ \\ ESTRATEGIAS DE IDENTIFICACIÓN $\downarrow$}

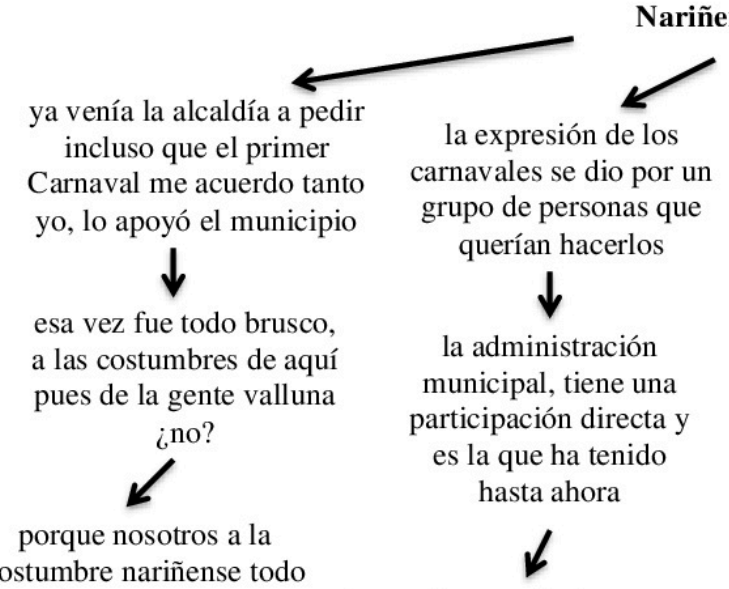

ostumbre nariñense todo

se hace con pausa

entonces tiene un factor muy importantes que es recursos, recursos que uno logra mediante el acompañamiento de toda la parte administrativa de los alcaldes.

mediante una proposición y un acuerdo se integra a la expresión de los Carnavales de Negros y

Blancos de Candelaria, como patrimonio cultural del municipio de Candelaria

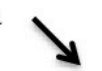

¿eso qué permite?, ya no solamente es una intención de las administraciones a acompañar, sino que esa expresión, hace parte de la cultura candelareña, y por lo tanto, independiente de quien sea el alcalde, con qué raíces o con qué afinidades, pues le den cumplimiento y pertenezca a la agenda de la expresión cultural de los Carnavales de Negros y Blancos

\section{En Nariño se celebraban} mucho los carnavales y en todos los municipios allá,

hace en todos los

municipios y veredas, en

Pasto ¡pues ni se diga! en

Pasto llega gente extranjera

\section{$\downarrow$}

y por eso los que estamos aquí como dijo Arquímedes que ya se trató de hacer los carnavales aqu

$$
\begin{gathered}
\text { entonces ya se hizo y se ha } \\
\text { seguido los carnavales }
\end{gathered}
$$

allá era casi todo el año en fiestas, entonces son con participación de la comunidad, los carnavales los hacen en todas las veredas, los corregimientos, municipios, en toda parte hacen los carnavales
Sí, los Carnavales de negros y blancos tienen un significado muy grande para los nariñenses, es la identidad cultural

o sea los carnavales, la guareña y el cuy yo diría que son la expresión como el orgullo de ser nariñenses ¿si?. $\downarrow$

Los carnavales de acá, como se organizan, es una expresión que se da en un día y tienen una expresión cultural que es un desfile de carrozas y comparsas, un desfile gastronómico

si algo se identifican los carnavales de Candelaria de negros y blancos es porque siempre en tarima o en presentación hay artistas de gran renombre nariñenses cuando hay carnavales mandamos a traer todo lo de allá

\section{Sinceramente yo como} nariñense, yo como nariñense traíamos la cultura nariñense que era los carnavales de Blancos y Negros, donde todos lo queríamos, todos queríamos ver, estar, participar 


\section{RELATOS DE IDENTIDAD CULTURAL \\ $\downarrow$ \\ ESTRATEGIAS DE IDENTIFICACIÓN \\ $\downarrow$}

Nariñenses asentados en Candelaria

La chaza empezó por ahí en los años 60, 66, ahí fue que se empezó $\downarrow$

En Candelaria fue un proceso muy largo, pero por la

persistencia de nosotros se han dado las cosas como están en el momento $\downarrow$

porque entonces no era todo eso construido como

$$
\stackrel{\text { está ahora }}{\downarrow}
$$

eso era un potrero, donde era el parque recreacional, en el polideportivo ahí empezamos

a practicar el deporte

$$
\downarrow
$$

nos agrupamos mucha gente de ahí, ya empezamos a agruparnos como le digo, organizarnos ya fue mas estable

Pues por lo menos, ahorita lo más tradicional aquí en

Candelaria por lo

menos, para nosotros es la chaza

\section{$\downarrow$}

porque nosotros, y carnavales, porque nosotros, mire usted por lo menos, esa cancha de chaza ahí llega todo el mundo, y ahí estamos con todo el mundo $\downarrow$

ahí, ahí no se le escoge, el que quiera jugar juega tranquilo, se divierte.

\section{$\downarrow$}

Tenemos esto pero por nosotros mismo y nunca vamos a dejar la tradición de venir aquí $\downarrow$

aquí a veces no hay juego, venimos

estamos aquí

sentados, cómo ve usted eso

$$
\downarrow
$$

[...] uno lo siente propio, uno prácticamente en la casa, uno sentado en la casa le da sueño $\downarrow$

viene por acá y uno conversando con los amigos, todo eso lo distrae

7

Aquí tradicionalmente aquí, lo del juego que yo se, es la chaza

y entonces eso es el juego de nosotros, el más apetecido por la recreación de nosotros, eso es

\section{$\downarrow$}

Aquí por ejemplo, antes no habían presidentes, el club de chaza no lo había

habíamos no más participantes, no más, ero ahí estaban hablando que por eso no nos asignaban un pedazo de tierra para que lo nombre como una cancha de chaza que actualmente es esta por la chaza, es la que nos ha traído a nosotros como para estar mas unidos

nos conocimos en el trabajo pero la unión mas fuerte fue la chaza

\section{$\downarrow$}

aquí empezamos a practicar, lo de la práctica de la chaza, aquí en esta parte,

ya hace aproximadamente 40 años

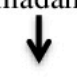

es que Candelaria últimamente hemos ganado tanto espacio y la parte de integración.

últimamente ha sido el epicentro

la cancha de chaza, por decir sábado y domingo allá

\section{$\downarrow$}

cuando nos vinimos por aquí, primero pues lógico, extrañar la familia, todo eso, y le digo que poco a poco nos fuimos ubicando, ya entonces, ya después de uno estar por acá, ¿qué extrañamos? Las costumbres y por eso gracias a Dios, gracias a la decisión de Dios, hicimos pero la mayoría si nos decidimos a conservar esas tradiciones
Pero ya mas tarde, a medida de la necesidad ya nos fuimos organizando entonces, pero lo primero que

llegó a Candelaria fue la práctica de chaza 


\section{RELATOS DE IDENTIDAD CULTURAL \\ $\downarrow$}

ESTRATEGIAS DE IDENTIFICACIÓN

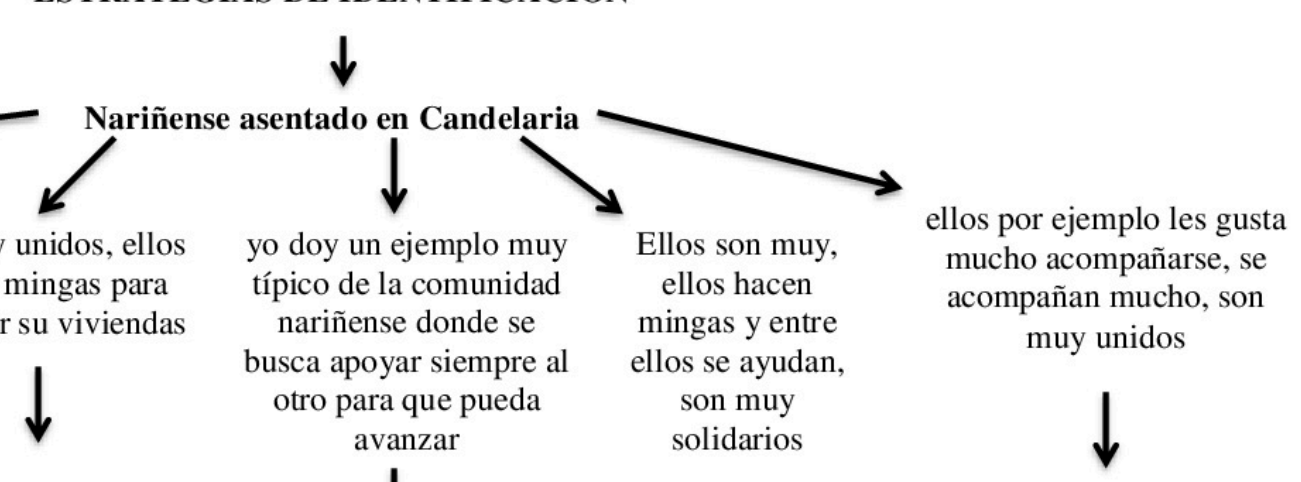

En Candelaria donde veían la montonera todos eran nariñenses, [...] la integración que hacíamos [...] las mingas...

\section{$\downarrow$}

la comida, y después de la comida venía la bebida, cervecita, aguardiente, la gente se iban

borrachitos pues; entonces esa era la costumbre..

\section{$\downarrow$}

Entonces las esposas hacían la comida para la gente que venía a la minga

\section{$\downarrow$}

yo invité más o menos a 20 por el trabajo, era en minga, en comunidad, no es como ahora, que traen al trompo y eso es rápido $\downarrow$

eso de la minga, nosotros los nariñenses hemos dejado un ejemplo son muy unidos, ellos hacían mingas para construir su viviendas

y eso era muy comunitario

\section{$\downarrow$}

el ejercicio del

trabajo comunitario,

las mingas para

poder hacer una

casa, a punta de

cerveza, a punta de comida

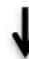

entonces digamos

eso es una cosa bien

interesante en el

apoyo solidario de la

comunidad otra costumbre que ellos tenían, eran las mingas, si por ejemplo un nariñense tenía problemas y llegaba y le ayudaban a armar su casa y se reunían y entre todos se ayudaban

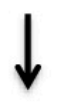

Los nariñenses ya están enseñados a las mingas y a todo eso 


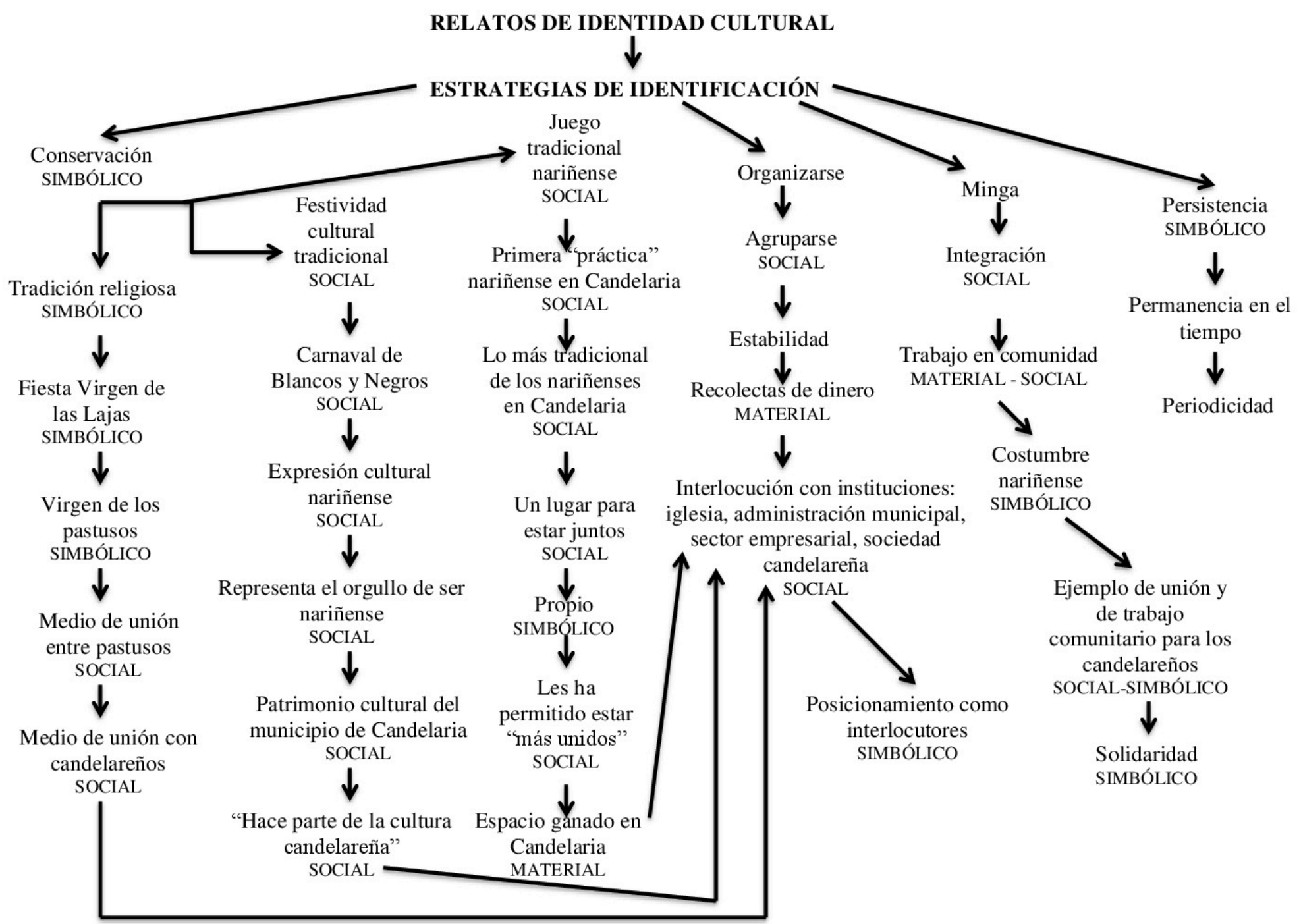




\section{RELATOS DE IDENTIDAD}

$\downarrow$

ESTRATEGIAS DE IDENTIFICACIÓN

$\downarrow$

¡Ah no! pues a mí me gusta traer los curíes,

\section{$\downarrow$}

Por lo menos allá se tuesta el maíz, lo tuestan y por lo menos aquí en el pueblo donde se compra todo el menú de puerco de marrano, ese se lo pican y se lo ponen ahí a fritar con el tostado, eso sabe buenísimo

$$
\downarrow
$$

aquí había una paisana,

Doña Carmela, ella era la que sacaba eso, se quitó

ella y se acabó eso

$$
\downarrow
$$

porque por ese tostado, siempre llegan por lo menos

los paisanos a comer, a buscar el maíz tostado, porque es sabroso.

\section{Reproducción de olores, sabores, sonidos}

Maíz, frijol, garbanzo, alverja, trigo, todo grano traigo yo de allá

$$
\downarrow
$$

por eso yo me siento muy nariñense, por la comida y todo

\section{$\downarrow$}

Por lo menos yo en la casa cuando no hay se come el maíz, se come el trigo, se come la cebada, el frijol, la alverja, el garbanzo, la lenteja

$$
\downarrow
$$

todo eso lo comemos nosotros, todo eso, la zanahoria, lo que acá le llaman la arracacha. como le digo, en los deportes de una parte y de otra, y

llegan, ahí llega la comida

$$
\downarrow
$$

la venta de empanadas nariñenses, la venta de la chicha de pronto el curí, bueno en fin

$$
\downarrow
$$

otra cosa que es importantísimo, el maíz pero el mote, ese es que el maíz se lo hacen de diferentes maneras, lo hacen en sopa de cuchuco es que le dicen, se le dice arniada, y aquí le dicen cuchuco esa sopa de maíz lleva cuchuco, papá, lleva, habas,

repollo, bueno de todo

esa son las comidas que no se pierden aquí, en la tradición.
De allá lo que no hay aquí, por ejemplo más que todo lo tradicional que es el curí.

\section{$\downarrow$}

No, eso cuando uno va para allá los trae preparados porque de eso hay

$$
\downarrow
$$

entonces allá la familia, la llegada de uno cuando uno va donde la familia no lo compran, lo preparan.

$$
\downarrow
$$

y así lo hacen cargar con un curí, tome un curí, eso es lo que traen ya de regalos pues, y si no los compra, se los compra y el queso cuajada que es lo que se da en Nariño

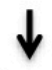

esa es la golosina de allá pues que hay, todo eso se trae $\downarrow$

y de pronto un manjar que es diferente al manjar de aquí, porque allá es ese manjar le echan de leche, como se dice natural de vaca y todo eso

o como el pan de maíz, que también es de otro porque para mi mamá, lo hacía; y eso le echan una cantidad de cosas que queda como es, un pan exquisito esa es la golosina de allá para acá. 


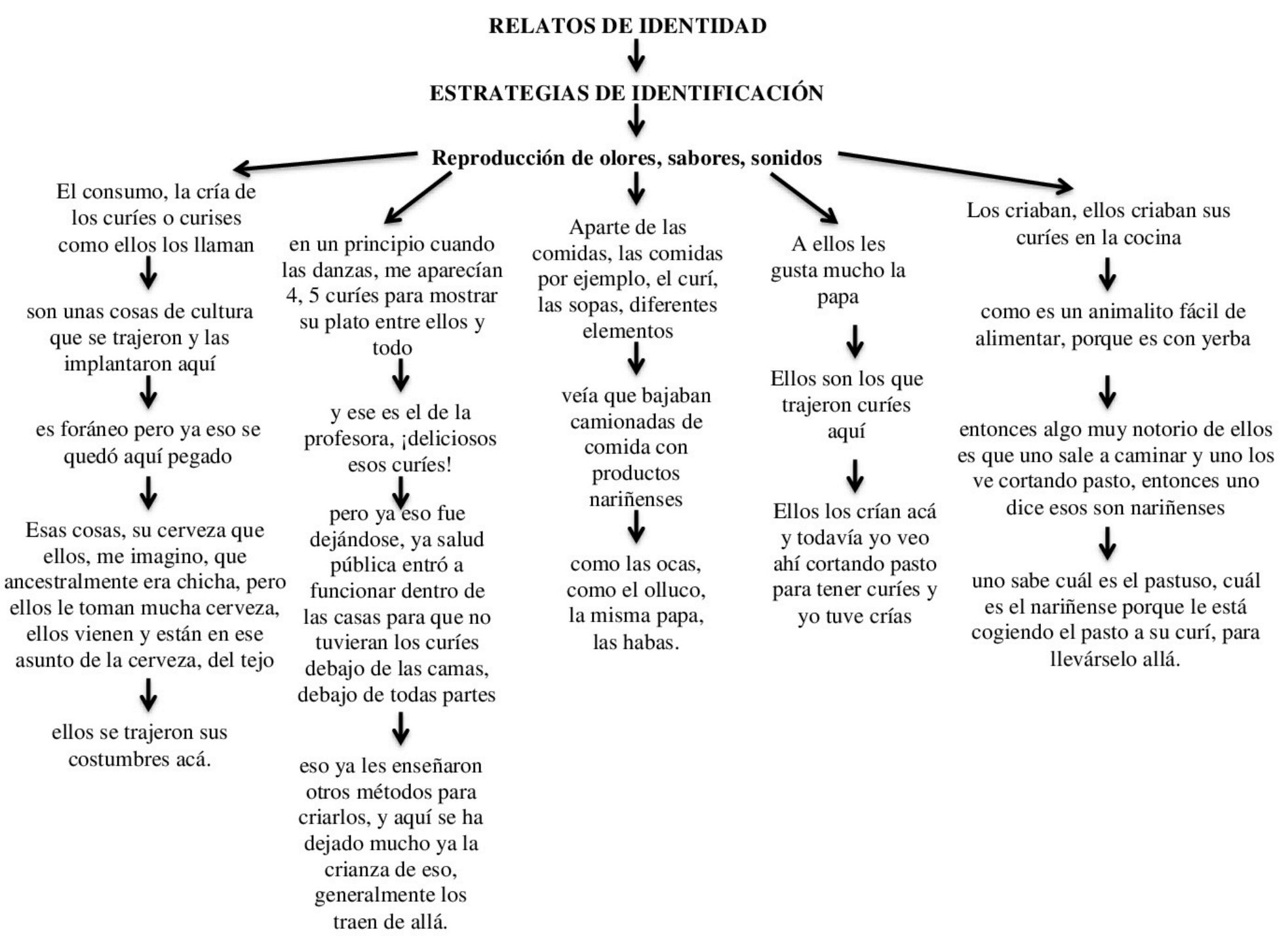




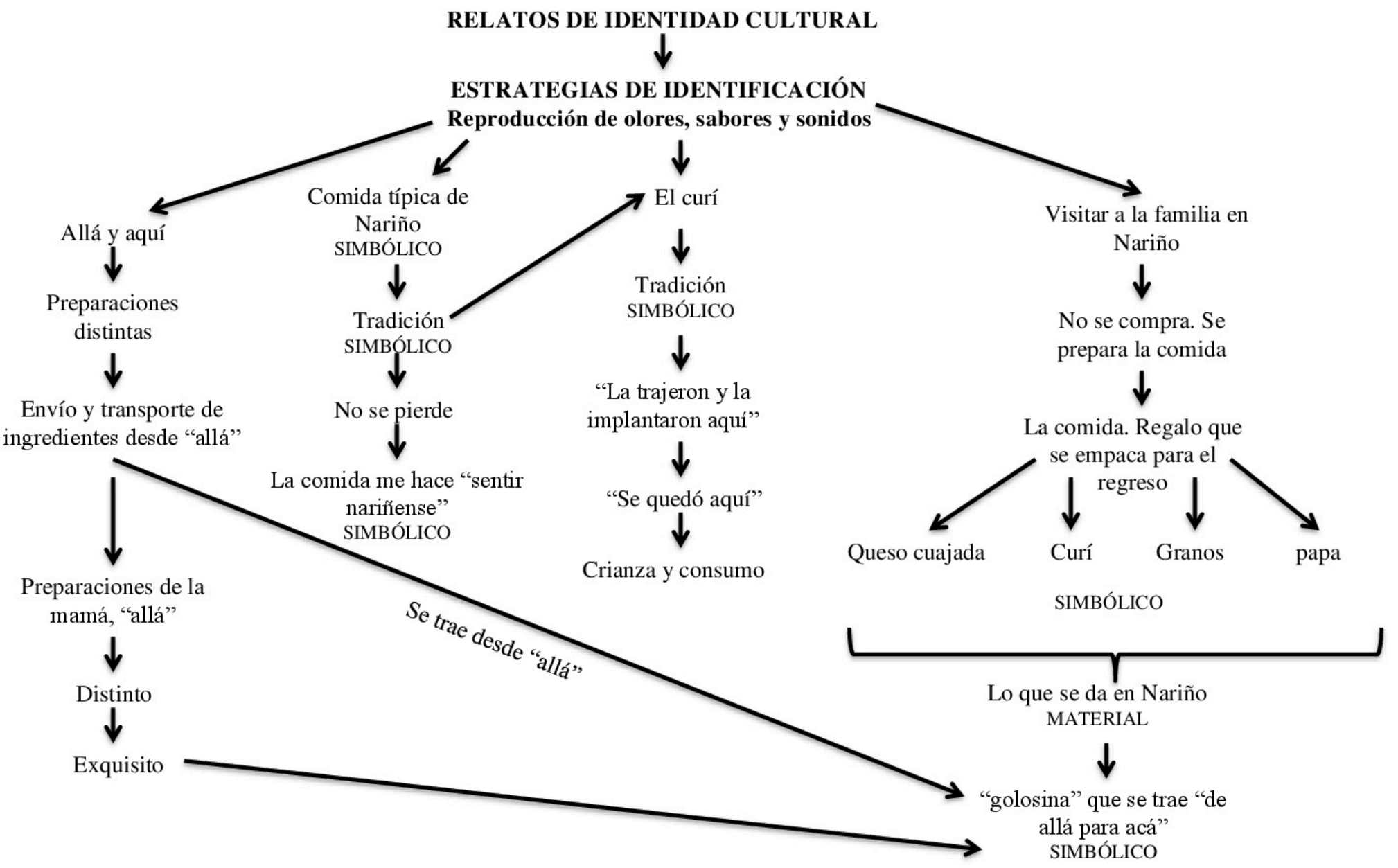


Como bien se planteó en el referente teórico de la investigación, el movimiento de una población de un lugar a otro conlleva de manera intrínseca transformaciones sociales y culturales debido a la interacción entre quienes llegan y los que están establecidos. Se genera lo que se ha denominado aculturación, desde donde se entiende que la transformación cultural por la influencia de otras culturas no implica una pérdida, sino un proceso de reapropiación y reinterpretación de los elementos culturales, una negociación de códigos que deviene la transformación de ambas culturas (de los que llegan y de los que reciben); dando lugar a un ser y a un estar entre prácticas de tradiciones propias y ajenas, en un escenario de interacción entre ambas culturas (Berry, 1997).

En este entendido, puede decirse que en marco de la migración de nariñenses hacia Candelaria, se fue consolidando una colonia -nariñense- en diálogo e interacción con la cultura candelareña, dando lugar a lo que desde los años 60 , y durante las décadas siguientes se fue legitimando a través de distintas prácticas y lugares de encuentro propios de lo nariñense en Candelaria, generando por una parte y tal como señalan Boss (2005) y Jaes (2002), situaciones de pérdidas ambiguas e incompletas, debido a que las personas y lugares queridos están físicamente ausentes, pero están presentes en los recursos, prácticas y discursos característicos; y por otra, estrategias de identificación que ayudan a apaciguar los efectos de la migración y que están atravesadas por prácticas cotidianas, por el mismo lenguaje, la comida y las redes de amistad que los vinculan con las sociedades de origen, todos estos denominados rituales espontáneos (Jaes, 2002).

Son estas entonces las estrategias generadas por un lado, para mantener conexión y relación, a lo largo del tiempo, con quienes permanecen en el lugar de origen e incluso muchas veces, conexión solo con el territorio de origen y con sus costumbres; que en el caso específico de los nariñenses, implicaron y aún implican, visitas periódicas a los familiares que continúan en sus pueblos natales durante la época de vacaciones y la visita al Santuario de las Lajas en Ipiales. Por otra parte, se pueden identificar también rituales de recreación que implican la reinvención de lugares de encuentro del pasado, tales como el juego de chaza y rituales culturales que permiten preservar las tradiciones, festividades y creencias, en este caso, los más comunes entre la población nariñense asentada en Candelaria, quien a través de prácticas como las mingas, la adoración a la virgen de Las 
Lajas y el carnaval de Blancos y Negros, intentan recrear identidades, revitalizarlas y reforzar la imagen de comunidad (Jaes, 2002) en un proceso permanente de identificación y posicionamiento frente al otro (el candelareño).

Frente a este posicionamiento que cada grupo cultural busca obtener en el municipio de Candelaria, se evidencia cómo nariñenses y candelareños construyen sus identidades en el marco de un diálogo que implica negociaciones y tensiones que tanto los unos como los otros interponen a la hora de enfrentarse con nuevas prácticas, celebraciones religiosas, fiestas regionales y juegos. A lo largo de este apartado se verá que en el proceso migratorio de Nariño a Candelaria se han configurado relatos de identidad cultural que tienden a constituirse como hegemónicos, en la medida en que cada grupo cultural reclama para sí un ascenso simbólico ante los que llegan o los que reciben, según sea el caso.

Para autores como Grimson (2001), Jaes (2002) y Demarchi (2012) las estrategias de identificación redefinen la cultura del migrante, refuerzan la imagen de la comunidad y perpetúan estilos de vida; aunque también es cierto que cada uno de estos autores denominó las estrategias de identificación de una forma distinta, a saber, para Grimson, son campos de interlocución, para Jaes son rituales de invención de la tradición y para Demarchi son marcos de comunicación. Lo que interesa rescatar de cada uno de estos aportes conceptuales es el análisis que desde ellos puede realizarse sobre las estrategias de identificación que desarrollaron los nariñenses, una vez tomaron la determinación de marcharse a Candelaria. Esta determinación impulsó a los migrantes a la configuración de un sentido propio de "colectividad", el cual sintetiza los sentidos de comunidad y de solidaridad de los nariñenses, vistos hasta el momento en diferentes escenarios que abarcan las prácticas en el trabajo y en la vida cotidiana.

Así, cuando dos grupos culturales como los nariñenses y los candelareños, confluyen en un mismo espacio, y su fisonomía difiere en los sentidos más esenciales de la existencia, como por ejemplo la motivación por el trabajo, la disposición a ahorrar y los ideales de adquirir una vivienda -que no solo ofrezca un lugar para pasar la noche o protegerse del frío, sino también confort-, es natural que comiencen a desear el 
reconocimiento del otro y que busquen manifestar fuera lo que son dentro como posibilidad de demostrarle a su interlocutor que a lo largo de su trayecto personal han ido inculcando ciertos valores, costumbres y tradiciones que los definen como gente pura y original.

La originalidad del nariñense y del candelareño proviene de la identidad que los diferencia de otros grupos culturales, de ese exterior constitutivo en el sentido de Hall (2003) por el hecho de disponer de prácticas, rituales y rasgos identitarios distintos a los suyos como la vestimenta, el acento y la gastronomía; siendo estos rasgos en el proceso migratorio, los que terminan por coexistir en un escenario de disputas que se crea cuando cada colectividad busca un posicionamiento identitario.

Desde el punto de vista de Grimson (2005), este posicionamiento responde a la necesidad que tienen, sobre todo los sujetos migrantes, de constituir un ámbito de interacción simbólica "intra - cultural”, de puesta en común, en el que se desarrollan las prácticas, las fiestas regionales y los juegos que definen a su cultura, como posibilidad de reforzar la imagen de la comunidad y de establecer contacto físico y simbólico con el pasado.

\subsubsection{El milagro en el abismo: la virgen de Las Lajas}

Uno de los aspectos que para los candelareños, caracteriza a los nariñenses en Candelaria, son sus prácticas religiosas tales como las novenas a distintos santos y el culto a La Virgen de Las Lajas que desde el año de 1984 aparece en Candelaria como una celebración nariñense:

Digamos que la celebración de la virgen no se origina, inmediatamente con la llegada de los nariñenses, va a ser posterior. Cuando hay intervención de los nariñenses que quieren que la patrona de ellos en Nariño, digamos tenga una celebración y ya va a ser digamos a finales de los 80 , principios de los 80 , que ya se estructuran en los barrios cuando va a haber la posibilidad de que eso crezca y que se solidifique el modelo de la celebración de la Virgen de Las Lajas. (entrevista personal, Víctor Mondragón, 2016) 
Esta práctica que no solo consiste en el ritual de veneración a una divinidad durante unos días al año, sino todo un proceso de trabajo comunitario a lo largo de este para recaudar fondos que permitan llevar a cabo la celebración, ha implicado un fuerte proceso de organización de la comunidad nariñense que desde 1986 legalizó su figura a través de la Sociedad Parroquial al Servicio Social "Nuestra Señora de Lajas".

A través de este grupo, también conocido como los fiesteros, se organiza la celebración anual en la que se convoca a la comunidad durante 9 días seguidos a una novena que se hace cada noche en una casa distinta y que culmina, el día 9, con una procesión por diferentes calles del pueblo en la que la gente sigue la imagen de la Virgen de las Lajas mientras le rezan y le cantan.

El grupo de los fiesteros es el encargado de liderar y organizar las novenas y la procesión, definen previamente y de manera concertada en reuniones, cuestiones tales como en qué casas se van a realizar las novenas además de hacer actividades durante el año para conseguir los fondos que permiten pagar durante los nueve días, el sonido, el alquiler de las sillas, los grupos musicales, la pólvora, el programa de mano, y todos los gastos que acarrea la celebración religiosa que en el último día (el día nueve) convoca alrededor de 500 personas, en torno a la fe que le profesan a la Virgen de las Lajas. 
Imagen 23. Momento previo a la realización de la novena del día 3 en la celebración de la Virgen de las Lajas

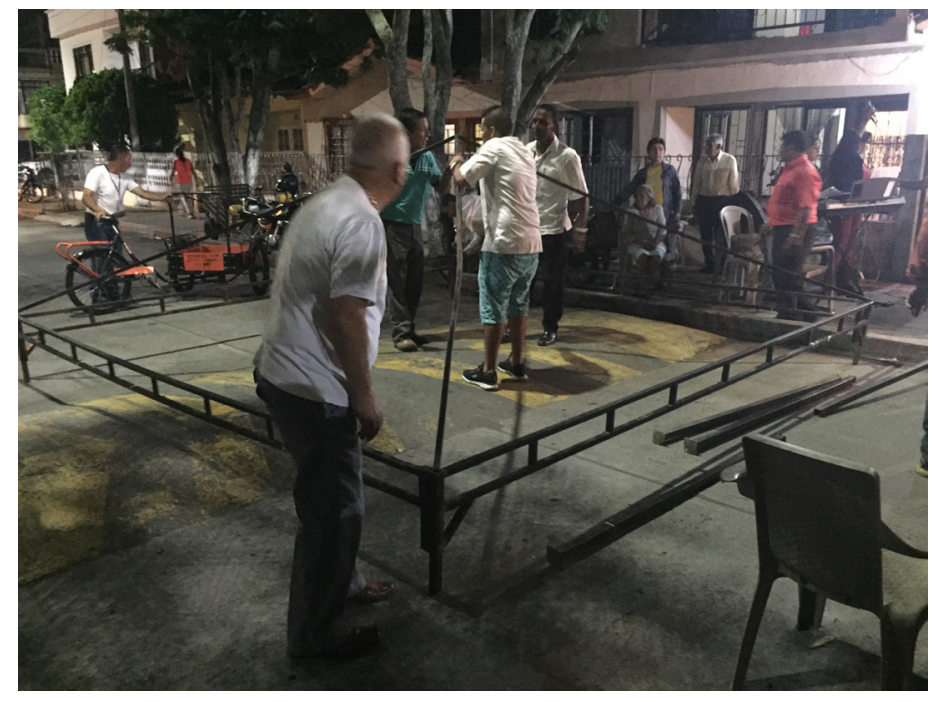

Fuente: fotografía tomada el 10 de septiembre de 2016.

Imagen 24. El grupo de fiesteros disponiendo el altar para la celebración de la novena del tercer día

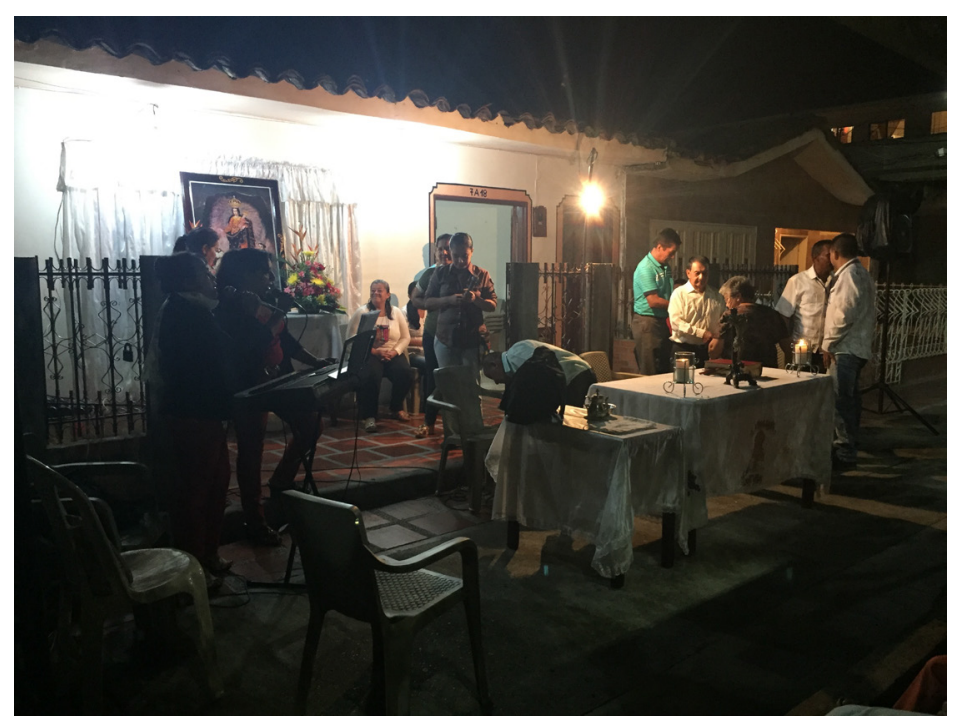

Fuente: fotografía tomada el 10 de septiembre de 2016. 
Es una celebración organizada y concertada que se ha llevado a cabo año tras año en Candelaria con el apoyo y el trabajo continuo de un grupo de nariñense que piensa cada detalle logístico para las novenas y para la procesión, deciden el orden en que se desfila, quién va primero, qué grupo después, cómo organizar las bandas e incluso, la noche de la procesión, este grupo de fiesteros camina de primero con sus camisas blancas, todas iguales, con un bordado de la Virgen de las Lajas y el nombre de la Fundación, controlan el ritmo de la procesión, hace las paradas y cuidan cada detalle del desfile.

Jorge Martínez, uno de los fundadores de la celebración cuenta:

Más o menos empezamos nueve días antes, pero es que empezamos días antes porque hacemos la celebración, terminamos la novena, siempre la hacíamos nosotros un día domingo, teníamos que celebrar la fiesta un día domingo, entonces teníamos que terminar la novena en viernes, sábado hacíamos lo que se dice, vísperas y luego hacemos lo que sería la fiesta.

Las fiestas no eran sino para celebrar cada año la misa y las vísperas, y nosotros la hacíamos con mucha pompa, con mucho interés, inclusive traíamos las bandas de Nariño para celebrar aquí las fiestas, desde ese año, desde el año 84, llevamos más de 30 años [...] nuestra intención es que una cantidad de personas, nos reunimos, nos llamábamos en ese momento fiesteros, y como fiesteros dábamos una cuota para celebrar la fiesta, entonces siempre tenemos la tradición de los fiesteros. (entrevista personal, Jorge Martínez, 2016) 


\section{Imagen 25. Procesión del día 9 en honor a la Virgen de las Lajas}

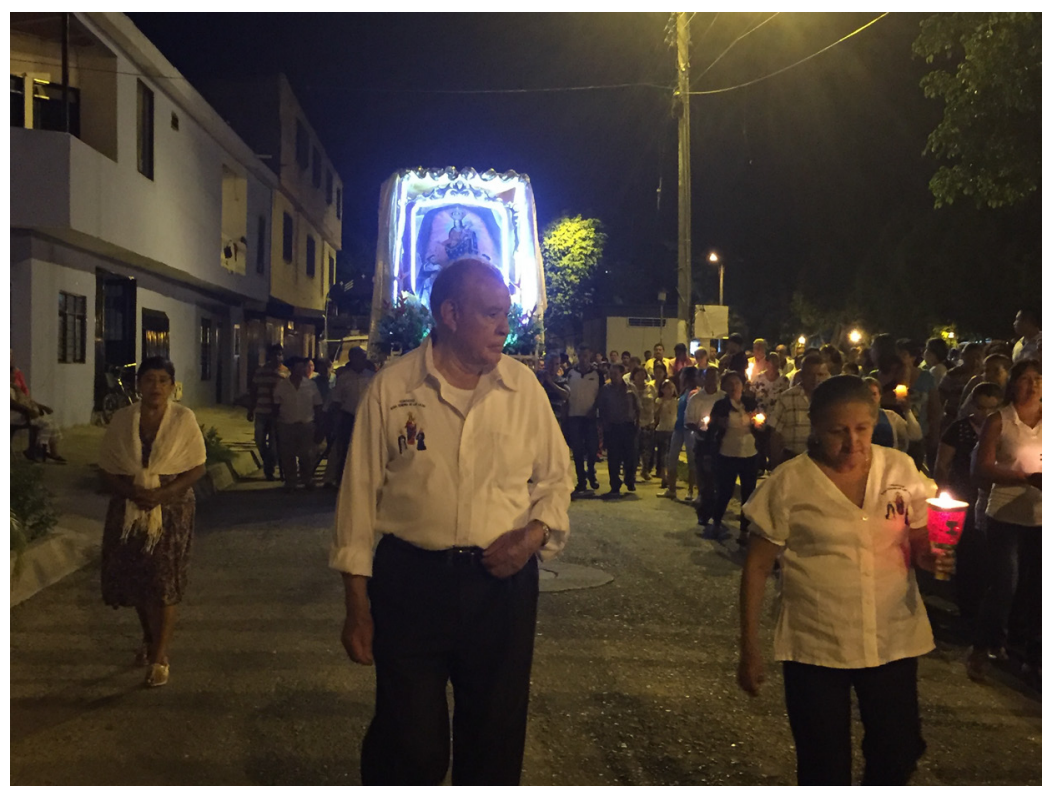

Fuente: fotografía tomada el 16 de septiembre de 2016.

En este marco, se entiende que celebraciones rituales como esta, hacen parte de las estrategias de identificación que al ser reproducidas dentro de la sociedad receptora, permiten la configuración de escenarios de interlocución en los que se define y redefine la cultura migrante. A este propósito la celebración ritual que realizan los nariñenses a la Virgen de las Lajas, puede comprenderse como una fase específica de la migración, por medio de la cual los nariñenses se ajustan a los cambios que conlleva trasladarse a otro territorio; este ajuste tiene que ver con la posibilidad de que los sujetos migrantes se adapten al medio ambiente de la sociedad receptora, de tal suerte que puedan manifestar allí lo que es perenne o eterno en su lugar de origen.

La celebración de la Virgen de las Lajas es una gran fiesta religiosa que presupone una regionalidad común, una cultura compartida y costumbres que al ser reproducidas en Candelaria hacen posible la continuidad con el sentido y la idea de comunidad nariñense. Según Gabriel Pascuasa, la religión es una de las tradiciones más importantes que se ha logrado conservar en Candelaria 
lo que creo que se ha logrado conservar, lo primero, lo más importante que se ha logrado conservar es la religión, la religión es lo más importante que se ha logrado conservar porque desde que se ha traído la Virgen de las Lajas, se trae cada año que va a ser la fiesta en Funes, se trae El Señor de la Buena Esperanza, se trae a San Pedro cada año, se lo traían ellos a hacer recolecciones aquí para las fiestas y cuando menos, menos se van con ellos se van con cinco, seis, siete millones de recolecta, no más para la fiesta, por eso le digo y lo más principal es la religión. (entrevista personal, Gabriel Pascuasa, 2016)

El énfasis que hace Gabriel Pascuasa en este relato que refiere la religión y las distintas figuras religiosas como la Virgen de las Lajas, el Señor de la Buena Esperanza y San Pedro, hace énfasis en el papel que cumple, más que nada, la fiesta de la Virgen de las Lajas en Candelaria como espacio formalmente organizado para la construcción de un código de comunicación desde el cual lo nariñense adquiere un fuerte sentido práctico; la practicidad a la cual se hace referencia es la que permite comprender que lo nariñense en Candelaria no solo se encuentra en proceso de disolución, sino también de desarrollo y crecimiento, en cuanto a lo que a la reproducción de los espacios identificados con lo nariñense se refiere.

La fiesta de la Virgen de las Lajas se originó en Candelaria en el año 1984 cuando algunos miembros de la comunidad parroquial, conformada por candelareños y nariñenses, decidieron organizarse para comenzar a trabajar en la configuración de la Sociedad parroquial de Servicio Social, Nuestra Señora de Las Lajas del municipio de Candelaria. A través de esta organización formal, se da paso a la recreación de las tradiciones y de los ritos como parte de la re-construcción de la cultura nariñense que se agrupa en el contexto migratorio. Esto último puede corroborarse en uno de los relatos del grupo de la Chaza, en el que además se identifican tensiones entre nariñenses y candelareños cuando los primeros buscan posicionar la fiesta de la Virgen de las Lajas, con el fin de mantener vivas las tradiciones que les ayudan, en pleno proceso migratorio, a cimentar el sentimiento de identidad cultural; 
Lo de la parte de la virgen de las lajas, cuando empezamos con la tradición de la Virgen de las Lajas, nos empezaron a criticar y ¿por qué? Porque decían que no, la gente decía pues no, es la virgen de los pastusos, y últimamente ya fueron entendiendo, la gente, y hoy en día, ya todo el mundo es integrado a esas actividades de la Virgen de las Lajas, entonces y lo de los carnavales, luego se empezó con los carnavales, y eso se empezó muy bien, fue muy sano, muy tradicional. (entrevista, Grupo de discusión, 2016)

Hay dos momentos clave en el relato que ofrecen los nariñenses, a saber, en primer lugar, la fiesta de la Virgen de las Lajas como circunstancia que propicia la recuperación del mundo perdido, y por qué no, de las tradiciones que se transmiten a los descendientes. En segundo lugar, la reacción que tuvieron los candelareños cuando los nariñenses empezaron la tradición de la Virgen de las Lajas, constituye un relato con el que los migrantes hablan de la sociedad receptora y de las diferencias y tensiones con esta.

Las diferencias realmente se encuentran en las tensiones que enfrentaron ambos grupos culturales en el marco del sentido práctico de sus fiestas; aquí es importante referirse tanto a la fiesta de la Virgen de las Lajas como a la fiesta de la Virgen de la Candelaria, en tanto constituyen una de las estrategias de identificación, que para los nariñenses fue necesaria desde el punto de vista del desarrollo y la expansión de los espacios de referencia de su cultura dentro de la sociedad receptora. Pero que para los candelareños significó el interés de una re-conquista del espacio para establecer algún posicionamiento importante entre lo otro -lo nariñense- y su propia definición identitaria.

Los nariñenses ponen en marcha las estrategias de identificación, tales como las tradiciones religiosas, con el propósito de establecer una comunicación con la sociedad candelareña, y más precisamente, con el fin de mostrarle su cultura y encontrar reconocimiento en ella. El reconocimiento de los candelareños hacia los sujetos migrantes se obtiene en la medida que se van estableciendo diversos modos de inclusión que van desde saludarlos hasta compartir con los nariñenses espacios tan suyos como la devoción por la Virgen de las Lajas: 
Con lo de la fiesta de la virgen de las lajas, que se supone pues que los nariñenses que la celebramos aquí cada año, y entonces por medio de esa fiesta que se hace cada año, se une mucha gente nariñense $\mathbf{y}$ no nariñense, y entonces pues en esas estamos, y ahora va a comenzar otra vez en septiembre la fiesta y estamos ya haciendo todas las actividades y las gestiones para que salga la fiesta, entonces ahí, que nosotros nos integramos con los nariñenses y con todo, se hacen las novenas se hace la fiesta. (entrevista, Grupo de Discusión Chaza, 2016)

El relato anterior muestra una situación de comunicación directa intercultural entre nariñenses "y no nariñenses" (personas de Candelaria y de otras regiones del Valle del Cauca), quienes negocian sus identidades, tal vez con la intención de obtener un posicionamiento igual dentro de la nueva sociedad. Sin embargo, en medio de las negociaciones y los conflictos se ve que los nariñenses nunca tuvieron el interés en asemejarse a los candelareños o por lo menos no en obtener un mismo posicionamiento simbólico cultural; como consecuencia de esto, el nariñense se convierte en un sujeto migrante cuya principal intención es la de situarse en la sociedad receptora como agente hegemónico que reafirma la decisión de separarse de la sociedad que lo recibe.

A este propósito, Grimson (2005) afirma que, "es en el conflicto entre diferentes construcciones de la relación nosotros/ellos que se establecen los parámetros que delimitan un colectivo y se postulan distintos modos de relación con los "otros"”; estos modos de relacionarse con los candelareños que fueron adquiriendo los nariñenses, señalan la necesidad de los migrantes por recordarle a las generaciones futuras y a los paisanos de su misma generación, quienes fueron los nariñenses y quienes son desde la perspectiva de la diferenciación cultural. Para Milena Medina uno de los aspectos que diferencia a los nariñenses de los candelareños es "esa parte de la religión" que quizá une aparentemente a ambos grupos culturales, por el hecho de que Candelaria no cuenta con dos capillas para rendirle culto a cada virgen, pero que, en caso de que el municipio cuente con dicho espacio, seguramente los nariñenses dejarían de habitar la iglesia como lugar de encuentro con la sociedad receptora, 
Entonces esa parte de la religión los diferencia mucho a ellos de esa parte y por eso me preocupa, acá entre nos, por eso me preocupa el hecho de, por eso me preocupa la idea de querer hacer una réplica del Santuario de las Lajas en Candelaria porque, hay concurrencia masiva a la iglesia nuestra por parte de ellos, y allí es la única parte como donde convergemos todos, ¿sí? A los oficios religiosos allí te encontrás con nariñenses, con el negro, con todos, y hay ese, esa forma de compartir, si hacemos una capilla, una réplica, otra iglesia grande, entonces ellos se van a aislar, y va a hacer todo, y sé que así va a pasar porque ellos dicen que vamos a tener nuestra iglesia y no, yo que le sugeriría al alcalde o al sacerdote, que no lo he hecho porque no me gusta como meterme en esos temas, de manera respetuosa, hagan una capilla donde semanalmente se pueda ir a hacer una misa, pero yo no soy partidaria de que hagan una iglesia porque en la única parte que realmente nos unimos y compartimos es ese espacio porque o si no ellos ya dirían, ya tenemos iglesia aparte. (entrevista personal, Milena Medina, 2016)

Y posiblemente también, los altares que los sujetos migrantes han preparado en sus casas para rendirle culto y homenaje a la Virgen de las Lajas, dejen de constituir uno de los espacios más sagrados y privados en los que constantemente reviven uno de los ritos que los define como gente "muy religiosa". Lo que desde la perspectiva de la integración intercultural, de igual forma puede significar un momento en el que los nariñenses abandonen la relación privada que han establecido desde sus hogares con la Virgen de las Lajas, para constituir como comunidad un espacio "público" (para su colectividad) en el que todos confluyan para adorar una figura religiosa distinta a la de la sociedad receptora -he aquí otra de las situaciones de desencuentro que podrían llegar a distanciar, aun más, a nariñenses y candelareños, frente a uno de los momentos más esenciales del espíritu de un pueblo, a saber, la religión. 
Imagen 26. Altar a la Virgen de las Lajas en casa de Humberto Tutalchá. Al lado, fotografía enmarcada del Santuario de las Lajas en Ipiales, Nariño.

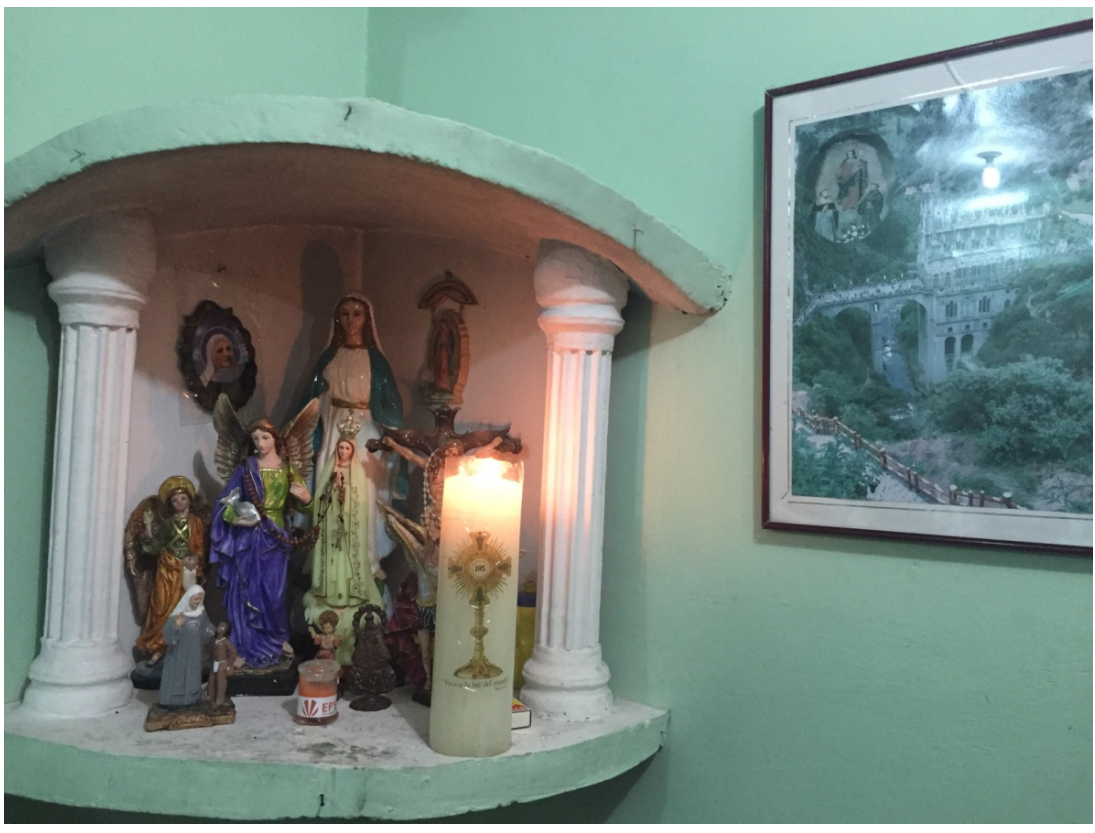

Fuente: fotografía tomada el 26 de agosto de 2016.

Es posible que la actitud de separación por parte de los nariñenses hacia la sociedad receptora se deba, más que a la búsqueda consciente de un posicionamiento hegemónico, a la lucha por recuperar lo conocido en medio del cambio, puesto que la migración implicó para los nariñenses ciertas pérdidas simbólicas como el cambio de rol de terrateniente al de obrero asalariado de la industria azucarera; este cambio le exigió al migrante un desarraigo con el territorio que alguna vez fue su sustento y también el espacio en el que configuró su identidad desde aspectos del "ser" como la religiosidad tan importantes para la institución de un sentido de lo nariñense. Es por esto que la conexión con el lugar de origen se vuelve aun más decisiva y se manifiesta, entre otras cosas, en el afán por recrear olores, sonidos, sabores y ritmos que tradicionalmente los han identificado.

La reproducción de olores, sabores y ritmos es una circunstancia que también se encuentra en la celebración de la fiesta de la Virgen de las Lajas, por como ella constituye un momento de re- construcción de una "cultura regional" como la nariñense y de una tradición que agrupa a los sujetos migrantes en el contexto migratorio que da lugar a un 
debate identitario alrededor de lo "comercial", lo "comunicativo" y lo "auténtico". Lo anterior tiene que ver con la aproximación a cada uno de los sentidos que tiene una celebración como la fiesta de la Virgen de las Lajas en Candelaria, los cuales atraviesan el sentido religioso, comercial, cultural y carnavalesco.

En ese marco, podemos intentar aproximarnos a cada uno de esos sentidos, intentando definirlos, pero considerando que, generalmente, no se presentan "en la realidad" como radicalmente separados, ya distinguidos, si no que, en gran medida, esa diferenciación es una operación analítica. Los sentidos más importantes son: el católico, el religioso no católico, el cultural secular (la nación como cultura), el carnavalesco, el comercial. (Grimson, 2005, p.72).

El sentido comercial y el cultural secular, también son predominantes durante la celebración de la fiesta de la Virgen de las Lajas, especialmente cuando se realizan las procesiones que recorren las calles más importantes de la sociedad receptora; lo cultural surge del espectáculo del baile de los nariñenses y tiene un lugar central en las procesiones, lo comercial se representa, en medio del lugar que tiene la religiosidad, de la venta de comida típica nariñense.

Imagen 27. Vitrina con comida típica nariñense ofrecida durante la noche de la procesión a la Virgen de las Lajas.

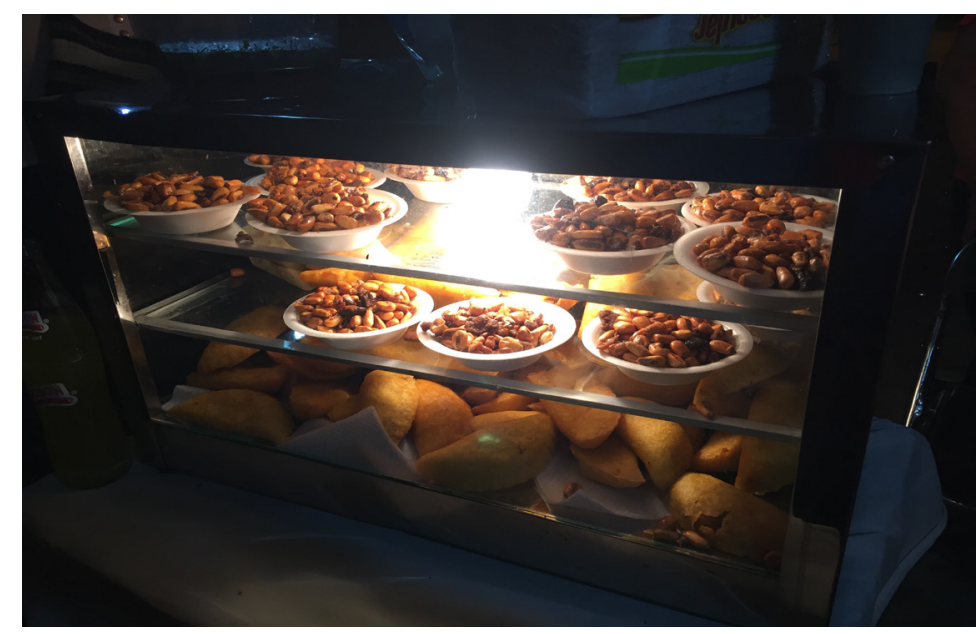

Fuente. Fotografía tomada el 16 de septiembre de 2016. 
Imagen 28. Fotografía en la que puede apreciarse el sentido cultural secular de las procesiones

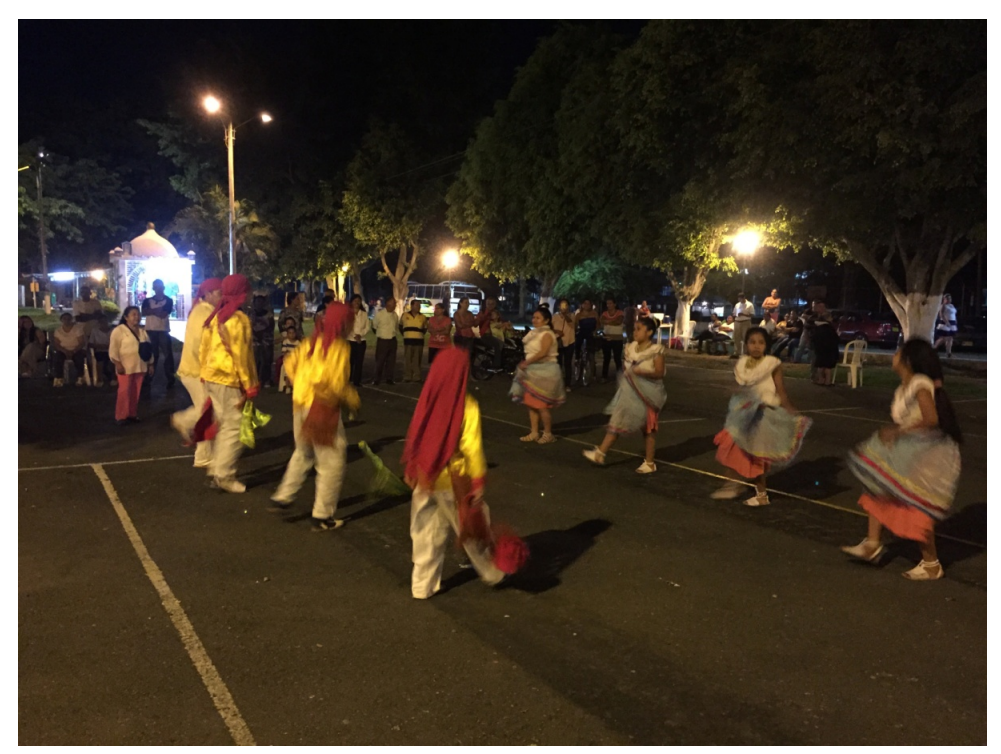

Fuente: fotografía tomada el 16 de septiembre de 2016.

El sentido comercial se adjudica a la fiesta de la Virgen de las Lajas como reproducción de distintos posicionamientos en la sociedad nariñense, que de una manera muy práctica como son las relaciones de carácter comercial, llega a establecer vínculos con el contexto migratorio actual.

\subsubsection{Carnavales de Blancos y Negros: diversión para nariñenses y candelareños}

El carnaval de Blancos y Negros también hace parte de la puesta en relación de la historia pasada con el presente de la migración; esta celebración es una estrategia de identificación cultural en la que se intersecta la construcción de una tradición que se asume como conocida para los migrantes en Candelaria, con las dificultades de una realidad, que al mismo tiempo, puede llegar a ser percibida como ajena, por los mismos nariñenses.

Para el año de 1989, posterior a la conformación de un comité organizador de la festividad, la alcaldía municipal emitió el decreto 004, en el que institucionalizó el 
Carnaval de blancos y negros como una fiesta de Candelaria. Carnaval que en Pasto, Nariño, fue declarado por la UNESCO en el 2009, como patrimonio cultural e inmaterial de la humanidad ${ }^{23}$ y que desde finales de la década de los 80 , se celebra en Candelaria, municipio del Valle del Cauca en donde sus habitantes cada año, un día del mes de enero, se pintan de blanco y negro entre las comparsas y los bailes típicos de Nariño, bailan con la amenización musical de grupos nariñenses originales y viven el carnaval, tal como si estuvieran en Pasto.

En la medida en que los migrantes se adaptan a la sociedad receptora desarrollan diversas estrategias para vincularse, las cuales, tal como se ha venido describiendo a lo largo de este escrito, van desde adquirir un trabajo y una vivienda, hasta la constitución en el nuevo contexto urbano de lugares y prácticas de identificación cultural como el Carnaval de Blancos y Negros. Esta celebración llama especialmente la atención por la forma en que los nariñenses acostumbran llevarla a cabo, a saber, se maquillan el rostro con pintas de cosmético negro y con talco, a fin de representar la igualdad étnica cultural entre quienes antiguamente eran llamados negros -esclavos- y blancos -a quienes se identifica con los conquistadores-.

\footnotetext{
${ }^{23}$ En el 2010, después de que la UNESCO declarara el Carnaval de blancos y negros como patrimonio cultural e inmaterial de la humanidad, el Ministerio de Cultura de Colombia lo incluyó en la lista representativa de patrimonio cultural inmaterial y aprobó un plan especial para la salvaguardia de esta festividad.
} 


\section{Imagen 29. Personas en el municipio de Candelaria pintándose de blanco y negro en la} celebración del Carnaval de blancos y negros.

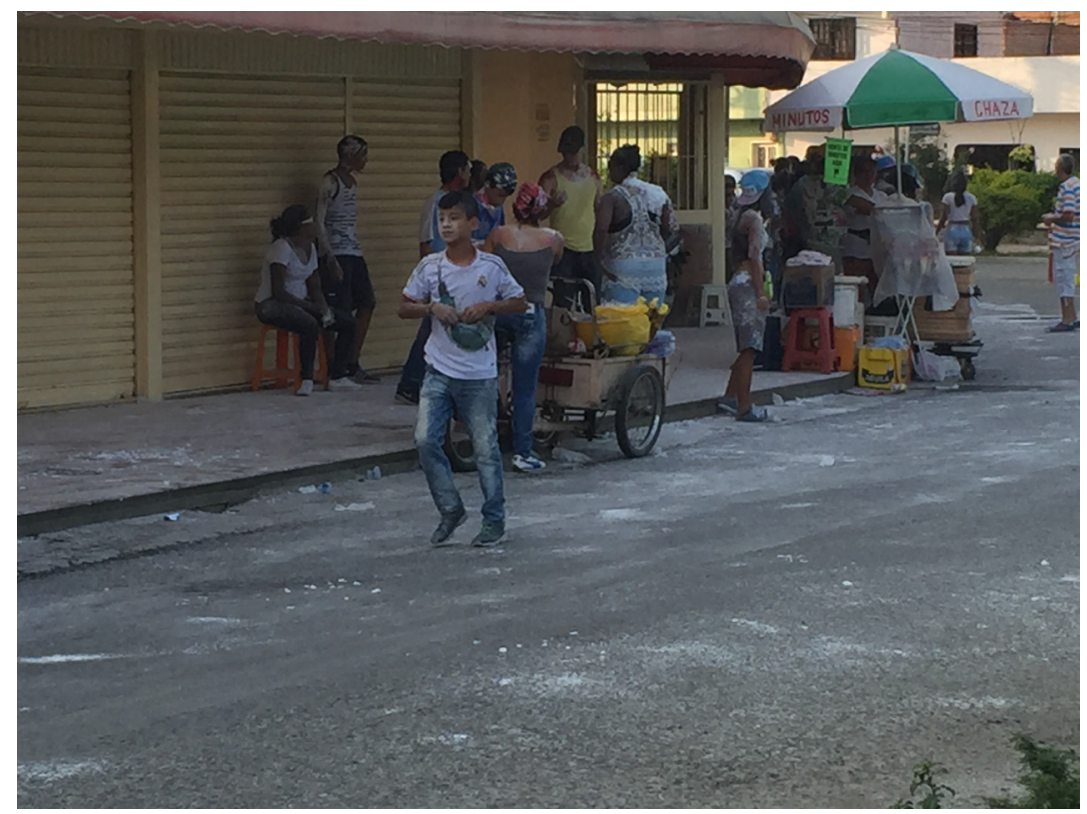

Fuente: fotografía tomada el 23 de enero de 2016.

El asunto es que esta práctica de maquillarse el rostro y de utilizar talco y pintura negra también para pintar a los demás paisanos, ha dado lugar a tensiones y enfrentamientos en Candelaria, en cuanto constituyen prácticas que incluyen el tacto y otros canales de comunicación no verbal, que no siempre son bienvenidos por la sociedad que recibe. En el relato de Gabriel Pascuasa es importante resaltar que el primer Carnaval que se celebró en Candelaria "fue todo brusco", pues casi que se celebró al modo de las costumbres de la gente valluna, muy diferente a como, según él, se celebra cada año en Nariño, esto es, con pausa:

ya venía la alcaldía a pedir incluso que el primer Carnaval me acuerdo tanto yo, lo apoyó el municipio, esa vez fue todo brusco, a las costumbres de aquí pues de la gente valluna ¿no? porque nosotros a la costumbre nariñense todo se hace con pausa, sin problemas esa vez, pues me acuerdo tanto la alcaldía por el lado de por allá, nos agarró la gente en los barcos cosméticos y unos paisanos de acá del Valle que les decimos los caleños, no les gustó y se formó la tremenda pelea al frente y entonces de ahí para allá, la gente ya se 
fue organizando más, lo mismo el alcalde del municipio, los empleados ¿no? dando explicaciones que fueran los Carnavales, que no eran para asunto de peleas y que no, al que no le gustara eso que no salieran. Entonces ya así no había problemas pero que el que le gusta disfrutar y que lo hiciera entonces si salía y a los que no les gustaba no salían y ahí se fueron ya tanto la mayoría que tenían en eso y ahora parejo ya participan. (entrevista personal, Gabriel Pascuasa, 2016)

Para los nariñenses la celebración de los carnavales significa la construcción de un espacio que ofrece un ámbito de confianza, de recuerdos compartidos, de problemas comunes y también de formas de diversión. Los canales de comunicación no verbal que recrean los carnavales y que se crean como vías para mantener el contacto con el mundo perdido son importantes si se mira desde las situaciones de interculturalidad a las que da lugar: la celebración de los carnavales de Blancos y Negros origina circunstancias en las cuales dos grupos -nariñenses y candelareños- producen identificaciones diferentes $\mathrm{y}$, de esta manera, construyen códigos comunicacionales imbricados con modos de posicionamiento distintos; es por esto que los carnavales, por constituir una de las estrategias de identificación, atraviesan diversas etapas en las que pueden llegar a convertirse en escenario de conflictos, malos entendidos, negociaciones y acuerdos.

En el relato que se muestra a continuación, construido por la candelareña Clara Díaz, pueden rescatarse los momentos a los cuales se hace alusión más arriba, sobre los conflictos, malos entendidos, negociaciones y acuerdos que atraviesa cualquier proceso de identificación puesto en marcha por la población migrante a través de estrategias que van posicionando sus prácticas y tradiciones en la sociedad que recibe.

Al principio había mucha pelea, inclusive llegó a haber hasta muertes, porque el que iba a trabajar bien y le echaban eso, se enojaba y respondía muy feo, pero eso a medida de que también lo fueron legalizando, lo fueron dando, y le fueron dando sus espacios, por ejemplo, que fueran en tal parte, los mandaron a determinado sitios, allá iban e íbamos porque yo también iba porque a mí me gusta vivir esa parte, no solo lo mío sino lo de los demás...eh los juegos, por 
ejemplo la chaza, es un juego hermoso para ellos y que si uno se coloca a verlos, pues se emociona también y grita como los otros. (entrevista personal, Clara Díaz, 2016)

Es así como los nariñenses van estableciendo formas de reivindicar sus propias propuestas de inserción en Candelaria, desde su particularidad sociocultural, buscan igualdad de derechos y legitimar sus tradiciones por vías no solo simbólicas (reproduciendo el pasado por medio de situaciones de encuentro y negociación cotidianas), sino también por vías legales, las cuales incluyen la participación de la administración pública candelareña para otorgar los permisos que se requieren para dar paso a las celebraciones y ferias, así como para informar a la comunidad acerca del sentido que acarrean estas prácticas. Además de la institucionalización de la fiesta de la Virgen de las Lajas, en 1988 se institucionalizó también el carnaval de Blancos y $\operatorname{Negros}^{24}$ que en sus inicios convocaba la participación de las familias nariñenses en comparsas preparadas con la utilización de elementos, prácticas propias y danzas típicas de Nariño. Carnaval al que actualmente confluye la sociedad candelareña, habitantes del mismo Nariño, y personas de municipios del Valle del Cauca aledaños a Candelaria en un evento que año tras año, se celebra en enero con la participación de la reina del carnaval en un recorrido por las calles principales del municipio que antes culminaba también en el barrio Panamericano y que hace aproximadamente tres años, tiene lugar en la cancha de chaza o en el polideportivo del municipio.

El relato de Milton Pozos, que enseguida se ofrecerá, bien puede comprenderse como un relato de integración entre ambos grupos culturales, por la forma en que muestra la inserción de los candelareños en la cultura nariñense. Como consecuencia de ello los

\footnotetext{
${ }^{24}$ Los orígenes de este carnaval (Celebrado en Nariño durante la primera semana de enero y celebrado en la misma época por la colonia nariñense en Candelaria) están ligados a las fiestas andinas ancestrales, a las que posteriormente se integraron tradiciones europeas y africanas. El 5 de enero, la población de esclavos negros celebraba "un día de libertad" y se lanzaba a las calles a revivir su música africana y en un gesto que expresaba su anhelo de igualdad, tiznaban con carbón a los blancos que encontraban a su paso. La alegría de la fiesta que desde entonces se le llamó la "fiesta de los negritos" contagió a los blancos que en muchas oportunidades participaron en la celebración. A finales del siglo XIX nuevos sectores sociales como el campesinado y los artesanos se integraron al carnaval para jugar un papel fundamental en la producción manufacturera; en este contexto aparece el 6 de enero como "el día de los blanquitos", día en que los artesanos de las carrozas participan desde 1920 con toda su creatividad y su trabajo manual plasmados en grandes esculturas de papel (Alcaldía municipal de Pasto, 2010)
} 
migrantes han instituido un sentido de colectividad en Candelaria a partir del cual los candelareños se han venido vinculando gradualmente y establecido un diálogo con lo nariñense; un diálogo que también está atravesado por la aceptación y la inserción en los diferentes sentidos polisémicos de las fiestas -en este caso de los Carnavales-, como el comercial, que puede verse en la venta de comida típica nariñense como el cuy asado, el puerco horneado, el maíz tostado y la mazorca, y en el sentido cultural secular característico de los bailes típicos de Nariño.

la expresión de los carnavales se dio por un grupo de personas que querían hacerlos, lo que hemos constituido los carnavales allá alrededor del año 2003, la administración municipal, tiene una participación directa y es la que ha tenido hasta ahora, o sea los carnavales se empiezan a realizar bajo la administración, valga la redundancia, de la alcaldía, pero aparte está adscrita la secretaria de educación, entonces tiene un factor muy importantes que es recursos, recursos que uno logra mediante el acompañamiento de toda la parte administrativa de los alcaldes. Eso se ha venido desarrollando, empezamos desde el 2003, en el 2008 cuando llego como a ocupar una curul al concejo y cuando la UNESCO ya había determinado que los carnavales eran patrimonio intangible de la humanidad, mediante una proposición y un acuerdo se integra a la expresión de los Carnavales de Negros y Blancos de Candelaria, como patrimonio cultural del municipio de Candelaria, ¿eso qué permite?, ya no solamente es una intención de las administraciones a acompañar, sino que esa expresión, hace parte de la cultura candelareña, y por lo tanto, independiente de quien sea el alcalde, con que raíces o con que afinidades, pues le den cumplimiento y pertenezca a la agenda a de la expresión cultural de los Carnavales de Negros y Blancos. (entrevista personal, Milton Posos, 2016) 
Imagen 30. El cuy, comida típica nariñense ofrecida en las carpas dispuestas en la celebración del Carnaval de Blancos y Negros realizado en Candelaria, Valle del Cauca.

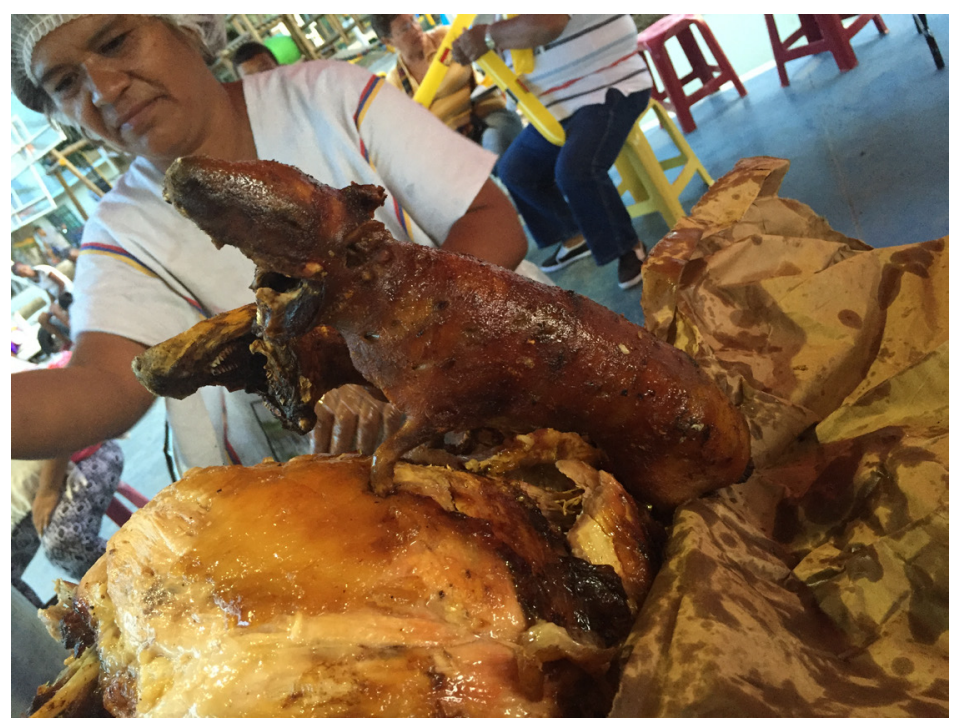

Fuente: fotografía tomada el 23 de enero de 2016.

Imagen 31. Bailes típicos de Nariño presentados en la celebración del Carnaval de Blancos y Negros realizado en Candelaria.

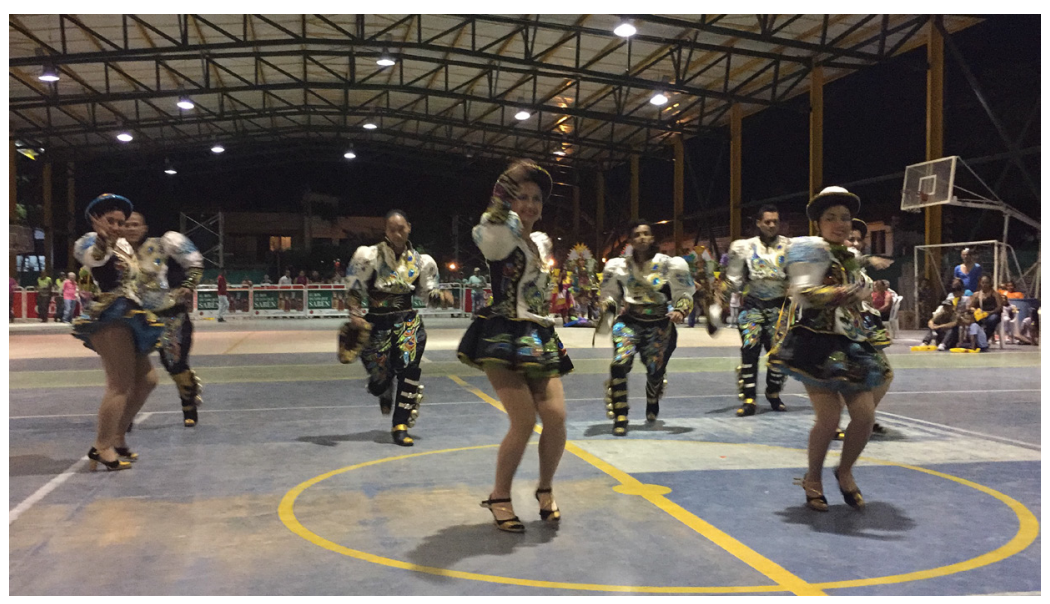

Fuente: fotografía tomada el 23 de enero de 2016. 


\subsubsection{La chaza: el tenis andino}

El hecho de sentirse nariñense en Candelaria, hace parte del proceso mediante el cual los sujetos migrantes luchan por mantener su identidad cultural de origen frente a las pérdidas físicas y simbólicas que acarrea la migración. Sin duda, este proceso abarca otro tipo de prácticas y tradiciones cuya reivindicación permite la continuidad con el pasado y con estilos de vida, tales como el deporte, si se tiene en cuenta que los nariñenses además de ser trabajadores, ahorrativos y religiosos, también son deportivos y sobre todo enérgicos cuando se trata de jugar chaza.

La chaza es un juego similar al tenis de campo que se juega en una cancha de cemento o de tierra, con mayor dimensión y sin una red visible que separe a los jugadores ubicados a lado y lado. Este juego, autóctono de la frontera colombo-ecuatoriana, ha sido practicado de manera tradicional en un departamento como Nariño y con la migración de esta comunidad al Valle del Cauca, llega el juego a Candelaria en donde se practica aproximadamente desde mediados de la década del 60.

Los nariñenses practican la chaza en dos modalidades, la de mano en la que utilizan la parte interna del antebrazo para darle a una pelota de caucho macizo, y la otra la de bombo, jugada con una especie de raqueta forrada con cuero de vaca templado. En ambas modalidades, el juego implica fuerza y precisión para enviar la pelota al otro lado de la cancha. Como es uno de esos juegos que no todas las personas puede realizar, especialmente por el estado físico que debe tenerse para participar en él, los habitantes de Candelaria lo recibieron con curiosidad y también con admiración, pues no sabían qué era lo que hacían los nariñenses como Manuel Alberto Díaz para practicar este juego:

En ese tiempo me miraban jugar y por verme jugar, paraban carros y motos y entraban a mirarme y decían, este señor si juega sabroso juepucha, decían, ¿por qué juega tan bien?, y decían, porque no bornea el brazo, porque yo nunca borneaba brazo, no, yo apenas llegaba, me paraba y apenas era así, pero eso es técnica y práctica, fuerza técnica y práctica ... y se quedaba la gente mirando esa cancha por lado y lado viéndome jugar, y había como cinco jugadores menos entre de florida y unos de allá de Cerritos, y veníamos 
y nos poníamos a jugar en ese tiempo y ya acá habían siete jugadores. (entrevista personal, Alberto Díaz, 2016)

La cancha "en ese entonces era en tierra" y estaba ubicada en donde hoy se encuentra el polideportivo del municipio. Algunos nariñenses recuerdan que dejaron de jugar allí y se pasaron al costado de donde está ubicada la cancha actualmente. De ahí "los mandaron" para detrás del barrio Santa Ana y posteriormente cerca de donde están ubicados hoy día.

La chaza empezó por ahí en los años 60, 66, ahí fue que se empezó. En Candelaria fue un proceso muy largo, pero por la persistencia de nosotros se han dado las cosas como están en el momento, porque entonces no era todo eso construido como está ahora $[\ldots]$ eso era un potrero, donde era el parque recreacional, en el polideportivo ahí empezamos a practicar el deporte. (entrevista personal, Alpala y Rosalba, 2016)

La chaza es percibida por los nariñenses como una posibilidad no solo de "entretenerse un rato" sino de encontrarse con amigos, un espacio de esparcimiento que aunque es concurrido todos los días después de las dos de la tarde, es especialmente habitado los sábados y domingos, días en los que funcionan las carpas en donde ponen música, venden cerveza, fritanga y alimentos propios de los nariñenses.

Pues por lo menos, ahorita lo más tradicional aquí en Candelaria por lo menos, para nosotros es la chaza, porque nosotros, y carnavales, porque nosotros, mire usted por lo menos, esa cancha de chaza ahí llega todo el mundo, y ahí estamos con todo el mundo ahí, ahí no se le escoge, el que quiera jugar juega tranquilo, se divierte. (entrevista personal, Grupo Chaza, 2016) 
Imagen 32. Empanadas nariñenses preparadas con harina de yuca. Ofrecidas para la venta en la cancha de chaza.

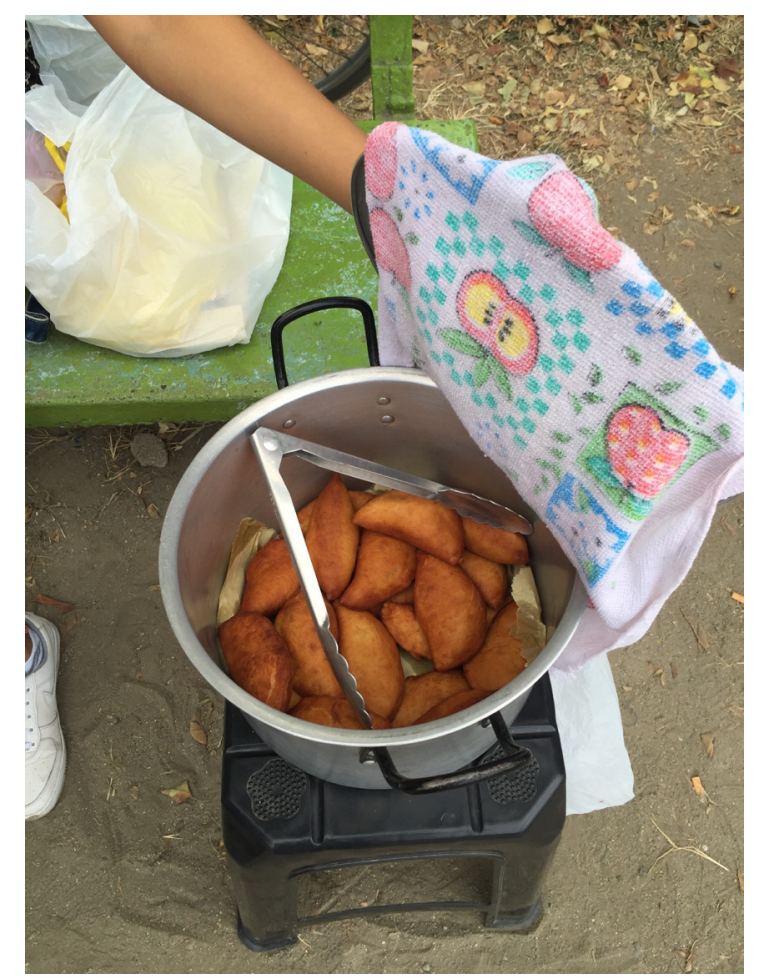

Fuente: fotografía tomada el 14 de agosto de 2016.

El reconocimiento entre dos grupos culturales distintos es un elemento que surge en medio del juego de la chaza entre los nariñenses que lo practican y los candelareños que disfrutan viendo a nariñenses como Manuel Alberto Díaz que "no bornean el brazo" para pegarle a la pelota. En este orden de cosas, la chaza fue un espacio en el que se configuró un entramado de referencias comunes, necesario para la construcción de un sentido del nosotros y de los otros, el cual empieza a desarrollarse con la apropiación del sentido de la vida cotidiana que abarca las relaciones interpersonales entre ambos grupos culturales. Dichas relaciones dan cuenta de las negociaciones y los acuerdos que pueden surgir en medio de malentendidos y conflictos, si se tiene en cuenta que la cancha donde es practicada la chaza se fue instituyendo en un lugar de diálogo, de identificación, y si se quiere, de recomposición del territorio regional de Candelaria desde la identificación de los nariñenses y candelareños. Esta identificación propició la construcción de sentidos 
frente a un nuevo espacio que ya comenzaba a ser compartido por ambas culturas: por un lado, los nariñenses que lo llevaron consigo al Valle, al constituir uno de los elementos tradicionales de su cultura y un momento crucial para establecer contacto con el lugar de origen; por otro lado, los candelareños que lo recibieron y lo reconocieron con curiosidad, pero también con admiración.

No, había mucha gente que venía a ver como hasta ahora, hay gente que viene de otra parte de ahí mismo lo llaman a uno y le dicen: vea ese juego cómo se llama, cómo es esa contabilidad que cuentan, apuestan plata, qué apuestan y si apuestan por recreación cualquier cinco mil pesos, hay bastante gente, los de la mano, los mayores que ellos juegan sino mil pesitos y antes era menos, no más 50 pesos y ahora ya como que juegan de a dos mil ellos. (entrevista personal, Pedro Castro, 2016)

Imagen 33. Nariñenses jugando a la chaza en la cancha de Candelaria, Valle del Cauca.

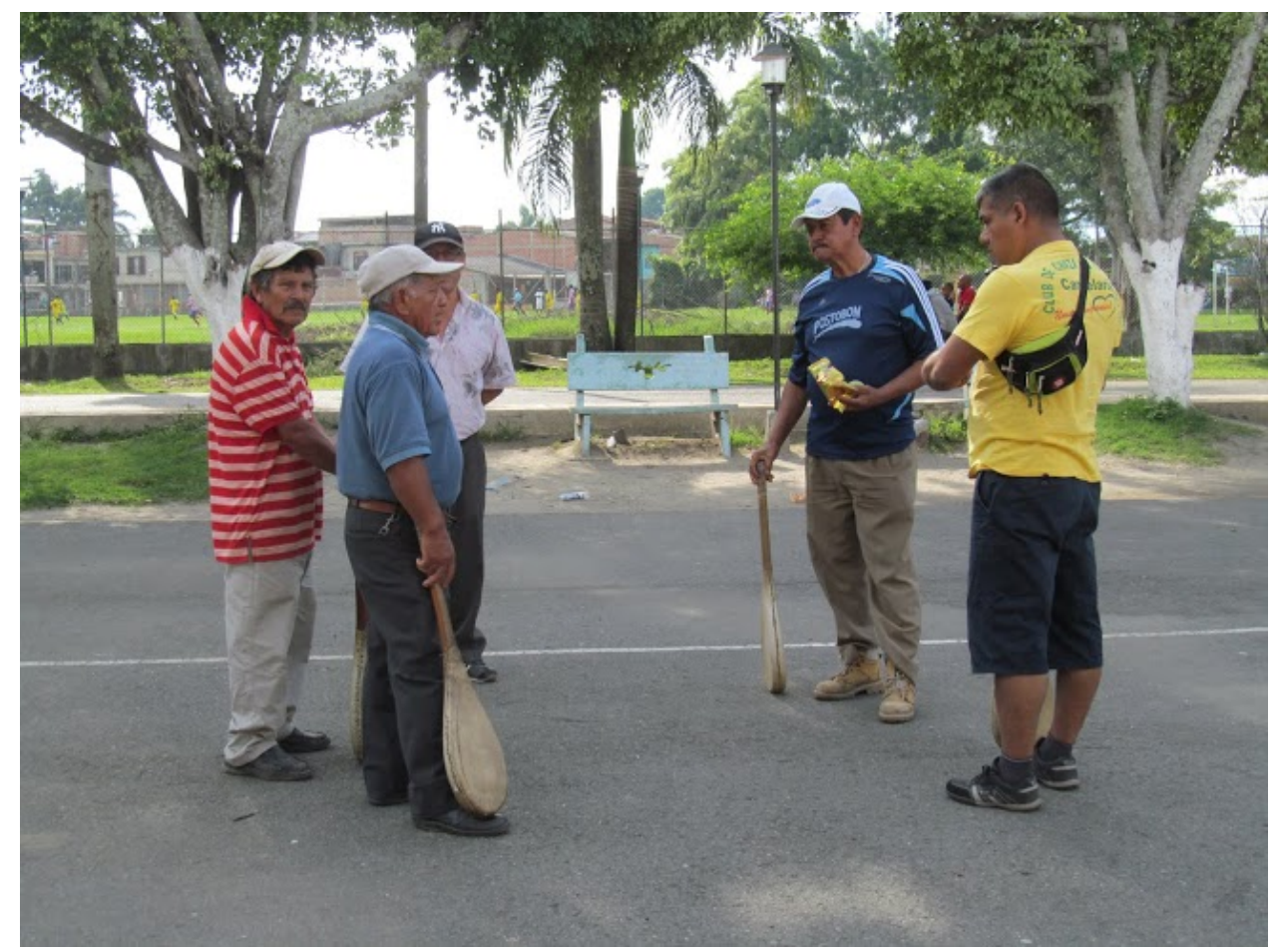

Fuente: fotografía tomada en febrero de 2014. 
En el relato de Víctor Mondragón es importante resaltar que el reconocimiento otorgado a los nariñenses y a una de las prácticas que configura de manera especial su identidad cultural, como es el juego de la chaza, se hizo de manera gradual y no espontáneamente, debido a las fases o momentos que atraviesan las estrategias de identificación cuando son puestas en marcha por los sujetos migrantes para reivindicar su cultura. Estas fases van desde disputas hasta negociaciones que, para el caso que se está analizando, hacen alusión a la competencia que se generó entre el fútbol y la chaza por obtener un papel hegemónico dentro del ocio de los nariñenses y de los candelareños.

Bien, digamos que inicialmente por aquello de que se tenían espacios para el deporte como era el futbol, digamos que la llegada de la chaza empezaba como a competir un poco con el futbol, pero poco a poco ellos fueron generando un especio propio para ellos, ya que inicialmente quedaba en el Panamericano y luego se va a trasladar al frente donde queda Santa Ana. Allí van a tener un espacio propio de reconocimiento por la cultura de la chaza que ha tenido pues el nombre y que ha tenido competencias con comunidades como la de Palmira y El Cerrito, ya donde se competía también en comunidades de nariñenses que estaban asentadas en Palmira y están asentadas en El Cerrito, entonces ellos van a compartir un poco de ese legado. (entrevista personal, Víctor Mondragón, 2016)

En este mutuo compartir de espacios e identidades, la cancha de chaza fue un punto de encuentro de identidad y de diferencias, ya que no solo fue utilizada para la práctica del tan mencionado juego nariñense, sino también para otro tipo de actividades realizadas por los candelareños; fue así como ambas culturas pudieron compartir la diferencia en un solo espacio que en el contexto migratorio originó una unidad intercultural, que desde el punto de vista de la configuración de las identidades en fronteras, favoreció el posicionamiento de la colectividad nariñense en Candelaria, no solo con base en su historia, sino también en función de las relaciones sociales que tejió en y con la sociedad receptora.

Hoy día, la cancha es un escenario que tiene el encanto de ser, no solo el espacio para jugar a la chaza, sino que se ha convertido en un sitio de encuentro, de fiesta 
popular, en el espacio en donde se convocan las mujeres para jugar al tenis a las 6:00 de la mañana, más tarde, a eso de las 9:00, llegan los adultos mayores que hacen parte del grupo Vida, a realizar sus aeróbicos; es un espacio concurrido que se presta también para que los niños patinen, en la tarde los nariñenses juegan a la chaza y en la noche se juega al fútbol.

Es un escenario multifuncional cuyo valor está atribuido por esta característica, por ser un espacio en donde algunos se encuentran a jugar rana, otros a jugar naipe y otros se encuentran en las casetas para escuchar música, observar el cotejo y compartir una cerveza. En general, se convirtió en un espacio de encuentro para el municipio, en un lugar en donde los bordes de la cancha se convirtieron en la posibilidad del encuentro de quienes juegan naipe, tejo, de la señora que vende la chicha o de la señora que vende el helado de paila.

Cabe señalar que la construcción de este espacio de encuentro, aunque contó con el apoyo del municipio, se logró también, y nuevamente, gracias al trabajo en minga por parte de los nariñenses que iniciaron un proceso mancomunado para poder tener su cancha justo en un momento en el que no tenían tanto reconocimiento como colectividad. Este proyecto, generó también la necesidad de organizarse con personería jurídica, dando lugar a lo que hoy, 40 años después, es La Junta de los Fundadores del Club de Chaza del municipio de Candelaria. 
Imagen 34. Minga para la construcción de la cancha de Chaza

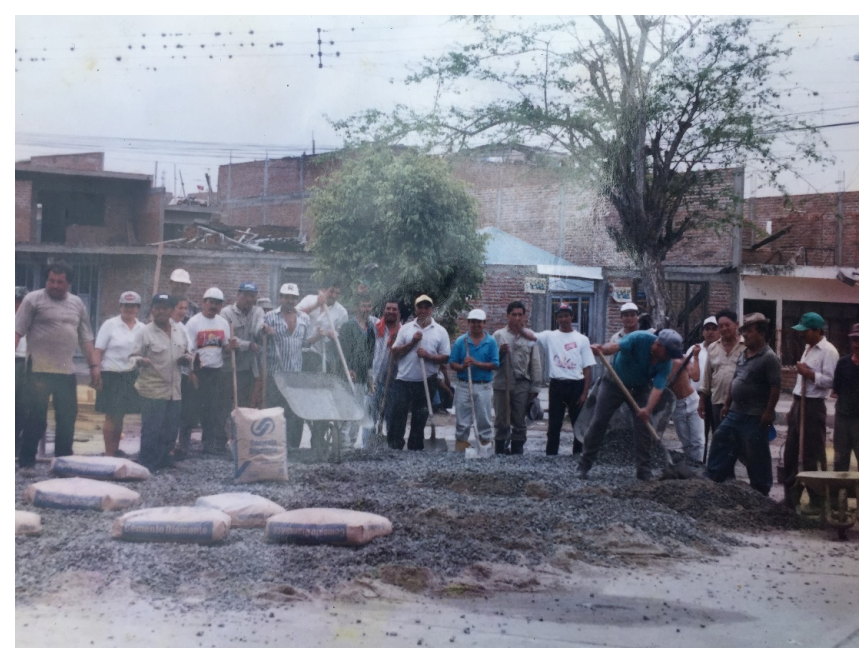

Fuente: fotografía tomada el 22 de julio de 2016 del álbum personal de José Alpala.

Imagen 35. Nariñenses espectadores del juego de la chaza en Candelaria.

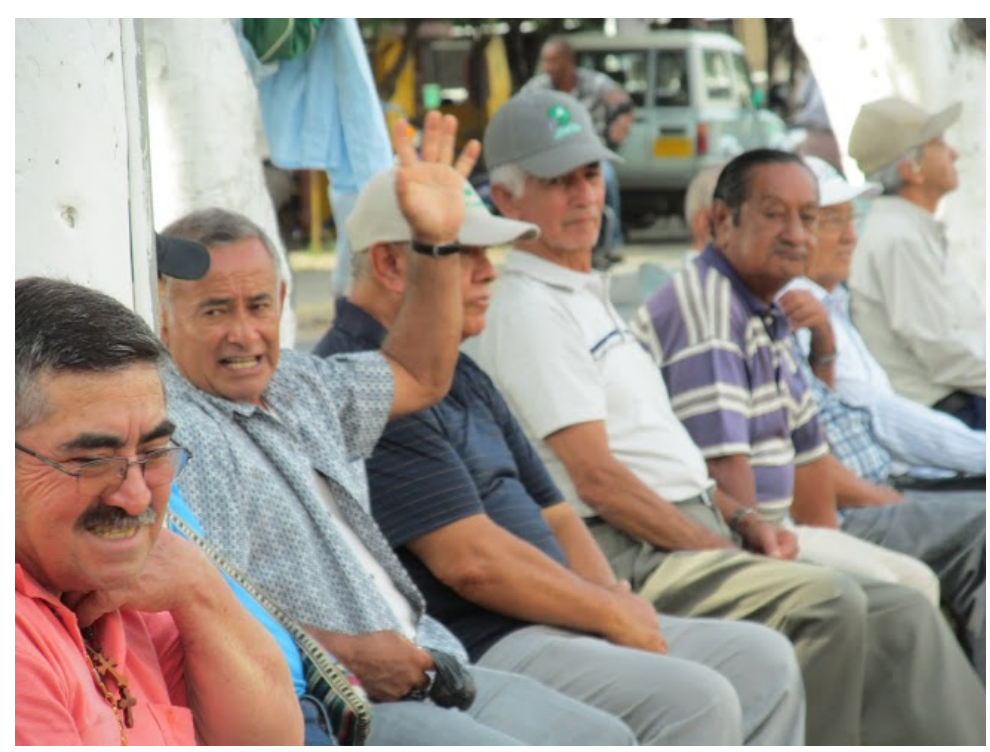

Fuente: fotografía tomada en enero de 2015. 


\section{Imagen 36. Cotejo de chaza en Candelaria, Valle del Cauca.}

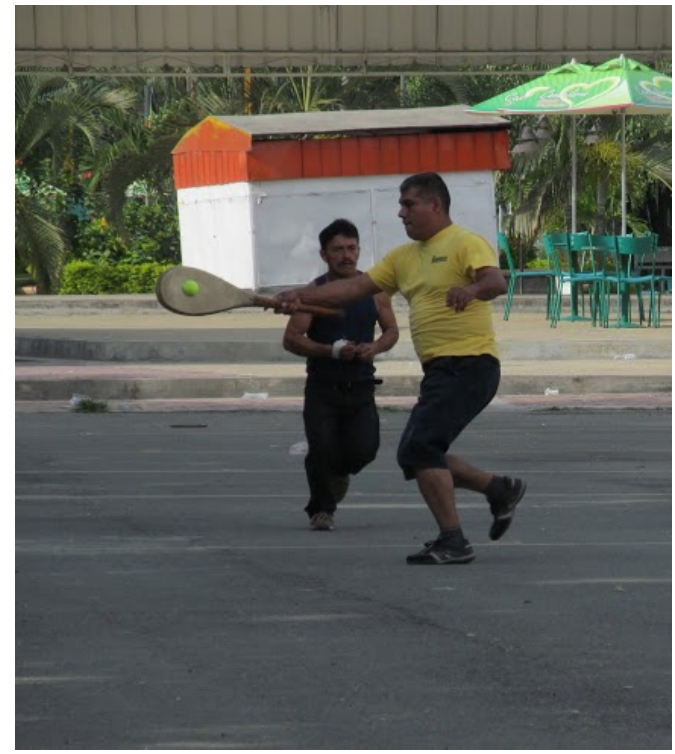

Fuente: fotografía tomada en Septiembre de 2015.

En este sentido, es importante destacar que dentro de este proceso de inserción de la chaza como estrategia de identificación cultural en la sociedad receptora, la forma en que los nariñenses institucionalizaron el juego por medio de la conformación de la personería jurídica, permitió entre otras cosas, obtener un acercamiento a los distintos proyectos de organización de la colectividad. Las organizaciones religiosas y deportivas se establecen por iniciativa de los sujetos migrantes para reunir grupos de resientes que incentiven y desarrollen tareas de mejoramiento, de negociación con ámbitos administrativos y empresariales con el fin de conseguir diferentes objetivos (Grimson, 2005), los cuales abarcan la obtención y legitimación de un espacio para llevar a cabo una práctica tan nariñense como el juego de la chaza.

La personería jurídica fue indispensable para institucionalizar en Candelaria el juego de la chaza; a este propósito, el nariñense Pedro Castro recuerda que la conformación de la personería jurídica les costó 900 pesos a quienes fueron los fundadores del juego: Hernando Bernal que era el presidente, Rodrigo Montilla, Fidencio Montilla, Guillermo Álvarez, Ricardo Sánchez y Francisco Guerrero. Algunos de los 
fundadores "ya son muertos" como lo relata Pedro Castro, solo que no sabe exactamente quiénes, porque la memoria se ha ido borrando con el tiempo:

no me acuerdo de más, estaba buscando un papel a ver si los tengo por ahí en un arrume de papeles, pero todos los quemé (...) la memoria se fue ahí y todo, y dije, acabé con todos los que anduvimos en ese tiempo. (entrevista personal, Pedro Castro, 2016)

No obstante el tiempo y las pérdidas que inevitablemente vienen con él, nariñenses como Pedro Castro han conservado recuerdos sobre los momentos que vivieron en torno a la chaza; la remembranza de estos momentos constituye una forma de mantener vivo el lugar de origen en medio de lo desconocido y un esfuerzo por otorgarle no solo un sentido práctico, sino también simbólico a las tradiciones y costumbres nariñenses en Candelaria.

En particular, Pedro Castro evoca en su relato las olimpiadas de chaza que jugaron los nariñenses cuando conformaron la personería jurídica, "a nivel de ingenios, hubo unas olimpiadas y entonces allá anduvimos en Florida, en Palmira, en Candelaria vinieron a jugar, como a hacer un encuentro". Las olimpiadas las realizó un valluno que se interesó por vincular el juego de la chaza a otras prácticas más típicas de Candelaria como el fútbol y el sapo, "había de todo lo que se tratara de deportes, todo eso, hasta mujeres jugando sapo y eso quedaron de campeonas las de aquí, de Palmira quedaron los hombres".

Con actividades como estas, se inculcaron valores y tradiciones en Candelaria como parte de la continuidad que los sujetos migrantes establecieron con el lugar de origen; en realidad la constitución legal de un espacio como la cancha de chaza para desarrollar esta práctica, fue un esfuerzo mancomunado que realizaron los mismos fundadores del juego para llevar a cabo las olimpiadas y demás torneos que se celebraron en otros lugares del Valle del Cauca, "como teníamos juntas, pusimos de a \$200, la colaboración de cada mes, unos daban de a 50 centavos para lo que hacía falta"; fue así como nació la chaza en Candelaria, 
Tenemos esto pero por nosotros mismos y nunca vamos a dejar la tradición de venir aquí, aquí a veces no hay juego, venimos estamos aquí sentados, cómo ve usted eso (...) uno lo siente propio, uno prácticamente en la casa, uno sentado en la casa le da sueño, viene por acá y uno conversando con los amigos, todo eso lo distrae. (entrevista Grupo chaza, 2016)

Imagen 37. Integrantes del Club de Chaza ubicados de manera intencional de espaladas al santuario a la Virgen de las Lajas ubicado a un costado de la cancha de chaza.

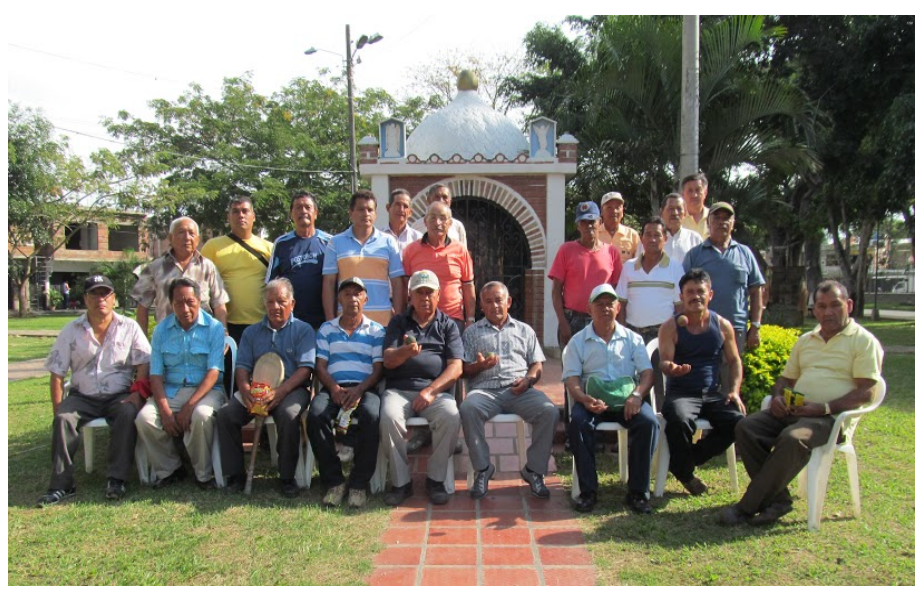

Fuente: fotografía tomada en marzo de 2014.

\subsubsection{Las mingas: trabajar, comer y tomar juntos}

La idea de comunidad, tal como se ha mencionado a lo largo de este análisis, es uno de los elementos pertenecientes a la cultura nariñense que dentro del proceso migratorio de Nariño a Candelaria tuvo, y en la actualidad tiene, varias formas de expresión dentro de las cuales se incluyen la práctica de costumbres como el juego de la chaza, la celebración de la virgen de las Lajas, el Carnaval de Blancos y Negros y la minga.

Cuando los nariñenses llegaron a Candelaria, luego de haber conseguido un empelo en el corte de caña que les permitiera comprar un lote para tener vivienda, comenzaron a construir en comunidad sus casas con material de ladrillo y concreto. La construcción de las viviendas de los nariñenses a partir de la minga, salta a la vista por 
hacer parte de una de las acciones cuyo sentido y fundamento se encuentra en la idea de comunidad y solidaridad; esta idea atraviesa todo el sentido de la práctica en mención, en tanto su naturaleza es la de llevar a cabo una labor en compañía de los paisanos, no importa cuántos sean, entre mayor sea el número, mucho mejor, porque así pueden disfrutar con más personas de la comida y la bebida que suelen hacer las mujeres nariñenses para alentar a sus esposos en esta labor.

Si bien la minga no fue un escenario de observación ni de exploración considerado inicialmente en el diseño metodológico de la investigación, comenzó a serlo en la medida en que fue apareciendo de manera reiterada en los relatos tanto de candelareños como de nariñenses, bien cuando los primeros hacían referencia a ellas con admiración y asombro, o bien cuando los mismos nariñenses las reconocían como una de las estrategias que implementaron para ayudarse entre ellos a mejorar sus viviendas en Candelaria, tal como lo hacían en sus pueblos antes de la migración.

Así, las mingas en Candelaria emergen como una práctica propia de los nariñenses que permite, además del encuentro entre ellos y sus familias, un trabajo mancomunado para facilitarle la construcción y mejora de las viviendas a los paisanos que poco a poco habían estado recogiendo materiales de construcción con el objetivo de ponerle a sus casa un mejor techo, "tirar la plancha", hacer el segundo piso y hasta el tercero. La construcción de las casas de los nariñenses con material de ladrillo y concreto, fue un trabajo conjunto entre cada uno de los nariñenses que llegó a Candelaria para continuar con el proceso de urbanización del municipio. Cuando algún nariñense decidía comprar un lote para construir su casa, invitaba a todos sus amigos, parientes y familiares más próximos para hacer el trabajo en minga, es decir, en comunidad; los nariñenses que eran convocados por algún paisano suyo, decidían prestarle su ayuda y colaboración, más que por la comida y la bebida ofrecida en contraprestación a sus servicios, por el mutuo compartir que implicaba esta tradición nariñense.

En uno de los relatos construido por Pedro Castro en torno a la minga, se ve cómo muchas veces la construcción de las viviendas a través de este método tradicional, traía 
problemas porque se acababa el material, y en consecuencia, porque había que pedirle a los paisanos un esfuerzo de más hasta culminar la actividad:

Había que darles cualquier desayuno, pero es que era jodido eso aquí, estuvieron como hasta las dos de la tarde, eso fue mejor dicho, como era grande la plancha, quedó grande y se nos acabo el material, al agua se nos abastecía, había que esperar a que se llenara una tina y luego seguir revolviendo. Entonces eso nos perjudicó también bastante y hasta que terminamos ahí la primera quedamos y después, pues siempre nos amanecimos tomando cualquier cervecita por ahí en uno o en otro lado, va con sus canastas de cerveza, todos sus amigos decían, no es la primera plancha que echamos aquí, contentos todo el mundo, eso bastante gente. Gracias a Dios se dio eso. (entrevista personal, Pedro Castro, 2016)

\section{Imagen 38. Nariñenses trabajando en minga.}

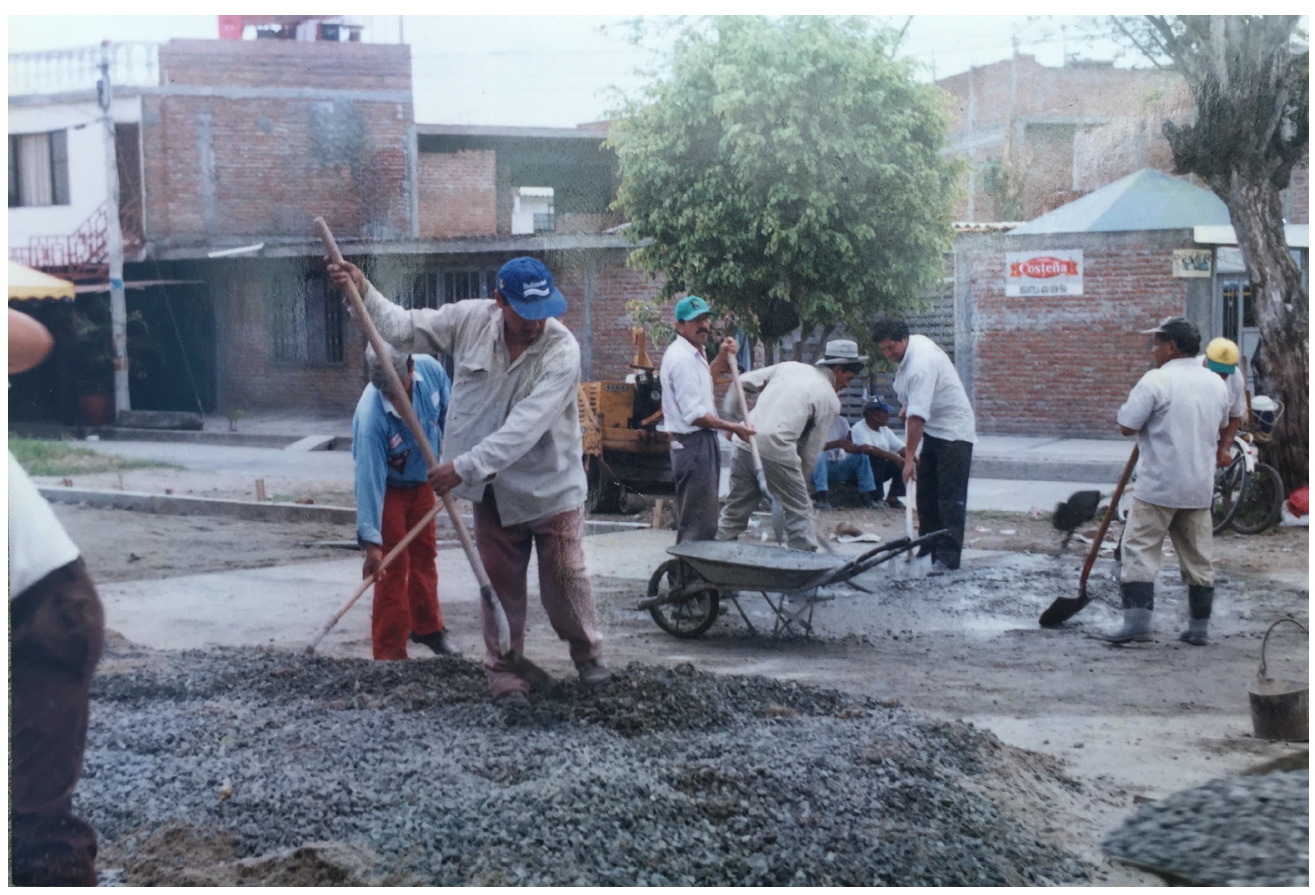

Fuente: fotografía tomada el 22 de julio de 2016 del álbum personal de José Alpala.

Aunque la tradición de las mingas, la mayoría de las veces le exigía a los nariñenses hacer un esfuerzo más allá del previsto por ellos, esto no era impedimento 
para hacer de ese momento de recreación de lo nariñense y de conexión con el mundo perdido, un espacio de diversión, y por qué no, de ocio formativo. El ocio, entendido como el tiempo libre del cual se dispone para enriquecer el cuerpo y el espíritu después del trabajo, era muy bien aprovechado por los nariñenses cuando lo utilizaban para construir sus casas y las de sus paisanos en miga: esta afirmación adquiere sentido si se comprende que la tradición de la mingas no solamente significó para los sujetos migrantes una estrategia de identificación con el lugar de origen, sino también y sobre todo, una forma de continuar desarrollando en la sociedad receptora uno de los valores y rasgos identitarios que transversalizan todas sus prácticas y costumbres, a saber, el sentido de comunidad y solidaridad.

Este sentido solidario se originó en el proceso del trabajo agrícola mancomunado que el nariñense realizó en su territorio con el apoyo de sus familiares más próximos como padres y abuelos; más tarde, vemos que este mismo sentido se expandió en Candelaria cuando los nariñenses tejieron redes de apoyo para adaptarse a este municipio obteniendo un empleo y un lugar donde vivir; finalmente, el sentido de solidaridad y comunidad que desde siempre orientó las acciones de los nariñenses, fue crucial para que dicha población desarrollara las estrategias de identificación que lo mantienen en contacto con el pasado, a fin de perpetuar los estilos de vida a los cuales estaba acostumbrado y tenía arraigados.

Es por esto que el ocio o, lo que es lo mismo, el tiempo libre del cual dispusieron los nariñenses en Candelaria, también se convirtió en una de las formas de mantener vivo el sentido de solidaridad que desde el lugar de origen orientó sus acciones en el trabajo y en la vida cotidiana. Las mingas hicieron parte de una de las actividades que más disfrutaron realizar los nariñenses en su tiempo libre, y en general, significaron un mecanismo mediante el cual enriquecieron su cuerpo y espíritu haciendo lo que más les gustaba: trabajar mientras comían y bebían juntos. Fue así como a través de la minga se produjo una identidad intercultural entre lo nariñense y lo candelareño, en tanto costumbre que sirvió de puente de presencia física y psicológica para recrear los códigos de comunicación y estrategias de significación con el pasado, y además, para perpetuar un nuevo estilo de vida dentro del cual los candelareños también eran espectadores. 
En los relatos de los candelareños, es reiterado el reconocimiento de las migas como parte de la tradición nariñense, e incluso la relación que establecen entre esta práctica que identifica a la comunidad de Nariño con una manera particular de ser solidarios, de apoyarse los unos a los otros y de acompañarse, aflorando nuevamente esa noción de comunidad, de estar y de ser juntos y nuevamente ese interés de progresar, representado en el mejoramiento continuo de una vivienda:

Bueno, los nariñenses tienen varias costumbres, ellos inclusive son muy arraigados a sus costumbres ancestrales, por eso es que tenemos aquí, ellos celebran todas las fiestas, las fiestas de su región, la fiesta de nuestra señora de Las Lajas, blancos y negros... ellos por ejemplo les gusta mucho acompañarse, se acompañan mucho, son muy unidos, otra costumbre que ellos tenían, eran las mingas, si por ejemplo un nariñense tenía problemas y llegaba y le ayudaban a armar su casa y se reunían y entre todos se ayudaban... (entrevista personal, Edgar Olave, 2016)

Pues los nariñenses eran más bien reservados, pero eran muy, como le dijera, tenían muchas iniciativas, lo que más admiro de ellos es su forma de comunicarse, es decir son muy unidos, ellos hacían mingas para construir su viviendas, por ejemplo usted iba a construir su vivienda hoy, entonces le ayudaban a construir su vivienda, y hacían todo eso, preparaban sancocho, todos los alimentos que ellos preparaban en la casa y eso era muy comunitario. (entrevista personal, Isaías Gamboa, 2016)

...yo doy un ejemplo muy típico de la comunidad nariñense donde se busca apoyar siempre al otro para que pueda avanzar, el ejercicio del trabajo comunitario, las mingas para poder hacer una casa, a punta de cerveza, a punta de comida, digamos dice mucho lo que hacen los nariñenses, ya muchas de las casa que están construidas aquí, no solamente en el Panamericano, sino en toda la población están hechas bajo la idea de que hace parte del amigo, vamos a colaborarle, lo único que necesitamos es que nos de cerveza, comida, de resto todo vale, entonces digamos eso es una cosa bien interesante en el apoyo solidario de la comunidad.(entrevista personal, Víctor Mondragón, 2016) 
Generalmente cuando se hacían las mingas, los nariñenses se daban cita los días sábados y domingos debido a que eran los días libres de sus compromisos laborales. Acordaban el encuentro entre paisanos y el dueño de la vivienda que se pretendía mejorar, ponía los materiales de construcción, la comida, la chicha y la cerveza. Todos los asistentes a la minga tenían una función, los hombres dedicarse a la construcción, las mujeres a la elaboración de los alimentos y los niños eran ayudantes o acompañantes en una actividad que indiscutiblemente, permitía reducir costos en la construcción debido a que no se rentaba maquinaria ni se pagaban jornales.

Así pues, la minga fue una costumbre que también practicaron las esposas de quienes ayudaron a reformar los ranchos; las mujeres tenían su propia forma de participar en la minga haciendo chicha, cerveza y sirviendo entre las comidas copitas de aguardiente para animar a sus esposos en el trabajo duro; en muchas ocasiones la minga daba hasta para comer y desayunar al otro día, pues si no se acababa temprano, se amanecían "después de la comida venia la bebida: cervecita y aguardiente. La gente se iba borrachita, pues entonces esa era la costumbre".

Muchos de los nariñenses que hoy días están en Candelaria, recuerdan en sus relatos a las mingas como la manera más afectiva para construir y mejorar sus casas:

Entonces les dije: los que vayan, lleven la palita, porque yo allá no tengo la herramienta. A las 6 de la mañana fueron llegando esa gente, eso se echó la plancha únicamente con mano de obra, sin maquinaria; los mismos se armaron los andamios, la mezcla iba de una parte a otra, hasta que llegaba a la plancha de donde venía ya el corte, hasta que se acabó a las 2 de la tarde. De ahí para allá se les entrega la comida, cuando el momento de la fundición de la plancha, hay que darles una cerveza, lo que uno tenga, si es posible la chicha nariñense porque es Nariño, es así de la tradición de la chicha de maíz (...) entonces se les daba eso a cada rato, cuando ya iba al almuerzo ya estaban mareados, ya con chicha, cerveza y así (...) cada uno se va yendo, hasta que queda el de la obra, queda solo, pero ya, esa es la unidad de los nariñenses. (entrevista personal, José Montilla, 2016) 
En Candelaria donde veían la montonera todos eran nariñenses, (...) la integración que hacíamos (...) las mingas... la comida, y después de la comida venía la bebida, cervecita, aguardiente, la gente se iban borrachitos pues; entonces esa era la costumbre (...) y le tiramos plancha, entonces le tiramos plancha. Cuando ya se hizo la hora de meter la plancha, yo invité más o menos a 20 por el trabajo, era en minga, en comunidad, no es como ahora, que traen al trompo y eso es rápido, cuando eso era a pala, era la minga que decíamos, eso de la minga, nosotros los nariñenses hemos dejado un ejemplo, cosa que ya se está perdiendo esas cosas. (entrevista personal, Alpala y Rosalba, 2016)

Imagen 39. Minga nariñense.

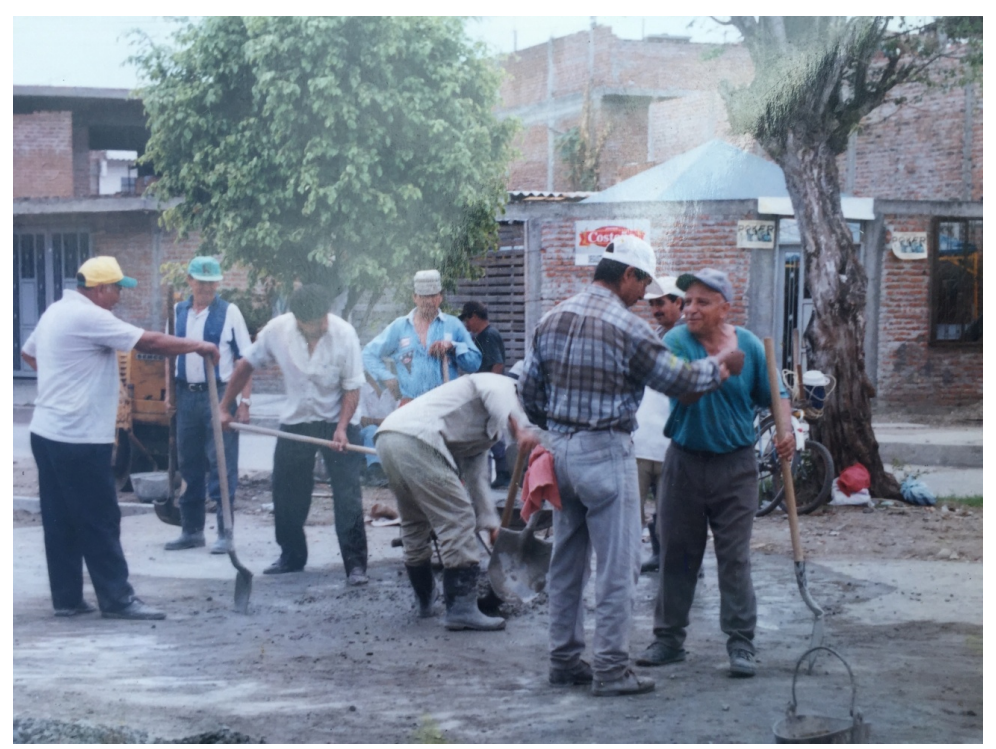

Fuente: fotografía tomada el 22 de julio de 2016 del álbum personal de José Alpala.

Sin embargo, hay que decir que los procesos civilizatorios y de modernización en el país fueron desplazando la costumbre de la minga por el uso de maquinaria, además, los nariñenses que llevaron esa iniciativa a Candelaria han muerto y esto ha ocasionado la pérdida gradual de dicha costumbre. No obstante, nariñenses como José María Alpala resaltan que en Nariño suelen practicarla todavía, sobre todo, en los caminos vecinales, 
así "cuando hay que renovar una entrada o un callejón se convoca a la minga. Allá funcionan mucho los cabildos, y hoy en día los cabildos son los que convocan a trabajar a la minga. Los cabildos en Nariño son muy organizados" (entrevista personal, José María Alpala, 2016). 
así era, la virgen de los patusos, la patrona de los pastusos, poco a poco se fueron concientizando a la gente y fueron entendiendo.

$\downarrow$

Lo de la chaza lo criticaban y hoy en día por lo menos todo el mundo, todo el mundo va a eso

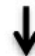

lo de los carnavales que decían que están locos, todo el mundo ha ido a los carnavales.

\section{RELATOS DE MIGRACIÓN}

$\downarrow$

\section{RELATOS DE INTEGRACIÓN}

\section{$\swarrow$}

ha tocado modificar a veces los espacios a tomarse por el carnaval $\downarrow$

porque la expresión del carnaval es ncomoda, echar harina, pintura, es un desborde total que causa mucha incomodidad en algunas personas que no comparten y tienen dentro de su lógica

$$
\downarrow
$$

Entonces ya nos toca sectorizarlo o en unos recintos hacer la expresión

$$
\downarrow
$$

pero la expresión del carnaval se sigue dando, la gente dice, el que quiera celebrar, quien quiera divertirse hágalo en tal sitio

$$
\downarrow
$$

no me venga a echar pintura a mi casa, no me venga a echar pintura a mi, porque los demás tienen su rutina diaria y a veces incomoda

$$
\downarrow
$$

pero más que todo es acoplemos la expresión en un sitio donde puedan hacer todo su desborde sin causar impacto negativo frente a las demás personas

\section{$\searrow$}

entonces yo miro a los candelareños que hoy en día tiene casi la misma cultura de nosotros $\downarrow$

porque ellos se han acoplado o nos hemos acoplado todos

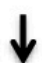

porque aquí estamos viviendo se puede decir 3 generaciones, la generación candelareña, la generación

nariñense y la negra

\section{$\checkmark$}

nosotros somos todos iguales y por eso es que queremos que esto salga para adelante y

logremos que Candelaria siga siendo más bonita de lo que es
Pues hoy en día ya estamos viejos, entonces nosotros ya hemos hecho nuestro hogar

\section{$\downarrow$}

los hijos ya han hecho los hogares de ellos, entonces de

esas descendencias de hoy en día es Candelaria

\section{$\downarrow$}

porque aquí el

candelareño, candelareño, eso es descendencia de los mismos nariñenses. 


\section{RELATOS DE MIGRACIÓN \\ $\downarrow$ \\ RELATOS DE INTEGRACIÓN \\ 

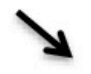

Bueno en un principio pensábamos que eran dos mundos distintos, que para los candelar nosotros está allá, en la cancha y usted dice vamos para la chaza y hoy domingo eso está lleno<smiles>C1CC1</smiles>

inclusive que le hacen

falta banquitas ya, nosotros los jugadores estamos jugando y cuando terminamos vamos a sentarnos y ya no hay donde cada uno hacía su parte y la otra, la otra parte

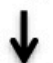

pero llegó un momento en que los gustos no

los detiene nadie, y se fueron fusionando

\section{$\downarrow$}

por los amores que les tocó vivir en el colegio, en la plaza, en el parque y todo porque de candelareñas habían niñas muy lindas y jóvenes muy apuestos, pero de los nariñenses también había eso mismo.
La gente que llegó ya se casó con candelareños, entonces ya, los que nacieron ya no son nariñenses, ya son mezclados entre candelareños y nariñenses

$$
\downarrow
$$

entonces, a mi esa situación de hacer como esa diferencia a mi me parece que ya en

Candelaria tampoco debe de ser tan marcada

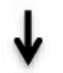

porque ya no hay nariñense nariñense nosotros ya por decir los hijos de nosotros ya es de descendencia de

$$
\text { pastusos }
$$

entonces ya la

discriminación es menos por lo que a raíz de ellos ya viene la gente

\section{$\downarrow$}

pues ahora con los hijos de nosotros pues son nacidos aquí pero vienen de raíces pastusas entonces eso ya va cambiando, es muy diferente.

\section{$\downarrow$}

Por lo menos actualmente ya no hay discriminación como antes, actualmente todos la pasamos bien. 


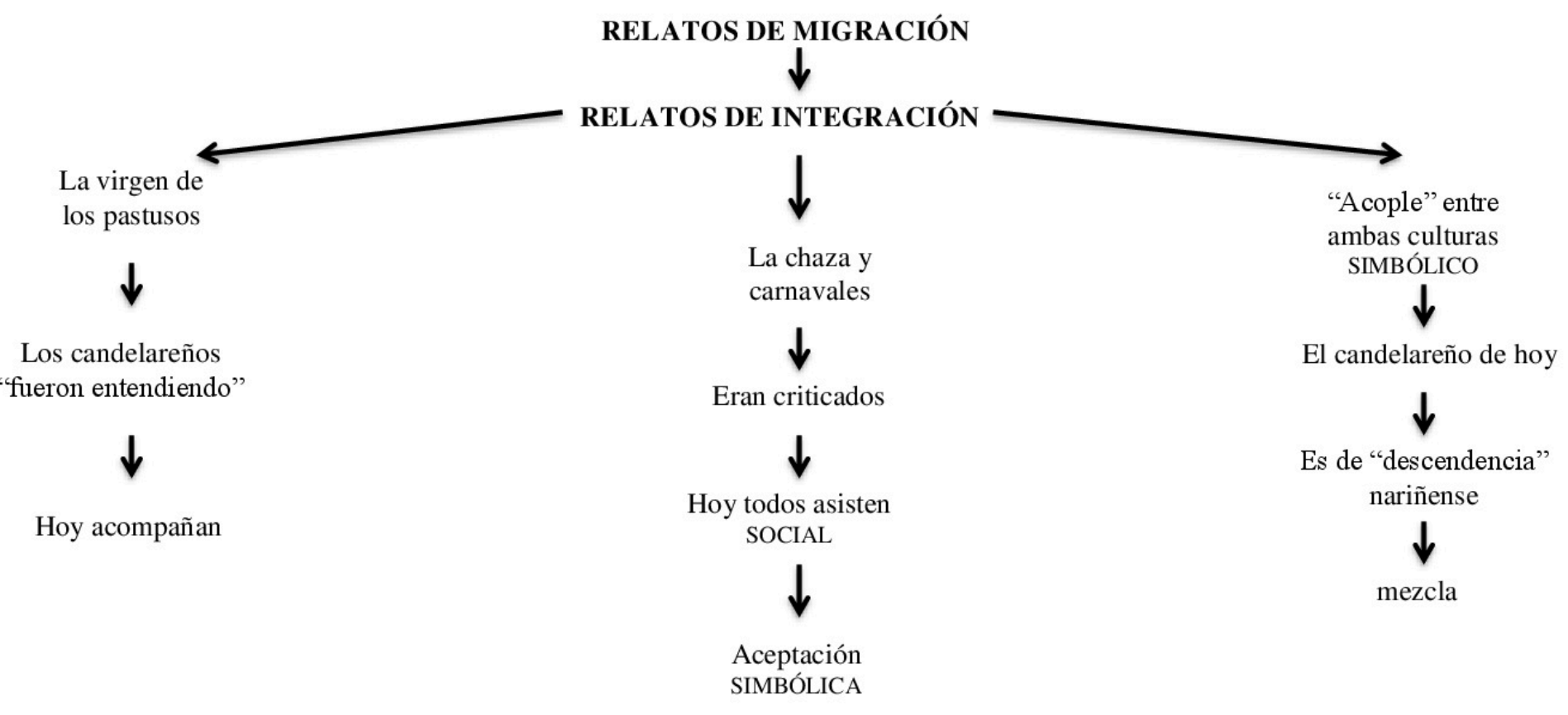


RELATOS DE INTEGRACIÓN

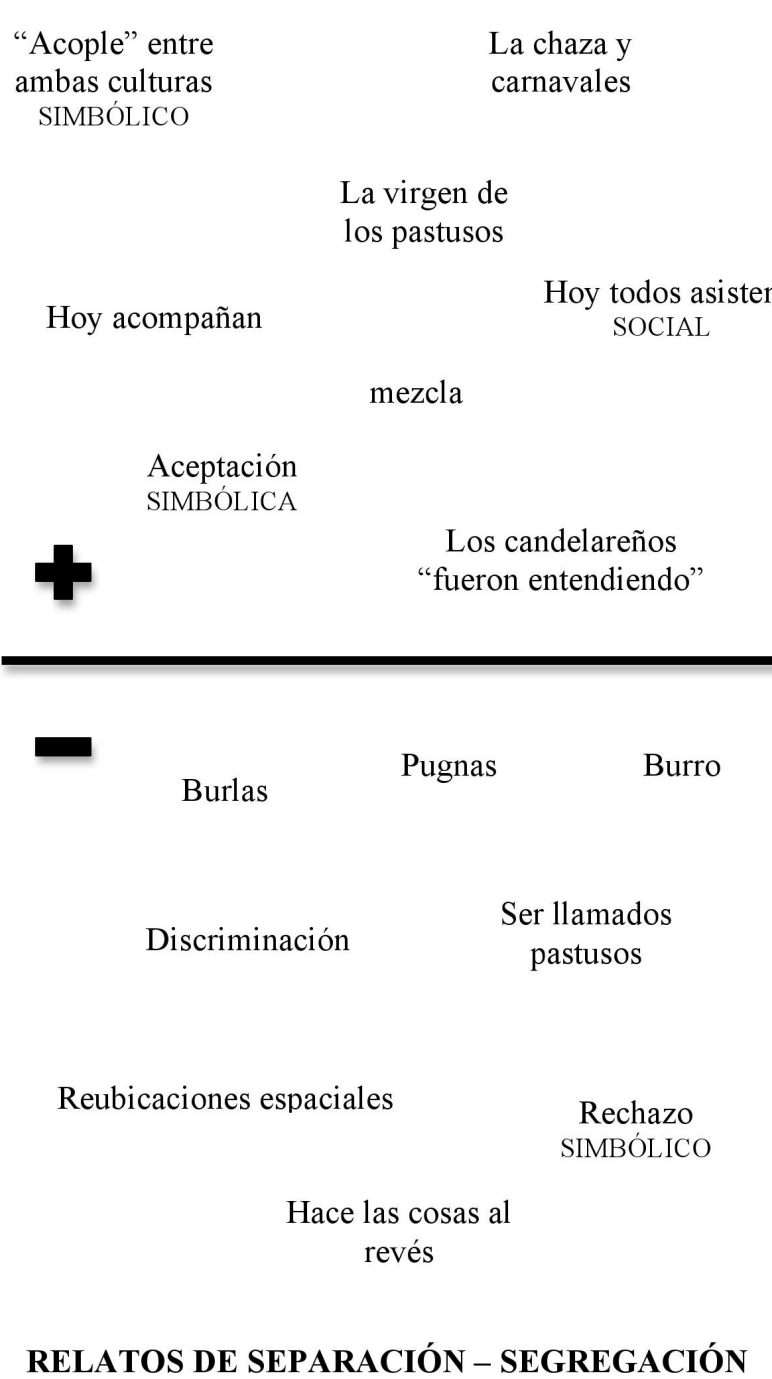

ESTRATEGIAS DE IDENTIFICACIÓN

\begin{tabular}{|c|c|c|c|}
\hline Conservación & Tradición religiosa & Agruparse & \\
\hline SIMBÓLICO & SIMBÓLICO & SOCIAL & Juego \\
\hline Minga & $\begin{array}{l}\text { Trabajo en comunidad } \\
\text { MATERIAL - SOCIAL }\end{array}$ & $\begin{array}{l}\text { Persistencia } \\
\text { SIMBÓLICO }\end{array}$ & $\begin{array}{c}\text { nariñense } \\
\text { SOCIAL }\end{array}$ \\
\hline
\end{tabular}

\section{NARRATIVAS DE LO NARIÑENSE}

Raza de empuje SIMBÓLICO

Trabajadores
MATERIAL

Tenacidad

\section{Luchadores}

SIMBÓLICO

$\begin{array}{cr}\text { Ahorradores } & \text { Solidarios } \\ \text { MATERIAL } & \text { SOCIAL - SIMBÓ }\end{array}$

A

Juiciosos -

responsables

Religiosidad

SIMBÓLICO

Sentido de comunidad

SIMBÓLICO

Acento y forma de

caminar

Trabajo

MATERIAL

MITO FUNDACIONAL

Oportunidades
MATERIAL

Pobreza

Ayudar a la familia FAMILIAR

Bienestar

Estabilidad

Ayuda y apoyo para establecerse Redes

\section{IDEA DE GENTE PURA Y ORIGINAL}

Tienen una forma de compartir

$$
\text { SOCIAL }
$$

$$
\begin{gathered}
\text { Fuertes para el } \\
\text { trabajo } \\
\text { MATERIAL }
\end{gathered}
$$

Nobleza

SIMBÓLICO

Capacidad
organizativa

\section{ORÍGENES NARIÑNENSES}

\section{Nariñense. Economía Distinción entre lo local y lo}

$$
\text { No pastuso }
$$

tradicional

Distinción entre lo
regional

Unidad

$\mathbf{T}$

I

V
$\mathbf{O}$

obreza

Trabajador. Campesino MATERIAL

T

rabaj MATERIAL de carácter familiar

Trabajo de la tierra como fuente de sustento $\mathbf{S}$ a la economía familiar 


\section{Consideraciones finales}

Por supuesto que en el marco de comprensión expuesto, van emergiendo de manera simultánea interrogantes que acompañan el proceso de interpretación y que van incorporando al investigador en un escenario que despliega cada vez nuevas comprensiones y al mismo tiempo, nuevas indagaciones.

Así, cabe preguntarse a esta altura cuestiones tales como ¿en dónde tienen lugar los procesos de integración de la comunidad nariñense en Candelaria? ¿qué papel juega el pasado en los procesos de configuración identitaria de esta comunidad migrante? ¿Resulta ese pasado conflictivo en estos procesos de configuración y reconfiguración de identidades? ¿en dónde se da la actualización identitaria de los nariñenses en Candelaria?; interrogantes que seguramente no serán resueltos en su totalidad, pero que a la luz de la evidencia empírica recolectada y a modo de conclusiones de esta propuesta investigativa, se arriesgarán algunos intentos de aclaración.

Inicialmente, es de mencionar que a pesar de que la actitud y la disposición de los nariñenses hacia el trabajo, sus ganas de salir adelante y de empezar a construir destino en medio de lo desconocido, fueron criticadas en un principio por los candelareños cuando catalogaban a los nariñenses como "burros de carga"; la satisfacción y el orgullo que esta colectividad siente hacia sus raíces - por cómo ella le dio continuidad a un proceso civilizatorio en Candelaria- se ha convertido en un argumento de los nariñenses para sentirse de allá y de acá.

Es como si el haber hecho parte del proceso mismo de construcción y crecimiento del municipio, y el haber jalonado desde sus iniciativas otras dinámicas en la construcción de vivienda que fueron transformando urbanísticamente a Candelaria, les concediera la posibilidad de posicionarse frente al candelareño, como un otro, con particularidades, creencias, gustos y costumbres, que aún sin ser las mismas de la sociedad receptora, se ha ido constituyendo y ha constituido a esa sociedad candelareña, a lo largo del tiempo. 
Así, los procesos de integración que se han dado por parte de los nariñenses en Candelaria, pasan incluso por el mismo posicionamiento que han logrado sus prácticas, las cuales emergieron desde hace décadas como estrategias de identificación y se fueron convirtiendo en elementos distintivos de Candelaria, en rasgos propios del municipio, en tradiciones de lo nariñense en Candelaria. Tradiciones que para muchos de ellos, permanecen dentro de la colectividad que se ha configurado de la mano de sus paisanos, asimismo, los modos de vida que han inculcado gradualmente al hacer parte integrante de la sociedad receptora -como el modo de vestir-, también permanecen en su cultura cuando deciden viajar a su lugar de origen.

En cambio nosotros yo no puedo decir que he perdido las tradiciones de mi pueblo de Nariño, no, yo tengo las mismas tradiciones, si estoy allá no pierdo mis tradiciones de acá, pero todo el mundo habla de todo y como yo voy cada año, ahí estoy allá en iglesias y bueno, y decir que perder la tradición, por ejemplo yo me pongo a pensar y hay gente que la comida, dejan lo que se come allá... cada que vamos para allá la comida es común y corriente. (entrevista personal, Pedro Castro, 2016)

En relación con las costumbres nariñenses que se conservan en Candelaria y por los elementos que identifican a los sujetos migrantes como nariñenses dentro de la sociedad receptora, puede decirse que la conexión con el origen territorial y cultural -que remite a lo que es tradicional del departamento de Nariño-, ha experimentando un proceso más de integración que de asimilación. Un proceso en el que si bien hay negociaciones con algunos códigos culturales de la sociedad que recibe, en este caso, de Candelaria, también ha habido ciertas pugnas por el mantenimiento de los códigos culturales propios del inmigrante nariñense, las cuales en su mayoría se han cifrado en códigos de aceptación, evidenciados en cuestiones tales como la celebración de "esa", que era la virgen de los pastusos, se haya convertido poco a poco en una celebración a la que todos concurren, en una fe que todos comparten y en últimas, en un escenario de encuentro en el que hoy día y desde hace varios años, confluyen nariñenses y candelareños. 
Se ha dado entonces la aceptación desde una dimensión simbólica de lo nariñense en Candelaria, en un escenario de interacción intercultural entre nariñenses y candelareños que se ha consolidado hasta el punto de que para los sujetos migrantes, no hace parte de sus planes a futuro regresar a su lugar de origen; aunque siga siendo importante conservar la comunicación y el contacto con su territorio, así como continuar tejiendo su historia en Candelaria,

Yo acabé, yo vivo con mi pensión y tengo la residencia ahí...mis hijos. No pienso volver para allá, pero no olvidarlos a la familia, no olvidar a la familia, hay que estar cuando haya un presupuestico de platica, viajar para allá. (entrevista personal, Aurelio Realpe, 2016)

"No olvidar a la familia" es la frase que nariñenses como Aurelio Realpe repiten mientras recuerdan su lugar de origen; la remembranza del pasado es la que, entre otras cosas, les permite a los nariñenses mantener contacto con aquello que alguna vez fue su morada, a través de los viajes constantes que realizan a Nariño, con el propósito de revivir los olores y los sabores cuando traen de este departamento elementos típicos de la gastronomía nariñense: Curíes, quesos, papas, abas, entre otros. Con estos elementos los nariñenses no solo permanecen en contacto con su pasado y su cultura de origen, sino que también reproducen olores, sabores y estructuras de significado a través de los cuales renuevan constantemente su identidad nariñense en el ejercicio de hacer parte de la sociedad receptora

A mí me gusta traer los Curíes, quesos, por ejemplo, ahora que yo fui traje eso, como cinco Curíes, como cinco quesos, como ellos tienen ganado entonces le dicen, "vea lucho, aquí le vamos a dejar treinta quesos para que el día que se vaya estén listos"'. (entrevista personal, Aurelio Realpe, 2016)

En el presente, la identidad cultural de origen del migrante se mantiene simultáneamente en el ejercicio de hacer parte de lo candelareño, gracias a la relación con el origen territorial -que remite todo el tiempo a lo que es tradicional de Nariño- desde la sociedad receptora que es Candelaria. Es por esto que los nariñenses expresan en sus 
relatos que "uno es de donde haya nacido", "de la tierra donde uno nació", así como de la tierra que lo recibió - he aquí la conciencia que se tiene del sí mismo y de los demás, experimentados en unidad y en términos de identidad intercultural.

En este último punto es importante retomar a Grimson (2005) en la medida en que permite comprender que las adscripciones identitarias no son procesos naturales y no están determinadas por la sangre o por el lugar de nacimiento; por eso es que en Candelaria hay hijos de nariñenses que se definen como candelareños y nariñenses que se definen a sí mismos tanto nariñenses como candelareños... quienes son producto de incesantes construcciones, imaginaciones e invenciones.

Es de anotar también que en el relato de los nariñenses hay una recurrencia al pasado que marca todas sus narraciones y que pone de manifiesto su interpelación a la memoria, al recuerdo de lo que ya pasó, a la remembranza de lo que fue, para lograr una referencia presente y para concretar lo que se es hoy, sin importar el lugar en el que se encuentren. Así, es recurrente encontrar testimonios de nariñenses que en su contar reiteran elementos tales como "yo me acuerdo que", "de lo que más me acuerdo es", "otra cosa que yo recuerdo es", "yo recuerdo que cuando estaba". Cuestiones que se les convierte como en un juego de la memoria sin el que muchas veces, no logran situarse en el presente o relatarse hoy en Candelaria.

En este marco, determinar qué va a pasar con la identidad cultural de origen nariñense en Candelaria, no solo depende de las costumbres y tradiciones que se sigan inculcando para mantener continuidad con el pasado,

Por eso el estudio de los procesos identitarios de un grupo migratorio, es fundamental, la exploración de un modo de constitución como grupo, los sentidos que entran en conflicto en ese proceso y la elaboración de relatos que den cuenta de su pertenencia, de su historia, de su unidad y de sus fronteras. (Grimson, 2005, p.184) 
Ahora lo que puede afirmarse es que, en efecto, existe un proceso de identidad intercultural conformada por lo nariñense y lo candelareño desde los años sesenta en Candelaria; y que esta interculturalidad responde a la unidad de los modos de vida que compartieron tanto nariñenses como candelareños dentro del proceso migratorio, esto es, en la experiencia del nosotros y de los otros que se configura a través de las vivencias que los nariñenses tienen de Candelaria y los Candelareños de Nariño.

Puede decirse aquí que prácticas como el juego de la chaza, la celebración de la Virgen de las Lajas, las mingas, el carnaval de blancos y negros, la crianza de curíes y otras formas de expresión cultural, permiten vincular pasado y presente, pues son capaces de extenderse más allá de los límites de tiempo y espacio, y por ende, posibilitan la apertura y disponibilidad para encuentros intersubjetivos e interculturales. Es como si se estuviera frente a un componente portátil de la identidad, que al mismo tiempo que se lleva consigo, se va re-configurando y re-significando en un escenario de interacción con los otros, con los códigos de estos y de aquellos, en tiempos y espacios que le van dando lugar a la actualización identitaria.

Es decir que tanto el juego de chaza, como la celebración religiosa, la festividad cultural y la minga, se convierten en dispositivos que posibilitan y han posibilitado a través del tiempo, el estar juntos en Candelaria y el asumirse como colectividad. En otras palabras, son prácticas que les permite estructurar-se como grupo y en todo caso, han permitido la subjetivación de la cultura vallecaucana desde el diferenciarse como un otro, o como unos otros.

Incluso, en algunos momentos del proceso investigativo se llegó a considerar el supuesto de que en este caso particular, el otro no fuera justamente quien llegó. Sino que las dinámicas de posicionamiento del inmigrante nariñense en Candelaria, han configurado como un nosotros a los nariñense y como los otros, a los candelareños. Sin embargo, en el trascurso del procesos investigativo se evidencia que es este un escenario que permite pensarse dos otros mutuamente constituidos y constituyentes, sin que esto de lugar a la ausencia de resistencias y negociaciones. 
En este sentido, puede decirse aquí que el juego de la chaza, la minga, la celebración de la Virgen de las Lajas y el carnaval de blancos y negros, como prácticas culturales, en este caso para la colonia nariñense asentada en Candelaria, le han dado lugar a las relaciones entre estos sujetos, posibilitando la incorporación de la cultura y al mismo tiempo, la negociación de códigos compartidos históricamente como colectividad.

Así, estas prácticas se asumen también como los lugares en donde recobra todo el sentido que estos sujetos han construido en torno a la solidaridad y a lo común, de tal manera que estas, en cuanto tal, traspasan los límites de la ocupación puramente biológica o física por parte de un grupo de personas. Están llenas de sentido, en ellas se evidencia un foco fundamental para los nariñenses que tiene que ver con la posibilidad de estar juntos, de congregarse, "la unidad y la fuerza" denominada por ellos mismos, manifiesta en la capacidad de organizarse como grupo, como "colonia nariñense", de ahí que de estas prácticas emanen posibilidades para construir lo común; por su significación y por su valor expresivo, por las conexiones sociales que estas crean y en últimas, por su función cohesionadora de lo colectivo, de lo común, articuladora y organizadora de grupalidad.

Son entonces estas estrategias de identificación, las que propician escenarios de subjetivación de la cultura, de incorporación de formas de ser y estar y se convierten para la colonia nariñense en la posibilidad de insertarse en una cultura que no le es propia, y empiezan a brindarle herramientas para negociar códigos culturales. Así, se crean en torno a la chaza, a los carnavales, a la Virgen de las Lajas y a las mingas, unas transacciones que están por fuera del mercado y que sugieren una configuración propia del ser y del estar, la cual entra en diálogo con el otro o con los otros.

En este sentido, en los escenarios que emergen a propósito del juego de la chaza, del carnaval de blancos y negros, de las mingas y de la celebración de la Virgen de las Lajas, se intenta posicionar algo como "nosotros somos otra cosa" y "nosotros hacemos otras cosas". De ahí que sea también una posibilidad de diferenciarse frente al otro, de reconocer-se como diferente al otro, pero también de reconocer la posibilidad de interacción con ese otro. Y en últimas la condición sine qua non de ser en interacción. 
La decisión de un determinado grupo social de distanciarse definitivamente de su lugar de origen es un hecho histórico que conlleva otras tantas circunstancias, que la mayoría de las veces, no son sopesadas por el grupo que decide tomar esta iniciativa, ya que dentro de las circunstancias que acarrea la migración, se encuentran el cambio de concepción del territorio - lo que más atrás hemos denominado "ver con nuevos ojos el lugar de origen"-, así como la permanente configuración de la identidad que inicia una nueva fase de construcción y reafirmación cuando los sujetos poseedores de determinados rasgos identitarios y de una cultura identitaria, comienzan a residir en la sociedad receptora y a entablar negociaciones, aunque otras veces disputas y conflictos, sobre las posiciones hegemónicas que cada grupo busca ostentar para situarse dentro de una perspectiva dominante en el marco de las migraciones.

En el caso que concierne a esta investigación, la migración de Nariño a Candelaria, Valle del Cauca, debe comprenderse en términos de una decisión que los nariñenses fueron asumiendo mancomunada y voluntariamente, debido a las condiciones sociales y económicas por las que atravesaba el departamento de Nariño a mediados de los años 50; en este orden de ideas, bien puede afirmarse que una de las categorías de análisis que permite abordar el fenómeno de la migración en Candelaria, como lo es el Mito Fundacional, responde más a un hecho histórico no buscado ni mucho menos planeado por los sujetos migrantes, que a una circunstancia de orden social y económica por la que los nariñenses llegaron al punto de desear otras condiciones de vida bajo otro tipo de circunstancias espacio temporales.

Es importante resaltar que la influencia que ejercieron las condiciones históricas en la determinación de los nariñenses de migrar a Candelaria, como el precapitalismo, la economía autárquica y tradicional que solamente daba para cubrir las necesidades inmediatas de los nariñenses, al final fueron el resultado de una situación hegemónica en la que el protagonismo lo ejerció la historia de la economía política nariñense. Esto es cierto, por lo menos en un primer momento, cuando los sujetos migrantes comprendieron que su territorio se quedaba corto frente a las pretensiones personales y proyectos pensados a futuro, de donde puede concluirse que los motivos de la migración hacen parte de la hegemonía del territorio sobre la libre decisión y voluntad de sus habitantes 
cuando de lo que se trata es de cubrir el sistema de necesidades que busca satisfacer las comodidades y el confort que se hacen conscientes en los nariñenses cuando se enfrentan a otro tipo de realidades más desarrolladas como las que ofrecía la agroindustria azucarera del Valle del Cauca.

Esto último hace parte de los acontecimientos propios de una Globalización que se vive desde abajo en el marco del desplazamiento de la producción artesanal por la fabril, en el que existe la posibilidad, siempre latente, de que un grupo social se inserte en las nuevas dinámicas de la producción industrial que elevan la posición económica y social, a través de las migraciones internas. Es por esto que decimos que la hegemonía del territorio cumple un papel esencial en el momento en que los nariñenses deciden migrar al Valle del Cauca: porque prevalecen hechos históricos como el fenómeno de la modernidad y la modernización que conducen, ineludiblemente, al desplazamiento del campo a la ciudad y de la tierra al capital, como producto de un fenómeno que da lugar a cambios en los universos culturales, sociales, políticos y económicos de los migrantes, sin que por ello hubieran sido buscados por los nariñenses o, lo que es lo mismo, sin decir que dichos sujetos fueran conscientes de las consecuencias de la migración antes de tomar la determinación de trasladarse a otro lugar.

Lo que sí se hace consciente en los sujetos migrantes, una vez hacen parte de la sociedad receptora a la que deciden trasladarse, por razones de orden histórico que en la mayoría de las veces los obligan a dejar su territorio, prácticas sociales, costumbres, tradiciones y festividades religiosas, son las consecuencias que acarrea la migración sobre cualquier grupo social que ve como posibilidad de ascenso económico y progreso social, dejar su lugar de origen. Se trata de las transformaciones sociales y culturales intrínsecas a la migración como el cambio de concepción que se tiene del lugar de origen, la inevitable pérdida de lo conocido en medio del cambio y de lo sentido como propio, así como de la reconfiguración y reafirmación de la identidad dentro de un nuevo espacio que como la sociedad receptora se convierte en un lugar de negociaciones y disputas.

La migración de Nariño a Candelaria, Valle del Cauca, es un fenómeno social que da lugar a uno de esos cambios en los universos sociales y culturales a los que Hall alude 
cuando se refiere a las migraciones. Los cambios que aquí se mencionan guardan una estrecha relación con el concepto de identidad, hasta el punto en que puede decirse que en tanto se produce un cambio en el universo social y cultural del migrante -como producto de la migración-, de igual manera se genera, de manera proporcional y directa, una transformación en las identidades. De esta transformación los sujetos son conscientes, en la medida en que las nuevas condiciones espaciotemporales le exigen unidad y coherencia en prácticas, costumbres y acciones dentro de la sociedad receptora; esto es así porque la migración como fenómeno social implica para los sujetos que la llevan a cabo una serie de procesos de configuración y de reconfiguración de sentidos, por cómo el contacto definitivo con el nuevo territorio hace que se pierdan elementos importantes del pasado imaginado y de la ancestralidad compartida.

En concordancia con lo anterior, los migrantes -nariñenses- esperan poder darle continuidad a sus habitus y comportamientos tradicionales como mecanismo de defensa y de reconfiguración de la identidad cultural en un espacio desconocido y de cambio constante, que a veces puede tornarse amenazador cuando las costumbres diversas entran en tensión dentro de un escenario de inclusiones y exclusiones interculturales: en este punto es pertinente hablar, desde la perspectiva de Grimson y de Hall, del campo de interlocución al que se ven sometidos tanto los de allá como los de acá, los migrantes y quienes los reciben, a fin de intercambiar códigos culturales diversos y reapropiarse nuevos elementos culturales, tradiciones, creencias y costumbres de la cultura propia.

Así, al tratarse de una de las consecuencias fundamentales de la migración debe hacerse hincapié en la identidad, pero también en las estrategias de identificación que sostienen los rasgos identitarios y que sirven de respaldo emocional, psicológico y simbólico para los nariñenses que se enfrentan al cambio. En efecto, después de hacer referencia al mito fundacional de la migración de Nariño a Candelaria, como resultado de una circunstancia que sitúa a la hegemonía del territorio, y sobre todo a las condiciones históricas, económicas y políticas de Nariño, como principales factores motivacionales a la hora de tomar la determinación de migrar al Valle, es importante abarcar las categorías de análisis que ponen de relieve el papel, no ya de las condiciones y circunstancias de la historia, sino más bien de los sujetos y de los actores sociales como responsables de su 
propia identidad y del proceso de configuración y reconfiguración de sentidos y significados identitarios.

La construcción de la identidad es un asunto que concierne a los sujetos que requieren redefinirla en momentos en que, como ya se dijo, puede ponerse en riesgo la cultura del migrante en escenarios de tensiones, conflictos y enfrentamientos con la sociedad receptora. Por este motivo, los nariñenses cumplen un papel activo en el proceso migratorio cuando comienzan a generar campos de interlocución en los que ponen en juego rasgos, características o diferencias desconocidas que el otro o los otros no esperan y no pueden clasificar. Estos rasgos según Hall hacen referencia a las fiestas, celebraciones, festividades, prácticas de la vida cotidiana, y en general, maneras de usar y de significar el tiempo a las que no está acostumbrada la sociedad receptora, pero que los migrantes conservan en el tiempo para que el choque con lo nuevo, esto es, con el grupo cultural que recibe, no sea tan fuerte. En este sentido, fue característico ver que los nariñenses preservaran sus rituales y costumbres más típicas como la gastronomía, la manera de vestir, los juegos, el dialecto, las festividades religiosas y las redes de apoyo y de amistad que formaron para mantener contacto con el pasado y con sus tradiciones.

Este revivir y poner en el presente los elementos culturales que definen la cultura del migrante, hace parte de lo que Jaes (2002) denomina Rituales espontáneos como formas de lidiar y afrontar las pérdidas que implica la migración, pérdidas tales como el papel que antes de la migración tenían los nariñenses en su lugar de origen cuando disponían de la tierra como medio de vida y de producción de la economía tradicional y de consumo inmediato. Por esta razón, las estrategias de identificación son tan esenciales desde el punto de vista de los recursos intangibles que ponen en juego las comunidades: porque su propósito es el de tejer redes estratégicas para sostener su cultura, si se parte del hecho de que los lugares y las personas queridas de los migrantes están físicamente ausentes, aunque psicológicamente presentes por medio de sus remembranzas, recuerdos e incluso a través de la nostalgia que genera la adaptación con la sociedad receptora cuando se extrañan los elementos propios del pasado imaginado. 
La función social que cumplen las estrategias de identificación se explica por el impacto que sufren los nariñenses en el momento en que se sitúan frente a otro grupo cultural, que como los candelareños, comparten diferentes rasgos identitarios. Este impacto tiene que ver con aquello que exige, desde la teoría de Hall, la indagación por la identidad, en cuanto esta es construida de múltiples maneras a partir de discursos, prácticas y posiciones sociales diferentes, aun cuando se trata de los procesos migratorios que traen como resultado la redefinición de la cultura. Este planteamiento adquiere sentido si se tiene en cuenta que justo en el momento en que el migrante empieza a ser parte de la sociedad receptora, debe iniciar un trabajo discursivo, de marcación y ratificación de límites simbólicos y de producción de efectos de frontera con el firme objetivo de constituir y reconstituir la identidad como un acto de poder social y simbólico que se lleva a cabo desde la posicionalidad del migrante.

A este respecto, Hall (2010) afirma que no existe una forma a través de la cual las personas del mundo pueden actuar, hablar, crear, entrar desde los márgenes y hacerse notar, o puedan empezar a reflejar su propia experiencia, si no es bajo la condición de que vengan de algún lugar, de alguna historia y de heredar ciertas tradiciones culturales. El autor afirma que lo que hasta el momento se ha podido aprender acerca de la teoría de la enunciación, se ha realizado en virtud de la posicionalidad. Motivo por el cual los grupos culturales, como el nariñense, tienen que posicionarse en algún lugar en aras de decir cualquier cosa, y más precisamente, de enunciar lo que desde su propio sentido identitario son y los define como diferentes frente a otras comunidades, "así, nosotros no podemos prescindir en ese sentido de nuestra propia posicionalidad que es connotado por el término de etnicidad" (Hall, 2010, p.346).

Hablar de la constitución de la identidad nariñense es importante en el marco del proceso migratorio, debido al impacto que sufrieron los migrantes durante la segunda mitad del siglo XX, luego de que los nuevos códigos de comunicación, prácticas y costumbres de la sociedad receptora se situaran en frente de sus rasgos culturales como medios de posicionamiento y defensa frente a lo desconocido. Una vez los grupos culturales -tanto nariñenses como candelareños- se encuentran en un mismo contexto, se sitúan en un espacio social en el que cada uno comparte un conjunto de posiciones 
distintas y coexistentes definidas en relación con las otras, por relaciones de distanciamiento y proximidad.

La distancia que surge en medio de este espacio compartido interculturalmente (cuya ubicación geográfica se encuentra en Candelaria, Valle del Cauca) se produce por el capital cultural y simbólico que pone en juego cada comunidad para posicionarse hegemónicamente frente a otro grupo social distinto. De esta manera, vemos cómo los nariñenses al querer posicionarse hegemónicamente ante los candelareños y al querer establecer fronteras y límites frente a lo diverso, comienzan a darle uso al capital simbólico -que a diferencia del capital económico y de los bienes materiales que representan el lugar que los sujetos ocupan en el sistema económico de producción-, dan cuenta de ciertas disposiciones, caracteres de personalidad y de comportamiento mediante los cuales los migrantes establecen principios de visión y de división, de gustos diferentes.

El capital cultural y simbólico, si se comprende desde una perspectiva Bourdeana (Bourdieu, 2008), hace referencia a las prácticas y bienes de una clase de agentes sociales que como los nariñenses y candelareños, utilizan conscientemente como principios de diferenciación o estructuras estructuradas desde donde se reproducen prácticas distintas como la alimentación, el deporte, las festividades, el juego, las opiniones y las diversas maneras de expresar el consumo y las actividades correspondientes a su cultura. Para Bourdieu es una condición social que pertenece a cualquier tipo de actor, visto en grupo o individualmente, en tanto se encarga de producir diferencias entre lo que es bueno y lo que es malo, lo que está bien y lo que está mal, lo distinguido y lo vulgar, "así, por ejemplo, el mismo comportamiento o el mismo bien puede parecer distinguido a uno, pretencioso a otro, vulgar a un tercero" (Bourdieu, 2008, p.34).

Si se emprende el ejercicio de aterrizar la teoría a la práctica, puede verse claramente que los nariñenses como grupo de migrantes capaces de compartir un mismo espacio social con la sociedad receptora, ponen en juego discursos, prácticas y posiciones diferentes con frecuencia cruzados y antagónicos en relación con los candelareños; nos referimos en este punto a las estrategias de identificación expresadas en la tradición 
religiosa, el sentido de comunidad, los juegos, la disposición y motivación hacia el trabajo, el acento y la forma de caminar del nariñense que lo hace un sujeto único ante el candelareño, por cuanto este también goza de disposiciones sociales distintas y de estructuras de distinción cultural que lo sitúan dentro de la escala de estratificación social en una posición distinta a la del nariñense, por lo menos en cuanto al ethos del trabajo y al sentido de comunidad que orienta sus acciones se refiere.

De esta suerte, se establece un diálogo dentro de un campo de interlocución cultural que sienta sus raíces en el espacio social donde nariñenses y candelareños empiezan a marcar sus fronteras; la forma en que ambos intentan situarse como grupos sociales auténticos a través de dicho campo comunicativo, se logra con la narración, elemento que por demás es esencial para la configuración de la identidad, si recordamos lo que sugiere Hall cuando habla de las prácticas discursivas y de las narraciones que construyen los mismos sujetos a fin de representarse a sí mismos y de contarse lo que son, para saber quiénes son. Según lo dicho, puede decirse que el rol activo que los nariñenses cumplen respecto a la redefinición de sentidos y significados, no solo consiste en emplear estrategias de identificación como mecanismo para reflejar las experiencias históricas comunes y los códigos culturales compartidos, sino también en hacer uso de la narrativa del sí mismo, que de igual forma, provee a los sujetos migrantes de significados y referencias culturales estables en medio de las vicisitudes y de los cambios continuos que trae consigo la distancia física con el territorio de origen.

A este propósito, Hall (2003) muestra que existe un punto de referencia central entre, por un lado, los discursos y prácticas que intentan interpelarnos, hablarnos o ponernos en nuestro lugar como sujetos sociales de discursos particulares y, por otro, los procesos que producen subjetividades, que nos construyen como sujetos susceptibles de decirse. Es por ello que "las identidades son puntos de adhesión temporaria a las posiciones subjetivas que nos construyen las prácticas discursivas" (Hall, 2003, p. 20).

Los relatos de migración, las prácticas discursivas y las narrativas nariñenses, se han construido para mostrar que la identidad no es una categoría de análisis estable ni unificada, sino que es fragmentada y fracturada, por cuanto es cosntruida de múltiples 
maneras mediante discursos, prácticas y posiciones, que bien pueden cumplir la funcion de ser estrategias de identificación para reconfigurar e hipostasiar los rasgos identitarios que definen la cultura del migrante. En vista de ello, los relatos, las narrativas y las estrategias de identificación, hacen parte de un solo escenario que se define por el nivel de consciencia y voluntad de los sujetos a la hora de responder preguntas como ¿Quiénes somos? ¿Cómo nos definimos? ¿Qué rasgos nos caracterizan? ¿Cuáles son los rasgos identitarios que más sobresalen en nuestra cultura?, entre otros cuestionamientos que permiten entender la identidad, precisamente, como la entiende Hall, en lo relativo al descentramiento de las identidades ante rasgos específicos como la raza, el género y las clases sociales.

En la actualidad el discurso sobre la identidad se enmarca dentro de otro tipo de categorías que no necesariamente involucran rasgos tan tradicionales como los de la nación, el género y la etnia. Antes bien, las nuevas interpretaciones de la identidad cultural reconocen múltiples escenarios vitales como las propias descripciones que hacen los sujetos sobre sí mismos en relación con los otros. Este tipo de descripciones adquieren especial interés cuando se intenta hacer una aproximación de los diversos mecanismos que reproducen la propia cultura en un espacio desconocido; la importancia que radica en los relatos y descripciones de los migrantes no es otra que el desarrollo de un trabajo discursivo en el que estos marcan y ratifican límites simbólicos con la sociedad que los recibe.

La marcación de fronteras, en lo que respecta a los nariñenses por ejemplo, es importante porque permite localizar los aspectos en los cuales este grupo cultural hace uso de su capital simbólico - de sus principios de diferenciación, de sus estructuras, prácticas y costumbres-, para conservar y al mismo tiempo transformar su identidad, atendiendo a las diferencias que Grimson (2001) establece sobre los elementos de toda identificación, a partir de los cuales las personas y los grupos se identifican de ciertas maneras o de otras en contextos históricos específicos y en el marco de relaciones sociales localizadas. Estos elementos hacen alusión al carácter relacional desde donde los migrantes al mismo tiempo que instituyen un "nosotros" definen un "ellos" en virtud de las diferencias asociadas, los bienes y las prácticas que instituyen un nuevo lenguaje que 
utilizan para posicionarse en la sociedad receptora.

Esto fue lo que hizo la comunidad nariñense cuando se trasladó a Candelaria, Valle del Cauca, a saber: dentro de los tiempos que definen el proceso migratorio, como el antes de migrar, donde se ubican las motivaciones y el papel de las redes de apoyo; durante la migración, que abarca las rutas y los momentos vividos en el trayecto del lugar de origen al lugar de destino y el momento de llegada, que comprende las relaciones establecidas con la sociedad receptora como son las estrategias que los migrantes configuran para permanecer en contacto con la sociedad de origen, los nariñenses situaron claramente un "nosotros" y un "ellos" en virtud de sus tradiciones, así como de sus relatos, del capital cultural y simbólico, del cual se ha hecho mención, por cuanto constituye un factor determinante para la construcción de la identidad nariñense.

Ciertamente, el capital cultural y simbólico de los nariñenses debe comprenderse con arreglo a las variables que contiene y que son fundamentales para la construcción de la identidad. Dentro de estas variables se destaca la trayectoria del grupo cultural en la que se definen y redefinen rasgos del carácter tales como la relación que suelen entablar los nariñenses con el trabajo pesado (la disposición y la motivación a ejercer actividades que exigen una mayor inversión de fuerza como la agricultura y el corte de caña); la capacidad ahorrativa que les permite pensar en proyectos a futuro como la compra y construcción en minga de sus casas de hasta dos y tres plantas; el juego de la chaza en el que se ponen a disposición otros tantos rasgos culturales como la fuerza, la concentración y la habilidad manual; las festividades religiosas en las que la devoción, la fe y los rituales a la Virgen de las Lajas muestran que los nariñenses son personas devotas cuyos logros y éxitos los atribuyen a la virgen y a su religiosidad.

Por último, los carnavales de Blancos y Negros que constituyen un acontecimiento de la comunidad nariñense en el que se recuerdan hechos históricos ancestrales que se perpetuán en el tiempo, en la forma de la igualdad de etnia y de raza...En fin, discursos y prácticas que lejos de constituir elementos con los cuales nacen los nariñenses, son formados y transformados dentro de y en relación con la representación. Todas estas prácticas y tradiciones que también se enuncian en las 
narrativas y en los relatos de los nariñenses son vehículos de reafirmación de la identidad, al mismo tiempo que dan lugar a tensiones y disputas con los candelareños, bajo los discursos de exclusión y separación que en ocasiones propician el distanciamiento por prácticas y comportamientos que no son vistos como iguales ni tampoco compartidos por todos desde la misma concepción: como sucede con los Carnavales de Blancos y Negros que se realizan en el Valle del Cauca, y que dan lugar a conflictos cuando la costumbre de pintar la cara puede tornarse molesta, y en algunos casos ofensiva para los candelareños.

Finalmente, y siguiendo a Hall, podemos concluir que sabemos qué es ser "nariñense" por la manera en que este grupo cultural ha venido a ser representado y a representarse a sí mismo como un conjunto de significados, a partir de su cultura nacional y también interregional desde donde reinventa y define constantemente lo que es.

La comunidad nariñense no es solamente una entidad histórica y política que ocupa un lugar y un espacio geográfico en nuestro país, sino también una entidad que produce significados, un sistema de representación cultural al cual se llega por medio de recursos, disposiciones y diversos capitales como el económico, cultural y simbólico, cuya historia y trayectoria dependen de acontecimientos colectivos importantes como las crisis y las guerras, o incluso acontecimientos individuales que pueden ser descritos como causalidades. A este respecto, las redes de apoyo que tejen los nariñenses son una oportunidad que, por una parte, los migrantes hacen posible y realizan, debido al capital cultural y simbólico que los determina y caracteriza como sujetos comunitarios con un sentido de solidaridad marcado. Pero por otra parte, dichas redes forman parte de un hecho dado por las mismas circunstancias en las que los migrantes pueden continuar reafirmándose como sujetos que otorgan un sentido social a sus acciones, al pensar en la comunidad nariñense.

Por eso es que podemos hablar de las redes de apoyo, y en general, de las estrategias de identificación, como una oportunidad en la que se pone en juego tanto el capital cultural y simbólico que los nariñenses traen consigo al inicio del proceso migratorio, así como del capital cultural y de la identidad que comienzan a construir y a 
perfilar los migrantes en la sociedad receptora, partiendo del hecho de que la identificación no es algo acabado, sino más bien -como la entiende Hall- una falta de totalidad que es "llenada" desde fuera de nosotros, por medio de las maneras en que puede imaginarse que somos vistos por otros y también por nosotros mismos. Desde este punto de vista, la trayectoria de los sujetos migrantes y de su identidad cultural, se establece teniendo en cuenta su origen en el territorio, y además, el tiempo a partir del cual se sitúan en la sociedad receptora, de tal modo que sus prácticas, costumbres y tradiciones se entienden como resultado de dos efectos: en primer lugar, el efecto de inculcación ejercido por la familia o por las condiciones de existencia originales. Y en segundo lugar, el efecto de trayectoria social que define a los sujetos migrantes en medio de las dinámicas de la vida cotidiana en la sociedad receptora como escenario de lucha y de apropiación simbólica.

La lucha es uno de los momentos necesarios que enfrentan los de allá y los de acá cuando ambos se ven obligados, por fuerza de las condiciones de la migración, a posicionar su identidad frente a la de los demás: este posicionamiento conlleva a establecer una relación de poder entre nariñenses y candelareños, cuyo campo de acción es el espacio social en el que ambas partes utilizan como mecanismo de defensa y de reapropiación de significados, sus distintos capitales e intentan situarlos y posicionarlos como rasgos identitarios superiores. De esta manera, las diversas tensiones que surgen de este enfrentamiento identitario hacen que se coloquen en el centro de las disputas los rasgos que pueden llegar a dotar a los sujetos de cualidades únicas, tal como ocurre con los nariñenses y su ethos del trabajo: en tanto un grupo cultural es más trabajador que otro, se posiciona en un lugar superior de la escala de estratificación social, toda vez que se encuentra en la capacidad de transformar la naturaleza, desarrollar sus habilidades manuales e intelectuales bajo ciertos lineamientos que permiten contribuir al progreso de la región, tal como sucedió con los nariñenses y el papel de corteros de caña de azúcar que ejercieron en el auge de la agroindustria azucarera.

Pero no todo lo relacionado con la configuración de la identidad conlleva a conflictos. Bien es sabido que la migración es uno de los procesos culturales que impone fronteras y a la vez las supera, cuando se trata de las experiencias de integración y de los 
relatos de identificación que marcan a nariñenses y candelareños en medio del curso de la construcción de su identidad. A pesar de los factores de distanciamiento y tensiones resultantes de prácticas y costumbres tradicionales ajenas, se configuran identidades compartidas, construidas y enriquecidas por dos comunidades o grupos culturales diversos, que como los nariñenses y candelareños, comparten un mismo espacio y una misma trayectoria, en la que empiezan a definirse a sí mismos y a contar su propia historia de vida desde tradiciones que tal vez al principio no formaron parte de sus rasgos identitarios de origen, pero que con el tiempo se fueron inculcando gracias a las relaciones de proximidad con otros grupos culturales.

Hoy, puede decirse que nariñenses y candelareños participan de varias prácticas que han sabido apropiarse en la vida cotidiana, como la manera de vestir y los espacios de encuentro religiosos en los cuales los símbolos y representaciones religiosas como la Virgen de las Lajas y la Virgen de la Candelaria, convocan desde la diferencia a un mismo espacio identitario. Una vez más, decimos que la identidad no es una entidad acabada ni homogénea, más bien es aquello que se sitúa en una historia común y con costumbres diversas que entran en diálogo y tensiones: el devenir y el constante fluir de la existencia humana forjan la identidad de los sujetos, siempre cambiante y siempre dispuesta a enriquecerse en medio y gracias a lo otro. 
Imagen 40. Collage de fotografías realizadas a nariñenses y prácticas propias, durante el trabajo de campo

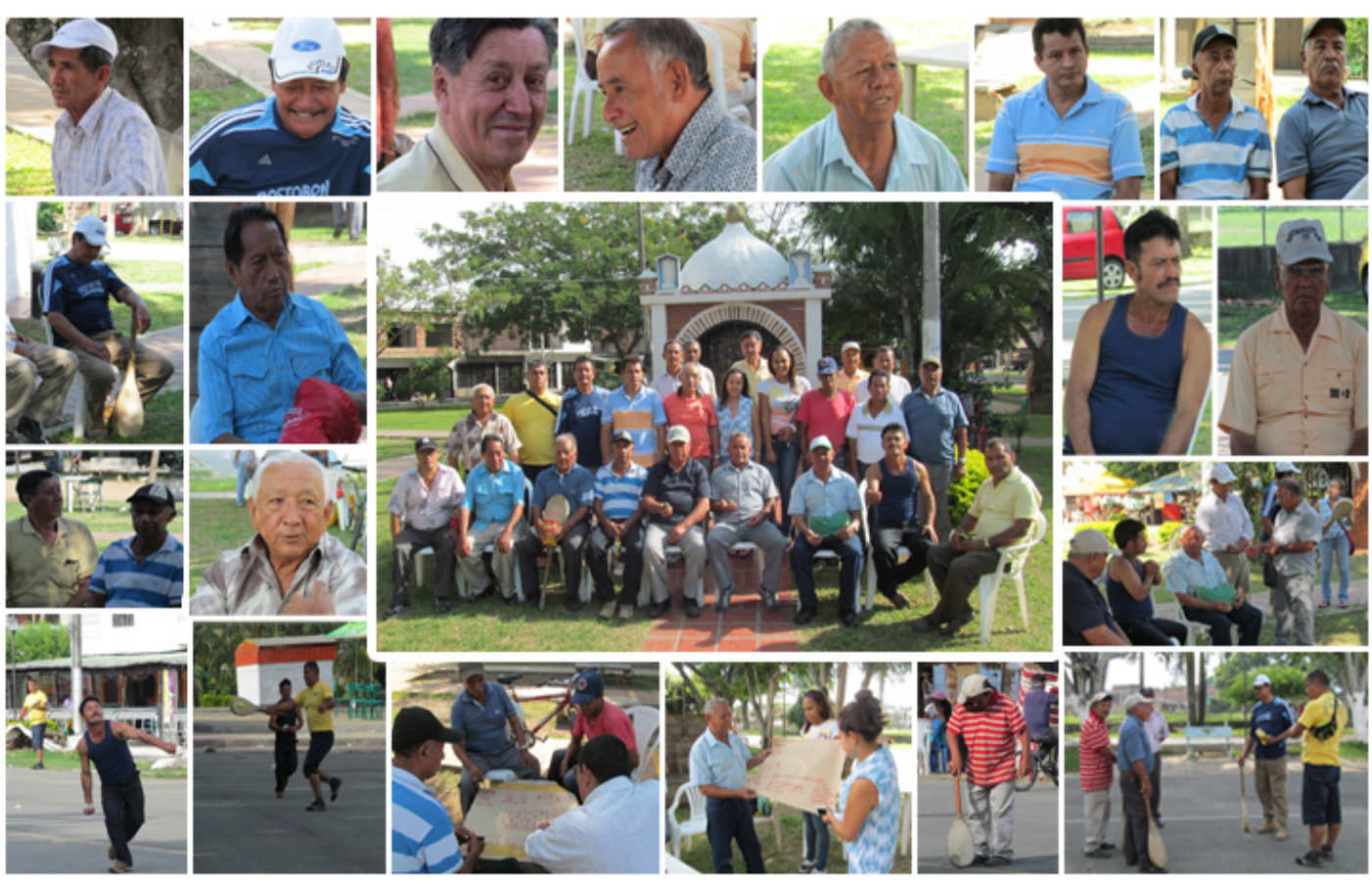

Fuente: recopilación propia de fotografías del trabajo de campo 


\section{CAPÍTULO VII. REFERENCIAS}

\section{Referencias bibliográficas}

Anderson, B. (1993). Comunidades imaginadas. Reflexiones sobre el origen y la difusión del nacionalismo. (E. Suárez, Trad.). México: Fondo de Cultura Económica.

Arboleda, S., Urrea, F., y Arias, J. (Julio de 2000). Construcción de redes familiares entre migrantes de la Costa Pacifica y sus descendientes en Cali. (C. Centro de Investigaciones y Documentación Socioeconomica, Ed.) Obtenido de Biblioteca virtual CLACSO: $\quad$ http://biblioteca.clacso.edu.ar/Colombia/cidseunivalle/20121116124726/Documento48.pdf

Ardila, G. (2006). Colombia: migraciones, transnacionalismo y desplazamiento. Bogotá, Colombia: Universidad Nacional de Colombia, Facultad de Ciencias Humanas, Centro de Estudios Sociales.

Arroyo, R. (2006). Los excluidos sociales del campo. (S. d. Agraria, Ed.). Estudios Agrarios. Revista de la Procuraduría Agraria (17).

Banguero, H. E. (1985). El proceso migratorio en Colombia: Determinantes y consecuencias. Boletín socioeconómico (13), 23-36.

Barbary, O., y Urrea, F. (2004). Gente negra en Colombia. Dinámicas sociopoliticas en Cali y el Pacífico. (E. L.-I. COLCIENCIAS, Ed.) Medellín, Colombia.

Barbary, O., Urrea, F., Bruyneel, S., y Ramírez, H. F. (1999). Biblioteca CLACSO. Recuperado el 13 de mayo de 2015, de Afrocolombianos en el área metropolitana de Cali. Documento de trabajo No.38: http://biblioteca.clacso.edu.ar/Colombia/cidseunivalle/20121115115638/Documento38.pdf

Bechis, M., Dabeningo, V., Freidin, B., Liberalotto, N., Masseroni, S., Navarro, A... (1999). El método biográfico. La reconstrucción de la sociedad a partir del testimonio de los actores. (R. (. Sautu, Ed.) Argentina: Editorial de Belgrano.

Bello, Á. (2002). Migracion, identidad y comunidad Mapuche en Chile entre utopismos y realidades. Asuntos Indígenas 3 (4), 40-48.

Berry, J. (1997). Integration, acculturation and adaptation. Applied Psychology: An International Review, 46 (1), 5-68. 
Bianchi, M. G., Trelles, V., y Fittipaldi, R. A. (2010). Sistemas y redes migratorias: implicancias socio-espaciales de la migración boliviana en Hilario Ascasubi. Huellas (14), 233-250.

Blanco, C. (2000). Las migraciones contemporáneas. (A. e. S.A., Ed.) Madrid, España.

Bonilla, E., Del Valle, C., y Martínez, G. (2012). El grupo de discusión como generador de discurso social: aproximaciones teórico-metodológicas. Revista Austral de Ciencias Sociales, (22), 101-114.

Boss, P. (2000). Ambiguous Loss: Learning to live with unresolved grief. (C. H. Press, Ed.)

Candelaria, A. d. (2004-2007). Plan básico de ordenamiento territorial. Municipio de Candelaria, Valle. 2005-2015. Recuperado el 27 de Marzo de 2015, de Alcaldía de Candelaria, Valle del Cauca: http://www.candelaria-valle.gov.co/apc-aafiles/653532353333666383438323432316538/PLAN BASICO_DE_ORDENAMI ENTO_TERRITORIAL_PARTTE_1.pdf

Casasa, P. (2008). Migración e identidad cultural. Revista Trabajo Social (19), 35-48.

Castells, M. (2003). La era de la información. El poder de la identidad (Vol. 2). Madrid, España: Editorial Alianza.

Centeno, C. (noviembre de 2012). De representaciones y sentidos socio-territoriales. El caso de afrocolombianos habitantes de Charco Azul, Mójica II, Cinta Sardi y la Colonia Nariñense en Cali. Prospectiva, 17, 47-85.

Clarke, J. (2000). Estilo. Recuperado el 20 de noviembre de 2014, de Scribd: https://es.scribd.com/doc/109366225/ESTILO-Elena-Berge-Traduccion-delcapitulo-Style-de-John-Clarke-publicado-en-Stuart-Hall-and-Tony-Jefferson-eds$\underline{\text { Resistance-through-rituals-Y }}$

CNP, C. N. (2002). El conglomerado del azucar del Valle del Cauca, Colombia. (N. Unidas, Ed.) Santiago de Chile, Chile: Comisión Económica para América Latina y el Caribe CEPAL y Sociedad Alemana de Cooperación Técnica GTZ.

Cubides, F., y Dominguez, C. (1999). Desplazados, migraciones internas y reestructuraciones territoriales. (F. Cubides, \& C. Dominguez, Edits.) Bogotá: Observatorio Socio-Político y Cultural, Centro de Estudios Sociales, Facultad de Ciencias Humanas, Universidad Nacional de Colombia.

DANE, D. A. (2005). Boletín censo general 2005. Perfil Candelaria, Valle del Cauca. Recuperado el 20 de Abril de 2015, de Departamento Administrativo Nacional de 
Estadística

DANE:

https://www.dane.gov.co/files/censo2005/perfiles/valle/candelaria.pdf

DANE, D. A. (2012). Atlas estadístico. (I. N. Colombia, Ed.) Bogotá, Colombia.

De la Torre, L. (2004). No llores, Prenda, pronto volveré. Migración, movilidad social, herida familiar y desarrollo. La Paz: Institut français d'études andines, Universidad Católica Boliviana San Pablo.

Del Olmo, N. (2003). Construcción de identidades colectivas entre inmigrantes: ¿interés, reconocimiento y/o refugio? Revista Española de Investigaciones Sociológicas (104), 29-56.

Demarchi, M. (2012). La espacialidad de la migración boliviana en el marco de las redes sociales. El caso del cinturón verde santafesino. Scripta Nova Revista electrónica de geografía y ciencias sociales, XVI (408).

Demera, J. D. (2007). Ciudad, migración y religión. Etnografía de los recursos identitarios y de la religiosidad del desplazado en Altos de Cazuca. Theologica Xaveriana, 57 (162), 303-319.

Dureau, F., Méndez, R., y Florez, C. E. (1996). Aguaitacaminos. Movilidad espacial en zonas de expansión: los casos de Yopal, Aguazul y Tauramena. Bogotá, Colombia: Centro de Estudios sobre Desarrollo Económico de la Universidad de los Andes e Instituto francés de Investigación para el desarrollo, ex- ORSTOM.

Escobar, J., Moreno, S., y Collazos, J. (2013). Composición de la economía de la región Suroccidente de Colombia. Ensayos sobre economía regional No. 52. Recuperado el 13 de agosto de 2015, de Banco de la República de Colombia: http://www.banrep.gov.co/sites/default/files/publicaciones/archivos/eser_52_suro ccidente 2013.pdf

Espinosa, E. (2003). Migraciones regionales y mercado laboral en Colombia, 1973-1993. Cartagena: Universidad Jorge Tadeo Lozano. Seccional del Caribe.

Fields, G. (1980). Migración permanente en Colombia: Prueba de la hipótesis de Ingreso Esperado. Desarrollo y Sociedad, 3, 99-115.

Fierro, M. (1973). Algunos problemas relacionados con la migración interna en Colombia. Documento CEDE No. 003. (U. d. Andes, Ed.). Bogotá, Colombia.

Ford, A. (1994). Navegaciones. (A. Editores, Ed.). Buenos Aires, Argentina.

Galvis, L. A. (2002). Determinantes de la migración interdepartamental en Colombia, 1988-1993. Editorial Andes Banco de la República. 
Gamboa, I., y Moreno, W. H. (1996). Candelaria 1950 a 1990 Cambios economicos y socioculturales. (G. MAURICIO, Ed.) Cali, Colombia.

García, J. (2000). Cuadernos metodológicos. Diarios de campo (Vol. 31). Madrid, España: Centro de investigaciones sociológicas .

García, J. A. (2013). Patrones de migracion en Colombia desde la perspectiva de la teoria de redes. Cuadernos de Economia, 32(59), 339-364.

García, N. (2006). El consumo cultural: una propuesta teórica. En J. Martín, N. García, E. Lozano, G. Orozco, M. Bisbal, P. Nicodemo, y C. A. Bello (Eds.), El consumo cultural en América Latina (p. 535). Bogota, Colombia.

Gavazzo, N. (2006). Las danzas de Oruro en Buenos Aires: tradición e innovación en el campo cultural boliviano. Cuadernos de la Facultad de Humanidades y Ciencias Sociales. Universidad Nacional de Jujuy, 79-105.

Giarracca, N., Bidaseca, K., y Mariotti, D. (2001). Trabajo, migraciones e identidades en tránsito: los zafreros en la actividad cañera tucumana. En E. Pérez, M. d. Baudel, M. Teubal, D. Siqueira, R. Osório, D. Barkin, y otros, ¿Una nueva ruralidad en América Latina? Buenos Aires, Argentina: Consejo Latinoamericano de Ciencias Sociales. CLACSO.

Giménez, G. (1981). Poder, Estado y discurso. Perspectivas sociológicas y semiológicas del discurso político-jurídico. (Universidad Autónoma de México) México D.F.

Gordon, M. (1964). The nature of assimilation. En M. Gordon, y N. Y. Press. (Eds.), Assimilation in American Life (pp. 60-83).

Grimson, A. (2001). Fronteras, estados e identificaciones en el Cono Sur. En L. Arizpe, G. Alonso, I. Cisneros, G. Espina, J. García, A. Grimson, y C. L. CLACSO (Eds.), Estudios latinoamericanos sobre cultura y transformaciones sociales en tiempos de globalización 2. Buenos Aires, Argentina.

Grimson, A. (2001). Interculturalidad y comunicación. Bogotá, Colombia: Editorial Norma.

Grimson, A. (2005). Relatos de la diferencia y la igualdad. Los bolivianos en Buenos Aires. Buenos Aires, Argentina: Eudeba.

Grimson, A. (2011). Doce equívocos sobre las migraciones. Nueva Sociedad (233).

Guataquí, J. C., y Roa, M. (2010). Características demográficas de la movilidad geográfica interna de la población colombiana a la luz de la información provista 
por el censo nacional de población 2005. (I. Nacional, Ed.) Bogotá, Colombia: Departamento Administrativo Nacional de Estadística (DANE).

Hall, E. (1990). The Silent Language. (A. Books, Ed.) New York, Estados Unidos.

Hall, P. (1996). Ciudades del mañana. Historia del urbanismo en el siglo XX. Barcelona, España: Ediciones del Serbal.

Hall, S. (2003). ¿Quién necesita la identidad? En S. Hall, P., du Gay, y A. Editores (Eds.), Cuestiones de Identidad. Buenos Aires, Argentina.

Hall, S. (2006). On ideology. Routledge: Studies.

Hall, S. (2010). Sin garantías: Trayectorias y problemáticas en estudios culturales. Popayán: Envión Editores.

Hall, S., y du Gay, P. (2003). Cuestiones de identidad cultural. Buenos Aires, Argentina: A. Editores.

Hall, S., y du Gay, P. (2003). Cuestiones de identidad cultural. Buenos Aires: Amorrortu.

Hall, S., y Jefferson, T. (. (2000). Resistance through rituals: youth subcultures in postwar Britain. (U. d. Birmingham, Ed.) New York: Routledge.

Hammersley, M., y Atkinson, P. (1994). Etnografia: métodos de investigación. Barcelona, España: Paidós Ibérica.

Harris, J., y Todaro, M. (1970). Migration, Unemployment and Development: A Twosector Analysis. American Economic Review, 60 (1), 126-42.

Herder, J. G. (2000). Genio nacional y medio ambiente. En la invención de la nación. Lecturas de la identidad de Herder a Homi Bhabha. Compilador: Álvaro Fernández Bravo. Buenos Aires, Argentina: Ediciones Manantial SRL.

Hernández, G. (2012). Cuatro aportes desde la antropología para comprender la emigración. Universitas Humanística (74), 35-56.

Histórica, C. N. (2014). "Patrones" y campesinos: tierra, poder y violencia en el Valle del Cauca (1960-2012). (I. N. Colombia, Ed.) Bogotá, Colombia: Informe del Centro Nacional de Memoria Historica.

Hoffmann, O. (2007). Comunidades negras en el Pacifico colombiano. Innovaciones y dinámicas étnicas. (I. I.-Y. Instituto francés de estudios andinos, Ed., y C. Pascal, Trad.) Quito, Ecuador. 
Jaes, C. (2002). Migración, pérdida ambigua y rituales. Perspectivas sistémicas, 13 (69).

Jaramillo, J. (2002). Parentesco y memoria familiar en una familia migrante de la Costa Pacífica en Cali. Virajes, 1 (4), 87-101.

Jaramillo, S. (1999). Migraciones e interaccion regional en Colombia, 1973-1993. Territorios : Revista de Estudios Urbanos y Regionales (1).

Jensen, F. (2012). La identidad al otro lado de la Cordillera: migración, identidad e integración. Ánfora, 19 (33).

Labrador, J. (2001). Identidad e inmigración: un estudio cualitativo con inmigrantes peruanos en Madrid. Madrid: Universidad Pontificia Comillas.

Laclau, E., y Mouffe, C. (1987). Hegemonía y estrategia socialista. Hacia una radicalización de la democracia. (S. XXI, Ed.) Madrid, España.

Landowski, E. (Enero de 1993). Ellos y nosotros: notas para una aproximación semiótica a algunas figuras de la alteridad social. (F. J. Gasset, Ed.). Revista de Occidente (140), 98-118.

Lee, E. (1966). A theory of migration. Demography, 3 (1), 47-57.

López, Á. (1968). Análisis demográfico de los censos colombianos, 1951 y 1964. Bogotá, Colombia: Universidad de los Andes.

López, Á. (1970). Migración y cambio social en Antioquia durante el siglo XIX. Bogotá, Colombia: Universidad de los Andes.

Marcus, G. (2001). Etnografía en/del sistema mundo. El surgimiento de la etnografía multilocal. Alteridades, 11 (22).

Marcuse, H. (1993). El hombre unidimensional. Ensayo sobre la ideología de la sociedad industrial avanzada. Barcelona, España: Planeta, Agostini.

Mariscal, B. (1995). Renovación y afirmación de las identidades culturales. Revista de literatura hispánica (42), 153-160.

Marmora, L. (2003). Las políticas de migraciones internacionales. (E. Paidos, Ed.) Buenos Aires.

Marroquín, A. (2005). Tres veces mojado. Migración internacional, cultura e identidad en El Salvador. Estudios centroamericanos. ECA. , 465-474.

Martín, J. (1987). De los medios a las mediaciones. Comunicación, cultura y hegemonía. México: (E. G. S.A., Ed.). 
Martínez, C. (2006). Las migraciones internas en Colombia : análisis territorial y demográfico según los censos de 1973 y 1993. Bogotá, Colombia: Universidad Externado de Colombia.

Marx, K. (1946). El Capital, Tomo I. México DF: Fondo de cultura económica.

Massey, D., Arango, J., Hugo, G., Kouaouci, A., Pellegrino, A., y Taylor, J. E. (Septiembre de 1993). Theories of International Migration: A Review and Appraisal. Population and Development Review, 19 (3), 431.466.

Méndez, M. (2008). El reconocimiento del derecho a la participación política de los inmigrantes: algunas experiencias. Derechos y libertades (18), 141-160. (R. d. Casas, Ed.)

Mendoza, C. (2012). Mapas mentales, sentido de lugar y procesos migratorios: la comunidad mexicana en Albuquerque (Nuevo México). Cuadernos de Geografía - Revista Colombiana de Geografía, 21 (2), 29-43.

Muñoz, G. (2007). ¿Identidades o subjetividades en construcción?. En U. T. Pereira (Ed.), Revista de Ciencias Humanas, 12(37), 69-89.

Murad Rivera, R. (2003). Estudio sobre la distribución espacial de la población en Colombia. Santiago de Chile: CEPAL.

OIM, O. I. (2001). Diagnóstico de población desplazada y comunidades de recepción en seis departamentos de Colombia. Recuperado de Organización Internacional para las migraciones: http://www.disasterinfo.net/desplazados/informes/oim/13dep4narino.htm

Olaya, P. (2014). Biblioteca digital Universidad del Valle. Recuperado de Proceso de individuación y subjetivación de cinco mujeres que llegan a Cali en medio del conflicto armado.: http://bibliotecadigital.univalle.edu.co/bitstream/10893/7585/1/0508699-p-14$\underline{\text { ms.pdf }}$

Park, R. (1999). La ciudad y otros ensayos de ecología urbana. En Martínez (Trad.), Barcelona, España: Ediciones del Serbal.

Pasto, A. m. (2010). Plan especial de salvaguardia del carnaval de negros y blancos de Pasto. Recuperado de Alcaldía del municipio de Pasto: https://www.google.com.co/\#q=Plan + especial + de + salvaguardia + del + carnaval + de + blancos $+\mathrm{y}+$ negros + de + pasto 
Pedone, C. (2010). Cadenas y redes migratorias: propuesta metodológica para el análisis diacrónico-temporal de los procesos migratorios. EMPIRIA. Revista de Metodología de las Ciencias Sociales(19), 101-132.

Pérez, E., Baudel, M. d., Teubal, M., Siqueira, D., Osório, R., Barkin, D... (2001). ¿Una nueva ruralidad en America Latina? Buenos Aires, Argentina: CLACSO.

Pérez Sáinz, P. (2014). Mercados y bárbaros. La persistencia de las desigualdades de excedente en América Latina. San José: FLACSO.

Posso, J. (2008). Indígenas en la ciudad y estrategias de supervivencia en Cali. Cali, Colombia: Universidad del Valle.

Posso, J. (2008). La inserción laboral de las mujeres inmigrantes negras en el servicio doméstico de la ciudad de Cali. Cali, Colombia: Universidad del Valle.

Prat, J. (2007). En busca del paraíso: historias de vida y migración. Revista de Dialectología y Tradiciones Populares, 62 (2), 21-61.

Provansal , D. (1996). Antropología de las migraciones: algunos apuntes e interrogantes. Ensayos de Antropología Cultural. Homenaje a Claudio Esteva Fabregat. Barcelona, España: Editorial Ariel.

Quintín, P. (1998). Memorias y relatos de lugares: a propósito de una migrante de la Costa Pacífica en Cali. En J. Camacho, E. (. Restrepo y E.-N.-I. C. Antropología (Ed.), De montes, ríos y ciudades: territorios e identidades de gente negra en Colombia. Bogotá, Colombia: Juana Camacho y Eduardo Restrepo.

Ramos, M. E., Aponte, R., Castro, A. E., Moctezuma, M., Rodríguez, W., Sieglin, V...(2009). Migración e identidad: emociones, familia, cultura. En F. León (Ed.) México.

Rangel, M. P., Hermel, J., Oliveira, A. P., Jorge, C., y Hofstaetter, C. (2005). Migración e identidad: familias hispanoamericanas en Porto Alegre (Brasil). Diversitas: Perspectivas en Psicología, 1 (1), 13-21.

Renan, E. (2010). ¿Qué es una nación? En Nación y narración. Entre la ilusión de una identidad y las diferencias culturales. Compilador: Homi K. Bhabha. Buenos Aires: Siglo XXI Editores.

Richard, N. (2005). Globalización académica, estudios culturales y crítica latinoamericana. En D. Mato, y C. L. CLACSO (Ed.), Cultura, política y sociedad. Perspectivas latinoamericanas (pp.455-470). Buenos Aires, Argentina. 
Rivera , S. (2010). Violencias (re) encubiertas en Bolivia. La Paz, Bolivia: Editorial Piedra Rota .

Rizo, M. (2004). Prácticas culturales y redefinición de las identidades de los inmigrantes en El Raval (Barcelona): aportaciones desde la comunicación. Recuperado de Centro de documentación en interculturalidad. CdDI.: http://migraciones.ugr.es/cddi/images/tesis/RizoGarcia2004.pdf

Salas, H. (1997). Los trabajadores temporeros en el Valle del Aconcagua: identidad social y cultural. Revista Mexicana de Sociología, 59 (3), 275-300.

Sassone, S. M. (2007). Migración, territorio e identidad cultural: construcción de "lugares bolivianos" en la Ciudad de Buenos Aires. Población de Buenos Aires, 4(6), 9-28.

Sautu, R. (1999). Estilos y prácticas de la investigación biográfica. En M. Bechis, V. Dabeningo, B. Freidin, N. Liberalotto, S. Masseroni, A. Navarro... El método biográfico. La reconstrucción de la sociedad a partir del testimonio de los actores. Argentina.

Sautu, R., Boniolo, P., y Elbert, R. (2005). Manual de metodología. Buenos Aires: Clacso.

Shultz, T. (1971). Rural - Urban Migration in Colombia. Review of Economics and Statistics, 53, 157-163.

Silva, A., y González, P. (2009). Un análisis espacial de las migraciones internas en Colombia (2000-2005). Revista Facultad de Ciencias Económicas: Investigación y Reflexión, 17 (1).

Solanes, Á. (2008). Inmigración, derechos y exclusión. (F. F. aplicada, Ed.) Recuperado de Fundación FOESSA: http://www.foessa.es/publicaciones download.aspx? $\mathrm{Id}=3865$

Stiglitz, J. (2002). El malestar en la globalización. Buenos Aires: Editorial Taurus.

Tobasura, I. (2003). Boyacenses en Caldas: una colonización silenciosa. Manizales, Colombia: Universidad de Caldas.

Tobasura, I. (2006). Boyacenses en Caldas: del quietismo social a la construcción de región. Cuadernos de Desarrollo Rural, 56, 29-52.

Todaro, M. (1969). A model of labor migration and urban unemployment in less developed countries. The American Economic Review, 59 (1), 138-148. 
Trpin, V. (2007). Identidades en movimiento: familias chilenas en la fruticultura del Alto Valle de Río Negro, Argentina. Cadernos Pagu (29), 227-255.

Urrea , F., Arboleda, S., y Arias, J. (1999). Redes familiares entre migrantes de la costa pacífica a Cali. Revista Colombiana de Antropología, 35, 180-241.

Urrea, F. (2012). Transformaciones sociodemográficas y grupos socio-raciales en Cali a lo largo del siglo XX y comienzos del siglo XXI. En U. d. Rosario (Ed.). Recuperado de Proyecto Afrolatin: http://afrolatinoproject.org/2012/06/28/transformaciones-sociodemograficas-ygrupos-socio-raciales-en-cali-a-lo-largo-del-siglo-xx-y-comienzos-del-siglo-xxi/

Urrea, F., Ramírez, H. F., y Viáfara, C. (2001). Perfiles sociodemográficos de la población afrocolombianas en contextos urbano-regionales del país a comienzos del siglo XXI. (C. d. CIDSE, Ed.) Recuperado de Biblioteca virtual CLACSO: http://bibliotecavirtual.clacso.org.ar/Colombia/cidseunivalle/20121113043151/Art2.pdf

Vásquez, N. S. (2008). Plan de desarrollo municipio Candelaria Valle 2008-2011. Recuperado de Alcaldía de candelaria, Valle del Cauca: http://www.candelariavalle.gov.co/apc-aafiles/62613866303864323265343637333336/PLAN_DESARROLLO.pdf

Velasco, L. (2000). Migración, género y etnicidad: mujeres indígenas en la frontera de Baja California y California. Revista Mexicana de Sociología, 62 (1), 145-171.

Velasco, L. (2002). Agentes étnicos transnacionales: las organizaciones de indígenas migrantes en la frontera México-Estados Unidos. Estudios Sociológicos, 20 (59), 335-369.

Velasco, L. (2004). Identidad y migración. Relato de vida. Historia, antropología y fuentes orales (31), 75-98.

Velasco, L. (2005). Desde que tengo memoria: narrativas de identidad en indígenas migrantes. Tijuana, México: El Colegio de la Frontera Norte. Fondo Nacional para la cultura y las artes.

Vélez, I. (2008). Habitar de mujeres uitoto en Bogotá: ocasiones para pensar la movilidad y la diferencia cultural. Bogotá, Colombia: Universidad Nacional de Colombia.

Veredas, S. (1999). Procesos de construccion de identidad entre la poblacion inmigrante. Papers. Revista de Sociología, 57. 
Viáfara, C. A., Urrea, F., y Correa, J. B. (2009). Desigualdades sociodemográficas y socioeconómicas, mercado laboral y discriminación étnico-racial en Colombia: análisis estadístico como sustento de acciones afirmativas a favor de la población afrocolombiana. En C. d.-C. Universidad Nacional de Colombia. Facultad de Ciencias Humanas (Ed.), Acciones Afirmativas y ciudadanía diferenciada étnicoracial negra, afrocolombiana, palenquera y raizal. Entre Bicentenarios de las Independencias y Constitución de 1991 (pp. 153-346). Bogotá, Colombia: Claudia Mosquera y Ruby Esther León. 


\section{CAPÍTULO VIII. ANEXOS}

\section{ANEXO 1. Protocolo de la entrevista biográfica}

\section{OBJETIVOS METODOLÓGICOS DE LA TÉCNICA}

- Reconstruir desde la perspectiva de los mismos actores, las situaciones, los contextos, comportamientos, percepciones, motivaciones y valoraciones que permitan la reconfiguración histórica de sucesos de vida o de experiencias construidas en torno a uno o varios focos de interés.

- Recolectar testimonios sobre el pasado en un ejercicio que implica el diálogo con un interlocutor que es quien invita a recordar.

- Motivar en los actores relatos de lo que ellos recuerdan haber vivido, pensado o sentido y de la manera tal como cada actor cree que se dieron las situaciones.

\section{OBJETIVO PARTICULAR DE LA INVESTIGACIÓN}

Comprender los procesos de configuración de identidad cultural de los migrantes nariñenses asentados desde los años 60 en Candelaria, Valle del Cauca, Colombia, a partir de sus relatos migratorios y de sus estrategias de identificación cultural generadas y evidenciadas en sus relatos de identidad cultural.

\section{DURACIÓN DE LA ENTREVISTA BIOGRÁFICA}

Entre una hora y una hora y media cada entrevista

\section{DISEÑO DE LA ENTREVISTA BIOGRÁFICA}

La entrevista tiene un bloque inicial en el que se indaga por algunos datos generales de cada entrevistado. 


\begin{tabular}{|c|c|c|c|c|c|c|c|}
\hline $\begin{array}{l}\text { Lugr y fecha de } \\
\text { la elfrevista }\end{array}$ & Nambredel entrevistado & $\begin{array}{l}\text { Lugir y fecta de } \\
\text { naciniento }\end{array}$ & Nived educativo & Edad & cénero & $\begin{array}{l}\text { Uuricipio } \\
\text { nTriñensede } \\
\text { procedencia }\end{array}$ & $\begin{array}{l}\text { Añode llagada (Valledel } \\
\text { CaucalCandaria) }\end{array}$ \\
\hline & & & & & & & \\
\hline
\end{tabular}

\section{BLOQUES TEMÁTICOS, SUBTEMAS Y POSIBLES PREGUNTAS}

\begin{tabular}{|c|c|c|c|}
\hline $\begin{array}{l}\text { MICROCATECORÍASDE } \\
\text { ANÁLISISQUE SE } \\
\text { NUTREN CON LA } \\
\text { APUCACIÓN DE LA } \\
\text { TÉCNICA }\end{array}$ & $\begin{array}{l}\text { BLOQUE } \\
\text { TEMÁTICO }\end{array}$ & SUBTEMAS & POSIBLESPREGUNTASORIENTADORAS \\
\hline \multirow{4}{*}{$\begin{array}{l}\text { 1. Narrativas de lo nariñense. } \\
\text { 2. Orígenes nariñenses. } \\
\text { 3. Estrategias de identificación. } \\
\text { 4. Idea de gente pura y original. } \\
\text { 5. Mito fundacional. } \\
\text { 6. Relatos de marginación- } \\
\text { exchusión. } \\
\text { 7. Relatos de segregación- } \\
\text { separación. } \\
\text { 8. Relatos de asimilación. } \\
\text { 9. Relatos de integración. }\end{array}$} & $\begin{array}{l}\text { 1. Datos } \\
\text { generales }\end{array}$ & $\begin{array}{c}\text { Lngar y fecha de nacimiento, procedencia } \\
\text { Año de llegada al Valle del Canca y a } \\
\text { Candelaria } \\
\text { Edad }\end{array}$ & $\begin{array}{l}\text { En dónde nació? En qué fecha nació? Cuál es su municipio de procedencia } \\
\text { antes de llegar al Valle del Canca? En qué año llegó al Valle del Canca? } \\
\text { Llegó inicialmente a Candelaria o a otro municipio? En qué año llegóa a } \\
\text { Candelaria? Qué edad tiene? }\end{array}$ \\
\hline & $\begin{array}{l}2 \text { Aspectos } \\
\text { relactionadoscon } \\
\text { la niñez }\end{array}$ & $\begin{array}{l}\text { Número de hermanos y ubicación actual } \\
\text { de los integrantes de la familia } \\
\text { Vinculación al sistema educativo y laboral } \\
\text { Actividades que se realizaban en la } \\
\text { infancia tales como juegos, historias, } \\
\text { quehaceres diarios, el ir a la escuela, los } \\
\text { amigos, el barrio, la casa y las } \\
\text { ocupaciones de sus padres. }\end{array}$ & $\begin{array}{l}\text { De dónde son sus padres? Cuántos hermanos fueron? Dónde están los demás } \\
\text { hermanos? A qué se dedicaban sus padres? Qué es lo que más recuenda de su } \\
\text { infancia? Cuáles eran las actividades que más realizaba cıando era niño? Iba } \\
\text { a la escuala? }\end{array}$ \\
\hline & 3 Juventurd & $\begin{array}{c}\text { Vinculación al sistema laboral } \\
\text { Actividades a las que se dedicaban con } \\
\text { mayor frecuencia en el1ugar donde vivian } \\
\text { y en su familia. }\end{array}$ & $\begin{array}{l}\text { A qué edad tuvo su primer trabajo? Qué debía hacer en ese trabajo? Qué } \\
\text { actividades realizaba frecuentemente cundo estaba joven? Cuáles de esas } \\
\text { actividades eran las que más disfrutaba? En dónde vivía? Con quién vivía? } \\
\text { Qué actividades recuenda con su familia en sı época de juventud? }\end{array}$ \\
\hline & $\begin{array}{l}\text { 4. Proceso } \\
\text { migratorio }\end{array}$ & \begin{tabular}{|} 
Motivaciones para migrar, redes de apoyo, \\
rutas, estrategias para minimizar los \\
riesgos en la ruta migratoria y en el lugar \\
de destino, vinculación laboral en el lugar \\
de destino, vivienda y educación en \\
destino, relación con el lugar de origen, \\
intercambio de apoyos, encargos y \\
commnicaciónes con el lugar de origen, \\
interlocución y generación de relaciones \\
en el lugar de destino.
\end{tabular} & 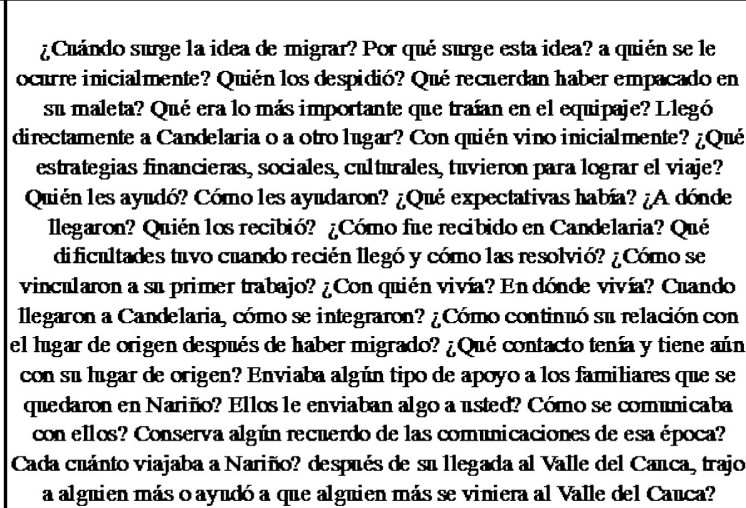 \\
\hline
\end{tabular}




\begin{tabular}{|c|c|c|c|}
\hline $\begin{array}{l}\text { MICROCATECORIASDE } \\
\text { ANÁUSISQUE SE } \\
\text { NUTREN CON LA } \\
\text { APUCACIÓN DE LA } \\
\text { TÉCNICA }\end{array}$ & $\begin{array}{l}\text { ELOQUE } \\
\text { TEMÁTICO }\end{array}$ & SUBTEMAS & POSBLES PREGUN TASORIENTADCRAS \\
\hline \multirow{5}{*}{$\begin{array}{l}\text { 1. Narrativas de lo narióense. } \\
\text { 2. Orígenes nariñenses. } \\
\text { 3. Estrategias de identificación. } \\
\text { 4. Idea de gente pura y original. } \\
\text { 5. Mito fundacional. } \\
\text { 6. Relatos de marginación- } \\
\text { exchusión. } \\
\text { 7. Relatos de segregación- } \\
\text { separación. } \\
\text { 8. Relatos de asimilación. } \\
\text { 9. Relatos de integración. }\end{array}$} & $\begin{array}{l}5 \text { Vind lación } \\
\text { laboral en } \\
\text { luggr de destino }\end{array}$ & $\begin{array}{l}\text { Primera vinculación labral en el hogar de } \\
\text { destino, enganches iniciales para } \\
\text { vinculación laboral, financiación del viaje } \\
\text { al inicio, ofertas de las organizaciones } \\
\text { para la vinculación laboral, jomadas } \\
\text { laborales, relación con los jefes y con las } \\
\text { organizaciones, relación con compañeros, } \\
\text { tiempos libres y de ocio, posibilidades } \\
\text { para mejorar calidad de vida a partir de la } \\
\text { opción laboral. }\end{array}$ & $\begin{array}{l}\text { Después de llegar al Valle del Canca, al cuánto tiempo empezó a trabajar? } \\
\text { Quién los contactó o recomendó? vinieron por cuenta propia o alguien } \\
\text { financió su viaje? cómo eran las jornadas laborales? qué prestaciones } \\
\text { sociales les ofrećá la empresa? qué ventajas les ofrećá la empresa para venir } \\
\text { a trabajar aqứ? cómo eran los pagos?, quién era el jefe al principio? cómo } \\
\text { era el jefe? cómo era la relación con los jefes y con la empresa?, quiénes eran } \\
\text { los compañeros? qué haćan en los tiempos libres? Siempre trabajó en el } \\
\text { mismo hugar o tuvo cambios? por qué cambió? La empresa le dio algún tipo } \\
\text { de posibilidades para mejorar su calidad de vida y la de su familia? cuáles? }\end{array}$ \\
\hline & $\begin{array}{l}\text { 6. La familia en } \\
\text { el marcodela } \\
\text { migraón }\end{array}$ & $\begin{array}{c}\text { Conformación familiar, procedencia del } \\
\text { compañero o compañera, metas familiares } \\
\text { al inicio de la historia migratoria, logros y } \\
\text { transformación de metas familianes, los } \\
\text { hijos y nietos. }\end{array}$ & $\begin{array}{l}\text { ¿Cómo formó su familia? Dónde conoce a su esposa? De dónde es su } \\
\text { esposa? Cuándo deciden casarse? Cuáles eran sus metas cıando decidieron } \\
\text { casarse? Las han logrado cumplir? En qué momento llegaron los hijos? }\end{array}$ \\
\hline & $\begin{array}{l}\text { 7. Lonarifiense } \\
\text { en Candalaria }\end{array}$ & $\begin{array}{c}\text { Estrategias de identificación nariñense al } \\
\text { inicio de la migración, motivaciones para } \\
\text { las estrategias de identificación, la colonia } \\
\text { nariñense en Candelaria, espacios de } \\
\text { encuentro de los nariñenes en Candelaria, } \\
\text { asistentes, periodicidad de los encuentros, } \\
\text { costımbres nariñenses, ser y hacer parte } \\
\text { de Candelaria. }\end{array}$ & 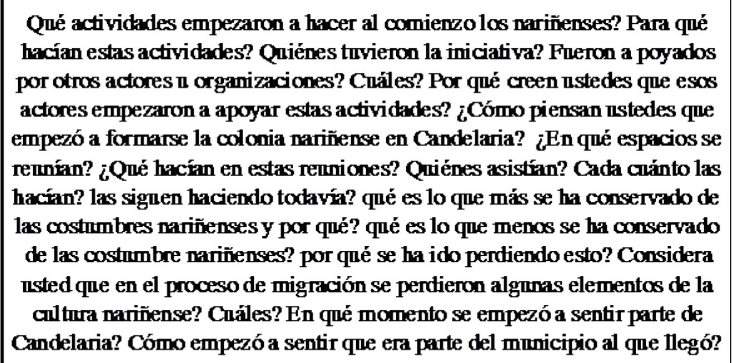 \\
\hline & $\begin{array}{l}\text { 8. Estrategias de } \\
\text { identificación de } \\
\text { losnariñenaes } \\
\text { en Candklaria }\end{array}$ & $\begin{array}{c}\text { Actividades de los nariñenses en } \\
\text { Candelaria, características de estas } \\
\text { actividades, costumbres narilenses en } \\
\text { Candelaria, convocatoria, vinculación de } \\
\text { candelareños en estas actividades, } \\
\text { importancia de las prácticas nariñenses en } \\
\text { Candelaria }\end{array}$ & 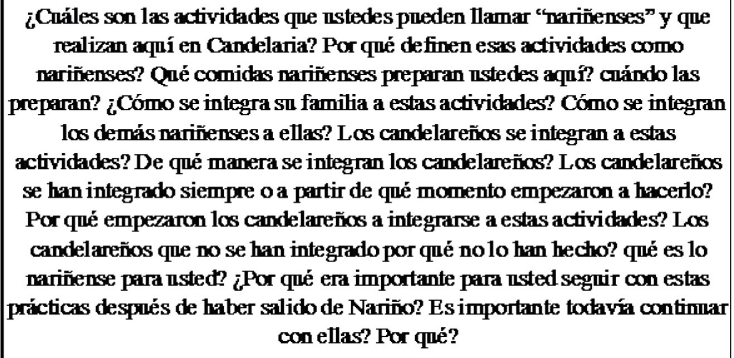 \\
\hline & $\begin{array}{l}\text { 9. Propactos } \\
\text { futuros }\end{array}$ & Planes familiares & $\begin{array}{l}\text { Qué tiene proyectado para usted y para sn familia de aquí en adelante? Pensó } \\
\text { en algín momento o piensa aín en regresar a su hugar de origen? }\end{array}$ \\
\hline
\end{tabular}

\section{FUENTES}

Se reconstruyen los trayectos biográficas de ocho sujetos migrantes nariñenses asentados en Candelaria, Valle del Cauca. Colombia, desde hace más de 40 años. Los sujetos propuestos para la reconstrucción de los trayectos biográficos fueron: Rosalba Getial, Jorge Rodrigo Martínez, Aurelio Realpe, José Alpala, Gabriel Pascuasa, Pedro Castro, Luis Alberto Díaz y José Montilla. 
Para esto se propuso realizar: 8 entrevistas biográficas a unos de los primeros migrantes que llegaron a trabajar en Candelaria, la mayoría de ellos al Ingenio Mayagüez.

\section{REQUERIMIENTOS}

\begin{tabular}{|l|l|l|}
\hline \multicolumn{1}{|c|}{ Técnicos } & \multicolumn{1}{|c|}{ Materiales } & \multicolumn{1}{|c|}{ Desplazamientos } \\
\hline $\begin{array}{l}\text { Grabadora digital de } \\
\text { audio }\end{array}$ & Diario de campo & $\begin{array}{l}\text { Para la aplicación de las } \\
\text { entrevistas biográficas se planean } \\
\text { desplazamientos diarios al } \\
\text { municipio de Candelaria durante } \\
\text { semanas. }\end{array}$ \\
\hline Pilas de repuesto & Lápiz & \\
\hline & Borrador & Sacapuntas \\
\hline
\end{tabular}

\section{APLICACIÓN DE LA ENTREVISTA BIOGRÁFICA}

\section{FASE 1: VALIDACIÓN DEL INSTRUMENTO}

Con el fin de comprobar la validez, confiabilidad y especificidad del instrumento, se cuenta con dos instancias de validación; la de expertos, realizada por la directora y el codirector de la propuesta de investigación y la validación social, realizada en campo.

A partir de ambas validaciones y de los resultados arrojados por ellas en cuanto a aciertos y desaciertos en el diseño del instrumento, se procede a realizar los ajustes para la aplicación con las personas definidas.

\section{FASE 2: APLICACIÓN DEL INSTRUMENTO}

\section{Concertación de citas y definición de espacios}

Se definen las citas con los entrevistados. La propuesta para esta concertación es adaptarse a los tiempos y disponibilidad de los actores de la investigación, además de optar por los espacios que ellos propongan como los más cómodos para la conversación. $\mathrm{Al}$ respecto se les solicita de manera previa que se elijan lugares que no sean ruidosos y que en lo posible tengan poco flujo vehicular y de personas. 


\section{Realización de la entrevista biográfica}

Inicialmente se le indica al interlocutor el objetivo de la entrevista y los bloques temáticos que esta tiene. El entrevistador tiene como guía las posibles preguntas orientadoras de cada uno de los bloques, cuidando de no plantear preguntas en el transcurso de la conversación que induzcan ciertas respuestas por parte del entrevistado y revisando que en la conversación se vayan cubriendo los subtemas contemplados en el diseño.

\section{Modalidades de registro}

Aquí se tienen en cuenta los tres diferentes instrumentos para registrar la entrevista biográfica en el momento de su aplicación. Estos son:

La ficha de datos generales en la que se diligencia la información general de cada entrevistado.

Las notas que el investigador toma durante la entrevista, en las que consigna elementos significativos que identifica durante la conversación, gestos del entrevistado que considere importantes para aportar en el análisis y la interpretación, y comentarios e impresiones generales sobre lo que se va conversando, para evitar que sean olvidados en el momento de construir el trayecto y de realizar el análisis.

El registro digital con el audio de toda la entrevista desde el momento inicial hasta finalizar el diálogo.

\section{FASE 3: ANÁLISIS DE LOS DATOS RECOGIDOS}

\section{Transcripción}

Posterior a la realización de las entrevistas biográficas se procede a la transcripción de los audios, ejercicio en el cual, el investigador puede ir generando unos memos al borde de página que le sirvan como guía para identificar de manera previa al análisis, elementos emergentes y aspectos relevantes de la entrevista biográfica.

En lo posible es recomendable que la transcripción de las entrevistas biográficas se realice en el menor tiempo posible posterior a su aplicación. Preferiblemente que no pasen más de tres o cuatro días para ser transcritas ya que esto facilita que el investigador pueda aprovechar elementos significativos que quedan en su memoria sobre el momento mismo del diálogo. 


\section{ANEXO 2. Protocolo de la entrevista focalizada individual}

\section{OBJETIVOS METODOLÓGICOS DE LA TÉCNICA}

- Generar un espacio para la escucha atenta y profunda del decir del otro.

- Reconstruir una experiencia personal relacionada con una situación concreta del entrevistado.

- Proponer el ejercicio de interlocución con el otro, como un escenario propicio para la reflexión sobre un tema específico.

\section{OBJETIVO PARTICULAR DE LA INVESTIGACIÓN}

Comprender los procesos de configuración de identidad cultural de los migrantes nariñenses asentados desde los años 60 en Candelaria, Valle del Cauca, Colombia, a partir de sus relatos migratorios y de sus estrategias de identificación cultural generadas y evidenciadas en sus relatos de identidad cultural.

\section{DURACIÓN DE LA ENTREVISTA}

Entre 30 y 40 minutos cada entrevista

\section{DISEÑO DE LA ENTREVISTA FOCALIZADA INDIVIDUAL}

La entrevista tiene una parte inicial en la que se hace el registro de algunos datos generales de cada entrevistado.

\begin{tabular}{|c|c|c|c|c|c|c}
\hline $\begin{array}{c}\text { Lugar y fecha de } \\
\text { la equrevista }\end{array}$ & Nombredel entrevistado & Lugar y fecha denacimiento & $\begin{array}{c}\text { Nivel } \\
\text { educativo }\end{array}$ & Edad & Género & Lugar deresidencia \\
\hline & & & & & & \\
\end{tabular}




\section{SUBTEMAS Y POSIBLES PREGUNTAS}

\begin{tabular}{|c|c|c|}
\hline $\begin{array}{l}\text { MICROCATEGORIASDE } \\
\text { ANÁLISISQUE SE NUTREN } \\
\text { CON LA APUCACIÓN DE } \\
\text { LA TÉCNICA }\end{array}$ & SUBTEMAS & POSIBLES PREGUNTASORIENTADORAS \\
\hline & $\begin{array}{c}\text { Datos generales del } \\
\text { entrevistado }\end{array}$ & $\begin{array}{l}\text { Nombre completo del entrevistado, en dónde nació? En qué fecha nació?, } \\
\text { nivel educativo, lugar de residencia, rol o roles que ha desempeñado dentro } \\
\text { del municipio. }\end{array}$ \\
\hline 1. Narrativas de lo nariñense. & $\begin{array}{c}\text { Narrativa de la migración } \\
\text { nariñense desde los } \\
\text { candelareños. ¿Cómo ven los } \\
\text { candelareños a los nariñenses? }\end{array}$ & $\begin{array}{l}\text { Qué es lo que caracteriza a un nariñense? Qué diférencia a un nariñense de } \\
\text { un candelareño? Qué tienen en común los nariñenses y los } \\
\text { candelareños?¿Qué recuerda de la época en la que legaron los nariñenses } \\
\text { al municipio? A dónde llegamban los nariñenses? Cómo eran los } \\
\text { nariñenses? Describa sus particularidades. ¿A qué vinieron los nariñenses a } \\
\text { Candelaria? ¿Cómo recuerda que fueron recibidos por los candelareños? } \\
\text { ¿cómo ha sido la relación entre los candelareños y los nariñenses a lo largo } \\
\text { del tiempo? ¿Quiénes son los nariñenses? Cuáles son las costumbres que } \\
\text { más caracterizan a los nariñenses? Es posible identificar a simple vista a un } \\
\text { nariñense? Cómo puede identificar usted a un nariñense? Qué les gusta } \\
\text { hacer a los nariñenses? Qué no les gusta hacer a los nariñenses? qué } \\
\text { diferencias existen entre los nariñenses y los candelareños? Qué } \\
\text { similitudes hay? Hay espacios de encuentro que solo sean de los } \\
\text { nariñenses aqư en Candelaria? Cuáles? }\end{array}$ \\
\hline $\begin{array}{l}\text { 2. Relatos de marginación- } \\
\text { exclusión. }\end{array}$ & \multirow[t]{2}{*}{$\begin{array}{c}\text { Relatos de aculturación en el } \\
\text { proceso migratorio }\end{array}$} & \multirow{2}{*}{$\begin{array}{l}\text { Recuerda qué pensaban usted y sus vecinos cuando los nariñenses } \\
\text { empezaron a llegar a Candelaria? Ha cambiado esta manera de pensar con } \\
\text { respecto a los nariñenses a lo largo del tiempo? El municipio de Candelaria } \\
\text { tuvo algunos cambios derivados de la llegada de los nariñenses? Mencione } \\
\text { algunos. Qué recuerda de las relaciones entre los candelareños y los } \\
\text { nariñenses en la época en la que llegaron los nariñenses al municipio? Han } \\
\text { cambiado a lo largo del tiempo estas relaciones? }\end{array}$} \\
\hline $\begin{array}{l}\text { 3. Relatos de segregación- } \\
\text { separación. }\end{array}$ & & \\
\hline
\end{tabular}

\section{FUENTES}

Se realizan ocho entrevistas focalizadas individuales a habitantes de Candelaria que en la misma época vivieron la llegada de los nariñenses al municipio. Entre las personas inicialmente sugeridas para las entrevistas están: Clara Díaz, Camilo Muñoz, Edgar Olave, Luis López, Isaías Gamboa, Milena Medina, Víctor Mondragón y Zoraida Zamorano.; cuyas familias son tradicionales en el municipio de Candelaria. 


\section{REQUERIMIENTOS}

\begin{tabular}{|c|c|c|}
\hline Técnicos & Materiales & Desplazamientos \\
\hline Grabadora digital de audio & Diario de campo & \multirow{4}{*}{$\begin{array}{l}\text { Para la aplicación de las entrevistas } \\
\text { focalizadas individuales se planean } \\
\text { desplazamientos diarios al } \\
\text { municipio de Candelaria durante } 1 \\
\text { semana. }\end{array}$} \\
\hline \multirow[t]{3}{*}{ Pilas de repuesto } & Lápiz & \\
\hline & Borrador & \\
\hline & Sacapuntas & \\
\hline
\end{tabular}

\section{APLICACIÓN DE LA ENTREVISTA FOCALIZADA INDIVIDUAL}

\section{FASE 1: VALIDACIÓN DEL INSTRUMENTO}

Con el fin de comprobar la validez, confiabilidad y especificidad del instrumento, se cuenta con dos instancias de validación; la de expertos, realizada por la directora y el codirector de la propuesta de investigación y la validación social, realizada en campo.

A partir de ambas validaciones y de los resultados arrojados por ellas en cuanto a aciertos y desaciertos en el diseño del instrumento, se procede a realizar los ajustes para la aplicación de la entrevista focalizada con las personas definidas.

\section{FASE 2: APLICACIÓN DEL INSTRUMENTO}

\section{Concertación de citas y definición de espacios}

Se definen las citas con los entrevistados. La propuesta para esta concertación es adaptarse a los tiempos y disponibilidad de los actores de la investigación, además de optar por los espacios que ellos propongan como los más cómodos para la conversación. $\mathrm{Al}$ respecto se les solicita de manera previa que se elijan lugares que no sean ruidosos y que en lo posible tengan poco flujo vehicular y de personas. 


\section{Realización de la entrevista focalizada individual}

Inicialmente se le indica al interlocutor el objetivo de la entrevista. El entrevistador tiene como guía las posibles preguntas orientadoras de los subtemas, cuidando de no plantear preguntas en el transcurso de la conversación que induzcan ciertas respuestas por parte del entrevistado y revisando que en la conversación se vayan cubriendo los subtemas contemplados en el diseño.

Para la aplicación de la entrevista focalizada es recomendable que el entrevistador tenga previamente un entrenamiento para que se sienta apropiado de los aspectos temáticos de la entrevista, lo cual le facilita por un lado, la formulación de preguntas más globales que le den la posibilidad al entrevistado de expresar su pensamiento de manera amplia y completa, y por otro, establecer con el entrevistado una relación de empatía poniendo especial atención en referirse a él con claridad y con precisión en las preguntas.

Por último se recomienda evitar preguntas que se respondan con un sí o un no.

\section{Modalidades de registro}

Aquí se tienen en cuenta los tres diferentes instrumentos para registrar la entrevista focalizada individual en el momento de su aplicación. Estos son:

La ficha de datos generales en la que se registra cada entrevistado.

Las notas que el investigador toma durante la entrevista, en las que consigna elementos significativos que identifica durante la conversación, gestos del entrevistado que considere importantes para aportar en el análisis y la interpretación, y comentarios e impresiones generales sobre lo que se va conversando, para evitar que sean olvidados en el momento de construir el trayecto y de realizar el análisis.

El registro digital con el audio de toda la entrevista desde el momento inicial hasta finalizar el diálogo.

\section{FASE 3: ANÁLISIS DE LOS DATOS RECOGIDOS}

\section{Transcripción}

Posterior a la realización de las entrevistas focalizadas se procede a la transcripción de los audios, ejercicio en el cual, el investigador puede ir generando unos memos al borde de 
página que le sirvan como guía para identificar de manera previa al análisis, elementos emergentes y aspectos relevantes de la entrevista.

En lo posible es recomendable que la transcripción de las entrevistas focalizadas se realice en el menor tiempo posible posterior a su aplicación. Preferiblemente que no pasen más de tres o cuatro días para ser transcritas ya que esto facilita que el investigador pueda aprovechar elementos significativos que quedan en su memoria sobre el momento mismo del diálogo.

\section{ANEXO 3. Protocolo de los grupos de discusión}

\section{OBJETIVOS METODOLÓGICOS DE LA TÉCNICA}

- Explorar el discurso social de determinadas colectividades.

- Motivar relatos colectivos en referencia a ciertas prácticas significativas de la vida cotidiana de los sujetos.

- Facilitar la construcción de la historia oral sobre temáticas definidas en el marco de un proceso comunicativo cuya producción de discurso se da al interior de una entrevista colectiva.

\section{OBJETIVO PARTICULAR DE LA INVESTIGACIÓN}

Comprender los procesos de configuración de identidad cultural de los migrantes nariñenses asentados desde los años 60 en Candelaria, Valle del Cauca, Colombia, a partir de sus relatos migratorios y de sus estrategias de identificación cultural generadas y evidenciadas en sus relatos de identidad cultural.

\section{DURACIÓN DEL GRUPO DE DISCUSIÓN}

Entre 60 minutos y 80 minutos de duración para cada grupo de discusión.

\section{DISEÑO DEL GRUPO DE DISCUSIÓN}

Cada grupo de discusión tiene un momento inicial en el que el investigador hace un reconocimiento de los integrantes que tiene el grupo, indagando por algunos datos generales de cada uno. 


\begin{tabular}{|c|c|c|c|c|c|c|}
\hline Mantredd integrate & Lugrar y ferta denacisieto & Fived edictivo & Edad & Género & 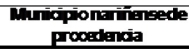 & 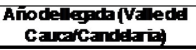 \\
\hline & & & & & & \\
\hline & & & & & & \\
\hline & & & & & & \\
\hline & & & & & & \\
\hline & & & & & & \\
\hline & & & & & & \\
\hline & & & & & & \\
\hline & & & & & & \\
\hline & & & & & & \\
\hline & & & & & & \\
\hline
\end{tabular}

\section{NÚCLEOS TEMÁTICOS Y POSIBLES PREGUNTAS PROVOCADORAS PARA}

\section{LOS GRUPOS DE DISCUSIÓN}




\begin{tabular}{|c|c|c|}
\hline \begin{tabular}{|l|} 
MICROCATEGORIASDE \\
ANÁLIS SQUE SE \\
NUTREN CON LA \\
APLICACIÓN DE LA \\
TÉCNICA \\
\end{tabular} & NÚCLEOS TEM ÁTICOSPARA LOS GRUPOSDE DISCUSÝN & $\begin{array}{l}\text { POSELES PREGUNTA SPROVOCADORAS PARA LOS } \\
\text { GRUPOS DE DI SCUSÓN }\end{array}$ \\
\hline 1. Origenes nariñenses & $\begin{array}{l}\text { Relatos contados acerea del pasado } \\
\text { Anécdotas de los lugares de origen }\end{array}$ & $\begin{array}{l}\text { Qué es lo que más recuerdan de Nariño y por qué? Cómo describińan } \\
\text { al Nariño que dejaron en el momento que decidieron venir a vivir al } \\
\text { Valle del Cauca? Cómo es la gente de Nariño? Qué es lo más } \\
\text { tradicional de Nariño? Mencionen tres coss que les gustaba hacer } \\
\text { cuando vivían en Narimo y tres lugares que les gustaba visitar Cómo } \\
\text { eran ustedes cuando estaban en Nariño. Qué ha cambiado de los } \\
\text { nariñenses? Qué no ha cambiado? ¿Qué ha sido lo que a lo lango del } \\
\text { tiempo más haN extrañado de Nariño? }\end{array}$ \\
\hline $\begin{array}{l}\text { 2. Estrategias de } \\
\text { identificacion. }\end{array}$ & $\begin{array}{c}\text { Reproducción de lugares del encunetro del pasado } \\
\text { Reproducción de olores } \\
\text { Reproducción de sabores } \\
\text { Reproducción visual de los espacios } \\
\text { Reproducción de sonidos } \\
\text { Juegos } \\
\text { Maneras de vestir } \\
\text { Reproducción del lenguaje del pueblo de origen, Comidas familiares } \\
\text { Higiene personal y del hogar } \\
\text { Maneras de saludar, Festividades } \\
\text { Rezos } \\
\text { Devociones, Matrimonios bautismos-aniversarios-funerales, Visitas } \\
\text { Emvíos de mensajes (cartas, telegramas) } \\
\text { Envios de dinero } \\
\text { Envio de objetos (fotografias, amuletos) } \\
\text { Envío de comidas y/o ingredientes }\end{array}$ & $\begin{array}{l}\text { Qué es lo que une a los nariñenses en Candelaria? Con qué se } \\
\text { identifican los nariñenses en Candelaria (en témminos de prácticas y } \\
\text { valores), ¿qué mandan a traer de Nariño cuando algún paisano va o } \\
\text { viene de allá? Cuáles son las costumbres nariñenses que usted más ha } \\
\text { intentado inculcarle a sus hijos y por qué? Qué tịo de misica } \\
\text { escuchan en sus reuniones familiares y sociales? Tienen los } \\
\text { nariñenses unas maneras de vestir que los caracterice frente a los } \\
\text { candelareños? }\end{array}$ \\
\hline $\begin{array}{l}\text { 3. Idea de gente pura y } \\
\text { original }\end{array}$ & ¿Cómo creemos que nos ven los candelareños? Ellos y nosotros & 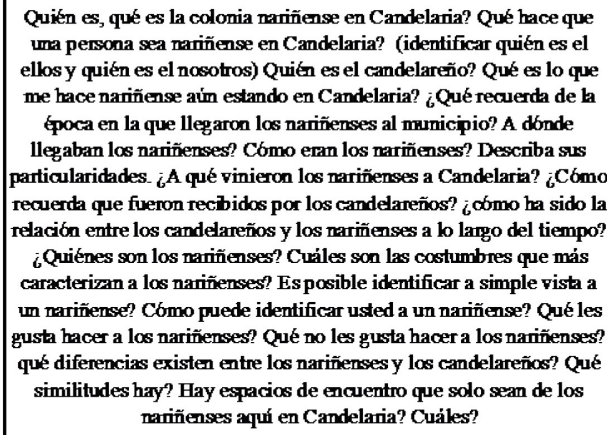 \\
\hline 4. Mito fundacional & $\begin{array}{l}\text { Rebatos del proceso migratorio, Motivaciones de la migración, redes de } \\
\text { apoyo, toma de decisión, nutas, trayectos entre lugar de origen y lugar de } \\
\text { destimo, el momento de llegada, relaciones establecidas, quién recibio en } \\
\text { destimo, a quién se trajeron despues, que relaciones tejieron, estrategias } \\
\text { de contacto con la sociedad de origen, obmo se empezaron a juntar los } \\
\text { nariñenses en Candelaria. }\end{array}$ & $\begin{array}{l}\text { Cómo empieza a formarse la colonia nariñense en Candelaraia? } \\
\text { Cómo llegaron? Quiénes fieron los primeros en llegar? De dónde } \\
\text { venían? Cuando llegaron a Candelaria, cómo se integraron? ¿Qué } \\
\text { objetos recuenda haber empacado en su maleta cuando decidib } \\
\text { emigrar? }\end{array}$ \\
\hline
\end{tabular}

\section{FUENTES}

Se sugiere que los grupos de discusión estén conformados por mínimo 6 y máximo 10 personas.

Se propone llevar a cabo 1 grupo de discusión con los integrantes del club de chaza, 1 grupo de discusión con los fiesteros (Hoy Fundación Nuestra Señora de las Lajas que es el grupo de personas que se encarga de la organización de la fiesta de la Virgen de las Lajas) y 1 grupo de discusión con el comité organizador del carnaval de blancos y negros que se realiza anualmente en Candelaria, Valle del Cauca. 


\section{REQUERIMIENTOS}

\begin{tabular}{|c|c|c|c|}
\hline Técricos & Materiales & Desplazamientos & \begin{tabular}{|c|}
$\begin{array}{c}\text { Espacio par a realización de gr upos } \\
\text { de discusión }\end{array}$ \\
\end{tabular} \\
\hline Grabadora digital de audio & Papel para toma de notas & \multirow{4}{*}{$\begin{array}{l}\text { Para la realización de los cuatro grupos } \\
\text { de discusión se r planean } \\
\text { desplazamientos diarios al municipio } \\
\text { durante una semana. }\end{array}$} & \multirow{4}{*}{$\begin{array}{l}\text { Para la realización de los grupos de } \\
\text { discusión se requiere la reserva de un } \\
\text { espacio acogedor, con buena } \\
\text { ventilación, iluminación y acústica Se } \\
\text { sugiere un auditorio de la Cámara de } \\
\text { Comercio o el auditorio de la casa de } \\
\text { la cultura de Candelaria. }\end{array}$} \\
\hline Vídeocámara & Lápiz & & \\
\hline Cámara fotográfica & Borrador & & \\
\hline $\begin{array}{l}\text { Pilas de repuesto para } \\
\text { grabadora de audio y } \\
\text { vídeocámara }\end{array}$ & & & \\
\hline
\end{tabular}

\section{APLICACIÓN DE LOS GRUPOS DE DISCUSIÓN}

\section{FASE 1: VALIDACIÓN DEL INSTRUMENTO}

Con el fin de comprobar la validez, confiabilidad y especificidad del instrumento, se cuenta con dos instancias de validación; la de expertos, realizada por la directora y el codirector de la propuesta de investigación y la validación social, realizada en campo.

A partir de ambas validaciones y de los resultados arrojados por ellas en cuanto a aciertos y desaciertos en el diseño del instrumento, se procede a realizar los ajustes para la aplicación con las personas definidas.

\section{FASE 2: APLICACIÓN DEL INSTRUMENTO}

\section{Concertación de citas y definición de espacio}

Previamente se gestiona la consecución de un espacio para convocar a quienes hacen parte del grupo de discusión. En lo posible, se sugiere un espacio acogedor, con buena ventilación, iluminación y acústica para que las grabaciones de audio y vídeo queden con buena calidad.

Se cita a los invitados a participar en el grupo de discusión con 30 minutos de anticipación a la hora de inicio.

El investigador cuida de que al momento de llegar los invitados, la videocámara ya se encuentre ubicada en un lugar estratégico desde el que se logre tener un encuadre de todo 
el lugar y en el que se pueda ver a cada uno de los que integra el grupo de discusión, sin que la presencia de la cámara alcance a ser invasiva o estorbosa para el grupo.

\section{Realización del grupo de discusión}

Se procede a iniciar el grupo de discusión indicándole a las persona que este va a ser grabado en vídeo y en audio y contándoles acerca de los temas que se van a abordar durante la sesión.

El rol de quien dirige el grupo es neutral, no interviene para dar opiniones, únicamente para plantear preguntas provocadoras que motiven en los integrantes su deseo de conversar sobre el tema.

Se propone también la presencia de un relator que se encargue de observar en silencio la realización del grupo de discusión y tomar algunas notas puntuales y significativas durante el transcurso de la realización del grupo.

\section{Modalidades de registro}

Aquí se tienen en cuenta los tres diferentes instrumentos para registrar los grupos de discusión en el momento de su aplicación. Estos son:

La ficha de datos generales en la que se diligencia la información general de cada uno de los invitados a participar en el grupo de discusión.

Las notas que el relator toma durante el grupo de discusión, en las que consigna elementos significativos que identifica durante la conversación, gestos de los integrantes del grupo que considere importantes para aportar en el análisis y la interpretación, y comentarios e impresiones generales sobre lo que se va conversando, para evitar que sean olvidados en el momento de construir el trayecto y de realizar el análisis.

El registro digital con el vídeo y el audio del grupo de discusión desde el momento inicial hasta finalizar la conversación colectiva.

\section{FASE 3: ANÁLISIS DE LOS DATOS RECOGIDOS}

\section{Transcripción}

Posterior a la realización del grupo de discusión se procede a la transcripción de los audios, ejercicio en el cual, el investigador puede ir generando unos memos al borde de 
página que le sirvan como guía para identificar de manera previa al análisis, elementos emergentes y aspectos relevantes del grupo de discusión.

Se recomienda que la transcripción de estos grupos se realice en el menor tiempo posible posterior a su aplicación. Preferiblemente que no pasen más de dos días para ser transcritos ya que esto facilita que el investigador pueda aprovechar elementos significativos que quedan en su memoria sobre el momento mismo del diálogo.

\section{ANEXO 4. Protocolo de la observación etnográfica}

\section{OBJETIVOS METODOLÓGICOS DE LA TÉCNICA}

- Describir los grupos, situaciones y escenarios sociales a través de la vivencia y experiencia de las personas implicadas.

- Develar las prácticas e interacciones socioculturales.

- Develar los sentidos de las percepciones, experiencias, motivaciones, valoraciones y prácticas de determinados actores sociales.

- Reconocer la significación y las diferentes connotaciones que tienen las expresiones y prácticas de las personas observadas.

\section{OBJETIVO PARTICULAR DE LA INVESTIGACIÓN}

Comprender los procesos de configuración de identidad cultural de los migrantes nariñenses asentados desde los años 60 en Candelaria, Valle del Cauca, Colombia, a partir de sus relatos migratorios y de sus estrategias de identificación cultural generadas y evidenciadas en sus relatos de identidad cultural.

\section{DURACIÓN DE LOS EJERCICIOS DE OBSERVACIÓN}

Una hora para cada ejercicio de observación 


\section{ESPACIOS Y ACTORES DE OBSERVACIÓN}

Cancha de Chaza como un espacio en el que confluyen jugadores de chaza, los integrantes del club de chaza, jugadores de rana, naipe, voleibol, tejo, asistentes que van a ver el juego, vendedores ambulantes (muchos de ellos con ofertas relacionadas con la gastronomía nariñense y otros con productos de la gastronomía vallecaucana), señoras y señores que atienden las casetas ubicadas alrededor de la chaza.

Celebraciones religiosas relacionadas y santuario de la Virgen de las Lajas como unos espacios en los que confluyen el grupo de los fiesteros, los representantes de la iglesia católica en el municipio, feligreses y devotos (nariñenses y candelareños) de la Virgen de las Lajas, administración municipal y organizaciones empresariales del municipio como entes financiadores de las actividades religiosas.

Celebración del carnaval de blancos y negros en Candelaria como festividad de tradición nariñense celebrada tanto en Nariño como en Candelaria anualmente y en la que confluyen nariñenses asentados en Candelaria y en municipios del Valle del Cauca aledaños, candelareños, grupos musicales de tradición en el sur del país, administración municipal y organizaciones empresariales del municipio como entes financiadores de la festividad.

Los hogares como escenarios en los que se dan lugar las diferentes generaciones que componen las familias de migrantes nariñenses asentadas en Candelaria, Valle del Cauca, desde hace más de 40 años. Muchos de estos hogares tienen la generación de abuelos nariñenses, quienes tomaron la decisión inicial de migrar al Valle; otra generación de hijos, algunos que llegaron pequeños desde Nariño y otros que nacieron en Candelaria; y la generación de nietos nacidos y criados por una familia nariñense asentada en el Valle del Cauca. 


\section{REQUERIMIENTOS}

\begin{tabular}{|l|l|l}
\hline \multicolumn{1}{|c|}{ Técnicos } & \multicolumn{1}{|c}{ Materiales } & \multicolumn{1}{c}{ Desplazamientos } \\
\hline Grabadora digital de audio & Diario de campo & $\begin{array}{l}\text { Para la realización de los ejercicios de } \\
\text { observación se planean desplazamientos } \\
\text { diarios al municipio durante un mes. }\end{array}$ \\
\hline Pilas de repuesto & Lápiz & \\
\hline Cámara fotográfica & Borrador & \\
\hline & Sacapuntas & \\
\hline
\end{tabular}

\section{NÚCLEOS TEMÁTICOS DE OBSERVACIÓN}

\begin{tabular}{|c|c|}
\hline $\begin{array}{l}\text { MICROCATEGORIAS DE ANÁLISS } \\
\text { QUE SE NUTREN CON LOS } \\
\text { EJERCICIOSDE OBSERVACIÓN }\end{array}$ & NÚCLEOSTEM ÁTICOSDE OBSERVACIÓN \\
\hline $\begin{array}{l}\text { 1. Narrativas de lo nariñense. } \\
\text { 2. Orígenes nariñenses. } \\
\text { 3. Estrategias de identificación. } \\
\text { 4. Idea de gente pura y original. } \\
\text { 5. Mito fundacional. } \\
\text { 6. Relatos de marginación-exchusión. } \\
\text { 7. Relatos de segregación-separación. } \\
\text { 8. Relatos de asimilación. }\end{array}$ & $\begin{array}{l}\text { IDENTI DAD CULTURAL. Prácticas que genera la comunidad para mantener ciertos valores, } \\
\text { costumbres y tradiciones nariñenses. } \\
\text { Prácticas culturales tales como celebraciones religiosas, fiestas nacionales o regionales, juegos, etc). } \\
\text { Espacios en donde se refuerce la imagen de la comunidad nariñense y se perpetúen sus estilos de vida } \\
\text { Espacios de reafirmación e invención de las identificaciones nariñenses. Reproducción de lugares del } \\
\text { encunetro del pasado } \\
\text { Reproducción de olores } \\
\text { Reproducción de sabores } \\
\text { Reproducción visual de los espacios } \\
\text { Reproducción de sonidos } \\
\text { Jeproducción del lenguaje del pueblo de origen, Comidas familiares } \\
\text { Juegos } \\
\text { Maneras de vestir } \\
\text { Higiene personal y del hogar } \\
\text { Maneras de saludar, Festividades } \\
\text { Rezos } \\
\text { Devociones, Matrimonios-bautismos-aniversarios-funerales, Visitas }\end{array}$ \\
\hline
\end{tabular}

M OVIM IENTO MIGRATORIO. Espacios de concentración de los migrantes de Nariño, relaciones establecidas con la sociedad en el lugar de destino, asociaciones de nariñenses.

DI M ENSIONES COM UNICATIVAS Personas y grupos con los que se interactúa diariamente, tipos de interacción cotidiana Otras formas de comunicación diferentes a la comunicación verbal: gestos, posturas, movimientos, expresiones faciales. Usos y aproiaciones del tiempo y de los espacios, maneras de habitar los espacios, maneras de significación del tiempo 


\section{FASES DE LA TÉCNICA}

\section{FASE 1: VALIDACIÓN DEL INSTRUMENTO}

Con el fin de comprobar la validez, confiabilidad y especificidad del instrumento, se cuenta con la validación de expertos, realizada por la directora y el co-director de la propuesta de investigación.

A partir de esta validación y de los resultados arrojados en cuanto a aciertos y desaciertos en el diseño del instrumento, se procede a realizar los ajustes para llevar a cabo los ejercicios de observación en campo.

\section{FASE 2: EJERCICIO DE OBSERVACIÓN}

\section{Espacios, actores y actividades a observar}

Se definen previamente los espacios, las personas y las actividades a ser observadas. Se tiene en cuenta que la observación en la cancha de chaza se lleva a cabo principalmente los fines de semana, sábados y domingos a partir de las 3:00 de la tarde que es el horario en el que confluye la mayor cantidad de personas al espacio deportivo. Esta observación conviene hacerla entre las 3:00 p.m. y las 6:00 p.m. debido a que rara vez el juego de chaza se extiende hasta el horario nocturno por la dificultad de los jugadores para ver la pelota de caucho durante el juego.

Por otra parte, aunque también se realiza observación durante la semana, en horas de la tarde, entre otras razones porque los nariñenses explican que en la tarde ya ha caído el sol y eso facilita el juego, se señala que observar durante los fines de semana permite un espacio habitado por todos sus actores: jugadores de naipe, voleibol, tejo, rana, espectadores de los juegos, vendedores ambulantes y todas las carpas de venta de cerveza

y comida en pleno funcionamiento, lo cual no se encuentra durante la semana en todo su esplendor.

La observación de la celebración religiosa y del carnaval de blancos y negros se hace durante cada uno de los festejos específicamente, pero también en la organización previa que implica cada festividad y en reuniones que congreguen a los grupos organizadores de estas. En este punto es importante señalar que el ejercicio de observación se hace tanto en el santuario de la Virgen de las Lajas ubicado en un extremo de la cancha de chaza, como 
en el altar que se tiene en honor a esta virgen, en la iglesia de Nuestra Señora de la Candelaria y en los espacios en donde se reúnan los grupos para tomar las decisiones relacionadas con cada festejo.

Los ejercicios de observación se realizan en diferentes ocasiones en los mismos lugares, para esto se tiene en cuenta una estrategia de observación que implique identificar espacios para micro focalizar la observación en ellos, por ejemplo, en el espacio de la cancha de chaza, micro focalizar la observación hacia el área de las comidas u otro lugar, en el que se desarrollan dinámicas paralelas. También es posible focalizar la observación en sujetos particulares, así por ejemplo observar, ¿qué hacen las mujeres?, ¿qué hacen los jóvenes? ¿ ¿qué hacen quiénes van a ver jugar a la chaza?

\section{Modalidades de registro}

Aquí se tienen en cuenta la manera como el investigador va registrando y dando cuenta de lo observado en su diario de campo.

El investigador realiza un registro descriptivo en el que hace descripciones puntuales de los comportamientos de los nariñenses en los espacios en los que se decide realizar la observación. Sus actividades, sus comportamientos verbales y no verbales y sus maneras de relacionarse. De la misma manera, una descripción de los espacios, su distribución, sus usos y cómo las personas que los habitan se apropian de ellos.

También se lleva a cabo un registro de carácter más narrativo en el que el investigador va relatando su experiencia en el trabajo de campo. En este registro se pueden consignar tanto las sensaciones e impresiones que va teniendo el observador como la interpretación inicial que este tenga sobre lo que va observando. 


\section{REJILLA PARA ORIENTAR LA OBSERVACIÓN ETNOGRÁFICA}

\section{PARTICIPANTE EN CAMPO}

Se señala que la rejilla propuesta incluye elementos para que el observador pueda hacer el registro descriptivo y narrativo de lo observado.

\begin{tabular}{|c|c|}
\hline Fecha y hor: & Fecha y hora en la que se realiza la observación. \\
\hline Lugar: & Lugar, espacio, en el que se realiza la observación. \\
\hline Descripción de espacios: & $\begin{array}{l}\text { Descripción de los espacios que estoy observando, ¿cómo están dispuestos? ¿Cómo es la infraestructura? En } \\
\text { este punto pueden elaborarse mapas de los espacios, o representaciones gráficas que permitan ubicar también } \\
\text { las actividades, micro espacios y sujetos que allí se encuentran. Son de vital apoyo las fotografias. }\end{array}$ \\
\hline Condiciones dimäticas & $\begin{array}{l}\text { Condiciones climáticas del espacio (aplica sobre todo para lugares abiertos), son relevantes en la medida en } \\
\text { que el cambio de clima afecta el desarrollo de las actividades. }\end{array}$ \\
\hline Actividades-prácticas & $\begin{array}{l}\text { ¿Qué actividades se están realizando en este espacio? ¿Puedo identificar algunas prácticas? } \\
\text { En el registro de las actividades observadas es importante considerar la identificación de prácticas comunes, } \\
\text { dinámicas que se repitan, sujetos frecuentes, así mismo, situaciones atípicas, o que imumpan el desarrollo de } \\
\text { dichas actividades o que parezcan “anormales” dentro de la dinámica que suele darse en el espacio } \\
\text { observado. }\end{array}$ \\
\hline Sujetos & $\begin{array}{l}\text { ¿Quiénes están presentes en este espacio? ¿Qué hacen las personas presentes en este espacio? ¿Qué grupos } \\
\text { identifico? ¿Cómo están ubicadas las personas en este espacio? }\end{array}$ \\
\hline $\begin{array}{l}\text { Posidión del investigador. } \\
\text { Impresionesy sensadiones }\end{array}$ & $\begin{array}{l}\text { ¿Cómo tuve acceso a este espacio? ¿Con quienes he entablado contacto o conversación? ¿Dónde y cómo } \\
\text { estoy ubicado en este espacio? } ¿ \text { Qué me incomoda? } ¿ \text { Qué me gusta o me disgusta? ¿Qué me llama la } \\
\text { atención? }\end{array}$ \\
\hline $\begin{array}{l}\text { Interpretacionesinicialesdd } \\
\text { observador }\end{array}$ & $\begin{array}{l}\text { Consignar tanto las sensaciones e impresiones que va teniendo el observador como la interpretación inicial } \\
\text { que este tenga sobre lo que va observando. }\end{array}$ \\
\hline Duración de la obser vación: & Tiempo de duración del ejercicio de observación. \\
\hline $\begin{array}{l}\text { I deas téricasy metodológicas } \\
\text { relevantes }\end{array}$ & $\begin{array}{l}\text { Algún tipo de análisis surgido a partir del ejercicio. Considerar aquí las categorías y micro categońas } \\
\text { relevantes en el análisis. ¿Qué tanto me aporta este espacio para recabar datos sobre estas micro categońas } \\
\text { que pretendo analizar? }\end{array}$ \\
\hline Codificación: & $\begin{array}{l}\text { Anotaciones indicando si algún aspecto observado aporta a las categorías fijadas previamente o da pistas para } \\
\text { la identificación de categońas emergentes }\end{array}$ \\
\hline
\end{tabular}



ANEXO 5. Clasificación de la evidencia empírica

\section{CATEGORÍAS INTERPRETATIVAS}

\section{CODIFICACIÓN}

\begin{tabular}{|c|c|c|c|c|}
\hline Nombre & Edad & Nivel educativo & $\begin{array}{l}\text { A qué edad llegó a } \\
\text { Candelaria }\end{array}$ & Lugar de procedencia \\
\hline Luis Aurelio Realpe Patiño & $\begin{array}{c}18 \text { de Marzo de } \\
1944\end{array}$ & $\begin{array}{l}\text { Tenemos } 5^{\circ} \text { año de } \\
\text { primaria }\end{array}$ & En el 80 & $\begin{array}{l}\text { Mi lugar de residencia es en } \\
\text { Túquerres Nariño }\end{array}$ \\
\hline José María Alpala Alpala & $\begin{array}{l}\text { Nací el } 12 \text { de julio } \\
\text { de } 1945\end{array}$ & Hasta 3o no más & A los 19 años & $\begin{array}{l}\text { Bueno, yo soy del departamento } \\
\text { de Nariño y del municipio de } \\
\text { Cumbal }\end{array}$ \\
\hline María Rosalba Getial & También en 1945 & $\begin{array}{c}2 \text { años alcancé a } \\
\text { estudiar de primaria }\end{array}$ & $\begin{array}{l}\text { A los } 16 \text { años ya } \\
\text { estuve acá }\end{array}$ & Yo soy de Consacá, Nariño \\
\hline Gabriel Pascuasa Díaz & En 1946 & $\begin{array}{l}\text { hasta el } 50 \text { de } \\
\text { primaria }\end{array}$ & En el 65 de 26 años & $\begin{array}{l}\text { El lugar de nacimiento es Funes, } \\
\text { Nariño }\end{array}$ \\
\hline $\begin{array}{l}\text { Pedro Nemecio Castro } \\
\text { Sambrano }\end{array}$ & \multicolumn{2}{|c|}{ El 15 de diciembre de 1940} & Fue en 1965 & $\begin{array}{l}\text { Yo nací en una vereda que } \\
\text { pertenece a Ipiales, se llama } \\
\text { Muellamués, pero ahí pues en } \\
\text { Ipiales. }\end{array}$ \\
\hline José Hilarión Montilla & $\begin{array}{l}\text { Yo nací en el año de } \\
1943\end{array}$ & $\begin{array}{l}\text { yo tengo apenas año y } \\
\text { medio de primaria }\end{array}$ & $\begin{array}{l}\text { Yo llegué a la edad de } \\
24 \text { años en el año de }\end{array}$ & $\begin{array}{l}\text { Yo vengo del corregimiento Rosal } \\
\text { del Monte, del municipio de }\end{array}$ \\
\hline
\end{tabular}




\begin{tabular}{|c|c|c|c|c|}
\hline & & & 1969 & Buesaco \\
\hline $\begin{array}{l}\text { Manuel Alberto Díaz } \\
\text { Santander }\end{array}$ & \multicolumn{2}{|c|}{ Yo nací en el 1946, 1 o de mayo } & A los 30 años & Santa Cruz, Nariño \\
\hline Jorge Martínez & Febrero de 1928 & $\begin{array}{l}\text { Tercer año de } \\
\text { primaria }\end{array}$ & En 1948 & $\begin{array}{l}\text { Yo nací en Cunchila que es un } \\
\text { corregimiento de Ospina, queda a } \\
\text { un lado de Túquerres. }\end{array}$ \\
\hline José Diogenes Ruiz & 1950 & Primaria & 1970 & Sotomayor, Nariño \\
\hline $\begin{array}{l}\text { Ricardo Ismael Sánchez } \\
\text { Ceballos }\end{array}$ & Febrero 20 de 1947 & Secundario & En 1970 & Funes, Nariño \\
\hline José Bernardo Rivera & $\begin{array}{c}\text { Diciembre } 12 \text { de } \\
1966\end{array}$ & Primaria & 1990 & Guachavés, Nariño \\
\hline Segundo Benjamín Delgado & Marzo 28 de 1954 & Primaria & 1978 & Linares, Nariño \\
\hline Segundo Pantoja & & & 1970 & \\
\hline Rubén Salcedo & & & 1990 & Buesaco, Nariño \\
\hline Humberto Tutalchá & 1947 & Segundo bacchiller & 1966 & Guachucal, Nariño \\
\hline Beatriz Erazo & & & 1969 & Arboleda \\
\hline Arquímedes Díaz & & & 1973 & El Tambo-Nariño \\
\hline Miguel Calderón & & & 1965 & Guachavés-Nariño \\
\hline
\end{tabular}




\section{ORÍGENES NARIÑENSES \\ Características del lugar de procedencia}

Allá la vida es más económica en víveres, todo eso. Aurelio Realpe

Cumbal es una parte muy fría, es muy fría pero es una tierra muy linda, muy querida. Alpala y Rosalba

Yo soy una parte de Cumbal, Nariño y eso es muy linda, allá es lo que produce el trabajo, es con el ganado, que es hoy en día es un comercio, muy avanzado, con la leche. Grupo Chaza

En Nariño se celebraban mucho los carnavales y en todos los municipios allá, se hace en todos los municipios y veredas, en Pasto ipues ni se diga!, en Pasto llega gente extranjera y por eso los que estamos aquí como dijo Arquímedes que ya se trató de hacer los carnavales aquí, entonces ya se hizo y se ha seguido los carnavales. Grupo 2

Yo extraño la cultura, la cultura nariñense la extraño, porque es que la cultura de aquí del Valle es buena, pero venimos de una cultura recreacional, que es muy buena, los carnavales, los aguinaldos, el día 5 de enero, allá era casi todo el año en fiestas, entonces son con participación de la comunidad, los carnavales los hacen en todas las veredas, los corregimientos, municipios, en toda parte hacen los carnavales, en el día de los negritos que es el día 5 de enero, eso lo celebran en todos los pueblitos también. Grupo 2

Es una cultura muy bonita en todo el departamento de Nariño, entonces por ejemplo la música, la música también me trae mucho recuerdo, nostalgia, porque prácticamente uno en Nariño se ha crecido, estuve hasta los 19 años, entonces uno se acostumbró es a la música de cuerda, que en este momento la música de cuerda ha ido como perdiendo, ya es muy poco lo que se escucha, en ese tiempo solo era música de cuerda, las fiestas que hacían mi familia era con música de cuerda, los aguinaldos era con música de cuerdas, desfile de comparsas con música de cuerda. Grupo 2

Las Lajas, lo llaman por eso le llaman Las Lajas, entonces viajábamos allá a veces, entonces esa fe que la tenemos de todo el departamento viajaban de todos los municipios, viajaban a las visitar la virgen y más que todo la fiesta que es en septiembre, yo me acuerdo que de niño me llevaban mis padres y desde ello yo sigo mi devoción a la virgen, pues ya es personal, ya no es cuestión de la virgen, ya es cuestión personales con la virgen que me ha hecho muchos milagros. Jorge Martínez 


\section{ORÍGENES NARIÑENSES}

\section{Actividad a la que se dedicaba en el lugar de procedencia}

Yo voy a volver a hacer el curso para policía, volví a la escuela Simón Bolívar, ahí cursamos 6 meses, a los 6 meses salí de policía, trabajé en Cali, en Alameda, ahí mismo éramos 45 que salíamos de la escuela de Tuluá, nos trasladaron de Popayán; el Cauca era ahí en ese tiempo tiro fijo, que había una, que había matado a dos policías una monjita, nos trasladaron para Inzá y nos dejaron en el Cauca y yo trabajé 11 años en el Cauca. Aurelio Realpe

Eso fue en el 80, entonces, entonces ya pues entonces dije ya, yo salí como le dije de la policía, pues como uno directamente como uno, yo le digo, yo nací de un hogar pues humilde, pobre pero honrado, nada de porque yo escuchaba y escucho, ustedes se meten a la policía, y dicen: - yo trabajo 3 años- , si yo consigo, yo lo voy a conseguir y me retiro-, así con esa mentalidad, pero yo no, en ese gracias a Dios no tenía esa mentalidad, bueno entonces como ya me retiro de la institución, entonces me fui otra vez a Cali, conseguí el trabajo por esas empresas de vigilancia privadas, trabajé allí, mi señora estaba aquí en Candelaria, con la hermana, como ahí llegamos. Aurelio Realpe

A trabajar la tierra, uno, hay que hablar la verdad, yo no tuve escuela, eso como lo normal casi fue en la parte del campo cuando mi mamá, mi papá dijeron vaya a la escuela, yo ya estaba grandecito, yo lo que quería era trabajar y ayudarle a mi papá, a mi mamá por que ya empecé a ganar, ya a jornalear. Alpala y Rosalba

El destino, allá le enseñan mucho de todo, la agricultura, los oficios de casa, eso es normal. Alpala y Rosalba

Pero yo me acuerdo que allá se trabajaba con puros bueyes y a halar el arado, yo de grandote que era en esas laderas pues, en terreno fangoso, metía para poder no dejarme arrastrar de los bueyes, metía el hombro y mi papá atrás con un juete, cuando medio me soltaba o me caía, ahí me levantaba a juete; bueno y así nos tuvo a mi y a mis hermanos así. Gabriel Pascuasa

Pasto, donde un primo que tenía una panadería, una pastelería y todo eso, entonces ahí me estuve un año, ahí trabajando en la pastelería, pero no me mandó así a trabajar entregando la pastelería ni pan ni nada, me mandó para la gente, me mandó a atender ahí, me dijo ayude a atender a la muchacha. Gabriel Pascuasa

Trabajábamos en agricultura, pero pues casi un poquito yo estuve ayudando a mi casa a mi papá, por que ellos sembraban bastante yo miraba así cualquier lotecito por ahí y sembraba yo ahí, de eso yo me mantenía para qué, nos daba pero no más era ayudándole a él, porque él tenia que trabajar y nosotros teníamos trabajadores y todo. Pedro Castro 
Entonces en esa época cuando trabajaba yo con ella, y éramos donde el patrón, en veces nos colocaban a nosotros en una parte y a la mujeres en otra, a cuestión de limpiar trigo es que se quedaba allá en Nariño a quitarle la maleza. José Montilla

Bueno, mi niñez desde que nací hasta los 20 años, hasta los 20 años que en ese tiempo prestábamos servicio militar a los 20 años, eso fue en la agricultura con mi padre y un hermano mío era nos manteníamos de la agricultura, tierra fría donde yo me crié donde sembramos papá, trigo, cebada, yuca, con todo esas cosas de tierra fría. Jorge Martínez 


\section{ESTRATEGIAS DE IDENTIFICACIÓN \\ Reproducción de lugares de encuentro}

Aquí tradicionalmente aquí, lo del juego que yo se, es la chaza, la chaza que llaman el jueguito, los que nos entretenemos y lo bueno pues aquí vea, jugamos, jugamos anteriormente donde es la piscina, jugamos acá en esta orilla, otros dicen que jugaban por allá, pero no conozco, y entonces eso es el juego de nosotros, el más apetecido por la recreación de nosotros, eso es. Aurelio Realpe.

Aquí por ejemplo, antes no habían presidentes, el club de chaza no lo había, habíamos no más participantes, no más, pero ahí estaban hablando que por eso no nos asignaban un pedazo de tierra para que lo nombre como una cancha de chaza que actualmente es esta, no sabía, nos tenían volando por allá. Aurelio Realpe.

La chaza se empezó en, por ahí en los años 60, 66 ahí fue que se empezó, en Candelaria fue un proceso muy largo pero por la persistencia de nosotros se han dado las cosas a como están en el momento, por que entonces no era todo eso construido como está ahora por que don Pedro, eso era un potrero, donde era el parque recreacional, en el polideportivo ahí empezamos a practicar el deporte. Alpala y Rosalba.

De la chaza, entonces luego hubo un palco de experiencia, esa primer personalidad jurídica por no estar activando se perdió, entonces, pero los primeros que de esas iniciativas de organización fue ahí, esta don Pedro Castro, don Hernando Bernal, de los que yo recuerdo nada, por que hay que mencionar los que viven, pues por que habían otros de la organización y ya murieron, entonces eso por falta de experiencia, por falta de conocimiento, se desactivó esa personería jurídica. Alpala y Rosalba.

El apoyo que empezó y que motivó a la gente, así como estábamos no había comodato no había nada, pero el primero que empezó fué eso, si recuerdo en los años 97 el primer alcalde popular que fue, Dagoberto Escobar y la esposa Zoraida Zamorano, él fue el que empezó con los torneos, él invito, dijo inviten a la gente de Pasto y hagamos un torneo, ese torneo, se lo hizo, cuando eso nosotros en esa época cuando nosotros nos ubicábamos a medida de que iban construyendo, nosotros nos íbamos corriendo, pero ahí nos organizábamos nuestra cancha y hágale y hágale, y entonces nosotros nos volvimos persistentes en eso y ya reconocieron, y ya metidos en la política, todo eso pues, todo eso nos tuvieron en cuenta. Alpala y Rosalba.

Claro, nos agrupamos mucha gente de ahí, ya empezamos a agruparnos como le digo, organizarnos ya fue mas estable, pero lo practicamos, lo hacíamos así sencillo i¿no?!, Pero ya mas tarde, a medida de la necesidad ya nos fuimos organizando entonces, pero lo primero que llegó a Candelaria fue la práctica de chaza en la cual los de Candelaria, los de aquí decían, bueno la expresión de ellos a veces gente que se sentía ofendía decía, esos pastusos están locos. Alpala y Rosalba. 
de las costumbres nariñenses, en el momento estamos hablando de las dos, de lo de la chaza a pesar de que esta débil como ya lo conversaba cuando nos comunicábamos por el material físico de la gente, pero por el momento se está conservado lo que de la chaza y las actividades de la virgen de Las Lajas, eso es lo que estamos conservando, esas cosas, por que lo de los carnavales eso, se fue como privatizando, eso lo están manejando otras personas. Alpala y Rosalba.

Empezaron por ahí dos o tres a buscar razón de jugar, y de ahí y nos volvimos paisanos que nos gustaban y se iban agrupando ahí y ya haciendo sus juegos también y se iba creciendo la gente, todo paisano iba a qué le gustaba ese juego se iba agregando, porque antes había jugadero aquí, antes bastante y ahí se fue consiguiendo la cancha para jugar y en varias partes se hizo esas canchas y después de eso, vino lo de la virgen de Las Lajas y ahí; y como le digo, se hizo en las agrupaciones para eso y la junta directiva se compró dónde iba a hacer, no se compró sino que lo cedió el ingeniero de Mayagüez y de aquí para allá todo era Mayagüez, lo cedió también el ingeniero de Mayagüez donde iba a ser la capilla y todo eso se perdió y ahí por ahí fueron inventando todo eso de los carnavales también el 31; también se ha hecho un grupo de todos las costumbres de Nariño. Gabriel Pascuasa.

Allí de la chaza, ahí se hacia el desfile a por bajaban allá, a la avenida, a la casa, saliendo al parque daban la vuelta y todo eso de ahí se va toda su vuelta por las calles jugando hasta cierta hora y ahí si se dejaba al publico jugará como quiera. Gabriel Pascuasa.

Ahí en el sector de la cancha, pero después lo empezamos a hacer ahí en... porque se hace un recorrido por el pueblo, el desfile, las carrozas, todo eso, pero posteriormente se terminaba o se remataba ahí en lo que es el parque de Comfandi, donde está la piscina. El Parque Nicanor. Julio Castro.

No, en los Carnavales, lo que pasa es que en los Carnavales en un principio se hacían en la cancha, después ya se hizo acá encerrado por más seguridad porque se prestaba para mucho vandalismo, la gente se emborrachaba, se tomaba sus tragos, salía, borracho o no borracho allá lo bolsequeaban, lo robaban, le ponían bolsas con harina, mientras te cubrías acá ya te habían robado, ya te habían bolsequeado y entonces se convirtió como en un peligro. Julio Castro.

900 pesos era la ida a Bogotá y sacar así de cosas pero es que vea, se fue a investigar a Pasto primero, y en Pasto no había en ninguna parte, en los pueblos ni en las capitales no había nada de personería jurídica sino que era así, y salían a jugar, así como salgamos y juguemos sale cualquiera y juega, no era mas, así cuando se invitaban, se invitaban, para dar el gusto de que inicio eso fue Hernando Bernal, él es el que quedo de presidente y de ahí pues los que estuvimos en esa junta de algo me acuerdo y de otros no, son varios muertos el que nos ayudó, y también no se de qué quedó él, Hernando Bernal era el presidente, me parece que fue Rodrigo Montilla, él ayudó mucho en ese tiempo, no sí, por que era concejal y otro que entró ahí era Fidencio Montillo, él si, Guillermo Álvarez, Ricardo Sánchez. Pedro Castro.

No, en seguida nomás, siempre se me olvidan las cosas, bueno, nos fuimos, jah! no fuimos a jugar ese día a Guacarí, de Guacarí para arriba y ese día estábamos jugando, bueno, cuando ya, tomando traguitos van, traguitos vienen, cuando pues yo le ignoro todo, no le he guardado nada; fue Don Alberto, iba borracho que con nada, estaba ultima hora jugando y tomando por que como yo no juego estuvimos apostando un rato con unos muchachos de allá, ganamos y perdimos, entonces camine tomamos cerveza mejor, y nos agarramos a tomar desde medio día para acá. Pedro Castro. 
Sí, los Carnavales de negros y blancos tienen un significado muy grande para los nariñenses, es la identidad cultural, o sea los carnavales, la guareña y el cuy yo diría que son la expresión como el orgullo de ser nariñenses ¿si?. Milton Posos.

Los carnavales de acá, como se organizan, es una expresión que se da en un día ¿si?, que se dan en un día, y tienen una expresión cultural que es un desfile de carrozas y comparsas, un desfile gastronómico que esta la expresión de toda la comida gastronómica, y también la representación artísticas, si algo se identifican los carnavales de Candelaria de negros y blancos es porque siempre en tarima o en presentación hay artistas de gran renombre nariñenses, toda la trayectoria cultural que ha pasado, que existe y la futura han hecho desfiles por la tarima del carnavales de negros y blancos, tríos, grupos, orquestas, hay mucha gente que dice, ¡no! yo voy a Candelaria por que se que allá van a traer artistas de Nariño y la gente quiere ver en un artista de carnaval de negros y blancos, artistas de Nariño. Milton Posos.

Pues por lo menos, ahorita lo más tradicional aquí en Candelaria por lo menos, para nosotros es la chaza, porque nosotros, y carnavales, por que nosotros, mire usted por lo menos, esa cancha de chaza ahí llega todo el mundo, y ahí estamos con todo el mundo ahí, ahí no se le escoge, el que quiera jugar juega tranquilo, se divierte. Grupo Chaza.

yo también practicaba el deporte de chaza en mi tierra soto mayor, y vine aquí, y cuando yo estaba trabajando practique unos días, de ahí no lo practique más, de hoy en día lo practico un poco, porque ya la edad no esta para tanto , pero es el deporte que mejor forma hay aquí de vista, de allanamiento, de estar reunido con los paisanos de estar compartiendo en una o en otra forma así, en los que se fuera, muchas veces se trata hasta de política porque pues es bueno estar empapado en todo. Grupo Chaza

pues yo quisiera decirle, aquí no hay colonia, por que llegan a florida y buscan la colonia y hay un grupo organizado, pero aquí la única organización que tenemos los nariñenses es el club, un club grande que a sido respetado en toda parte y muy nombrado, nosotros tenemos mucha fuerza ahí.

Llegamos y de todas maneras por aquí cuando yo llegué en 1970, lo primero que se, por la chaza, es la que nos ha traído a nosotros como para estar mas unidos

- sí, por que por lo menos, antes pues todos somos compañeros de trabajo, nos conocimos en el trabajo pero la unión mas fuerte fue la chaza, antes pues sí de pronto al señor lo distinguía pero no sabia como se llamaba

- no sabia ni cómo le decían (Risas)

- y la otra fuerza grande que le digo es donde esta el señor y estamos casi todos, en al virgen de Las Lajas, las novenas se las hacemos y Don Humberto y hay mucha gente que hace disfraces, y maso menos hay un promedio de 300 personas que hacemos las novenas. Grupo Chaza.

Otra de las cosas, que no han traído por ejemplo han sido, nos traen por ejemplo, unos santos, a San Pedro, entonces han instituido también el día de San Pedro y lo traen en una chiva de por allá de Funes, Nariño, por allá y vienen y le dan una misa allí a la imagen y luego lo traen por acá y lo meten en un casa y lo tienen dos días. Camilo Muñoz. 
Cada año, pero no me acuerdo del mes, si, yo vivo pendiente entonces yo voy y miro, y entonces ellos invierten. Eso ahí tienen que haber unas personas que invierten para poder traerlo, entonces lo traen, es una imagen muy bonita y lo traen en una, y viene una delegación y lo traen. Camilo Muñoz.

Nosotros aquí hicimos primero la cancha, después se hizo la batería sanitaria y después se hizo la capillita. Grupo Chaza.

Por lo principal, a veces cuando hay torneo, se hace festival. Grupo chaza.

Tenemos esto pero por nosotros mismos y nunca vamos a dejar la tradición de venir aquí... aquí a veces no hay juego, venimos, estamos aquí sentados, cómo ve usted eso...

Integrantes: uno lo siente propio... uno prácticamente en la casa, uno sentado en la casa le da sueño, viene por acá y uno conversando con los amigos, todo eso lo distrae. Grupo chaza.

El barrio Panamericano es el barrio pues que nosotros decimos, que concentró la población nariñense, fue al principio de una sola, de un solo piso las casas y todo el mundo estaba pendiente de sus cosas, las casas sí, si analizamos, tenían unas ventanas muy pequeñas, patios internos no habían, pero todos cabían allí, y cabían no solo la familia de ellos, sino que si venía otra, la albergan ahí mientras conseguían el lote, casi todo nariñense ubicó su lote y ubicó su casa, si usted hace un barrido por Candelaria, casi todos tienen casa, porque ese era como su punto de partida dentro de lo que traían acá para poderse asentar. Tener casa. Clara Díaz.

Las canchas de chaza y todas esas panamericanas, porque a ellos les dieron el espacio, igual que le dieron la otra parte de Candelaria al lado de acá, pero qué pasa, los de acá no estaban tan organizados como ellos, entonces ellos sí se organizaron, hicieron respetar su espacio, han tenido los servicios públicos que es algo primordial para la gente, en una forma que los han conservado y los han hecho valer. Entonces todo eso ha ayudado muchísimo, pero ellos tienen sus toldas y esos sí, salen domingos así el lunes tengan que ir a trabajar, todo ese domingo, todo ese domingo se ve, más que sábado. Clara Díaz.

El juego de chaza que ya se institucionalizó, casi en Candelaria, y se les hizo su cancha, se les hizo todo su espacio para que ellos hicieran todo su despliegue de su deporte llama muchísimo la atención, y llama muchísimo la atención que no tiene eco sino en ellos, es un deporte casi jugado por ellos y tienen otra cosa, que ellos juegan un tenis de malla bajita y también son muy cerrados ahí cuando uno los ve, solo a ellos, solo a ellos en esos espacios. Milena Medina.

Cuando hacen los carnavales, el 6 de enero y toda esa cosa, ellos traen gente de Nariño, traen bandas, papayeras de Nariño que eso alegra mucho el ambiente, todo eso y hacen procesiones con la virgen y todo eso. Isaías Gamboa.

Y hacen desfiles de comparsas que anteriormente en Candelaria se hacían pero con la familia Castañeda, que venían de Pasto, unos señores y se disfrazaban pues, esa era la familia Castañeda. Isaías Gamboa. 
Sí, pero era un lujo vernos jugar, no le digo que eso se llenaban esas canchas y esa gente, ¡hermano! como lo ve, esas carpas como lo ve, eso se llenaba de gente hermano y eso ijuepucha! y una habladera de eso de juego y pura gente borracha que decían, no que va, como dios nada juega más, solo juega este verraco sí juega, a este no le gana nadie, así la habladera no? Pero a uno le da gusto porque, que hable la gente particular que no equivoque de decir ve, yo soy el mejor jugador no, era la gente y hasta ahora lo dicen, pero no me ven jugar ya. Alberto Díaz.

Nosotros íbamos y no hacíamos torneos no, hacíamos desafíos entre nosotros mismos, pero la plata era de nuestro bolsillo, cualquier peso que apostábamos era de nuestro bolsillo, que el pasaje era de nuestro bolsillo todo, pues si ya ganábamos nosotros a veces, ¡eh! ya ganamos nos sentábamos a tomar cerveza y a veces llegábamos y nos cogía la tarde, 12 de la noche 1 para hartarse, todo se nos pasaba a nosotros pero contentos nosotros, y no nos pasaba nada, no éramos de decir que, que vamos de borrachos a maltratarnos o alguna cosa, ¡no!, mira que en esta cancha nosotros venimos cuántos años, tiene esa cancha, pero nunca se ha visto una pelea hasta el sol de hoy. Alberto Díaz.

Por lo menos con lo del polideportivo pues lo que hay actividades deportivas, hay eventos culturales donde hacen festivales que hablamos, entonces aquí los encontramos. Grupo Chaza.

Y para aquí, ya pues la cancha de chaza de pronto un poquito de historia. Todo esto del polideportivo es lo que era zona verde, aquí empezamos a practicar, lo de la práctica de la chaza, aquí en esta parte, ya hace aproximadamente 40 años, esta parte era entonces del ingenio Mayagüez, esto que ahora es zona verde era del ingenio Mayagüez y aquí nos ubicamos a practicar la chaza y esto eran propiedades de Mayagüez, como Mayagüez en esa parte el doctor Correa él fue muy consciente y él todo el tiempo apreció a sus trabajadores. Grupo.

No sé, no porque nosotros no valoremos en esa parte, sino es que Candelaria últimamente hemos ganado tanto espacio y la parte de integración donde tengo estos punticos últimamente ha sido el epicentro la cancha de chaza, por decir sábado y domingo allá. Grupo.

El parque porque también lo utilizamos y de aquí pasamos a acá y esto se dio estas cosas y eso un mensaje para todos por estar organizados, organizados y unidos porque nosotros cuando nos empezamos a organizar ya sacamos personería jurídica, todo eso, entonces de ahí fue que ya fuimos más escuchados del municipio, entonces ya dijeron no, ya ustedes tienen un derecho y ahí fue que ya nos ubicaron. Aquí en la cancha de chaza tuvimos un tiempo que estuvimos en esta parte a un ladito que es para el lado de allá atrás. Entonces cuando ya, cuando desde aquí del parque recreacional nos pasamos acá. Grupo.

Mis amigos, todos los compañeros, la gente que se invita de otras partes, ya lo van distinguiendo a uno de otras partes, también entonces ahí se encuentra con varias personas y estos puntos que le digo aquí, este punto que es otro punto de recreación de nosotros. Grupo. 
Porque para mí lo más importante, donde más se reúne la colonia nariñense, los días festivos, días que hay eventos, todo eso, ahí es donde nos reunimos toda la colonia nariñense y no solo nariñense sino ya la mayoría de vallunos también, los Candelareños. Y se invita a gente de otras poblaciones que también vienen allí, por eso yo digo que para mi importante, eso. Más que todo, pues también importante también, es la iglesia; porque ahí es donde nosotros corremos cada ocho a escuchar la misa. Grupo.

El polideportivo, como decía don Alpala, eso allá hacen eventos de una clase, de otra, traen grupos artísticos o las festividades que hacemos nosotros aquí los nariñenses, los carnavales, todo se hace allí o sino se hace allá. Grupo.

Por lo regular, por la mañana se hace un desfile en todo el pueblo, ya por la tarde pa festejarlo ya la gente que quiere gozar su rato bailando ya es allá en el polideportivo, ¿por qué se hace eso? Porque aquí en la calle no se puede hacer, porque el vandalismo bueno, ya empiezan a robar, A la gente del Valle aquí no le gusta eso. Entonces uno para entrar tiene que pagar su entradita y juega sabroso, se toma sus aguardientes porque por acá el vandalismo como le dicen uno de pronto le tiran harina a los ojos y ahí mismito le van mandando la mano al bolsillo, allá la policía está más pendiente. Grupo.

Si, ahí charlamos un rato, cuando ya es por la tarde ya nos retiramos. Yo no practico la chaza, no. Pero si me gusta ir allá a ver un rato, estar un rato allá a ver eventos, a bailar y todo tipo, vamos con la esposa, mi esposa casi no le gusta salir pero de pronto vamos a ver allá y vamos un rato entonces. Grupo

Eso aquí se ha ido perdiendo la costumbre, entonces nosotros como nariñenses tratamos de traer esa cultura porque de aquí salíamos para Nariño y se contrataban carros para la celebración de Blancos y Negros, entonces eso es muy costoso, a veces uno quiere ir pero no tiene con que ir, entonces eso fue que en ese entonces se jugaba chaza en un parque, ahí nació la idea jugando chaza que había carpa de baile y todo eso, y entonces ahí nació la idea de grupo de amigos, el que propuso la idea fue un señor que se llamaba Sergio Marlo, él fue el que propuso la idea. Grupo 2 


\section{ESTRATEGIAS DE IDENTIFICACIÓN}

\section{Reproducción de olores, sabores (comida), sonidos (música)}

No, pero es que como yo le explico anteriormente las costumbres por ejemplo de Nariño ya es en el esposo, en la esposa mía, en la esposa porque dice allá en Nariño no más dicen no, que van a una sopa de habas, de cebada que allá que le dicen arriada. Aurelio Realpe.

¡Ah no! pues a mí me gusta traer los curíes, quesos, por ejemplo ahora que yo fui traje eso, como 5 cuis como 5 quesos, como ellos tienen ganado entonces le dicen, vea Lucho aquí le vamos a dejar 30 quesos para que el día que vaya estén listos. Aurelio Realpe.

La hijastra, ella fue la que empezó a vender chicha. Alpala y Rosalba.

A ayudar y sí a ayudar, porque el trabajo era duro, entonces, porque la chicha era de primero que había que prepararla y eso después la cerveza ya para irse calentando. La copita de aguardiente, todo eso y el almuerzo ya había necesidad pues si no se acababa temprano a veces desayuno, almuerzo y hasta comida. Alpala y Rosalba.

Maíz, frijol, garbanzo, alverja, trigo, todo grano traigo yo de allá y lo que le gusta a la mujer de aquí, traigo yo de allá, y si no vuelvo pues de pronto lo traigo de Nariño, lo traigo de allá, entonces por eso yo me siento muy nariñense, por la comida y todo. Gabriel Pascuasa.

Por lo menos yo en la casa cuando no hay se come el maíz, se come el trigo, se come la cebada, el frijol, la alverja, el garbanzo, la lenteja, todo eso lo comemos nosotros, todo eso, la zanahoria, lo que acá le llaman la arracacha. Gabriel Pascuasa.

Ese lo echan es calabaza, habas si hay alverja si, papa, todo hacen un revuelto así y sabe delicioso, la vitamina que hay. José Montilla.

De allá lo que no hay aquí, por ejemplo más que todo lo tradicional que es el curí. José Montilla. 
No, eso cuando uno va para allá los trae preparados porque de eso hay, usted va a Ipiales a conocer Las Lajas, la virgen de Las Lajas, eso en los restaurantes están ahí puestos un curí con algo de papa le vale 30 mil pesos, eso es caro; entonces allá la familia, la llegada de uno cuando uno va donde la familia no lo compran, lo preparan. Uno también le lleva así cualesquier cosa de allá para acá y así lo hacen cargar con un curí, tome un curí, eso es lo que traen ya de regalos pues, y si no los compra, se los compra y el queso cuajada que es lo que se da en Nariño, esa es la golosina de allá pues que hay, todo eso se trae, y de pronto un manjar que es diferente al manjar de aquí, porque allá es ese manjar le echan de leche como se dice natural de vaca y todo eso, o como el pan de maíz, que también es de otro porque para mi mamá, lo hacía; y eso le echan una cantidad de cosas que queda como es, un pan exquisito esa es la golosina de allá para acá. José Montilla.

De pronto la costumbre que hasta el momento hay, es la tradición gastronómica, eso si se ha logrado mantener hasta ahora; porque aquí hay un deporte que se llama chaza, en esa chaza se juega con una pelota como el tenis, pero acá es con la mano, y hay otros con bombo, con eso, entonces eso se ha logrado mantener y se está haciendo, pues creo yo en este momentico había un cambio de junta porque la gente ya, los viejos nos damos es no haciendo una misma deporte, estamos buscando que la juventud se una para que eso no se pierda, en esa gastronomía se hace, como le digo, en los deportes de una parte y de otra, y llegan, ahí llega la comida, la venta de empanadas nariñenses, la venta de la chicha de pronto el curí, bueno en fin, otra cosa que es importantísimo, el maíz pero el mote, ese es que el maíz se lo hacen de diferentes maneras, lo hacen en sopa de cuchuco es que le dicen, se le dice arniada, y aquí le dicen cuchuco esa sopa de maíz lleva cuchuco, papá, lleva, habas, repollo, bueno de todo, dice lacerada que es otra comida, y hasta fresca para la cuestión del hígado, esa son las comidas que no se pierden aquí, en la tradición. José Montilla.

$\mathrm{Si}$, los carnavales de negros y blancos tienen un significado muy grande para los nariñenses, es la identidad cultural, o sea los carnavales, la guareña y el cuy, yo diría que son la expresión como el orgullo de ser nariñenses, si?. Milton Posos.

Por lo menos allá se tuesta el maíz, lo tuestan y por lo menos aquí en el pueblo donde se compra todo el menú de puerco de marrano, ese se lo pican y se lo ponen ahí a fritar con el tostado, eso sabe buenísimo, aquí había una paisana, Doña Carmela, ella era la que sacaba eso, se quitó ella y se acabó eso, porque por ese tostado, siempre llegan por lo menos los paisanos a comer, a buscar el maíz tostado, porque es sabroso. Grupo Chaza.

El consumo, la cría de los curíes o curises como ellos los llaman, son unas cosas de cultura que se trajeron y las implantaron aquí, es foráneo pero ya eso se quedó aquí pegado, ¿no? Esas cosas, su cerveza que ellos, me imagino, que ancestralmente era chicha, pero ellos le toman mucha cerveza, ellos vienen y están en ese asunto de la cerveza, del tejo, ellos se trajeron sus costumbres acá. Camilo Muñoz.

Lo único niña, aquí es que cuando usted ve a los nariñenses tomando, el señor viene por allá repartiendo cerveza, el otro va con ron por aquí, el otro con aguardiente, de todo. Grupo Chaza. 


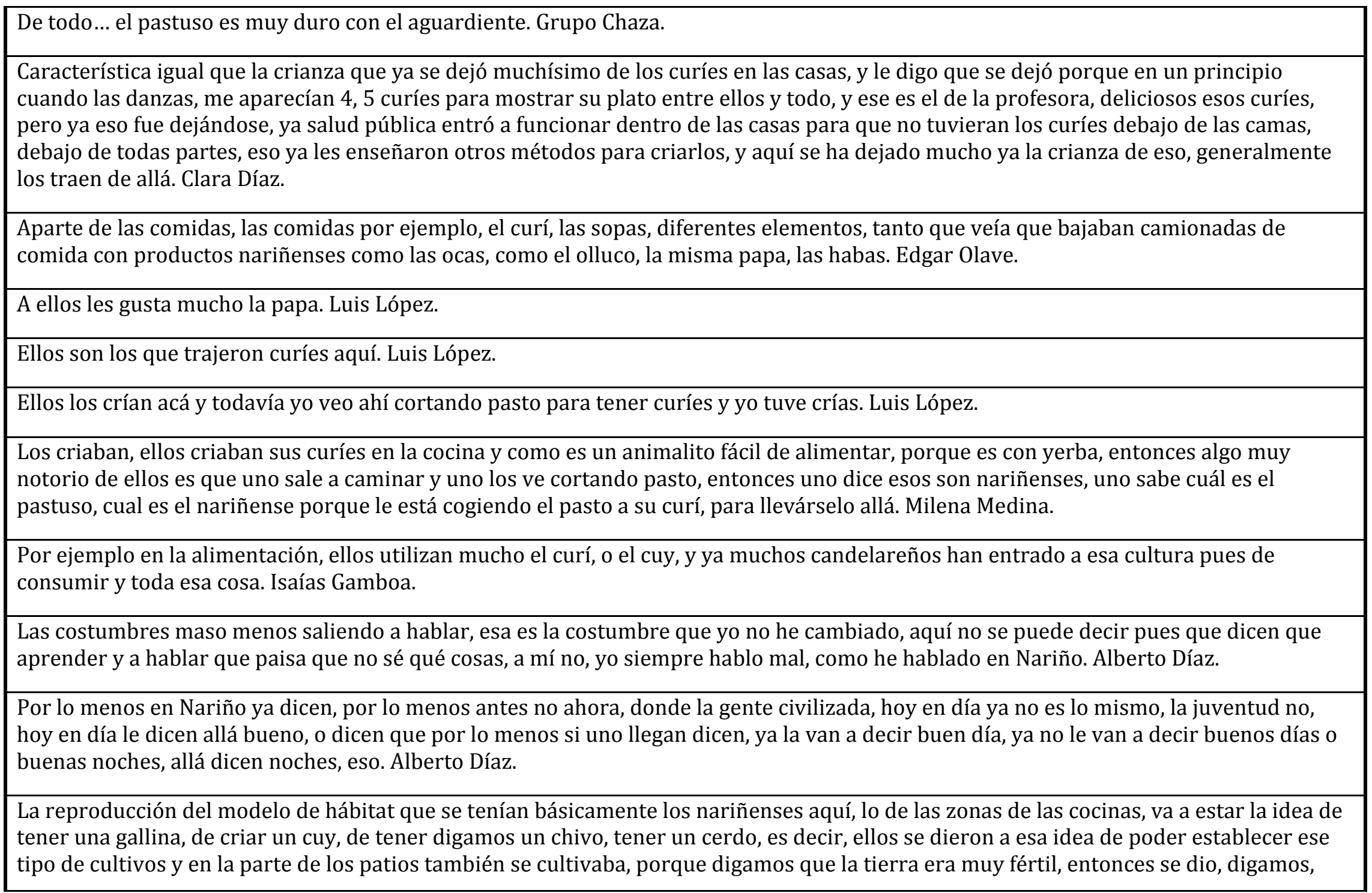


buena posibilidad para eso. Víctor Mondragón.

en relación a la gastronomía no es tan fuerte, digamos, porque la comunidad de los nariñenses con el cuy es otra cosa y digamos que ellos solamente se comía cuy cuando había la celebración de blancos y negros, de resto no había cuy, o cuando se celebraba la virgen de las

lajas, de resto no había cuy, mas sin embargo ellos al interior de su familia, mantenían digamos el consumo, los criaban y se los comían, digamos que el pollo, las gallinitas, digamos que era muy cotidiano de tener el patio y un patio vivo con animales para poder mantener una actividad, un alimento dietario para la familia. Víctor Mondragón. 


\section{ESTRATEGIAS DE IDENTIFICACIÓN}

\section{Formas de vestir/corporales}

Por el modo de caminar o por el modo de vestir es como sí, el modo de hablar. Grupo Chaza.

Andaban muchas veces con atuendos, no total de ellos de allá, pero si andaban con sus sacos, de pronto un chaleco, de pronto un poncho. Clara Díaz.

No, uno los veía al principio muy diferentes porque ellos venían con sus trajes, venían con sus zapatos especialmente de trabajo, zapato de trabajo y no hacían la diferencia entre el zapato dominguero y el del trabajo, no hacían una diferencia, sino que era como el mismo, para ellos era el mismo. Clara Díaz.

Cuando uno baja montaña, uno trata de caminar así, como saltadito subiendo montaña, como subiendo grada, ellos como permanentemente tratan de subir montaña, entonces vienen con el caminadito así, eso también al principio los podía identificar con eso, los veía pasar y ve, están recién llegados o algo, por que traían ese caminado, su vestido, en ese tiempo, estoy hablando de ese tiempo cierto, ellos utilizaban mucho, pues debido al calor tuvieron que cambiar su vestimenta, pero ellos traían sus ponchos, sus ruanas, su sombrerito, ya? Inclusive uno ahora ve que no se quitan su sombrero, de eso hablo, de los sombreritos pequeños de paño, igual sus vestidos de paño. Edgar Olave.

Si, uno lo distingue por el caminado, por ejemplo, el nariñense por ejemplo, ellos caminan así, como así, un poco agachados y eso es porque ellos viven en terrenos que no son planos, entonces cuando uno sube una loma, es como agachado, entonces yo creo que uno ya en ese sentido distingue. Isaías Gamboa.

La manera de hablar también, porque nosotros nos comemos las "s", a veces ellos se marcan por qué no, ellos el castellano lo manejan mejor en ese sentido. Isaías Gamboa.

Vaya a ver que por lo menos la juventud ya no es lo mismo que en ese tiempo antes, se ponían chalecos, se ponían sacos, buzos, ruanas, se ponían sombrero, se ponían botas, ahora ya no es así, ahora el cuerpito es lo mismo que aquí. Alberto Díaz. 


\section{ESTRATEGIAS DE IDENTIFICACIÓN}

\section{Ritos y prácticas}

Claro que nosotros sí, al menos en la chaza, porque esto de la chaza aquí, uno por ejemplo, yo nací; mi deporte de la chaza cuando yo estaba en 16 años; en Túquerres practicamos la pelotica que es la de la chaza, uno se sabía ese juego, pero ya llegué aquí, como aquí es, como le estoy comentado anterior, eran todos nariñenses, sabían del juego aquí de la chaza y uno vuelve a compartir el juego con ellos. Aurelio Realpe.

Fue duro, pero como le digo, la gente dice: -pero usted qué hacía, qué tanto para esas cosas y eso era la duda de mi suegro, porque yo no tenía otras distracciones sino mi juego de Chaza. Alpala y Rosalba.

Costumbre nariñense, porque eso en Candelaria donde veían la montonera, todos eran nariñenses, hasta yo me he reunido, yo estoy vinculado a unas organizaciones en el hospital y ellos recuerdan de los nariñenses la integración que hacíamos y la cual las mingas se perdieron, porque una, era pues porque nosotros lo hacíamos era por la edad, y la otra que se descubrió que era más incómodo, como más costoso, porque la comida, y después de la comida venía la bebida, cervecita, aguardiente, la gente se iban borrachitos pues; entonces esa era la costumbre, pero eso por una parte, los mismos de aquí de Candelaria se preocupan porque se perdieron lo de las mingas, porque lo de las mingas es, pero estábamos aquí en el barrio como reactivamos las mingas. Alpala y Rosalba.

Y en Nariño las hacen todavía, más que todo las hacen en los caminos vecinales, esas son las mingas, cuando hay que renovar una entrada un callejón convocan a la minga y entonces ahí hay una organización; allá hoy en día funciona mucho los cabildos, y hoy en día los cabildos son los que convocan a trabajar, a la minga entonces hoy en día son los cabildos y hablando de cabildos aquí se ofrecen conversas, los cabildos en Nariño son muy organizados. Alpala y Rosalba.

La chaza se empezó en, por ahí en los años 60,66, ahí fue que se empezó, en la Candelaria; fue un proceso muy largo, pero por la persistencia de nosotros se han dado las cosas a como están en el momento, porque entonces no era todo eso construido como esta hora, por que Don Pedro, eso era un Potrero, donde era el parque recreacional, en el polideportivo, ahí empezamos a practicar el deporte. Alpala y Rosalba.

Del, de la chaza, mucha gente de los de la chaza nos vinculamos al evento de los carnavales, al evento de la virgen de Las Lajas, muchos de los mismos de la chaza todavía estamos allá. Alpala y Rosalba.

Pero los carnavales son de mucho tiempo, los carnavales es igual en los mismo años 80. Alpala y Rosalba. 
Y la virgen de Las Lajas ¿es más o menos cómo en la época de los carnavales? Sí, en la época de los carnavales entonces. Alpala y Rosalba.

De las costumbres nariñenses, en el momento estamos hablando de las dos, de lo de la chaza a pesar de que esta débil, como ya lo conversaba cuando nos comunicábamos por el material físico de la gente, pero por el momento se está conservando lo que de la chaza y las actividades de la virgen de Las Lajas, eso es lo que estamos conservando, esas cosas, porque lo de los carnavales, eso se fue como privatizando, eso lo están manejando otras personas. Alpala y Rosalba.

Aquí por lo menos la gente en Candelaria, cuando se empezó a agruparse la gente, se trajo la virgen de Las Lajas, entonces hicieron una en donde decimos el polideportivo, eso era ahí una caseta que se había comprado para la capilla de la virgen de la iglesia y bueno ahí habían festividades cada 15 o cada mes, buenas festividades para recolectar fondos para hacer la capilla, la iglesia, y bueno, para la iglesia eso; y bueno, en últimas, como toda junta o administración no actúan bien algunos, son deshonestos, esa plata se perdió, se bajaron hasta el rancho que había en la caseta, hasta las hojas, todo se perdió, se lo llevaron, entonces de ahí la gente se desanimó, fue desalojando y todo eso, pero más sin embargo no se ha dejado, hablamos unos pocos todavía que nos agrupábamos y vamos haciendo algo, entonces ahí pues ya las festividades se siguen haciendo, por lo de la virgen y el asunto de los carnavales también, otro grupito armando y haciendo sus inventos ahí. Gabriel Pascuasa.

Si, uno dice que por colaborar y va a las festividades no?, y pero uno dice que eso no más, pero no deja la plata allá, sí pero más lo hace uno por chupar, si a eso me agrupaba yo en eso. Gabriel Pascuasa.

Sí, la Virgen de Las Lajas fue la primera, ahh no! las actividades nariñenses. Lo primero que empezamos fue el juego de chaza, esas fueron las primeras agrupaciones de nosotros los nariñenses. Gabriel Pascuasa.

Empezaron por ahí dos o tres a buscar razón de jugar, y de ahí y nos volvimos paisanos que nos gustaba y se iban agrupando ahí y ya haciendo sus juegos también y se iba creciendo la gente, todo paisano iba, al que le gustaba ese fuego se iba agregando, porque antes había jugadero; aquí, antes bastante y ahí se fue consiguiendo la cancha para jugar y en varias partes se hizo esas canchas; y después de eso, vino lo de la virgen de Las Lajas y ahí y como le digo, se hizo las agrupaciones para eso y la junta directiva se compró dónde iba a hacer, no se compró, sino que lo cedió el ingeniero de Mayagüez y de aquí para allá todo era Mayagüez, lo cedió también el ingeniero de Mayagüez donde iba a ser la capilla y todo eso se perdió y ahí por ahí fueron inventando todo eso de los carnavales, también el 31. También se ha hecho un grupo de todas las costumbres de Nariño. Gabriel Pascuasa.

Las actividades nariñenses pues como le digo, son las los carnavales, las festividades de la Virgen de las Lajas y lo de la chaza, cuando se hacen esos torneos esas son actividades que yo le considero nariñenses. Gabriel Pascuasa. 
Donde, cuando se empezaron los carnavales pues que habría que mirar las fechas bien. Pero hace unos 20 años, 21, 22 años por allá. Se hizo como los primeros. Si, como 21 años más o menos. Recuerdo porque mi esposa estaba en embarazo y mi hija ya cumplió 21 y por esa época se hizo el primero, creo yo, Festivales de Blancos y Negros. Por ejemplo eso se hizo dónde está la cancha de Club, ahí al frente, ahí se, se hacía eso. Julio Castro.

no se la fecha exactamente, pero allá en Nariño es 5 y 6, lo que pasa es que aquí también lo hace San Antonio, lo hacen en Palmira, en Samorano y entonces a veces coincide o a veces esperan que sea allá y después acá o primero aquí y después allá, pero generalmente a los 8 días de que es allá, 5, 6, entonces diga usted por ahí el 13, 12 en este caso, por ahí debe ser el 12, a veces se ha corrido otra semana, dos semanas más. Julio Castro.

Fue donde nació la chaza aquí, por eso somos los fundadores, un día estábamos, ya nos habían sacado de este lote, a ver, ah si ya nos habían sacado del lote estábamos ya jugando allá donde estábamos pero en tierra. Pedro Castro.

No había mucha gente que venía a ver, como hasta ahora, hay gente que viene de otra parte de ahí mismo lo llaman a uno y le dicen -vea ese juego cómo se llama, cómo es esa contabilidad que cuentan, apuestan plata, qué apuestan- y si apuestan por recreación cualquier 5 mil pesos por recreación, entonces ya no. Hay bastante gente, los de la mano, los mayores que ellos juegan sino mil pesitos y antes era menos, 50 no más, 50 pesos; y ahora ya como que juegan de a dos mil ellos. Pedro Castro.

Ah pues aquí es el deporte la chaza, los carnavales, todo eso, eso es de allá y así, eso siempre, cuando hoy en día los carnavales no eran de lo nariñenses. Pedro Castro.

Pues eso si ya en veces es por falta de plata, porque en Nariño qué comercio hay, así digan; pero comercio sí hay, entonces allá todavía no es como aquí, que aquí todo le pesan, una libra, media libra, no, allá hasta el momento va a la galería de Pasto y hay uno más coquitas, y esas coquitas en veces vale mil y así. José Montilla.

Entonces les dije, los que vayan lleven la palita, por que yo allá no tengo la herramienta, a las 6 de la mañana fueron llegando eso gente hasta mala, eso se echó la plancha únicamente con mano de obra sin maquinaria, nada, los mismos se armaron los andamios, la mezcla iba de una parte a otra, a la otra; hasta que llegaba a la plancha de donde venía ya el corte, hasta que se acabó, a las 2 de la tarde se acabó. De ahí para allá se les entrega la comida, cuando el momento de la fundación de la plancha, hay que darles una cerveza, lo que uno tenga bien si es posible, la chicha nariñense por que es Nariño , es así de la tradición de la chicha de maíz, si todo de eso es de maíz allá no hay de la otra, puro maíz, y esa se les preparaba por que la mujer, sabia preparar eso, entonces se les daba eso a cada nada cuando ya iba al almuerzo ya estaban mareados, ya con chicha cerveza y así, y así después de que termino una ronda ahora sí, todos sentados y a cada uno se le iba pasando la comida, y hasta que ahí después rematan con cerveza y cada uno se va lindo hasta que queda el de la obra 
queda solo, pero ya, esa es la unidad de los nariñenses. José Montilla.

Cabe notar que si bien están organizados los carnavales de negros y blancos en la última década, 12 años algo así, también hay que decir que es un evento que se venía dando desde hace muchos años, otras 2 décadas a partir de esta fecha, expresión que se da, debido a los grupos que se organizaron de nariñenses, no grupos totalmente legalmente constituidos, no, grupos con unidades de base, amistades, grupos de juego de chaza, grupo de compañeros de trabajo en el ingenio Mayagüez. Milton Posos.

Los carnavales de negro y blancos en Nariño son un día cívico, la expresión no se da solo en San Juan de Pasto, sino en todos los municipios, en todos los corregimientos, en todas las veredas En Nariño, la gente el 6 de enero puede claro, un lunes o un martes la gente, ese es un día cívico, la gente no trabaja, la gente sale a divertirse y esa es la diferencia de otras expresiones con otros sitios, ese día juegan en todas las partes, nadie hace sus labores, se dedican al carnaval, uno ese; entonces la gente aquí tenían un horario de trabajo un compromiso y les llenaba nostalgia no poder estar allá, no participar, entonces ese sentido de pertenencia lo vamos a celebrar la expresión un día domingo aquí, aquí nos echamos polvo y todo y eso fue lo que se dio, ahora desde hace 3 décadas. Antes los carnavales hace como 2 décadas salieron una ley y se incorporan como patrimonio cultural de Colombia, entonces una expresión que en su debida fecha su debido tiempo. Milton Posos.

A ver, no cambia, o sea el sentido, no cambia, aumenta, aumenta, porque? Por que es que cuando uno está y la gente está en Nariño; uno disfruta los carnavales, sí porque ya son de ahí, y es la fecha que llego y tal, pero aquí aumenta el sentimiento por que uno se los disfruta, la misma nostalgia y las muchas ganas de querer estar y evocando épocas pasadas, y épocas de la juventud, de la niñez entonces el sentimiento no cambia, yo diría que aumenta el sentimiento de expresión hacia los carnavales de negros y blancos. Milton Posos.

Yo voy a hablar de lo que dijo Don Alpala, también yo soy muy aficionado a la chaza, porque a veces yo me siento como estresado y juego la chaza, y ahí se me quita todo, por que ya pensionado por que ya es diferente por que tanto estar en la casa también es como aburrido y ese calor tan tremendo, y me voy a divertirme allá. Grupo Chaza.

Pues ellos tienen unas costumbres muy de ellos, y tanto que nos trajeron a la Virgen de Las Lajas, ellos tienen una especie de juego que parece un tenis, pero no es un tenis, es un tenis con la mano, la chaza, eso lo trajeron y lo implantaron aquí y eso se quedó aquí en Palmira, todo estos lados, la chaza. Camilo Muñoz.

Otra de las cosas que no han traído, por ejemplo han sido, nos traen por ejemplo, unos santos, a San Pedro, entonces han instituido también el día de San Pedro y lo traen en una chiva de por allá de Funes, Nariño, por allá y vienen y le dan una misa allí a la imagen y luego lo traen por acá y lo meten en un casa y lo tienen dos días. Camilo Muñoz. 
Cada año, pero no me acuerdo del mes, sí, yo vivo pendiente, entonces yo voy y miro, y entonces ellos invierten. Eso ahí tienen que haber unas personas que invierten para poder traerlo, entonces lo traen, es una imagen muy bonita y lo traen en una, y viene una delegación y lo traen. Camilo Muñoz.

Cada año, pero no me acuerdo del mes, sí, yo vivo pendiente entonces yo voy y miro, y entonces ellos invierten. Eso ahí tienen que haber unas personas que invierten para poder traerlo, entonces lo traen, es una imagen muy bonita y lo traen en una, y viene una delegación y lo traen. Clara Díaz.

Montaban la guareña, y eso era importante! traían sus mantas de allá y todo eso, entonces cada papá se pulía por hacer todas esas cosas, entonces yo le estoy hablando en el término mío, entonces para mí fue tan importante el nariñense como el nuestro y como el antioqueño también, como grupos también, yo les daba mucha libertar para que organizaran los grupos de baile. Clara Díaz.

Yo también he participado en las fiestas del 6 de enero, la fiesta para anotar algo muy lindo de los nariñenses, trajeron para una de las fiestas de hace años, trajeron la banda de allá de Nariño, eran 100 músicos, era una cantidad de gente, y cuando llegaron al parque, eran varios buses y todos los instrumentos, y yo me preguntaba a dónde irán si aquí no hay un hotel, y realmente aquí en Candelaria no hay un hotel que uno diga, alberga a toda esa gente. Todos habían cedido su mejor alcoba en su casa, para albergar a los músicos, eso es de admirar. Clara Díaz.

Especialmente los señores ya maduros, que le dedican bastante tiempo, y muchos de ellos madrugan a las 6 de la mañana, 5 y media de la mañana a jugar para irse a organizar y seguir su jornada laboral. Clara Díaz.

Las costumbres que tenían ellos por ejemplo, de tomar mucho, ellos les gustaba mucho el trago y a veces salían diferencias y eran muy guapos para la pelea, así como para el trabajo, entonces habían discusiones, pero era más que todo por cuestiones de licor, pero no habían así como diferencias por ocupar el espacio, por que inclusive Candelaria, llego un momento que podemos decir que Candelaria podía ser un 80-20 un 80\% nariñense y un 20\% candelareños, entonces era grandísimo. Edgar Olave.

Bueno, los nariñenses tienen varias costumbres, ellos inclusive son muy arraigados a sus costumbres ancestrales, por eso es que tenemos aquí, ellos celebran todas las fiestas, las fiestas de su región, la fiesta de nuestra señora de Las Lajas, blancos y negros, inclusive que sus costumbres a veces de entierros, entierros ellos por ejemplo les gusta mucho acompañarse, se acompañan mucho, son muy unidos, otra costumbre que ellos tenían, eran las mingas, si por ejemplo un nariñense tenía problemas y llegaba y le ayudaban a armar su casa y se reunían y entre todos se ayudaban cosa que se ha perdido. Edgar Olave.

Los nariñenses son muy religiosos, ellos tienen la tradición de la virgen de Las Lajas, y ellos celebran la virgen de Las Lajas por los meses 
de octubre o noviembre, algo así, yo creo que para este mes que viene ya comienzan la novena de la virgen de Las Lajas. Isaías Gamboa.

Eso, como le acabo de contar que le estaba contando hace rato, eso propiamente yo lo aprendí sin que nadie me explique sin que nadie me enseñe, nada de eso, yo lo aprendí yo solito, viendo a los demás como jugaban, había jugadores que me interesaba mucho verlos jugar, yo me paraba a verlos jugar, miraba la forma de pararse de ellos, miraba la forma de pegarle a la bola, miraba la forma de cómo, si era puño o a mano abierta, o con cocas, yo miraba todo eso, y me analizaba cuando yo jugaba o cuando yo estaba jugando, miraba el jueguito de los otros señores cómo volvía, cómo sacaba, cómo se paraba, de qué forma él entraba, cómo salía para atrás, cómo daba la vuelta, porque uno da unas vueltas, yo daba dos vueltas, cuando la bola me venía muy larga yo daba dos vueltas de para atrás y cualquiera no las da, una sí, pero dos vueltas rápidas no, no lo había visto y eso era que se admiraban conmigo, por que en ese tiempo era joven, en ese tiempo tenía 20 años cuando yo hacía eso, y en los 15 años era peor, y eso lo aprendí yo propiamente mirando, por eso decían, vos porque miras, les aprendiste tanto vos, es que mira ve, como saca el, saca a mano abierta le dije, mira saca, y al volver vuelve puño y yo analizaba a los jugadores así. Alberto Díaz.

Es muy hermoso allá, si aquí por lo menos en el tiempo de antes, sí se vio algo, por lo menos en cuestión de la virgen de Las Lajas, se dio festivales pero cosas importantes, grandes, pero que habían gente, yo no sé de dónde venía tanta gente, por esos festivales de la virgen de Las Lajas, pero esos si eran en cantidad de gente por dios. Alberto Díaz.

Bueno, es que por lo menos eso siempre lo pasaban por aquí, también hay una junta no, en el juego de chaza hay una junta ahí hay un presidente, vicepresidente, secretario, todo eso lo tienen ahí, porque esa cancha no es así no más, esa cancha tiene todas las estadísticas propias de dar un respeto. Alberto Díaz.

Primero que todo los que pertenecemos como la junta, entonces nos reunimos para hablar a ver qué pasó es a seguir y ya pues cómo vamos a hacer económicamente, a quien vamos a pedir y entonces ya se comienza a hacer, a mandar, a hacer programas, a hablar con el padre, para las misas, los que van a llevar los barrios la novena, y de ahí ya pues se consigue el dinero es para comprar pólvora, antes se contrataban bandas, hasta de Nariño se trajo una vez, 3 años trajimos bandas de Nariño, pero eso nos salía muy costoso, quedamos debiendo, y ya pues el alcalde siempre nos ha colaborado, este año sino, el alcalde que esta ahorita no. Grupo 2

Las fiestas no eran sino para celebrar cada año la misa y las vísperas, nosotros la hacíamos con mucha pompa, con mucho interés, inclusive traíamos las bandas de Nariño para celebrar aquí las fiestas, desde ese año, desde el año 84, llevamos más de 30 años. Jorge Martínez

Nuestra intención es que una cantidad de personas, nos reunimos, nos llamábamos en ese momento fiesteros y como fiesteros dábamos una cuota para celebrar la fiesta, entonces siempre tenemos la tradición de los fiesteros. Jorge Martínez 
Para los nariñenses por que relativamente, allá se venera mucho a la virgen y de allá los que vivimos en otros pueblos por que de allá, apareció en una vereda de Ipiales pero nosotros somos de otros municipios y con esa devoción que viajábamos en ese tiempo, de niño todavía viajamos de a pie, caminando a pie día y medio, a pie por una lomas, hasta llegar allá. Jorge Martínez

Desde agosto, antes de agosto, empezamos ya a hacer los programas y a planear la fiesta, así es que para ya septiembre, ya tenemos listo el programa, siempre lo hacemos en septiembre, que allá en Las Lajas, si quiere vamos con los tiempos. Jorge Martínez 


\section{ESTRATEGIAS DE IDENTIFICACIÓN}

\section{Envío de mensajes/objetos/comida}

Cuando pues, no pero nosotros al principio, en el ejército más o menos por medio de cartas, porque en ese tiempo por teléfono es como muy, no lo había, y teléfonos a dónde lo va a ver, entonces por medio de cartas. Aurelio Realpe.

Entonces en ese tiempo cuando era por carta, era por carta en correo. Alpala y Rosalba.

En este tiempo pues no es como ahora que hay celulares, teléfonos y todo eso, no, en ese tiempo era a puras cartas correo y a veces ellos dejaron su tiempito y venían a visitarlo, se estaban acá 8 días y traían cositas de la comida pues. Gabriel Pascuasa.

Traían papa, traía maíz, garbanzo, frijol lo que se daba por allá y se estaban 8 - 15 días y de ahí se iban y uno cuando salía a vacaciones pues también agarraba y se iba y se estaba sus 8 o 15 días por allá también descansando. Gabriel Pascuasa.

Ellos traían todo, hasta el café no lo traían hasta molidito, porque allá cosechamos mucho café en el pueblo de donde soy yo, entonces ellos tostaban su café allá y lo molían y lo traían molidito. Gabriel Pascuasa.

Todo el tiempo, claro que ellos ya luego que estaba yo acá, llamaban por aquí, pues por ejemplo, yo le pedía una cita a Telecom se apartaba el tiempo en tal parte y llamábamos a tal hora, exacto había que estar allá y cuando llamaban uno estaba ahí. Pedro Castro.

Nos mandan papa, las habas, la calabaza, cada rato como se dice la sopa de calabaza o como dicen allá el locro. Pedro Castro.

En eso si era a través de cartas, eso era escribir una carta y se demoraba 15 días, otras 8 días, hasta más; las cartas en veces se extraviaban, no llegaban, se volvían, y era difícil. José Montilla.

No, sí permaneció siempre y cuando digamos, cada 3 meses, cada 6 meses o de pronto cuando había alguna prioridad de allá para acá o de aquí para allá o cuando habían veces venían paisanos se iban, eso era, se mandan razones cartas, plata, en fin. José Montilla.

No, ya no, yo me quedé trabajando ahí, ya tenía 3 años, a los 3 años me dieron vacaciones, entonces me fui para la casa a ver a mis abuelos, allá todo eso les compre ropa, les compre remesa, les compre, así. Pero como yo les compraba de acá eso, yo les giraba. Alberto Díaz. 
No, ya era diferente, ya no era lo mismo como cuando yo tenía a mi mamá, ya no. Por lo menos allá tenia a una hermana, ella era casada con un muchacho allá que ya lleva muerto hace días por hace tiene sus 15 años de muerte, pero cuando yo ya estaba así, yo iba pero pues iba a veces a los dos años, ya no era lo mismo cuando estaba mi mamá. Alberto Díaz.

Luego con el resto de familias que hay allá pues nos comunicamos, hemos viajado después a allá en el pueblo, sino a la vereda donde yo me crié, pero ahorita ya no me conocen tampoco allá y si yo voy, ya no conozco a la gente porque todo el mundo ya se desapareció, los tíos que tenía ya han muerto, si es difícil llegar allá después de tantos años. Jorge Martínez 


\section{IDEA DE GENTE PURA Y ORIGINAL}

\section{Cómo somos los nariñenses}

Pero aquí 90\% son de Nariño, aquí en Candelaria, entonces no hay tanta discriminación, pero porque aquí el 90\%, sí, aquí no más; rebájemele que sea el $80 \%$. Pregunte aquí no más de pueblo qué cómo está aquí, es de puros nariñenses. Aurelio Realpe.

Pues claro, en ese sentido uno no debe negar la tierra, de qué parte nació uno, no?, pero hay que compartir, yo digo hay que compartir por que ya uno deja el dialecto, otros por el modo del estudio, a nivel del estudio, no dejan de hablar el dialecto, son cerrados, del mismo, porque yo quisiera que todo mundo fuéramos de pasto con un nivel de estudio, pero muchas veces que nos ve ahí, muy cerraditos, no tenemos estudio y por eso les digo, ahí está en su observación que ha hecho ahí hay siempre, no hay nadie, el que más habla ahí, es Alpala. Aurelio Realpe.

No, yo de las dos partes, porque yo no olvido, yo no olvido de dónde yo nací, porque allá tengo a mi familia, ya la mayor parte de mi vida mía, es aquí, en el valle. Aurelio Realpe.

No pero aquí de, no los de Valle no les gusta el, el juego de chaza. No los he visto pues, siempre somos los de Nariño. Aurelio Realpe.

Pues por, será que por el, identificarlos por lo que uno ya los conoce y todo eso, por el modo de hablar, por el sentido, por el mismo personal que uno conoce de Nariño, primero somos muy callados. Aurelio Realpe.

Muy callados, no habla nada, ellos, nos gusta escuchar y a veces, pero como yo les digo a ellos mismos, yo por lo que yo pase por la policía, pues yo aprendí un poquito, no? Pero con ese nivel de estudio que tengo de 5 de primaria, hay otros que no lo tienen, y más de esos que somos campesinos, entonces muy dificultoso, la dificultad para uno expresarse, por eso usted ha visto ahí, y eso que el mismo Alpala y eso que es el mismo presidente y eso que tiene años de estar de presidente, él es cortico también, y como yo le digo a él, yo le crítico. Aurelio Realpe.

Y le tiramos plancha, entonces le tiramos plancha cuando ya se hizo la hora de meter la plancha; yo invite más o menos a 20 por el trabajo, eran en minga, en comunidad, no es como ahora, que traen al trompo y eso es rápido, cuando eso era a pala, era la minga que decíamos, eso de la minga, nosotros los nariñenses hemos dejado un ejemplo, cosa que ya se está perdiendo esas cosas. Alpala y Rosalba. 
Costumbre nariñense, porque eso en Candelaria, donde veían la montonera todos, era nariñense; hasta yo me reunía, yo estoy vinculado a unas organizaciones en el hospital, y ellos recuerdan de los Nariñenses la integración que hacíamos y la cual las mingas se perdieron, porque una, era pues porque nosotros lo hacíamos era por la edad, y la otra que se descubrió que era más incómodo, como más costoso, porque la comida, y después de la comida venia la bebida, cervecita, aguardiente, la gente se iban borrachitos pues, entonces esa era la costumbre, pero eso por una parte, los mismos de aquí de Candelaria se preocupan porque se perdieron lo de las mingas, porque lo de las mingas es, pero estábamos aquí en el barrio, como reactivamos las mingas. Alpala y Rosalba.

Entonces las esposas hacían la comida para la gente que venía a la minga. Alpala y Rosalba.

La colonia nariñense se conformó, se integró por las mismas entidades, charlas de las que estamos hablando, unos por la chaza, otros por los carnavales, otros por lo de la virgen de Las Lajas, de esas tres partes se formó la integración de nariñenses y por esas tres partes a nosotros nos han tenido mucho en cuenta los nariñenses en Candelaria, que sí somos organizados. Alpala y Rosalba.

Así las agrupaciones se hacen, entre paisanos se va inventando tal cosa y dice sí, esta idea ya esta buena, vamos a hacerlo, va consiguiendo más gente contándole las opiniones, dando opiniones y aportando opiniones y así se va haciendo las cosas. Gabriel Pascuasa.

Bueno, por lo menos aquí uno que había tenido esas iniciativas era don Próspero Gómez era uno; otro ¿Quién era? Me parece que Don Pedro Castro, participó en eso, otros paisanos que son pensionados de por acá abajo también; Bueno ahí iban surgiendo las opiniones de la misma gente; Entonces ellos veían que sí se podía y empezaban a inventar sus opiniones y se hacía así, no se quedaba ahí. Gabriel Pascuasa.

Yo me emociono mucho con lo de Nariño, yo por lo menos cada que viajó para allá, llego allá y me emociono mucho con la sobrina y la familia, la comida, que esto, que lo otro. Bueno, hay muchas cosas que me hacen sentir, incluso que cuando voy para allá yo traigo mucho grano de allá de Nariño para acá. Gabriel Pascuasa.

Y eso me hace recordar muchas cosas a mí, me significa asociarme, hacer compañerismo, agruparme con los demás paisanos, así sean del mismo pueblo o no sean del mismo pueblo, que sean de otras poblaciones, pero me hace sentir nariñense con todos ellos, pues simplemente llevamos una conversa, una charla me hace sentir muy bien con ellos y ellos se sienten bien con uno, que uno sepa cómo llevarle las ideas y uno le lleva las ideas a ellos y ellos a uno como se dice bromas, porque las bromas son las que lo más lo unen a uno, el humor eso es lo que más la grupa uno con la gente, todo eso me hace sentir muy bien. Gabriel Pascuasa.

Los nariñenses nos caracterizamos por principalmente por el juego y ya, y segundo, muchas veces por las bebidas, porque los nariñenses 
toman mucho. Gabriel Pascuasa.

Fue donde nació la chaza, aquí, por eso somos los fundadores, un día estábamos, ya nos habían sacado de este lote, a ver, ¡ah sí! Ya nos habían sacado del lote, estábamos ya jugando allá donde estábamos pero en tierra. Pedro Castro.

En cambio nosotros, yo no puedo decir que he perdido las tradiciones de mi pueblo de Nariño, no, yo tengo las mismas tradiciones y estoy allá y no pierdo mis tradiciones de acá, pero todo el mundo habla de todo y como yo voy cada año, ahí estoy allá en iglesias y bueno, y decir que perder la tradición, por ejemplo yo me pongo a pensar y hay gente que la comida, dejan lo que se come allá y eso pasamos cada que vamos para allá la comida común y corriente. Pedro Castro.

Pues soy nariñense como digo de cepa, pero vivo aquí hace 40 años, y mis hijos son de aquí, vallunos, entonces estamos entre, Valle y Nariño, entonces como le digo, ni el dialecto nos ha cambiado, que por que estamos con los nariñenses se nos olvida lo del Valle, no, estamos aquí y se nos olvida de lo del nariñense, tampoco; siempre las cosas se nombrar por lo que es acá y las cosas acá se nombran por lo de allá, las nombra igual que aquí, no va cambiando como se nombran las cosas y hay muchas cosas que aquí le ponen un nombre y allá es otro. Pedro Castro.

Exacto, eso es donde estemos, los años que estemos nos sentimos de nuestra tierra, la tierra que nacimos, donde nacimos, no se puede negar nada de ella, porque si está negando la tierra está negando a la madre. Pedro Castro.

Bueno, para conseguir esa casa pues siempre me encontré con otro paisano que ya murió también, tomamos una casa en arriendo, entre las dos familias y usted sabe que entre los paisanos nosotros siempre hemos sido solidarios, nos ayudamos mucho, eso tiene la colonia nariñense, solidaria, no es como a veces la pintan, solidaria. José Montilla.

Lo nariñense es el estilo, como le digo, cómo se dice eso, la paciencia o cómo le dijera yo, el nariñense no tiene esa impostranidad de ser una cosa activa, él es pasivo, no? Y es tranquilo y por eso en veces lo tildan, pero es mientras él no llega a tener esa, pero cuando llega es más que el paisa pues. José Montilla.

Así lo es, por que los que han estado en Nariño no se han hecho resaltar en su inteligencia, a cuando si es capaz pero no se han hecho resaltar con esa inteligencia, entonces lo han dejado como una persona pasiva, la persona nariñense como una persona pasiva en todo, cuando ha habido algunas normas de reclamación, el nariñense ha participado, por decir algo, como los altos impuestos, del agua, de la luz antes; unas reclamaciones masivas donde se hacían propuesta. José Montilla. 
Pues a ver, yo los describiría, la gente nariñense somos de una cultura yo digo que, en parte cultural, un amor muy grande por lo cultural, si?, la gente de Nariño, es gente noble, poco conflictiva y muy dedicada a querer hacer las cosas bien, a querer que el entorno donde se vive este mejor, a mantener la familia, la cultura y sobretodo amantes del sitio donde vivimos, yo puedo decir, y no solamente es mi sentir, me siento orgulloso de ser nariñense. Milton Posos.

Bueno, las características digamos, de diferencias, serian muchas, la gente nariñenses nos caracterizamos por ser muy poco explosivos, muy poco controvertidos, ¿sí? , pero características que se asimilan sobretodo es la forma de compartir entre el grupo de nariñenses, entre el grupo de nariñenses, yo creo la diferencia está entre que los nariñenses tenemos la capacidad de unirnos para buscar una expresión cultural. Milton Posos.

Lo que más recuerdo mucho de Nariño es que yo, la humildad, la sencillez de la gente, cuando, y esa parte todavía, lo conservamos por acá. Grupo Chaza.

Los de Candelaria, nos acogieron bien acogidos, y aquí estamos; por otra parte, claro que nosotros lo que es la parte nariñense, lo que es la parte del choco, todo eso, nosotros hemos sido muy fuertes, para el trabajo del campo, para el trabajo, entonces eso nos ha dado una acogida muy bien para todas las partes. Grupo Chaza.

La gente de Nariño, vea, la base fundamental que nosotros tenemos es el carisma de ser respetuosos, honrados, cariñosos, eso es la cultura y lo que nosotros tenemos donde sea, la honradez, la franqueza, porque eso es lo más importante que los nariñenses tenemos y por eso donde nosotros a cualesquier municipio o departamento donde nosotros lleguemos, siempre somos apetecidos ¿por qué? Porque somos una para el trabajo, es para lo que nos toque, el todo es que nos digan -vea esto hay que hacerlo-, y nosotros lo hacemos, eso lo tenemos, lo más fundamental. Grupo Chaza.

El nariñense, como dice Sánchez, nos distinguimos es por la honradez, el trabajo y por eso hemos sido apetecidos. Grupo Chaza.

La cultura de nosotros, por lo menos nosotros somos los que somos nariñenses y tenemos esa cultura o esa de creer en lo que nos dijeron nuestros padres, por lo menos en la virgen de Las Lajas; nosotros somos, en ese sentido, muy católicos, me entiende, por lo menos él dice, la música, la música también es una cordura que se tiene. Grupo Chaza.

El nariñense por lo general se ha caracterizado por ser respetuoso más que todo, y ser sincero, dicte de lleno a lo que le toque ir, mientras que usted ve de uno de aquí de Candelaria, la verdad, uno no se espera nada de ellos de aquí, mientras que nosotros los nariñenses nos cuidamos uno del otro, ellos no están viendo a quién cuidar. Grupo Chaza. 
Lo que Don Sánchez acaba de expresarse, eso nosotros lo, gracias a dios, lo estamos sosteniendo por los principios que han dejado nuestros padres, entonces porque esa formación, esa formación ha sido de nuestros padres, eso es lo que nos enseñaron a respetar, nos enseñaron, en la época en que yo recuerdo, el respeto así sea, sea tío o no sea tío, había que pedirle el nombre de dios. Grupo Chaza.

Aquí, damos gracias a dios, aquí ha sido propiamente la organización, ha sido muy buena aquí, somos todos muy colaboradores en lo que sea, somos muy unidos todos. La colonia nariñense es muy respetable. Para cualquier evento es muy organizada la colonia nariñense, para las fiestas de las vírgenes, para las juntas, para todo es muy organizada. Grupo Chaza.

Nosotros por lo menos aquí vestimos normal, como cualquiera, como me ve, así vestimos, nosotros ya no, ponernos esa relación de allá, pues ya es diferente, a veces el clima también lo quita a uno, pero de todas maneras uno ya no va a decir que porque ya está aquí, que no sé qué, tiene otro semblante. Alberto Díaz.

Lo único que pueda decirme, pues que ya dicen muchos de usted, es pastuso, yo no soy pastuso, eso sí lo estoy, porque el que es pastuso es el que es de Pasto propiamente, nacido en Pasto, mientras que nosotros somos de Nariño, yo soy nacido en Santa Cruz, Nariño, que llama Guachas el pueblito. Alberto Díaz.

A nosotros la verdad nos hace nariñenses, la única que yo le puedo dar es que el nariñense es muy único y el nariñense tiene mucho respeto y el nariñense es muy trabajador, y el nariñense nunca lo maltrata nadie, a no ser de que le den el motivo y eso es lo que yo sé. Alberto Díaz

Qué nos decían a nosotros, pastusos burros, porque nosotros cortábamos caña, -y mire los pastusos burros-, todo lo que le hicieron a este pueblo, esto es hecho de empresas, con todo los anticipos se hizo todas las empresas; de los trabajadores todos tenemos nuestro rancho, ¿por qué se agrando? Fue por los pastusos, por los burros que nos decían y hasta sol día vea donde va ahorita, aquí se está agrandando más el pueblito, más de la iglesia para allá esas son cosas del dueño de ese terreno que está edificando más y vendiendo las casas, pero eso si ya cambia la casas, jah! pero hasta ahí, todo lo que es todo de Candelaria, todo va a hacer de las empresas y va a ser nariñenses. Alberto Díaz.

Nosotros los nariñenses que vemos que somos muy unidos, cree en la gente por que antes que comenzaron a hacer nos facilitamos entre compañeros y como antes no había trombos va a hacer una losa, eso mejor dicho, todos los paisanos, mejor dicho llegaban y eso es un día se hacia un arroz a pura mano, y entonces creían que nosotros somos muy unidos pero la verdad, la verdad para podernos amontonar un ratito que estamos aquí, es como trabajoso. Grupo 2 
Nosotros los nariñenses fuimos fuertes para trabajar y ahora que hay más, lo que los ingenios lo que a nosotros nos han dado para entendernos bien, ha sido muy poquitos, pero por eso hemos podido luchar, somos dignos a las empresas azucareras. Grupo 2 


\begin{tabular}{|l|}
\hline \multicolumn{1}{|c|}{ IDEA DE GENTE PURA Y ORIGINAL } \\
\multicolumn{1}{|c|}{ Cómo son los candelareños desde los nariñenses } \\
\hline $\begin{array}{l}\text { Si, digamos los nariñenses somos más callados, los vallunos son más, sí, hablan más. Es lo mismo de los paisas, a ellos no les importa que } \\
\text { entre más montañero sea, mas habla (Risas) en cuanto sea a los trancazos pero habla, bastante bien. Aurelio Realpe. }\end{array}$ \\
$\begin{array}{l}\text { Por que de todas maneras ellos políticamente, políticamente nos han utilizado, porque ellos, la rama Nariñense en Candelaria somos } \\
\text { entre un } 60 \% \text { o 70\%. Alpala y Rosalba. }\end{array}$ \\
\hline $\begin{array}{l}\text { Mucha gente, y entonces ellos, ellos como sea, esos aportes en la parte política los logran; claro los logran y pues en esa parte si, en } \\
\text { nosotros hemos mirado por eso lo digo en esa expresión por una, nos colaboran por otra nos utilizan, ¿por qué? Alpala y Rosalba. }\end{array}$ \\
\hline $\begin{array}{l}\text { Yo creo que hoy en día la población candelareña ha sufrido diversidades, y por lo tanto, la identidad esta como un poco tras de afro, tras } \\
\text { de lo nariñense disperso, esas son las características que diferenciarían a un candelareño de un nariñense. Milton Posos. }\end{array}$ \\
\hline $\begin{array}{l}\text { Porque la gente que nosotros encontramos aquí, en realidad no les gustaba el corte de caña, muy poquitos y nosotros los nariñenses } \\
\text { fuimos tan aferrados al corte de caña que, luchamos, luchamos hasta poder conseguir nuestra pensión. Grupo Chaza. }\end{array}$ \\
\hline $\begin{array}{l}\text { El carnaval no es normal aquí, solo juegan con harina, con tierra, con barro, con lo que sea y eso no es juego, no es como en Nariño, en } \\
\text { Nariño si lo respetan, ese es un juego y se ve tanta carrosa tan linda, ¿Usted no ha estado allá? Alberto Díaz. }\end{array}$ \\
\hline $\begin{array}{l}\text { Del valluno, con todo el perdón de usted, el valluno a lo único que no le gustaba era trabajar en ese tiempo, el tiempo que yo llegué aquí, } \\
\text { no les gustaba trabajar, mire que cuando yo llegué aquí habían como sacase unas } 8 \text { casas, pero el techo era de hoja de caña, y ahí vivían } \\
\text { ellos, pero nunca les decían vea, habiendo tanta empresa para trabajar. Alberto Díaz. }\end{array}$ \\
\hline
\end{tabular}


IDEA DE GENTE PURA Y ORIGINAL

\section{Cómo son los nariñenses desde los candelareños}

Ellos son muy, ellos hacen mingas y entre ellos se ayudan, son muy solidarios, y entonces el pueblo fue creciendo a la par de que ellos crecían también económicamente y socialmente, el pueblo también fue creciendo, ya hubo el cruce entre grupos étnicos. Camilo Muñoz.

Pues lo que caracteriza a ellos son una raza de empuje, ¿no? son definitivamente visionarios del futuro, ellos son dueños aquí de muchos negocios y como te dije anteriormente, se metieron a la política, ellos tienen mucho empuje, mucho compromiso, aunque no son muy cívicos, digo yo que no se meten a la cosa cívica, pero por el lado económico, ellos han permitido que el pueblo florezca, que el municipio florezca, pero a ellos les hace falta meterse en la cosa cívica, en la cosa, digamos nosotros somos comunales, ellos ahí poco participan, entonces hemos notado como que a eso no le halan, como se dice prácticamente. Camilo Muñoz.

Pues, ellos les halan con ganas al comercio, son algunos casa tenientes, digamos porque hay unos que hicieron con el boom de la caña, se hicieron a varias casas y alquilan esas casas y, pero a la cosa como del compromiso cívico, comunitario ellos no son muy, no se integran, ellos son difíciles de integrarse, entre ellos sí, pero entre, para el resto de la comunidad no, entonces eso es lo que de pronto falta que ellos se... Camilo Muñoz.

El aspecto que aquí se manejó mucho la acción comunal aquí, tuvo un florecimiento extraordinario hace 30 años o más, eso se cayó, eso no, aunque pudo haber sido en todo el país, pero como yo ya dije, ellos no son buenos para esas cosas de sociales, que juntas de acción comunal o clubes, como clubes de Leones que tuvimos uno aquí y eso no prosperó, de pronto esas cosas no pudieron, o no pudieron seguir siendo buenas y de impacto porque ellos no se meten en esas cosas, son poco sociables en eso, esas cosas se nos han perdido mucho, el civismo. Camilo Muñoz.

Tras cosas que hayan podido florecer son el aspecto religioso, son muy religiosos, son muy católicos, eso ayudó al florecimiento pues del catolicismo, y en cuanto a la política, se han metido a la política partidista y han sido partícipes de las administraciones y han, claro que han ayudado a que cambie el estilo de política que se manejaba antes, claro que sí. Camilo Muñoz.

Así mencionaba uno de vez en cuando, y resulta que esa gente es muy astuta, es muy inteligente, no son ningunos tontos. Camilo Muñoz. 
El grupo era muy unido, cuando yo tuve alumnos que eran muy unidos, eran como le digo, una gente muy sana, lo que llama usted sano, y andaban muchas veces con atuendos, no total de ellos de allá, pero si andaban con sus sacos, de pronto un chaleco, de pronto un poncho, todo eso los caracterizaba a ellos. Clara Díaz.

Más que todo su forma de ser, son unas personas muy nobles, unas personas que hacen todavía, cuando a mí me tocaron esos alumnos, todavía los veía como haciendo un poquito de inclinación en su cabecita y eso ayudaba a que uno los identificara ahí mismo, muy callados, pero cuando usted llamaba a colaboración, todos iban. Clara Díaz.

Entonces imagínese que si usted ve las casas, es decir, si somos ingratos con la forma de trabajar de la persona, le vemos miles de defectos, pero si analizamos esa forma de trabajar es perfecta, se unen, comparten, se ayudan, no hay que invertir plata si no lo de los materiales y la comida. Y eso que el que tiene en su casa también llevaba para aumentar la olla. Clara Díaz.

Las costumbres son completamente distintas, cada uno tiene sus costumbres, por ejemplo nosotros acostumbrábamos al famoso comedor, nosotros y comida ahí, mientras ellos les interesaba más una sala, y allí mismo comían, bueno. El caso del estudio, siempre, siempre les compraban el cuaderno que podían recibir de algún grupo político o de alguien que lo daba, mientras el candelareño siempre trataba de pulirse y comprar el cuadernito, así fuese económico en sus maletines, mientras los muchachos usaban, su maletín tratando de tener el de moda, como el personaje de moda, ellos siempre andaban con su mochila y andaban muchos con su mochilita tejida por ellos mismos, por cositas, dibujos de la mamá o algo, eso se veía mucho en el colegio. Clara Díaz.

Ellos han progresado, pero nosotros, el nariñense no nos ha estancado, el nariñense ha sido una persona de la que podemos aprender, porque son unidos, trabajadores, dedicados a sus casa, y generalmente con un pensamiento bonito de tener familia. Clara Díaz.

Ellos son, son tenaces para hacer algo, son tenaces, es que no mas con la hechura de sus casas se nota, cómo hacen, cómo hacen, ellos no dicen no puedo, vengan ayúdenme, vamos a hacer esto, y lo hacían y lo digo porque tuve muchas mamás que no sabían hacer un traje típico y llamaban a las otras. ¡Vamos a hacerlo! y lo hacían, fulana de tal enseña por el municipio, enseña modistería, vamos donde ella, a ver si nos enseña y le mandaban una señora a que les enseñara y aprendían y hacían los trajes, entonces sacan tiempo también, dedican mucho tiempo a sus hijos. Clara Díaz.

Bueno, el nariñense es una persona muy buena, o sea muy buena en el sentido sana, que no tiene perjuicios, ¿Si me entendés? Aunque de pronto los hijos de ellos, ya tienen una ideología muy distinta, pero los que llegaron eran gente muy sana, muy buena, gente creíble, honrada, correcta, gente y o sea en ese tiempo gente, y aparte de eso muy trabajadora, como te digo, formaban familia muy fácilmente, traían su familia. Edgar Olave. 


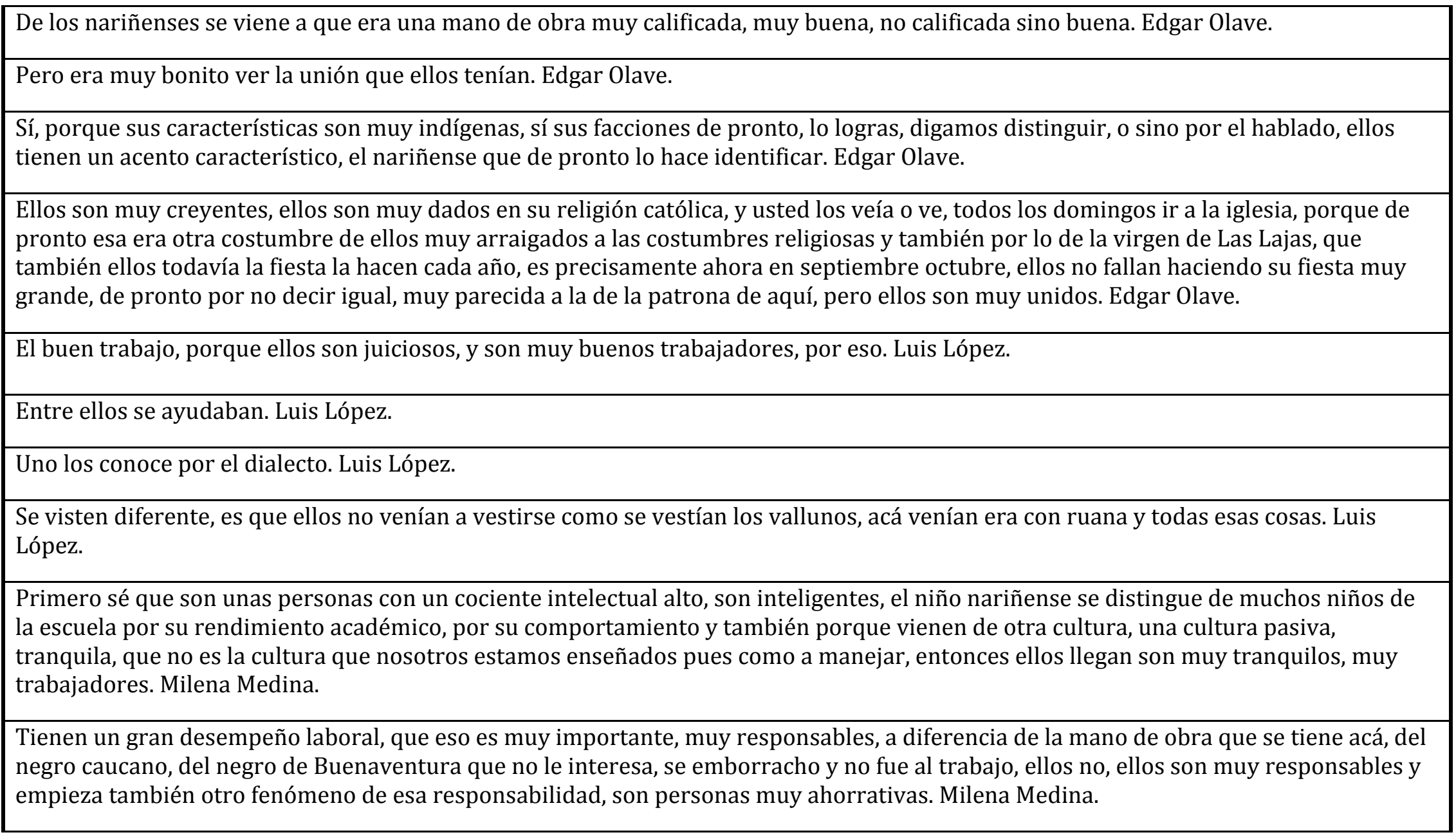


Si vas a las casas de ellos son largas, piezas, piezas, piezas. No se preocupan por la buena ambientación, que haya luz, que haya ventilación, sino piezas como para albergar en su momento al que vaya llegando, me imagino yo que era como pensando eso. Entonces ahorrativos, muy mesurados para vivir, no les gusta demostrar, entonces ellos no son los que muestran el equipo de sonido, al contrario del negro que te saca el equipo así no coma, lo primero su comida, primero la responsabilidad de ellos con su familia, que es también es muy diciente de ellos, muy propio de ellos; primero es tengo que llevar la comida, tengo que llevar esto a la casa, entonces también, muy preocupados porque sus niños coman y vayan a la escuela, esa es otra cosa bien interesante y personas. Milena Medina

Si me preocupa algo de ellos, muy metidos en sus círculos, entonces no son personas que no le generen mucho desarrollo a su comunidad, porque sean solidarios, son solidarios con ellos, eso es lo que yo he podido percibir de ellos, solidarios con ellos; entonces está la colonia nariñense y es la colonia nariñense, entonces la chaza es allí y es de ellos, si me entendés? Pero no los ves proponiendo para la comunidad, no los ves proponiendo para que Candelaria progrese, como en otras cosas, allí en esa parte los veo como un poquito amarrados. Milena Medina

Entonces, los de antes eran muy cerrados, era el círculos de ellos, muy cerrados para que la gente pueda entrar, incluso, pienso que eso en el fondo, todavía les queda, pero se ha disminuido, pero ellos querían ser como un circulo muy cerrado, muy cerrado. Milena Medina

Si andamos en la calle así en un evento, bueno también podemos distinguirla por su forma de caminar, por su forma de hablar, por muchas cosas, pero entonces en las reuniones de los niños ellas son así, como muy bien puestas, como muy estiradas y se creen como de otro nivel; yo siempre he observado como eso en ellas, pero igual es como la idiosincrasia, de lo mismo que te decía, una cultura tranquila, pasiva, es todo eso. Milena Medina

La parte religiosa de ellos es muy arraigada y sobre todo la parte del catolicismo, muy arraigado, el nariñense que sea, y son muy cerrados en esas cosas, pero igual, son muy participativos en las cosas de la iglesia, allí si los ves, allí si ves a los nariñenses, ahí si los ves actuando, ahí si los ves asistiendo en las novenas, en la fiesta de febrero en la misa del corazón de Jesús en la sociedad del corazón de Jesús, si te pones a ver, hay mucho nariñense ahí y muy con esa cuestión religiosa, en esa parte son solidarios y están allí. Milena Medina

Por eso te digo que son muy participativos, porque es que ellos son muy religiosos, ellos son muy religiosos, entonces si ves a los adoradores, a los señores del santo sepulcro muchos son nariñenses, si ves a las socias del corazón de Jesús, todas las viejitas casi son nariñenses y ellas son felices en esa parte, para la novena del niño dios, los grupos que tiene la iglesia. Milena Medina

a ellos esa parte lo que es el ritual para ellos es muy importante eso, todas esas cosas que te marca la iglesia católica para ellos son fundamentales, el matrimonio, todo las procesiones, celebrar las fechas importantes, el corpus todo eso es fuerte en ellos, es muy fuerte. 
Milena Medina

A ellos que les gusta mucho esta parte del ahorro, esta parte de todo esto de ahorrar, precisamente en la cooperativa, Cootrainc, la que vino hoy, allí hay unos 3 o 4 nariñenses que hacen parte de la junta directiva y son personas casi analfabetas. Milena Medina

pero entonces ellos porque es que ellos son, así bien cortantes con todo, y todo tiene que ser como es, y tiene que ser derecho y me gusta, me encanta eso de ellos, esa parte del trabajo de ellos. Milena Medina

Pues los nariñenses eran más bien reservados, pero eran muy, como le dijera, tenían muchas iniciativas, lo que más admiro de ellos es su forma de comunicarse, es decir son muy unidos, ellos hacían mingas para construir su viviendas, por ejemplo usted iba a construir su vivienda hoy entonces ... y le ayudaban a construir su vivienda, y hacían todo eso, preparaban sancocho, todos los alimentos que ellos preparaban en la casa y eso era muy comunitario. Isaías Gamboa

Los nariñenses son muy religiosos, ellos tienen la tradición de la virgen de Las Lajas, y ellos celebran por los meses de octubre o noviembre, algo así, yo creo que para este mes que viene ya comienzan la novena de la virgen de Las Lajas. Isaías Gamboa

Los nariñenses ya están enseñados a las mingas y a todo eso, pues yo lo digo por experiencia, yo fui presidente de la junta del barrio María Auxiliadora de Candelaria, cuando estaba María Fernanda precisamente y entonces yo percibí eso, que quien más le colabora a uno son los nariñenses, yo tenia mucha gente en la junta de acción comunal y ellos me colaboraron muchísimo, lo mismo que la asociación de usuarios, a la que yo pertenecí, a la asociación de usuarios de la Nueva EPS, en el seguro decían que era periódicamente y los nariñenses colaboran muchísimo en eso. Isaías Gamboa

Ellos tienen un sentido de pertenencia, entran a una asociación y se apersonas de eso, y eso es muy bueno, eso es muy sano, porque le da fuerza y carácter a la asociación, a cualquier asociación de cualquier clase que sea. Isaías Gamboa

ellos son muy constantes en el trabajo y son muy perseverantes en todo, y cuando se proponen una meta, ellos tratan de lograrla. Isaías Gamboa

Constantes, reservados y alegres en cierto sentido. Isaías Gamboa

Describirlos, bueno de hecho son personas muy nobles, muy arraigados, el arraigo familiar, arraigo personal y el arraigo de la región marcan mucho, porque podemos encontrar personas que son de lugares muy fríos y también de lugares muy calientes, que comparten digamos diferentes puntos de vista de su cosmovisión. Víctor Mondragón 
Un aspecto clave de lo que he podido percibir de la gente desde la comunidad nariñense, son una comunidad que es muy solidaria, se ayuda entre ellos, se apoya, también por el ejercicio que son migrantes, todo migrante requiere de apoyo para poder alcanzar una meta, crean cooperativas, hacen ahorros, dan celebraciones, es decir, siempre están buscando que la unidad de ellos se mantenga, muchos de esos núcleos todavía se mantienen unidos ya sea porque viven en el misma casa o porque comparten intereses comunes dentro de la misma casa. Entonces eso es importante en una sociedad en la cual se necesita del apoyo de la familia para seguir adelante, para poder avanzar, yo doy un ejemplo muy típico de la comunidad nariñense donde se busca apoyar siempre al otro para que pueda avanzar, el ejercicio del trabajo comunitario, las mingas para poder hacer una casa, a punta de cerveza, a punta de comida, digamos dice mucho lo que hacen los nariñenses, ya muchas de las casa que están construidas aquí, no solamente en el Panamericano, sino en toda la población están hecho bajo la idea de que hace parte del amigo, vamos a colaborarle, lo único que necesitamos es que nos de cerveza, comida, de resto todo vale, entonces digamos eso es una cosa bien interesante en el apoyo solidario de la comunidad. Víctor Mondragón

a mi me parece que la calidad humana de los nariñenses, permitió que se pudieran establecer aquí, ellos son muy solidarios. Zoraida Zamorano

Ellos tuvieron también como la fortuna de contar con diligencia en Candelaria, entonces ellos son una gente buena y trabajadora, luchadora, yo digo que con mucho amor por la familia ¿no?, pudieron hacer casa y hogar aquí en Candelaria. Zoraida Zamorano

pero había una cosa, que los nariñenses, perdóneme doctora, eran verracos, se le apuntaron al trabajo del corte de caña, aquí habían una gente de aquí, nuestro digamos raizales peor no tantos, como ellos y los chocoanos y los de las costas que también era templados. Zoraida Zamorano

En un minutico esto estuvo lleno de nariñenses, pero eran muy trabajadores, ellos y sus mujeres, usted se imagina levantarse a esa mujer, levantarse a las 3 de la mañana para hacerle la comida al marido y luego ese poco de hijos que tenían, y luego seguir todo el día trabajando. Zoraida Zamorano

pero no esa gente era luchadora, trabajadora, los fines de semana se pagaban unas rascas. Zoraida Zamorano

Que son religiosos, ellos viven en Candelaria, pero aman profundamente a su Nariño y ellos periódicamente están viajando, ellos son muy ahorradores y por eso tienen lo que tienen, es que usted va a esas casas de ellos y no es cualquier cosita, y eso da gusto, si como le digo, yo lo que le veo a ellos, les gusta tomar su cervecita, les gusta jugar el tejo, lo de la chaza también, no queriendo decir que no practiquen otros deportes. Zoraida Zamorano

Yo los defiendo desde la perspectiva de que no se les ha regalado nada, el posicionamiento que tienen en la comunidad, se lo han ganado ellos por su trabajo, por su capacidad de servicio, ellos son una gente con una fe profunda en dios y en la virgen de Las Lajas también. 
Zoraida Zamorano

Ellos supieron qué tenían que hacer y lo hicieron, además por eso le digo, ganaron ellos y ganamos nosotros, claro nosotros le hemos aprendido a ellos su constancia, perseverancia, el interés, ellos la tenían clara, la mejor manera de mejorar, dándole oportunidades a los hijos para que fueran a estudiar. Zoraida Zamorano 


\section{IDEA DE GENTE PURA Y ORIGINAL}

\section{Cómo son los candelareños}

Digamos nosotros somos comunales, ellos ahí poco participan, entonces hemos notado como que a eso no le halan, como se dice prácticamente. Camilo Muñoz

Acá cada uno hacía su casa con trabajadores, el candelareño, en cambio ellos si vinieron e hicieron eso, hicieron muchas casas. Clara Díaz

Pero sí habían diferencias, en que los de acá tenían una forma de juegos distintos, eran más recocheros, los de allá, los muchachos venían muy tímidos en general, cuando llegaban, eran unas personas, tímidas, al enfrentarse al nuevo mundo que ellos traían. Clara Díaz

Mientras uno cierra las puertas como valluno, por temor a muchas cosas, ellos las abren y acomodaron a toda esa gente, estuvieron aquí como 4 días, los llevaban a comer juntos, pero la dormida era en las casas. Clara Díaz

Es liberal. Luis López

Los candelareños no son tan solidarios, con ellos cuando la fiesta de Las Lajas, no somos solidarios. Milena Medina

Los candelareños son de espíritu muy alegre, muy abierto, son tímidos en cierto aspecto, pero cuando ya entran a una relación dejan la timidez, la mayoría en realidad son muy abiertos. Isaías Gamboa

El nariñense en esa época era muy reservado, pero ya después, digamos así, ya los nariñenses ya comenzaron a ser abiertos y todos, es decir ,se hizo una etnia especial entre nariñenses y candelareños. Isaías Gamboa

El candelareño es muy disipado, por ejemplo hace una fiesta y al otro día amanece enguayabado y a veces no va a trabajar, a veces pierden el puesto por eso, los nariñenses no, ellos van como sea y trabajan como sea, son muy constantes en su trabajo. Isaías Gamboa

El candelareño, muy abierto, alegre y muy disipado. Isaías Gamboa 


\section{MITO FUNDACIONAL}

\section{Motivos de la migración}

Yo voy a hablar al ingenio Mayagüez y fui hable allá con Carlos Molina, le dije doctor hágame un favor acá en la empresa, porque es que yo le digo, tengo 7 hijos, y le digo, estamos aguantando hambre, yo soy pensionado de la policía y no me ha llegado esas prestaciones, nada, ni la pensión, por favor, entonces dijo: no, no se puede. Yo le dije: pero para tener la esperanza, doctor deme un formulario y dijo: tampoco no lo hay, pero él era el jefe de personal. Aurelio Realpe

En Nariño anteriormente era muy escaso el trabajo, entonces el Valle con tantos ingenios que tiene, azucareros, entonces llene eso, se vine a llenar de puros nariñenses y aquí porque por el mismo trabajo que hay, y en Pasto en el departamento de Nariño no lo hay ¿entonces que pasa? Que se viene a aglomerar un poco de personas de Nariño, que por ejemplo, que si yo me vengo yo traigo el nieto y traigo el sobrino, traigo todo así. Y así han hecho entonces, se crece toda la colonia de Nariño y así se ha crecido en Candelaria, por ese mismo sentido, primeramente por el económico, que ahí en Nariño no hay trabajo y aquí lo hay, había, porque ahorita está como malito la cosa del trabajo. Aurelio Realpe

No, la niñez mía fue muy triste porque falleció mi mamá cuando yo tenia 7 años y medio, entonces mi papá ya viajó para acá y ya después cuando yo tuve 16 años él me llamo que me viniera y ya estuve acá. Alpala y Rosalba

Si, y entonces bueno me vine para acá y yo le dije a mi mamá, yo me voy por un año y ya vuelvo y nunca pasó eso, me quede por acá. Alpala y Rosalba

$\mathrm{Si}$, y qué pasó Chavelo no, "quiero contarle un problema" le dije, yo no lo quise hacer pero pues usted sabe que las cosas son como crítica, le dije así, yo pensando primero en ustedes sus hermanos, su papá, mamá, le dije que son muy fregados, le dije, no quería este problema, pero pues, "su hermana" le dije "se enamoró y yo también me enamoré de ella, pero yo me venia solo para acá y ella me siguió y yo quiero que usted lo sepa de una vez, camine vamos para donde yo vivo para que la salude" Gabriel Pascuasa

Principalmente lo que motivó venirme para acá antes de la violencia de mi papá, después ya la forma de buscar el dinero, el trabajo y sostenerme y darme mis gustos que necesitaba, porque con mi papá no se podía eso, mi papá era todo para la casa y si nos daba un vestidito en el año era mucho, entonces eso me motivo más que todo y luego ya vino una mujer ya a formalizar un hogar, y los hijos y todo eso. Gabriel Pascuasa 
Agricultura, bueno trabajé dos años y me fue tan mal que perdí todo lo que lleve, un día domingo le dije a mi mujer vámonos mija que ya tenemos hijos, vámonos para el Valle otra vez, llegamos aquí y aquí si ya sabían, pues ella ya tenia al papá, la mamá, los hermanos, llegamos a la casa de ellos entonces ya me estuve como un mes y así me fui, me coloqué aquí en Mayagüez. Gabriel Pascuasa

Fue en el 1965 ahí la venida, fue de un rato para otro que me provocó venirme a trabajar. Pedro Castro

En esa época había mucha gente que estaba aquí en el Valle y entonces siempre en el departamento de Nariño habían algunas crisis económicas, de trabajo y resulta pues que viendo esas oportunidades en ese tiempo, que había trabajo aquí en el Valle en el corte de caña, salió un paisano y familiar, salieron a pasar vacaciones y me dieron una inducción de cómo venir y todo eso y me vine con ellos. José Montilla

Principalmente ha sido un campamento para todos los nariñenses, nosotros los nariñenses llegamos en los años 54, 55 a Candelaria, donde llegamos a trabajar, aquí en Candelaria como los ingenios y muchos nariñenses que han progresado, y aquí vivimos pensionados y vivimos bien. Grupo Chaza

Yo creo que hay unos que llevan más de 50 años aquí, como los Martínez, son gente que vino aquí hace mucho tiempo, pues buscando, son gente que hasta tenían tierras y propiedades en Nariño, pero vinieron con el boom de la agroindustria de la caña de azúcar, se fueron viniendo y esos iban contando, iban refiriéndole a sus otros familiares de allá y esos a su vez se iban viniendo buscando ese florecimiento económico, y eso a ellos le debemos mucho que el pueblo hoy en día esté moderno. Camilo Muñoz

Muchos llegaron por el convencimiento de que acá era otras tierras, otros llegaban porque sus amigos que volvían allá les decían, vámonos que allá hay trabajo, y era una mano de obra manual pero bien pagada, comparada con lo que hacían ellos allá en Nariño, y por otra parte porque las familias se les iban creciendo y necesitaban darles otra calidad de vida a la familia. Clara Díaz

Cuando se han establecido y empiezan a digamos a establecer otros ingenios digamos, por que en primera instancia habían unos ingenios, luego ya se establecen los demás, entonces ellos empiezan a traer porque de pronto el valluno no ha sido muy bueno para el corte de caña, entonces en vista de que era un trabajo tipo de fuerza, obrero, entonces empiezan a llamar a los familiares a la gente de Nariño y de igual manera también llegan los afro descendientes. Edgar Olave

Lo que pasa es que vieron, que la mano de obra de este sector, era una mano de obra buena pero no excelente, o sea no eran buenos obreros en el sentido de producción, o sea no estaban acostumbrados a la parte de la tierra, al trabajo duro, por que la caña era un trabajo fuerte y duro, entonces algún nariñense o alguno de ellos exactamente no se quien, porque no se puede decir exactamente quien, , lo contratan y ven que es gente que trabaja muy bien y entonces se riega la bola. Edgar Olave 
Llegan por aquello de que necesitan trabajo o remuneración, porque digamos que su trabajo si lo pueden tener en su tierra, Nariño, grandes terrenos para cultivar, pero el pago de la mano de obra me imagino que no es el mejor, entonces se les da esa oportunidad y se vienen a trabajar. Milena Medina

Bueno, los nariñenses fueron llegando digamos así por grupos, a raíz de los ingenios azucareros, seguramente en busca de trabajo, para buscar un nuevo bien de vida, seguramente, en aquella época, la época del 50 del 40. Isaías Gamboa

Pero bueno me fui a trabajar, y aquí le pagaban a los 8 días y me pagaron a los 8 días, porque yo entré jueves, viernes y sábado y me pagaron esos 3 días y era buena plata, porque me había ganado 40 pesos en ese tiempo, eso era mucha plata para mi y eso fue lo que a mi me atrajo propiamente del trabajo. Y esto es una empresa le dije al hermano, le pregunté "qué es lo que le pagan tanto a uno" y esto aquí le pagan bien, le dije me pagan bien, propiamente a ti te pagan hasta por tus hijos, el subsidio, te van a pagar primas, prima de navidad, te van a pagar intereses y te van a pagar cesantías, pero le dije ¿Todo eso? Pues bueno pero yo me quede así, yo me quedé trabajando y le digo pues que yo me desesperaba trabajando, por que me rendía el trabajo. Sacando el peso de la caña y todo eso, me puede sacar cuentas, yo tenia 70 toneladas, y aquí con 70 toneladas cuánto es lo que me van a pagar, cuando voy viendo allá, disque 10 pesos y eso era como ganarse 10 millones de pesos en ese tiempo. Alberto Díaz

En la comunidad nariñense digamos que hay una situación que impactó mucho la llegada nariñense a Candelaria y fue precisamente factores externos, que aunados con el desarrollo del bajo jornal que se mantenía en las zonas de donde eran oriundos, ayudó a la salida de esta gente de las zonas de campo ya que los jornales eran muy bajos. El desarrollo que se dio a partir del impulso de la agroindustria en el Valle del Cauca con los ingenios azucareros, motivó la vinculación de personas que tuvieran el manejo agroindustrial, agrícola, si? el manejo de la tierra, y sobre la base de eso entonces empezaron a hacer enganches sobre los ingenios, que inicialmente se dio sobre las partes cercanas al ingenio, en zonas campamentarias y sobre esas zonas campamentarias se crearon precisamente vínculos muy fuertes entre lo que era el ingenio y lo que era el trabajador. Víctor Mondragón

Yo creo que los nariñenses empezaron a llegar a Candelaria en busca de mejores oportunidades de ingresos, aquí el ingenio de Mayagüez antes de ser ingenio, por lo que me han contado los ciudadanos mayores se llamaba un trapiche Catatumbo, entonces después se transformó en lo que hoy es el ingenio Mayagüez y ellos con el cultivo de la caña de azúcar necesitaban mucha mano de obra. Zoraida Zamorano

Bueno, eso es una historia muy larga, pues allá campesinos no había sino que trabajar y trabajar entonces era muy pobres, pobres y entonces yo le pedí a la virgen, fui a pedirle a la virgen que me llevaran al ejército para poder salir de allá porque no había otro modo. Jorge Martínez 
Yo no nací en la cabecera del pueblo sino en un corregimiento que se llama Cunchila, eso sería mi niñez, entonces cómo le contaba yo, porque en ese tiempo póngale cuantos años, salir de allá es como los que piensan en irse ahorita para Estados Unidos, es difícil no era cualquier cosa pues el transporte, para venirse al Valle, todo el mundo aspirados venirse al Valle pero nadie podía porque salir en ese día ya era un problema en ese tiempo y de niños menos. Jorge Martínez

La promesa era que me llevarán al ejército para tener la posibilidad de salir de allá del campo, esa fue la promesa para poder ayudar a mi familia y así fue, entonces ya desde eso le agradezco a la virgen, incluso ganando más plata y bueno cumplir lo que la virgen me cumplió con eso y soy muy devoto a ella. Cuando terminé el ejército volví a la casa pero ya llegué yo pues sin saber que hacer allá en Cunchila, entonces le dije yo a mi papá, conozco el Valle me voy para allá a conseguir trabajo para poderlo ayudar y entonces volví otra vez donde la virgen a pedirle pues que en ese viaje me fuera bien. Jorge Martínez 


\section{MITO FUNDACIONAL}

\section{Redes de apoyo}

Ah no pues, como la familia de la señora mía viven aquí en Candelaria, viven otras en Miranda, viven otras en San Andrés, entonces llegamos a donde una cuñada, donde la hermana de la esposa mía. Aurelio Realpe

Si, ahí también vivía la suegra todo eso, ahí nos estuvimos como unos 6 meses, ahí mientras me llegaba la pensión, entonces ya días después salimos de ahí porque ya había como pagar un arriendo todo eso. Aurelio Realpe

Yo sabia pues que por ahí jornaleando el pasaje no era costoso, reuní el pasaje, pero yo sabia que acá estaba mi hermano y así fue. Alpala y Rosalba

El hermano, entonces era así con esa esperanza. Alpala y Rosalba

Él ya estaba trabajando acá. Alpala y Rosalba

Él empezó a trabajar en el ingenio en Mayagüez. Alpala y Rosalba

Mientras mi hermano me ayudaba allá en la empresa Mayagüez, porque no tenia la libreta, el hermano mío tenía muchas relación porque era juiciocito para trabajar allá en la empresa, entonces cuando eso no era los jefes, eran los mayordomos, entonces le comentó al mayordomo y dijo: traiga con el recibo de la libreta, tráigalo, entonces, me vinculé a Mayagüez a trabajar allá y ya, trabajé 4 años. Alpala y Rosalba

Si, claro, en esa parte, pues por lo menos los paisanos que ya venían después se les ayudaba, se prestaba mucho por el trabajo, había mucho trabajo, demasiado trabajo, entonces que hacia uno para ayudar: entonces yo quiero ir a trabajar a Mayagüez, yo quiero a Castilla, a Manuela, a todas esas partes se le daba la iniciativa, como vaya a donde tiene que llegar. Alpala y Rosalba

El esposo de mi hermana trabajaba en corte caña de Mayagüez y el hermano de ella trabajaba también en una fábrica de un ingenio azucarero que en ese tiempo se llamaba María Luisa, eso y entonces ahí trabajaban ellos, y cuando llegué aquí porque yo llegué fue sábado, porque mañana es domingo y llegué al otro día y pegué para San Antonio por que el hermano de ella vivía en San Antonio. Gabriel Pascuasa 


\begin{tabular}{|l|}
\hline Aquí teníamos un amigo y él me ayudó hasta en el trabajo, se llama Luis Lara. Pedro Castro \\
\hline $\begin{array}{l}\text { Pues que viendo esas oportunidades que en ese tiempo había trabajo aquí en el Valle en el corte de caña, salió un paisano y familiar, } \\
\text { salieron a pasar vacaciones y me dieron una inducción de cómo venir y todo eso y me vine con ellos y posteriormente aquí encontré un } \\
\text { familiar, él nos dio la alimentación y la posada mientras conseguimos el trabajo, posteriormente a los 15, } 20 \text { días hubo la entrevista en } \\
\text { la empresa y logré conseguir el trabajo y de ahí no salí hasta que me pensione. José Montilla }\end{array}$ \\
\hline $\begin{array}{l}\text { Pues para yo venir para acá como le cuento fue por el familiar y paisano entonces en esa época para el transporte no había terminal, } \\
\text { eso tocaba en Cali por ahí en la } 16 \text { en el parque Santa Rosa, por ahí había un era donde llegaban los buses, la Flota Magdalena en fin } \\
\text { todas esas empresas y el pasaje me costo } 40 \text { pesos. José Montilla }\end{array}$ \\
\hline $\begin{array}{l}\text { Si un ingenio azucarero, el ingenio Mayagüez, ahí estaba él trabajando entonces de ahí para allá, él mismo nos ayudo, el familiar, hasta } \\
\text { que conseguimos el trabajo. José Montilla }\end{array}$ \\
\hline $\begin{array}{l}\text { Si sus paisanos recibían a esos, eran los anfitriones de los que iban llegando y servían de trampolín y los iban ayudando a colocar en los } \\
\text { ingenios, en los trapiches todo lo que era fuerza laboral, más que todo fuerza laboral pues de campo. Camilo Muñoz }\end{array}$ \\
\hline $\begin{array}{l}\text { El paisano, ellos venían y traían la familia, pero ellos si fueron tratando de comprar sus...o sea vendían allá y compraban acá su } \\
\text { pedacito de tierra y empezaban a hacer sus casa. Edgar Olave }\end{array}$ \\
\hline Aquí don Pedro Trujillo que era el mayordomo general, el era un emisario de Nariño, entonces mandaban. Luis López \\
\hline $\begin{array}{l}\text { Un emisario, como decir un cuidador, vulgarmente lo llaman un cuidador, entonces comenzaron a llegar aquí de Patía y de la Costa, } \\
\text { llegaron, hasta ahora. Luis López }\end{array}$ \\
\hline Pues ellos siempre buscaban a sus familiares, la mayoría llegaban donde sus familiares o sus amigos, o sus amistades. Isaías Gamboa \\
\hline Llegué aquí a Candelaria, porque en ese tiempo trabajaba un hermano mío aquí en el ingenio Mayagüez. Alberto Díaz \\
\hline
\end{tabular}




\section{MITO FUNDACIONAL}

\section{Llegada}

Ya mi papá tenia la segunda esposa ya trabajamos alimentando personas del ingenio. Alpala y Rosalba

Si, yo llegué entonces el hermano vivía en un campamento alrededor del ingenio, habían unos campamentos, unas casitas ahí para que el ingenio, la empresa les turnaba para que ellos vivieran allí, entones yo sabia que en Mayagüez trabajaba él, entonces cuando llegué aquí yo busqué a mi hermano. Alpala y Rosalba

No, él vivía arrendando fuera de Mayagüez. Alpala y Rosalba

Si, ella era casada y tenía pues el esposo trabajando en Mayagüez. Gabriel Pascuasa

Si, aquí en Candelaria, entré a visitarla y ahí me fui para Nariño otra vez, se me cumplió la licencia y volví, cuando salí de baja, me quedé donde mi hermana ya no fui a Nariño, me quedé aquí no mas. Gabriel Pascuasa

Nadie, nada, mi hermana incluso esos días llamó que esos días no estaba acá, que se había ido para Nariño, nosotros agarramos y ya pues uno como dice de muchacho, agarre y se va sin saber a donde va a llegar, yo simplemente tenia el conocimiento de paisanos que eran de ahí del pueblo mismo, que era creo Popayán y vivía por allá, entonces yo llegué y acá en el parque me lo encontré, casualmente yo me bajo del bus y me lo encontré a él ahí. Gabriel Pascuasa

Me ayudó a conseguir el trabajo, al principio estaba entrando cuando recién llegué, yo entré a trabajar en un trapiche aquí que lo conocemos como El Pailón que queda por aquí cerquita, entonces ahí trabajé cuando ya era compadre, ahora es compadre Tiberio Mafla, él me ayudó ahí, después dije no, cuando también que el otro es compadre vamos a ir a Mayagüez a ver si hay trabajo y dije bueno, para el corte no le metamos, métase a la ministra y ahí se va a organizar. Pedro Castro

No, yo venia con un primo, con un primo llegamos a Cali y pasamos para acá y aquí llegamos de noche, sin conocer, pero ahí tocamos puertas y nos abrieron y les contamos la historia, y nos dieron posada hasta el otro día. José Montilla

Esa fue la venida para acá y ya después aquí él ya nos dio la alimentación, ya conseguimos el trabajo por ahí, mientras conseguíamos en la empresa y el nos regalo la alimentación como más de un mes y de ahí para allá si conseguimos el trabajo y aportábamos la alimentación. José Montilla 
Seguimos viviendo ahí, nos asignó una pieza y ya como familia mismo, así fue, hasta que ya cada uno se va independizando por que ya va comprando sus cosas, todo eso, y ya el primo dijo: si, ya vayan buscando donde se alimentan, busquen que queden mejor y así fue, hasta que pues ya con el tiempo coge una ya cancha como se dice, experiencia y va consiguiendo la compañera. José Montilla

Yo me imagino que ellos llegaban a las casas de los amigos y familiares y se iban hacinando mientras tanto en una casa, y de ahí salían y como en ese tiempo diga usted, yo me acuerdo que se ganaba un cortero de caña 350 mil pesos semanales, que eso era un poconón de plata, ellos se fueron haciendo rápido a sus propiedades y ellos recibían a los otros y a los otros. Camilo Muñoz

Bueno, muy importante su pregunta y la viví con mis estudiantes, yo empecé a trabajar un 21 de noviembre de 1966 en lo que hoy es el colegio German Nieto, estaba apenas inaugurándose, tenía 5 años de fundado el colegio, allí me tocó recibir mucho estudiante que venía del lejano departamento de Nariño, como le decían ellos, les decían, no hablaban tanto del departamento del Nariño sino que decían era "llegaron los pastusos", así era el lenguaje que se hablaba. Hubo que hablarles mucho, sobre que una cosa era la capital como Pasto y otra cosa era el departamento de Nariño para que ellos quedaran integrados. Clara Díaz

Ellos llegaban aquí en un principio, a una casa que le llamaban la casa nariñense, ella está ubicada de aquí más o menos dos cuadras, de aquí de mi casa dos cuadras, allí llegaban ellos y era la embajada, los muchachos, yo hablo muchas cosas es porque como me tocaban los alumnos, ellos decían es que apenas llegaron mis papás, llegaron a la embajada, la embajada era la casa nariñense que ellos tenían. Clara Díaz

No recuerdo, pero si he escuchado y si he visto fotos, entonces por ejemplo se vienen y se agrupan en una casa y el uno como llamando al otro para que se venga para acá, acá hay un buen clima, un buen territorio, acá podemos surgir, acá podemos avanzar. Milena Medina

La mayor parte eran nariñenses, se dio a través del modelo del enganche, el enganche es que iban, promocionaban, iban del ingenio en camiones y en buses, promocionando digamos el jornal, un jornal mucho más elevado, diríamos como unas 3 veces, 4 veces, el valor del jornal que se pagaba en Nariño, y entonces eso dio la oportunidad también a que mucho nariñense que ya trabajaba el campo pues, vieran una posibilidad de trabajo aquí. Víctor Mondragón

Estas personas con el recurso compraron vivienda, compraron y generaron infraestructura pero el diseño de las casas era precisamente con el propósito de crear muchas habitaciones para permitir la llegada. Digamos que ellos sirvieron como un colchón, amortiguar la llegada de otros que eran también coterráneos, de diferentes lugares de Nariño ,que eran vecinos o parientes y así fue dándose, se fue dando digamos el traslado de la comunidad de Nariño aquí a Candelaria. Víctor Mondragón 
Las segundas oleadas, ya son oleadas que van a contar con una mayor ventaja, pero digamos que aquellos que lograron generar modelos de habitación a manera de colchón para las siguientes generaciones, pues digamos empezaron a sentir la presión de expansión, se generaron modelos de hacinamiento donde digamos en una casa, podían estar 3 familias, y cada familia en una habitación. Víctor Mondragón

Ellos llegaban y llegaban a la casas de arrendo, ese fue uno de los asuntos que hizo que por ejemplo se comprara el municipio, comprara ese lote que hoy se llama el barrio Panamericano, para construir ahí ese barrio porque la gente estaba sin nada, ya porque el hecho del ingenio Mayagüez se constituyó como un gran polo de desarrollo. Zoraida Zamorano

Inicialmente llegué a Palmira, porque pues tenía algunos paisanos que estaban trabajando en Palmira para allá, en un ingenio ya llegué y me presenté a trabajar en ese ingenio de Palmira; bueno en todo caso ahí estuve un tiempito poco y luego un hermano que yo tenía que vivía aquí en Candelaria que ya había venido antes me dijo: no pues yo he trabajado tanto en esos campos en el ingenio Manuelita cómo era y ahorita en la policía, camine para la policía. Entonces me vine y me metí a la policía, que en ese tiempo la policía era departamental, no era nacional como ahora y ahí me coloqué como agente y yo siempre pidiéndole a la virgen que me ayude, me metieron a un curso para tránsito, aprobé bien y luego me mandaban a dar clases de transito a todos los lugares como Tuluá a Cartago. Jorge Martínez 


\begin{tabular}{|c|}
\hline $\begin{array}{l}\text { MITO FUNDACIONAL } \\
\text { Relaciones establecidas en el nuevo territorio }\end{array}$ \\
\hline $\begin{array}{l}\text { Yo llegué allá, cuando ya llegó la mujer nos sacamos una casa de arriendo pero no estuvo sino como dos meses y ya, y de ahí ya volví } \\
\text { ahí a hablarle al dueño de la casa que era paisano también y nosotros mismos, le dijo Don Alfonso voy a arrendar con la mujer y dijo } \\
\text { claro únase, me arrendo ahí, ahí viví } 11 \text { años a lo último dijeron usted ya tiene tantos años arrendando que tiene derecho a la mitad de } \\
\text { la casa, y le dije no, yo por mi parte le agradezco mucho cuando yo me vaya de aquí no les voy a pedir un peso de nada, porque antes le } \\
\text { doy gracias por que mis hijos se criaron ahí, se criaron bien criados como se dice con un respeto tanto de los unos como de los otros, } \\
\text { ahí no se oía una mala palabra de nadie, entonces ellos se criaron bien gracias a dios. Pedro Castro }\end{array}$ \\
\hline $\begin{array}{l}\text { Aquí todos son paisanos, entonces dijo mira, llegó una muchacha, dijo de tal parte y queremos hablar un rato, si quieres vas y ese fue el } \\
\text { primer encuentro con ella. José Montilla }\end{array}$ \\
\hline $\begin{array}{l}\text { También de Nariño, pero no del pueblo mío, sino de otro pueblo, se llama Uncuya Nariño, entonces ella pues había tenido una niña y } \\
\text { llegamos así a estar y a lo último hicimos un acuerdo, que yo era viudo y tenia otra niña y ella dijo, yo también tengo la niña entonces } \\
\text { hicimos ese acuerdo que teníamos una responsabilidad y fue bueno y ya, nos ajuntamos con ella, cuando ya hicimos el pacto de } \\
\text { ajuntarnos como decir hasta hoy duermo solo, ya mañana duermo con la que me encontré. José Montilla }\end{array}$ \\
\hline Si, aquí ya después de que nos ajuntamos con ella porque no estábamos casados, unión libre. José Montilla \\
\hline $\begin{array}{l}\text { Bueno para conseguir esa casa pues siempre me encontré con otro paisano que ya murió también, tomamos una casa en arriendo, } \\
\text { entre las dos familias y usted sabe que entre los paisanos nosotros siempre hemos sido solidarios, nos ayudamos mucho, eso tiene la } \\
\text { colonia nariñense, solidaria, no es como a veces la pintan, solidaria, entonces ahí estuve } 7 \text { años, a los } 7 \text { años, el señor me dijo Don } \\
\text { Montilla ustedes han estado en mi casa y la han hecho como cosa propia y la han mantenido bien entonces yo la voy a vender. José } \\
\text { Montilla }\end{array}$ \\
\hline $\begin{array}{l}\text { Pues ellos siempre buscaban a sus familiares, la mayoría llegaban sus familiares o sus amigos, o sus amistades, y luego se relacionaban } \\
\text { con los candelareños y entablaban relación con los candelareños o un nariñense con un candelareño y se casaban y ya. Isaías Gamboa }\end{array}$ \\
\hline
\end{tabular}


Ella estaba trabajando en Cali, en casa de familia, de todas maneras como tuvimos allí ya pues ella conversamos todo eso y dijimos

busquemos un piecita para arrendar, pero entonces nos conseguimos, así en la tintero y allá en la pieza era más o menos así de grande como esto y tenían con cocina sola, pero eso era lo que lo amañaba a uno todas esas piezas tenían cocina sola y eso lo amañaba a uno. Alberto Díaz 


\section{MITO FUNDACIONAL}

\section{Quiénes llegaron después}

Y entonces siguiendo el caso de mis padres, últimamente ellos ya nosotros ubicados por acá, mi hermana y yo resolvimos hay que traerlos para acá que fue difícil, que fue una lucha porque del campo venir al pueblo para ellos es difícil que se puedan acostumbrar, entonces de todas maneras eso lo hicimos y fue por opinión de mi hermanito que esta en Venezuela y de todas manera los convencimos. Alpala y Rosalba

El que últimamente se ubicó por acá fue mi hermano, pero le digo fue duro y para la familia, para los hijos. Alpala y Rosalba

Y se vino con toda la familia y también se cuadró a trabajar en Castilla y ya es pensionado y ahí si cuando ya llegaron todos ahí si ya me casé acá en Candelaria. Gabriel Pascuasa

Hay como 3 paisanos que yo le dije, vengasen para acá, el trabajo uno sabe que el salario en Nariño es difícil, en cuestión de empleo en Nariño eso es fatal, no vengasen para acá ustedes están jóvenes, pueden trabajar acá y hacer sus platicas y si quieren devolverse para allá hacen su platica, si quieren y ya si se amañan por acá. Y por aquí se quedaron varios, hay como unos 10 paisanos de los que yo les dije, entonces por eso le digo, el trabajo es muy principal acá, en Nariño pues es bueno pero por la comida y todo eso, porque pues allá uno la trabaja pero por plata es difícil, eso allá es difícil no es como acá que es quincenal, no como antes que era cada ocho. Gabriel Pascuasa

Si, yo me la traje de allá porque mi mamá estaba enferma, porque mis abuelos ya habían muerto y allá quedó mi mamá. Alberto Díaz

No, me traje a los 3 porque tenia una hermana también, los traje a los 3 y arrendé una pieza y la puse a mi mamá, a la muchacha y al otro hermano, nos metimos a Mayagüez también a trabajar y a los 8 días ya estaba trabajando, porque en ese tiempo de antes a uno lo recibían sin cédula y sin nada. Alberto Díaz 
Se me vino el cuento de la familia que pues estaba pobre, tenía yo cuatro hermanas menores, tenía dos hermanos menores, tenía tres hermanos porque hay un hermano gordo que hay aquí que parecía viejo en ese tiempo vino de 3 años; entonces me di cuenta de que mi papá había vendido una finquita que tenía y se trasladó del municipio de donde nosotros vivimos, ya había ido a Pasto disque a poner un negocio, resulta pues que venir un campesino a poner un negocio en una capital, pues fracasó. Ahí nos robaron y la comunicación en ese tiempo no había teléfono tan fácil como ahora, puras cartas nos escribíamos que estaba mal, mal, que se acabó entonces le dije que le queda de la plata todavía y me dijo que me quedan 200 mil pesos de lo que yo traje, pero ya estoy acabado ya no sé qué entonces, le dije que se viniera llegó aquí al Valle en ese momento y yo estaba aquí en Candelaria como agente, entonces con mi hermano nos pusimos a buscar y a buscar donde conseguimos una propiedad. Jorge Martínez

Un familiar que vino y en ese tiempo vivíamos allá y como le digo, en ese tiempo hicimos la casa grande como le digo y nos cayó y le digo, ahí vivió con nosotros, lo ayudamos a colocar hasta que el ya se independizó y ahora vive en Cali, vive muy bien, yo si he ayudado a familias y lo mismo, los nietos, y sobrinos mi hermano mayor que decía que vivía aquí en Candelaria. Jorge Martínez 


\begin{tabular}{|c|}
\hline $\begin{array}{l}\text { MITO FUNDACIONAL } \\
\text { Formas de contacto con el lugar de origen }\end{array}$ \\
\hline $\begin{array}{l}\text { Pues allá cuando ya es la infancia de uno, pues si usted como sabe, todos los muchachos de } 15 \text { años hasta los } 16 \text { vivíamos fuera del } \\
\text { pueblito de Túquerres, teníamos una finca, hasta ahora mis hermanos viven allá. Aurelio Realpe }\end{array}$ \\
\hline $\begin{array}{l}\mathrm{Si} \text {, ahora hace como un mes estuve en Túquerres con mi esposa, estuvimos en Las Lajas, está muy bien para que, ahora no trabajan toda } \\
\text { esa agricultura como antes, es la ganadería, puros potreros, porque el negocio de los cultivos ya no es fácil, sembrar zanahoria, repollo, } \\
\text { les da mas renta es el ganado, la ganadería. Aurelio Realpe }\end{array}$ \\
\hline Y yo tenia mi papá, mi mamá por allá, entonces claro, y si claro había contacto. Alpala y Rosalba \\
\hline Ya casi no vamos, por lo menos ahora la hija mía, los hijos dijeron ustedes se van a dar un paseíto y nos fuimos. Alpala y Rosalba \\
\hline Fuimos a Las Lajas. Alpala y Rosalba \\
\hline Nos mandan papa, las habas, la calabaza, cada rato como se dice la sopa de calabaza o como dicen allá el ocro. Pedro Castro \\
\hline $\begin{array}{l}\text { Pues con los que hay siempre llamo a mi hermana o al hermano cada } 2 \text { meses, cada } 3 \text { meses por que siempre a esta edad por lo menos } \\
\text { ellos también por poco nada se enferman entonces hay que estar en contacto. José Montilla }\end{array}$ \\
\hline $\begin{array}{l}\text { Si ahora no más que mucho fui con una hermana mayor, estuve en Ipiales porque el hermano vive en Túquerres, ahora la otra semana, } \\
\text { para donde uno va es frio y uno ya para el frio no aguanta, ya es difícil. José Montilla }\end{array}$ \\
\hline $\begin{array}{l}\text { Papa, frijol, lo primero que mando a traer el curí, cuando hay carnavales mandamos a traer todo lo de allá, palo de maíz } \\
\text { Grupo Chaza }\end{array}$ \\
\hline $\begin{array}{l}\text { Allá lo hacen, queso, mote, inclusive una chiva traen encomiendas y traían a vender } \\
\text { Grupo Chaza }\end{array}$ \\
\hline $\begin{array}{l}\text { Lo que uno extraña, lo que uno come así pues. Al caballero le dieron un poco de habas tostadas, riquísimas, y ahora me las llevé. Grupo } \\
\text { Chaza }\end{array}$ \\
\hline
\end{tabular}


Cuando hacen los carnavales, el 6 de enero y toda esa cosa, ellos traen gente de Nariño, traen bandas, papayeras de Nariño que eso alegra mucho el ambiente, todo eso y hacen procesiones con la virgen y todo eso. Isaías Gamboa

Ahora yo me comunico también, yo tengo allá dos sobrinas pero ya no me comunico como antes, por que ellos ya no... tampoco se comunican conmigo y yo ya no tengo propiamente a veces, es decir que yo no tenga tal vez que decir...pero ahora no me he comunicado hace como por ahí unos 8 meses. Alberto Díaz

Yo ya casi, ya no voy porque pues la verdad ya no tengo por decir... propiamente la realidad es cuando uno tiene a su padre o su madre entonces si es lindo ir, de resto ya es diferente, llega uno donde una sobrina o llega donde... allá tengo un cuñado que es marido de mi hermana pero pues, ya no es lo mismo llegar allá, por tiempo a veces yo voy pero me estoy un día o dos días y ya me vengo, yo no me amaño allá. Alberto Díaz

Si, vienen familiares, por ejemplo el hermano mayor, el se radicó en Pasto, el ya murió y el tiene familia allá, el tiene hijos y esta muy relacionado con los sobrinos míos pues, y de allá vienen también han venido, hace días no nos visitan pero ahorita va a venir una que va a salir a vacaciones, va a salir mi pensión y de allá me voy, si nos visitamos todavía. Jorge Martínez 


\section{MITO FUNDACIONAL}

\section{Primer empleo}

Yo le dije -sí doctor-, y qué te dijo, pues que no había formularios ni para vacantes, nada, dijo -camina vamos- fuimos allá donde Carlos Molina, cuando entramos a él no le gusto, se sorprendió y dijo, ve Carlos, ayúdale al muchacho ayúdale, entonces el no tuvo nada que hacer más y dijo -no, anda y le reclamas un formulario allá en la secretaria (Risas)-, oiga al señor no le gustó nada; bueno me dieron el formulario, entonces lo llené pues me pegué una foto allí y entonces bueno como a los 15 días me salió el trabajo como vigilante de Mayagüez. Aurelio Realpe.

Ya, a los por ahí, a los 8 días yo ya empecé a trabajar, no en la empresa, sino es que yo le dije, yo quiero venir, yo voy a trabajar porque en ese tiempo había mucho trabajo, entonces él dijo vaya en el momento a acá a un trapiche en el arenal que se llamaba, y ahí empecé a trabajar y es como donde estuve su pregunta, aquí en este barrio que nosotros vivimos eran cañales y aquí fue que vine a aprender a cortar caña. Alpala y Rosalba.

No, no pues para nada, eso es muy diferente, a uno le da duro, pues para empezar de todas maneras como es un corte de caña es un trabajo material, y nosotros somos de la parte de trabajos materiales, nos preocupábamos un poquito hasta cogerle la práctica y ya empezamos, estuve por ahí como unos 6 meses así. Alpala y Rosalba.

Y de ahí, bueno, me estuve unos días y me volví a ir, allá llegué y trabajé en una hacienda de los vecinos que tenían los carros, tenían una hacienda y bueno me fui a trabajar a esa hacienda a manejarle un tractor y manejar la hacienda, ahí me estuve dos años. Gabriel Pascuasa.

A bueno, en ese, laboralmente Mayagüez necesitaba gente, eso yo primero me fui a Castilla, llegue allá y en el jefe de personal solicité el trabajo y dijo -sí, trabajo sí hay, qué sabe hacer-y dije " pues lo que me mande" le dije lo que me mande y lo que pueda hacer lo hago. Gabriel Pascuasa.

Sí, yo, hay para corte de caña y digo -bueno, no importa, lo que haya-, y bueno ahí me dieron la boleta y me mandaron a hacer los exámenes a Cali, en ese tiempo lo mandaba a Cali a hacer los exámenes de sangre y pulmones, todo lo físico, bueno ya ahí hice los exámenes, me presente y me dieron el machete -y desde tal día viene a trabajar-. Gabriel Pascuasa. 
A sembrar, a cultivar la caña, a preservarla, a fumigarla, todo eso nos tocaba, luego después ya con el tiempo como yo ya que estuve trabajando en el pailón yo allá me mandaron, yo allá cortaba caña y me tocaba pailandar para traer la caña; hasta acá llegaban y cuadraban los vagones y yo había cortado mi caña entonces dijo -alce ese vagón mientras hacemos el regado-, y corrían los vagones ellos mismos, y yo en ese alzaba ese vagón solo y luego pues ya me tocaba ir a enganchar y todo eso. Pedro Castro.

Sí, en ese después de completar la prueba, ahí me lleve, hubo un tiempo en el que sacaron personas a hacer unos cursos de monitores, cuando yo me toco, que le contaba antes, que no tengo sino año y medio de primaria, aquí me toco terminarla. José Montilla.

Entonces ellos pagaban arriendo, pienso, porque yo nunca fui, pero si pasaba por ahí, y la veía y allí llegaban y se instalaban aquí, generalmente en los ingenios que habían primeramente el Pailón que era al frente de la carretera que va Cali, Palmira, el ingenio La Quinta que también es al pie del cementerio y Mayagüez, entonces son 3 ingenios que daban mucho albergue aquí en Candelaria, entonces ellos los atrajeron fue así y era una mano de obra muy barata comparada con la de aquí, pero a ellos les servía muchísimo, entonces ellos se fueron viniendo, además habían muchos trapiches en las haciendas y en los corregimientos, habían trapiches que ellos podían ir a trabajar también. Clara Díaz.

Pero de todas maneras primeramente lo que hice yo, es ir a pedir boleta, ya en Mayagüez me la dieron todo eso, el día lunes y el día martes me fui para los exámenes a Cali, tampoco yo lo conocía pero me fui con otro amigo, y fui y me llevaron, y bueno nos hicieron los exámenes, todo, y ya el día miércoles me entregaron, por que yo pedí para corte y caña, ya el miércoles me entregaron el machete y bueno. Alberto Díaz.

Estando de vacaciones pedí la baja y de alguna manera me vine para Candelaria y ya tuve vacaciones, me vine de civil y le voy a contar toda la historia como es me fui para Mayagüez y luego de la policía me dieron encarguito que había en ese tiempo y si inmediatamente me coloqué allá a trabajar. Jorge Martínez 


\section{MITO FUNDACIONAL}

\section{Cómo se comenzaron a juntar en Candelaria}

Como le conté, que usted me preguntó qué hacía con mi papá, alimentábamos personas del ingenio, y ahí nos conocimos. Alpala y Rosalba.

Un comensal (Risas) sí, entonces ahí fue el encuentro, en el 69, y de ahí ya me entré a Castilla, entonces de ahí pensamos en el 71 ya hubo el primer hijo, ya mi suegro QEPD se molestó, todo eso, entonces ellos fueron, los mayores fueron regios, entonces una vez le dijo, por que yo vivía ahí, yo pagaba una piecita, yo pagaba arriendo; entonces bueno, cuando yo estaba escuchando y la regaño y le dijo por qué no te vas-, entonces yo le dije -pues vea mija, la solución esta fácil, vámonos-. Alpala y Rosalba.

La colonia nariñense se conformó, se integró por las mismas entidades, charlas de las que estamos hablando, unos por la chaza, otros por los carnavales, otros por lo de la virgen de Las Lajas, de esas tres partes se formó la integración de nariñenses y por esas tres partes a nosotros nos han tenido mucho en cuenta lo nariñenses en Candelaria, que sí somos organizados. Alpala y Rosalba 
RELATOS DE SEPARACIÓN - SEGREGACIÓN

\section{Situaciones de segregación separación}

En el parque, donde es el parque recreacional, ahí era la cancha, ya ahí fue que hizo el primer torneo Dagoberto Escobar, bueno como, cuando ya hubo proyectos de que de allí nos movían, entonces ya, entonces allí Don Pedro ya con la primer personería jurídica ya dijo, pero pues claro no la aplicaron bien como era, falto de experiencia claro, se fue Dagoberto Escobar y llegó Armando Vásquez, llegó al mando Vásquez y dijeron que de ahí nos iban a trasladar, entonces ya dijimos que a dónde, primero nos ubicaron donde era la cancha, al otro lado, por el otro lado de allá, donde usted da la vueltica, en ese barrio ahí lleno de árboles, en todo eso hubo un poquito de egoísmo con la comunidad, porque por cortar ese espacio de la práctica, se cogieron a sembrar árboles, entonces nos quitaron de ahí Armando Vásquez; entonces ya nos pusimos a reclamar ese espacio, él fue que nos ubicó donde estamos. Alpala y Rosalba.

Mucha gente, y entonces ellos, ellos como sea esos aportes en la parte política los logran, claro los logran y pues en esa parte si, en nosotros hemos mirado, por eso lo digo en esa expresión, por una, nos colaboran, por otra nos utilizan, ¿por qué? porque nosotros, yo ahora que miro que pasaron las elecciones, la hija mía se postuló al consejo, todo eso, y yo veo un aporte, pero grande, unas votaciones grandes, y ahí estuvimos los nariñenses y yo le entro a las alcaldías y las secretarías y veo oportunidades por todas partes entre, yo no veo diga una hija de una nariñense, un hijo de un nariñense que esté bien, entonces por esa parte no se si mi expresión es o no es, por una parte nos colaboran, pero por esa parte nos utilizan. Alpala y Rosalba.

Incluso con la chaza ha habido pleitos, allí entre comillas pues, por la bulla, en defensa pues de los otros. Pero resulta que hay un

bailadero allí que es El Son de Rosario y ese ocupa la calle y pone música hasta tarde, nosotros solo hasta las 10 de la noche. Pero, ¿qué se queda la gente? Dice, es que un día domingo uno no puede sentarse a ver televisión porque con la bulla de allá no se puede y en eso tienen razón. Y uno se pone en el zapato de ellos y dice ¡ehhh! ¡Juepucha! Pero pues como eso tiene el respaldo de acá... ahora, ¿qué es lo que se pide? Que el volumen sea moderado y hasta las 10:30 de la noche, de ahí para allá tienen que apagar la música, pero ahí están los otros griles que han montado, que eso, uno no puede...Julio Castro.

Le digo que antes había una cosa que en los morochos más que todo, a toda hora, este pastuso, este pastuso eso era lo más cansón. Pedro Castro. 


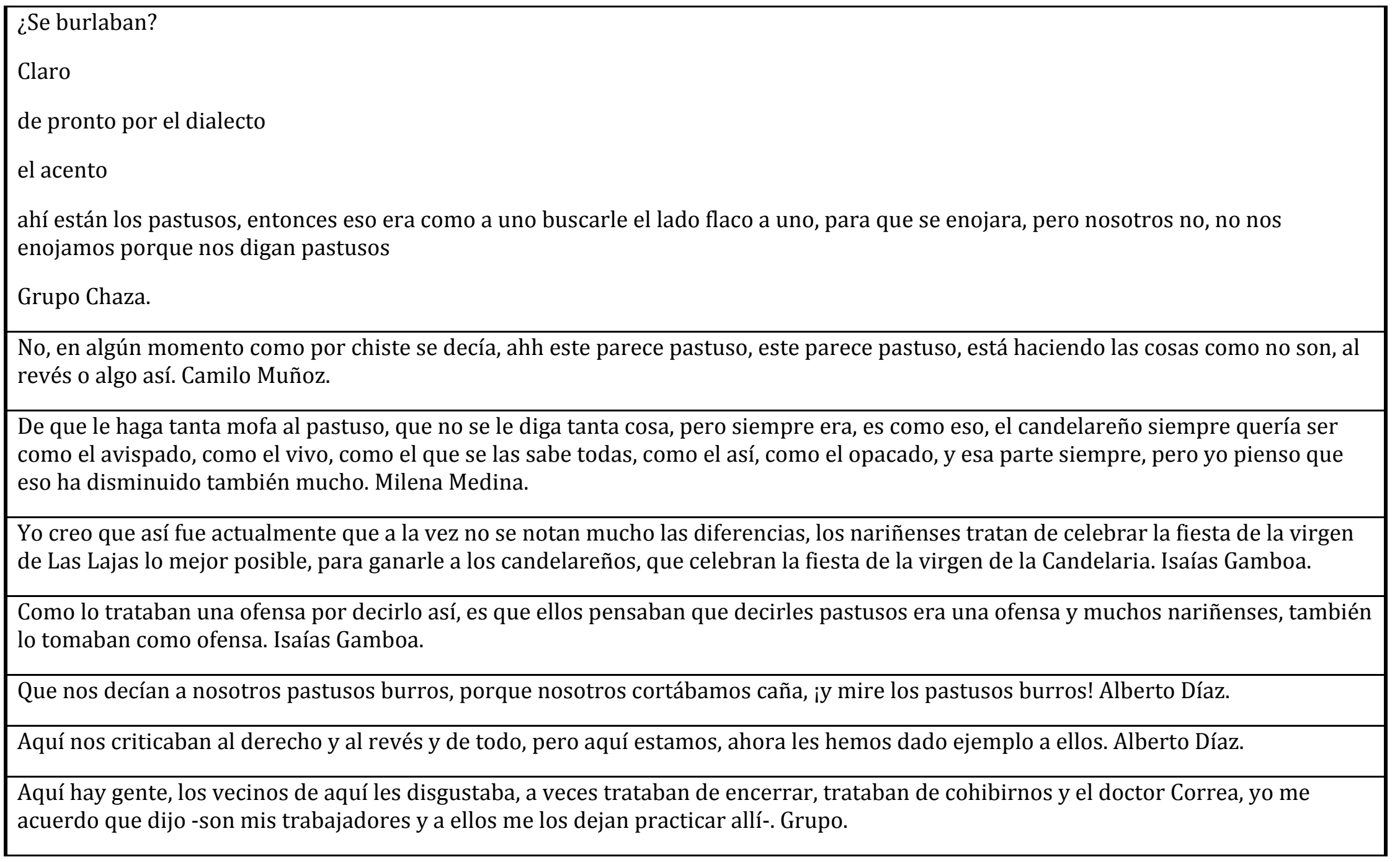


Porque entonces estamos hablando, como decía ahora, como la discriminación, como la bulla, bueno, cosas que no les gustaba, porque otra cosa que yo recuerdo, aquí era un potrero; entonces ahí había gente, más que todo lo utilizaba para hierba, para ganado y los que tenían ese ganado nada tenían que ver con Mayagüez, nada, entonces no les gustaba que nosotros fuéramos a utilizar esta parte.

Grupo.

Perdón, esa época por ahí hace cuarenta o cincuenta años que hace que yo estoy por aquí, en esa época los que jugábamos chaza éramos poquitos y como decimos nosotros, el pastuso era discriminado, el valluno se creía más alto que los demás y porque el pastuso iba por todas estas partes por el trabajo, porque el pastuso como se dice, el nariñense para el trabajo rústico o lo que sea no se ha dejado atrás para nada. Entonces eso era la discriminación, hasta actualmente hay mucha gente que lo discrimina a uno, le dice pastuso que no sé qué. Yo digo, me dicen pastuso, me siento honorable de eso, pero hay gente que no se aguanta, esa época si existía, en la época existía mucho la discriminación, posiblemente porque éramos unos tres poquitos pastusos por aquí. Grupo.

Lo de cuando las iniciativas de la fiesta de Las Lajas ya eso los nativos de aquí, decían que esa era la virgen de los pastusos, así era, la virgen de los patusos, la patrona de los pastusos, poco a poco se fueron concientizando a la gente y fueron entendiendo. Lo de la chaza lo criticaban y hoy en día por lo menos todo el mundo, todo el mundo va a eso; lo de los carnavales que decían que están locos, todo el mundo ha ido a los carnavales. Grupo 2

Si, de pronto por la señalidad de todos los nariñense y es que eso si era verdad que uno si hablaba el pastuso, si hacía las cosas mal, ipastuso tenía que ser!, si usted inmediato se escondía, que el pastuso, casaba a los 8 días y así, y entonces de pronto se achantaban a un poco de personas. Grupo 2 


\section{RELATOS DE SEPARACIÓN - SEGREGACIÓN}

\section{Problemas con los nariñenses}

Pues muchos celos sí ¿por qué? porque para nosotros el día de la virgen de la Candelaria, 2 de febrero, ¡es un día grandiooooso! y para nosotros creíamos que era lo máximo, pero llegaron el grupo nariñense y ellos también implantaron su patrona, que es Nuestra Señora de las Lajas, mientras nosotros celebrábamos en febrero, ellos la celebran en septiembre, pero se fusionan de todas maneras ellos nos acompañan y nosotros los acompañamos. Clara Díaz

Se manifestaban como dicen "Ay no, ellos ya van a creer que el pueblo es de ellos, mire ese 6 de enero con la fiesta de blancos y negros, ellos se creen dueños de Candelaria” Clara Díaz

Ellos solo se unen con la colonia de acá cuando va a hacer la fiesta desordenada de esas de los blancos y negros que me parece horrible, yo eso no es por regionalismos ni nada, sino que se le dio la connotación que no es, nos trajimos, nos trajimos de una cultura lo malo y si hacemos el desfiles de comparsas como lo hacen ellos con esa majestuosidad increíble, ir a verlo y participar de él, que te echen la carioca y que te unten el betún ese, pero como lo hacen en Candelaria me parece desastroso, entonces son solidarios para ese desorden. Milena Medina

Entonces esa parte de la religión los diferencia mucho a ellos de esa parte y por eso me preocupa, acá entre nos, por eso me preocupa la idea de querer hacer una replica del santuario de Las Lajas en Candelaria porque hay concurrencia masiva a la iglesia nuestra por parte de ellos, y allí es la única parte como donde convergemos todo ¿si? A los oficios religiosos allí te encontrás con nariñenses, con el negro, con todos y hay esa forma de compartir, si hacemos una capilla, una réplica, otra iglesia grande entonces ellos se van a aislar, se que así va a pasar, ellos dicen vamos a tener nuestra iglesia. Yo que le sugeriría al alcalde o al sacerdote, que no lo he hecho por que no me gusta como meterme en esos temas de manera respetuosa, hagan una capilla donde semanalmente se pueda ir a hacer una misa, pero yo no soy partidaria de que hagan una iglesia por que en la única parte que realmente nos unimos y compartimos es ese espacio porque o sino ellos ya dirían, ya tenemos iglesia aparte ya. Milena Medina

Pues un rechazo en si no lo hubo, pero si muchas veces en los ingenios o en las empresas o en la alcaldía se quejaban de que los nariñenses le habían quitado el trabajo a los candelareños, así por el estilo, cositas así, como envidia, cosas así, pero ya después eso se acabó. Isaías Gamboa 


\begin{tabular}{l} 
Cuando se fundó los carnavales hubieron criticas, no de los vallecaucanos, de los mismos nariñenses, hubieron criticas, por ejemplo, yo \\
voy a hablar con nombre propio, el señor no se, Costa dijo: que vos vas a celebrar los carnavales de Blancos y Negros? Deja de ser \\
bruto, para que vas a hacer eso, si querés tanto al Valle porque no te vas para Pasto, pero aquí no vamos a celebrar los carnavales, \\
entonces yo le dije: después de que el alcalde nos de el permiso, me tiene sin cuidado el resto, entonces se hicieron los carnavales. \\
Grupo 2 \\
\hline $\begin{array}{l}\text { Sinceramente yo como nariñense, yo como nariñense traíamos la cultura nariñense que era los carnavales de Blancos y Negros, donde } \\
\text { todos lo queríamos, todos queríamos ver, estar, participar y hubieron paisanos de que no lo aceptaron, pero los dos primeros años, al } \\
\text { tercer año ya había circulación ya de ahí para ya la gente se vinculó. Grupo } 2\end{array}$
\end{tabular}


RELATOS DE ASIMILACIÓN

\section{Pérdida de prácticas en los nariñenses}

Entonces esa, la parte de la mingas aquí se han perdido, pero recuerdo mucho aquí me dicen cuando recordamos Alpala lo de la minga y hay que mirar a ver. Alpala y Rosalba

No se, yo pienso como digo los de la iniciativa de las mingas somos nosotros, ya mucha gente ha muerto, unas se han ido. Alpala y Rosalba

En los tiempos libres, por lo regular no quedaba tiempo libre, cuando yo estuve por lo menos ahora último que siempre estuve en cosecha de caña, eso era sábado, domingo día de fiestas, trabaje, trabaje, únicamente era un día descanso cada 15 días, ese día de descanso uno lo aprovechaba para estarse en la casa así como así para descansar, no salía ni nada, yo como le digo a la casa vine a salir cuando era pensionado, a los 25 años salí a medio hacer práctica otra vez, de resto el tiempo libre casi siempre lo aprovechamos en descansar verdad, porque ese trabajo en Mayagüez lo que se trate de cosecha de caña eso es duro pero y no se adapta (Risas) Gabriel Pascuasa

Lo que veo que no se está logrando conservar es el juego autóctono de la chaza, hemos luchado por llevar a los muchachos y la juventud pero no les gusta, entonces eso se nos está acabando, ya no estamos sino unos poquitos viejitos que salimos como por hacer ejercicio, nosotros ya no servimos para competir con nadie, sólo para hacer ejercicios y lo hacemos pero eso sí se está acabando, ya no hay gente no hay juventud para eso, sí hay uno no hay dos pues. Gabriel Pascuasa

Porque dicen que es duro, hay que coger esa bola y darle con la mano pelada y eso les cae como piedra dicen ellos y con bombo pues no les gusta, la mayoría de los que ya se pasaron a eso de los viejos pero jóvenes si hay como unos 3 ó 4 no hay, de resto somos todos los viejos y como le digo a la bola a esa le tienen miedo y en cambio nosotros ya la costumbre y todo eso. Gabriel Pascuasa

Eso siempre cuando hoy en día los carnavales no eran de lo nariñenses si no de todos, de vallunos de todo mundo y un tiempito pues se dieron en... en la cancha no se podía pasar de un lado al otro a pedir una cerveza por que estábamos unos al lado de la tarima y no pues pasábamos para allá, a la camisa hecho nudo y lo cogían cuando iba pasando y hacían el camino y de lado a lado los morochos a darle a uno en la cabeza, yo salí bruto de allá, yo le digo, yo para allá no vuelvo más y en esas estaba pues el alcalde, Oscar López y dije, vea el problema aquí es mejor que eso se haga encerrado por que no vienen ellos a divertirse dándole golpes a uno y de ahí ya estuvo Milton, y eso y yo le dije a Milton pues que es mejor cerrar, se libra de robos, se libra de todo, claro, porque a la gente la robaban que daba 
miedo. Pedro Castro

Pues eso no, mas como decir pues en conjunto no, sino que eso si lo necesitaban para otro compañero hacer la casa era lo mismo, eso ya ha cambiado hasta ahora, la juventud de ahora ya no tiene esa misma misión de visión, porque una cosa es la misión de uno y otra cosa es la visión hasta donde vamos y los que llegan ahora ya no es lo mismo, se acogen a lo moderno, no quieren gastar y ahí yo no me meto en gastos, yo pago y ya, entonces eso se va perdiendo, la unidad de solidaridad. José Montilla

Por ejemplo, ya no tengo presente lo que era antes con fulano ya cada uno hace aparte, ya cuando se encuentra es que dice, ah yo hace tiempo que no te he visto, qué pasa con esto y esto cuando hay encuentros de resto, ya no es como antes, ya eso si se ha perdido. José Montilla

El carnaval no es normal aquí, solo juegan con harina, con tierra, con barro con lo que sea y eso no es juego, no es como en Nariño, en Nariño si lo respetan, ese es un juego y se ve tanta carrosa tan linda, ¿Usted no ha estado allá? Alberto Díaz

Yo la verdad con los carnavales si me siento muy desmotivado y por eso no quise seguir con el evento, la gente dice que yo entregué los carnavales, yo no los entregué y Miguel está de testigo que no los entregué, si no que las cosas se querían manejar políticamente y yo no quise que se manejara políticamente los carnavales, son una evento cultural de los nariñenses, nosotros como nariñenses no podemos meterle política o color político, entonces eso es lo que querían, entonces cuando el señor alcalde Oscar López, él se postuló primero para el consejo o sea él apareció como candidato nariñense, y yo también entonces el discurso de el era, que el era de los primeros encostalados que vinieron. Grupo 2 


\section{RELATOS DE ASIMILACIÓN}

\section{Pérdida de prácticas en los candelareños}

Claro, si han influenciado mucho y yo creo que las costumbres propias de aquí se han ido quedando atrás, porque ellos prácticamente nos colonizaron, nos invadieron y las costumbres de ellos y su folclor se asentó aquí tanto que han ido desplazándolo, las costumbres de nosotros acá, claro! y como ellos son mayoría, eso se nota mucho. Camilo Muñoz

Nosotros decíamos estos se nos apoderarán de pueblo porque ya están consiguiendo más, están ganando más que nosotros, eso era una de las cosas que decíamos, pero pues bueno, hoy en día han demostrado que sí, que si les fue bien y que sus hijos y sus nietos han estudiado y que hoy dominan prácticamente esta población y el sur del Valle. Camilo Muñoz 


\section{RELATOS DE INTEGRACIÓN}

\section{Integración a través de la ubicación y trayectoria laboral}

Yo ya llevaba como 6 años trabajando ahí, de como vigilante por la empresa de Mayagüez, entonces Carlos Molina me decía -pásame los informes, que vos tienes buena letra y te entiendo-, entonces pero, el me decía a mí, por que como a mí me tocaba por la parte de allá de la entrada de trailers y todo eso de caña, que salía allí, entonces decía, pasa los informes, pasa los informes, y cuando también no iba a trabajar le pasaban a uno no, para que vaya a descargos y todo eso decía, cuídate que vos con tu pensión no vas a vivir, si vos me cometes 3 veces por la misma, te voy a liquidar y yo le dije -no Don Carlos Molina hasta allá no puede llegar (Risas), hasta allá no puede llegar-, entonces él me aconsejaba todo eso, y yo pues como me gustaba la cocha, no fui a trabajar 3 domingos. Aurelio Realpe.

No, aquí, por ejemplo, no yo no, no había discriminación, y en todo el tiempo de que yo trabajo por ejemplo yo como le digo, yo trabaje en el Choco en Cali, a la edad de 18 años, en Popayán y por último que hemos tenido más tiempo, por que hemos tenido la residencia propia acá en Candelaria, pero aquí $90 \%$ son de Nariño, aquí en Candelaria; entonces no hay tanta discriminación, pero por que aquí el 90\%, sí aquí no más, rebájemele que sea el $80 \%$, pregunte aquí no más de pueblo que cómo está aquí, es de puros nariñenses. Aurelio Realpe.

Yo me pensione de Castilla, ¿qué hacia yo?, a mí me querían ubicar ahí donde a mí me hizo falta el estudio, de ahí fue donde nació esa base del estudio, por que a mi me decían - ¿Alpala usted tiene quinto de primaria?- Y yo decía -No, no lo tengo-, - ¿Usted sabe leer o escribir?-, sí pero es que aquí necesitamos como mínimo que tenga quinto para ubicarlo, me daban oportunidades para sacarme de cortar caña. Alpala y Rosalba.

A hacer otras cosas, pero ya tenía que estar un poquito preparado, y yo no tuve esa oportunidad, entonces ¿cuál fue esa base que me nació a mí?, yo dije, mis hijos no se van a quedar así, como yo me quede, y ahí fue que yo, nosotros empezamos a que mis hijo estudien y gracias a dios lo hicieron. Alpala y Rosalba.

Yo era afiliado a el trabajito, me ayudaba mucho, yo era afiliado a dos cooperativas, a la cooperativa de la empresa y a otra cooperativa en Cali, entonces yo allá ahorraba y qué hacía, por que cuando eso todavía se pagaba mensualidad. Alpala y Rosalba.

Yo tenía un puestico de venta, teníamos un puestico de venta, cuando eso vivíamos donde Don Pedro, de cerveza gaseosa; la primera hijastra

R+: Ella de 8 años aprendió a hacer empanadas y usted de pronto escucho que antes usaban el fogón de candela, entonces lo cargaba 
en una cajita y fogón, eso y candela, que eso venía con petróleo era, y se paraba en esa cancha, niñita de 8 años. Alpala y Rosalba.

Si, a trabajar entonces, yo que le decía mire, aquí se ayuda, nos ayudamos y aprende, aprenden a trabajar y eso fue, que eso fue el resultado, porque tengo la primera hija, la hijastra, ella fue la que empezó a vender chicha con esa carreta que venía la chicha, la chicha y ella se quedó con ese ambiente. Alpala y Rosalba.

Como en el 75, miento como en el 85 y ahí dije me voy de aquí, por muy aburrido que este dije -de aquí no me salgo, hasta que mi dios me tenga con vida-, y así fue, no me volví a salir de ahí hasta que salí pensionado

$\mathrm{P}^{*}:$ ¿De Mayagüez?

$\mathrm{R}^{*}$ : Sí, ahí me entre a cortar caña y me entre fijo y a otro y a otro y por último termine operando maquinas, ahí termine jornada. Gabriel Pascuasa.

Sí, exacto, hasta ahora es así, ya les dan créditos, incluso este barrio de Santana para allá, los dos barrios, eso son lotes de lo que ha dado la empresa, todo es tierras de la empresa y les prestó la plata para que construyeran y todo y el que quiere comprar ahí mismo no hace sino solicitar el crédito y presentar papeles y ya la empresa le presta. Gabriel Pascuasa.

Ah no, ofréceles no simplemente la seguridad, el trabajo, la estadía, todo eso va como uno se portara, si uno se iba a portar mal pues lo despedían, pero si uno se portaba bien, no antes, subían de un trabajo a otro a otro a otro así y el pago también iba mejorando más y más y más, fue como por lo menos yo empecé, ganando por ahí en ese tiempo unos, qué le dijera, en ese tiempo eran 50 mil pesos, era mucha plata, semanal y a lo último yo salí, pues también me subieron como a operador de máquinas y salía ganando millón y medio, ochocientos semanales. Gabriel Pascuasa.

Usted sabe los problemas que ha habido en las empresas, persecuciones, amonestación, me vincule a la organización civil sindical para defender los derechos por que es que era difícil, a nosotros nos explotaban mucho en el peso de la caña, entonces se había un sindicato de base en la cual me afilie y empecé a estudiar, eso entonces me pare ya en una biblioteca del sindicato, y código laboral, penal, policial, civil y me fue ascendiendo ascendiendo y me fui, cargos de todos, presidentes tesorero. José Montilla. 
Bueno, entre los nariñenses en esa cuestión de trabajo no había discriminación, había solidaridad entre nosotros mismos, de pronto fueron un poquito esquivos los afros cuando llegaron a esta empresa, por que a esta empresa no le gustaba dar trabajo a los afro por su comportamiento de, cómo le digo, del ser como son ellos alborotados, habían unos que no hacían el trabajo bien, querían que de pronto les pagaran haciendo cualquier cosita, siempre había eso, pero eso se fue dando, hasta que los afros se fueron acomodando e irse rigiendo a las normas de la empresa, hasta que a lo último habían unos que llegaban a ser parte de la organización sindical. José Montilla.

Pero recuerdo yo, que cuando estaba en Sotomayor me ganaba cien pesos el día trabajando duro, en Las Vegas por que yo cogí una parte cafetera, clima medio, para medio ganarse uno un peso, había que trabajar a las canteras y allá en el clima medio, ganaba 15 centavos; entonces en 1970, yo me casé y procedí a venirme para el Valle y de aquí a Candelaria, estuve un año con oficios varios, en una casa, en otra, hasta que me ubique a trabajar en una empresa llamada Transcañas, Transcañas estuve trabajando como unos 8 meses, de ahí traslade mi trabajo, me trasladaron a Mayagüez, en Mayagüez trabajé 39 años y de ahí continúe pensionado. Grupo Chaza.

Hasta ha habido alcaldes nariñenses o de descendencia nariñense y hoy en día hay mucha gente vinculada a la administración municipal, y departamental que son descendientes nariñenses, de manera de que eso fue en este siglo 21, y en el siglo 20 fue el florecimiento económico del Valle del Cauca, dependiendo de todas esas colonizaciones, digamos, de todas esas migraciones de gente que llegó aquí, como ellos más que todo. Camilo Muñoz.

Ya las generaciones nuevas ya han estudiado, lograron estudiar, entonces ya los hijos de ellos si son técnicos y profesionales muchos, y ellos llegaron fue a tareas, a faenas del campo. Camilo Muñoz.

Pues hombre, yo considero que era muy buena, era muy buena por que no había como el celo de que iban a quitar la fuente de trabajo, por que no había ese celo, por que había trabajo para todo el mundo, inclusive, -no, tráigase a su familia-, inclusive el ingenio empezó a hacer unos, cómo se llama eso, unos casinos o espacios donde le daban habitación, le daban habitación a las personas que llegaban, le daban como el albergue y dormían en unos grandes galpones, dormían allí y también tenían asistencia, o sea que al principio el mismo dueño decía que el ingenio no era de ellos, sino de sus trabajadores, por que ellos eran los que habían hecho que el creciera, que esos ingenios crecieran, luego llegaron los familiares y ya, vinieron con otro tipo de, visión no?, más económica, pero de todas formas si era muy familiar con sus trabajadores, Don Nicanor y Doña julia Holguín, ellos eran muy familiares con sus trabajadores, 0 sea era como una vida de familia, y los acogieron a los nariñenses y les daban pues todas las publicaciones, los escuchaban, los ayudaban, con sus familias inclusive, les ayudaban para que se trajeran a su familia. Edgar Olave. 
Claro, entonces, entonces nos hacían, nos metíamos a veces 30,40, 50, 60, 70 toneladas, pero eso, uno había que, también se decía uno antes había que remojar mucho el remiendo, pero pues, valía, valía en ese tiempo en el 80, que me acuerdo tanto en el 80, en el 80 llego una caña australiana que llamaba, pero eso era todo así, como los dedos, derechita toda, y podían quemar 5, 6 parcelas y se veía el mismo nivel y en ese tiempo nos dejaban a nosotros una línea, se llamaba parcela por ser una cuadra como esta, y nos cortábamos 30 toneladas hasta las 11, volteábamos la otra línea, eso era a las 6 de la tarde y nosotros vomitábamos lo que teníamos en la barriga, de cansados, pero así yo vine a pagar en 2 años, esos 70 mil pesos. Alberto Díaz

Pero no tengo propiamente mi casa, de decir de plancha y de esas plantas, por qué no la tengo, porque le tuve que dar a los hijos universidad, todos los hijos son con universidad, todos tienen su estudio. Alberto Díaz.

Hubo una etapa en que, a pesar de que eran trabajadores de Candelaria, incursionaron mucho la parte política de Candelaria, entonces con los alcaldes que se dieron en esas épocas, por ejemplo el municipio, adquiría lotes de terreno, por ejemplo el barrio Panamericano y otros barrios, no solamente sino en diferentes corregimientos, y se compraban por viviendas para trabajadores, entonces el interés de esos alcaldes cierto, no era adquirir, lotes de terreno para venderlos a costos elevados, hacer como negocios no, sino brindarle la oportunidad, como ellos ya estaban, estaban establecidos en Candelaria que les pudieran entregar el ingenio Mayagüez y pues castilla y todos, sus anticipos de cesantía, para que ellos pudieran construir sus casitas, entonces si usted va al barrio Panamericano, un alto porcentaje de esas personas son nariñenses. Zoraida Zamorano. 


\section{RELATOS DE INTEGRACIÓN}

\section{Integración a través de la vivienda}

En la cooperativa yo le decía a mi esposa, pero nosotros con tantos hijos no nos arriendan una casa o dos piezas no, nosotros teníamos que tener unas 3 o 4 piezas, entonces yo con ese fin dije, yo voy a dejar una parte del dinero en la cooperativa de pronto hay un lotecito y ahí pues, uno tiene una platica disponible en cualquier momento se le presenta, como se nos presentó un lote de allá donde yo vivo, si yo no hubiera tenido esos 100 pesos, ese lote me costó 80 y en ese tipo para uno tener 100 mil pesos, se tenia que tener un ojo, pues no mucho, pero tenia que tenerlo. Aurelio Realpe

En el momento llegamos acá yo ya tenia un parte adelantada, luego la dueña de esta casita aquí me encuentra a doña Rosalba que voy a buscar un casita, un ranchito, un lote y le dijo pues vaya a ver a tal parte esa es mi casa, mi rancho si les gusta negociamos, yo ya había estado hablando eso y yo ya tenia una base , una platica, un ahorro, entonces se dio y se dieron las cosas, esto era de techo, tenía estas dos piecitas, era de techo y ya nos pusimos de acuerdo y negociamos y dijo: qué plata tiene don Alpala y yo le dije hay yo tengo 300 por que valía 60. Alpala y Rosalba

No y la oportunidad que nos dio era no, yo quiero que se hagan a su rancho págueme despacio, págueme como pueda, y así se dio entonces estaba así como está este salón y las dos piecitas y ya bueno, vámonos. Alpala y Rosalba

En esa pieza que alquilamos estuvimos como 2 años y ahí ya nos salimos para otra parte y así andaba yo pagando arriendo, hasta lo último pues ya, yo ya iba, ya trabajaba en Central Castilla, ahorré mis pesitos aquí en la cooperativa de Cootrainc y se me dio y dije yo no voy a pagar más arriendo, ya tengo mis ahorros allí, voy a sacar un crédito para comprar una vivienda y así fue. Gabriel Pascuasa

Si y eso, yo mis ranchos los construía así, a fuerza de créditos de la cooperativa por que yo ahí ya han sido más de 40 años de ser asociado, entonces eso es lo que me ha servido y yo he vuelto como le digo si, ya con mi familia, ya todos han estudiado, pues no le voy a decir que le he dado estudio de cómo se dice universidad, no, todo el bachiller y el Sena a los que han querido. Gabriel Pascuasa

Vamos a buscar a ver si conseguimos una casita que allá hay forma de comprarla y así fue, nos fuimos por allá al frente del colegio de la calle cuarta hay una casa pero pues, había pues de pared una pieza no más, lo demás era guadua con esterilla; bueno, nos fuimos para allá, allá llegamos y estuvimos allá, una cosa a otra y metí el anticipo a Mayagüez, Mayagüez me prestó plata y me faltó, por ahí yo tenia alguito de ahorros y ahí completamos, y bueno ya ahí seguimos, trabajamos, ya tenia la plata para seguir, ya tenia material para seguir adelante, ya tenia cimientos y todo. Pedro Castro 
Em ese tiempo esos lotes los compraban solamente a 3,600 y a mi me lo vendió en 20 millones éste, yo hice un préstamo a la empresa, me los prestaron, pagué esa plata, se lo pagué fue en un mes ya le pagué todos los 20 millones, porque a mi me rendía mucho, yo pagué eso ligerito y entonces yo le dije a la mujer $i$ y ahora que hacemos, por dios, con que construimos? y dijo: pues esperemos un poquito, me fui a la empresa yo ya había pagado el préstamo, yo me fui a la empresa y dije: yo necesito un préstamo, y dijeron pero todavía no completa los 4 años, no tenés derecho a préstamo, le prestamos eso porque compró ese lote, le dije, pero por favor doctor Correa, hágame un favor, le dije, yo quiero construir, yo no quiero estar pagando arriendo, arriendo y arriendo, ya compré el lote, ustedes me ayudaron a comprar el lote, pues ayúdeme cuanto sea para levantar una pieza, dos piezas para meterme yo ahí, y dijo: pero cuanto necesitas, y yo le dije: présteme 65 millones (Risas) y dijo "eso no se te puede prestar, te vamos a prestar 60 mil". Alberto Díaz

Una importancia muy buena porque para mí, cuando yo entré a trabajar a ese ingenio Mayagüez no tenía vivienda, yo no tenía pues nada, solo el trabajito, a los tres años yo estaba cooperado ya de ser asociado, saqué un crédito ahí pa comprarme mi rancho, eso fue importante para mi porque yo no tenía en donde tener mi familia, pues a pesar de que pues apenas era la señora y mi persona no mas, pero ahí ya venía la familia, entonces yo me preocupé por hacerme mi rancho primero con el crédito de la cooperativa. Grupo 2 


\section{RELATOS DE INTEGRACIÓN}

\section{Integración a través de las prácticas}

Para esos baños, las baterías sanitarias, hubo que gestionar, entonces allí el que nos ayudó mucho, el alcalde Rodrigo Tojil, donde nos entregaba, primero nos exigió la personería jurídica. Alpala y Rosalba.

Para poder, por que eso es un proceso, para hacer obras allí, entonces primero dijo -para darles el comodato ustedes tienen que activar la personería jurídica-, entonces nosotros activamos la personería jurídica y de allí sí se siguió el proceso para lo de las baterías sanitarias, entonces de allí fue que se empezó eso y entonces aquí, donde esta él, está hablando que ya estábamos organizados, ya teníamos la personería jurídica, aquella gestiono ya el comodato, ahí ya nos entregó el comodato, de ahí es donde ya se podía seguir trabajando, luego cuando ya se le venció el periodo a él, ya me toco. A la próxima, que se llama Elvia lozano, ella fue que mejor, por que para esas baterías sanitarias necesitan el comodato y para tener el comodato hay que estar activado con la personería jurídica, o sea son las dos cosas; no por que eso lo pedían en planeación el comodato, para eso, es para agua, para energía, para construir, esas cosas, entonces por eso lo hicimos, esas cosas, y entonces de allí para acá es como esta eso. Alpala y Rosalba.

Si, esa fue una minga, esa es la minga, entonces este, este, lo que la doctora Tania lo hizo que se pavimento todo eso; cuando llego otra directiva del club, hicieron otras peticiones y entonces que le colocaran asfalto, el asfalto es lo que esta ahora, por eso, esa cancha es muy fuerte, aguanta mucho porque lo que nosotros hicimos es como un cimiento, se quedó tapado eso, pero hoy en día eso está con una capa de asfalto. Alpala y Rosalba.

El apoyo que empezó y que motivó a la gente, así como estábamos no había comodato no había nada, pero el primero que empezó fue, eso si recuerdo en los años 97, el primer alcalde popular que fue Dagoberto Escobar y la esposa Zoraida Zamorano, él fue el que empezó con los torneos, él invito, dijo inviten a la gente de Pasto y hagamos un torneo, ese torneo, se lo hizo; cuando eso, nosotros en esa época, cuando nosotros nos ubicábamos a medida de que iban construyendo, nosotros nos íbamos corriendo, pero ahí nos organizábamos nuestra cancha y hágale y hágale y entonces nosotros nos volvimos persistentes en eso y ya reconocieron y ya metidos en la política, todo eso pues, todo eso nos tuvieron en cuenta. Alpala y Rosalba.

Yo reconozco desde el primer alcalde, el que hizo el torneo, y de ahí para acá le reconozco a las administraciones que han puesto la mano, poco o arto, pero nos han tenido en cuenta. Alpala y Rosalba. 
Pero ya más tarde, a medida de la necesidad, ya nos fuimos organizando entonces, pero lo primero que llegó a Candelaria fue la práctica de chaza, en la cual los de Candelaria, los de aquí decían, bueno, la expresión de ellos, a veces gente que se sentía ofendida decía -esos pastusos están locos-. Alpala y Rosalba.

Porque como no sabían nada, entonces poco a poco fueron entendiendo y fueron, y dijeron no; pues hoy en día en esa cancha de chaza va todo el mundo a mirar, todo el mundo va a mirar. Alpala y Rosalba.

¿Pero hay candelareños que van a mirar?

R*: Claro, van a mirar, hay candelareños que van a mirar, igual en esos eventos que se hacen ahí, si todo el mundo se integra.

Alpala y Rosalba.

No , ya no son tan nariñenses, eso ya están por otras partes, si lo hacen, los celebran, todo eso, pero ya no, esa parte se puede decir que se ha perdido, no total, pero lo que lo hacen no lo hacen como original, como cuando se empezó una; por que los primeros que entro a organizar eso, se retiraron, y la otra, que por la inseguridad, la inseguridad, eso ha sido la administración, eso es la estrategia que usan y la inseguridad, eso es cierto que esta; ya en este año que pasó, ya no se hizo el desfile como se hacía, entonces solamente eso está por no acabarlo totalmente, en el momento lo que tenemos es que estamos conservando lo de la chaza, no sé, no le digo cuántos años puede durar por que no sé, también qué ira a pasar, por que no hay muchachos, no hay jóvenes, que se quieran vincular, no les gusta, lo que estamos sosteniendo no somos nosotros, los de, entonces, eso está en un tiempo muy corto de acabar esas cosas, pero en el momento sí estamos sosteniendo esas tradiciones que empezamos, lo de la chazas y lo de la virgen de Las Lajas, eso estamos haciendo. Alpala y Rosalba.

Empezaron por ahí dos o tres a buscar razón de jugar, y de ahí, y nos volvimos paisanos que nos gustaban y se iban agrupando ahí, y ya haciendo sus juegos también, y se iba creciendo la gente. Todo paisano iba a qué, le gustaba ese fuego, se iba agregando, porque antes había jugadero, aquí antes bastante y ahí se fue consiguiendo la cancha para jugar, y en varias partes se hizo esas canchas; y después de eso, vino lo de la virgen de Las Lajas y ahí y como le digo se hizo en las agrupaciones para eso; y la junta directiva se compró dónde iba a hacer, no se compró, sino que lo cedió el ingeniero de Mayagüez, y de aquí para allá todo era Mayagüez, lo cedió también el ingeniero de Mayagüez donde iba a ser la capilla y todo eso se perdió, y ahí por ahí fueron inventando todo eso de los carnavales, también el 31, también se ha hecho un grupo de todos las costumbres de Nariño. Gabriel Pascuasa. 
Ya venía la alcaldía a pedir incluso que el primer Carnaval, me acuerdo tanto yo, lo apoyo el municipio, esa vez fue todo brusco a las costumbres de aquí, pues de la gente valluna ¿no?, porque nosotros a la costumbre nariñense todo se hace con pausa, sin problemas esa vez; pues me acuerdo tanto, la alcaldía por el lado de por allá, nos agarró la gente en los barcos cosméticos y unos paisanos de acá del Valle, que les decimos los caleños, no les gustó y se formó la tremenda pelea al frente, y entonces de ahí para allá, la gente ya se fue organizando más, lo mismo lo alcalde del municipio, los empleados, no dando explicaciones, que fueran, los carnavales que no eran para asunto de peleas y que no, al que no le gustará eso, que no salieran; Entonces ya así no había problemas, pero que el que le gusta disfrutar y que lo hiciera entonces, sí salía, y a los que no les gustaba, no salían, y ahí se fueron ya, tanto la mayoría que tenían en eso y ahora parejo ya participan. Gabriel Pascuasa.

Sí, por todo Candelaria, y ya la gente se adaptó, ya no hay problema, todo el mundo juega como, y entonces ya no hay problemas, por eso le digo, ya todo lo hace la enseñanza también y que sepa la gente comprender, todos los carnavales que son hasta para distracción de la misma gente. Gabriel Pascuasa.

Exacto, sí, y como ha habido tan gobernantes del municipio, tal como de dónde salió este tal López que fue alcalde nariñense, este que entregó ahorita también Wilson, también es del pueblo de donde yo soy nariñense, ellos también; ayuda mucho porque ellos también saben cómo son las costumbres, porque este Wilson cada rato iba también para arriba a Nariño, entonces ellos saben cómo es. Gabriel Pascuasa.

Lo que sea creo que se ha logrado conservar, lo primero, lo más importante que se ha logrado conservar es la religión, la religión es lo más importante que se ha logrado conservar, porque desde que se ha traído la virgen de Las Lajas, se trae cada año que va a ser la fiesta en Funes, se trae el señor de la buena esperanza, se trae a San Pedro, cada año se lo traía ellos a hacer recolecciones aquí para las fiestas, y cuando menos, menos se van con ellos, se van con 5, 6,7 millones de recolecta, no más para la fiesta, por eso le digo y lo más principal es la religión. Gabriel Pascuasa.

Por eso le digo, lo único que no hemos podido continuar es eso por falta de juventud, por falta de personal para eso, lo demás sí, lo demás, los carnavales cada año se agrandan más, no ve que aquí ya vienen de la otras poblaciones, vienen a festejarlo aquí; Entonces eso es uno que está atrayendo más a la gente. Gabriel Pascuasa.

Eh, precisamente lo que te decía, eeh, los candidatos, en este caso los candidatos, cuando estuvo Antonio Dorado, él fue el que empezó, mejor dicho Antonio Dorado empezó con, apoyando lo de los carnavales y trayendo grupos nariñenses de allá. Sí, como los Regueros de San Juan, eh, Jaime el Requinto de oro, Rubio Hoyos, que llaman, que tuvo su fama también, Tuvios Fronterizos, aquí a la gente le gustaba mucho, en esa época estaba en su furor y entonces él los traía. Yyyy, eso era, acudía masivamente la gente. Julio Castro. 
Ehhh, después los organizó la Junta de Chaza, ehh, posteriormente lo hicieron, o lo hicimos, la Junta de Chaza con la alcaldía. Luego ya lo cogió solo la alcaldía, porque eso era un problema ahí pues, manejar eso, el presupuesto. Anteriormente porque Antonio Dorado nos patrocinaba con los grupos y tal, entonces era mucho más fácil. Cuando ya nos tocaba así, bueno, de las entradas todo, pues había que partir gastos y tal. Posteriormente ya se nombró una junta acá. Ehh, Milton Pozos empezó incluso a liderar esa parte y ya se le organizó la misma junta de festejos que colocó la mano allí. Julio Castro.

Lo que pasa es que, ehh, alguna vez te decía que la colonia acá ha tenido mucho peso ¿si?; Y detrás de esa cauda electoral que se puede lograr allí, o sea, los intereses políticos que se tienen, entonces viene el apoyo. Nosotros pedimos para los torneos, nos han apoyado. Ehh, incluso en el material, cuando dieron los bombos, cuando se juega con bombo, Dagoberto, el alcalde Dagoberto fue el que nos dio los primeros bombos. Julio Castro.

Ehh, para conseguir los lotes, los espacios, pues ha sido con la administración, porque anteriormente había mucha más gente que jugaba. Pero entonces a raíz de que, digamos, la recreación y todo eso es parte importante y como gobierno pues debe proveerse, la gente empezó a reclamar y siempre se han tenido, ellos han buscado los espacios, aquí jugaban, han jugado en varias partes. Julio Castro.

El compadrazgo ha sido... el paisanazgo y compadrazgo pues en este caso, han permitido esas relaciones ehh, sociopolíticas, podríamos llamarlas aquí ¿si?, Ehh donde por esa misma amistad, cercanía o compadrazgo -veee, apóyenos aquí y ta, ta, tá- y le hacen pues el juego a ellos también acá. Entonces claro, cuando necesitan, ahh vea! Y entonces, y han salido!, han contado con buen respaldo, entonces qué pasa, Ehh, cuando se ha necesitado, han venido a solicitar yyy, y no se les ha negado. Entonces de allí viene, o sea, de hace muchos años, el apoyo que se ha obtenido no es de ahora, o sea ha sido tradicional, $i$ si?, Entonces por eso se tiene comodato de la cancha, yyy o sea, ha sido todo un proceso de larga lucha. Julio Castro.

Realmente fue cuando nosotros empezamos a jugar por acá, al frente donde un señor López que tenía un lote pero de Mayagüez; Mayagüez le había dicho que nos prestara ese lote para jugar, él no dijo que no, dijo que sí en vez de emborracharse e irse para Cali, Armenia y llegar al otro día borrachos -si, jueguen-. Pedro Castro.

La memoria se fue ahí y todo, y dije -acabé con todos-, pues todos anduvimos en ese tiempo, después de lo que se sacó la personería jurídica, ya todos éramos jurídicos, se ofreció a unas olimpiadas a nivel de ingenios, ya le debí a ver contado una parte de esto. Pedro Castro. 
No, no era nariñense, era valluno, pero trabajaba en una empresa, entonces dijo -metámoslo aquí también-, y hablamos con ellos y ahí ya había, todo lo que pasa, jugar futbol, futbolito juego de sapo, de todo, había de todo lo que se tratara de deportes, todo eso, hasta mujeres jugando sapo y eso quedaron de campeonas las de aquí, de Palmira quedaron los hombres. Pedro Castro.

No había mucha gente que venía a ver como hasta ahora, hay gente que viene de otra parte, de ahí mismo lo llaman a uno y le dicen vea, ese juego cómo se llama-, -cómo es esa contabilidad que cuentan, apuestan plata, qué apuestan y si apuestan por recreación cualquier 5 mil pesos por recreación entonces ya no-, hay bastante gente, los de la mano, los mayores que ellos juegan sino mil pesitos y antes era menos, 50, no más 50 pesos, y ahora ya como que juegan de a 2 mil ellos. Pedro Castro.

La expresión de los carnavales se dio por un grupo de personas que querían hacerlos, lo que hemos constituido de los carnavales allá alrededor del año 2003; la administración municipal tiene una participación directa y es la que ha tenido hasta ahora, o sea los carnavales se empiezan a realizar bajo la administración, valga la redundancia, de la alcandía, pero aparte de cultura, la cultura está escrita, la Secretaria de educación entonces, tiene un factor muy importante, que es recursos, recursos que uno logra mediante el acompañamiento de toda la parte administrativa de los alcaldes, eso se ha venido desarrollando, empezamos desde el 2003, en el 2008 cuando llego como a ocupar una curul al concejo y cuando la UNESCO ya había determinado que los carnavales eran patrimonio intangible de la humanidad, mediante una proposición y un acuerdo se integra a la expresión de los carnavales de negro y blancos de Candelaria, como patrimonio cultural del municipio de Candelaria, eso qué permite, ya no solamente es una intención de las administraciones a acompañar, sino que esa expresión, hace parte de la cultura candelareño y por lo tanto, independiente de quién sea el alcalde, con qué raíces o con qué afinidades pues, le dé cumplimiento y pertenezca a la agenda de la expresión cultural de los carnavales de negros y blancos. Milton Posos.

A ver, míremelo desde el ámbito político, la verdad en el ámbito político sí hubo una diferencia entre algunos concejales, de qué, pues Candelaria era muy diferente a la expresión y que Candelaria tenía su propia expresión cultural ¿si?, digamos, no apoyaron el

Proyecto de Acuerdo, y digamos, tenían algunas razones diferentes, pero se logró un consenso de mayorías cuando se expresa de que la cultura no tiene unos cercos limítrofes, ni regionales; y hoy en día, así como creo que ha llegado la globalización económica, ha llegado la globalización cultural, y Candelaria, es un municipio multiétnico ¿si?, donde por diversas razones, asentamientos tenemos, expresiones de toda de la Costa Pacífica, del eje cafetero y de Nariño, por ser una más antigua, y logramos que sea acompañamiento; Además, como se había venido desarrollando la festividad de los carnavales en un ámbito tranquilo, en un ámbito de aceptación y donde el municipio hace su acompañamiento. Milton Posos. 
Estamos seguros de que en Candelaria la expresión de los carnavales se va a seguir dando, se va a seguir cultivando, porque la administración municipal quiere seguir aportando a todas las expresiones culturales que sí hay en Candelaria, además de eso es un deber ¿no? es un deber, y la idea es que a medida de que eso, corrijamos ciertas impases, incomodidades que causa el carnaval, la expresión de los carnavales crezca más en sí, para enriquecimiento cultural de Candelaria. Milton Posos.

Entonces he sido el responsable por mi cultura, por ser orgullosamente nariñense, he tenido esa responsabilidad frente a la administración, yo sé que el día de que, tal vez ya no tenga una cercanía con alguna administración o algo, va a haber otra persona, por que las personas, tanto la colonia nariñense, está ganando espacios, las personas que tenemos esta representación, que amamos esta tierra, que nos sentimos orgullosos por haber nacido allá, también tienen su diversa participación, entonces vamos a seguir buscando y compartiendo esa expresión, creo que por muchos años más. Milton Posos.

Diversidad de comunidad, la verdad que cada vez me quedo más complacido porque, comunidad de todos los índoles, de todos los estratos, gente del eje cafetero, de la parte del pacífico, gente que viene de la capital, gente que quiere conocer y que quiere explorar que es esto de los carnavales ¿si?. Entonces complacido por la asistencia, los resultados, a veces aquí en Candelaria hemos manejado unas cifras, más a veces se da la gente que viene hacia afuera que la gente de acá, porque la gente de afuera se siente y se identifica. Milton Posos.

Lo de la parte de la virgen de Las Lajas, aquí vamos, cuando empezamos con la tradición de la virgen de Las Lajas, nos empezaron a criticar. $\mathrm{P}^{*}:$ ¿Y por qué?

R6: Porque decían que no, la gente decía pues no, es la virgen de los pastusos, y últimamente ya fueron entendiendo la gente, y hoy en día, ya todo el mundo es integrado a esas actividades de la virgen de Las Lajas, entonces y lo de los carnavales, luego se empezó con los carnavales, y eso se empezó muy bien, fue muy sano, muy tradicional. Grupo Chaza.

Con lo de la fiesta de la virgen de Las Lajas, que se supone pues, que los nariñenses que la celebramos aquí cada año; y entonces por medio de esa fiesta que se hace cada año, se une mucha gente nariñense y no nariñense, y entonces pues en esa estamos, y ahora va a comenzar otra vez en septiembre la fiesta y estamos ya haciendo todas las actividades y las gestiones para que salga la fiesta, entonces ahí, que nosotros nos integramos con los nariñenses y con todo, se hacen las novenas, se hace la fiesta y ahora se hace la chaza no más. Grupo Chaza.

Era como un boom de gente que era muy campesina, y que tal vez allá tenían sus tierras y que todavía tienen, pero que llegaban aquí, y veían otro mundo distinto, en que empezaban a ver semanalmente que en ese tiempo, creo que les pagaban semanal, unas cantidades de plata que ellos no manejaban, de dinero. Camilo Muñoz. 
Nos dio primeramente el sitio, cuando nosotros principiamos a trabajar aquí, entonces el ingenio Mayagüez, le solicitamos nosotros, le mandamos una carta allá y el ingenio Mayagüez nos dio 200 bultos de cemento para que pudiéramos seguir trabajando. Grupo Chaza.

Al principio si era duro, porque a la gente no les gustaba que le echara la cosa negra, la cosa blanca. Al principio no les gustaba porque había peleas, pero ya poco a poco se fue animando. Grupo Chaza.

Ya por medio de la alcaldía, ya también se fue organizando eso de que era prohibido echar barro. Porque la gente de aquí empezó a echar hasta barro, y todo eso se fue impidiendo. Únicamente fueran cosméticos y talcos. Y por ahí ya se fue organizando, cuando la alcaldía intervino mucho en la organización. Grupo Chaza.

Entonces hubo fusión y aquí hay mucho, mucho que esta fusionado, los dos grupos se fusionaron bien, sin temores de nada, eso era lo más bonito, y lo más hermoso de la fusión que hubo era que Candelaria y dio campo al grupo nariñense, tanto que se organizaron aquí, hicieron sus costumbres aquí, y antes de nosotros rechazarlas, las acogimos, antes, y le digo por qué, porque yo tenía grupo de danzas, en el colegio lo tuve 25 años de danzas folclóricas, y antes de nosotros ir a rechazar un baile nariñense, la guareña por ejemplo, era la primera que funcionaba cuando íbamos a repartir los grupos. Clara Díaz.

Sobre todo en la parte religiosa ¿no?, en la parte religiosa es muy importante el espacio de cada uno, pero que como le explicaba antes, se fusionaron, se ayudaron; pero también hay fiestas, las fiestas de ferias y todo eso también, la fiesta del 6 de enero, el Carnaval de Blancos y Negros donde ya nos dejamos echar pinturita y talcos. Clara Díaz.

Al principio había mucha pelea, inclusive llegó a haber hasta muertes, porque el que iba a trabajar bien y le echaban eso, se enojaba y respondía muy feo, pero eso a medida de que también lo fueron legalizando, lo fueron dando, y le fueron dando sus espacios, por ejemplo que fueran en tal parte, los mandaron a determinado sitios, allá iban e íbamos porque yo también iba, porque a mí me gusta vivir esa parte, no solo lo mío sino lo de los demás, ehh los juegos, por ejemplo la chaza, es un juego hermoso para ellos y que si uno se coloca a verlos, pues se emociona también y grita como los otros, pero lo importante. Clara Díaz.

Bueno, ahorita en este momento ya es más difícil, porque ya todo el mundo se aculturizó, y ellos ya están con lo nuestro también, haga de cuenta como cuando íbamos a la loma y vemos a todo nuestro grupo de indígenas con botas Panam, lo mismo acá, ellos ya no se ponen mucho traje de allá, sino que se volvieron normalitos aquí, unas personas que están usando toda la vestimenta de acá, ellos cambiaron también, ellos es decir, dejaron lo de ellos pero cogieron parte de lo de nosotros, y yo creo que eso es bien. Clara Díaz.

Traen por ejemplo a galería el día sábado, usted consigue habas, el mote, que es el que pelan ellos allá, y lo traen, también lo traen y 
así muchas cositas que traen, porque como hay gente nariñense. Edgar Olave.

Eso si las cosas fueron más y más fácil, porque mira que yo, cuando yo a los 8 días, yo estuve almorzando allá con un muchacho que jugaba chaza allá en el ingenio

$\mathrm{P}^{*}:$ ¿En el ingenio tenían cancha?

$\mathrm{R}^{*}$ : Sí, allá nos hicieron una cancha, y bonita cancha, bien hecha, con todos los deseos de la empresa propiamente dijo -ustedes tienen que venir a jugar a los torneos aquí también-, en ese tiempo habían 16 jugadores en esa empresa y por eso nos hicieron esa cancha y esa cancha la hicieron con todos los detalles.

Alberto Díaz.

Pero nosotros, quién propiamente nos ayudó a nosotros para tener esa cancha, es el ingenio Mayagüez, ese terreno era del dueño de Mayagüez, y el doctor Correa dijo,-ustedes por qué-, dijo -no han venido aquí-, entonces yo fui con otros dos, fuimos y hablamos y dijo -listo-, yo voy a ir y dijo -voy el sábado para enseñarles en la cancha de chaza-, pero tampoco creíamos, porque ellos son así, hablan y a veces no cumplen, y preciso dijo -a las 9 voy-, dejar tanto oficio que tienen esa gente y llegó acá y nos entregó ese lote, era más grande, hasta acá abajo donde están esos ranchos, hasta ahí era, pero no pudimos nosotros construirlo todo, pero ya hasta ahí algo hacemos, y se construyó eso, vea nos ayudo sabe quién, nos dio el terreno y nos dio 100 bultos de cemento eso es de cemento, pero un, y lo terminamos hasta donde ahí está. Alberto Díaz.

Porque nos dicen que la única parte en Candelaria, la única parte de recrearse la gente, han valorado es esta parte, la cancha de chaza. Grupo.

Aquí en el escenario deportivo sintético, ahí se reúnen la mayoría de jóvenes, ya directamente muchos han terminado estudio,

muchos no han terminado estudio, se reúnen en las noches a jugar aquí en esta cancha, porque yo paso de hacer deporte acá, y aquí encuentro mucho joven jugando, muchas damas jugando, muchachas, jugando el deporte, porque ese lo practican hombres y mujeres. Grupo. 
Bien, digamos que inicialmente por aquello de que se tenían espacios para el deporte como era el futbol, digamos que la llegada de la chaza empezaba como a competir un poco con el futbol, pero poco a poco ellos fueron generando un especio propio para ellos, ya que inicialmente quedaba en el Panamericano y luego se va a trasladar al frente donde queda Santa Ana, y allí van a tener un espacio propio de reconocimiento por la cultura de la chaza que ha tenido pues el hombre, y que ha tenido competencias con comunidades como la de Palmira y Cerrito, ya donde se competían también en comunidades de nariñenses que estaban asentadas en Palmira y están asentadas en Cerrito, entonces ellos van a compartir un poco de ese legado. Víctor Mondragón.

Y el reconocimiento de la virgen, aquí como somos bastante Marianos, el hecho de que tengamos una virgen que sea la misma vocación, otra vocación de la misma virgen pues hace posible también que la gente lo reconozca, entonces hace que la gente lo vea positivo. Víctor Mondragón.

Nos tocaba mandar cartas de comercio, los mismos paisanos nos respondían mal en el comercio y de los que no eran paisanos recibíamos más aporte y las empresas, Águila Roja, nos colaboraba con una empresa, la Licorera del Valle nos colaboraba también, Bavaria nos colaboraba y haciendo eventos, los puestos para hacer las casetas, vendíamos los puestos para que vendan los productos por que eso cuando se abrió el evento todo el mundo llegaba a vender pero no querían aportar, entonces nos toco hablar con el gobierno para que nos apoye, compramos la caja de 100 tacos. Grupo 2

Yo creo que fue la chaza, primero porque no recuerdo si fue en el año 66, yo trabajé en Mayagüez y ahí empezamos a practicar la chaza, y ahí había una cancha, la quinta, pero eso si fue un proceso que jugamos en el polideportivo, en el parque recreacional, entonces lo de la practica del deporte de la chaza fue el primero de aquí. Ya se empezó las iniciativas para la virgen de Las Lajas. Usted profe decía que más extrañaba, primero pues uno dice, cuando nos vinimos por aquí, primero pues lógico, extrañar la familia, todo eso, y le digo que poco a poco nos fuimos ubicando, ya entonces, ya después de uno estar por acá, ¿qué extrañamos? Las costumbres y por eso gracias a Dios, gracias a la decisión de Dios, hicimos pero la mayoría si nos decidimos a conservar esas tradiciones, estamos pocos, porque la chaza y otras iniciativas y ahora la cuestión, porque en septiembre, bueno hubo iniciativas mucho y nos organizamos para la virgen de Las Lajas, entonces las iniciativas fueron así, de todos conservando las costumbres, para empezar fue duro. Grupo 2

La iniciativa de esos carnavales fue aquí, después empezaron por otras partes, ese día de todas las partes y eso era lo que lo motivaba a uno, que hizo la gente en Candelaria porque ya venían de otras partes, de otros municipios a organizar con sus comparsas sus cosas, y eso era lo que motivaba a los organizadores y en parte se sigue celebrando la tradición de los carnavales. Grupo 2 
Hay gente candelareño que tenía y cree en la virgen de Lasa, entonces esa gente apoya esas festividades, creo que hay gente de los candelareños que apoyan esa fiesta y mire a pesar de que hay candelareños que apoyan esa fiesta, y así hoy le doy la gracias al pueblo nos a recibido con mucho cariño que no faltan personas de que no estén de acuerdo. Grupo 2

Como le digo la fiesta la empezamos aquí con esa tradición de fiesteros y con el ánimo de llevar a cabo pues nuestra fiesta y devoción, ya no solamente y en el momento no somos los nariñenses sino que se ha vinculado mucha gente que de aquí de Candelaria, hasta de Cali hay gente que se vincula a la fiesta y nos acompaña por que ya es una devoción a la virgen. Jorge Martínez

El lote que teníamos quedaba muy cerca de la capilla de Candelaria, entonces nos hacemos en otra parte y este es el momento que los alcaldes no nos han podido, este alcalde que nos iban a dar un lote, entonces los sacerdotes han puesto mucho interés como éste que vino ahora, este si tiene una devoción y viene con un interés de hacer la parroquia porque yo les dije, pues nuestro interés en ese tiempo, nuestra junta, que hicimos la junta parroquial no era hacer la parroquia sino celebrar la fiesta de la virgen y ya el que si vino con el interés de hacer la parroquia es el padre Abelardo, entonces él está haciendo muchas cuentas que en la parroquia hay que hacerla, que Candelaria está muy grande, que Candelaria no puede con una sola parroquia entonces en eso estamos. Jorge Martínez

Salí a vacaciones y me vine aquí, cuando en ese tiempo en vacaciones unos paisanos aquí andaban pidiendo unas limosnas que para hacer una fiestica a la virgen, para hacer una misa a la virgen, entonces yo me acuerdo que les di 500 pesos y toda esa gente dijo: este señor sí y ahí por allá me metí yo, ellos eran los que estaban organizando la primer fiesta para representar, pidiéndole limosnita a la virgen en una misa y me metí yo a eso a organizar, organizamos lo que se pudo y bueno, yo pues cuando venía ya con la mucha experiencia para ver cómo se organizaron las cosas, cómo se hacían, ya organizamos en realidad la fiesta a la Virgen en el 80 en Candelaria. Jorge Martínez

Pues como le digo, una iniciativa había sido de dos señoras, que querían que celebrara la misa cada año, una misa a la virgen de Las Lajas, entonces cuando yo ya estaba aquí y ellos empezaron a pedir más limosna y que yo les di, ellos pensaron que me tendrían que vincular a mi por que el único que les llevaba los 500 pesos. Entonces en realidad hablan conmigo yo les dije claro, antes la virgen me las mando ustedes a mi por que si ella es la que sabe que yo tengo que dedicarme y nos dedicamos a eso y con un sacerdote que hubo aquí, yo no se él le debía algo a la virgen se dedicó, él era el que solicitó a Mayagüez para que nos de un lote, y en realidad nos dio un lote pequeño para hacer la capilla, mientras tanto hicimos una caseta donde teníamos unos festivales y conseguíamos la platica para hacer la fiesta que empezamos a hacer fiesta cada año, y cada año le hacíamos la fiesta a la virgen y traíamos inclusive las bandas que tienen tanto aprecio en Nariño, bandas musicales venían de todos los municipios de allá, traíamos una banda y hacíamos una fiesta muy pomposa para la virgen, pero el caso es que no hemos podido como se dice pues ya dedicarnos a hacer la parroquia por que nosotros no podíamos dedicarnos a hacer la capilla sin autorización del párroco. Jorge Martínez 
Empezamos en noviembre, en septiembre, ahora este año va a ser la misma fecha que celebran en Las Lajas que es el 16 de

septiembre, entonces la novena la empezamos a hacer 9 días antes y la hacemos en los barrios, el padre ya nos sale así, sale a los barrios donde el padre Fierro y el padre Henri que ya murió QEPD, con ellos salíamos, acostumbrábamos a salir a los barrios entonces en una parte dice, bueno en mi casa vamos a hacer, pero no en la casa, en la calle vamos a hacerlo, en la casa yo no puedo celebrar las misas, algo así, pero entonces por ejemplo aquí que en la casa de Don Jorge se hace la fiesta, la misa aquí en la calle, entonces para empezar novena, dice no la novena es la programa, que en la casa de fulano, en la casa de sutano y así lo seguimos todavía. Jorge Martínez

Pues el municipio nos aporta y luego pues a veces que el banco de Bogotá nos da aun aporte, Águila Roja nos daba, ya no nos da, organizaciones muy poco, la fiesta donde más recolectamos es que habíamos una cantidad de personas que nos llamamos fiesteros y damos una cuota para la fiesta, una cuota y luego repartimos unos sobres y por lo regular la gente nos aporta mucho con sobres, en sobres nos dan la limosna y poquito, a veces que 10, a veces que 500 pesos, 50 mil y así, entonces con eso, reunimos y siempre nos quedan los ahorros a parte de los gastos que hacen para todo lo que hay que pagar. Jorge Martínez

Muy bueno, aquí hay mucha gente que no es Nariñense y que hacen parte de la fiesta de Las Lajas, porque por ejemplo cuando vino el nuevo párroco celebró la primer misa y nos dijo en la misa porque el sabia y habló sobre la virgen de Las Lajas y entonces dijo: levantad la mano los nariñenses que apoyan la virgen de Las Lajas en la iglesia, entonces así unos pocos y al terminar eso hicimos una reunión con el padre y yo le advertí, padre no vuelva a discriminar para la fiesta de Las Lajas a los nariñenses, porque hay mucha gente que no es nariñense y que está apoyando la virgen de Las Lajas, entonces es un problema que entonces nos separa, y dijo pues hombre perdóname yo no lo vuelvo a decir y nunca mas volvió a decir, verdad por que no solo son los nariñenses sino los de acá de Candelaria y de otras partes, y dijo: entonces tenemos esa tradición de que no solamente los nariñenses celebramos la fiesta de Las Lajas. Jorge Martínez 


\section{RELATOS DE INTEGRACIÓN}

\section{Relación entre candelareños y nariñenses}

Yo que le puedo decir, ha tocado a veces modificar ciertas cosas por la aceptación, o sea la gente, unos que hay muy grato y todavía, que la gente sale, sale a jugar, o sea sale a participar y sale a participar la gente que viene, la gente afro, gente del eje cafetero, gente paisa. Entonces además de una aceptación es una participación a eso, entonces se convierte en una participación, que ha tocado modificar a veces los espacios a tomarse por el carnaval, porque la expresión del carnaval es incomoda, echar harina, pintura, es un desborde total que causa mucha incomodidad en algunas personas que no comparten y tienen dentro de su lógica. Entonces ya nos toca sectorizarlo o en unos recintos hacer la expresión, pero la expresión del carnaval se sigue dando, la gente dice, el que quiera celebrar, quien quiera divertirse hágalo en tal sitio, no me venga a echar pintura a mi casa, no me venga a echar pintura a mi, porque los demás tienen su rutina diaria y a veces incomoda, pero más que todo es acoplemos la expresión en un sitio donde puedan hacer todo su desborde sin causar impacto negativo frente a las demás personas. Milton Posos

No por lo menos ahorita, en estos momentos, ellos con nosotros mejor dicho son como mas bien agradecidos, porque mire lo que pasa, ellos siendo de Candelaria y vendieron su vivienda y no tienen donde vivir, y en estos momentos llegar es a arrendarle al que llegó, al pastuso, entonces mire ese cambio que hay, entonces ya no nos miran como nos miraban al principio. Grupo Chaza

Entonces por ese sentido, hoy en día con los que yo he compartido, con los que yo trato porque aquí no hay solamente candelareños, porque hay gente negra, también mucha gente que comparte con uno, con nosotros muchas veces vecinos, de todo, entonces yo miro a los candelareños que hoy en día tiene casi la misma cultura de nosotros porque ellos se han acoplado o nos hemos acoplado todos, porque aquí estamos viviendo se puede decir 3 generaciones, la generación candelareña, la generación nariñense y la negra, yo se no podemos discriminar a nadie, nosotros somos todos iguales y por eso es que queremos que esto salga para adelante y logremos que Candelaria siga siendo más bonita de lo que es. Grupo Chaza

Pues hoy en día ya estamos viejos, entonces nosotros ya hemos hecho nuestro hogar, los hijos ya han hecho los hogares de ellos, entonces de esas descendencias de hoy en día es Candelaria porque aquí el candelareño, candelareño, eso es descendencia de los mismos nariñenses. Grupo Chaza 
Pues hay unos candelareños que no les gusta la chaza, y dicen esos pastusos corriendo para arriba y para abajo, porque hay unos que no les gusta, no lo entienden, prácticamente no lo entienden, eso es lo único que yo creo que no les gusta a ellos. Pero ahorita la diversión para los candelareños y nosotros está allá, en la cancha y usted dice vamos para la chaza y hoy domingo eso está lleno, inclusive que le hacen falta banquitas ya, nosotros los jugadores estamos jugando y cuando terminamos vamos a sentarnos y ya no hay donde, las banquitas y es aprovechando eso de la junta nueva que hacemos unos asientos fijos. De pronto con la ayuda suya y nosotros los nariñenses, nos gusta la chaza y eso nos gusta, y nos sabe igual que la comida, pero los candelareños también van con uno porque por ejemplo yo siempre he sido director técnico del juego de fútbol entonces ellos son felices de que nosotros los apoyáramos en una forma o de otra, que comparemos que también juegan fútbol y estuvo en el equipo donde yo lo manejo y ya no es día de hoy, yo lo manejo hace más de veinte pico de años y no, entonces contentos con uno los muchachos candelareños que están jugando fútbol y uno de estar con ellos, porque uno los apoya en Candelaria, porque uno también mete la mano al bolsillo para poder pagar algo, para poder pagar el alquiler de la cancha bueno.. nosotros nos sentimos contentos, y como dicen ellos, eso es lo que se quiere aquí en Candelaria, porque estas prenderías son de nariñenses, mire lo que puede mirarse en Candelaria que hay buenas prenderías con pagos con bajo interés ¿por qué? Porque de allá vinieron a trabajar aquí y eso es lo que ellos nos miran a nosotros, como una forma de poder compartir también con nosotros, de poder estar, sino están jugando con nosotros chaza pero les gusta jugar su fútbol, entonces nosotros también necesitamos de ellos. Grupo Chaza

Porque el candelareño también es católico, es que eso como ya viene de descendencia, entonces casi la mayoría es católica ya, y si es hijo de nariñenses mejor, sino son de allá pero ya tienen sangre nariñense. Grupo Chaza

Siempre fue muy cordial cierto, muy buena si, tanto que pues se hicieron a familias, se educaron familias con nosotros, se fueron cruzando y siempre ha sido buena la relación. Camilo Muñoz

Bueno en un principio pensábamos que eran dos mundos distintos, que cada uno hacía su parte y la otra, la otra parte, pero llegó un momento en que los gustos no los detiene nadie, y se fueron fusionando, por los amores que les tocó vivir en el colegio, en la plaza, en el parque y todo porque de candelareñas habían niñas muy lindas y jóvenes muy apuestos, pero de los nariñenses también había eso mismo. Clara Díaz

Pues hombre, yo considero que era muy buena, era muy buena por que no había como el celo de que iban a quitar la fuente de trabajo porque no había ese celo, porque había trabajo para todo el mundo. Edgar Olave

La gente que llegó ya se casó con candelareños, entonces ya, los que nacieron ya no son nariñenses, ya son mezclados entre candelareños y nariñenses entonces, a mi esa situación de hacer como esa diferencia a mi me parece que ya en Candelaria tampoco 
debe de ser tan marcada, porque ya no hay nariñense nariñense, los viejos. Milena Medina

Pero de todas maneras las costumbres pienso que no son muy diferentes, es decir, yo no lo veo como con una gran diferencia de costumbres, entonces se han querido implementar cosas de ellos acá en nuestro municipio que tampoco me parece que las tengamos que albergar de esa manera, es Candelaria, acá tenemos un territorio, llegaron y ya todos somos como este territorio, entonces hablo específicamente de la fiesta de blancos y negros, no es algo autóctono de nosotros y se nos convirtió en un problema porque en vez de volverse un problema no se trajo la esencia cultural de allá, sino que se trajo algo que se convirtió en desorden para Candelaria, entonces que quiere decir, que tanto como nariñenses como candelareños que estamos allí no reconocemos esa fiesta como algo cultural, sino que lo tomamos como una diversión y luego se nos convierte en un problema, porque hay muertes. Milena Medina

Muchos candelareños ya se unieron con los nariñenses, formaron sus familias y todo eso. Isaías Gamboa

Es que que pasa por decir algo, nosotros ya por decir los hijos de nosotros ya es de descendencia de pastusos, entonces ya la discriminación es menos por lo que a raíz de ellos ya viene la gente. Más antes de los poquitos que había ya la mayoría eran vallunos y por eso también es la discriminación, pues ahora con los hijos de nosotros pues son nacidos aquí pero vienen de raíces pastusas entonces eso ya va cambiando, es muy diferente. Por lo menos actualmente ya no hay discriminación como antes, actualmente todos la pasamos bien. Primero aquí la discriminación empezó con los nariñenses y después con la gente de color porque en esas empresas nosotros ya somos de estar un poco de tiempo por aquí, a la gente de color no las recibían en las empresas, todo era nariñense, hoy en día no, todo el mundo es parejo ya. Grupo

Entonces yo pienso que no ha habido, digamos no percibo un situación de conflicto, no se dio una situación de conflicto, digamos que hay una aceptación de rasgos culturales, de hecho no fueron los únicos rasgos culturales que se empezaron a establecer sino también comunidades del Pacífico. Víctor Mondragón

Porque como le digo doctora, eran buenísimos para el trabajo del campo, esas mujeres eran bondadosas, pero yo creo que Dios les puso en el corazón de ellos en el corte y todo, y ellas muchas de ellas iban a las reuniones políticas, entonces cuando había que adjudicar lotes, a quien iba a adjudicar a los de Palmira que habían estado en la lucha, porque es que también hay que decir, ellos se ganaron también esas oportunidades de mejorar su calidad de vida, yo se lo digo, y se lo digo con el corazón y de verdad que lo creo así señora, ellos aquí no se les regaló nada, ellos llegaron y hombro a hombro con los otros participaron en los procesos, y nos ayudaban y no importaba si la convocatoria era a las 5 de la mañana, aparecían en directorio y sabían que trabajar en autogestión también. Zoraida Zamorano 


\section{RELATOS DE INTEGRACIÓN}

\section{Aportes de los nariñenses a Candelaria}

A ver... si nosotros evacuamos el desarrollo de la historia de Candelaria, Candelaria unas 3 décadas y media hacia atrás, era un municipio pequeño donde se empezaban a dar asentamientos de población, llegaba la población nariñense y los nariñenses llegamos a trabajar, a servir, pero desde allí va naciendo hijos de esa descendencia aquí en el valle. Digo 2003 -2004 llega un alcalde vallecaucano pero de decencia nariñense y yo creo que la cultura, la raíces, se llevan en la sangre, entonces entré con un apoyo decidido a apoyar los carnavales y luego queda una alcaldesa que también va mirado el aporte significativo que a hecho la colonia nariñense, y yo creo que reconocen y miran que la expresión cultural es como un pequeño reconocimiento al desarrollo de inversión que han hecho en la parte de creación urbanística, comercial y en la instrucción gastronómica. Milton Posos

La expresión de los carnavales crezca más en si, para enriquecimiento cultural de Candelaria. Milton Posos

Yo recuerdo en el ingenio Mayagüez era muy pequeño y con el tiempo se hicieron unos montajes bien organizados, bien grandes, pero ha sido todo el mundo, ese aporte de fuerza y todo ha sido el 100\% los nariñenses. Grupo Chaza

Por lo menos lo que le decía acá mi compañero, cuando nosotros llegamos aquí a Candelaria por aquí no habían sino casitas de paja, de teja, nosotros a nivel de nosotros llegar a una empresa se le dio el cambio al municipio de Candelaria ¿Por qué? Porque ya nosotros teníamos para hacer nuestro ranchito y ya el ranchito muchas veces no fue de teja sino de loza, entonces ahí vienen como ellos dicen, no con mejores casas, porque yo tuve un agarrón con uno de la administración porque me dijo así porque me dijo usted es un mal.. porque cuando hay que decirlas, me dijo que nosotros éramos malagradecidos que cuando habíamos llegado dormíamos unos encima de otros y ahora vaya a verlos con casas de dos y de tres pisos, pero yo le dije, yo no me vine a sentar aquí al parque como son los de Candelaria que se salen a sentar al parque, nosotros llegamos a un ingenio a trabajar y a darle lo que Candelaria es ahorita. Grupo Chaza

El pueblo fue creciendo a la par de que ellos crecían también económicamente y socialmente, el pueblo también fue creciendo, ya hubo el cruce entre grupos étnicos, entonces se empezaron a cruzar con los candelareños, con las otras etnias y así se ha formado Candelaria, es una, como digamos así, una entre mezcla de grupos étnicos, sobretodo con ellos fue más que todo y entonces el pueblo creció a la par de que ellos hicieron grande la industria azucarera aquí, a ellos se les debe y a la población negra que el pueblo 
creciera y que hoy seamos lo que somos. Camilo Muñoz

Si, la construcción de vivienda, Candelaria en un momento no era tan grande y habían muchos lotes baldíos, llegan ellos, no eran como la colonia afro descendiente que ellos alquilaban una pieza de una casa y ahí se metían todos, le alquilaban a dos o tres cuando menos pensaban habían 15 o 20, acá no, ellos trataron de comprar, además de que el ingenio cuando veían que eran buenos trabajadores les colaboraban para que compraran su terrenito y pudieran hacer su casita, entonces encuentras que las casas de ellos no eran sino piezas, porque ellos, la idea de ellos eran hacer piezas para meter personas, por que eran familias numerosas, eran familias muy numerosas. Edgar Olave

Candelaria en ese tiempo, que por ejemplo en el año 44 pongámosle, era muy pequeñito, como 4 casitas y ahí que han hecho los candelareños. Luis López

Con la ayuda del municipio y los ingenios, que el ingenio nos prestaba plata para construir, Mayagüez le prestaba plata a muchos trabajadores. Luis López

Yo pienso que ese trabajo de ellos ha hecho que la cooperativa esté como está, porque ellos parecen hormiguitas trabajando. Milena Medina

Nace de la iniciativa casi de ellos y la han sostenido por muchos años, ellos pelean para que el recurso que les queda a ellos de utilidades se invierta y se invierta bien, entonces esa parte también es... y ellos han hecho que esa cooperativa, y ahí están los dos, los candelareños y los nariñenses han hecho un muy buen equipo en esa parte. Milena Medina

Anteriormente en Candelaria eran 4, 5 o 6 barrios, con la llegada de los nariñenses se formaron otros barrios, cuando Mayagüez lote o digamos as, unos terrenos que tenia cultivados de caña, los loteo para darle a sus trabajadores tierras por un precio muy bajito, incluso yo trabajé en Mayagüez también y se formó el barrio, el barrio Santa Ana y le colocaron Santa Ana por doña Ana Julia Holguín , el colegio Ana julia Holguín auspiciado también por Mayagüez, eso le ha dado mucho progreso también a Candelaria, pero como le digo, los nariñenses han tenido su parte muy importante en eso, por que ellos son unos trabajadores. Isaías Gamboa

La espiritualidad de los nariñenses contagió al materialismo de Candelaria, porque en Candelaria eran muy apegados a sus fiestas, a sus bailes y a todas esas cosas, y la religión no era como una especie de, como le dijera, como un fanatismo nada más y luego como ir los domingos a misa y ya con los nariñenses, se apersonaron más de la religión, se volvieron muy religiosos, y pero eso ha favorecido también mucho al progreso. Isaías Gamboa 
La espiritualidad tuvo un auge con la llegada de los nariñenses, ellos han contribuido mucho a la espiritualidad candelareña, es decir al ser altruistas, es decir no, al conseguir logros, en ese sentido yo creo que hay una diferencia, o un aporte de la colonia nariñense a la colonia de Candelaria. Isaías Gamboa

Eso digamos que se ha dado a partir de la década de los 60, finales de los 60, principios de los 70, la llegada de toda esta comunidad, ellos generaron un primer modelo de expansión, de lo que ha sido la cabecera municipal, ya que existían anteriormente grandes manzanas con 3 o 4 viviendas y sobre la base de esas viviendas se empezaron a generar el loteo, y el loteo significaba era comprar la tierra para poder construir y entonces así se fue dando digamos el modelo de la expansión y de loteo. Víctor Mondragón

A mi me parece que obvio ellos les trajeron su cultura, la parte de sus artesanías y sus cosas también, yo creo que en el municipio hemos estado un poquitico, que le digo, no le hemos dado como todo el valor de toda esa riqueza que ellos tienen, nosotros somos un municipio pluricultural por la cultura de ellos. Zoraida Zamorano

Nosotros fuimos los que les dimos el 100\%, tampoco ha sido muy poquito, pudimos aprovecharlos, entonces esa parte como fue, todos esos cambios que hubo ha sido por los nariñenses. Grupo 2 


\section{RELATOS DE INTEGRACIÓN}

\section{Solidaridad de vecinos y amigos}

Por eso yo agradezco y la empresa era pues que me apoyaba mucho por el trabajito pues, entonces cuando yo ya me preparé ya tenia un ahorrito allá y entonces dije vamos a ver que hacemos, reformamos el techo o le metemos nuevo y todo, y de ahí vino don Pedro, otros amigos uno de ellos ya es muerto no se si por aquí esta, el proyecto mío era cambiar el techo entonces todos los que nos ayudaron dijeron no, Alpala haga un esfuercito y métale la plancha, entonces don Pedro y otro amigo que ya murió dijo no, vamos por votación aquí (Risas) vamos por votación, vamos por techo o le metemos plancha. Alpala y Rosalba

Y le tiramos plancha, cuando ya se hizo la hora de meter la plancha yo invité mas o menos a 20 por el trabajo, eran en minga, en comunidad, no es como ahora que traen al trompo y eso es rápido, cuando eso era a pala, era la minga que decíamos, eso de la minga, nosotros los nariñenses hemos dejado un ejemplo, cosa que ya se está perdiendo. Alpala y Rosalba

El caso es de que llegaron a mirar de que era costoso y más incomodo, porque aquí toda la casa comprábamos las mezclas y todo eso, si era bueno pero era más costosito porque yo invité a 25 amigos que me vengan a ayudar y arrimaron más de 30 . Alpala y Rosalba

Si, claro, en esa parte, pues por lo menos los paisanos que ya venían después y venían después se les ayudaba, se prestaba mucho por el trabajo, había mucho trabajo, demasiado trabajo, entonces que hacia uno para ayudar, entonces yo quiero ir a trabajar a

Mayagüez, yo quiero a Castilla, a Manuela, a todas esas partes se le daba la iniciativa, como a donde tiene que llegar. Alpala y Rosalba

Si, contacto y ya se daban las cosas, ya llegaban y bueno conseguí el trabajo y ahora me falta esto, y claro se le ayudaba con la ropita, se les ayudaba con la herramienta, se le ayudaba con todas las cositas que les hacían falta para trabajar, pronto la alimentación, se ponía de acuerdo, casi a nosotros no nos paso muchas cosas, si ayudábamos, pero habían partes que decían bueno, aquí le vamos a ayudar con la comidita, todo eso por hay unos 15 días mientras se organice, porque empezaba a trabajar y el paguito se lo pagaban. Alpala y Rosalba

Claro y dijo yo le presto 25 pesos hágale y éramos compadres y nos agarramos y eso quedo enterrado, yo le dije al maestro, porque me hace el favor y no sube otra tabla para arriba que abre y quedaba eso así y póngale la otra tabla y echémosle material y aquí va a caer enterrado y dijo no, es que esto queda bien ahí y no se que y no me hizo caso, y yo pues trabajando y el día que no estaba hizo eso, y luego pues ya se hizo las paredes, cuando ya pensaron, ya estaba todo listo, ya no hubo nada que hacer y todo que este lote si me pertenecía a mi dijeron, los vecinos por fin y cuando eso todo el mundo me ayudaba a trabajar, y aquí había gente cuando echamos la primer plancha eso. Pedro Castro 
Había que darles cualquier desayuno, pero es que era jodido eso aquí estuvieron como hasta las dos de la tarde, eso fue mejor dicho como era grande plancha, quedo grande y se nos acabó el material, al agua se nos abastecía, había que esperar a que llene una tina y luego seguir revolviendo entonces esa nos perjudicó también bastante y hasta que terminamos ahí la primera quedamos; y después pues siempre nos amanecimos tomando cualquier cervecita por ahí en uno o en otro lado, va sus canastas de cerveza, todos sus amigos decían, no es la primer plancha que echamos aquí, contentos todo mundo, eso con bastante gente se dio eso gracias a dios. Pedro Castro

Para eso comenzando con mi persona, que ya era un poquito más conocido por todos los nariñenses entonces nos íbamos juntando la solidaridad. Un ejemplo, cuando yo hice mi casa, porque la casa que hice, la hice ya de ladrillo con concreto y todo eso, porque la que compré ya era una ramada digámoslo así, entonces ahí yo me alisté con las gallinas, la bebida y toda la comida, porque en Nariño se hace minga, entonces uno se prepara en la comida y en la bebida, y yo les dije a los compañeros un día por decir algo, compañeros para el sábado voy a tener la fundición de la plancha de la casa donde yo vivo, los que me van a ayudar a fundir la plancha, entonces para yo aprensarme y dijeron todos. José Montilla

Iniciamos y ya después empezamos a trabajar cada uno, cada jugador ponían de a dos bultos de cemento y el labor de trabajo. Grupo Chaza

Nosotros mismos trabajando, nosotros mismos comprábamos el cemento, comprábamos todo y nosotros mismos trabajábamos, porque a nosotros mismos viejitos que eran jugadores nos tocaba entre dos bultos de cemento, los que estábamos trabajando en la empresa nos tocaba un solo o dos bultos ,pero así hicimos ese trabajo, que nadie nos ayudó, por lo menos en la alcaldía se les pasó, a nosotros no. Alberto Díaz 


\section{RELATOS DE INTEGRACIÓN}

\section{Posibilidades de retorno}

Pues no, porque ya por el clima yo he ensayado el clima y tengo un pedacito de tierra allá, los hermanos míos que cultivan allá, lo dejan de potrero para el ganado y yo hágale, yo acá vivo con mi pensión, tengo la residencia aquí, mis hijos, no pienso volver para allá, pero no olvidar a la familia, cuando haya un presupuestico de platica, viajo para allá. Aurelio Realpe

Pues la realidad yo sí estuve cuando salí pensionado, yo sí tuve mucha intención de irme para Nariño, yo tengo allá terrenos lo que me dejó mi papá, tengo bastante terreno, casa y la idea mía era irme para allá y le digo mija, le dije a mi mujer "vámonos, vamos a trabajar allá el terreno que se está quedando sin sembrar y hay muchas cosas que se pierden" y dijo "mijo si se quiere ir, váyase y usted sólo, yo de aquí no me voy". Les comenté a los muchachos, los senté un día y los reuní en la sala y les dije "muchachos yo tengo el terreno allá porque no nos vamos para Nariño" papá si quiere ir, váyase. Gabriel Pascuasa

"No, no he podido, no me pude ir por eso, ya porque ninguno de los hijos quiere, todos son nacidos aquí". Gabriel Pascuasa Entonces yo como le digo, pues yo ahora voy, visitó mi familia y vuelvo, no es más lo que hago, el resto prácticamente ya determiné quedarme aquí, eso es todo. Gabriel Pascuasa

Allá tiene un hermano pero no quiere ir, yo por eso viajo, yo le neceo bastante pero no quiere y fue como 3 veces no más con nosotros y no ha vuelto más. Gabriel Pascuasa

Yo si, claro, lógico, yo diría y me dice, Montilla usted con esa pensión usted en Nariño vive y mejor dicho le sobra plata, lógico y uno estando allá. Pero dos cosas, uno ya el frio es difícil, no es lo mismo, ya cambia, entonces esa es la cuestión; el otro es por los hijos, porque hasta no hace mucho era todavía unos 5 años todos vivían ahí y se comía de la misma boca. José Montilla

Pues no, yo ya no, en este tiempo ya no, pues vivir aquí y todo la familia de aquí y mi esposa aquí y ya volver allá si es difícil, ir de visita de pronto, y a visitar la virgen de Las Lajas que tengo que ir otra vez allá a una promesa, pero ya irme a radicar allá es difícil por que pues, es en pueblo donde yo me crie, la finquita que tenia mi papá eso se vendió, y llega uno y eso totalmente distinto cuando uno se crio allá, eso ya no es difícil, el lugar, ya se perdió de ir a volver a Nariño, a vivir no, además eso como le digo, mi hogar está aquí, mi esposa es de aquí de Candelaria, mis hijos son de aquí de Candelaria, ya es difícil volver a Nariño. Jorge Martínez 